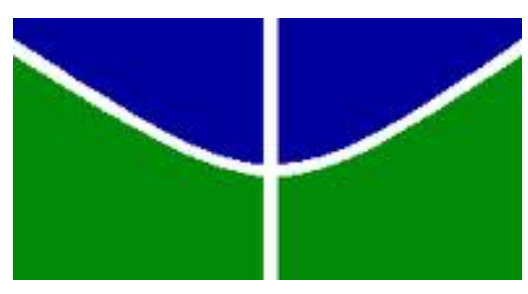

Universidade de Brasília

Instituto de Ciências Humanas

Departamento de Geografia

\begin{abstract}
A INSERÇÃO DOS CERRADOS PIAUIENSES NA DINÂMICA DA AGRICULTURA MODERNA NO BRASIL CENTRAL: TRANSFORMAÇÕES NA REDE URBANA DO SUDOESTE DO PIAUÍ
\end{abstract}

Tiago Fernandes Rufo

Dissertação de Mestrado

BRASÍLIA/DF

Dezembro, 2015 


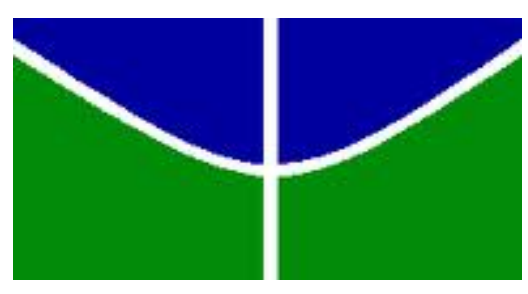

Universidade de Brasília

Instituto de Ciências Humanas

Departamento de Geografia

\begin{abstract}
A INSERÇÃO DOS CERRAdOS PIAUIENSES NA DINÂMICA DA AGRICULTURA MODERNA NO BRASIL CENTRAL: TRANSFORMAÇÕES NA REDE URBANA DO SUDOESTE DO PIAUÍ
\end{abstract}

Tiago Fernandes Rufo

Orientador: Prof. Dr. Fernando Araújo Sobrinho

Dissertação de Mestrado

BRASÍLIA/DF

Dezembro, 2015 


\author{
Universidade de Brasília \\ Instituto de Ciências Humanas \\ Departamento de Geografia
}

\title{
A INSERÇÃO DOS CERRADOS PIAUIENSES NA DINÂMICA DA AGRICULTURA MODERNA NO BRASIL CENTRAL: TRANSFORMAÇÕES NA REDE URBANA DO SUDOESTE DO PIAUÍ
}

\section{Tiago Fernandes Rufo}

Dissertação de Mestrado submetida ao Departamento de Geografia da Universidade de Brasília, como parte dos requisitos necessários para a obtenção do Grau de Mestre em Geografia, área de concentração Gestão Ambiental e Territorial, opção Acadêmica.

Aprovador por

Prof. Dr. Fernando Luiz Araújo Sobrinho (UnB)

Orientador

Prof. Dr. Juscelino Eudâmidas Bezerra (UnB)

Examinador Interno

Profa. Dra. Maria Erlan Inocêncio (UEG)

Examinador Externo 
Ficha Catalográfica

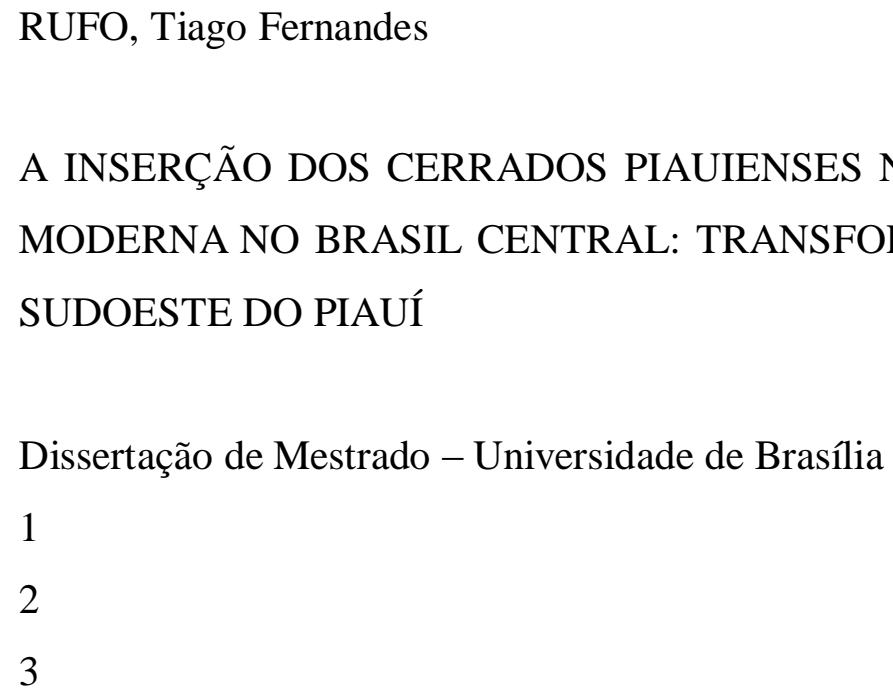

É concedida à Universidade de Brasília permissão para reproduzir cópias desta dissertação (tese) e emprestar ou vender tais cópias somente para propósitos acadêmicos e científicos. $\mathrm{O}$ autor reserva outros direitos de publicação e nenhuma parte desta dissertação de mestrado (tese de doutorado) pode ser reproduzida sem a autorização por escrito do autor.

Tiago Fernandes Rufo 
Aos meus familiares e amigos,

Em especial aos meus primos Henrique e Matheus, que para sempre estarão nos nossos corações. 


\section{AGRADECIMENTOS}

Agradeço primeiramente a Deus, pela minha saúde, e, principalmente, por ter-me cedido a oportunidade de conviver com uma família maravilhosa.

Aos meus pais João Rufo e Evandia Fernandes, que, até hoje, souberam me guiar pelos melhores caminhos possíveis.

Ao meu orientador Prof. Dr. Fernando Luiz Araújo Sobrinho, que desempenhou verdadeiro papel de orientação, inclusive em relação a questões alheias ao ambiente acadêmico, e cujos conselhos me serão proveitosos para sempre.

Ao professor Dante Flávio da Costa Reis Júnior, docente que, durante minha graduação, ministrou a disciplina "Metodologia da Geografia", no âmbito da qual concebi o meu projeto de monografia, que influenciou diretamente a temática do presente estudo.

Ao geógrafo Vicente Eudes Lemos Alves, pelas contribuições via e-mail para a redação do pré-projeto de seleção de mestrado.

Aos meus irmãos Gabriel Fernandes, Fernanda Fernandes e Ana Carolina, que, direta ou indiretamente, contribuíram para o desenvolvimento do meu trabalho.

Ao meu tio Edjânio, sempre presente no convívio familiar.

À minha namorada e companheira Halanna Marques, pela compreensão, e por ter-me incentivado a superar as adversidades e continuar desenvolvendo o projeto.

Aos meus amigos Adriel e Aldimon, meus primos, e também parceiros de saídas de campo.

Ao meu primo Edivan Rufo, pelas conversas que tivemos sobre o meu projeto, e por ter compartilhado comigo sua vivência da região. 
À minhas cunhadas Adriana Marques e Edla Lustosa, pelo auxílio nas visitas às cidades de Corrente e Bom Jesus, respectivamente.

À professora Deianny Santos, do Instituto Federal de Educação, Ciência e Tecnologia do Piauí (IFPI), e a Dário Ribeiro, pelas conversas informais sobre as transformações que, ao decorrer dos anos, tomaram lugar na região que é objeto deste estudo.

Ao professor de geografia Gilvan Charles Cerqueira de Araújo, meu colega de trabalho, pelas inúmeras indicações de referências bibliográficas, pelas proposições destacadas ao longo do trabalho e pelo auxílio na formatação do mesmo.

Ao grande geógrafo e doutorando em Geografia (UnB) Wallace Pantoja, pela ajuda na correção de alguns artigos, que foram fundamentais para o desenvolvimento deste trabalho.

À equipe de professores do CEF 03 do Paranoá, em especial à coordenadora Denise Mota, pela flexibilização do meu horário de trabalho, o que facilitou a redação final da dissertação.

Aos integrantes da banca dessa dissertação, pelas eventuais correções e colocações referentes ao texto, essenciais para o desenvolvimento científico e para a qualidade do trabalho.

Por fim, a todas as pessoas que, direta ou indiretamente, participaram do desenvolvimento da minha pesquisa ao longo destes seis anos - quatro de graduação, e dois de mestrado -, bem como na superação dos eventuais problemas. 
"Piauí, terra querida

Filha do Sol do Equador

Pertencem-te a nossa vida

Nosso sonho, nosso amor!

As águas do Parnaíba

Rio abaixo, rio arriba

Espalham pelo sertão

E levam pelas quebradas

Pelas várzeas e chapadas

Teu canto de exaltação."

(Trecho do Hino do Piauí, Francisco da Costa e Silva) 


\section{RESUMO}

O objetivo desta pesquisa é analisar as transformações e novas dinâmicas da rede urbana no Sudoeste Piauiense diante da inserção dos Cerrados piauienses como nova fronteira agrícola do país, mais especificamente das Microrregiões Alto Parnaíba Piauiense e Alto Médio Gurguéia, e do município de Corrente, pertencente à Microrregião Chapadas do Extremo Sul Piauiense. Este recorte corresponde à área de expansão da agricultura moderna nos Cerrados piauienses, onde estão localizados os municípios com a maior produção agrícola do Estado do Piauí; além disso, é palco de evidentes transformações urbanas, sobretudo nas chamadas cidades do agronegócio, a saber, Bom Jesus, Uruçuí, e também Corrente - importante centro urbano considerado, pelo IBGE (2008), um Centro de Zona A, polarizando inúmeras cidades no extremo sul e Sudoeste Piauiense. A modernização agrícola nos Cerrados piauienses é um claro exemplo das dinâmicas adotadas no chamado Brasil Central, extensa área onde se verifica a consolidação do agronegócio, que funciona como propulsor da economia brasileira. A expansão da fronteira agrícola, arquitetada e incentivada pelo Estado, possibilitou a ocupação de inúmeros recortes territoriais brasileiros, engendrando, assim, reconfigurações dos espaços urbanos e rurais. Como metodologia de pesquisa, partindo de Elias $(2011,2012)$, e visando respostas aos objetivos propostos e organização das informações, três eixos estruturantes foram definidos: a) Uso e ocupação do espaço agrário; b) Economia urbana e c) Infraestrutura e equipamentos urbanos. Tal definição contribui para a melhoria das análises das transformações urbanas e das novas dinâmicas da área de estudo, já que se verificou que a modernização agrícola nos Cerrados piauienses é responsável, cada vez mais, pela reconfiguração da rede de cidades inseridas nessa nova fronteira agrícola brasileira; as cidades do agronegócio, especialmente Bom Jesus e Uruçuí, gradativamente obtém centralidade no Sudoeste Piauiense. Em Bom Jesus, percebe-se clara influência da modernização agrícola, com grandes transformações na economia urbana e na centralização de equipamentos urbanos; o município passou, inclusive, a exercer o papel de cidade média/intermediária, ao se considerar o contexto da rede de cidades no qual está inserido. Neste aspecto, nota-se, entre as cidades de Bom Jesus e Corrente, o acirramento da disputa pelo status de centro urbano mais importante dessa região agrícola.

Palavras-Chave: Modernização agrícola, Brasil Central, Sudoeste Piauiense, Rede Urbana. 


\begin{abstract}
This research aims to analyze the new dynamics of the urban network in Piauí's Southwest, regarding the insertion of this state as the new Brazilian agricultural frontier, mainly the Microregions Alto Parnaíba Piauiense, Alto Médio Gurguéia and Corrente city, which belongs to the micro-region Chapadas of Southern Piauí. This cutoff selected is precisely the area of expansion of modern agriculture in Piaui closed, therefore, is where are the cities with the largest agricultural production of the state of Piaui and in addition, produce clear urban transformations, especially in towns called agribusiness, if Bom Jesus and Uruçuí, and in current, important urban center and considered by IBGE (2008) as a Zone Centre A, polarizing numerous cities in the far south and southwest Piauiense. The agricultural modernization in Piaui is a closed course of the dynamics observed in Brazil called Central, extensive "region" where there is the consolidation of agribusiness, which acts as driver of the Brazilian economy. The expansion of the agricultural frontier, engineered and encouraged by the State, enabled the occupation of numerous Brazilian territorial clippings, so I undertake reconfigurations in urban and rural areas. As a methodological approach, based on Elias (2011, 2012), seeking answers to the proposed objectives and organization of information, defined by three structural axes: a) use and occupation of the agrarian space; b) Urban Economics c) infrastructure and urban facilities. This choice contributes to the improvement of the analysis around the urban transformations and new dynamics present in the study area. Noteworthy is that research has shown that agricultural modernization in Piaui clenched comes, increasingly, reconfiguring the network inserted cities in this new Brazilian agricultural frontier, where it was found that cities agribusiness, especially Bom Jesus and Uruçuí, are becoming increasing centrality in Piauiense Southwest. Bom Jesus is the city where we see the clear influence of agricultural modernization, with major transformations in the urban economy and centralization of urban facilities, including playing a role of medium/ intermediate city when considering the context of cities network in which it operates. In this respect, noticed a worsening of the dispute between Bom Jesus and the current most important urban center status of this agricultural region, where there was loss of centrality of second city.
\end{abstract}

Keywords: Agricultural modernization, Central Brazil, Piauiense Southwest, Urban Network. 


\section{LISTA DE FIGURAS}

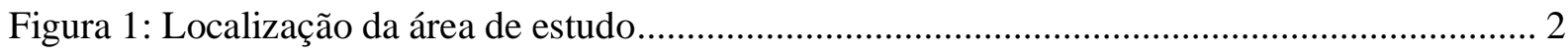

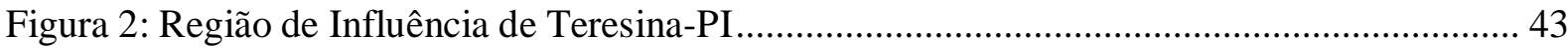

Figura 3: Área Original dos Cerrados- Brasil Central .................................................................. 59

Figura 4: Região do MAPITOBA e os municípios do agronegócio .............................................. 78

Figura 5: Atividades pecuárias nas bordas dos Chapadões dos platôs piauienses .......................... 87

Figura 6: Interiorização da Fronteira Agrícola brasileira ............................................................. 90

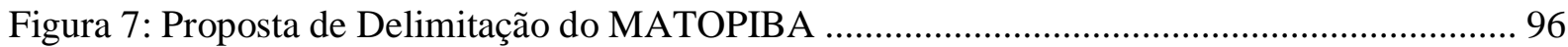

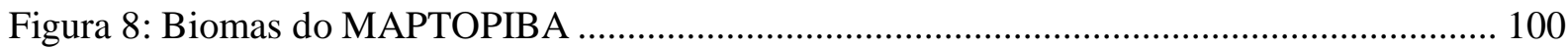

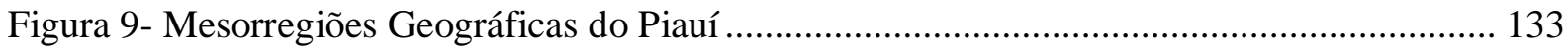

Figura 10: Densidade Demográfica no Estado do Piauí................................................................. 134

Figura 11: Microrregiões Geográficas do Piauí ............................................................................ 139

Figura 12: IDH-M- Estado do Piauí (2000) ……................................................................... 145

Figura 13: Índice de Desenvolvimento Humano o Piauí- 2010 (IDHM 2010) ............................ 146

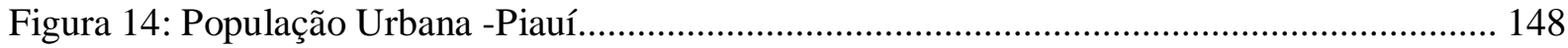

Figura 15: Mapa Hipsométrico dos municípios da área de estudo............................................... 157

Figura 16: Vista parcial dos baixões e dos platôs.......................................................................... 159

Figura 17: Vista dos platôs da Serra do Quilombo- município de Cristino Castro ....................... 159

Figura 18: Fases da Expansão da Fronteira Agrícola nos Cerrados Piauienses ........................... 161

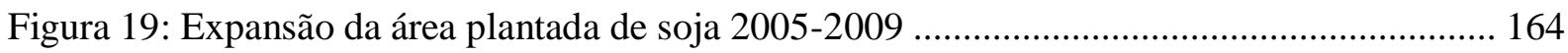

Figura 20: Produção de Soja no MATOPIBA (2012) ................................................................ 168

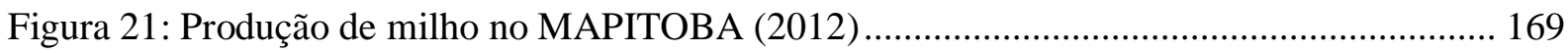

Figura 22: Composição colorida com imagens Lansat-TM 5 junho de 2010- Bom Jesus-PI ..... 171

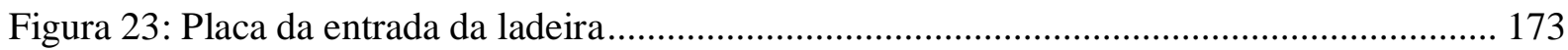

Figura 24: Subida da ladeira DBS- Monte Alegre do Piauí ....................................................... 174

Figura 25: tanques para controle do fluxo da água..................................................................... 175

Figura 26: Eletrificação Rural na entrada da Fazenda Celeiro ................................................... 176

Figura 27: Escritório de Logística de transportes e comercialização da Fazenda Celeiro ............ 178

Figura 28: Balança de pesagem de cargas- Fazenda Celeiro.......................................................... 179

Figura 29: Silos de armazenagem de grãos- Fazenda Celeiro ....................................................... 180

Figura 30: Prédio de armazenagem de grãos e insumos ................................................................ 181

Figura 31: Expansão da agricultura moderna nos Cerrados piauienses- 1995, 2005, 2015 ......... 182

Figura 32: Entrada da cidade de Bom Jesus: reflexo do agronegócio ......................................... 193 
Figura 33: Empreendimento de lazer em Cristino Castro

Figura 34: Construção de Shopping Center em Bom Jesus (PI)

Figura 35: Obra de construção civil presente em Bom Jesus

Figura 36: Expansão da área urbana da cidade de Bom Jesus-PI................................................. 206

Figura 37: Churrascaria e hotel de alto padrão em Bom Jesus, próximo à BR-135-PI................ 207

Figura 38: Loja especializada em atividades agropecuárias em Uruçuí-PI.................................. 208

Figura 39: Loja especializada em atividades agropecuárias em Bom Jesus-PI........................... 208

Figura 40: Loja vinculada à construção civil em Bom Jesus ..................................................... 210

Figura 41: Laboratório Médio em Bom Jesus-PI ....................................................................... 211

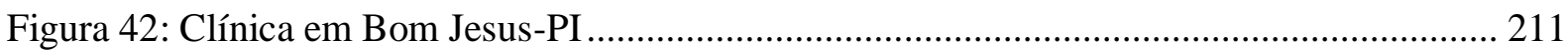

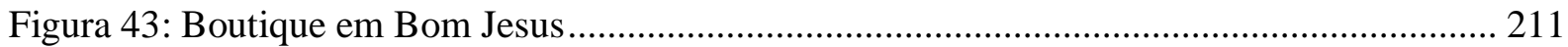

Figura 44: Redes de óticas de Brasília presente em Bom Jesus .................................................. 212

Figura 45: Avenida Comercial da Cidade de Uruçuí-PI ............................................................. 213

Figura 46: Entrada do Condomínio Consórcio das Águas- Bom Jesus.......................................... 217

Figura 47: Casa de alto padrão do Condomínio Consórcio das Águas .......................................... 218

Figura 48: Casas com cercas elétricas no Condomínio Consórcio das Águas ............................. 219

Figura 49: Residência no Condomínio Consórcio das Águas II ................................................. 219

Figura 50: Ruas sem asfaltamento em Bom Jesus-PI.................................................................... 220

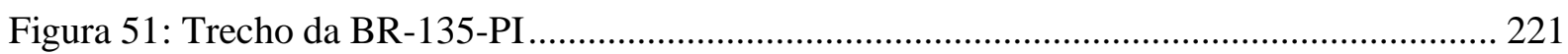

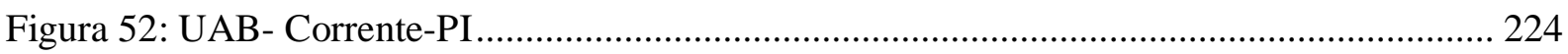

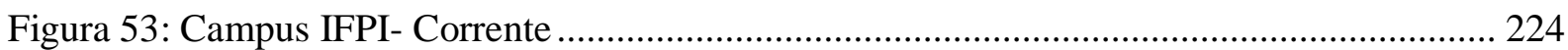

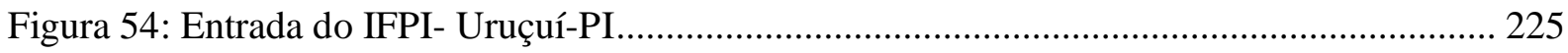

Figura 55: Universidade Federal do Piauí- Campus Professora Cinobelina Elvas ...................... 226

Figura 56: Hospital Veterinário Universitário- Campus UFPI- Bom Jesus .................................. 227

Figura 57: UESPI- Campus D. José Vásquez Díaz- Bom Jesus ................................................. 228

Figura 58: Colégio Técnico de Bom Jesus, vinculado à UFPI.................................................. 228

Figura 59: Prédio da Universidade Anhanguera- Bom Jesus-PI .................................................... 229

Figura 60: empresa de ensino de línguas estrangeiras em Bom Jesus........................................ 229

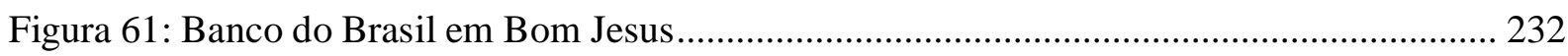

Figura 62: Elemento de controle do trânsito em Bom Jesus-PI. ................................................ 237

Figura 63: Região de Influência dos principais centros urbanos do Sudoeste Piauiense ............. 246

Figura 64: Placa de casa à venda no Condomínio Consórcio das Águas- Bom Jesus-PI.............. 248 


\section{LISTA DE TABELAS}

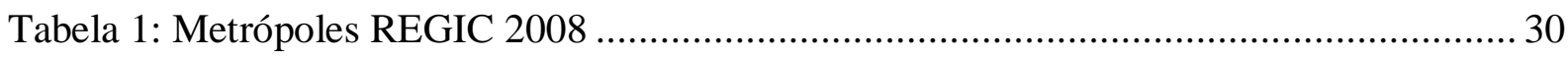

Tabela 2: Rede de Influência das metrópoles- Dimensão das redes de primeiro nível ........... 32

Tabela 3: Região de Influência dos Centros Sub Regionais A do Estado do Piauí.................. 36

Tabela 4: Região de Influência dos Centros Sub Regionais B do Estado do Piauí .................. 39

Tabela 5: Região de Influência dos Centros de Zona A do Estado do Piauí........................... 40

Tabela 6: Região de Influência dos Centros de Zona B do Estado do Piauí ........................... 42

Tabela 7- Síntese dos dados populacionais dos municípios do agronegócio do MAPITOBA 87

Tabela 8: Microrregiões Piauienses pertencentes ao PDR- MAPITOBA ............................ 101

Tabela 9: Evolução da Produção de soja e de grãos no MAPITOBA entre 1933 e 2011...... 102

Tabela 10: População Residente por Situação do Domicílio em 2000 e 2010...................... 136

Tabela 11: Municípios mais populosos do Piauí ….......................................................... 138

Tabela 12: As 6 microrregiões maiores produtoras de soja do MAPITOBA em 2012 ......... 140

Tabela 13: Chapadas do Extremo Sul Piauiense- Dados da População (2010) e da produção

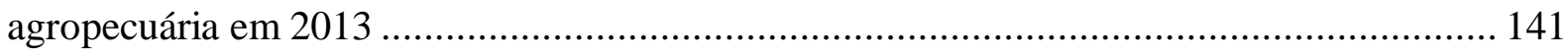

Tabela 14: Dados populacionais dos municípios da área de Estudo .................................. 143

Tabela 15: População Residente por situação de Domicílio (2010)- Área de estudo............ 147

Tabela 16: População Urbana e Rural dos municípios da Microrregião Alto Médio Gurguéia e em Corrente (Chapadas do Extremo Sul Piauiense) (2010)............................................. 149

Tabela 17: População Residente por situação de Domicílio (2010)- Área de estudo, com exceção dos três municípios mais populosos e com maior urbanização.............................. 150

Tabela 18: Confronto dos resultados dos dados estruturais dos Censos Agropecuários- Piauí-

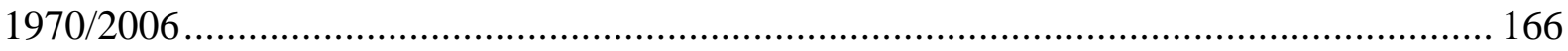

Tabela 19: Condição do produtor em relação à terra- Confronto dos resultados dos censos 1995 e 2006 166

Tabela 20: Energia Elétrica utilizada pelos estabelecimentos, por tipo de fonte, Estado do

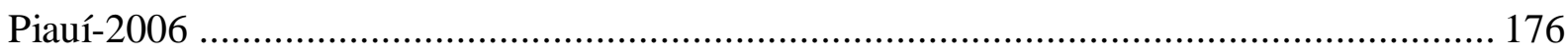

Tabela 21: Estabelecimentos com eletrodomésticos utilizados, por tipo, no Estado do Piauí2006 177

Tabela 22: silos para forragens e depósitos e silos para guarda da produção de grãos existentes nos estabelecimentos- Piauí- 2006. 180 
Tabela 23: Estado do Piauí; Produção agrícola estimada em 2015 e realizada em 2014 (t)-

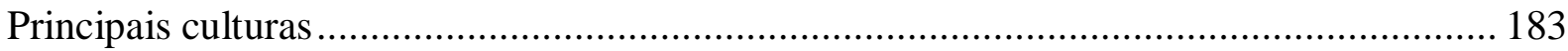

Tabela 24: Área Plantada do Piauí (ha)- Principais culturas............................................ 184

Tabela 25: Produção Agrícola Municipal- Microrregião Alto Médio Gurguéia-2004 e 2013

Tabela 26: Produção Agrícola Municipal- Microrregião Alto Parnaíba Piauiense 187

Tabela 27: Produção Agrícola Municipal- Milho- Microrregião Alto Médio Gurguéia 189

Tabela 28: Produção Agrícola Municipal- Milho- Microrregião Alto Parnaíba Piauiense ... 190

Tabela 29: Destino da produção agrícola (soja e milho)

Figura 32: Entrada da cidade de Bom Jesus: reflexo do agronegócio ................................ 193

Tabela 30: Estatísticas do cadastro central de empresas-2013 195

Tabela 31: Proporção de ocupado com 18 anos ou mais nos diferentes setores econômicos da economia (2010) 198

Tabela 32: Cadastro Nacional de endereços para fins estatísticos (2010) 201

Tabela 33: Grau de formação dos ocupados- 18 anos ou mais (2010) ................................ 202

Tabela 34: População Residente por lugar de Nascimento ................................................ 204

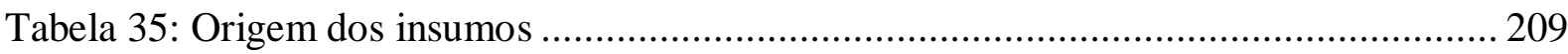

Tabela 36: Destino transportes coletivos

Tabela 37: Número de Estabelecimentos de Ensino Superior, Técnico/Profissional da área de estudo.

Tabela 38: Número de Agências Bancárias- 2014

Tabela 39: Total de estabelecimentos agropecuários, de ensino e de saúde em 2010 233

Tabela 40: Nível de Centralidade de Saúde 234

Tabela 41: Quantidade total de veículos por municípios em 2009 e 2014 ......................... 235

Tabela 42: Número de Caminhões e Tratores na área de estudo (2014) ............................. 238

Tabela 43: População residente por situação do domicílio- Bom Jesus-PI.......................... 242

Tabela 44: Situação de Bom Jesus, Corrente e Uruçuí nos REGIC de 1987, 1993 e 2007 ... 243 


\section{LISTA DE SIGLAS}

$\mathrm{ADM}$

Agrishow

ANA

CAI

CEPRO

CTG's

CPT

EMBRAPA

EXPOCORRENTE

FAESF

FHC

FINOR

FISET

FPM

$\mathrm{Hab} . / \mathrm{Km}^{2}$

IBGE

IDH

IDHM

INCRA

KM

LULA

MAPITOBA

MAPA

MATOPIBA

NOVAPI

$\mathrm{OAB}$

PADAP

PCI
Archer Daniels Midland

Feira Internacional de Tecnologia Agrícola em Ação

Avaliação Nacional de Aprendizagem

Complexo Agroindustrial

Fundação Centro de Pesquisas Econômicas e Sociais do Piauí

Centro de Tradições Gaúchas

Comissão Pastoral da Terra

Empresa Brasileira de Pesquisa Agropecuária

Exposição Agropecuária de Corrente-PI

Faculdade de Ensino Superior de Floriano

Fernando Henrique Cardoso

Fundo de Investimento do Nordeste

Fundo de Investimento Setorial

Fundo de Participação de Municípios

Habitantes por Quilômetro Quadrado

Instituto Brasileiro de Geografia e Estatística

Índice de Desenvolvimento Humano

Índice de Desenvolvimento Humano Municipal

Instituto Nacional de Colonização e Reforma Agrária

Quilômetros

Luís Inácio Lula da Silva

Maranhão, Piauí, Tocantins e Bahia

Ministério da Agricultura, Pecuária e Abastecimento

Maranhão, Tocantins, Piauí e Bahia

Centro Universitário da Faculdade de Saúde, Ciências

Humanas e Tecnológicas do Piauí

Ordem dos Advogados do Brasil

Programa de Assentamento Dirigido do Alto Paranaíba

Programa de Crédito Integrado do Cerrado 
PDA

PIB

PNDR

POLOAMAZÔNIA

POLOCENTRO

POLONORDESTE

PRODECER

PRONAF

REGIC

RPA

RPA's

SENAC

SENAI

SUDAM

SUDENE

$\mathrm{UAB}$

UESPI

UFPI

UNESCO

UNOPAR
Plano de Desenvolvimento Agropecuário

Produto Interno Bruto

Política Nacional de Desenvolvimento Regional

Programa de Desenvolvimento da Amazônia

Programa de Desenvolvimento dos Cerrados

Programa de Desenvolvimento do Nordeste

Programa de Cooperação Nipo-Brasileira para o

Desenvolvimento dos Cerrados

Programa Nacional de Fortalecimento da Agricultura Familiar

Região de Influência de Cidade

Região Produtiva Agrícola

Regiões Produtivas Agrícolas

Serviço Nacional de Aprendizagem

Serviço Nacional de Aprendizagem Industrial

Superintendência do Desenvolvimento da Amazônia

Superintendência do Desenvolvimento do Nordeste

Universidade Aberta do Brasil

Universidade Estadual do Piauí

Universidade Federal do Piauí

Organização das Nações Unidas para a Educação, Ciência e Cultura

Universidade Norte do Paraná 


\section{SUMÁRIO}

INTRODUÇÃO. 1

Procedimentos Metodológicos 5

CAPÍTULO I - O URBANO E O RURAL EM TRANSFORMAÇÃO NO BRASIL: REDE URBANA, REGIC E HISTÓRICO DE OCUPAÇÃO DO TERRITÓRIO PIAUIENSE 9

$1.1 \mathrm{O}$ rural em transformação no Brasil 12

1.2 Um pouco sobre a Rede Urbana Brasileira: Tendências e Dinâmicas Atuais 21

1.3 As Regiões de Influência das Cidades (REGIC) 28

1.4 Contexto Piauiense no REGIC 2008 e os Principais Centros Urbanos do Estado 33

1.5 Contextualização Histórica e Formação Territorial do Piauí ............................................... 44 48

\section{CAPÍTULO II - MODERNIZAÇÃo AGRÍCOLA NO CERRADO BRASILEIRO:} TRANSFORMAÇÕES SOCIOESPACIAIS 53

2.1 Modernização Agrícola: periodização e expansão da fronteira agrícola para os Cerrados 61

2.2 Breve Contextualização da região MAPITOBA e a Agência de Desenvolvimento denominada MATOPIBA: migração de sulistas, novos contextos e possibilidades ...... 75

2. 2. 1. Breve caracterização das cidades do agronegócio do MAPITOBA 82 
2.4 O papel do Estado como indutor da Modernização Agrícola, em especial nos Cerrados brasileiros

2.5 Migrações de Sulistas para o Brasil Central, em especial para os estados nordestinos ... 116 2.6 Expansão e Reconfigurações das Regiões Produtivas Agrícolas e Reestruturação do Processo de Urbanização

2.6.1 Definição dos Eixos Estruturantes para análise do Processo de Modernização Agrícola Piauiense e os impactos na rede urbana desse Estado.

\section{CAPÍTULO III - MODERNIZAÇÃO AGRÍCOLA E TRASNFORMAÇÕES URBANAS NO SUDOSTE PIAUIENSE: NOVAS DINÂMICAS, AGENTES, NÚCLEOS URBANOS E ALTERAÇÃO DAS CENTRALIDADES URBANAS 132}

3.1 Divisão Mesorregional do Piauí, Rede Urbana e distribuição populacional 132

3.1.1 Dados Populacionais da área de estudo 147

3.2 O processo de modernização agrícola no Sudoeste Piauiense: inserção, fases e atuais contextos

3.3 Uso e Ocupação do Espaço Agrário 163

3.4 Economia Urbana

3.5 Infraestrutura e Equipamentos Urbanos ... 216

3.6 Bom Jesus: cidade média? 242 


\section{INTRODUÇÃO}

O tema norteador desta pesquisa é a modernização agrícola no Sudoeste Piauiense, e as transformações urbanas na rede de cidades como resultado da expansão da fronteira agrícola do Brasil Central. O debate acerca de tais transformações é fundamental para o entendimento da atual configuração da rede urbana do Sudoeste Piauiense, que revela uma lógica presente no Brasil Central, sobretudo em relação às cidades do agronegócio do Estado do Piauí. Tais cidades vêm se multiplicando rapidamente nos últimos anos e passando a desempenhar diversificadas funções, ligadas à produção agrícola e industrial do país (ELIAS, 2006).

Devido à grande extensão da Mesorregião Sudoeste Piauiense ${ }^{1}$ e à quantidade de municípios que integram essa região - a saber, sessenta e dois -, optou-se pela seleção de duas microrregiões para o desenvolvimento deste estudo: Alto Parnaíba Piauiense, que abrange quatro municípios, e Alto Médio Gurguéia, que abrange onze. O município de Corrente (PI), pertencente à Microrregião Chapadas do Extremo Sul Piauiense, foi também selecionado para análise em função de seu grande protagonismo no contexto mesorregional, além do fato de ser considerado um Centro de Zona A, segundo dados do estudo das Regiões de Influência de Cidades (REGIC) de $2007^{2}$ (IBGE, 2008). Abaixo, a localização da área de estudo na figura 1:

${ }^{1}$ Divisão Mesorregional e microrregional oficiais do IBGE.

${ }^{2}$ Documento analisado no capítulo 1 , com foco no contexto piauiense. 
Figura 1: Localização da área de estudo

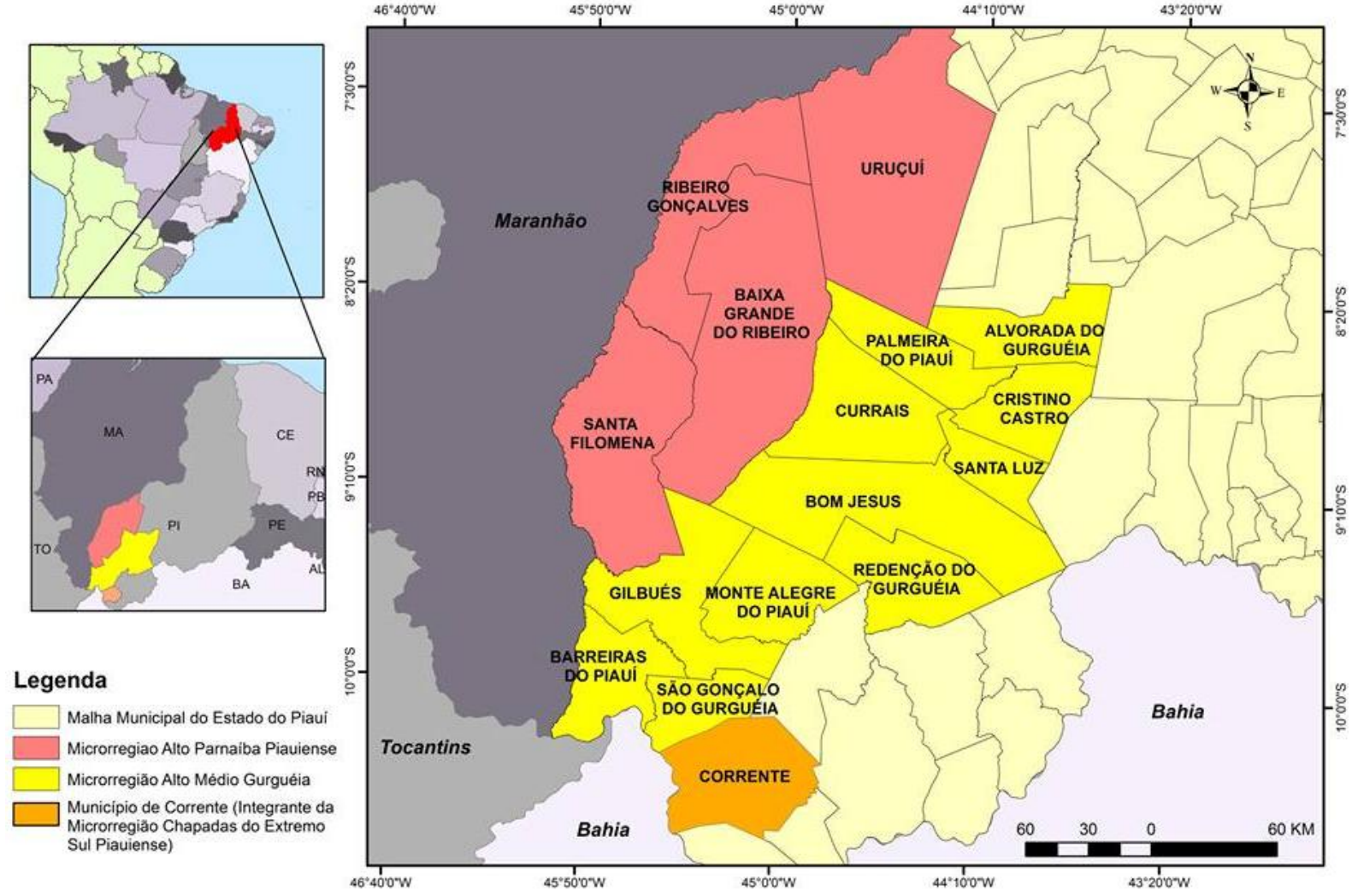

Fonte: Dados do IBGE, Elaborado por Lucas Garcia (colaborador) e Tiago Rufo.

No total, portanto, a área de estudo envolve dezesseis municípios. Trata-se de uma extensa área com a predominância da vegetação dos Cerrados, próxima da fronteira do Piauí com os Estados da Bahia, Maranhão, e Tocantins, e que vem sendo intensamente ocupada pelas atividades agrícolas modernas, que impõem novas dinâmicas às áreas urbanas e rurais. A análise concentra-se no período pós década de 1990, que, segundo Monteiro (2002), é o período de intensificação do processo de ocupação dos platôs (chapadões) piauienses.

Uma vez que o objetivo principal do trabalho é, portanto, o de analisar as transformações e novas dinâmicas da rede urbana no Sudoeste Piauiense diante da inserção dos Cerrados piauienses como nova fronteira agrícola do país, definimos os seguintes objetivos específicos:

a) Caracterizar as novas dinâmicas urbanas decorrentes da modernização das atividades agrícolas mesorregionais;

b) Identificar o papel desempenhado pela rede de cidades do Sudoeste Piauiense, a partir do processo de modernização agrícola, nas transformações geradas com a expansão da 
fronteira agrícola, identificando e caracterizando os principais núcleos urbanos onde o agronegócio se desenvolve.

c) Compreender as transformações da nova rede urbana piauiense, com ênfase nos municípios com os maiores índices de produção agrícola do estado, em relação às características demográficas dessas cidades, à emergência de novos agentes e atores, às alterações no comércio e ao surgimento de novos equipamentos urbanos.

d) Analisar o surgimento de novos bairros urbanos nas principais cidades do agronegócio do Sudoeste Piauiense, bem como a entrada de capital e a criação de novas infraestruturas de apoio ao agronegócio.

A escolha das microrregiões foi baseada nos dados referentes à produção agrícola, a partir dos quais foi possível perceber que o Alto Parnaíba Piauiense e o Alto médio Gurguéia estão entre as maiores micorregiões produtoras da chamada região do MAPITOBA ${ }^{3}$ - junção das siglas dos Estados do Maranhão, Piauí, Tocantins e Bahia -, que vem recebendo maior atenção por parte do Estado, como, por exemplo, a criação do Plano de Desenvolvimento Agropecuário (PDA) do MATOPIBA, cujo objetivo é aumentar a produção agrícola dessa extensa região e promover um suposto desenvolvimento nessa área. Este grupo de Estados se insere na tendência de ocupação dos Cerrados pelas atividades relacionadas à agricultura moderna, a exemplo, a extensa área denominada Brasil Central, que contempla os Estados da região Centro-Oeste, o norte de Minas Gerais, o oeste da Bahia, o sudoeste do Piauí, o sul do Maranhão e a porção centro-norte do Tocantins.

É preciso considerar, portanto, que o Estado do Piauí se insere em um novo circuito de produção agropecuária que influencia o surgimento de transformações socioespaciais. A ocupação dos Cerrados piaueinses envolveu a participação ativa do Estado na disponibilização de créditos e no estabelecimento de condições propícias ao desenvolvimento do agronegócio, como a inplantação de infraestrutura. O campo e o urbano, dessa maneira, passam por inúmeras metamorfoses em diversos aspectos, inclusive provocando oscilação na questão das articulações entre os diferentes municípios, o que altera as relações de importância e de centralidade das cidades (BRASIL, 2005). A instalação da moderna agricultura, portanto, acarreta no aparecimento de novas centralidades no âmbito do urbano.

\footnotetext{
${ }^{3}$ Durante o trabalho, usaremos as duas siglas: MAPITOBA e MATOPIBA. Sendo a primeira utilizada pelos atores locais dos Estados Integrantes, o segundo termo foi uma "inovação" do Estado, por meio da criação do PDA-MATOPIBA. No entanto, trata-se da mesma região.
} 
Há, por conseguinte, grande tendência de modificação das hierarquias existentes nos centros urbanos regionais e de suas devidas áreas de influência. Nesse sentido, vale ressaltar que as mudanças no âmbito regional desencadeiam a tendência de modificação e rearticulação das relações com outras escalas - macrorregional, nacional, e internacional. A partir daí, a pergunta norteadora da pesquisa pode ser sintetizada da seguinte maneira: de que forma a modernização da agricultura influencia na emergência de novas transformações e no surgimento de novos contextos na rede urbana regional do Sudoeste Piauiense?

Para responder a essa questão, o foco das análises da pesquisa serão as chamadas cidades do agronegócio do Estado do Piauí, quais sejam, Uruçuí, Corrente e Bom Jesus, que exercem o comando das ações em relação à modernização agrícola, e no sentido de maior protagonimo mesorregional, em virtude da centralização de serviços, comércio e equipamentos urbanos, bem como de sua maior concentração populacional, inclusive com alta urbanização, levando-se em conta o contexto da área de estudo. Considera-se, porém, que a cidade de Bom Jesus é a que simboliza a modernização agrícola no Sudoeste Piauiense, uma vez que tem concentrado essas ações. Defendemos que, para o contexto da rede de cidades do Piauí, especialmente do Sudoeste Piauiense, Bom Jesus vem desempenhando papel de uma cidade média, por conta da sua importância no contexto da área em estudo - a sede do PDAMAPITOBA no Estado do Piauí, por exemplo, será construída em Bom Jesus. É possível dizer que o município encontra-se em tal posição justamente por que se beneficia da realidade que o cerca, já que se sobressai em meio às pequenas cidades do Sudoeste Piauiense, o que se pode constatar pelo fluxo migratório existente entre a zona rural e as cidades mais importantes da região produtiva agrícola, entre as quais figura, principalmente, Bom Jesus. Da mesma forma, o agronegócio no Estado do Piauí influencia diretamente nessa centralidade. De fato, a única cidade capaz de competir, nesse âmbito, com Bom Jesus, é a cidade de Corrente, considerada pelo Instituto Brasileiro de Geografia e Estatística (IBGE), através do REGIC 2007, como um Centro de Zona $\mathrm{A}^{4}$. Esta última, porém, vem perdendo importância no contexto mesorregional por conta do fortalecimento da primeira enquanto centro comercial, educacional, e concentrador de equipamentos urbanos.

Nesse sentido, uma das questões abordadas no trabalho é, ainda, o embate entre os municípios de Corrente e Bom Jesus pela centralização dos equipamentos urbanos, da infraestrutura, e por maior relevância na porção sul do Estado do Piauí, semelhante ao acirramento das disputas entre as cidades de Barreiras e Luiz Eduardo Magalhões, localizadas

\footnotetext{
${ }^{4}$ Esse termo será abordado no capítulo 1 deste trabalho.
} 
no oeste baiano. Assim, é possível afirmar que a modernização da agricultura promove reconfigurações e transformações na rede urbana piauiense, em que se destaca o protagonismo das cidades do agronegócio (ELIAS, 2012).

\section{Procedimentos Metodológicos}

A sistematização da metodologia, essencial para o desenvolvimento da pesquisa, está em consonância com os objetivos e a questão norteadora do estudo já elencados na introdução, e a sua organização atrela-se ao delineamento do que o presente trabalho busca demonstrar, além de indicar a maneira como a poblemática do estudo será abordada empiricamente.

Elias $(2011,2012)$ estabelece cinco eixos estruturantes com o objetivo de analisar a realidade dos espaços agrícolas, as novas relações entre campo e cidade, as transformações urbanas e a reestruturação regional, quais sejam, eixo um - uso e ocupação do espaço agrário; eixo dois - ramos industriais representativos das redes agroindustriais; eixo três - economia urbana; eixo quatro - mercado de trabalho e dinâmica populacional; eixo cinco - infraestrutura e equipamentos urbanos. Para desenvolver nossos objetivos propostos, baseamo-nos em Elias (2011, 2012) para adotar três eixos estruturantes: 1) Uso e Ocupação do espaço agrário; 2) Economia Urbana e 3) Infraestrutura e equipamentos urbanos. Os dois outros eixos temáticos propostos pelo autora - "ramos industriais representativos e das redes agroindustriais" e "mercado de trabalho e dinâmica populacional" - podem figurar em futuros trabalhos, entendemos que os três eixos selecionados respondem melhor aos objetivos propostos, uma vez que desejamos focar a questão urbana, e que levamos em consideração que a agricultura moderna no Estado do Piauí é, ainda, muito recente.

Em seguida, partindo da definição dos eixos de análise, fez-se necessário realizar um levantamento bibliográfico sobre temas-chave para a pesquisa, tais como modernização agrícola, modernização agrícola nos Cerrados, papel do Estado na expansão da fronteira agrícola, Rede Urbana, Restruturação Produtiva, Cidades do Agronegócio, Cidades médias/intermediárias e Sudoeste Piauiense. O levantamento de dados foi realizado através da consulta a livros e a artigos científicos de bibliotecas digitais de diferentes universidades brasileiras, da pesquisa nos textos de disciplinas cursadas durante a graduação - como "Geografia Agrária" e "Geografia Urbana" -, bem como nos de disciplinas do mestrado acadêmico, principalmente "Teoria e Métodos em Geografia e Desenvolvimento Regional” e 
“Desenvolvimento Regional e Novas Regionalizações". Destacamos, ainda, que, como o tema desta dissertação é uma continuidade da temática desenvolvida no projeto de monografia de graduação, finalizada no ano de 2013, e intitulada "Modernização Agrícola no Sudoeste Piauiense: impactos da rede urbana regional, no meio ambiente e nas comunidades" (RUFO, 2013), dispúnhamos de uma base de trabalhos que abordavam essa temática, e pudemos então formar um banco de dados.

Embora a pesquisa de dados e informações referentes aos três eixos norteadores do estudo tenha sido realizada majoritariamente no site "IBGE cidades", que providenciou dados populacionais e sobre a produção agropecuária, além de índices sociais e estatísticos sobre os municípios analisados, outros sites institucionais contribuíram para o levantamento de dados, tais como o site da Fundação Centro de Pesquisas Econômicas e Sociais do Piauí (CEPRO), o do Atlas do Desenvolvimento Humano no Brasil, o do Ministério da Educação, e o de instituições de ensino superior brasileiras, como a Universidade Federal do Piauí e a Universidade Estadual do Piauí. A pesquisa e formação de um banco de figuras, imagens, fotos e mapas ligados à área de estudo também foi necessária.

Chegamos, então, a uma das etapas mais importantes do desenvolvimento da pesquisa: os trabalhos de campo em algumas cidades da área de estudo, realizados em dois momentos. O primeiro foi executado entre o dia 28 de dezembro de 2014 e o dia 8 de janeiro de 2015 , durante o qual fotografamos a área dos platôs piaueinses, nas divisas municipais de Bom Jesus, Monte Alegre do Piauí, e Gilbués, onde visitamos a Fazenda Celeiro, que tem sua sede em Luziânia-GO. Conversamos, ainda, com os responsáveis pela logística de transportes dessa empresa agrícola instalada nos Cerrados piauienses. Observamos, majoritariamente, a questão do uso do solo nas áreas dos platôs piauienses, a caracterização da paisagem, a estrutura das fazendas e a questão da utilização de tecnologia na produção. $O$ trabalho também incluiu a viagem à cidade de Bom Jesus, onde buscamos analisar o contexto de sua economia urbana, as mudanças no comércio, a dinâmica do transporte e trânsito, a rede bancária e surgimento de novos bairros urbanos, focando nos de menor infraestrutura e menor padrão econômico. Fizemos uma visita técnica à Universidade Federal do Piauí para estabelecer diálogos com alguns estudantes e professores. Por fim, visitamos, ainda, as cidades de Monte Alegre do Piauí, Redenção do Gurguéia e Gilbués.

O segundo trabalho de campo, por sua vez, foi realizado entre os dias 18 e 28 de julho de 2015, com foco nas cidades do agronegócio piaueinse: visitamos a cidade de Corrente, a fim de analisar a questão dos equipamentos urbanos, o que incluiu a ida às universidades e ao 
comércio do município, bem como ao Instituto Federal de Educação, Ciência e Tecnologia (IFPI), onde novamente buscamos diálogo com estudantes, professores e demais profissionais da instituição. Visitamos ainda uma vez a cidade de Bom Jesus, para analisar a questão da expansão da área física da cidade, como a caracterização do surgimento de novos bairros urbanos de alto padrão, novos condomínios e similares, que, predominantemente, servem de moradia a migrantes sulistas, denominados nas cidades da área de estudo como "gaúchos", independente do local de nascimento. Nesse sentido, mesmo se o migrante veio de São Paulo, por exemplo, ele será denominado de "gaúcho". Analisamos, nessas cidades, os comércios e serviços voltados ao que denominamos classe média do agronegócio, que contempla migrantes sulistas, professores universitários, engenheiros, agrônomos, comerciantes e empresários locais. Visitamos, por último, a cidade de Uruçuí, onde fizemos o mesmo tipo de análise realizada nos dois primeiros municípios citados. Em tempo, salientamos que, no geral, a distância física entre Brasília, cidade em que se encontra o campus da UnB, e a área de estudo - cerca de mil quilômetros - constituiu uma das grandes dificuldades da etapa de pesquisa de campo, mas a vivência que possuo da região e os conhecimentos prévios de determinadas características da rede urbana e do meio rural dos municípios tornaram sua conclusão possível.

Quanto à estrutura do trabalho, a dissertação foi organizada em três capítulos. O primeiro capítulo fornece as bases conceituais para discutir as transformações urbanas na área de estudo definida. Nesse sentido, procura analisar a relação entre campo e cidade no Brasil, especialmente entre os séculos XX e XXI, evidenciando as transformações no campo brasileiro e as novas tendências da urbanização e rede urbana brasileira. Analisamos, também, o documento do IBGE denominado REGIC de 2007, destacando o contexto piauiense e colocando em evidência os principais centros urbanos da rede urbana do Piauí, e ainda as principais características do processo de ocupação do território piauiense, principalmente da Mesorregião Piauense, para evidenciar a mudança de uso do solo e caracterizar a atual localização das principais cidades piauienses.

O segundo capítulo discute criticamente o processo de modernização e ocupação dos Cerrados brasileiros. Assim, destacamos as periodizações consideradas por diferentes e importantes autores que trabalham com a temática da modernização agrícola no Brasil, ou com a temática dos Cerrados, como, por exemplo, Martine (1989), Frederico (2013), Oliveira (1999), Denise Elias (2011, 2012, 2006a, 2006b), Thomaz Júnior (2010), Matos e Pessoa (2011). Fez-se breve análise do papel do Estado como propulsor do desenvolvimento do 
agronegócio no Brasil, bem como do contexto da região denominada MAPITOBA, a fim de demonstrar que o Piauí se insere em uma nova realidade econômica e socioespacial, destacando a questão da migração sulista para essa grande região agrícola (ELIAS, 2011).

No terceiro e último capítulo abordamos a questão da modernização agrícola nos Cerrados piauienses e os impactos na rede urbana nos municípios selecionados, considerando os eixos estruturantes para evidenciar essas transformações. Nesse sentido, focamos as cidades do agronegócio piauiense e analisamos as novas tendências relacionadas às centralidades urbanas no Estado do Piauí. Utilizamos a divisão mesoregional do Piauí, evidenciando as principais questões relacionadas aos aspectos demográficos e à rede urbana do Estado do Piauí. Neste capítulo, propomos uma periodização da modernização agrícola dos Cerrados piaueinses. Por fim, analisamos as transformações urbanas baseando-nos nos três eixos temáticos - Uso e Ocupação do Espaço Agrário, Economia Urbana, Infraestrutura e Equipamentos Urbanos - a fim de realizarmos os objetivos propostos no estudo.

Por fim, destacamos que conhecimento desta temática e do contexto da mesorregião do Estado do Piauí permite que haja maiores possibilidades para o entendimento e compreensão da nova fronteira agrícola brasileira e das transformações dos espaços urbanos do conjunto de cidades que formam o Sudoeste Piauiense. Além disso, os estudos que envolvem a modernização agrícola no Estado do Piauí são importantes para amenizar a polarização das produções em torno do oeste baiano e em outros recortes do Centro-Oeste brasileiro. 


\section{CAPÍTULO I - O URBANO E O RURAL EM TRANSFORMAÇÃO NO BRASIL: REDE URBANA, REGIC E HISTÓRICO DE OCUPAÇÃO DO TERRITÓRIO PIAUIENSE}

Atualmente, o Brasil enfrenta intensas transformações socioespaciais, em áreas tanto urbanas como rurais, o que altera profundamente a relação campo-cidade em diferentes Estados brasileiros, especialmente nos localizados no Brasil Central. De acordo com Silva (1997, p.2), “[...] parece não haver mais dúvidas de que as transformações nos campos políticos, econômico e social ocorridas neste final de século apontam para uma nova sociedade em gestação". A colocação do autor permite-nos afirmar que o atual contexto da sociedade brasileira é marcado por rupturas; é possível dizer que essas transformações sociais nos espaços urbanos e rurais são consequência da disseminação do processo de globalização e das mudanças nas formas de produção - que advém da modernização desses espaços -, o que altera de forma intensa a localização espacial dos grandes empreendimentos econômicos, além de estabelecer mudanças nas questões ligadas ao trabalho (SILVA, 1997).

$\mathrm{Na}$ visão de Harvey (2000, p.80), “[...] a globalização pode ser vista como um processo, como uma condição ou como um tipo específico de projeto político”. Nesse sentido, segundo o autor, a globalização é um sistema complexo e contraditório, que envolve premissas tais como a inovação tecnológica e de produtos, as alterações na dinâmica econômica e política mundial, com tendência à formação de blocos econômicos regionais, a revolução da informação através da ampliação e renovação do sistema de mídia e das telecomunicações, e a modernização e aceleração dos meios de transportes. Harvey ainda elenca consequências da globalização, não raro de natureza contraditória: alteração das formas de produção e organização; ampliação do trabalho assalariado; mudanças na sociedade global, como aumento de processos migratórios; aumento da urbanização, que desencadeia o processo denominado hiperurbização; modificação do papel do Estado, agora encarregado de criar ambientes favoráveis à expansão das atividades econômicas ligadas ao capitalismo; transformação da geopolítica mundial, com a preocupação dos Estados no que concerne à questão da competitividade global; aumento dos problemas ambientais, face à ampliação da exploração dos recursos naturais do planeta; e, por fim, protagonismo das particularidades e singularidades culturais mesmo com a propagação de discursos que defendem a homogeneidade (HARVEY, 2000). Assim, considerando as novas imposições geradas pela 
globalização, Harvey (2000) acredita que as relações sociais se transformam cada vez mais e dão origem a novas tendências e realidades em nível mundial. A sua fala é corroborada pela de Santos (2008, p.45), que afirma que "[...] a globalização constitui o estágio supremo da internacionalização, a amplificação em 'sistema-mundo' de todos os lugares e de todos os indivíduos, embora em graus diversos".

No Brasil, o processo de globalização afeta diretamente o espaço urbano e o rural. Neste último, o processo de expansão da fronteira econômica através do agronegócio ganha destaque, na medida em que sua complexidade permite a observação de algumas das alterações e consequências desencadeadas pela globalização e descritas por Harvey (2000). Considerando o contexto do avanço do agronegócio em diferentes áreas do Brasil, e fazendo um balanço do atual panorama econômico vivenciado por diversos países, inclusive o Brasil, perceberemos que essa atividade econômica mantém padrões de crescimento até mesmo em períodos de crise econômica, o que nos desafia ainda mais a pensar sobre a dinâmica dos processos globalizantes.

Uma das características da globalização são as incertezas econômicas de um mundo marcado por crises em diferentes períodos - lembremos, a tempo, da crise de 1930, por exemplo, e do período após o ano 2008, sobre o qual Mota (2013, p.52) destaca: “[...] a crise do setor imobiliário (subprime) nos Estados Unidos contagia o mercado financeiro mundial, lançando o mundo em mais uma onda recessiva". Dessa forma, a crise de 2008 influencia a conjuntura econômica mundial, afetando diretamente os rumos do desenvolvimento econômico de diferentes países. Para o IPEA (2010, p.15), “[...] a primeira década do século XXI foi marcada pela dinâmica extraordinária de crescimento entre 2003 e 2007, pela crise financeira sistêmica do quarto trimestre de 2008 e pela rápida recuperação do crescimento econômico dos países em desenvolvimento." Ao contrário do que afirma o estudo do IPEA (2010), porém, a realidade do momento atual é diversa, com países sofrendo em relação à queda do crescimento econômico. Países como China, que antes apresentava taxas de crescimento vultosas, reduziram drasticamente esse crescimento econômico nos últimos anos.

No atual contexto vivido pelo Brasil, marcado pelas preocupações econômicas póscrise de 2008, nota-se que, mesmo com as incertezas do mercado e com nítidas políticas de controle e corte de gastos - que caracterizam o início de uma pequena política de "austeridade econômica" 5 -, o agronegócio tem crescido de forma impressionante, especialmente na

\footnotetext{
${ }^{5}$ No ano de 2015, por exemplo, foram inúmeros os cortes de gastos na área educacional do país. O que revela uma contradição ao atual lema do governo federal, intitulando o Brasil como pátria educadora. O agronegócio
} 
porção central do Brasil, o que revela sua maturidade e resistência mesmo em período de crise, como na década de 1980, em que, segundo Martine (1989), a agricultura manteve certa estabilidade na produção. Tal resistência pode ser explicada pelo fato de que o Brasil tem dedicado grande atenção ao campo brasileiro, principalmente às áreas de cerrado do país, destinadas à agropecuária moderna, especialmente a partir da década de 1970, e tem se consolidado cada vez mais como um grande produtor e exportador de produtos ligados ao setor primário da economia. De fato, o país sublinha esse caráter de produtor e exportador de gêneros alimentícios e de commodities na medida em que é, atualmente, o maior produtor de café, açúcar e laranja do planeta, e o segundo maior de soja, carne bovina e aves (ALVES; CONTINI; HAINZELIN, 2005). Essa grande produção é destinada a vários países, dentre eles Estados Unidos, Alemanha, França, Reino Unido, Rússia, Japão, e China.

Dessa forma, como pontuam Simões e Amaral (2001), verifica-se a preocupação do Estado em relação ao setor externo, que os incentivos à desconcentração das atividades econômicas do país via processo produtivo corroboram. Este processo teve início na década de 1970, e investiu em Estados como Bahia, Maranhão, Tocantins e Piauí. Segundo Elias (2012),

\footnotetext{
Uma das consequências da reestruturação produtiva da agropecuária no Brasil é o processo acelerado de urbanização e crescimento urbano promovido, entre outras, pelas novas relações entre o campo e a cidade, por sua vez, desencadeadas pelas novas necessidades de consumo produtivo das redes agroindustriais, o qual cresce rapidamente do que o consumo consultivo. (ELIAS, 2012, p.10).
}

Essa realidade da urbanização brasileira introduz nova complexidade em diferentes espaços urbanos ligados às atividades agropecuárias modernas no país. A mudança no processo de urbanização brasileira, a partir da expansão das atividades agropecuárias, é apenas um exemplo das transformações que tem ocorrido em diversas áreas urbanas e rurais do país nos últimos tempos. Becker e Egler (1993) afirmam que as tendências relacionadas à urbanização brasileira representam a inserção do Brasil na economia-mundo como uma semiperiferia. Os centros urbanos são responsáveis por essa articulação da economia brasileira com as tendências mundiais, pois servem de sede a grandes empresas e instituições hegemônicas ligadas à produção, seja de produtos primários, seja de bens, serviços e capitais. A complexidade, pois, dessas mudanças pode ser constatada quando se observa a dificuldade

continua crescendo a pleno vapor, inclusive com o incentivo do Estado, em contraposição percebe-se que os investimentos nas áreas educacionais e de saúde estão estagnados. 
que se tem, hoje, no Brasil, de definir os limites entre rural e urbano, pois há intensa conexão entre os dois espaços. Esse impasse se deve, majoritariamente, à influência dos processos globalizantes, os processos ligados à modernização (SANTOS; SILVEIRA, 2001).

Antes de aprofundar a análise das questões relacionadas à relação campo-cidade no Brasil, entretanto, é preciso ressaltar que esses elementos de análise geográfica representam, em um viés crítico, a divisão social, técnica e territorial do trabalho (HESPANHOL, 2013). Nesse caso, entende-se também que o campo e a cidade são construções sociais, resultados da atuação dos diferentes agentes presentes no espaço geográfico.

\subsection{O rural em transformação no Brasil}

O campo brasileiro, especialmente as áreas de cerrado, tem sido intensamente modificado, a partir, sobretudo, da incorporação de tecnologia destinada à produção. Diante disso, tem-se uma ruptura na forma de $\operatorname{produzir}^{6}$, uma vez que as pequenas atividades agropecuárias dão lugar às grandes atividades agropecuárias modernas, acentuando a transformação dessas áreas, e gerando impactos em áreas urbanas e rurais do Brasil.

Dessa forma, de acordo com Elias (2012), a divisão pura e simples entre urbano e rural, na atual conjuntura do país, não é congruente, visto que a realidade do Brasil é marcada pela expansão das regiões produtivas agrícolas, com difusão da agricultura moderna em diferentes áreas de Estados brasileiros - esse processo de modernização se deu, por exemplo, a partir de forte apoio do Estado, em um claro favorecimento dos agentes hegemônicos, como as grandes empresas (HESPANHOL, 2013) -, o que intensifica a ligação entre o urbano e o rural, dificultando a delimitação precisa de tais espaços. De fato, os avanços da ciência, e, sobretudo, a disseminação da informação e da tecnologia, levam à completa transformação da realidade socioespacial brasileira, o que contribui, também, para a dificuldade do trabalho de definição teórica e perceptível do que é o espaço urbano e o rural no Brasil.

É possível dizer que a origem dessa dificuldade está nas transformações que o campo e a cidades brasileiras começaram a sofrer no século XX, o que culminou em novas realidades sociais, econômicas, culturais e políticas, alterando, assim, a relação entre o rural e o urbano. Isso foi possibilitado pelas mudanças ocorridas nos espaços rurais como consequência da modernização do campo, aumento do êxodo rural e da consequente urbanização brasileira

\footnotetext{
${ }^{6}$ O processo de modernização agrícola no Brasil será abordado com mais atenção no próximo capítulo deste trabalho, que foca a modernização da agricultura nas áreas de cerrado do Brasil Central.
} 
(HESPANHOL, 2013). É preciso pontuar, contudo, que existem diferentes linhas de abordagens quanto às definições do que é rural e do que é urbano. Para Hespanhol (2013), são três as abordagens principais: a dicotômica, a de existência de um continuum entre os dois espaços, e a de permanência das ruralidades.

A primeira abordagem, a dicotômica, considera que há uma oposição entre o campo e cidade, de maneira que o primeiro seria destinado basicamente à produção agropecuária, e, a segunda, por sua vez, à produção industrial e à disponibilização dos serviços e mercadorias. É possível dizer, portanto, que, de acordo com essa abordagem, o campo seria, por definição, o lugar do atraso, e a cidade, o da modernidade. Nesse ponto de vista, o mundo rural no Brasil poderia ser entendido como a representação do passado e do velho, e a atividade industrial, instalada nas cidades, não somente como o moderno, mas como o caminho mais adequado para o crescimento econômico e o desenvolvimento do país. Em outras palavras, a urbanização e a industrialização faziam parte dos discursos dominantes e eram, consequentemente, padrões a serem valorizados e seguidos. Nas palavras de Silva (1977), porém,

A visão que se tem do mundo rural ainda está completamente vinculada à evolução do mundo agrário, enquanto a indústria e os serviços parecem ser características "naturais" do meio urbano, mas já não se pode falar em meio rural identificando-o exclusivamente com as atividades agropecuárias [...]. (SILVA, 1997, p.3).

Embora essa abordagem tenha sido dominante no Brasil apenas até o início dos anos 1980, no imaginário atual, já na segunda década do século XXI, essa dicotomia ainda prevalece como fato natural, como é possível perceber inclusive no ensino básico brasileiro, em que, no geral, os professores, livros didáticos e alunos pressupõem essa oposição entre os espaços rurais e urbanos (HESPANHOL, 2013). Além disso, ainda vigora, no Brasil, a ideia de que as atividades primárias são sinônimos do meio rural (VEIGA, 2001); o campo é ainda rotulado como local de produção de alimentos de gênero primário. Nas palavras de Veiga, porém,

[...] a agropecuária é a fonte de apenas $32 \%$ da renda das famílias rurais empregadas, e de $45 \%$ das famílias rurais de quem trabalha por conta própria, ou de quem é empregador. $\mathrm{O}$ que permite estimar que economia agrícola represente no máximo um terço da efetiva economia rural. (VEIGA, 2001, p.102).

Os dados evidenciam que no meio rural não existem apenas atividades primárias, mas também atividades ligadas ao setor secundário e terciário da economia. Nesse sentido, o 
campo é também lugar de desenvolvimento de outras atividades econômicas, como os serviços e a indústria, inclusive com utilização massiva de tecnologia, em padrão similar ou mesmo maior que nas áreas urbanas. Veiga (2005), de modo perseverante, caracteriza a visão oposicionista/dicotômica entre urbano e rural como jurássica, pois os órgãos oficiais de pesquisas nacionais ainda se baseiam em critérios muito antigos para a definição de áreas urbanas e rurais no Brasil.

A segunda abordagem, que assinala a existência de um continuum do rural e do urbano, por outro lado, defende que o rural está chegando ao fim em razão da difusão do processo de industrialização e o aumento da urbanização. Para Hespanhol (2013), há, ainda, nesse ponto de vista, clara oposição entre o urbano e rural, pois pressupõe-se que o primeiro está invadindo o segundo, o que acarretaria no desaparecimento e perda das características dos espaços rurais e na maior diversificação das atividades desenvolvidas neste espaço. Nas palavras de Oliveira (1999, p.103), "O processo contraditório e desigual de desenvolvimento da agricultura pela via da industrialização tem eliminado gradativamente a separação entre cidade e o campo, entre o rural e o urbano, unificando-os numa unidade dialética."

Essa complementaridade entre os espaços urbanos e rurais, segundo Silva (1997), acaba dificultando na delimitação do que é urbano e do que é rural. Nas palavras do autor:

\footnotetext{
Na verdade, está cada vez mais difícil delimitar o que é rural e o que é urbano. Mas isso que aparentemente poderia ser um tema relevante, não o é: a diferença entre o rural e o urbano é cada vez menos importante. Pode-se dizer que o rural hoje só pode ser entendido como um "continuum" do urbano do ponto de vista espacial; e do ponto de vista da organização da atividade econômica, as cidades não podem mais ser identificadas apenas com a atividade industrial, nem os campos com a agricultura e a pecuária. (SILVA, 1997, p.1).
}

O autor alerta para o equívoco de fazer oposição entre o rural e o urbano, visto que os espaços se complementam, o que pode ser atribuído aos atuais processos emergentes, como o processo de globalização e industrialização, que afeta diretamente os espaços rurais e suas reconfigurações socioespaciais. Silva (1997), porém, é mais radical e defende que o meio rural brasileiro passou por um processo de urbanização, influenciado pelo processo de modernização ou industrialização da agricultura brasileira, de maneira que a expansão das áreas urbanas, tanto das áreas físicas como das áreas de suas influências, teria chegado ao campo e transformado as áreas rurais em urbanas.

Santos (2008, p.50), contudo, afirma categoricamente que “[ [...] na verdade, porém, o espaço torna-se mais diversificado e heterogêneo, e à divisão tradicional em regiões 
acrescenta-se uma outra, produzida pelos vetores da modernidade e da regulação", indo na contramão da ideia de homogeneização do espaço no mundo atual. Apesar da intensa complementaridade entre os espaços rurais e urbanos, de fato, é ainda possível observar a manutenção das ruralidades no Brasil, inclusive em áreas urbanas, o que é justamente a derradeira visão de Hespanhol (2013).

A terceira e última abordagem é a que considera a permanência de ruralidades nos diferentes espaços. Segundo Hespanhol (2013),

\begin{abstract}
O espaço e a sociedade rural mudaram, pois parte da população residente no campo incorporou hábitos urbanos em decorrência da expansão da infraestrutura, da maior fluidez propiciada pela melhoria das vias e dos meios de transporte e do intenso fluxo de informações veiculadas pelas mídias, principalmente pela televisão. Assim como parte da população rural que migrou para as cidades também procura manter o seu modo de vida, por meio do cultivo de hortas e da criação de pequenos animais nos quintais, bem como pelas manifestações culturais e religiosas. (HESPANHOL, 2013, p. 108).
\end{abstract}

Dessa forma, considera-se que ainda existem claros traços que diferenciam o espaço urbano e o rural, e que se baseiam em memórias sociais. De fato, Elias (2012) afirma que estes espaços se tornam cada vez mais distintos e suas particularidades se acentuam mesmo com a expansão do capital e da tecnologia. Os discursos que defendem a homogeneização dos espaços urbanos e rurais, portanto, devem ser contestados, em virtude do fato de que, sobretudo na realidade brasileira, ainda persistem traços distintivos entre o campo e a cidade, na medida em que cada um deles possui características específicas que os diferencia e complementa ao mesmo tempo; o Estado do Piauí, onde a realidade do conjunto de municípios das Microrregiões Alto Parnaíba Piauiense e Alto Médio Gurguéia está embasada na escala rural, e as cidades são um espelho dessa grande influência do modo de vida rural, é um exemplo. Reforçamos, portanto, que os espaços urbanos e rurais brasileiros possuem particularidades específicas que são influenciadas pelas características econômicas, demográficas e culturais brasileiras.

O Brasil, hoje, cujas cidades apresentam inúmeros problemas urbanos relacionados à violência, ausência e/ou baixa qualidade de serviços básicos, como transporte público, saúde, educação e saneamento básico ${ }^{7}$, volta a dedicar atenção ao campo brasileiro ${ }^{8}$, que é, segundo Hespanhol (2013),

\footnotetext{
${ }^{7}$ Algo recorrente no país como um todo, não somente em cidades pequenas brasileiras.

${ }^{8}$ Hespanhol (2013) destaca que alguns atores da sociedade, como aposentados, trabalhadores urbanos e famílias têm optado a residir no campo ao invés de na cidade, não raro em virtude dos problemas verificados nas áreas
} 
Não apenas como lugar de desenvolvimento das atividades agropecuárias, mas também como espaço para se viver e desenvolver outras atividades, emergindo novas ruralidades derivadas da presença de atividades não agrícolas, como o turismo, a prestação de serviços, etc. (HESPANHOL, 2013, p.104).

A partir da década de 1960, o Brasil passa a inverter a lógica dominante até então: de um país essencialmente rural, passa a ser um país com grande urbanização, segundo os dados dos órgãos oficiais responsáveis pelas estatísticas do país. Isso resultou no aumento considerável da população urbana e na diminuição representativa da população rural brasileira (HESPANHOL, 2013). Ao mesmo tempo, a área do perímetro urbano de diversas cidades brasileiras aumentou, invadindo áreas anteriormente consideradas como rurais. Tal conjuntura culmina no aumento da complexidade das características dos espaços rurais brasileiros já no final do século XX e início do século XXI.

A partir deste momento, portanto, o rural não pode ser encarado apenas como o local onde se encontram as atividades ligadas à agropecuária, já que, segundo Hespanhol (2013), novas atividades e formas de ocupação do território - que não raro possuem pouca ou nenhuma ligação com atividades rurais, tais como o surgimento de serviços diferenciados e os novos empreendimentos de moradia e lazer, como a expansão de atividades ligadas ao comércio, como pesque-pague, os hotéis-fazenda, o turismo sertanejo, as trilhas e a presença de agroindústrias - se estabelecem. Dessa forma, é possível dizer que os espaços rurais brasileiros ainda possuem grande representatividade e importância no cenário do país. Considerar indiscutível a ideia de que o Brasil é altamente urbanizado é camuflar a verdadeira situação de muitas cidades brasileiras nas quais nota-se uma ligação muito maior com os espaços rurais em detrimento dos urbanos, embora o Brasil seja considerado um país eminentemente urbanizado, com cerca de $80 \%$ da população vivendo em cidades. Esse processo de urbanização aconteceu, de acordo com Becker e Egler (1993), de forma acelerada e em poucas décadas. Nas palavras dos autores (1993, p.182), “[...] entre 1950-80, dobrou o número total de cidades, mas o crescimento mais significativo ocorreu nas cidades médias e grandes.” Becker e Egler (1993, p.182) ainda afirmam que, no Brasil, “As cidades de mais de 100.000 habitantes passaram de 11 para 95, representando, em 1980, 48,7\% da população urbana do país". Esse aumento da urbanização, sobretudo em grandes centros urbanos, foi

urbanas, como a violência, o elevado custo de vida, o desemprego e a agitação cotidiana. Apesar de mudarem-se para o campo, muitos desses novos residentes ainda retém intensas ligações com os espaços urbanos e com o modo de vida dessas áreas, o que é possível em função do avanço da modernidade no campo, como a expansão dos sistemas de transporte e comunicação. 
impulsionado pela atividade industrial. Ultimamente, porém, verifica-se, no Brasil, um crescimento das cidades que deriva de outras atividades ligadas ao ramo agroindustrial.

Vale ressaltar, porém, que, para alguns autores, o nível de urbanização do Brasil é discutível; Veiga (2005), por exemplo, defende que essa ideia é uma falácia. Nas suas palavras,

Pelo critério em vigor, nem $20 \%$ dos domicílios brasileiros são rurais. O que pensar, então, de qualquer comparação entre eles e os mais de $80 \%$ oficialmente urbanos? Existiria alguma homogeneidade entre as quais 40 milhões unidades de consumo amalgamadas sob o rótulo "urbano". Claro que não! (VEIGA, 2005, p.66).

$\mathrm{O}$ autor tece duras críticas aos modelos e critérios implantados pelos órgãos oficiais ligados à estatística e aos estudos urbanos no Brasil. Considerando os dados do Censo de 2000 do IBGE, Veiga (2001) afirma ainda que: “[...] são oficialmente urbanos 25 dos 45 milhões de pessoas que habitam municípios acanhados, remotíssimos e de irrisória densidade (VEIGA, 2005, p.67)”. De fato, a análise cuidadosa do contexto de grande parte de pequenos municípios brasileiros leva à percepção de que muitos deles, apesar de possuírem população urbana relevante, têm intensa ligação com as áreas rurais. Isso fica ainda mais nítido quando se observa, de acordo com Moura (2009), a ligação dos pequenos municípios brasileiros com atividades ligadas à agropecuária, que, muitas vezes, ditam o ritmo e a rotina de sua vida econômica, de maneira que caracterizam o que podemos chamar de cidades rurais - onde a economia, a cultura e o ritmo do comércio estão fortemente atrelados ao campo, por vezes até mesmo em relações de dependência -, o que pode-se ainda corroborar pelo fato de que, na maioria dos casos, estes são espaços pouco populosos.

Para o IBGE, são consideradas como áreas urbanas todas as sedes municipais (as cidades) e de distritos (as vilas), independente das suas funcionalidades (VEIGA, 2005). A análise dos dados do Censo de 2000, porém, evidencia que várias sedes municipais brasileiras apresentam população pouquíssima numerosa. Tal situação é possível porque, no Brasil, a definição de cidade é baseada em critérios administrativos. De acordo com o Decreto Lei número 311 de 02 de março de 1938, artigos 11 e 12, a sede municipal, que cede nome ao município, deve possuir no mínimo duzentas moradias para ser considerada sede de município, e trinta para ser considerado um distrito (SOARES; MELO, 2008) - é importante notar que, em plena segunda década do século XXI, no Brasil ainda vigora uma lei criada há oitenta anos. 
Essa definição revela-se como um problema justamente em função do fato de ser baseada em critérios administrativos e estatísticos, pois há, no país, uma série de pequenos municípios que recebem muitos recursos da União e dos Estados, gerando inúmeras despesas administrativas e constitucionais, sem, porém, gerarem receita, na medida em que, como assinala Soares e Melo (2008, p.337), “[...] as pequenas cidades não conseguem gerar receitas internas e ficam na dependência de transferências externas, como o do Fundo de Participação dos municípios".

Uma característica das pequenas cidades brasileiras é a o grande papel que têm os serviços públicos na composição do PIB municipal (MOURA, 2009), o que significa que esses municípios, na grande maioria dos casos, possuem grande dependência dos recursos destinados às prefeituras, ao funcionalismo público municipal, e à previdência rural. Além disso, ainda segundo Moura (2009), grande parte da população dessas cidades migra para grandes centros, como consequência da existência de poucos postos de trabalho.

É ainda importante frisar que a pobreza no Brasil pode ser, em grande parte, atribuída aos pequenos centros ditos urbanos. De acordo com Becker e Egler (1993),

\begin{abstract}
A pobreza relacionada ao campo brasileiro está fortemente ligada aos centros urbanos. A maior parte da população de miseráveis ocorre em áreas "urbanas", isto é, núcleos urbanos com menos de 20.000 habitantes, onde a população depende tanto de empregos sazonais e temporários na agricultura como de empregos na cidade. (BECKER; EGLER, 1993, p.177).
\end{abstract}

Dessa forma, os autores consideram os núcleos urbanos com menos de vinte mil habitantes como áreas ligadas à escala do rural. Acrescentam, ainda, que essa pobreza está concentrada no campo brasileiro, especialmente no Nordeste.

Após o advento da Constituição de 1967, a criação dos municípios foi atribuída à União, e, durante esse período, poucos municípios foram criados. Entretanto, com a aprovação da Emenda Constitucional número quinze, de doze de setembro de 1996, da Constituição de 1988, a criação dos municípios torna-se, novamente, uma atribuição dos Estados, o que leva, por conseguinte, a novo aumento na criação de municípios no Brasil (SOARES; MELO, 2008). Segundo Soares e Melo (2008, p.321), “[...] só entre os anos de 1991 e 2001, foram instalados 1.070 municípios no país”. Esses pequenos municípios são marcados pela fragilidade econômica e pela falta de equipamentos urbanos, de maneira que, no geral, possuem relação de extrema dependência com outros centros mais preparados. 
De acordo com Veiga (2005, p.70), "Entre os 5.507 sedes de municípios recenseadas em 2000, havia, por exemplo, 1.563 com menos de 2,5 mil habitantes”. Além da população pouco numerosa, essas sedes municipais apresentam, em sua grande maioria, baixa densidade demográfica. O autor acrescenta, ainda, que 4.300 municípios tinham sede municipal com menos de 20.000 habitantes, sendo que, muitas vezes, as sedes não ofereciam serviços básicos à população. Segundo o censo 2008 do $\operatorname{IBGE}(2008$, p.9), “[...] de um universo de 5.564 municípios vigentes em 2007, foram pesquisados 4.624, dos quais cerca de $85 \%$ têm menos de 20.000 habitantes". Essa grande quantidade de pequenos municípios, ainda de acordo com Veiga (2005), acaba inflacionando as áreas urbanas brasileiras. O autor ainda pontua que, não raro, essas pequenas sedes municipais não deveriam ser consideradas urbanas. Como sustenta Moura (2009. p.17): “[...] verifica-se que, no Brasil, a relação existente entre número de municípios é inversamente proporcional à concentração de população/geração de riqueza", ou seja, apesar da grande maioria dos municípios brasileiros serem considerados pequenos, há concentração de riquezas e população nos grandes centros urbanos.

Embora o IBGE (2008) destaque uma das características do Brasil, que é a presença maciça de pequenos municípios, devemos sublinhar que grande parte deles possui população representativa residindo em áreas rurais de alguns Estados brasileiros. De acordo com Moura (2009),

O universo de pequenos municípios em território brasileiro é expressivo e, embora não respondam por grande proporção da população, ocupam consideráveis extensões do território. Quase sempre compõem áreas pouco densas, o que oferece condições para que constituam cidades confortáveis à vida das populações. (MOURA, 2009, p.18).

Para Soares e Melo (2008), as pequenas cidades são justamente as com menos de vinte mil habitantes, onde o urbano e o rural estão muito próximos um do outro. Da mesma forma, Moura (2009) afirma que

Tanto no meio rural quanto em pequenos núcleos urbanos, uma parcela da população residente totalmente integrada- por meio dos circuitos de produção, comunicações e trasnportes- ao mais avançado padrão de produção e consumo ofertado pelos grandes centros. (MOURA, 2009, p.22).

Nos últimos anos, houve aumento representativo de pessoas residindo em cidades de pequeno porte, sobretudo naquelas com menos de cinquenta mil habitantes (SOARES; MELO, 2008). Por outro lado, Moura (2008) afirma que os pequenos municípios que 
obtiveram crescimento populacional normalmente estão próximos ou inseridos nas aglomerações urbanas e centros regionais. Com efeito, Soares e Melo (2008) também alertam para o perigo no uso de apenas dados censitários na definição do que é urbano e do que é rural no Brasil, pois é preciso considerar a localização e conjuntura dos mesmos, levando em conta o contexto e dinâmica regional em que estão inseridos. Veiga (2005), por sua vez, corrobora esta ideia, uma vez que sustenta que a análise não deve se resumir aos dados oficiais, mas sim combinar os dados referentes ao tamanho da população em relação aos dados de densidade demográfica e de localização do município em análise. Para o autor, o município com menos de vinte mil habitantes localizado em uma região metropolitana se diferencia de outro com a mesma quantidade de moradores, porém localizado em uma área com pequenos municípios ao redor e com a presença de atividades agropecuárias.

Na realidade brasileira, porém, uma cidade de menos de vinte mil habitantes não deve ser necessariamente considerada pequena, já que, não raro, na conjuntura de certa porção territorial de um Estado brasileiro, uma cidade de tal porte pode ser tão importante quanto uma de mais de cem mil habitantes em Estados mais populosos do Brasil. Nas palavras de Soares e Melo (2008), “[...] pensar em uma caracterização única para as pequenas cidades no Brasil é, portanto, uma tarefa complexa e quase impossível", o que se deve às diferentes realidades e caracterizações de cada Estado brasileiro, como é o caso da rede urbana da Mesorregião Sudoeste Piauiense - que analisaremos mais à frente -, caracterizada pela presença de um grande conjunto de pequenas cidades com população abaixo de quinze mil habitantes, salvo algumas exceções com população entre vinte mil e trinta mil habitantes, mas que desempenham, muitas vezes, papel semelhante ao de uma cidade média de outras regiões com população mais numerosa.

Deste modo, é possível afirmar que algumas áreas consideradas cidades no Brasil se revelam muito mais como áreas rurais do que propriamente urbanas, pois suas características e dinâmicas econômicas, culturais e políticas estão fundamentadas e ligadas aos espaços rurais, caracterizando, assim, o que Veiga (2005) denomina de municípios rurais. Esses mesmos são caracterizados pela pouca presença de hospitais, de universidades, de uma página oficial do município na Internet, de serviços de Internet efetivos, de coleta de esgoto, de teatro ou casa de espetáculo, de plano de desenvolvimento (Plano Diretor), de coleta de lixo domiciliar, de manutenção de vias públicas, etc. (VEIGA, 2005).

Os órgãos de pesquisas urbanas e demográficas do Brasil utilizam, de maneira equivocada, apenas critérios estruturais, como a localização, o número populacional, e a 
quantidade de residências, para definição do que é urbano e o que é rural. ${ }^{9}$ Idealmente, as características funcionais destas áreas, tal como a presença ou não da oferta de serviços básicos para a população urbana - hospitais, transporte público, estabelecimentos de ensino mais estruturados, corpo de bombeiros, entre outros -, deveriam ser consideradas no momento dessa definição (VEIGA, 2005). Aqui ressaltamos, porém, que esta pesquisa não pretende desvalorizar os pequenos municípios no Brasil, pois os mesmos possuem grande importância no processo de análise mais detalhada do estudo.

De acordo com Moura (2009),

Pode-se dizer que mesmo núcleos pequenos organizam-se para a vivência coletiva e, ao seu modo, para a política e para a cidadania. Respeitadas as escalas, a densidade material ou a capacidade inovativa, todos assumem um papel na divisão social do trabalho e têm uma participação na teia da rede da rede urbana. E são estruturadores na dinâmica do território municipal como um todo e de suas relações com a região e o Estado. (MOURA, 2009, p.17).

Soma-se, a isso, o fato das pequenas cidades estarem sujeitas às modificações à medida que novos processos e dinâmicas surgem, pois as cidades precisam se adaptar às necessidades impostas pelas novas transformações, como é o caso de municípios agrícolas, que funcionam como suporte à grande produção e aos novos agentes ligados ao agronegócio, sobretudo de elites locais. Essas novas realidades dos espaços rurais brasileiros contribuem diretamente para aumentar a complexidade da rede urbana brasileira e impor novas tendências, sobretudo no que diz respeito ao surgimento de novas centralidades urbanas e na origem de diferentes realidades urbanas.

\subsection{Um pouco sobre a Rede Urbana Brasileira: Tendências e Dinâmicas Atuais}

Em primeiro lugar, precisamos entender o conceito de rede urbana regional para então caracterizar a rede urbana brasileira. Salientamos que, embora este não seja o objetivo do trabalho, a compreensão do conceito é fundamental para adentrarmos a análise da rede urbana do Sudoeste Piauiense, com foco nas Microrregiões Alto Parnaíba Piauiense e Alto Médio Gurguéia $^{10}$. Assim, de acordo com Sousa (2003), a rede urbana regional é entendida como

\footnotetext{
9 Mais à frente veremos que a maior parte dos municípios das microrregiões localizadas na Mesorregião Sudoeste Piauiense possuem grande parcela da população vivendo em áreas rurais.

${ }^{10}$ Destacamos que a análise da rede urbana piauiense pressupõe o debate sobre a atual rede urbana brasileira. A visão mais abrangente neste capítulo é necessária para o aprofundamento do estudo sobre rede urbana piauiense e as atuais transformações em torno da mesma.
} 
Uma região com uma forte coerência de identidade sócio espacial e de fluxos de internos; contudo ela sempre será, ao mesmo tempo, um subconjunto de uma rede urbana maior, nacional, a qual, por sua vez, estará menos ou mais fortemente articulada no interior de uma rede urbana global. (SOUSA, 2003, p.50).

Sousa (2003) evidencia a complexidade do conceito e os seus variados níveis. Com efeito, para Corrêa (2000, p.424), a "Rede urbana, entendida como um conjunto de centros funcionando articulados, constitui-se em um reflexo social, resultado de complexos e mutáveis processos engendrados por diversos agentes sociais." Nesse sentido, ela envolve a articulação entre diferentes espaços urbanos, bem como a questão da presença de características marcantes que promovem a formação de uma identidade, sempre ligada a aspectos socioeconômicos. Novamente de acordo com Sousa (2003, p.50), “[...] seja no interior de um país, seja em escala planetária, nenhuma cidade existe totalmente isolada, sem trocar informação e bens de consumo com o exterior, caso contrário não seria uma cidade". $\mathrm{O}$ autor acrescenta, ainda, que as cidades estão conectadas umas às outras em uma rede urbana. Essa articulação é efetivada através dos meios de comunicação, do fluxo de produtos e mercadorias, e dos meios de transporte, de maneira que, direta ou indiretamente, essas cidades estão ligadas por meio de aspectos políticos, econômicos ou sociais. É possível afirmar, portanto, que uma rede urbana recebe influência direta dos avanços e mudanças empreendidos pelo processo de globalização.

Nesse sentido, de acordo com Corrêa (2000), a cidade inserida em determinada rede urbana, por menor que seja, participa de processos de refuncionalização e ressignificações impostas por novas realidades econômicas e políticas, que podem inclusive alterar sua função nessa rede urbana; esta última possui grande ligação com a formação espacial, pois pode expor características de diferentes momentos históricos e marcas de diferentes processos dos quais já fez parte ou com os quais teve relação. Assim, conforme sustenta O’Neill (2007, p.262), “[...] as redes urbanas, síntese de múltiplas redes geográficas, são a base técnica, os nós que entrelaçam as ligações entre os lugares, e existem para viabilizar- de forma constante e instantânea- a circulação da produção, pessoas, imagens, ordens, etc.”

Nessa perspectiva, a rede urbana brasileira possui uma grande ligação com a formação espacial do território brasileiro. Corrêa (2000) destaca que: 
A formação espacial brasileira, assim identificada em uma escala, aparece dotada de grande heterogeneidade interna quanto altera-se a escala de análise. A heterogeneidade resulta de uma combinação desigual, tanto no espaço como no tempo, de processos naturais e sociais. (CORRÊA, 2000, p. 226).

Essa combinação desigual originou, no Brasil, uma rede urbana de particularidades evidentes, resultado do seu processo de ocupação territorial e desenvolvimento/expansão de atividades econômicas, bem como do incentivo do Estado, com projetos estruturantes e grades agentes hegemônicos, como as corporações multinacionais.

$\mathrm{Na}$ atualidade, a rede urbana brasileira pode ser caracterizada pela presença de grandes centros metropolitanos, como, por exemplo, São Paulo, Rio de Janeiro, Belo Horizonte, Brasília, Fortaleza e Salvador. Por outro lado, o Brasil apresenta, também, uma rede urbana marcada por pequenas cidades, assim como afirma O’Neill (2007), baseando-se em dados do IBGE de 2007:

\begin{abstract}
Contudo, a urbanização brasileira cresceu, de modo geral, desigual, expandindo de forma primaz poucas cidades que concentram, cada vez mais, população e riqueza, e multiplicando pequenos centros urbanos, que, majoritariamente, abrigam uma força de trabalho pouco qualificada e, muitas vezes, fortemente vinculada às atividades primárias. O Processo de macrourbanização consubstanciado nas aglomerações urbanas e cidades com mais de 350000 habitantes, num total de 49, abriga 50,0/\% dos habitantes em situação urbana no País e detém, aproximadamente, 65\% do Produto Interno Bruto-PIB nacional. No outro extremo da escala urbana, estão 4.295 municípios com menos de 25.000 habitantes que correspondem por $12,9 \%$ do PIB. (O’NEILL, 2007, p.261).
\end{abstract}

A população de grande parte dos municípios brasileiros é, portanto, inferior aos 25.000 habitantes $^{11}$, e tem pouca participação no PIB nacional. Como, porém, o processo de urbanização do Brasil tem se reconfigurado, podemos observar que até mesmo estes pequenos municípios começam a se tornar mais relevantes para a economia do país. Mesmo sem uma descentralização econômica efetiva, isso torna a rede urbana e a economia brasileira ainda mais complexa.

A expansão da estrutura econômica brasileira para outras áreas é conhecida como desconcentração concentrada, pois, mesmo após a expansão das atividades econômicas para novas áreas, as mais importantes decisões econômicas continuam presentes nos grandes centros urbanos do país, principalmente na chamada região Centro-Sul, de maneira que,

${ }^{11}$ No capítulo 3, mostraremos que na Mesorregião Sudoeste Piauiense, principalmente nas microrregiões Alto Parnaíba Piauiense e Alto Médio Gurguéia, todos os municípios possuem menos de 25.000 habitantes. Isso revela uma das grandes características da densidade demográfica do Estado do Piauí: a macrocefalia urbana, que é o resultado da existência de uma grande cidade e centro, e a presença de grande quantidade de pequenas cidades, é uma característica fundamental da rede urbana piauiense, que analisaremos no capítulo 3. 
mesmo em vista da existência de novas áreas econômicas, os pequenos municípios ainda dependem economicamente dos grandes centros. Nesse aspecto, São Paulo ainda é o grande centro da economia brasileira, mesmo após o início da desconcentração industrial e econômica do país, e continua a expandir sua área de influência para outras áreas, muito embora, nos últimos anos, em detrimento do maior povoamento do interior do país, têm-se percebido certa estabilização no crescimento de determinadas regiões metropolitanas.

De acordo com Simões e Amaral (2001), podemos afirmar que, no início do século XXI, houve um processo de arrefecimento da metropolização brasileira, por conta do avanço do movimento de interiorização da ocupação do país, iniciado na década de 1970 e em consolidação nos últimos anos, motivado pela expansão das atividades econômicas para novas áreas do centro do Brasil, dando origem a novas centralidades urbanas. Muitas dessas novas áreas, que eram anteriormente condenadas à estagnação econômica, sem disporem de um dinamismo econômico representativo, começam a participar de novas realidades econômicas ligadas às atividades agropecuárias, atividades de mineração, geração de energia elétrica, ampliação da indústria, dentre outros.

Nas últimas décadas, o processo de urbanização do Brasil tem acompanhado as tendências econômicas do país. $\mathrm{E}$ isso se confirma quando se observa as atuais dinâmicas presentes nas escalas urbanas no país, como a “[...] interiorização do fenômeno urbano; acelerada urbanização das áreas de fronteira econômica; crescimento das cidades médias; periferização dos centros urbanos; e formação e consolidação de aglomerações urbanas de caráter metropolitano e não-metropolitano". (MOTTA; AJARA, 2001, p.6). Esse contexto afeta diretamente as tendências relacionadas à urbanização, sobretudo com mudanças significativas nas áreas sociais, econômicas, políticas e sociais. O aumento das migrações, por exemplo, é um dos novos processos que está em destaque no Brasil e que merece atenção, bem como a expansão da fronteira econômica para novas áreas do país, alterando de forma significativa a centralidade de certas regiões em diferentes estados brasileiros, influenciando diretamente na localização das pessoas e dos negócios.

Até 1970, havia concentração industrial em São Paulo. Logo após esse período, outros estados começaram a participar mais ativamente da atividade industrial do país, entre os quais "Minas Gerais, Rio Grande do Sul, Santa Catarina e, em menor medida, Estado da Bahia." (SIMÕES; AMARAL, 2001, p.555). Simões e Amaral (2001) destacam que 
É evidente que tal processo em si não é novo. A grande novidade é sua escala econômica e amplitude geográfica. A exploração agropecuária das áreas de cerrado do Noroeste de Minas Gerais, do Centro-Oeste e do Nordeste Meridional é caracterizada como exploração em grande escala, de elevado nível de mecanização e uso intensivo de insumos químicos. (SIMÕES; AMARAL, 2001, p. 554).

Além da expansão das atividades agropecuárias, os autores ainda apontam a expansão da exploração mineral como fator motivador para a interiorização do país. Através desta última, inúmeros fluxos migratórios sofrem um processo de redirecionamento para as novas áreas de expansão da fronteira econômica do país, e muitos migrantes retornam para os seus locais de origem em busca de trabalho, deixando grandes centros urbanos, de maneira que se gera grande fortalecimento de novos centros urbanos; há a formação de novas centralidades urbanas no país, com formação de novas cidades médias ligadas a essa expansão da fronteira econômica (SIMÕES; AMARAL, 2001), e é justamente por isso que é necessário analisar as consequências desses novos processos nos diferentes territórios espalhados pelo país.

Segundo Becker e Egler (1993), a tendência da descontração urbana, produtiva e econômica no Brasil tem três modalidades. A primeira, nas palavras do autor,

[...] é a extensão contínua de centros urbanos a partir da cidade mundial; trata-se de cidades ricas que balizam regiões de agricultura diversificada e regiões basicamente pecuaristas por onde avança a agricultura moderna da soja e da cana-de-açúcar. (BECKER; EGLER, 1993, p.184).

A segunda modalidade, por sua vez, seria originada pela influência e centralidade das capitais presentes em Estados do centro-norte, que fazem a intermediação com São Paulo, denominada cidade mundial pelos autores. A terceira e última modalidade, por fim, seria resultado da expansão da fronteira econômica, sobretudo para a região Amazônica, incluindo centros regionais ligados à expansão da fronteira agrícola e mineral. Esses centros, nos quais dispõe-se de mão de obra também móvel, de acordo com as novas tendências de expansão de busca de novas áreas, funcionariam como suporte à expansão da fronteira econômica. Nesse caso, é possível citar, como exemplo, o município de Bom Jesus, no Estado do Piauí, e os de Barreiras e Luiz Eduardo Magalhães, na Bahia.

Para Simões e Amaral (2001, p 555), emerge, no Brasil, uma rede urbana "embrionariamente policêntrica" face ao surgimento de novas centralidades em recortes territoriais de estados localizados no chamado Brasil Central (regiões Centro-Norte e Nordeste). O que ocorre, portanto, é certa reversão da polarização de algumas atividades econômicas do país e, consequentemente, novas cidades emergem como centralidades 
urbanas e como espelho do processo de desconcentração da estrutura econômica-produtiva do Brasil.

A emergência dessas novas centralidades acarreta na modificação da rede urbana nos diferentes Estados brasileiros envolvidos nesse processo, pois, com o maior protagonismo de algumas cidades, uma série de outras cidades, muitas vezes de outros Estados, passam a pertencer às suas regiões de influência, muito em decorrência dos novos fluxos econômicos e demográficos, e ligações políticas e culturais.

Outra grande questão que merece atenção, inclusive por parte do Estado, é a formação de disparidades econômicas e demográficas dentro de uma Unidade Federativa, que causa uma série de desequilíbrios regionais. Assim, é preciso refrear a ampliação das desigualdades sociais e regionais em cada estado brasileiro, pois, em maior escala, provocam o aumento das desigualdades sociais e regionais no país. Outra consequência da expansão da fronteira econômica no Brasil é o desejo da criação de novos estados brasileiros, o que alteraria a estrutura federativa brasileira. Como exemplo, é possível mencionar os diversos comentários em torno da criação do Estado do Gurguéia no Piauí, do Estado do Maranhão do Sul, e do Estado de São Francisco na Bahia. Essas possibilidades podem ganhar força em um futuro próximo, como resultado do aumento das disparidades regionais e sociais dentro desses Estados, possibilitado pela atuação de novos agentes econômicos, políticos e sociais, como grandes empresas ligadas a diferentes atividades, migração de sulistas e atuação diferenciada do Estado. É interessante pontuar, porém, que apesar evidência do processo de desconcentração das atividades econômicas, algumas linhas de pensamento ainda sustentam que este processo representou apenas a desconcentração da estrutura produtiva e industrial, e que a centralidade de São Paulo permanece a mesma e, até mesmo, amplia-se.

Para entendermos melhor a rede urbana brasileira, sobretudo em relação às modificações das centralidades, recorremos à argumentação de Santos e Silveira (2001), que defendem a existência de três grandes períodos da história territorial do país. Nas suas palavras,

O primeiro, que dura até a Segunda Guerra Mundial, é anterior à unificação do território e do mercado. O segundo, com o Brasil unificado, teria como fator dinâmico a indústria e com objetivo a construção nacional. O terceiro coincide com o processo de globalização e vige até os nossos dias. (SANTOS; SILVEIRA, 2001).

De acordo com os autores, portanto, no primeiro período o Brasil é policêntrico; o poder se concentra no Governo Geral e, depois, no Vice-Reinado e no Império. Nesse período, as regiões produtoras tinham ligação com centros litorâneos, que possibilitavam a 
conexão com o mercado externo. Essa organização se reflete, de certa forma, nos dias atuais, pois grande parte da população brasileira se concentra próxima ao litoral, especialmente nas regiões Sul, Sudeste e Nordeste. Nesta última, a concentração é tão intensa que, das nove capitais dos Estados Nordestinos, oito estão localizadas justamente no Litoral - a exceção fica por conta da capital do Piauí, Teresina.

O segundo período, que se inicia no século XIX, é marcado pela centralização de ferrovias, e pela divisão territorial no Brasil. Nessa época, surgiram os primeiros indícios do que Santos chama de Região Concentrada, e Rio de Janeiro e São Paulo se estabeleceram como centralidades no país, embora até então a relação destas cidades com restante do país tenha sido incompleta. Segundo Santos e Silveira (2001), este período marca o início do crescimento das disparidades regionais no Brasil. De acordo com Corrêa (2001), a rede urbana brasileira possuía três características: 1) Pequena complexidade funcional dos centros urbanos; 2) Interações Predominantemente Regionais, com funções de diferentes centros urbanos pouco complexas; 3) Padrão Espacial da rede urbana. O Rio de Janeiro, neste período, apresentava maior concentração industrial, e, aos poucos, foi perdendo/cedendo lugar a São Paulo - é importante ressaltar que, neste momento, era justamente a atividade industrial o motor da economia nacional.

O Brasil, no entanto, precisava unificar seu território e diminuir a concentração populacional nas cidades litorâneas; daí, o início de maior interligação de estradas de ferro e construção de rodovias, que Santos e Silveira (2001) chama de unificação para dentro. A construção de Brasília se encaixa nesse processo, e origina nova centralidade no país. O Rio de Janeiro, por outro lado, cada vez mais perde sua centralidade política e econômica, respectivamente, para Brasília e São Paulo. Os autores afirmam que Brasília e Rio de Janeiro, tinham, então, uma relação conflitiva. São Paulo e Brasília, em contrapartida, colaboravam mutuamente, pois, naquele momento, o Brasil necessitava de um centro político como sede do poder público, e, ao mesmo tempo, da consolidação de um centro financeiro, ou seja, São Paulo.

No terceiro período, porém, que contempla a influência do processo de globalização, a indústria deixa de ser protagonista e dá lugar à informação, ainda que a atividade industrial continue a crescer lentamente em São Paulo. Tomam lugar, nesse momento, as atividades ligadas ao setor terciário. Neste período, Brasília se consolida como centro político e, São Paulo, como centro financeiro/econômico do Brasil. No entanto, Santos e Silveira (2001, p.268) afirmam que “[...] as 'ordens' se situam fora da competência territorial e deixam 
pequena margem para escolha de caminhos suscetíveis de atribuir, de dentro, um destino próprio territorial nacional.” Os mesmos autores ainda acrescentam que, nesse período, “[...] uma coisa é certa: nas condições atuais, tanto Brasília quanto São Paulo vêem comprometido o seu papel de regulação, tornando-se ainda mais periférico", de maneira que é possível dizer que existe, então, certa desconcentração da estrutura concentradora em múltiplos aspectos do território brasileiro, embora este processo não implique necessariamente da descentralização das principais decisões econômicas.

Para entender melhor a atual rede urbana brasileira e seus principais centros, portanto, analisamos, abaixo, os principais pontos destacados pelo documento denominado Regiões de Influência das Cidades, elaborado pelo IBGE em 2008. Em seguida, focaremos a análise na rede urbana piauiense.

\subsection{As Regiões de Influência das Cidades (REGIC)}

O Instituto Brasileiro de Geografia e Estatística, lançou, em 2008, o documento intitulado "Regiões de Influência das Cidades (REGIC)", na tentativa de caracterizar a rede urbana brasileira. A partir dele, levantaremos as questões mais relevantes sobre a rede urbana brasileira e suas principais centralidades, para, no capítulo 3, analisarmos as centralidades urbanas fundamentais no Estado do Piauí e as possíveis transformações na rede urbana piauiense com o advento da modernização agrícola na Mesorregião Sudoeste Piauiense. Consideramos este passo fundamental para a análise da rede urbana piauiense focada no Sudoeste Piauiense, pois a mesma está inserida em um contexto amplo em que é influenciada por outros centros urbanos brasileiros; partiremos, portanto, de um enquadramento mais amplo, para em seguida tratarmos das questões mais específicas, apontando as principais tendências após a instalação de projetos de agricultura moderna nos Cerrados piauienses e os impactos decorrentes desse processo nas relações entre as cidades do Sudoeste Piauiense.

De acordo com o IBGE (2008), o REGIC “[...] visa construir um quadro nacional, apontando as permanências e as modificações registradas nesta rede, no início do Século XXI”. Segundo Moura (2009, p.25), “[...] os resultados dessa medida traduzem a diferenciação entre localidades centrais e estabelecem a escala hierárquica dos centros urbanos brasileiros". Visa, além disso, auxiliar o planejamento estatal, servindo como suporte nas decisões econômicas, sobretudo em relação à localização de atividades econômicas de 
produção; pode-se afirmar, assim, que o REGIC serve de apoio à aplicação de políticas públicas no país.

De acordo com o IBGE (2008),

Na última década, a introdução de novas tecnologias e alterações nas redes técnicas, o aprofundamento da globalização da economia brasileira e o avanço da fronteira de ocupação imprimiram modificações marcantes no território, o que indica a oportunidade de atualizar-se o quadro das regiões de influência das cidades. (IBGE, 2008, p.9).

Nesse caso, pode-se afirmar que o IBGE preocupou-se em destacar as principais mudanças com o advento da globalização. Ressaltamos que um dos processos que podem transformar uma rede urbana é justamente o de modernização da agricultura, ou a expansão da agricultura científica, como preferem alguns autores. Tal processo, como já dissemos anteriormente, possui ampla ligação com as mudanças que tomaram lugar após a disseminação das tendências globalizantes. Assim, o IBGE utilizou os seguintes critérios para definição das centralidades urbanas no Brasil:

Para a definição dos centros da rede urbana brasileira, buscam-se informações de subordinação administrativa no setor público federal, para definir a gestão federal, e de localização das sedes e filiais de empresas, para estabelecer a gestão empresarial. A oferta de distintos equipamentos e serviços capazes de dotar uma cidade de centralidade - informações de ligações aéreas, de deslocamentos para internações hospitalares, das áreas de cobertura das emissoras de televisão, da oferta de ensino superior, da diversidade de atividades comerciais e de serviços, da oferta de serviços bancários, e da presença de domínios de Internet - complementa a identificação dos centros de gestão do território. (IBGE, 2008, p. 9).

Basicamente, o IBGE (2008) focou a questão da função da gestão do território, destacando níveis de centralidade do Poder Executivo e do Judiciário em nível federal, além da questão das centralidades empresariais e dos serviços e equipamentos urbanos.

A partir destes dados, foram identificados os principais centros urbanos do diferentes estados. Logo em seguida, aplicou-se um questionário em alguns municípios selecionados. É importante destacar, porém, que as informações não foram exatamente quantificadas, uma vez que os próprios agentes do IBGE de diferentes áreas passaram informações com o suporte de dados e fontes locais, investigando os seguintes pontos: 
1) as principais ligações de transportes regulares, em particular as que se dirigem aos centros de gestão; e 2) os principais destinos dos moradores dos municípios pesquisados para obter produtos e serviços (tais como compras em geral, educação superior, aeroportos, serviços de saúde, bem como os fluxos para aquisição de insumos e o destino dos produtos agropecuários). (IBGE, 2008, p.9).

O REGIC dividiu as cidades brasileiras em 5 grandes níveis: 1) Metrópoles (Subdivididas nos níveis A, B e C); 2) Capital Regional (Subdividido em A, B e C); 3) Centro Sub-Regional (subdividido em A e B); 4) Centro de Zona (Subdividido em A e B); 5) Centro Local. Abaixo, é possível analisar as metrópoles identificadas pelo IBGE (2008):

Tabela 1: Metrópoles REGIC 2008

\begin{tabular}{|c|c|}
\hline Categoria-Cidade (s) & Cidades/População \\
\hline A- Grande Metrópole Nacional & $\begin{array}{c}\text { São Paulo- Maior centro urbano do País, com 19,9 } \\
\text { milhões de habitantes em } 2007\end{array}$ \\
\hline B- Metrópole Nacional & $\begin{array}{c}\text { Rio de Janeiro- População de 11,8 e 3,2 milhões } \\
\text { de habitantes. Brasília- 3,2 milhões de habitantes. }\end{array}$ \\
C- Metrópoles & $\begin{array}{c}\text { Manaus, Belém, Fortaleza, Recife, Salvador, } \\
\text { Belo Horizonte, Curitiba, Goiânia e Porto } \\
\text { Alegre- população varia de 1,6 milhões (Manaus) } \\
\text { até 5,1 milhões habitantes (Belo Horizonte). }\end{array}$ \\
\hline
\end{tabular}

Fonte: IBGE (2008), dados de 2007.

As metrópoles, segundo O’Neill (2007), concentram 34\% da população brasileira, o que representa apenas 3,5\% dos municípios brasileiros, e revela a grande assimetria na rede urbana brasileira. Além disso, foram identificados 70 centros de Capitais Regionais, que possuem ampla capacidade de gestão e influência maior em âmbito regional; essa divisão possui três categorias (A, B e C), como já mencionado. A categoria A é constituída pelas capitais não selecionadas como Metrópoles, e a B e C são constituídas de cidades com diferenciação em relação ao tamanho físico e à influência regional. Destaca-se que, de acordo com o IBGE 2008, as Capitais Regionais nível B estão mais presentes no Centro-Sul do país, e as de nível C, na Amazônia e no Nordeste brasileiro. As Capitais Regionais Nível A são representadas por 11 cidades do país; as Nível B o são por 20 cidades, e as nível C totalizam 39 cidades.

No terceiro nível estão os Centros Sub-regionais, que somam 169 cidades, com área de atuação menor e com atividades ligadas à gestão. Estes centros estão subdivididos nas categorias A e B, que possuem 85 e 79 cidades respectivamente. A categoria A apresenta 
média de 95 mil habitantes, enquanto a B, de 71 mil habitantes. No quarto nível, por outro lado, estão as 556 cidades denominadas Centro de Zona, caracterizadas pela escala restrita e pelo pequeno porte. São também divididas nas categorias A e B, sendo que a primeira categoria contempla 192 cidades com média de 45 mil habitantes, e, a segunda, 364 cidades com média de 23 mil habitantes.

No último nível, por fim, estão as cidades denominadas Centro-Local, que reúne todas as que não foram consideradas nos níveis anteriores - um total de 4.473 cidades, com média de dez mil habitantes, que são caracterizadas pela ausência de influência em outras cidades, e são funcionais apenas para os habitantes locais.

De acordo com o IBGE (2008), a rede urbana brasileira é marcada pela má distribuição dos níveis hierárquicos, e pode ser caracterizada pela presença de áreas pouco povoadas e com pouca articulação, principalmente em Estados da região Norte, Nordeste, e alguns espaços menos habitados do Centro-Oeste. O Centro-Sul brasileiro é onde se encontram os principais centros urbanos do Brasil, além de contar com o maior número de capitais regionais e centro-sub-regionais, caracterizados pela sua grande articulação.

Abaixo, apresentamos a tabela 2 sobre as Regiões de Influências, com a dimensão das redes consideradas de primeiro nível, inclusive com os dados referentes ao tamanho da população e às unidades federativas com as quais de alguma forma se relacionam, visto que muitas metrópoles possuem uma escala de abrangência que extrapola os limites territoriais entre os Estados. As metrópoles foram consideradas em três níveis de acordo com sua importância e centralidade: 1) Grande Metrópole nacional; 2) metrópoles nacionais e 3) metrópoles nacionais. 
Tabela 2: Rede de Influência das metrópoles- Dimensão das redes de primeiro nível

\begin{tabular}{|c|c|c|c|c|c|c|}
\hline $\begin{array}{c}\text { Rede } \\
\text { Urbana }\end{array}$ & $\begin{array}{c}\text { Número } \\
\text { de } \\
\text { capitais } \\
\text { regionais }\end{array}$ & $\begin{array}{c}\text { Número } \\
\text { de } \\
\text { Centros } \\
\text { Sub- } \\
\text { Regionais }\end{array}$ & $\begin{array}{c}\text { Número } \\
\text { de } \\
\text { Centros } \\
\text { de Zona }\end{array}$ & $\begin{array}{c}\text { Número } \\
\text { de } \\
\text { municípios } \\
\text { envolvidos }\end{array}$ & $\begin{array}{c}\text { Unidades } \\
\text { Federativas } \\
\text { abrangidas }\end{array}$ & $\begin{array}{c}\text { População } \\
\text { (2007) }\end{array}$ \\
\hline $\begin{array}{c}\text { São Paulo } \\
(1)\end{array}$ & 20 & 33 & 124 & 1028 & $\begin{array}{c}\text { SP, MG, MT, } \\
\text { MS, RO, AC }\end{array}$ & 51.020 .582 \\
\hline $\begin{array}{c}\text { Rio de } \\
\text { Janeiro (2) }\end{array}$ & 5 & 5 & 25 & 264 & $\begin{array}{c}\text { RJ, ES, BA, } \\
\text { MG }\end{array}$ & 20.750 .595 \\
\hline $\begin{array}{c}\text { Brasília (2) } \\
\text { Recife (3) }\end{array}$ & 8 & 10 & 44 & 298 & $\begin{array}{c}\text { DF, GO, BA, } \\
\text { MG }\end{array}$ & 9.680 .621 \\
\hline $\begin{array}{c}\text { Belo } \\
\text { Horizonte } \\
(3)\end{array}$ & 8 & 15 & 77 & 698 & $\begin{array}{c}\text { MG, PB, AL, } \\
\text { RN, BA }\end{array}$ & 18.875 .595 \\
\hline Salvador (3) & 6 & 16 & 41 & 486 & BA, SE, PE & 16.745 .821 \\
\hline Curitiba (3) & 9 & 28 & 67 & 666 & PR, SC & 16.178 .968 \\
\hline $\begin{array}{c}\text { Porto } \\
\text { Alegre (3) }\end{array}$ & 10 & 24 & 89 & 733 & RS, SC & 15.302 .496 \\
\hline $\begin{array}{c}\text { Fortaleza } \\
(3)\end{array}$ & 7 & 21 & 86 & 786 & CE, PI, MA, & 20.573 .035 \\
\hline Belém (3) & 3 & 11 & 10 & 161 & PA, AP, MA & 7.686 .082 \\
\hline Goiânia (3) & 2 & 6 & 45 & 363 & GO, TO & 6.408 .542 \\
\hline Manaus (3) & 1 & 2 & 4 & 72 & AM, RR & 3.480 .028 \\
\hline
\end{tabular}

Fonte: IBGE (2008), dados de 2007.

De acordo com o IBGE (2008), existem redes mais complexas em virtude da ligação com mais de um centro, como é o caso de Natal, que se insere na rede comandada por Recife e Fortaleza. Analisando a tabela, percebe-se que São Paulo é a única metrópole nível 1, o que é possível explicar pela sua grande escala de abrangência nacional, e pelo destaque também enquanto grande centro global. É notória a grandiosidade de sua região de influência, uma vez que abrange todo o país; no entanto, o IBGE (2008) considera que os estados que mais recebem essa influência se localizam no próprio Estado de São Paulo, e em parte do Triângulo Mineiro, o sul de Minas Gerais, Mato Grosso do Sul e Mato Grosso, Rondônia e Acre. São Paulo influencia diretamente e com maior intensidade, portanto, Estados da região Norte, Centro Oeste e Sudeste do país. Segundo o estudo, a região de influência de São Paulo concentra municípios que representam $28 \%$ da população brasileira, e compõem $40 \%$ do Produto Interno Bruto brasileiro (PIB).

A REGIC do Rio de Janeiro, metrópole nível 2, também é grandiosa; contempla o próprio estado, além de Minas Gerais, Espírito Santo e Bahia. De acordo com os dados do 
estudo, compõe 11,3\% da população do país e 14,4\% do PIB do País. A REGIC de Brasília, por outro lado, representa apenas $2,5 \%$ da população brasileira e $4,3 \%$ do PIB brasileiro. A sua escala de abrangência também não é tão significativa, pois influencia com maior intensidade o oeste baiano, alguns municípios de Goiás e o noroeste de Minas Gerais, mas é a rede com a maior PIB per capita.

O’ Neill (2007) considera significativo o eixo Brasília-Goiânia, presente no Planalto Central, e que influencia um amplo território, na medida em que Brasília é sede do Governo Federal, e portanto centro político, e Goiânia é metrópole precoce - a cidade é relativamente nova se comparada a outros centros do país -, dotada de uma centralização de fluxos ligados à agricultura globalizada, ao comércio, serviços e capitais, privilegiada por sua localização no centro do país e próxima de importantes capitais brasileiras.

Nesse sentido, observa-se que as metrópoles brasileiras exercem influência sobre grande parte do território nacional e concentram a maior parte da população do país, interferindo diretamente na configuração da rede urbana brasileira.

Depois de destacar alguns pontos importantes sobre a atual rede urbana brasileira, portanto, no próximo tópico analisaremos o contexto da rede urbana do Estado do Piauí de acordo com o REGIC de 2007, o que será importante para adentrarmos, no terceiro capítulo, na análise sobre as transformações recentes do Sudoeste Piauiense, em especial nas Microrregiões Alto Médio Gurguéia e Alto Parnaíba Piauiense, além do município de Corrente.

\subsection{Contexto Piauiense no REGIC 2008 e os Principais Centros Urbanos do Estado}

Analisando o contexto da rede urbana piauiense no REGIC de 2008, percebe-se que a capital regional Teresina está inserida na Região de Influência de Fortaleza, considerada como uma metrópole nível 3. A REGIC de Teresina possui, ao todo, 4.338 .876 habitantes, ao passo que, de acordo com dados do Censo de 2010-IBGE, Teresina possui 814.230 habitantes. A rede de Fortaleza, que contempla os Estados do Piauí, do Ceará, do Maranhão, e divide influência sobre a área do Rio Grande do Norte com o Recife, representa 11,2\% da população do País e apenas 4,5\% do PIB nacional - possui o menor PIB per capita de todos os centros, embora contemple três Capitais Regionais Nível A, quais sejam, Teresina, São Luís e Natal. A sua população é distribuída de maneira dispersa, sendo que apenas $15,8 \%$ residem na metrópole. 
De acordo com o IBGE (2008), a rede urbana da região Nordeste do Brasil é marcada pela grande centralidade das capitais, onde concentra-se a maior parte da oferta de equipamentos e serviços, e grande parte de seus estados possui poucos centros de nível intermediário. De acordo com Soares e Melo (2008),

Os núcleos de pequeno porte demográfico, mesmo com uma participação inferior em relação às demais, no total da população brasileira, e apresentando queda no crescimento anual, compõem o maior número de cidades no país, com destaque para as regiões Nordeste e Centro-Oeste. (SOARES; MELO, 2008, p.320).

$\mathrm{Na}$ região Nordeste do Brasil, assim, predomina uma rede de pequenos centros urbanos. Nesse sentido, as capitais nordestinas exercem o papel de centralidade urbana com maior intensidade do que outras de estados de outras regiões brasileiras.

Essa configuração da rede urbana de parte do Nordeste é resultado da influência do passado de ocupação territorial. Segundo Prado Júnior (2006), a ocupação de áreas do centro do Nordeste foi irregularmente distribuída, no que a atividade pecuária teve papel fundamental. Além disso, não houve grande desenvolvimento do comércio, o que contribuiu para a formação de pequenas aglomerações urbanas, pouco relevantes e distantes umas das outras. Nas palavras de Santos e Silveira (2001),

\footnotetext{
Herança da antiguidade da ocupação econômica, realizada no período pré-mecânico, o número de núcleos urbanos é grande em virtude da baixa mecanização do território, sua densidade é relativamente importante, mas a taxa regional de urbanização é baixa. Se as aglomerações são numerosas, a urbanização é, de modo geral, raquítica. São causas e conseqüências da fraqueza da vida de relações, formando um círculo vicioso. (SANTOS; SILVEIRA, 2001, p.272).
}

Como é possível perceber, a influência de que falávamos está pressuposta na fala dos autores. A taxa de urbanização da rede é baixa se comparado às outras regiões, mesmo com a grande quantidade de pequenos municípios. Por outro lado, é possível afirmar que a rede urbana Piauiense se caracteriza exatamente da mesma forma que o contexto Nordestino, com a presença da capital Teresina, considerada pelo REGIC de 2008 como uma Capital Regional Nível A.

Com efeito, o Estado do Piauí não possui nenhuma outra capital Regional nível B ou C além dessa cidade, o que revela grande assimetria da rede urbana do Estado. Há apenas uma grande cidade - Teresina -, e várias pequenas cidades e centros-urbanos no interior. A comparação entre o Piauí e o Estado da Bahia, por exemplo, evidencia que a rede urbana 
piauiense é muito inferior no que se refere à presença de níveis de centralidade, pois a Bahia possui, ao todo, três capitais regionais nível B - Feira de Santana, Ilhéus/Itabuna e Vitória da Conquista -, e duas capitais regionais nível C, Barreiras e Juazeiro/Petrolina.

Em relação aos Centros sub Regionais, o Estado do Piauí possui três centros nível A, como já mencionado - Floriano, Parnaíba e Picos. Na tabela abaixo, é possível observar a região de influência de cada Centro sub Regional do Estado do Piauí: 
Tabela 3: Região de Influência dos Centros Sub Regionais A do Estado do Piauí

\begin{tabular}{|c|c|c|c|c|}
\hline $\begin{array}{ll}\text { Centro } & \text { Sub } \\
\text { Regional A } & \end{array}$ & $\begin{array}{lr}\text { Centro } & \text { Sub } \\
\text { Regional B de } & \text { sua } \\
\text { influência } & \\
\end{array}$ & $\begin{array}{l}\text { Centro de Zona A } \\
\text { de sua influência }\end{array}$ & 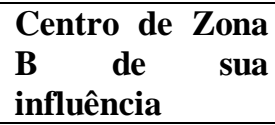 & Centro Local de sua influência \\
\hline FLORIANO & & & Uruçuí & $\begin{array}{l}\text { Barão de Grajaú (MA), Antônio Almeida (PI), Arraial (PI), } \\
\text { Bertolínia (PI), Canavieira (PI), Flores do Piauí (PI), } \\
\text { Francisco Ayres (PI), Guadalupe (PI), Itaueira (PI) } \\
\text { Jerumenha (PI), Landri Sales (PI), Manoel Emídio (PI) } \\
\text { Marcos Parente (PI), Nazaré do Piauí (PI), Pavussu (PI), } \\
\text { Porto Alegre do Piauí (PI), Rio Grande do Piauí (PI), São } \\
\text { Francisco do Piauí (PI), São José do Peixe (PI), Sebastião } \\
\text { Leal (PI) }\end{array}$ \\
\hline PARNAÍBA & & & $\begin{array}{c}\text { Araioses (MA) } \\
\text { Tutóia (MA) }\end{array}$ & $\begin{array}{l}\text { Magalhães de Almeida (MA), Milagres do Maranhão (MA), } \\
\text { Sta. Quitéria do Maranhão (MA), Santana do Maranhão } \\
\text { (MA), São Bernardo (MA), Bom Princípio do Piauí (PI), } \\
\text { Buriti dos Lopes (PI) Cajueiro da Praia (PI), Caraúbas do } \\
\text { Piauí (PI) Caxingó (PI) Cocal (PI), Cocal dos Alves (PI), } \\
\text { Ilha Grande (PI), Joaquim Pires (PI), Luís Correia (PI), } \\
\text { Murici dos Portelas (PI) }\end{array}$ \\
\hline PICOS & & & $\begin{array}{l}\text { Fronteiras (PI) } \\
\text { Jaicós (PI) } \\
\text { Paulistana (PI) }\end{array}$ & $\begin{array}{l}\text { Alagoinha do Piauí (PI), Alegrete do Piauí (PI), Aroeiras do } \\
\text { Itaim (PI), Bocaina (PI), Campo Grande do Piauí (PI), Dom } \\
\text { Expedito Lopes (PI) Francisco Macedo (PI), Francisco } \\
\text { Santos (PI), Geminiano (PI), Isaías Coelho (PI), Itainópolis } \\
\text { (PI), Marcolândia (PI), Monsenhor Hipólito (PI), Padre } \\
\text { Marcos (PI), Paquetá (PI), Pio IX (PI), Santa Cruz do Piauí } \\
\text { (PI), Santana do Piauí (PI), Santo Antônio de Lisboa (PI), } \\
\text { São João da Canabrava (PI), São José do Piauí (PI), São } \\
\text { Luis do Piauí (PI), Sussuapara (PI), Vera Mendes (PI), Vila } \\
\text { Nova do Piauí (PI), Wall Ferraz (PI) }\end{array}$ \\
\hline
\end{tabular}

Fonte: IBGE (2008), elaborada pelo autor. 
A partir dos dados da tabela, observa-se que Floriano, município localizado na Mesorregião Sudoeste Piauiense, possui vinte municípios considerados como centros locais totalmente ligados à sua região de Influência direta, e ainda centraliza a cidade de Uruçuí (PI), considerada como Centro de Zona $\mathrm{B}$, e que abrange quatro municípios em sua área de influência - Benedito Leite (MA), São Domingos do Azeitão (MA), Baixa Grande do Ribeiro e Ribeiro Gonçalves. Segundo dados do Censo de 2010 do IBGE, Floriano ${ }^{12}$ possui 57.690 habitantes, sendo, assim, o município mais populoso da porção sul do território piauiense. Além disso, está localizado no vale do Rio Parnaíba, na fronteira dos Estados do Piauí e do Maranhão, e também faz fronteira, a oeste, com o município de Barão do Grajaú, pertencente à sua Região de Influência - é justamente em função dessa posição privilegiada, já que se pode dizer que Floriano é um município de transição entre a porção sul, sudeste e norte do Piauí, que o município é central neste Estado, o que é reforçado pelo fato de que Floriano é, atualmente, considerado polo educacional do Estado do Piauí e Maranhão. O município possui grande quantidade de escolas públicas e privadas dos diferentes níveis da educação básica e abriga, também, importantes centros educacionais ligados ao ensino superior e técnico, tais como a Universidade Estadual do Piauí (UESPI), a Universidade Federal do Piauí (UFPI), o Instituto Federal de Educação, Ciência e Tecnologia (UFPI), o Serviço Nacional de Aprendizagem (SENAC), Faculdade de Ensino Superior de Floriano (FAESF), dentre outras instituições. Floriano é, ainda, o terceiro município do Estado do Piauí que mais arrecada tributos, ficando atrás apenas de Teresina e Picos, segundo dados do IBGE (2010) existem, na cidade, indústrias ligadas à fabricação de sorvetes e medicamentos, de maneira que ela pode ser também considerada um centro de comércio e serviços no Piauí.

Parnaíba, por outro lado, de acordo com os dados da tabela, possui dezesseis municípios centro locais diretamente ligados a sua região de influência, além de centralizar dois centros de zona, Araioses, que centraliza o município de Água Doce do Maranhão (MA), e Tabóia, que centraliza Paulino Neves (MA), ambos localizados no Estado do Maranhão. Segundo dados do Censo (2010) do IBGE, Parnaíba é o segundo município piauiense mais populoso, com 145.705 habitantes. Localiza-se na Mesorregião Norte Piauiense, sendo um dos quatro municípios piauienses localizados no litoral ${ }^{13}$, que, por sinal, é o menor do país. A cidade possui, também, aeroporto internacional em funcionamento. Sua economia é baseada

\footnotetext{
12 As informações dos municípios Piauienses foram coletadas do site do IBGE Cidades, em que estão disponibilizados os dados municipais.

${ }^{13}$ Além de Parnaíba, Luís Corrêa, Ilha Grande e Cajueiro da Praia também se localizam no litoral piauiense.
} 
no turismo, comércio, serviços e indústria, além de possuir importantes institutos de educação superior e profissional, como a UESPI, UFPI, IFPI, SENAC, entre outros.

Picos, por sua vez, é um município piauiense localizado na Mesorregião Sudeste Piauiense, que, segundo o Censo 2010, possui cerca de 73.417 habitantes, sendo o terceiro município mais populoso do Estado do Piauí. Sua localização, no centro do Estado, é também privilegiada. O município é centro comercial do Piauí e é conhecido pela grande produção de mel, uma das maiores do Brasil. Também concentra instituições ligadas à educação superior, o que atrai estudantes de outros municípios do Piauí e até mesmo de outros Estados brasileiros. Conforme os dados da tabela 3, Picos tem vinte e seis municípios centro locais diretamente ligados ao seu centro piauiense, e ainda centraliza três Centros de Zona: Fronteiras (PI), a qual centraliza São Julião (PI); Jaicós, a qual centraliza os municípios de Belém do Piauí (PI) e Massapê do Piauí (PI); e Paulista, a qual centraliza os municípios de Acauã (PI), Betânia do Piauí (PI), Jacobina (PI), Patos do Piauí (PI) e Queimada Nova (PI) com efeito, em função da quantidade de municípios ligados a sua região de influência, Picos pode ser considerada a principal cidade piauiense logo após a capital.

O Estado do Piauí ainda apresenta dois Centros sub Regionais nível B: Campo Maior e São Raimundo Nonato. Destaca-se que todos os centros anteriormente citados contemplam a região de influência da grande metrópole Fortaleza. 
Tabela 4: Região de Influência dos Centros Sub Regionais B do Estado do Piauí

\begin{tabular}{|c|c|c|c|c|}
\hline $\begin{array}{l}\text { Centro Sub } \\
\text { Regionais B }\end{array}$ & $\begin{array}{l}\text { Centro de } \\
\text { Zona A de } \\
\text { sua influência }\end{array}$ & $\begin{array}{l}\text { Centro de } \\
\text { Zona A de sua } \\
\text { influência }\end{array}$ & $\begin{array}{l}\text { Centro de Zona B } \\
\text { de sua influência }\end{array}$ & $\begin{array}{l}\text { Centro Local de sua } \\
\text { influência }\end{array}$ \\
\hline Campo Maior & & & $\begin{array}{l}\text { Castelo do Piauí, } \\
\text { São Miguel do } \\
\text { Tapuio }\end{array}$ & $\begin{array}{l}\text { Boqueirão do Piauí } \\
\text { (PI), Cocal de Telha } \\
\text { (PI), Jatobá do Piaú } \\
\text { (PI), Nossa Senhora de } \\
\text { Nazaré (PI), Sigefredo } \\
\text { Pacheco (PI) }\end{array}$ \\
\hline $\begin{array}{l}\text { São Raimundo } \\
\text { Nonato }\end{array}$ & & & $\begin{array}{l}\text { Antônio de Abreu, } \\
\text { Caracol }\end{array}$ & $\begin{array}{l}\text { Bonfim do Piauí (PI), } \\
\text { Coronel José Dias (PI), } \\
\text { Dirceu Arcoverde (PI), } \\
\text { Dom Inocêncio (PI), } \\
\text { Fartura do Piauí (PI), } \\
\text { São Braz do Piauí (PI) } \\
\text { São Lourenço do Piauí } \\
\text { (PI), Várzea Branca } \\
\text { (PI) }\end{array}$ \\
\hline
\end{tabular}

Fonte: IBGE (2008), elaborada pelo autor.

A análise da tabela 4 evidencia que Campo Maior possui cinco municípios centro locais diretamente ligados à sua área de influência, e centraliza dois Centros de Zona B, Castelo do Piauí e São Miguel do Tapui; o primeiro centraliza quatro municípios centro locais - Assunção do Piauí, Buriti dos Montes (PI), Juazeiro do Piauí (PI) e São João da Serra (PI) e o segundo também centraliza Assunção do Piauí. A população de Campo Maior é 45.180 habitantes, segundo o Censo (2010) do IBGE. Trata-se de um município em que há concentração das atividades ligadas ao comércio e serviços e à agropecuária, principalmente a criação de bovinos e caprinos.

Segundo a tabela, São Raimundo Nonato, por outro lado, centraliza diretamente oito municípios centros locais, além de dois Centros de Zona B: Antônio de Abreu e Caracol, que, por sua vez, centralizam o centro local Jurema (PI) e o centro local de Guaribas (PI), respectivamente. São Raimundo Nonato possui, segundo Censo 2010, 32.327 habitantes. A economia municipal baseia-se na agropecuária e no setor de serviços e comércio, do qual se destaca também o turismo, em decorrência da presença do Parque Nacional Serra da Capivara e do Parque Nacional da Serra das Confusões, considerados Patrimônio Histórico e Cultural da Humanidade pela UNESCO. Nesse município estão presentes, além da UESPI, o IFPI, a UFPI, e a Universidade Federal do Vale do São Francisco e, além disso, o Aeroporto de São Raimundo Nonato, que pode contribuir para a maior integração da porção sul do Estado à 
capital Teresina e a outros Estados brasileiros, está em fase de testes, realizando voos apenas para a capital do Estado.

O Estado do Piauí apresenta, ainda, os seguintes Centros de Zona A: Bom Jesus, Corrente, Piripiri, Oeiras, e Esperantina.

Tabela 5: Região de Influência dos Centros de Zona A do Estado do Piauí

\begin{tabular}{|c|c|c|}
\hline Centro de Zona A & $\begin{array}{l}\text { Centro de Zona } B \text { de sua } \\
\text { influência }\end{array}$ & $\begin{array}{llll}\text { Centros locais } & \text { de } & \text { sua } \\
\text { influência } & & & \\
& & & \end{array}$ \\
\hline Bom Jesus & Curimatá (PI) & $\begin{array}{lccc}\text { Alvorada do } & \text { Gurguéia } & (\mathrm{PI}), \\
\text { Colônia do } & \text { Gurguéia } & (\mathrm{PI}) \text {, } \\
\text { Cristino Castro (PI), Currais } & (\mathrm{PI}) \\
\text { Monte Alegre do Piauí } & (\mathrm{PI}) \text {, } \\
\text { Palmeira do Piauí } & (\mathrm{PI}) \text {, } \\
\text { Redenção do Gurguéia } & (\mathrm{PI}) \text {, } \\
\text { Santa Luz (PI) } & & \end{array}$ \\
\hline Corrente & $\begin{array}{l}\text { Avelino Lopes (PI), } \\
\text { Gilbués (PI) }\end{array}$ & $\begin{array}{l}\text { Cristalândia do Piauí (PI), } \\
\text { Parnaguá (PI), Riacho Frio (PI) } \\
\text { São Gonçalo do Gurguéia (PI) } \\
\text { Sebastião Barros (PI) }\end{array}$ \\
\hline Piripiri & Piracuruca (PI) & $\begin{array}{l}\text { Brasileira (PI) } \\
\text { Capitão de Campos (PI) } \\
\text { Domingos Mourão (PI) } \\
\text { Lagoa de São Francisco (PI), } \\
\text { São João da Fronteira (PI) }\end{array}$ \\
\hline Oeiras & & $\begin{array}{l}\text { Cajazeiras do Piauí (PI), } \\
\text { Colônia do Piauí (PI), } \\
\text { Floresta do Piauí (PI), } \\
\text { Santa Rosa do Piauí (PI), } \\
\text { Santo Inácio do Piauí (PI), } \\
\text { São João da Varjota (PI), } \\
\text { São Miguel do Fidalgo (PI), } \\
\text { Tanque do Piauí (PI) }\end{array}$ \\
\hline Esperantina & & $\begin{array}{l}\text { Campo Largo do Piauí (PI) } \\
\text { Joaquim Pires (PI) } \\
\text { Matias Olímpio (PI) } \\
\text { Morro do Chapéu do Piauí (PI), } \\
\text { São João do Arraial (PI) }\end{array}$ \\
\hline
\end{tabular}

Fonte: IBGE (2008), elaborada pelo autor.

A rede urbana piauiense não possui nenhum município com população abaixo de trinta mil habitantes entre as principais centralidades superiores da hierarquia urbana do Estado do Piauí. Esses municípios só aparecem no nível denominado de Centro de Zona A e B. Analisando a tabela, percebe-se que Bom Jesus ${ }^{14}$ possui oito municípios Centros Locais diretamente ligados à sua escala de influência, além de possuir ligação com Curimatá

\footnotetext{
${ }^{14}$ Alguns dados referentes ao município constarão no terceiro capítulo.
} 
(PI), considerado Centro de Zona B, o qual centraliza o município centro local de Júlio Borges.

Corrente $^{15}$, por sua vez, possui ligação com cinco municípios centro locais, e centraliza dois municípios considerados centros de zona B: Avelino Lopes (PI) - que centraliza o município de Morro Cabeça no Tempo - e Gilbués (PI), que centraliza Monte Alegre do Piauí (PI) e Barreiras do Piauí (PI).

Piripiri centraliza cinco centros locais, além de Piracuruca, centro de zona B, a qual também centraliza São José do Divino (PI). O município possui 62.600 habitantes, segundo dados do Censo 2010, e localiza-se na Mesorregião Norte Piauiense, a cerca de $160 \mathrm{~km} \mathrm{da}$ capital Teresina, em posição privilegiada.

Já Oeiras centraliza oito municípios centro locais diretamente. Sua população é de 36.266 habitantes, segundo dados do Censo 2010, e localiza-se na Mesorregião Sudeste Piauiense. A renda municipal de Oeiras é baseada no comércio.

Esperantina centraliza cinco centros locais de forma direta e está localizada na Mesorregião Norte Piauiense, com população de 37.765 habitantes segundo o Censo 2010.

Os Centros de Zona B do Estado do Piauí são os seguintes: Gilbués, Canto do Buriti, Castelo do Piauí, Uruçuí, União, Pedro II, Barras, Piracuruca, Luzilândia, Valença do Piauí, Paulistana, São João do Piauí, São Miguel do Tapuio, Jaicós, Amarante, Água Branca, Simões, Simplício Mendes, Fronteiras, Avelino Lopes, Curimatá, Anísio de Abreu, Santa Filomena, Caracol, Alto Longá. Os municípios influenciados por esses Centros de Zona B podem ser observados na tabela abaixo:

${ }^{15}$ Dados municipais presentes no capítulo III. 
Tabela 6: Região de Influência dos Centros de Zona B do Estado do Piauí

\begin{tabular}{|c|c|}
\hline Centros de Zona & Centros locais de sua influência \\
\hline Gilbués & Barreiras do Piauí, Monte Alegre do Piauí \\
\hline Canto do Buriti & $\begin{array}{l}\text { Brejo do Piauí, Eliseu Martins (PI), Pajeú do Piauí, } \\
\text { Tamboril do Piauí }\end{array}$ \\
\hline Castelo do Piauí & $\begin{array}{l}\text { Assunção do Piauí, Buriti dos Montes (PI), } \\
\text { Juazeiro do Piauí, São João da Serra (PI) }\end{array}$ \\
\hline Uruçuí & $\begin{array}{l}\text { Benedito Leite (MA), s. Domingos do Azeitão } \\
\text { (MA), Baixa Grande do Ribeiro (PI), Ribeiro } \\
\text { Gonçalves (PI). }\end{array}$ \\
\hline União & Lagoa Alegre (PI) \\
\hline Pedro II & Lagoa de São Francisco (PI), Milton Brandão (PI) \\
\hline Barras & $\begin{array}{l}\text { Boa Hora (PI), Campo Largo do Piauí, Nossa } \\
\text { Senhora dos Remédios (PI), Porto (PI) }\end{array}$ \\
\hline Piracuruca & São José do Divino (PI) \\
\hline Luzilândia & Joca Marques (PI), Madeiro (PI) \\
\hline Valença do Piauí & $\begin{array}{l}\text { Lagoa do Sítio (PI), Novo Oriente do Piauí, } \\
\text { Pimenteiras (PI) }\end{array}$ \\
\hline Paulistana & $\begin{array}{l}\text { Açauã (PI), Betânia do Piauí, Jacobina do Piauí, } \\
\text { Patos do Piauí, Queimada Nova (PI). }\end{array}$ \\
\hline São João do Piauí & $\begin{array}{l}\text { Campo Alegre do Fidálogo (PI), Capitão Gervásio } \\
\text { Oliveira (PI), João Costa (PI), Lagoa do Barro do } \\
\text { Piauí, Pedro Laurentino, Nova Santa Rita (PI), } \\
\text { Ribeira do Piauí (PI) }\end{array}$ \\
\hline São Miguel do Tapuio & Assunção do Piauí (PI) \\
\hline Jaicós & Belém do Piauí, Massapê do Piauí. \\
\hline Amarante & S. Francisco do Maranhão (MA) \\
\hline Água Branca & Sto. Antônio dos Milagres (PI) \\
\hline \multicolumn{2}{|l|}{ Simões } \\
\hline Simplício Mendes & $\begin{array}{l}\text { Bela Vista do Piauí, Campinas do Piauí, Conceição } \\
\text { do Canindé (PI), Paes Landim (PI), S. Francisco de } \\
\text { Assis do Piauí, Socorro do Piauí }\end{array}$ \\
\hline Fronteiras & São Julião (PI) \\
\hline Avelino Lopes & Morro Cabeça no Tempo (PI) \\
\hline Curimatá & Júlio Borges \\
\hline Anísio de Abreu & Jurema (PI) \\
\hline Santa Filomena & Alto Parnaíba (MA) \\
\hline Caracol & Guaribas (PI) \\
\hline Alto Longá & Novo Santo Antônio (PI) \\
\hline
\end{tabular}

Fonte: IBGE (2008), elaborada pelo autor.

Destacam-se, na tabela 6, os municípios de Castelo do Piauí, Uruçuí ${ }^{16}$, São João do Piauí e Simplício Mendes, que possuem grande influência sobre muitos municípios piauienses. Ressaltamos que Santa Filomena está ligada ao município de Alto Parnaíba-MA,

${ }^{16}$ Este município será abordado no capítulo 3. 
um Centro de Zona B, que, por sua vez, está conectado à Região de Influência de Balsas-MA, um Centro-Sub Regional B do Estado do Maranhão, ligado à Teresina.

A figura abaixo refere-se à Região de Influência da cidade de Teresina, capital Regional do Estado do Piauí:

Figura 2: Região de Influência de Teresina-PI

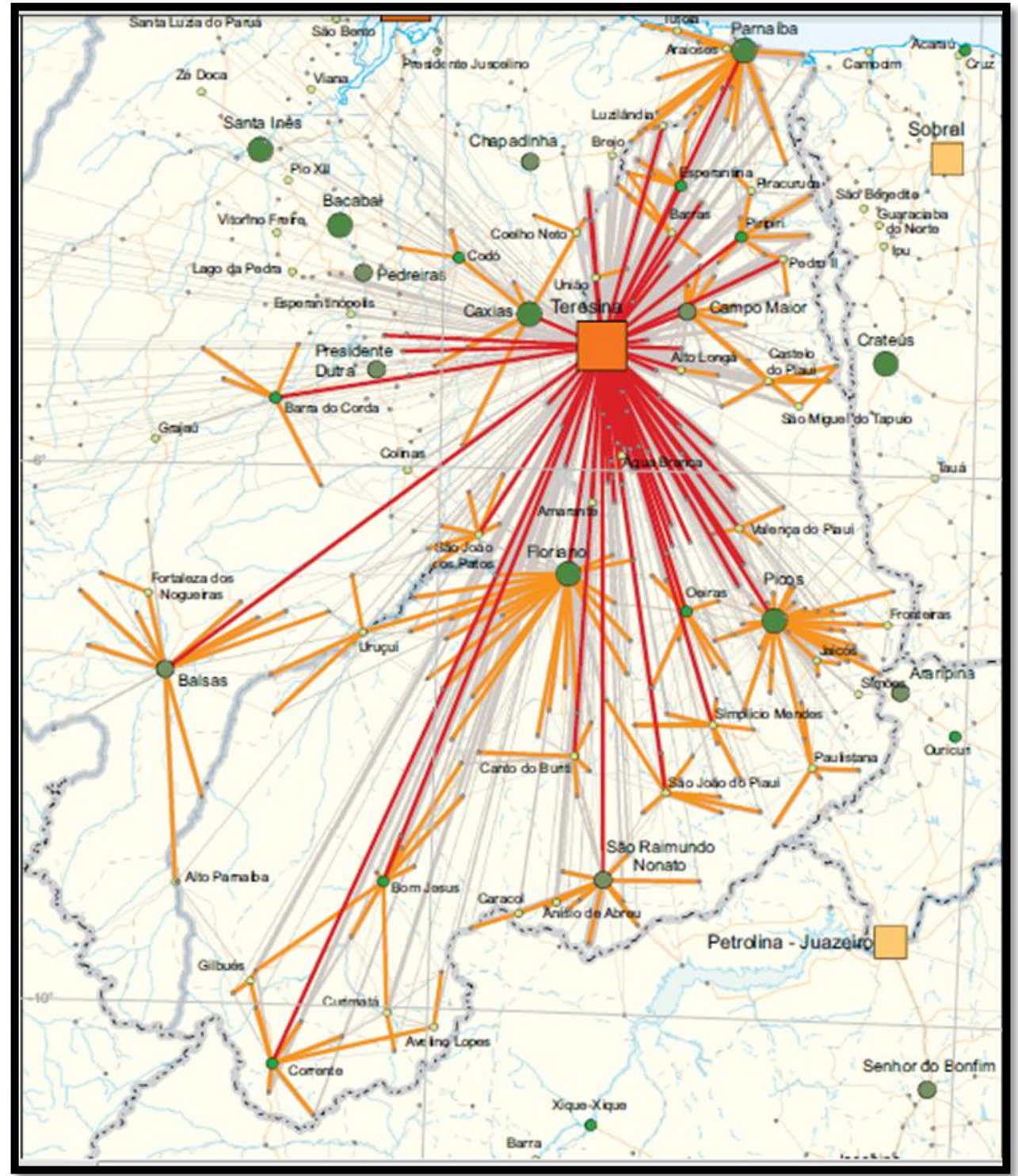

Fonte: IBGE (2008)- REGIC

De acordo com o IBGE (2008), Teresina articula uma ampla rede de cidades, mantendo superioridade hierárquica em relação a centros Subregionais A, como Floriano, Paraíba e Picos, no Estado do Piauí, e Caxias, no Maranhão. Além disso, as cidades de 
Campo Maior e São Raimundo Nonato (PI), e a cidade de Balsas, localizada no sul do Maranhão e ligada à agropecuária moderna, são todas consideradas Centros Subregionais B.

A partir do mapa, é possível dizer que Teresina influencia diretamente alguns importantes Centros de Zona A, como Bom Jesus e Corrente, cidades de grande importância para o contexto do Sudoeste Piauiense, além de cidades como Esperantina, Oeiras e Piripiri. Cidades como Canto do Buriti e Uruçuí - que está inserida na rota do agronegócio e tem se destacado como importante centro urbano piauiense -, ambas do Estado do Piauí e consideradas Centros de Zona B, são também centralizadas por Teresina.

A figura 2 evidencia, ainda, a importância da cidade de Floriano para o contexto da porção sul do Estado do Piauí, embora apenas Uruçuí, das três principais cidades piauienses ligadas à agricultura moderna, mantenha relações mais próximas com Floriano. Os outros dois municípios, Bom Jesus e Corrente, mantém relações quase que diretas com a capital Teresina. Nesse sentido, é possível dizer que, para a realidade do agronegócio, Floriano não é um município de grande relevância; de fato, poder-se-ia dizer o mesmo em relação à Teresina, já que a cidade não possui ampla ligação com as atividades da agricultura moderna.

Embora já tenhamos destacado os principais centros de influência urbanas do Piauí, é necessário nos referirmos ao passado para entendermos o processo de ocupação do Estado do Piauí, de maneira a compreender o que levou o Estado a ter uma rede urbana fragmentada com a presença de centros urbanos representativos. Esta análise do processo de ocupação territorial do Piauí contribuirá, também, para a comparação com a atual ocupação de terras no Sudoeste Piauiense, promovida especialmente pela agricultura moderna.

\subsection{Contextualização Histórica e Formação Territorial do Piauí}

Atualmente, o território do Piauí passa por inúmeras transformações econômicas, sociais, e culturais que, entre outras coisas, fazem com que o Estado tenha um dos maiores índices de crescimento do Produto Interno Bruto do país ${ }^{17}$. Contudo, em função da persistência de inúmeros problemas sociais e da fragilidade econômica, ligados à formação histórica de seu território, às limitações climáticas e a fatores geográficas, o Estado do Piauí ainda figura entre as piores economias do país. Com efeito, de acordo com Sousa (2008), é

\footnotetext{
${ }^{17}$ Segundo dados do IBGE, em 2008 o estado do Piauí obteve um crescimento de 8,8\% do seu produto interno bruto, a taxa de crescimento mais alta de todos os estados brasileiros. Em 2009, teve um crescimento de 6,2\%, ficando atrás apenas do estado de Rondônia.
} 
comum a referência negativa e mesmo pejorativa ao Piauí por parte de outras regiões do país, que não raro o veem como um Estado marcado pelo atraso em seu processo histórico, que envolveu o "[...] antagonismo entre grandes proprietários e os substratos de classe que comporam e formaram este espaço talvez explique as condições políticas que a região padece." (SOUSA, 2008, p.23).

Para explicar esse atraso é importante considerar que as condições climáticas do semiárido são marcadas pelas secas que acabam afetando diretamente o desenvolvimento econômico. Além disso, os fatores geográficos e o deslocamento do polo exportador da região Nordeste para a região Centro Sul do país influenciaram diretamente nos processos migratórios da região Nordeste. É, porém, igualmente importante evitar o erro de incorrer em determinismos ambientais e climáticos (SOUSA, 2008), pois não raro o atraso econômico tem intrínseca relação questões políticas e históricas complexas.

O processo de formação histórica do território piauiense tem início no final do século XVII, quando pequenos agricultores vindos da Bahia, próximos ao Vale do rio São Francisco, chegam ao Estado e fundam as primeiras fazendas de gado. A intensa ocupação da Zona da Mata, acompanhada do sucesso da economia açucareira, também contribuem para a ocupação do Estado, pois havia, naquela época, grande necessidade de descoberta de novas áreas interioranas do país, principalmente no Nordeste, que pudessem servir de pontos concentradores de atividades que subsidiassem e complementassem a economia brasileira baseada na produção do açúcar (ALVES, 2003). A pecuária era uma das atividades complementares da economia açucareira, e se fez presente desde o início da ocupação do território piauiense, no sudoeste e sul do Estado, próximo à divisa com a Bahia ${ }^{18}$. Nesse caso, é possível dizer que a ocupação e o início da trajetória econômica do Estado do Piauí foram baseados diretamente em uma atividade econômica considerada então secundária, pois o lucro envolvido na atividade pecuária era menor àquele gerado pela produção e comercialização do açúcar. Segundo Furtado (2005, p. 65), “[...] a renda total gerada pela economia criatória do Nordeste seguramente não excederia 5 por cento do valor da exportação de açúcar”.

De certa forma, portanto, isso se reflete nos dias atuais, em que o Estado do Piauí ainda se caracteriza por grande dependência econômica de outros centros urbanos localizados fora do Estado, como Fortaleza. Ainda assim, de acordo com FURTADO (2005), a atividade açucareira no Brasil, em função de seus grandes níveis e projeção, necessitava de outras atividades complementares para o prosseguimento do desenvolvimento, como a pecuária. Daí

${ }^{18}$ O município baiano de Formosa de Rio Preto faz divisa com o municio de Cristalândia-PI e Corrente-PI. 
a especialização e disseminação desta última em recortes territoriais de diversos Estados nordestinos, já que não se dispunha, naquela época, da possibilidade de criação de gado na faixa litorânea nordestina, uma vez que as terras eram destinadas às grandes plantações de cana-de-açúcar.

A pecuária piauiense, assim, começou a obter rápido crescimento em decorrência de condições favoráveis, tais como a presença abundante das pastagens naturais, a disponibilidade de terras e a presença de um clima sub úmido e úmido, e, portanto diferenciado, com chuvas abundantes e distribuídas (ALVES, 2003). Fica claro, assim, que existe grande ligação entre a ocupação do território piauiense e as características físicas do seu espaço.

Vale ressaltar que o Piauí localiza-se próximo à região Norte do País ${ }^{19}$, o que gera grande importância política do Estado, principalmente em decorrência do fato de que suas porções sudoeste e extremo sul pertencem ao chamado "Brasil Central" - que abrange territórios dos Estados da região Centro Oeste, além de recortes territoriais dos estados de Tocantins, localizado na região Norte do país, do oeste baiano e do sul do Maranhão -, região caracterizada pela presença do bioma cerrado e pela modernização das atividades produtivas em decorrência do agronegócio, da produção de energia, da mineração e da indústria, desde os anos 1970, e objeto de inúmeras transformações, em conjunto ao surgimento de novas dinâmicas. Dessa forma, a expansão do agronegócio é evidente na vasta região conhecida como “MAPITOBA”, que é a junção das siglas dos Estados do Maranhão, Piauí, Tocantins e Bahia (MOTA, 2012). É possível notar um novo tipo de regionalização advinda do agronegócio no país, que deflagra a nova tendência de ocupação de áreas da região Nordeste do país, devido à emergência dos Cerrados na dinâmica da produção de mercadorias agrícolas.

Nessa região próxima à Bahia, situa-se a cidade de Corrente, localizada entre os municípios com os maiores rebanhos de gado do Estado do Piaú́, e cuja atividade econômica predominante é, até hoje, a agropecuária. A sua localização é relevante justamente por que, normalmente, de outubro a março, o gado podia se deslocar para os chamados Gerais ${ }^{20}$, mais especificamente os platôs piauienses ou chapadas da região, que eram usados para a engorda

${ }^{19}$ O município de Barreiras do Piaú faz fronteira com o município de Mateiros, no Tocantins, no qual se situa parte do Parque Estadual do Jalapão.

${ }^{20}$ Terras mais elevadas localizadas na Mesorregião Sudoeste Piauiense, conhecidas como Gerais, ou Riachão, também pode ser consideradas como grandes Chapadas ou platôs, com terras planas, sendo o cerrado a vegetação predominante. As duas mais conhecidas são chamadas regionalmente de Serra do Uruçuí e do Quilombo. 
dos rebanhos no período chuvoso, em razão da grande disponibilidade de pastagens naturais excelentes para consumo animal, característica particular dessas áreas, que diminui o custo da implantação das fazendas de gado (SOUSA, 2008).

A formação histórica e territorial de grande parte do Estado do Piauí, com efeito, especialmente nas Mesorregiões Sudoeste e Sudeste Piauiense, está ligada à pecuária extensiva, que, no momento de ocupação do território piauiense, poderia ser considerada como atividade complementar, portanto secundária, ligada à interiorização do Brasil. Essa atividade influenciou o modo de vida da zona rural piauiense em vários aspectos, como, por exemplo, a alimentação baseada no consumo da carne seca e de águas das cacimbas ${ }^{21}$, nas vestimentas do homem do campo e dos vaqueiros, nos utensílios advindos do couro e até mesmo na caracterização da linguagem, bem como, é claro, na ocupação territorial do Estado.

Destacamos o papel fundamental da pecuária na ocupação do interior do Nordeste como forma de ocupação das áreas da caatinga e dos Cerrados nordestinos (localizados principalmente nos Estados do Piauí, Maranhão e Bahia). Mesmo com as condições climáticas adversas do semiárido nordestino, houve grande expansão da pecuária na região. Nas palavras de Prado Júnior,

\begin{abstract}
Apesar das condições desvantajosas - em parte graças a elas porque forçaram uma grande dispersão, as fazendas de gado se multiplicaram rapidamente, estendendo-se, embora numa ocupação muito rala e cheia de vácuos, por grandes áreas. Seus centros de irradiação são a Bahia e Pernambuco. A partir do primeiro, elas se espalham, sobretudo para norte e noroeste em direção do rio São Francisco, que já é alcançado em seu curso médio no correr do séc. XVII. De Pernambuco, o movimento também segue uma direção norte e noroeste, indo ocupar o interior dos atuais Estados da Paraíba e do Rio Grande do Norte. Um núcleo secundário que também deu origem a certo movimento expansionista de fazendas de gado é o Maranhão: elas se localizam aí ao longo do rio Itapicuru. (PRADO JÚNIOR, 2006, p. 29).
\end{abstract}

Prado Júnior (2006) também destaca o grande potencial das terras piauienses para a pecuária, que se torna um dos principais Estados engajados nessa atividade, destacando-se como abastecedor de diversos mercados brasileiros. Segundo o autor,

\footnotetext{
${ }^{21}$ Poço de água potável, natural ou "produzido pelo homem", olho d'água ou fonte.
} 
A outra direção que toma a progressão das fazendas de gado depois de atingido o rio São Francisco é para o Norte. O rio é transposto, e em fins do séc. XVII começa a ser ocupado o interior do atual Estado do Piauí. As condições naturais já são aí melhores que no setor ocupado anteriormente: pluviosidade mais elevada e melhor distribuída, cursos de água permanentes. Daí também uma forragem natural de melhor qualidade. As fazendas do Piauí tornar-se-ão logo as mais importantes de todo o Nordeste, e a maior parte do gado consumido na Bahia provém delas, embora tivesse de percorrer para alcançar seu mercado cerca de mil e mais quilômetros de caminho. (PRADO JÚNIOR, 2006, p.45).

$\mathrm{O}$ atual Estado do Piauí, portanto, consolida o processo de povoamento do interior nordestino através de suas primeiras ocupações, que, no entanto, se deram de maneira dispersa, o que pode ser facilmente verificado no atual território piauiense - as atuais cidades piauienses possuem características de localização próximas aos cursos d'água e distantes umas das outras, o que confirma a tendência de ocupação de grande parte da região Nordeste do Brasil, pois as primeiras fazendas de gado localizavam-se, de fato, distantes e desconexas umas das outras (SOUSA, 2008).

A ocupação do território piauiense também foi responsável pelo povoamento das margens do rio Balsas, no atual município de Balsas (MA), que hoje figura como o maior produtor grãos advindos da agricultura moderna do Estado do Maranhão e acaba polarizando uma vasta área. A ocupação do atual Estado do Piauí, portanto, empreendeu também a chegada de vários pequenos agricultores no território do atual Estado do Maranhão (ALVES, 2003).

\subsubsection{O Processo de Ocupação do atual Território Piauiense}

A ocupação do território piauiense foi realizada principalmente por pequenos agricultores e investidores baianos que alcançaram, primeiramente o Vale Médio do São Francisco, e, logo a seguir, as Chapadas das Mangabeiras ${ }^{22}$, à procura de terras e com o objetivo de aprisionar índios (ALVES, 2003). As primeiras ocupações foram condicionadas em grande parte aos fatores naturais, pois os vaqueiros instalavam as grandes fazendas ao longo dos cursos d'águas existentes, de maneira que a ocupação aconteceu próxima aos rios perenes e intermitentes da região, em decorrência também da atividade. A presença dos rios, portanto, condicionaram as primeiras ocupações do território Piauiense.

${ }^{22}$ Localizada entre os estados do Piauí, Bahia, Tocantins e Maranhão, possui uma rica fauna e platôs onde predominam a vegetação dos cerrados, bem como um caráter de transição entre os cerrados e a caatinga. 
Analisando a conjuntura atual do Estado do Piauí, verifica-se que esse padrão de ocupação do território transforma-se totalmente em virtude da expansão da fronteira agrícola, pois os grandes projetos são direcionados às áreas mais elevadas, sobretudo de Chapadas, e os cursos d'água deixam de ser tão relevantes, enquanto as primeiras ocupações, na segunda metade do século XVII, concentraram-se em torno de afluentes da Bacia do Rio Parnaíba, como o rio Piauí, o rio Canindé, o Paraim e o Gurguéia ${ }^{23}$, ou seja, áreas de fundo de vales úmidos, nas quais praticavam suas principais atividades: a pecuária, a caça e o extrativismo (ALVES, 2003). Os grandes produtores e empresas hegemônicas ligadas à grande produção, hoje, buscam, em contrapartida, justamente as terras planas localizadas nas serras piauienses e não se interessam pelas áreas próximas aos fundos de vales, a não ser para destinação de áreas de reservas obrigatórias.

Sendo assim, podemos dizer que a implantação do agronegócio nos Cerrados piauienses foi, em grande medida, influenciada pela associação entre as grandes empresas privadas com os diferentes governos piauienses, numa clara tentativa de estímulo ao crescimento econômico e à competitividade das atividades econômicas do Piauí (MONTEIRO, 2002).

A ocupação das primeiras áreas do Estado do Piauí, na segunda metade do século XVII, concentrou-se na porção sul e central do Estado, em decorrência da proximidade dos Estados da Bahia e Pernambuco. Esse avanço em terras piauienses foi consequência direta dos investimentos da Casa da Torre (ALVES, 2003), instituição baiana relacionada à conquista de terras e aprisionamento de índios. Porém, segundo Alves,

\begin{abstract}
Conforme o primeiro relato da capitania do Piauí, não se pode atribuir a conquista daquelas terras a um seleto grupo de desbravadores, associados à Casa da Torre. Na realidade, tal feito é de quase inteira responsabilidade de pessoas anônimas, especialmente arrendatários e vaqueiros que, correndo riscos de suas vidas, adentram nos sertões em busca de novas terras, as quais posteriormente eram repassadas aos seus tradicionais donatários, ficando em prejuízo os verdadeiros conquistadores. (ALVES, 2003, p. 60).
\end{abstract}

Os verdadeiros responsáveis pela ocupação piauiense foram, portanto, pessoas simples que possuíam um espírito aventureiro e desbravador, pois essas fazendas ficavam sob a guarda dos vaqueiros e os grandes donos das terras moravam nos principais centros urbanos baianos da época. Infere-se que não havia preocupação em desenvolver ou modernizar as

\footnotetext{
${ }^{23}$ Maior afluente do rio Parnaíba pelo lado direito, suas nascentes estão no município de Corrente, com extensão total de aproximadamente $532 \mathrm{~m}$. Entre os seus principais afluentes estão os rios Paraim, Curimatá e Corrente.
} 
atividades ali existentes, e sim em destinar os lucros para outras áreas do país, o que revela o caráter então secundário das áreas piauienses na economia nordestina e nacional, servindo como atividade complementar à produção da cana-de-açúcar e, posteriormente, à mineração.

Outro grande problema da ocupação do território piauiense foi o isolamento das fazendas de gado em relação à Zona da Mata e ao litoral nordestino em si. Segundo Alves (2003, p. 62), "Frequentemente o contato com o mundo fora das fazendas somente ocorria quando passavam por ali os transportadores das boiadas; eram eles que levavam e traziam notícias de outras áreas". Portanto, o Piauí teve um isolamento político, econômico e até mesmo físico, pois, no início do século XVIII, a presença de estradas ligando as fazendas era bem reduzida e de difícil acesso (ALVES, 2003).

É importante ressaltar, além do mais, que a pecuária extensiva, a base da economia piauiense, não pôde criar uma classe média em virtude do fracasso na construção de uma economia interna consolidada, já que dependia de outras capitanias em outras atividades, como no comércio e agropecuária. A pequena e lenta expansão dos centros urbanos no Piauí impossibilitou maior consolidação e fortalecimento da economia piauiense e manteve o caráter de dependência a outros centros urbanos de outras áreas fora do território piauiense (SOUSA, 2008). Podemos afirmar que a economia local não era suficiente para a promoção e consolidação do comércio nos centros urbanos piauienses do final do século XVII, e, assim, todas essas características de irregularidades das ocupações e alto grau de concentração de terras impossibilitaram o desenvolvimento de centros urbanos e até mesmo a constituição das primeiras vilas de maneira mais rápida.

No final do século XVIII, porém, a pecuária piauiense desenvolveu-se bastante, tornando a capitania do Piauí um dos maiores e mais importantes produtores de gado vacum e com rebanhos cavalar ${ }^{24}$ de todo o país naquele momento (SOUSA, 2008). A produção era destinada ao abastecimento de Pernambuco e Bahia - os rebanhos do centro da capitania, onde se localizava Oeiras (na época, capital do Piauí), eram destinados a Pernambuco, e os rebanhos da porção sul do Estado, região da Chapada das Mangabeiras, à Bahia, em função da proximidade geográfica (ALVES, 2003).

Com efeito, a pecuária piauiense expandiu-se de forma tão impressionante que acabou chegando a outras capitanias, atuais Estados do Maranhão, Pará, Minas Gerais, Paraíba, Rio Grande do Norte, Rio de Janeiro, e até mesmo à Guiana Francesa (SOUSA 2008). Segundo Sousa (2008), somente a antiga vila de São João da Parnaíba abatia, em 1762, 13.000 cabeças

\footnotetext{
${ }^{24}$ Criação de bovinos para comércio da carne e criação e domesticação de cavalos e equinos.
} 
de gado. O porto da Parnaíba recebia cerca de dez embarcações por ano, partindo para outros Estados logo em seguida. Ainda de acordo com Sousa (2008), em 1771 Parnaíba abatia 40.000 cabeças de gado, o que representava $25 \%$ da produção de bovinos piauienses. A não reversão dos lucros em investimentos na região, porém, que, caso contrário, dariam ao Piauí caráter de dependência aos principais centros, levou à não consolidação, integração e efetivação da sua unidade política, econômica, e até mesmo cultural.

Outra questão que contribuiu para o grande fortalecimento da pecuária foi o caráter secundário que a agropecuária possuía nas grandes fazendas, pois as melhores terras eram destinadas exclusivamente às pastagens para consumo dos rebanhos de gado. Dessa forma, a atual configuração espacial do Piauí foi influenciada pela atividade criatória, pois as fazendas eram marcadas pelas grandes extensões e por grande dispersão da população, o que se reflete nas características dos limites territoriais atuais do Piauí: o alargamento ao sul do Estado e o estreitamento no litoral, devido à intensidade das atividades pecuárias na porção central e sul do Estado (ALVES, 2003). Assim, a atividade pecuária piauiense influenciou diretamente a existência de inúmeras áreas na porção sul do Estado com baixa densidade demográfica, pois, segundo Furtado (2005, p. 66), “[...] a população que se ocupava com a atividade criatória era evidentemente muito escassa". Ainda de acordo com o autor, a mão de obra das grandes fazendas de gado era baseada no aprisionamento de indígenas, forçando-os a adaptarem-se à atividade econômica em questão.

As poucas atividades relacionadas à agricultura eram praticadas apenas para a subsistência dos moradores. Em alguns casos, os pequenos proprietários de terra realizavam a troca de parte da sua produção por algumas cabeças de gado de grandes pecuaristas da região, que, em alguns períodos do ano, traquejavam o gado para outras áreas abundantes em pastagens naturais. Normalmente, o gado utilizado para escambo já não suportava mais as grandes viagens, o que não dava aos vaqueiros muitas opções a não ser deixarem os bovinos pelo caminho ou trocarem-nos por alimentos cultivados por alguns moradores locais, que localizavam-se próximos às estradas (SOUSA, 2008).

O declínio da atividade pecuária piauiense começou já em meados do século XVIII, em decorrência das características internas de organização da atividade criatória, já que as grandes fazendas eram concentradas em grandes latifúndios e baseadas na exploração extensiva. Além disso, a desconexão entre as fazendas e inexistência de centros urbanos consolidados no Piauí contribuiu para a crise, na medida em que impedia que o comércio fosse realizado dentro do território piauiense e gerava grande dependência do Piauí em 
relação aos grandes centros urbanos localizados fora dos seus limites, especialmente aos atuais Estados da Bahia e Pernambuco.

Soma-se, a tudo isso, o caráter extensivo das atividades pecuárias, baseadas em pastagens naturais, sem cercas nas propriedades, que fazia com que o gado vivesse solto (SOUSA, 2008). Alguns condicionantes externos, como a grande concorrência gaúcha no comércio de carne, responsável por suplantar grande parte da freguesia piauiense em outros Estados, também contribuíram para a queda da atividade; O Rio Grande do Sul tinha como vantagens a modernização e as condições naturais mais favoráveis para a atividade pecuária (ALVES, 2003).

Além disso, de acordo com Furtado (2005, p.66), “[...] à medida com que os pastos se distanciavam do litoral, os custos iam crescendo, pois o transporte do gado se tornava mais oneroso". Como a atividade criatória no Nordeste utilizava uma grande quantidade de terras, baseadas nas pastagens naturais, a necessidade de expansão dessa atividade levou à inserção de novas áreas distantes do litoral, como no caso piauiense, o que fazia com que os preços em relação ao transporte aumentassem consideravelmente. Nesse caso, embora a atividade pecuária piauiense tenha alcançado um elevado nível de produção, ela gerava muitos custos em razão da distância em relação à Zona da Mata.

A decadência de alguns mercados, como o da Zona da Mata no século XVIII - o comércio de açúcar estava em queda devido à concorrência do açúcar produzido na Antilhas, pertencentes aos ingleses e holandeses (ALVES, 2003), também constituiu fator responsável pela crise da pecuária piauiense. Outros fatores, de acordo com Furtado (2005), também contribuíram para a crise da economia açucareira, como, por exemplo, o aumento do preço dos escravos e emigração da mão de obra especializada, atraída agora pelas atividades mineradoras em outras áreas do país.

A crise da atividade pecuária fez com o que a mesma se concentrasse ao nível interno - basicamente, portanto, a produção pecuária passa a ser destinada à demanda de alimentação interna do Estado do Piauí, caracterizada, em algumas áreas, como um meio de subsistência. O declínio da atividade pecuária no Estado do Piauí contribui, é claro, para a atual configuração econômica e territorial do Estado.

Sendo assim, torna-se necessário analisarmos o atual panorama de modernização agrícola no Piauí, atividade econômica em expansão nesse Estado e que possui características diferentes em relação à atividade pecuária inicialmente estabelecida. No entanto, precisamos debater sobre a temática da modernização agrícola no Brasil, sobretudo nos Cerrados. 


\section{CAPÍTULO II - MODERNIZAÇÃO AGRÍCOLA NO CERRADO BRASILEIRO: TRANSFORMAÇÕES SOCIOESPACIAIS}

Novas reflexões sobre as recentes dinâmicas e tendências ligadas aos processos hegemônicos são essenciais para o conhecimento científico. Nesse sentido, o debate sobre a temática da modernização agrícola revela-se uma discussão relevante para a ciência geográfica e demais áreas do conhecimento associadas e complementares, na medida em que é um processo inerente às reconfigurações socioespaciais e gera de grandes impactos econômicos, sociais, ambientais, políticos e culturais.

O avanço da modernização agrícola em diferentes recortes territoriais de Unidades da Federação impacta diretamente os espaços urbanos e rurais. A paisagem urbana se reconfigura com chegada do chamado progresso e impõe novas padronizações e realidades, inclusive com novas atividades e tendências produtivas e econômicas, o que mostra a força e potencialidade pujante de um evento hegemônico. A paisagem do campo também sofre grande metamorfose com o advento da expansão dos grandes projetos, com o maior fluxo de máquinas ligadas à grande produção, e, sobretudo com o desmatamento e substituição de paisagens naturais, principalmente dos Cerrados, por paisagens praticamente homogêneas do cultivo de soja, do milho, do algodão, do sorgo, da cana de açúcar, do arroz, dentre outras culturas agrícolas.

Conforme afirma Oliveira (1999, p.94), “O Estado atuou estimulando esses setores competitivos, deixando praticamente abandonados aquelas culturas que têm se constituído, historicamente, na alimentação dos trabalhadores brasileiros", inclusive com a expansão de atividades ligadas à pecuária, principalmente da criação de bovinos, que é direcionada ao mercado externo, como já mencionado no capítulo anterior, e que caracteriza, assim, a agropecuária moderna do país, mais complexa que simplesmente agricultura moderna.

De acordo com Corrêa (2000),

O campo se adapta, metamorfoseia-se com relativa facilidade às demandas da formação espacial da qual faz parte. Fala-se em "urbanização do campo" e "industrialização da agricultura", como expressões do papel da cidade, sobretudo das grandes metrópoles, nas transformações do campo. (CORRÊA, 2000, p.125).

O autor evidencia o processo de urbanização e industrialização do campo, o que, de certa forma, amplia uma visão já bem difundida no Brasil, que prevê o fim do campo brasileiro. O foco da nossa discussão, contudo, é outro: o da expansão da agricultura científica 
para o campo brasileiro, e a maneira isso como gera ressignificações das cidades envolvidas na modernização da estrutura agrária e econômica, embora muitos municípios sejam excluídos desse processo, o que contribui para a acentuação das desigualdades dentro de uma mesma região ou de um mesmo estado.

Analisaremos, agora, a passagem em que Santos (2004) aborda a transformação das paisagens naturais em decorrência da expansão de certas atividades econômicas, por meio da instalação de sistemas de engenharia ligados à produção. Nas palavras do autor,

[...] tais investimentos, cuja tendência é dar-se, cada vez mais, em forma de capital fixo, modificam o meio ecológico através de sistemas de engenharia que, superpondo-se uns aos outros total ou parcialmente, vão modificando o próprio meio ecológico, adaptado às condições emergentes da produção. (SANTOS, 2004, p.18).

Isso evidencia, de certa forma, a influência de tendências modernizantes e globalitárias no campo brasileiro. No caso da agricultura moderna, pode-se citar a instalação dos grandes projetos, com sedes de fazendas equipadas e ligadas ao mercado global de commodities de grãos, o que novamente revela a grande ligação da agricultura moderna com o panorama econômico mundial e com o processo de globalização.

Corrêa (2000), por sua vez, aponta um dos motivos que influenciou diretamente a inserção do Brasil no processo de globalização e que contribuiu para a integração nacional:

\footnotetext{
Industrialização do campo, fase além da simples modernização da agricultura. Implica ela na reestruturação fundiária e das relações sociais de produção, em sistemas agrícolas de cultivos contínuos, por vezes associado a uma rotação de culturas e no abandono da tradicional rotação de terras, em novos cultivos, dos quais o da soja torna-se emblemático, e na adoção de novas variedades de plantas e animais, muitos dos quais produzidos em estações experimentais. (CORRÊA, 2001, p.427)
}

Todas essas novas tendências e realidades do meio rural abordadas pelo autor influenciam diretamente na sua reestruturação e originam uma paisagem de maior vazio demográfico, resultando no aumento do êxodo rural, tanto para grandes centros urbanos brasileiros, como para pequenos e médios. Segundo Moura (2009, p.18), “[...] esse mundo rural modernizado esvazia-se de grandes contingentes populacionais e isola pedaços do território, incapazes de cumprir as exigências de uma produção que se opera sob racionalidades externas".

Esse esvaziamento do mundo rural abordado por Moura (2009) atrela-se à questão das disputas fundiárias presentes nessas áreas de modernização agrícola. A questão do êxodo rural 
e da expropriação da terra do pequeno produtor é abordada por Martins (1986), que defende que o principal fator da expansão do capitalismo através de processos hegemônicos é justamente o fato de que

[...] os trabalhadores se transformam em trabalhadores livres, isto é, libertos de toda propriedade que não seja a propriedade da sua força de trabalho, da sua capacidade de trabalhar. Como já não são proprietários nem dos instrumentos de trabalho nem dos objetos, das matérias-primas, empregados no trabalho, não têm outra alternativa senão a de vender sua força de trabalho, ao patrão. (MARTINS, 1986, p.152).

Das inúmeras polêmicas relacionadas à agricultura moderna, uma é a questão do trabalho, que envolve as condições que o trabalhador encontra em grandes projetos, e o baixo emprego de mão de obra no campo modernizado, o que obrigada o morador e (ou) trabalhador rural a migrar para cidades em busca de trabalho.

De certa forma, porém, a partir de uma visão mais abrangente, o fluxo de pessoas residentes no campo que migram para as cidades, em razão da modernização da expansão das atividades agropecuárias, amplia o processo de urbanização no país. É pertinente a fala de Oliveira (1999): "Na formação territorial capitalista do Brasil esses processos contraditórios produzem/geram movimentos de concentração da população, primeiro nas regiões metropolitanas, depois nas capitais regionais e em geral nas cidades" (OLIVEIRA, 1999, p.75).

É preciso, ainda, considerar a ampliação das múltiplas desigualdades e as possibilidades da suplantação dos pequenos agricultores brasileiros. Segundo Oliveira (1999),

\begin{abstract}
O estudo da agricultura brasileira deve ser feito levando-se em conta que o processo de desenvolvimento do modo capitalista de produção no território brasileiro é contraditório e combinado. Isso quer dizer que, ao mesmo tempo que esse desenvolvimento avança reproduzindo relações especificamente capitalistas (implantando o trabalho assalariado pela presença no campo do bóia-fria), ele (o capitalismo), produz também, em igual e contraditoriamente, relações camponesas de produção (pela presença e aumento do trabalho familiar no campo). (OLIVEIRA, 1999, p.73).
\end{abstract}

O autor afirma, portanto, que a intensidade com que o modo capitalista de produção se alastra, através da agricultura moderna/científica, é proporcional à resistência a essa expansão, pois a agricultura familiar continua a resistir ao modelo hegemônico. $\mathrm{O}$ seu ponto de vista, por conseguinte, nega a ideia de que a agricultura moderna acabará suplantando a pequena agricultura familiar. Com efeito, também Martine (1989) considera essa possibilidade uma 
falácia, pois, nas suas palavras, “[...] vários trabalhos documentam a persistência, e até crescimento, do setor informal e da pequena produção familiar, seja ela urbana ou rural, até em países de capitalismo avançado (MARTINE, 1989, p.19)".

Algumas características do processo de globalização em relação direta com a modernização da agricultura são citadas por Santos (2008), quais sejam

\begin{abstract}
A exacerbação das especializações produtivas no nível do Espaço; a transformação dos territórios nacionais em espaços nacionais da economia internacional; a concentração da produção em unidade menores, com o aumento da relação entre produto e superfície; aceleração de todas as formas de circulação; a produtividade espacial como dado na escolha das localizações; a tensão crescente entre localidade e globalidade à proporção que avança o processo de globalização. (SANTOS, 2008, p.47).
\end{abstract}

Os grandes índices de desigualdades sociais do Brasil, em escala tanto regional como nacional, indicam a relevância dessa temática. Sendo assim, o processo de modernização da agricultura deve ser analisado de forma criteriosa em relação às reais possibilidades de acentuação das desigualdades sociais e regionais. Ademais, a compreensão do contexto do surgimento do processo de modernização da agricultura face à emergência dos processos e atores hegemônicos é vital para o entendimento das novas dinâmicas do país.

A modernização agrícola não pode ser desvinculada do quadro do pós-guerra e do período denominado como revolução da ciência, que influencia a mudança do padrão da produção de alimentos, acompanhada pela expansão das atividades ligadas à agricultura moderna. Nesse caso, pode-se considerar que a modernização da agricultura surge em um contexto marcado por incertezas, crises rupturas.

De acordo com Kuhn (1998), as mudanças de caráter científico e o surgimento de novas realidades e paradigmas apresentam, ao mesmo tempo, um caráter construtivo e destrutivo, pois, segundo o autor, a emergência de novas ideias é precedida por períodos de insegurança em um contexto problemático. Os novos contextos e realidades geradas a partir das crises e incertezas são claras respostas às crises. Nas palavras do autor,

Na manufatura, como na ciência- a produção de novos instrumentos é uma extravagância reservada para ocasiões que o exigem. O significado das crises consiste exatamente no fato de que indicam que é a chegada a ocasião para renovar instrumentos. (KUHN, 1998, p.105). 
No caso da agricultura científica, ou moderna, as mudanças, sobretudo na renovação dos "instrumentos", reflexo da revolução técnica ${ }^{25}$, podem ser observadas no surgimento de máquinas agrícolas, insumos, fertilizantes, adubos químicos e sementes selecionadas voltadas para a nova tendência e visando o aumento da produção de alimentos em nível mundial, inclusive em países subdesenvolvidos, a partir da década de 1960. Analisando o contexto atual de grande produção ligada à agropecuária moderna, porém, é possível notar que a produção e a produtividade mundial aumentaram de forma impressionante, mas a fome não foi superada - o discurso de justificativa da expansão da agricultura nos países subdesenvolvidos pode ser chamado, portanto, de verdadeira falácia, que podemos explicar com a observação de que os grandes agentes hegemônicos e processos globalizantes objetivam de maneira intensa a busca pelo lucro e pelo poder. Poder-se-ia mesmo afirmar que o objetivo da agricultura moderna não é a produção de alimentos para a sociedade, mas sim a obtenção de lucro e o acúmulo de riquezas. De acordo com Martine (1989, p.5), até então, “[...] embora a modernização viesse se processando desde o pós-guerra, a tecnologia agrícola utilizada na maior parte do país ainda era bastante rudimentar até meados da década de 60 ". A modernização agrícola, portanto, chega ao Brasil do pós-guerra, no contexto da Guerra Fria, envolvendo Estados Unidos e União Soviética.

A renovação dos instrumentos de que fala Kuhn (1998) possui um significado amplo, pois pode representar também as mudanças geradas no padrão da produção de alimentos, com a incorporação de tecnologia na produção. No entanto, deve-se considerar que, até o período atual, o chamado saber camponês - denominado por Martine (1989) - ainda possui grande importância na questão da produção moderna (MARTINE, 1989), na medida em que as máquinas ainda não foram capazes de substituir a mão de obra e os saberes humanos, principalmente no que concerne ao acompanhamento da evolução da produção: o contato diário com o cultivo das diferentes culturas agrícolas ainda é necessário.

É possível dizer que, no início do período pós-guerra, o suposto grande objetivo dessa expansão da agricultura para os países subdesenvolvidos, então conhecidos historicamente como países de Terceiro Mundo (ELIAS, 2006a), era o de modificar a estrutura da produção de alimentos visando a superação da fome em países mais pobres e maior segurança alimentar da humanidade. Este é um recurso discursivo, técnico, econômico e geopolítico muito utilizado para justificar o celeiro central brasileiro, a nível nacional e mundial.

\footnotetext{
${ }^{25}$ Entende-se que a revolução técnica se diferencia da revolução científica, pois esta última revela uma mudança não apenas dos instrumentos, mas também dos paradigmas, e desencadeia rupturas nas formas de pensar.
} 
As transformações e as reestruturações produtivas da agropecuária, como já dito, afetaram diretamente a sua base técnica, econômica e social, gerando novas transformações dos espaços agrícolas e urbanos (ELIAS, 2006a). Nesse sentido, a agricultura incorpora ideais modernizantes como clara consequência da revolução tecnológica do século XX (ELIAS, 2006b), justamente a razão pela qual é necessário analisar a relação intrínseca entre a modernização da agricultura e o período das guerras. As inovações na agricultura, como o surgimento de máquinas agrícolas, fertilizantes, adubos químicos, venenos e técnicas de correção do solo são consequências diretas e indiretas dos avanços tecnológicos do pósguerra. Nesse sentido, a "revolução científica" do período da Segunda Guerra Mundial contribuiu fortemente para a modernização da agricultura, pois acarreta na migração de algumas indústrias de armamentos, de indústria pesada, química e de aviação para a fabricação de tratores e máquinas agrícolas (ALVES, 2012a), o que é visível no padrão estético de algumas máquinas modernas usadas na produção de grãos, semelhantes aos tanques de guerra desenvolvidos no contexto da corrida armamentista.

O cenário de inovações na agricultura marca, assim, um novo contexto na produção de alimentos mundial: a denominada Revolução Verde, que introduz mecanismos científicos e possibilita a adaptação do cultivo de algumas culturas em diferentes ambientes e condições climáticas, sejam elas adversas ou favoráveis. Esse processo tem início nos Estados Unidos, em que tiveram lugar uma série de inovações nos processos produtivos e de avanços na tecnologia de produção (MATOS; PESSÔA, 2011). Essa revolução foi determinante para a aceleração da produção agrícola, principalmente para a soja, que, depois da Segunda Guerra Mundial, passou a ser consumida com maior intensidade em âmbito mundial, inclusive para fabricação de ração animal e óleo de soja misturado com o milho, em decorrência dos novos padrões de consumo de proteínas (ALVES, 2012a).

Além disso, é importante salientar que a modernização da agricultura e produção de grãos como a soja e milho acaba consolidando as mudanças no padrão alimentar da sociedade atual. Elias (2006b, p.1) cita alguns itens inseridos no que ela chama de nova alimentação mundial: “[...] alimentos semiprontos, congelados, enlatados, iogurtes, margarinas, maioneses produtos derivados do açúcar, bebidas lácteas, óleo de soja, produtos diet, light, desnatados, bebidas isotônicas, refrigerantes, legumes pré-cozidos etc.” A autora ainda comenta o novo contexto de valorização da ciência e da tecnologia voltada para a produção agropecuária: 
Desde que a ciência, a tecnologia e a informação passaram a se constituir nas mais marcantes forças produtivas, o homem imprime intensa velocidade de renovação das forças produtivas e, dessa forma, passa a ter grande poder de interferência na natureza. Estas novas possibilidades modificaram radicalmente a relação homemnatureza. (ELIAS, 2006a, p.31).

Enfatizamos, assim, que a modernização da agricultura é um processo complexo, que altera intensamente a relação entre o homem e natureza. No Brasil, o bioma dos Cerrados, localizados em grande parte do Brasil Central, sofre profundas alterações, que incluem o aumento do desmatamento como consequência da expansão da área plantada em muitos Estados presentes nessa região. Ademais, muitas áreas de transição e de contato entre biomas também estão sendo inseridas nesse processo de expansão agrícola, como é o caso do sul do Piauí, do oeste baiano e do sul do Maranhão, agravando ainda mais a transformação da natureza das questões socioespaciais.

Na figura abaixo, pode-se observar a localização dos Cerrados.

\section{Figura 3: Área Original dos Cerrados- Brasil Central}

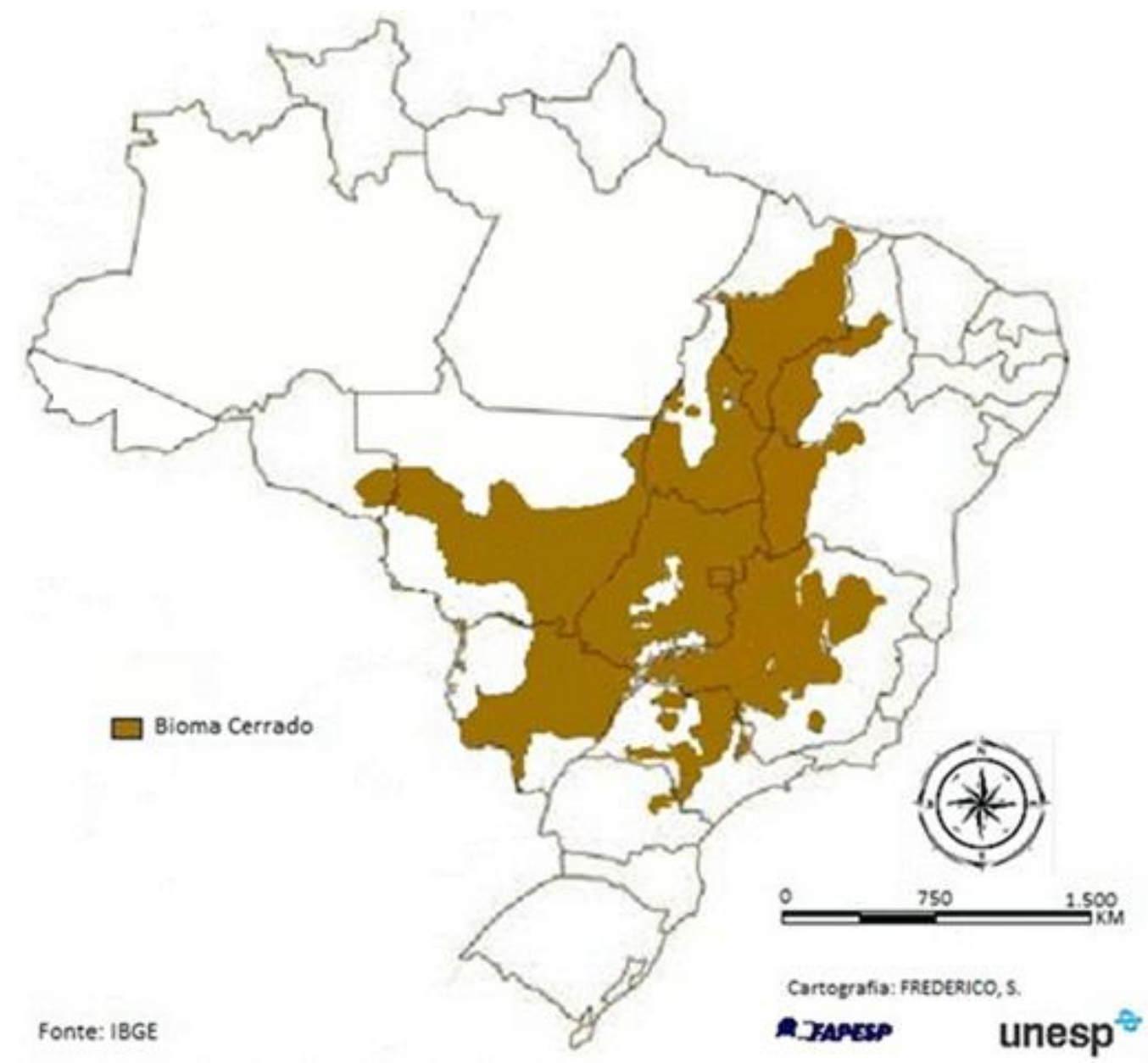

Fonte: FREDERICO (2013), disponível em <http://confins.revues.org/8153?lang=pt\#quotation> 
Percebe-se que o domínio dos Cerrados está presente em todas as regiões brasileiras. As áreas alvo da agricultura moderna são as que possuem cerrado que ocupa "[...] maciços planaltos de estrutura complexa, dotados de superfícies aplainadas de cimeira, e um conjunto significativo de planaltos sedimentares compartimentados, situados em níveis que variam entre 300 e 1700 m de altitude.” (AB' SABER, 2003, p.117-118). Essa ocupação do cerrado marca uma ruptura em relação ao que se pensava sobre a potencialidade produtiva desse bioma, já que, de acordo com Inocêncio e Calaça (2009), esse bioma era considerado um grande sertão condenado à estagnação econômica, ao atraso e à falta de perspectivas de desenvolvimento. Foi, assim, o avanço das pesquisas agropecuárias e o desenvolvimento de insumos que evidenciaram o grande potencial dos Cerrados. De acordo com Santos (1999), entretanto, embora as condições artificialmente criadas por conta do meio técnico científico informacional sobressaiam, é preciso ainda considerar as condições naturais de cada lugar. Segundo Elias (2006b),

[...] a agropecuária tornou-se crescentemente dependente do processo científicotécnico de base industrial, e minimiza a anterior vantagem relativa representada pela produção localizada nos melhores solos, nas topografias mais adequadas, entre outros. Além disso, aumentou a possibilidade de aproveitamento dos solos menos férteis e de ocupação intensiva de territórios despreparados para tal atividade, relativizando-se as questões locacionais, antes imprescindíveis. (ELIAS, 2006b, p.1).

O cerrado possui características propícias ao desenvolvimento da agricultura moderna, como, por exemplo, o aplainamento do relevo, que facilita o trabalho das máquinas, e que são encontradas principalmente nas áreas de chapadões com presença da vegetação dos Cerrados, localizadas nas áreas de planaltos do Brasil Central, ou seja, o Planalto Central Brasileiro. De acordo com Ab’Saber (2003), os Cerrados são

\footnotetext{
Certamente o domínio morfoclimático brasileiro onde ocorre a maior massividade, extensividade e homogeneidade relativa de formas topográficas planálticas do Brasil intertropical. [...] Nunca será demais lembrar que o conjunto espacial do domínio dos Cerrados, nos altiplanos centrais, representa mais ou menos a metade da área total do gigantesco conjunto de terras altas, de mediana altitude (600 a $1100 \mathrm{~m})$, designado por Planalto Brasileiro. (AB' SABER, 2003, p.122).
}

Essas áreas se estendem a diversos estados brasileiros dominados pelos Cerrados, onde se observa a remoção dessa vegetação para a instalação dos grandes projetos de agricultura moderna. 
Hoje, especialmente no chamado Brasil Central ${ }^{26}$, o país apresenta um quadro de expansão da fronteira agrícola, uma extensa região com presença abundante da vegetação dos Cerrados, onde a ocupação territorial pela agricultura moderna envolveu uma série de fatores naturais, políticos, econômicos e culturais. Faz-se necessário, portanto, explicar o conceito de fronteira agrícola, que, de acordo com Frederico (2013, p.20), são “[...] as áreas ocupadas por uma agricultura intensiva em capital e tecnologia, em substituição à vegetação original, as áreas de pastagens e as formas tradicionais de agricultura praticadas por pequenos agricultores." Ab'Saber (2003) ainda aponta que,

Em nosso país, no decorrer três décadas, algumas regiões mudaram em quase tudo, incorporando padrões modernos que, muitas vezes, abafaram por substituição velhas e arcaicas estruturas sociais e econômicas. Tais mudanças se ligaram, sobretudo, à implantação de novas infra-estruturas viárias e energéticas e à descoberta de impensadas vocações dos solos regionais para atividades agrárias rentáveis. (AB'SABER, 2003, p.116).

O autor, assim, caracteriza muito bem a expansão de atividades agropecuárias modernas para áreas do Brasil Central, região que se encontra, de acordo com o autor, intimamente conectada ao crescimento econômico brasileiro. De acordo com Frederico (2013, p.4), “Atualmente, o Cerrado é a principal região produtora de grãos, apresentando os maiores índices de produtividade em diversas culturas como soja, algodão herbáceo, milho e café.” É preciso, contudo, realizar uma leitura crítica desse processo em relação aos seus efeitos contraditórios nas características socioespaciais de cada área ocupada.

\subsection{Processo de Modernização Agrícola: periodização e expansão da fronteira agrícola para os Cerrados}

A modernização agrícola deve ser entendida como um processo de consolidação de grandes empresas e corporações transnacionais, que acabam dominando o segmento da agricultura voltada para a produção de grãos, especialmente de soja. Frederico (2013) define o termo modernização agrícola no Brasil como sendo

\footnotetext{
${ }^{26}$ O Brasil Central compreende tanto a região Centro-Oeste brasileira como também recortes territoriais de outros estados da região Nordeste- Sul do Maranhão, Sudoeste Piauiense e Oeste baiano, além da região CentroNorte de Tocantins, localizado na região Norte do país, e o norte de Minas Gerais.
} 
[...] a nova forma de organização do agronegócio brasileiro, emergente na década de 1990, caracterizada principalmente pela incorporação das novas tecnologias da informação ao campo e pela menor intervenção estatal. Trata-se da transição de um período de forte intervenção estatal na agricultura, predominante desde a década de 1990, para uma maior regulação das empresas mundiais do comércio agrícola (tradings); e do aperfeiçoamento e uso mais intensivo dos mecanismos químicos, biológicos e mecânicos difundidos pelo paradigma da Revolução Verde. (FREDERICO, 2013, p.1).

O autor atribui grande importância à década de 1990 no que diz respeito à expansão da modernização agrícola no Brasil, o que se deve à neutralidade ${ }^{27}$ do Estado nessa década em relação aos agentes envolvidos no contexto do neoliberalismo, que com tal conduta maximizava as possibilidades de expansão do agronegócio promovido por empresas multinacionais. Segundo Thomaz Junior (2010),

Esse processo transformou o meio rural com a mecanização, a utilização de insumos químicos e sintéticos, a industrialização, a consolidação dos negócios à base dos grandes conglomerados agroquímicos alimentar-financeiros, em transações transcontinentais. (THOMAZ JUNIOR, 2010, p.3).

Nesse caso, a liberalização econômica, com o advento do neoliberalismo, possibilitou a intensificação da modernização agrícola de algumas áreas, dentre as quais se destaca o Sudoeste Piauiense, que, de acordo com Monteiro (2002), foi inserido na rota do agronegócio e ocupado com maior intensidade a partir da década de 1990. Inferimos, assim, que a ação do Estado nesse período possibilitou a expansão da agricultura moderna de forma mais intensa.

Frederico (2013) propõe a divisão da modernização agrícola brasileira em dois períodos:

[...] um primeiro, entre as décadas de 1960 e 1980, caracterizado pela adoção do paradigma da Revolução Verde, pela constituição dos complexos agroindustriais e pela centralidade da atuação do Estado; e um segundo, a partir da década de 1990, pautado no uso das novas tecnologias da informação e comunicação (NTIC) no campo e na "desregulamentação" política e econômica. (FREDERICO, 2013, p.6).

O primeiro período proposto pelo autor é caracterizado pela política organizacional da agricultura brasileira, com a atuação marcante do Estado, no sentido de fortalecer as atividades da agricultura moderna e os complexos agroindustriais (CA's). Este processo, arquitetado pelo Estado e com incentivo aos grandes agricultores e empresas, iniciou-se na

\footnotetext{
${ }^{27}$ Neutralidade no sentido de permitir que as empresas e agentes hegemônicos desenvolvessem suas atividades econômicas se um devido controle.
} 
região Sul do Brasil no início da década de 1960 (MATOS; PESSÔA, 2011). Tais incentivos se deram através

[...] do fornecimento de crédito subsidiado para custeio e investimento, atrelado à adoção da nova base técnica; da internalização da indústria a montante, produtora de bens de capital; das articulações entre as empresas públicas de pesquisa responsáveis pelo desenvolvimento de novas cultivares - e as multinacionais produtoras de insumos químicos e mecânicos; do incentivo fiscal e creditício às agroindústrias; da extensão rural, difundindo as novas técnicas de manejo; da criação de uma rede de armazéns públicos e dos investimentos em transporte e energia. (FREDERICO, 2013, p.8).

O segundo período proposto pelo autor acontece a partir da década de 1990, já caracterizado anteriormente, mas que, em resumo, apresentou a consolidação da agricultura moderna/científica no Brasil, com a atuação do Estado na questão da produção e um grande protagonismo de grandes empresas, propiciados pelo incentivo do Estado na questão da promoção das condições ideais para o seus desenvolvimento: os grandes investimentos em infraestrutura, seja de transportes ou de comunicação, e os investimentos em pesquisa voltadas para a tecnologia de produção. De acordo com o autor, é possível definir três características desse período:

a) aperfeiçoamento e, em certa medida, a superação do padrão tecnológico difundido pelo paradigma da Revolução Verde, com a adoção das NTIC como a informática, a microeletrônica, a biotecnologia, a engenharia genética e a formação e transmissão de bancos de dados; b) o aumento das exportações de produtos primários em detrimento dos produtos processados, como é o caso da soja (principal commodity agrícola de exportação); c) e a menor atuação do Estado como o principal regulador da agricultura, com a privatização e/ou sucateamento da maioria das empresas e instituições públicas responsáveis pelos diferentes aspectos da produção agrícola (financiamento, política de preços mínimos, armazenamento, produção de adubos e fertilizantes). (FREDERICO, 2013, p. 12).

O segundo período proposto por Frederico (2013), dessa forma, influencia diretamente na expansão da fronteira agrícola para outras porções territoriais do país, com grande ampliação das áreas plantadas e grande alteração do meio ambiente através do desmatamento e incorporação do cultivo de grãos, sobretudo a soja. Antes de adentrarmos a análise questões recentes ligadas ao Brasil Central, entretanto, é preciso analisar a periodização da modernização agrícola Brasileira, realizada por Martine (1989), que a divide em três fases:

[...] o período de modernização conservadora (1965-79), em que o governo induziu a modernização via crédito subsidiado, o período de crise (1980-85), que encontrou a agricultura num estágio de relativa maturidade, e o período pós-1985, marcada pela colheita de várias supersafras. (MARTINE, 1989, p.5). 
O primeiro período, denominado por Martine de Modernização Conservadora (196579), trata do estágio inicial da modernização agrícola, sob gestão do governo militar no Brasil (1964-1985), época conhecida pelo “milagre econômico brasileiro". Além disso, marca o período da inserção de mudanças empreendidas pela Revolução Verde, que significou uma mudança no padrão de produção agropecuária mundial, com inserção de tecnologia e ciência na produção (MARTINE, 1989). Neste período, "foi alterada a base técnica desenvolvida pela indústria fornecedora de meios de produção para a agricultura e ampliada, em linhas modernas, a indústria processadora de alimentos e matérias-primas" (MARTINE, 1989, p.6). Com isso, o autor afirma que a chamada Revolução Verde trouxe inúmeras consequências socioespaciais para diversos países, em especial o Brasil.

Becker e Egler (1993) denominam de conservador o processo de modernização econômica brasileira iniciado em 1970, o Estado dedicava maior atenção a determinadas áreas do país, destacadamente São Paulo, a partir da qual emergem novos centros urbanos ligados à expansão da indústria e da fronteira econômica, sobretudo com a expansão da fronteira agropecuária e mineral.

A Modernização Conservadora marca a atuação massiva do Estado na disponibilização de crédito aos grandes agricultores, com o objetivo de inserção de tecnologia e pesquisa na estrutura produtiva, privilegiando as grandes propriedades em detrimento dos pequenos agricultores, a quem foram relegadas terras menos férteis. Esse período também é marcado pela expulsão da mão de obra, que se dirigiu para centros urbanos por conta da intensa mecanização do campo, e pela redução do número dos diferentes tipos de produtores, como arrendatários, parceiros, posseiros e pequenos agricultores, que afetou diretamente a concentração de terras no Brasil e o aumento da urbanização brasileira (MARTINE, 1989).

O segundo período, da Crise e Retração (1980-84), é marcado pela crise econômica. A década de 1980 é comumente conhecida como a "década perdida" para os países da América Latina, como consequência do fraco crescimento econômico e contração do PIB. Dessa forma, o crédito destinado à agricultura pelo Estado sofre queda de mais de 50\%. Mesmo com a redução do crédito, porém, a agricultura moderna manteve uma produção, o que revela que a solidez da base do agronegócio, sobretudo em relação a uma estrutura produtiva com suporte tecnológico adequado, inclusive no uso racional de insumos modernos, com grande capacidade de aumento da produtividade das culturas agrícolas (MARTINE, 1989). Além disso, segundo Martine (1989), a incorporação de novas áreas ao circuito da produção moderna de grãos, principalmente soja, em decorrência do alto custo da aquisição de terras no 
sul do Brasil, influencia essa estabilidade. Pode-se destacar os estados da região Centro-Oeste e alguns estados da região Norte e Nordeste do Brasil, que serão abordados mais à frente.

Além da questão da aquisição de terras, é preciso enfatizar que os grandes agricultores também precisavam estar atentos à disponibilização de capital para aquisição de insumos, equipamentos e tecnologia para serem incrementados à produção (MARTINE, 1989).

O terceiro e último período é denominado de Recuperação e Supersafras- 1985-89 e designa o início da recuperação econômica do país, marcada por maior dinamização do emprego urbano, o que estimulou a produção agropecuária em virtude de maior demanda interna, inclusive com fortalecimento da indústria, destinada a exportação de produtos, mesmo os processados advindos do setor primário. O Estado, através de inúmeros incentivos, sustentou este aumento da produção. Tudo isso contribui para a maior pressão aos pequenos produtores em decorrência do maior incentivo aos grandes agricultores, e para o consequente aumento da área plantada, influenciando no aumento do êxodo rural (MARTINE, 1989).

Segundo Oliveira $\left(1999^{28}\right)$, na região Sul, houve declínio de $6 \%$ dos diferentes tipos de produtores entre os anos 1970-85 (6\% de queda para proprietários, menos 17\% dos arrendatários, menos $28 \%$ para parceiros e menos $2 \%$ para posseiros). Na região Sudeste, ainda de acordo com o autor, houve diminuição de $4 \%$ de todos os tipos de produtores (sendo proprietários $2 \%$, arrendatários $23 \%$, parceiros $14 \%$ e posseiros $6 \%$ ) entre os anos de 1970 80, enquanto, no período de 1980-85, tem lugar um aumento de $7 \%$ de todos os tipos de produtores (sendo $10 \%$ dos proprietários, $23 \%$ dos posseiros), com declínio de $26 \%$ dos arrendatários e 5\% de parceiros. A região Nordeste, por outro lado, apresentou, no período de 1970-85, crescimento de $39 \%$ do número de posseiros e de $100 \%$ do número de parceiros, o que diverge do contexto nacional de queda nesse tipo de agricultor (OLIVEIRA, 1999).

Essa tendência de aumento do número de posseiros e de parceiros no Nordeste também é comentada por Martine (1989), que defende que houve um crescimento, no período de 1980-84, do número de pequenos estabelecimentos na região, processo que o autor denomina de "minifundização", e que teria ocorrido em virtude da pouca valorização e interesse do capital produtivo em relação à terra. Tal processo teria possibilitado o aumento do número de posseiros e parceiros, conferindo-lhes fôlego, quando o período era marcado

${ }^{28}$ Oliveira (1999) defende que a disseminação do capitalismo no campo brasileiro, sobretudo por meio da agricultura moderna, empreende novas realidades. No entanto, o autor sustenta que a atividade camponesa não será suplantada e os movimentos de resistência (não capitalistas) emergem cada vez mais, caracterizando assim um processo contraditório de expansão da fronteira agrícola. 
pelo avanço dos grandes projetos agropecuários modernos nessa região, o que ameaçava diretamente os agentes locais envolvidos na agricultura familiar.

No Centro-Oeste, por sua vez, houve diminuição de $16 \%$ do número de posseiros entre os anos 1970-85, o que, de certa forma, caracteriza essa região marcada pela grande concentração de terras. Na região Norte, entre os anos de 1970-85, houve aumento de $48 \%$ do número de parceiros, sendo que os posseiros cresceram 48\% entre 1970-85. É justamente na região Norte do Brasil que o número de posseiros é o mais representativo entre todas as regiões brasileiras (OLIVEIRA, 1999).

A análise dos números de Oliveira (1999) permite concluir que a concentração de terras se ampliou no país no período que compreende a década de 1970 e fim da década de 1980, fato também apontado por Martine (1989, p.12): “[...] o direcionamento de recursos estatais para um número mais limitado de produtores modernos teria sido suficiente para manter os níveis de produção e produtividade do setor como um todo, durante o período de crise", o que quer dizer que o Estado priorizou e, de alguma forma, estimulou a concentração de terras no Brasil, pois esses grandes agricultores, na medida em que ampliavam sua monopolização da terra, agravavam o problema da concentração fundiária do país.

Em algumas regiões, contudo, o número de posseiros aumentou, o que revela a persistência de uma resistência à concentração de terras, que é ainda uma realidade nos dias de hoje, em que existem inúmeros conflitos por terra envolvendo grandes agricultores, pequenos agricultores e agentes locais nas diferentes áreas rurais dos estados brasileiros (THOMAZ JUNIOR, 2010).

Acrescentamos que, de acordo com Martine (1989), a agricultura familiar ainda possui grande importância no cenário brasileiro, mesmo que em declínio. Muitos desses pequenos e médios agricultores familiares, porém, já se relacionam aos Complexos Agroindustriais, revelando assim que muitos empreendimentos de pequeno porte recebem maior atenção dos grandes mercados, inclusive da agroindústria, em virtude da maior flexibilidade na produção de matéria-prima. A agricultura familiar, portanto, é ainda muito importante para a população brasileira, na medida em que servia de base para o abastecimento interno. Consideramos, também, que a agricultura familiar dispõe de maiores possibilidades em virtude das condições diferenciadas da questão tecnológica, do tipo de cultura agrícola desenvolvido, da localização dos empreendimentos, etc (MARTINE, 1989).

É preciso ressaltar que a expansão da agricultura moderna empreende também um aumento do trabalho assalariado no campo (OLIVEIRA, 1999), já que o pequeno agricultor 
não vê possibilidade de competição com a grande agricultura e a expansão dos grandes projetos. Nesse caso, esses pequenos agricultores tendem a migrar para cidades ou a continuar residindo no campo e trabalhando nos grandes projetos, principalmente no período das safras, o que afeta, é claro, a agricultura familiar. O período de 1970-85 definido por Oliveira (1999) é justamente uma época marcada pela expansão da agricultura moderna para outras áreas do Brasil, quando milhares de agricultores migraram para outros recortes territoriais das regiões Centro-Oeste, Nordeste e Norte.

O cenário brasileiro atual, por outro lado, marca um período de grandes avanços da fronteira agrícola para o chamado Brasil Central com produção destinada à indústria e ao mercado externo. Destacamos uma passagem de Oliveira (1999) que consideramos interessante e profunda:

O desenvolvimento da agricultura (pela industrialização) revela assim que o capitalismo está unificando contraditoriamente o que ele separou no início do seu desenvolvimento: indústria e agricultura. Essa unificação está sendo possível porque o capitalismo tornou-se também proprietário da terra, portanto latifundiário. (OLIVEIRA, 1999, p.105).

Nesse sentido, a agricultura é revalorizada no contexto contemporâneo e introduz novos mecanismos e realidades no campo brasileiro - a agricultura moderna, pela sua condição dependente da indústria, dá origem à chamada agroindústria, que Martine (1989, p.4) denomina de "caificação" do padrão agrícola, em decorrência do "[...] crescimento do número, tamanho, importância, poder e integração dos complexos agroindustriais". O autor ainda acrescenta que

$\mathrm{Na}$ interpretação corrente, a dinâmica da indústria teria passado a comandar definitivamente o desenvolvimento da agricultura, pois, com o aprofundamento da divisão do trabalho, a agricultura converteu-se num ramo de produção industrial, que compra insumos e vende matérias-primas para outros ramos industriais. (MARTINE, 1989, p.15).

Nesse sentido, a agricultura torna-se um ramo específico da indústria, e ambas mantém relação de mútua dependência. A agricultura moderna acompanha as imposições da indústria e do mercado exterior. De acordo com Oliveira (1999), em relação ao Brasil, 
[...] é importante salientar também que a soja é responsável pela transformação radical do cerrado brasileiro, tendo se expandido para novas áreas produtoras nos estados de Mato Grosso (Rondonópolis, Diamantino Tangará da Serra, Sorriso e Barra do Garça), Goiás (Jataí, Rio Verde etc), Bahia (Barreiras, Tocantins (Formoso) e Balsas do Maranhão. (OLIVEIRA, 1999, p.96).

O autor destaca o papel da soja na questão da expansão da fronteira agrícola para diferentes estados brasileiros com vegetação dos Cerrados a partir da década de 1970, embora não cite o estado do Piauí, onde a fronteira agrícola, como veremos mais à frente, chega com maior intensidade na década de 1990, de acordo com Monteiro (2002).

Para Martine (1989, p.18), “[...] na verdade, a lógica da vantagem de escala na agricultura brasileira é fortemente atrelada à experiência da soja (protótipo da aplicação do pacote tecnológico da Revolução Verde) e da cana-de-açúcar (beneficiada pelo Proálcool)." Nesse cenário, a soja e a cana de açúcar são os grandes provedores da expansão agrícola no Brasil, influenciando diretamente na transformação de algumas áreas rurais no Brasil em verdadeiros "mares verdes". E nesse avanço da fronteira agrícola para o Brasil Central o Estado age de forma contraditória no atendimento aos interesses hegemônicos, como de grandes agricultores e grandes corporações transnacionais. As ações seletivas do Estado em certas áreas e regiões revelam-se um problema em relação às possibilidades de acentuação das desigualdades sociais e regionais, especialmente em regiões com forte presença da agricultura moderna.

A temática sobre a modernização da agricultura abrange também o debate em relação à técnica, para o qual contribuem Adorno e Horkheimer (1985) ao defenderem que a técnica é a essência do saber e que a mesma está atrelada à transformação da natureza, ao poder e à dominação. Dessa forma, faz-se necessário analisar o lado perverso do progresso e da modernização, pois os detentores do aparelho técnico e do poder possuem domínio incomparável aos demais grupos desprivilegiados, de maneira que os poderes econômicos contribuem fortemente para a anulação do indivíduo (ADORNO; HORKHEIMER, 1985).

A naturalização dos homens hoje não é dissociável do progresso social. O aumento da produtividade econômica, que por um lado produz condições para um mundo mais justo, confere por outro lado ao aparelho técnico e aos grupos sociais que o controlam uma superioridade imensa sobre o resta da população. (ADORNO; HORKHEIMER, 1985, p.14).

Portando, é preciso tomar cuidado especial na análise de processos hegemônicos e ligados ao progresso, que, novamente, segundo Adorno e Horkheimer (1985), pode se 
converter em regressão em virtude dos seus efeitos contraditórios. Deve-se partir, então, do pressuposto de que o processo de modernização da agricultura exige visão crítica em relação aos seus efeitos contraditórios ligados aos grandes agentes econômicos, destacadamente o Estado e as grandes corporações transnacionais atreladas ao agronegócio.

Segundo Oliveira (1999), os processos contraditórios gerados a partir da agricultura moderna estão ligados ao contexto de expansão do capitalismo. Na visão do autor, “[...] esses processos contraditórios produzem e se reproduzem em diferentes partes do mundo atual, criando dessa forma processos e relações de interdependência entre estados, nações e, sobretudo empresas de diferentes lugares do globo". (OLIVEIRA, 1999, p.74). Nesse caso, Milton Santos revela-se um autor fundamental para o entendimento das dinâmicas geradas nos processos hegemônicos e modernizantes. Ele aborda, em seu discurso, a centralidade da técnica e as consequências socioespaciais da expansão de processos globalizantes.

O conceito de Meio Técnico-Científico-Informacional, por exemplo, possui grande importância na análise do atual momento do Brasil Central, especialmente do Sudoeste Piauiense, onde os atores hegemônicos - instituições supranacionais, empresas multinacionais e o Estado - comandam as ações em relação ao processo de modernização da agricultura, que envolve ciência, tecnologia e informação nos processos produtivos atuais ligados ao circuito econômico mundial (SANTOS, 2008), o que contribui para a chamada tecnificação da paisagem, tal como afirma Santos (1999, p.12).

Dessa forma, os diferentes espaços são moldados de acordo com os interesses, desejos e necessidades de grandes agentes hegemônicos e de processos hegemonizantes. Santos (1999) afirma que

\footnotetext{
Os espaços assim requalificados atendem sobretudo os interesses dos atores hegemônicos da economia, da cultura e da política e são incorporados plenamente às novas correntes mundiais. O meio técnico-científico-informacional é a cara da globalização. (SANTOS, 1999, p.11).
}

As empresas agrícolas e agroindustriais, nacionais e multinacionais, desempenham um importante papel nos novos arranjos territoriais, acirrando as disputas que envolvem questões sociais e territoriais ligadas ao trabalho, às dinâmicas de conflitos por terra e à especulação fundiária (ELIAS, 2006b). Segundo Frederico (2013), 
A organização reticular dessas empresas, além de lhes permitir uma ação mundial, monopolizando o comércio de grãos, possibilita também o estabelecimento de círculos de cooperação com empresas que atuam em segmentos complementares, controlando a logística e as inovações tecnológicas (sementes, fertilizantes, defensivos e maquinário). Elas atuam nas diversas etapas da produção - desde o fornecimento do crédito de custeio e de insumos químicos, até o armazenamento, transporte, beneficiamento e comércio dos grãos -, e estão presentes nas principais áreas produtoras, portos exportadores/importadores e centros consumidores. (FREDERICO, 2013, p.42).

Nesse sentido, as grandes empresas multinacionais ligadas ao agronegócio se articulam com setores complementares. Pode-se afirmar que a presença desses novos agentes em diferentes cidades empreende novas realidades até mesmo no comércio e serviços, substituindo os padrões dessas áreas pelos ditos mais modernos.

De fato, essa conjuntura pode ser atribuída à potencialidade da agricultura no cerrado brasileiro, na qual não se acreditava antes de 1970, e que mais tarde foi impulsionada pelo avanço da ciência, como através da incorporação de fertilizantes, da correção do solo e do uso de produtos químicos no combate às pragas (MATOS; PESSÔA, 2011). Isso só a confirma a visão de Santos (1999, p.12), segundo quem "[...] a ciência e tecnologia, junto com a informação, estão na própria base da produção, da utilização e do funcionamento do espaço e tendem a constituir o seu substrato".

O processo de modernização agrícola, como já dissemos, foi iniciado no sul do Brasil, mais especificamente nas regiões Sul e Sudeste do país, como um projeto de modernidade arquitetado e planejado pelo Estado, que na época se encontrava sob o Regime Militar ${ }^{29}$, que durou de 1964 a 1985, e foi caracterizado por grandes investimentos nas áreas de infraestrutura do país, evidenciando a modernização conservadora, pois alavancou as desigualdades regionais e sociais presentes no país. (MONTEIRO, 2002). Apesar dos avanços na área de infraestrutura econômica e da indústria durante as duas décadas de Regime Militar, houve clara concentração dos benefícios na região Sudeste do país, especialmente no eixo São Paulo-Rio de Janeiro.

De acordo com Oliveira (1999, p.91), “[...] as políticas fomentadas pelos governos militares, por intermédio das cooperativas no sul do Brasil, levaram à expansão da cultura de soja naquela região". É nesse momento que a soja é inserida como grande símbolo da agricultura moderna. Ainda conforme o mesmo autor, a produção moderna de grãos se

${ }^{29} \mathrm{O}$ advento do Regime Militar relaciona-se com uma série de fatores políticos e ideológicos presentes, então, no Brasil no mundo, como, por exemplo, a Guerra Fria. Nesse sentido, os Estados Unidos tiveram participação primordial na efetivação do militarismo no Brasil visando a supressão do regime socialista, que ameaçava vigorar no país. 
desenvolveu no sul do país por meio da dupla soja-trigo, na tentativa de diminuir a necessidade do país de importação.

Assim, a modernização agrícola brasileira inicia-se na chamada Região Concentrada, que, segundo Santos e Silveira (2001, p. 269), “[...] abrange São Paulo, Rio de Janeiro, Minas Gerais, Espírito Santo, Paraná, Santa Catarina e Rio Grande do Sul”, e é caracterizada pela maior implantação de suportes ligados à ciência, técnica e informação. Segundo Elias (2006b),

É a Região Concentrada que desde o início da reestruturação da agropecuária, se adapta progressiva e eficientemente aos interesses do capital hegemônico, reconstituindo-se à imagem do presente técnico-científico-informacional e transformando-se na área com maior expansão da agricultura científica e do agronegócio. (ELIAS, 2006b, p.10).

Tudo isso visava o aumento da produção para destinação ao mercado exterior, como corrobora Oliveira (1999) na seguinte passagem:

\begin{abstract}
A industrialização da agricultura brasileira vem sendo feita no interior do processo de internacionalização da economia brasileira, ou seja, a lógica contraditória do desenvolvimento capitalista na agricultura se fez e se faz no seio de um capitalismo mundializado (OLIVEIRA, 1999, p.76).
\end{abstract}

Nesse sentido, a modernização da agricultura brasileira insere-se na lógica da inserção do Brasil, enquanto grande produtor de gêneros agropecuários, na Divisão Internacional do Trabalho promovida pelo sistema capitalista. Assim, o Brasil passa a produzir culturas agrícolas destinadas ao mercado exterior, como a soja, o café, a laranja e a cana de açúcar, em detrimento da produção de produtos alimentícios primários e básicos para a população, como o feijão, arroz, mandioca, legumes, verduras, etc. (OLIVEIRA, 1999, p.77).

É preciso destacar, entretanto, que, de acordo com Martine (1989, p.5), “[...] de fato, embora a modernização viesse se processando desde o pós-guerra, a tecnologia agrícola utilizada na maior parte do país ainda era bastante rudimentar até meados da década de 60 ”. O campo brasileiro ainda não está, então, totalmente modernizado, e existem inúmeras áreas com pouca modernização das atividades agropecuárias (Oliveira, 1999). Martine (1989) nos ajuda a compreender essa tendência na seguinte colocação:

Entretanto, grande parte do terreno e topografia brasileiros, assim como várias culturas, ou impedem a utilização de tratores, rotores, colheitadeira e outros implementos modernos, ou exigem maior intensidade de mão de obra- o que significa necessariamente ausência de capital (MARTINE, 1989, p.21). 
Nesse sentido, grande parte do campo brasileiro, bem como das atividades agropecuárias, ainda não incorporou tendências mais modernas por conta de características físicas ou da exigência, por parta de algumas atividades, do uso da força braçal em detrimento do uso de máquinas.

De fato, existem atividades modernas ligadas ao agronegócio que demandam maior utilização da força de trabalho humana, como é o caso da produção de frutas no agronegócio que, de acordo com Bezerra (2008), ainda exige a força de trabalho (braçal) na colheita de melão, melancia, uva, laranja, goiaba, entre outras, por mais que sejam utilizados, por exemplo, insumos químicos e tecnologia de irrigação.

Tal fato fica nítido em relação à questão do relevo e topografia. O sul do Estado de Goiás, por exemplo, possui um relevo com maior aplainamento, e nele predominam atividades de agricultura moderna. Já grande parte do território do norte goiano possui relevo mais movimentado, o que, de certa forma, impede a disseminação de máquinas colheitadeiras, máquinas de preparação do solo, etc., e exige o trabalho braçal. Isso também ocorre no Estado do Piauí, onde as características topográficas influenciam diretamente na localização dos diferentes empreendimentos agrícolas. Dessa forma, as áreas de vegetação dos Cerrados, sobretudo localizados em áreas de planaltos e chapadas, recebem mais atenção dos grandes agricultores e do capital globalizado.

A incorporação dos Cerrados na rota da agricultura moderna também obedeceu aos dois períodos marcantes da expansão da agricultura científica no Brasil, defendidos por Frederico (2013) e já abordados anteriormente. O primeiro se caracteriza, de acordo com o autor, pela atuação do Estado na questão da promoção da ocupação dos Cerrados. Os incentivos foram direcionados ao apoio dos grandes agentes na aquisição de máquinas, através da disponibilização de crédito, e da construção e implementação de sistemas que facilitassem o escoamento da produção, como transportes e energia. O segundo período, por sua vez, marca a atuação em massa de grandes empresas agrícolas em direção aos Cerrados, favorecidas pelas ações estatais do período anterior.

A expansão da fronteira agrícola para alguns biomas brasileiros, em especial para as áreas do cerrado e de transição do cerrado-amazônia e cerrado-caatinga, impacta de forma esmagadora o meio ambiente. O Brasil vive um momento de preocupação em relação à questão hídrica, de maneira que a preservação de áreas dos Cerrados é vital, pois tem relação intrínseca com a manutenção de nascentes de rios no Brasil. Fala-se muito da preservação da 
Amazônia brasileira, e, no entanto, esquece-se que os Cerrados também são um dos biomas com grande biodiversidade.

Nesse sentido, a expansão da fronteira agrícola pode contribuir para a destruição dos Cerrados brasileiros. De acordo com Martine (1989),

\begin{abstract}
A preocupação com a nocividade da mecanização e a utilização de insumos químicos do pacote tecnológico prevalecente para o solo, os rios, a fauna, a flora e o próprio organismo humano- particularmente em vista da necessidade de doses cada vez maiores de fertilizantes e defensivos- têm gerado uma polêmica mundial. (MARTINE, 1989, p.30).
\end{abstract}

Essa questão é ainda mais complexa na medida em que as polêmicas em torno do agronegócio ultrapassam a questão ambiental. Ab’ Saber (2003) já chamava atenção para a necessidade de preservação do bioma do cerrado e da primordialidade de concepção de uma política efetiva de zoneamento que, de alguma forma, auxilie o uso equilibrado desse domínio. Nas palavras do autor (2003),

[...] o não-atendimento da preservação integral das florestas galeria existentes no Planalto Central pode acarretar conseqüências graves para o abastecimento d'água, o ravimento das baixas vertentes e o aprofundamento e dessecamento dos lençóis d'água subsuperficiais na maior parte do domínio dos cerrados. (AB' SABER, 2003, p.132).

O autor também alerta para a necessidade de preservação das áreas suscetíveis à expansão das atividades agropecuárias modernas, principalmente as de fundo de vale e cabeceiras de drenagem, presentes no Piauí, Maranhão e Bahia.

A expansão da agricultura para áreas dos Cerrados envolve grande uso da terra, seguido de extrema concentração da estrutura fundiária - que pressupõe a seleção de determinada área - que contribui para a ampliação das disparidades regionais no Brasil, sobre a qual Thomaz Júnior (2010, p.5) afirma: “[...] desde as capitanias hereditárias até os latifúndios modernos, a estrutura fundiária vem sendo mantida pelos mais elevados índices de concentração do mundo. Esse modelo insustentável sempre se impôs por meio do poder e da violência."

É possível, portanto, caracterizar a moderna agricultura como seletiva, excludente e concentradora. A seletividade se dá quando na escolha de diferentes áreas consideradas dinâmicas e nos financiamentos obtidos, estes últimos abordados por Oliveira (1999). Também Martine (1989) destacava que 
[...] a ênfase dada à maturidade e à abrangência desse processo pode levar o leitor desavisado a concluir que o Brasil encontra-se num estágio avançado de desenvolvimento da sua produção agropecuária, tendo as formas modernas e autosustentadas de produção penetrado homogeneamente em todas as regiões e setores, com capacidade para competir de igual para igual no mercado internacional e gerar uma prosperidade generalizada para a sociedade brasileira (MARTINE, 1989, p.16).

De fato, o Brasil não é plenamente próspero, apesar de alguns avanços em questões socioeconômicas. A realidade da agropecuária brasileira, contudo, mostra que o Brasil tem, sim, potencial para competir em termos de igualdade com países com alta exportação de produtos primários, sendo líder na venda de certas culturas já destacadas no capítulo anterior. Devemos, porém, questionar o quão positivas são estas constatações, já que o ideal seria o país demonstrar maior preocupação com o fator qualitativo do que com o quantitativa, ou seja, privilegiar a melhoria da qualidade de vida da população em atividades econômicas que lhe tragam impactos verdadeiramente positivos.

Analisando criteriosamente a realidade atual brasileira, percebe-se claramente que, mesmo com o intenso avanço da fronteira agrícola e com a consolidação do Brasil como um dos maiores exportadores de produtos primários, o país ainda não conseguiu superar os dilemas que insistem em atrapalhar o seu desenvolvimento, como o da pobreza e distribuição desigual de renda. Segundo Martine (1989),

\footnotetext{
Os elevados gastos públicos praticados na agropecuária geraram muita renda entre as elites, mas pouco afetaram a grande massa de produtores, a não ser em termos negativos: perda da terra, redução das oportunidades de emprego, migração para as fronteiras ou para as cidades. (MARTINE, 1989, p.35).
}

Pode-se concluir, assim, que a modernização agrícola, acompanhada da alta produção e do aumento da produtividade no país afeta positivamente apenas uma pequena parcela de agentes. Assim, a seguir, analisaremos as novas dinâmicas de expansão da agricultura moderna no Brasil, especialmente para região denominada MAPITOBA, onde se percebem claros traços das transformações empreendidas pelos processos globalizantes, como o maior protagonismo de novos agentes, o aumento da urbanização, a transformação das áreas rurais e urbanas, dentre outros. 


\title{
2.2 Breve Contextualização da região MAPITOBA e a Agência de Desenvolvimento denominada MATOPIBA: migração de sulistas, novos contextos e possibilidades
}

As regiões Sul, Sudeste e Centro-Oeste do Brasil foram as primeiras a serem intensamente ocupadas pela agricultura moderna, que nas últimas décadas consolidou a expansão das atividades modernas ligadas à agropecuária (ELIAS, 2006a). Essas três regiões são as que possuem a maior composição técnica e organização do espaço agrícola, principalmente o Estado de São Paulo, que constitui o centro das decisões econômicas que refletem diretamente na agricultura moderna do país.

Segundo Elias (2006b), a cidade de São Paulo sintetiza a importância da chamada Região Concentrada, onde estão as principais empresas agropecuárias e agroindustriais ligadas ao setor em destaque. Nas palavras de Oliveira (1999),

\begin{abstract}
A forte concentração industrial e metropolitana de São Paulo articula hoje praticamente toda a produção agrícola brasileira. São Paulo não só sedia a Bolsa de Cereais oficial, como também sua similar clandestina, a "bolsinha", na região da rua da Cantareira, próximo ao Mercado Central da cidade. Além dessas duas, São Paulo conta também com a Bolsa de Mercadorias e Futuros, que atua fortemente no mercado de commodities (mercadorias tais como: café, soja, boi gordo etc). (OLIVEIRA, 1999, p.94).
\end{abstract}

De maneira que infere-se que a produção agrícola brasileira ainda depende do grande centro metropolitano de São Paulo, que acaba articulando a questão dos preços, da comercialização e da centralidade industrial.

A concentração produtiva no eixo Rio-São Paulo é uma marca das políticas de desenvolvimento regional brasileiro; mesmo após 60 anos de políticas de desenvolvimento regional, o Brasil ainda não reverteu as assimetrias em relação à concentração de renda. Esse movimento de condensação da estrutura produtiva em torno dessa região surge em virtude do desenvolvimento econômico e social baseado na rápida industrialização e intensa urbanização (CARLEIAL, 2012). Em outras palavras, ao longo do século XX, consolidaram-se as desigualdades regionais no país, que se refletem nas desigualdades sociais e de renda no país, mesmo após tentativas de descentralização da estrutura produtiva, de maneira que as decisões em relação às principais atividades econômicas e sociais ainda cabem ao eixo Rio-São Paulo. Com efeito, de acordo com Frederico (2013, p.31), “[...] hoje, a maior parte dos grãos produzidos na fronteira agrícola moderna é exportada através dos escritórios 
das tradings localizados na cidade de São Paulo, o que demonstra a onipresença da metrópole paulistana."

Na visão de Pochamann (2004), o Brasil possui características singulares em relação à questão da exclusão e das desigualdades sociais e regionais. $\mathrm{O}$ autor explica:

Como se sabe, em um país de industrialização tardia como o Brasil, o processo conciliatório entre o velho, representado pelo latifúndio e pelo passado colonial escravista, e o novo, expresso pela modernização capitalista, tendeu a resultar na sua forma concentradora, autoritária e excludente. (POCHAMANN, 2004).

A concentração industrial no Brasil, assim, afeta diretamente as políticas de desenvolvimento regional brasileira e a ampliação das desigualdades regionais. $\mathrm{O}$ autor ainda defende que a acumulação industrial no Brasil agravou de maneira significativa as desigualdades de renda e, consequentemente, o distanciamento das classes populares do poder, o que caracteriza o controle autoritário da relação capital-trabalho no Brasil. De fato, para Santos e Silveira (2001), no Brasil, existem espaços que "mandam" e espaços que "obedecem". Nas palavras dos autores,

Os espaços do mandar são os ordenadores da produção, do movimento e do pensamento em relação ao território como um todo. Influenciados pelas tendências da produção moderna. Normalmente os espaços do mandar são também os espaços da rapidez. (SANTOS; SILVEIRA, 20001, p.263).

Assim, pode-se considerar São Paulo como um espaço do mandar no Brasil, tendo Brasília como uma cidade com centralidade administrativa e política. A capital paulista, porém, em função de sua ampla área de influência, dita as questões econômicas brasileiras.

Com o intenso uso do solo nas regiões Sul, Sudeste e Centro-Oeste, a agricultura moderna se expandiu para algumas porções territoriais de alguns Estados da região Nordeste, como o oeste baiano, o sul do Maranhão, o sudoeste piauiense, e o norte de Tocantins. Essas áreas eram anteriormente conhecidas pelo atraso econômico, pela baixa modernização das atividades agrícolas e pela forte dependência das outras regiões. Segundo Oliveira (1999),

Cabe lembrar também que essa expansão no cerrado vem sendo possível pela imigração de sulistas para o centro do país, em razão dos processos de concentração da terra gerados, contraditoriamente, pela própria expansão da soja no Sul do Brasil. Cabe também deixar registrado o movimento de mudança das rotas de investimentos que capitalistas do setor da soja têm feito para realizar investimentos na produção no Paraguai e na Bolívia, em decorrência dos baixos preços. (OLIVEIRA, 1999, p.91). 
Do que podemos concluir que o processo de expansão da agricultura para áreas dos Cerrados brasileiros do Brasil Central marca a disseminação de um processo complexo e gigantesco, que envolve também a expansão para recortes territoriais de outros países da América do Sul em virtude dos baixos preços das terras. Além disso, apesar da modernização das atividades agricultáveis nos Estados citados, a esmagadora maioria ainda depende de outras regiões, onde se encontram as sedes de grandes empresas agrícolas e grandes agricultores.

A discussão em relação à temática da modernização agrícola no Brasil Central também envolve o debate acerca das regionalizações e da questão das fronteiras estaduais e municipais. De acordo com SILVEIRA (2006), atualmente, as questões relacionadas às fronteiras, distâncias e limites são seriamente questionadas em detrimento da pujança da atuação de agentes hegemônicos e suas ideias, o que valoriza ainda mais o conceito de rede.

É essa a realidade vivida atualmente nova região do agronegócio em alguns Estados do Nordeste e Norte do país, onde as fronteiras estaduais ficam em segundo plano. Esse cenário integra a nova região agrícola do Brasil Central denominada MAPITOBA ${ }^{30}$, que é a junção das siglas dos Estados do Maranhão, Piauí, Tocantins e Bahia (MOTA, 2012), como pode ser observado na figura abaixo:

\footnotetext{
${ }^{30}$ Denominada recentemente pelo Ministério da Agricultura e Abastecimento como região do MATOPIBA. Nesse caso, a sigla MAPITOBA, amplamente já difundida nos estados integrantes, é deixada de lado, talvez por conta de critérios ligados à estética e um movimento pela idealização do moderno, evitando talvez o dualismo das interpretações. Entende-se que a ordem das siglas dos Estados Integrantes foram despojadas de forma a permitir uma maior facilitação à pronúncia, evitando assim a ordem alfabética, por exemplo.
} 
Figura 4: Região do MAPITOBA e os municípios do agronegócio

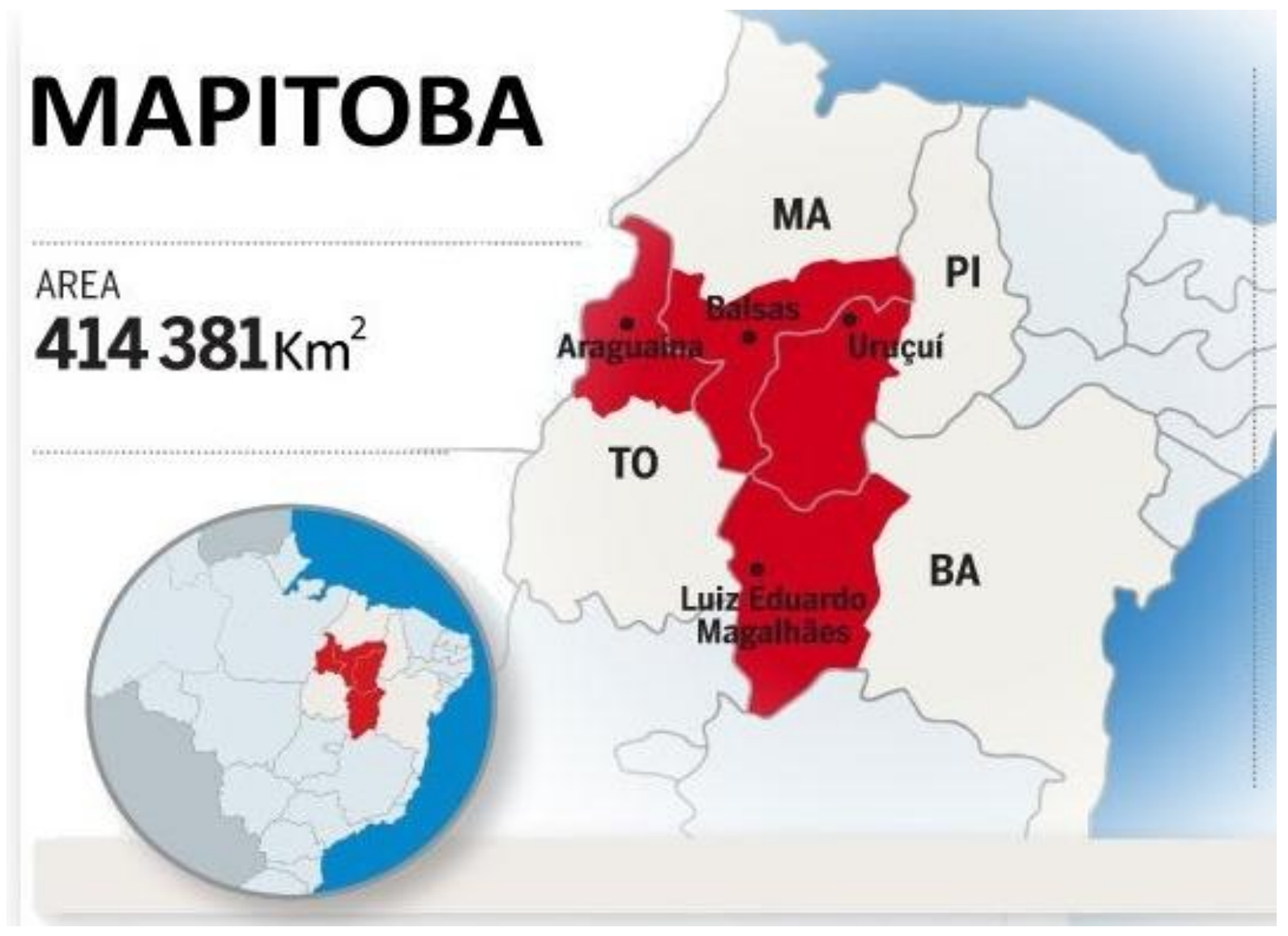

Fonte:http://exame.abril.com.br/revista-exame/edicoes/947/noticias/sertao-agora-assim-482542, acesso em março de 2013.

A partir da figura é possível observar que cada estado do MAPITOBA possui um município do agronegócio: Luiz Eduardo Magalhães, no estado da Bahia, Uruçuí, no Estado do Piauí, Araguaína, no Tocantins, e Balsas, no Estado do Maranhão. Alves (2005) comenta a presença dos principais centros difusores do agronegócio, em especial nos Cerrados nordestinos:

Essa região de recente desenvolvimento agropecuário apresenta uma configuração com três pólos de modernização: Oeste da Bahia (comandado por Barreiras e Luis Eduardo Magalhães), Sul do Maranhão (comandado por Balsas) e Sul do Piauí (comandado por Uruçuí e Bom Jesus). Apesar desses pólos fazerem parte de um mesmo processo de imposição de uma nova lógica de reprodução capitalista e serem interdependentes, eles apresentam um grau de crescimento econômico diferenciado. (ALVES, 2005, p.2).

Corrêa (2000) denomina as capitais regionais ligadas ao agronegócio "fazendões iluminados" ou "fazendões asfaltados", devido ao alto grau de envolvimento dessas cidades com as áreas rurais. Além disso, os recortes territoriais desses estados de ocupação mais 
recente são caracterizados pela grande concentração das grandes propriedades rurais presentes nessas cidades. Frederico (2013) alerta que

\begin{abstract}
Nas áreas de ocupação mais recente, a concentração fundiária é ainda mais acentuada, contando com produtores capitalizados, sistemas técnicos modernos e ganhos pronunciados de produtividade. Junto com os produtores chegaram também as tradings, responsáveis por assegurar a maior parte do crédito de custeio, os insumos químicos e a logística de escoamento dos grãos. (FREDERICO, 2013, p.27).
\end{abstract}

$\mathrm{O}$ autor ainda considera que a distância dessas novas áreas agrícolas em relação às regiões Sul e Sudeste aumenta a necessidade de melhoria das condições do transporte e escoamento dos grãos. E o Estado vem atendendo essas exigências da grande produção instalação de novas infraestruturas, sobretudo de transporte - com o objetivo de intensificar a competitividade dessas novas áreas produtoras. Frederico (2013) cita alguns projetos em andamento:

[...] o Estado tem planejado e construído diversos "eixos" de exportação em parceria com a iniciativa privada, como: a Ferrovia Norte-Sul, a Hidrovia do Madeira, a pavimentação da BR-163 (trecho paraense), a Ferrovia Nova Transnordestina e a Ferrovia Oeste-Leste. (FREDERICO, 2013, p.29).

Essas necessidades e novos desafios empreendem algumas dificuldades e aumento dos gastos para muitos grandes agricultores e empresas, mas, no entanto, a atividade ainda gera compensação satisfatória, a julgar pela persistência e expansão desses projetos, como veremos no caso piauiense.

Apesar de o Estado continuar promovendo a instalação de infraestruturas de suporte ao agronegócio, para Frederico (2013),

\begin{abstract}
As tradings também possuem uma atuação direta na logística de escoamento dos grãos. A crescente distância entre as novas áreas produtoras e os principais portos exportadores e o déficit e a precariedade das infraestruturas de armazenamento e transporte tornou o controle da logística uma das principais formas de regulação da produção. Na fronteira agrícola moderna, as principais infraestruturas e sistemas de transporte construídos para escoar os grãos são controlados diretamente pelas tradings ou através de parcerias com as empresas concessionárias. (FREDERICO, 2013, p.47)
\end{abstract}

Nesse sentido, as grandes empresas estão diretamente associadas à logística de transportes de grãos. O autor menciona três empresas que articulam essa questão - a Cargill, ADM e a Bunge, e também explica que a produção de três dos estados do MAPITOBA, a 
saber, Piauí, Tocantins e Maranhão, é comercializada no Porto de Itaqui, no estado do Maranhão, comercialização possibilitada pela parceria entre as principais empresas multinacionais do agronegócio - as mesmas Bunge, Cargill e ADM, com a empresa Vale, que é a administradora das ferrovias do Carajás e Norte-Sul.

Sendo assim, as grandes empresas multinacionais do agronegócio globalizado atuam no MAPITOBA em parceria com outras empresas associadas à produção, no caso, as responsáveis pela administração de ferrovias e portos. Essa parceria é possibilitada pelo grande incentivo do Estado em implementar tais infraestruturas para viabilizar maior competitividade dessas áreas. Além disso, consideramos que a expansão das fronteiras agrícolas tem cunho político, pois as diferentes gestões dos municípios ligados ao agronegócio e governos estaduais e federal estarão relacionadas diretamente ao planejamento e determinação de áreas alvo de implementação de infraestrutura e de políticas públicas de incentivo à grande produção, consolidando, assim, uma extensa área voltada para a produção moderna de grãos destinados à agroindústria. Segundo Santos e Silveira (2001),

\begin{abstract}
A influência do fenômeno da globalização e a instalação do meio técnico-científicoinformacional em certas manchas do território regional, como nas áreas irrigadas (o caso do vale do São Francisco), vão-se dar sobre um quadro socioespacial praticamente engessado. Essa situação abre a perspectiva de importantes fraturas na história social, com mudanças brutais dos papéis econômicos e políticos de grupos de pessoas e também de lugares. (SANTOS; SILVEIRA, 2001, p. 272).
\end{abstract}

Pode-se aplicar a análise dos autores à realidade de expansão do processo de modernização agrícola para áreas dos Cerrados da nova região denominada MATOPIBA, também conhecida regionalmente como MAPITOBA, onde as mudanças econômicas, políticas e sociais são claras consequências da expansão do agronegócio, e consequentemente da expansão do meio técnico-científico-informacional.

Segundo ELIAS (2006), esses espaços dinâmicos localizados na região Nordeste representam os pontos luminosos do espaço agrícola nordestino. A autora ainda sustenta que, nesses espaços, considerados dinâmicos pela agricultura científica, "[...] o meio técnicocientífico-informacional tem substituído o meio natural e o meio técnico" (ELIAS, 2006a, p.30). No caso do Sudoeste Piauiense, isso se verifica na valorização de diferentes espaços que, até então, estavam condenados à estagnação econômica e produtiva.

Nesse sentindo, amplia-se a diferenciação entre alguns recortes territoriais na região Nordeste, com áreas excluídas do processo modernizante e áreas atrativas para grandes empresas e agricultores, contribuindo, assim, para o aumento das desigualdades 
socioespaciais. É o que Elias (2006b) chama de existência de vários Nordestes no Brasil, pois algumas áreas dessa região participaram de intensas reestruturações produtivas, se transformando em subespaços dinâmicos (grifo da autora). A autora ainda denomina as áreas condenadas à estagnação e esquecidas nos Cerrados nordestinos como exército de lugares de reserva para o agronegócio - tanto as áreas dos fundos de vales do semi-árido, utilizadas para o cultivo de frutas voltadas para a exportação, como as áreas dos Cerrados presentes no Nordeste brasileiro, voltadas para a plantação de grãos, sobretudo soja, milho, arroz e sorgo.

Essa seleção de áreas para reserva do agronegócio segue uma tendência defendida por Oliveira (1999), segundo a qual determinadas áreas são inicialmente destinadas à pecuária e outras atividades, para depois serem inseridas na rota da grande produção da agricultura moderna. Também Martine (1989) aborda essa questão:

[...] a produção de alguns grandes conglomerados é significativa, mas muitos deles utilizam a terra apenas para obter recursos subsidiados ou como reserva de valor; por outro lado, os estabelecimentos de menos de 50 ha ainda contribuem com $40 \%$ do valor da produção total em 1980 (MARTINE, 1989).

A questão da destinação das terras para reserva de valor era algo comum nesse período e, posteriormente, muitas dessas áreas foram incorporadas no circuito da produção moderna de grãos, principalmente no Brasil Central. Oliveira (1999, p.87) ainda acrescenta que é “"[...] esse papel da terra mercadoria na economia brasileira que tem caracterizado a estrutura básica no nosso campo". A seleção de áreas para futuras instalações, portanto, é uma característica do capitalismo global, representada, nesse caso, pela modernização da agricultura. Nas palavras de Martine (1989),

\begin{abstract}
A conivência do Estado tem sido decisiva na determinação do tamanho da área mantida como reserva de valor; por que o Estado não teria agora a preocupação de redefinir a utilização social de parte dessa terra? Se o CAI já atingiu um certo grau de maturidade, sobram recursos para outras categorias sociais. A "territorialização do capital" tornou-se parte da estratégia dos setores oligopólicos, não por exigência do capitalismo moderno, mas sua lucratividade dentro deu um estilo de desenvolvimento que, frequentemente, privilegia a atividade especulativa em detrimento da produtiva. (MARTINE, 1989, p.37).
\end{abstract}

Nesse sentido, o autor já chamava atenção para a destinação das áreas reserva da agricultura moderna, sobretudo para a questão do papel do Estado na disseminação dessas áreas. O autor levanta a bandeira de uma nova destinação social dessas terras. No entanto, a disseminação do agronegócio para novas áreas do Brasil Central, sobretudo para o MAPITOBA, é uma realidade consolidada e, portanto, praticamente irreversível. 


\section{2. 1. Breve caracterização das cidades do agronegócio do MAPITOBA}

A agricultura moderna disseminada nas áreas do MAPITOBA selecionou cidades para funcionar como suporte aos seus grandes agentes. Essas cidades recebem vários investimentos diferenciados e servem como moradia para os migrantes sulistas e novos agentes presentes nessas regiões, pois também são sedes de grandes empresas multinacionais e de atendimento às necessidades dos grandes projetos, como fornecimento de insumos e máquinas agrícolas, e também de novos comerciantes e prestadores de serviços, como hotéis de alto padrão, redes de supermercados, e lojas de materiais de construção, que são denominados de Home Centers.

Há, também, nessas cidades, universidades e institutos de educação técnica, de maneira que atraem vários estudantes, professores e profissionais. Claramente, portanto, são mais do que meras cidades do agronegócio, mas se configuram como cidades universitárias, com cursos superiores e técnicos voltados para o atendimento das demandas da agricultura moderna. Sobre o termo "cidades do agronegócio", Elias (2011) disserta:

\footnotetext{
O que chamo de cidades do agronegócio seriam os espaços urbanos inseridos em RPAs $^{31}$ nos quais se dá a gestão local ou regional do agronegócio globalizado, que desempenham muitas novas funções urbanas, diretamente inerentes a esse. Transformam-se, então, em lugares de todas as formas de cooperação erigidas pelo agronegócio e resultam em muitas novas territorialidades. (ELIAS, 2011, p.161).
}

Segundo a autora, portanto, as cidades do agronegócio são novas tipologias de cidades, bastante presentes nas áreas recém incorporadas à produção agropecuária moderna. Além disso, essas cidades recebem um grande reforço no sentido de reestruturação da economia urbana e da urbanização (ELIAS, 2006b). Ainda nas palavras de Elias (2006b, p.16), essas cidades, “[...] ao mesmo tempo, dinamizam o terciário e, consequentemente, a economia urbana, e evidenciam que é na cidade que se realiza a regulação, a gestão e normatização das transformações verificadas nos pontos luminosos do espaço agrícola".

Pode-se afirmar, então, que a cidade do agronegócio é aquela que se beneficia economicamente - quantitativamente e qualitativamente - em relação às demais cidades vizinhas, estas dependentes dos serviços contidos nas cidades do agronegócio. No caso do MATOPIBA, como já apontamos, cada estado integrante possui uma cidade centralizadora/especializada no atendimento às demandas do agronegócio. A seguir, caracterizaremos brevemente cada uma delas, destacando questões importantes.

\footnotetext{
${ }^{31}$ Regiões Produtivas Agrícolas (RPAs)
} 
Para Elias (2006, 2006b), como também para Alves (2005), o oeste baiano, polarizado e centralizado pelo município de Barreias, foi a primeira porção territorial da região Nordeste inserida na dinâmica da agricultura moderna, mais especificamente na produção de grãos, angariada pela soja (ELIAS, 2006b). Segundo Haesbaert (1998), os sulistas chegam nessa região e deparam-se uma área com características do Centro-oeste, recorte territorial que estava inserido no chamado "Polígono das Secas", o que, de certa forma, facilitou os incentivos do Estado. De fato, para Alves (2005), o oeste baiano é a área mais consolidada em relação ao agronegócio, centralizando algumas atividades nos Cerrados nordestinos, inclusive recepcionando fluxos de produtores vindos de outros estados em busca do comércio e serviços voltados para a venda de maquinários de peças, além de possuir melhor infraestrutura em relação ao escoamento da produção.

Atualmente nota-se a grande importância da cidade de Luiz Eduardo Magalhães, localizada próximo de Barreiras, e com a qual encontra-se associada. Chamam a atenção as intensas transformações dos espaços urbanos e rurais e uma grande polarização da área de influência dessas cidades, com destaque para vários municípios inseridos na rota da expansão da fronteira agrícola. Luiz Eduardo Magalhães e Barreiras, além de grandes produtores de grãos, são municípios que funcionam como articuladores e centralizadores de determinados serviços e equipamentos, inclusive para o Estado do Piauí.

Segundo o IBGE (2008), Barreiras e Luís Eduardo Magalhães possuem grande articulação com Brasília, tanto que a BR-020 liga a capital do país ao oeste baiano. A primeira possui a maior população desta região, com 137.427 habitantes, segundo o Censo 2010. De acordo com Alves (2005), Barreiras constitui-se como grande centro polarizador dos Cerrados nordestinos - a construção de Brasília acabou por ceder a Barreira importante localização, já que se tornou um ponto da passagem para a população que migrava para a recém criada capital do Brasil, no entroncamento de ligação entre as regiões Nordeste, Norte e CentroOeste do país. As duas cidades apresentam grandes transformações nos seus espaços urbanos, como, por exemplo, no processo de verticalização, na criação de condomínios de alto padrão, no surgimento de comércios e serviços diferenciados, na grande quantidade de eventos de grande porte, ligados à agricultura, à música, à segregação socioespacial, além da presença de áreas periféricas e bairros mais modernos, etc. (ALVES, 2005).

Até os dias atuais, Barreiras se destaca pela centralização de serviços e do comércio, inclusive para cidades piauienses, como Corrente, que fica localizada no sul do Estado do Piauí. É muito frequente, por exemplo, que moradores das cidades do sul piauiense realizem 
compras em comércios específicos de Barreiras, que fica distante cerca de $300 \mathrm{~km}$ de grande parte dessas cidades. Verifica-se, inclusive, que pequenos agricultores locais se deslocam para Barreiras em busca de insumos para o cultivo de peixes, como para a criação de tambaquis, e, nesse caso, buscam os alevinos para o cultivo em suas propriedades ${ }^{32}$.

Hoje, Luís Eduardo Magalhães, antigo Distrito denominado Mimoso do Oeste, pertencente a Barreiras, se destaca no Nordeste e no contexto nacional como um dos grandes municípios do agronegócio, com presença de grandes empresas multinacionais, como a Bunge, a Cargill e a Mauricéia (ALVES, 2005). É conhecida como cidade do agronegócio e também possui localização privilegiada, pois está situada exatamente no entroncamento de três capitais brasileiras: Palmas, Salvador e Brasília (ALVES, 2005). Nas palavras de Elias (2011),

Luís Eduardo Magalhães é um dos lugares de reserva recentemente tomado pelas grandes empresas associadas ás redes agroindustriais hegemônicas do complexo carnes-grãos (especialmente a multinacional Bunge Fertilizantes e Bunge Alimentos, instadas na década de 1980). (ELIAS, 2011, p.162).

A autora, assim, destaca o papel da atuação de grandes empresas hegemônicas ligadas ao grande capital na influência da reconfiguração das paisagens urbanas e rurais das cidades do agronegócio. A população do município de Luís, por exemplo, tem aumentado; em 2007, era de 44.265 habitantes, e já no censo de 2010, era de 60.165 habitantes. As projeções do IBGE indicam, ainda, que a população já gira em torno de 79.162 habitantes. No ano de sua emancipação, 2000, segundo Alves (2005), a população da cidade era de cerca de 20 mil habitantes. Até 2015, deste modo, a população de Luís Eduardo Magalhães cresceu cerca de $295,8 \%$. Tal crescimento está diretamente relacionado às mudanças geradas pela agricultura moderna. Outra informação interessante é que Luis Eduardo é palco da Feira Internacional de Tecnologia Agrícola em Ação (Agrishow), que expõe inovações tecnológicas e tem lugar quase todos os anos. Luis Eduardo é a única cidade do agronegócio do Nordeste que recebe esse evento, além de Ribeirão Preto (SP), Rio Verde (GO) e Rondonópolis (MT) (ELIAS, 2011).

O sul do Maranhão e o sul do Piauí foram inseridos na dinâmica da agricultura moderna entre o final da década de 1980 e o início da década de 1990, ocupando novas áreas de reserva da grande agricultura (ELIAS, 2006a). No Maranhão, o município de Balsas exerce

${ }^{32}$ Tais informações resultam da vivência do autor nessa região do sul do Piauí, bem como das saídas de campo em Bom Jesus, nas quais se verificou que existem os alevinos nessas cidades, porém mais caros que em Barreiras. 
o comando das ações em relação à agricultura moderna. Possui 83.528 habitantes, segundo dados do censo de 2001 - sendo que, no censo 2000, esse município possuía 60.163 habitantes. Vale ressaltar que a população urbana do município é de 72.771 habitantes. E a população rural, é de 10.757 , de maneira que cerca de $87,1 \%$ da população de Balsas vive na zona urbana ${ }^{33}$, fato que, segundo Alves (2005), diferencia Balsas do contexto dos municípios do sul do maranhense, dos quais a maior parte apresenta população rural mais expressiva. Além disso, segundo o mesmo autor, revela que Balsas acaba atendendo as necessidades internas e dos municípios vizinhos, mesmo de municípios piauienses, como Santa Filomena e até Uruçuí.

Segundo Alves (2005) e Elias (2006a), os Cerrados piauienses foram inseridos mais tardiamente em relação aos demais estados, sendo mais intensamente povoados por grupos sulistas a partir da segunda metade da década de 1990, influenciados pela expansão da fronteira agrícola no oeste baiano e no sul do Maranhão. É bem difundida a ideia de que o Estado do Piauí representa a última fronteira agrícola do país, ou seja, que seria uma das áreas mais recentemente incorporadas ao circuito da grande produção moderna, sobretudo de grãos. No entanto, devemos considerar que ainda existem inúmeras áreas não exploradas pelo agronegócio, que, em um futuro próximo, podem ser incorporadas à produção agropecuária moderna.

As duas cidades que mais ganham destaque no Estado do Piauí são Uruçuí e Bom Jesus, mas aprofundaremos sua análise apenas no capítulo 3, quando já conheceremos o processo histórico de ocupação da agricultura moderna nos Cerrados piauienses.

No Estado de Tocantins, por sua vez, quem realiza o controle das ações em relação à agropecuária moderna é o município de Araguaína, que é o município do agronegócio mais populoso da região do MAPITOBA, com 154.484 habitantes. Destaca-se que Araguaína é comumente conhecida como "capital do boi gordo", e possui o segundo maior PIB municipal, bem como a segunda maior população do Tocantins, perdendo somente para a capital Palmas. A cidade angaria maior projeção a partir da construção da rodovia Belém-Brasília (GOMES JUNIOR, 2015). Segundo Gomes Júnior (2015), o crescimento da sua importância no contexto amazônico evidencia também a importância das cidades intermediárias como receptoras de grandes atividades e processos econômicos vigentes no contexto brasileiro e mundial. As ideias defendidas pelo autor também servem de base para análise do crescimento

\footnotetext{
${ }^{33}$ Dados coletados do Censo de 2000 e 2010 do IBGE.
} 
de outras cidades médias na região agrícola denominada MAPITOBA. Ainda de acordo com Gomes Júnior (2015), as cidades intermediárias, denominadas por ele, seriam

[...] as responsáveis pela intermediação entre as metrópoles regionais, metrópole nacional e cadeias globais de produção e comercialização de um lado; e suas regiões de influência imediata, que compreendem cidades com baixos níveis de centralidade de outro. São cidades responsáveis pela organização dos processos de geração e transferência de valor em suas regiões (GOMES JÚNIOR, 2015, p.20).

Nesse caso, o autor considera que Araguaína exerce esse papel centralizador de investimentos de atividades econômicas ligadas aos diferentes setores, destacando-se pelas atividades ligadas à expansão da fronteira agrícola. Inclusive, é importante ressaltar que Araguaína situa-se próxima dos limites entre o Tocantins e o Estado do Pará. Sendo assim, verifica-se que a expansão do agronegócio tem integrado também recortes territoriais da região amazônica, configurando, assim, o que Gomes Junior (2015) denomina de borda da floresta amazônica.

Araguaína pode, ainda, ser considerada como espelho do avanço das atividades ligadas à agricultura e à pecuária moderna, pois nota-se que, apesar desse município se destacar na produção de carne bovina, está localizado em uma área de influência dessa agricultura moderna, o que revela a tendência de complementação e localização próxima de ambas as atividades em diferentes recortes espaciais no Brasil, já que, por exemplo, muitos grandes fazendeiros cultivam soja e milho para a produção de ração animal e engorda através do sistema de confinamento.

No Piauí, a associação das duas atividades econômicas ligadas ao setor primário já tem sido notada em algumas áreas de expansão da agropecuária moderna e nos arredores dos grandes projetos, como pode observado na imagem a seguir, foto da serra do Uruçuí, mais especificamente do município de Monte Alegre do Piauí, próximo à fronteira municipal com Bom Jesus, na qual observa-se a existência da criação de bovinos das bordas dos chapadões, próximos aos grandes projetos de soja e milho. 
Figura 5: Atividades pecuárias nas bordas dos Chapadões dos platôs piauienses

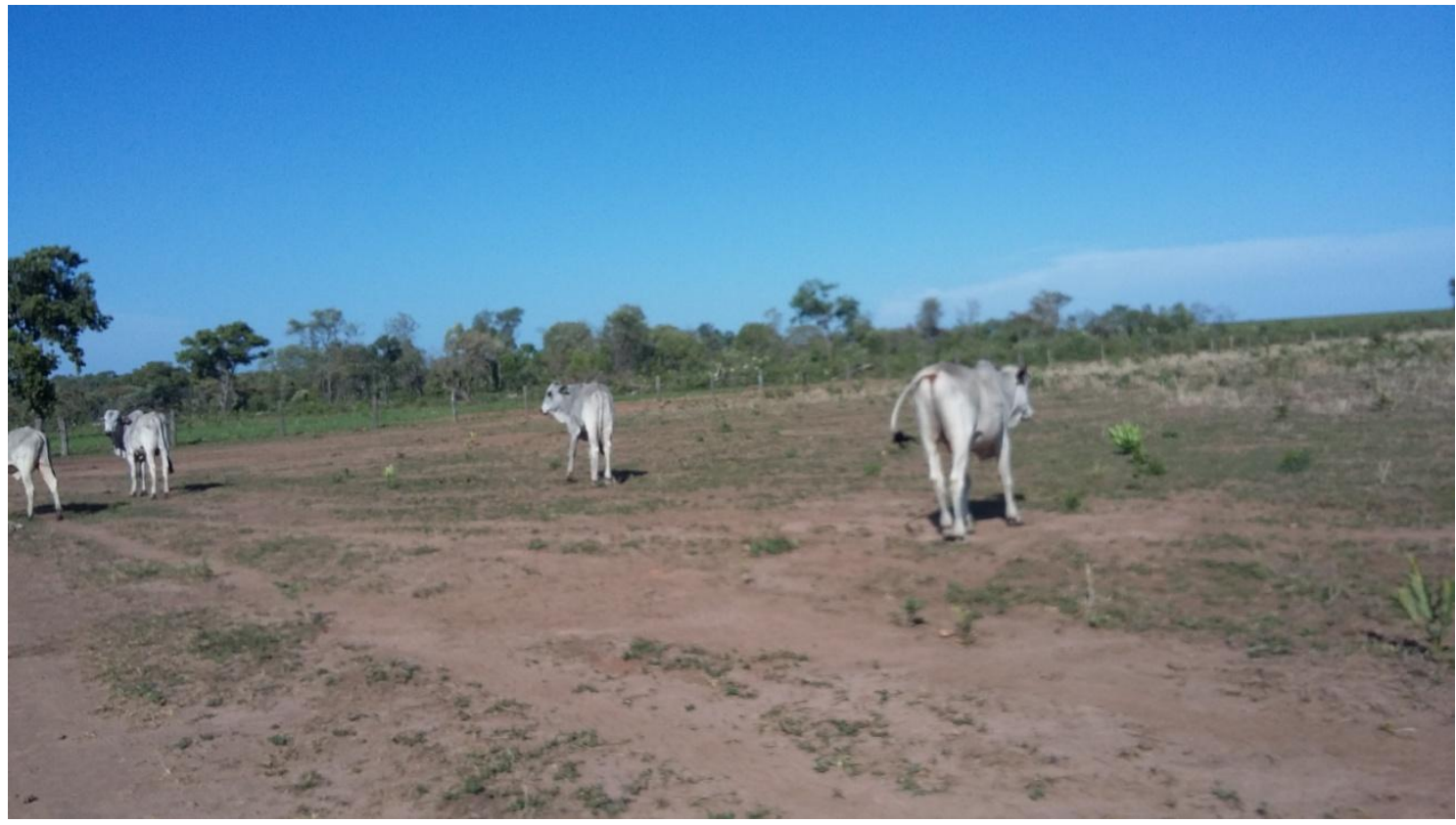

Fonte: o autor, (2015).

Apesar de ainda serem atividades de pequeno e médio porte, a criação de bovinos próxima aos grandes projetos de agricultura moderna corrobora a complementaridade entre as atividades e aponta o possível futuro de muitas áreas dos platôs piauienses, que indicam também o crescimento das atividades pecuárias modernas no Sudoeste Piauiense, região de expansão da fronteira agrícola.

Abaixo, é possível conferir algumas informações analisadas sobre os municípios do agronegócio referentes aos dados populacionais.

Tabela 7- Síntese dos dados populacionais dos municípios do agronegócio do MAPITOBA

\begin{tabular}{|c|c|c|c|c|c|c|}
\hline $\begin{array}{c}\text { Município } \\
\text { UF }\end{array}$ & $\begin{array}{c}\text { População } \\
\mathbf{2 0 0 0}\end{array}$ & $\begin{array}{c}\text { População } \\
\text { Urbana } \\
\mathbf{2 0 0 0}\end{array}$ & $\begin{array}{c}\text { Taxa de } \\
\text { Urbanização } \\
\mathbf{2 0 0 0}\end{array}$ & $\begin{array}{c}\text { População } \\
\mathbf{2 0 1 0}\end{array}$ & $\begin{array}{c}\text { População } \\
\text { Urbana } \\
\mathbf{2 0 1 0}\end{array}$ & $\begin{array}{c}\text { Taxa de } \\
\text { Urbanização } \\
\mathbf{2 0 1 0}\end{array}$ \\
\hline Barreiras/BA & 131335 & 115331 & $87,8 \%$ & 137.427 & 123.741 & $90 \%$ \\
\hline $\begin{array}{c}\text { Luís Eduardo } \\
\text { Magalhães }\end{array}$ & $20.000 *$ & - & - & 60.105 & 54.881 & $91,3 \%$ \\
\hline Balsas/MA & 60.163 & 50.132 & $83,3 \%$ & 83.528 & 77.771 & $87,1 \%$ \\
\hline Uruçuí/PI & 17.003 & 11.106 & $65,3 \%$ & 20.149 & 15.505 & $77 \%$ \\
\hline Bom Jesus/PI & 15.898 & 10.942 & $68,8 \%$ & 22.629 & 17.623 & $77,9 \%$ \\
\hline Araguaina/TO & 113.090 & 105.822 & $93,6 \%$ & 150.484 & 142.925 & $95 \%$ \\
\hline
\end{tabular}

Fonte: Elaborada pelo autor, dados dos Censos 2000 e 2010. 
Primeiramente, esclareçamos que os dados referentes à população urbana e à taxa de urbanização de Luís Eduardo Magalhães em 2000 não figuram na tabela pois foi justamente nesse ano em que o município se desmembrou de Barreiras. A população do ano 2000 era de cerca de 20 mil habitantes, como aponta Alves (2005), e como já mencionado. Isto posto, observa-se que em todas essas cidades houve crescimento populacional significativo, com exceção de Barreiras e de Uruçuí, bem como crescimento da taxa de urbanização, que se deve aos novos dinamismos gerados por conta da modernização agrícola.

No mais, é importante ressaltar que as capitais do agronegócio no Piauí são, justamente, os municípios menos urbanizados entre os que foram considerados do MATOPIBA, o que evidencia o caráter atrasado da inserção dos Cerrados piauienses na dinâmica da agricultura moderna brasileira. Da mesma forma, também é muito importante destacar o grande crescimento populacional da cidade de Luís Eduardo Magalhães, que tem atraído mais migrantes para essa cidade, o que faz Barreiras perder inúmeros sulistas e novos agentes para a nova capital do agronegócio do Estado da Bahia, o que, em certa medida, explica a quase estagnação do crescimento populacional e da taxa de urbanização do município.

Apesar de ser um município muito novo, com apenas quinze anos, Luís Eduardo Magalhães cada vez mais reconfigura sua paisagem, sobretudo a urbana ${ }^{34}$, com a expansão de bairros de alto e de baixo padrão de moradia, por exemplo. Elias (2011) destaca algumas características de sua paisagem urbana:

\begin{abstract}
Um visitante desavisado vai se surpreender ao chegar à cidade e se deparar com as grandes lojas de tratores, colheitadeiras, insumos químicos etc. que se perfilam pela entrada principal de Luis Eduardo Magalhães. O espanto continua quando, logo em seguida, o visitante se depara com as plantas industriais da Bunge, com seus portentosos silos, dentro do perímetro urbano da cidade, junto à área residencial. (ELIAS, 2011, p.163)
\end{abstract}

A partir dos dados da tabela 7 e tudo que já foi abordado, pode-se afirmar que todas as cidades do agronegócio apresentam reconfigurações das áreas urbanas e rurais - há grande concentração da população na zona urbana, modificações no comércio e serviços, novos agentes, presença de eventos diferenciados, exclusão socioespacial representativa e crescente, etc. Em relação às elevadas taxas de urbanização, pode-se afirmar que isso ocorre tanto por

${ }^{34}$ Essas mudanças da paisagem urbana de Luís Eduardo Magalhães foram observadas nas inúmeras viagens realizadas para o Estado do Piauí, já que esse município está no caminho que sai do Distrito Federal. A quantidade de novos prédios, de empreendimentos como escolas, postos de combustíveis, revendedoras de automóveis, surgimento de condomínios fechados e novas construções só fazem aumentar. 
conta da migração de sulistas para essas cidades, como também de camponeses e moradores locais vindos de outros municípios para as áreas urbanas.

Analisemos, agora, a figura abaixo, na qual estão expostos alguns dados referentes à região do MATOPIBA e aos principais municípios ligados ao agronegócio. 


\section{Figura 6: Interiorização da Fronteira Agrícola brasileira}

Mais riqueza no interior o Mapitoba já se destaca produzindo $10 \%$ da soja do país. Outras culturas estão crescendo na região

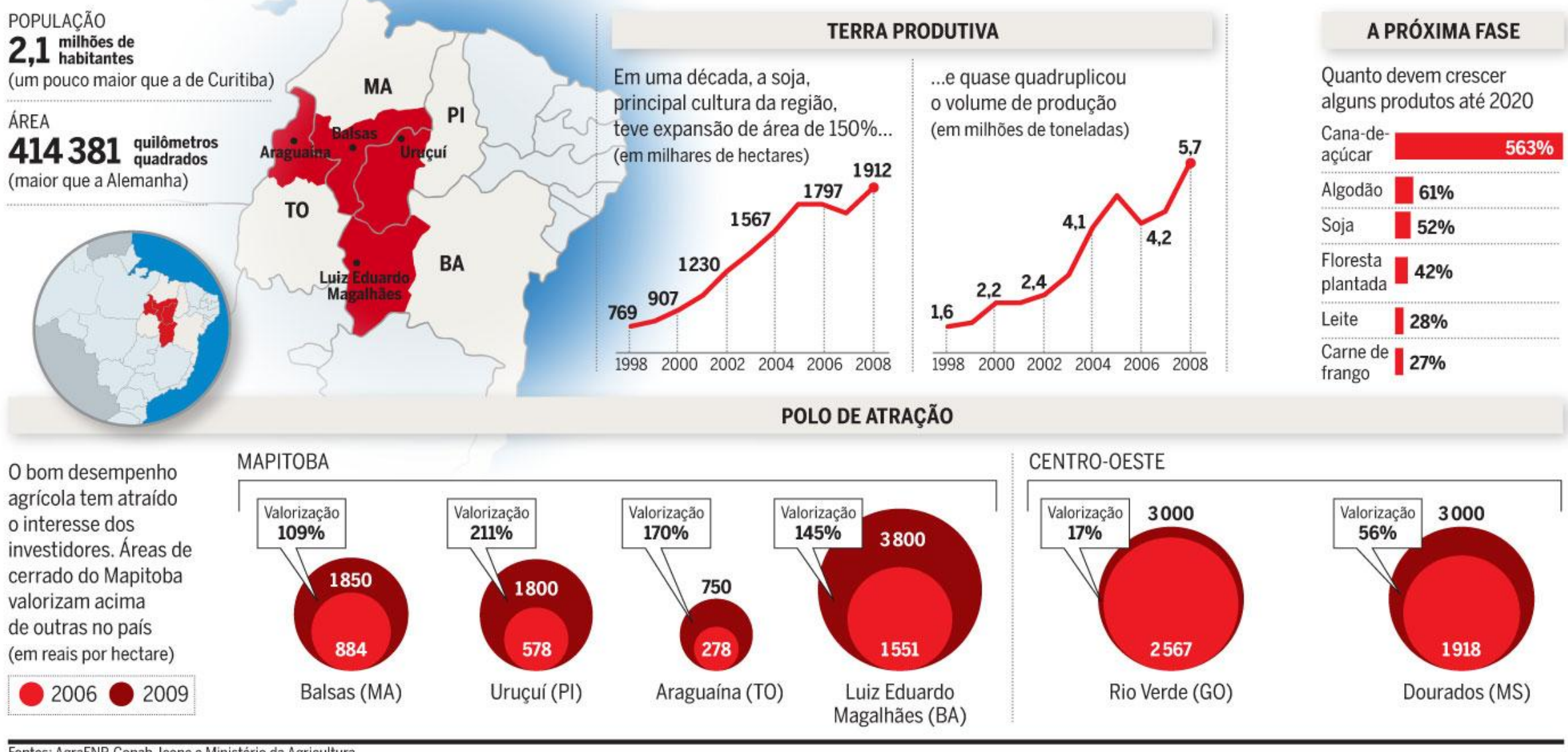

Fontes: AgraFNP, Conab, Icone e Ministério da Agricultura

Fonte: http://exame.abril.com.br/revista-exame/edicoes/mm2009/noticias/campeas-desempenho-481689, acesso em março de 2013. 
A figura apresenta alguns dados obtidos no Ministério da Agricultura, que destacam que o MAPITOBA já representa 10\% da produção de soja do Brasil. Além disso, percebe-se que a soja teve uma expansão de 150\% entre os períodos de 1998 a 2008 na área plantada em hectares. O volume da produção em hectares quase quadriplicou. A figura ainda projeta o crescimento de certas culturas agrícolas até o ano de 2020, dais quais se destaca a expansão da cana-de-açúcar em 563\%. As paisagens das áreas dos Cerrados do MATOPIBA, portanto, sevem sofrer ainda maiores alterações com a inserção da cana-de-açúcar na produção. O algodão deverá crescer em torno de $61 \%$, enquanto a soja, cerca de $52 \%$. Além disso, as áreas de florestas plantadas, como o eucalipto, crescerão em torno de $42 \%$.

É interessante o destaque de algumas cidades piauienses na questão da atração dos investimentos em reais por hectares, no período de 2006 a 2009, em que figuram a cidade de Balsas, no Maranhão, de Uruçuí, no Piauí, de Araguaína, no Tocantins, e de Luiz Eduardo Magalhães, na Bahia. Dentre as quatro, Uruçuí é a que mais obteve crescimento dos investimentos por hectare - cerca de $211 \%$, superior até mesmo a Luiz Eduardo Magalhães, com 149\%. É possível afirmar, assim, que Uruçuí torna-se cada vez mais um pólo de atração de investimentos e um dos centros do agronegócio no Piauí, ao lado de Bom Jesus.

A figura ainda compara o crescimento dos investimentos por hectares com cidades da região Centro-Oeste já consolidadas como centros do agronegócio, como Rio Verde (GO) e Dourados (MT). A primeira apresenta crescimento em torno de $17 \%$, e a segunda, de 56\%. As cidades do MAPITOBA, portanto, tem recebido grande quantidade de investimentos de grandes empresas, o que gera um aumento na área plantada e no volume da produção.

Para se evidenciar a lógica da incorporação de novas áreas agrícolas no MAPITOBA, recorremos à análise de Frederico (2013), na qual o autor evidencia a expansão da área plantada no Nordeste brasileiro:

Entre 2005 e 2009, enquanto a área plantada de soja no território brasileiro recuou $7 \%$, a quantidade produzida aumentou $12 \%$. Os percentuais variam de acordo com a escala de análise. A região Sul (área de produção tradicional) foi a que teve o maior crescimento percentual da quantidade produzida: enquanto essa cresceu 47\%, a área plantada diminuiu 5\%. Em todas as demais regiões houve diminuição da área plantada de soja no período analisado, com exceção do Nordeste onde a área aumentou 14\%. (FREDERICO, 2013, p.36). 
Nesse sentido, a expansão da área plantada no Nordeste, de acordo com o autor, segue lógica contrária em relação ao restante do país, no qual se observa o recuo da área plantada e aumento da produtividade, o que é, justamente, a lógica contemporânea, apontada por Elias (2006b), e que visa a diminuição de gastos, sendo o incremento tecnológico o grande aliado do agronegócio. É o que a autora denomina de "formas mais eficazes de produção".

Esse aumento da produtividade era algo para o qual Martine (1989) chamava a atenção como uma necessidade do país. O autor destaca a expansão da agricultura com as novas áreas incorporadas em cada estado:

Com relação às regiões de expansão da área plantada de soja no Cerrado observa-se que: no Maranhão, as plantações têm se expandido na região de Chapadinha, no nordeste do estado, e da região sul (município de Balsas) em direção à área central e leste; no Piauí, a área cultivada continua a se expandir na região sudoeste (Gurguéia); na Bahia, o crescimento da área continua a ocorrer no extremo oeste, partindo dos municípios de Barreiras e Luís Eduardo Magalhães em direção aos municípios de Formosa do Rio Preto (sentido norte) e Cocos (sentido sul); [...] (FREDERICO, 2013, p.39).

O autor cita, nessa passagem, os municípios ligados ao agronegócio. Com relação à Bahia, nota-se que a influência de Barreiras sobre outros municípios tem aumentado, enquanto em Formosa do Rio Preto, município próximo à divisa com o Estado do Piauí, são desenvolvidos grande parte dos projetos de agricultura moderna.

Essa mudança no padrão de produção nos estados da região do MAPITOBA proporciona novas realidades a esses estados e, de certa forma, desconstrói a ideia de atraso econômico e pouco dinamismo da região Nordeste do Brasil, ainda bem presente no país. Além das áreas dos Cerrados nordestinos, Elias (2006b) cita também áreas de vales úmidos, como o submédio do São Francisco e o baixo curso dos rios Açu e Jaguaripe.

Alves (2005) destaca essa mudança da estrutura produtiva dos Cerrados nordestinos e caracteriza o processo de inserção dessas novas áreas produtoras:

De espaço de pouca expressão econômica, sustentado na pecuária extensiva e na agricultura de subsistência transforma-se, a partir do final da década de 1970, num produtor de commodities agrícolas, destacadamente de grãos, que se amplia também para outras ramificações da cadeia produtiva do setor agroindustrial. (ALVES, 2005, p.1).

É necessário, contudo, analisar cuidadosamente o processo de modernização das atividades agropecuárias na região Nordeste, sobretudo nos Cerrados, pois, de acordo 
com Bezerra (2008, p.74), "O Nordeste compõe atualmente uma das regiões brasileiras que tem sofrido com a expansão e ocupação de lugares voltados para a produção de uma agropecuária atenta aos ditames do agronegócio.” Nesse sentido, algumas áreas dessa região são alvo de um processo hegemônico, e exigem análise mais cuidadosa em decorrência da existência de processos contraditórios que se desenvolvem a partir da expansão do agronegócio no Nordeste, região esta marcada por processos históricosociais particulares, sendo até hoje referida como "região dos problemas", da pobreza, da estagnação econômica e pela presença de um clima marcado por secas que assolam a população (BEZERRA, 2008).

De acordo com Santos e Silveira (2001),

No Brasil, a região Nordeste foi durante muito tempo um subespaço dotado de uma razoável rede rodovia de uma razoável rede rodoviária criada para minorar as consequências das secas, enquanto o uso dessa rede era limitado a certos momentos (por exemplo, as secas) e a certas funções. (SANTOS; SILVEIRA, 2001, p.262).

Algumas áreas do nordeste tem sido reconfiguradas em seus territórios, criando, assim, alguns espaços luminosos, termo utilizado pelos autores destacados acima, mais tarde utilizado também por Elias (2006a, 2006b) nas análises do processo de reestruturação produtiva de algumas áreas rurais brasileiras. O termo nos remete contraditoriamente às ideias de Adorno e Horkheimer (1985), que defendem que o progresso pode resultar em regressão. A chegada do progresso em áreas supostamente estagnadas economicamente, portanto, pode influenciar diretamente no surgimento de efeitos contraditórios e perversos ligados à chegada dos instrumentos modernizantes da estrutura econômica e produtiva.

Oliveira (2009) demonstra, em seu trabalho, que a região Nordeste é historicamente uma região de resistência do movimento camponês no Brasil, de relações não capitalistas de produção, com grande número de posseiros, inclusive sendo a região brasileira campeã nesse quesito. Bezerra (2008) corrobora essa ideia em seu trabalho, enfatizando que, mesmo com o avanço do agronegócio do Nordeste, contraditoriamente, os movimentos oposicionistas às atividades hegemônicas se instalam, como é o caso de movimentos de luta pela terra, organizados por agentes que desempenham “[...] agricultora camponesa de base familiar tradicional” (BEZERRA, 2008, p.67).

Pode-se caracterizar, assim, a expansão da agricultura moderna para áreas do Nordeste como um marco na história dessa região. Além disso, é interessante considerar 
que a expansão da agricultura moderna nos faz alerta para novas possibilidades de ampliação de disputas fundiárias e conflitos nesses estados de expansão da fronteira agrícola, pois, segundo Oliveira (1999, p.85), “[...] o traço essencial da estrutura fundiária brasileira é o caráter concentrador da terra", com clara ampliação das áreas destinadas à agricultura moderna.

No processo de reestruturação de novas áreas inseridas no processo de modernização da agricultura, há clara interação entre o novo e o velho, o poder do Estado e do mercado, resistência de movimentos sociais (ELIAS, 2006a). A expansão da agricultura moderna para áreas distantes do Brasil Central consideradas "estagnadas" ${ }^{35}$, em especial para o MAPITOBA, representa não mais que a desconcentração da estrutura produtiva do país em detrimento do "inchaço" da produção na região sul do Brasil. Ainda persiste, porém, no país, o caráter centralizador das "decisões econômicas".

Através da intensificação da globalização, da produção e do consumo, consumase a dispersão espacial da produção. A palavra “dispersão", utilizada por ELIAS (2006), pode ser também empregada para analisar a atual realidade de expansão da fronteira agrícola nas áreas dos Cerrados brasileiros, sobretudo os nordestinos. No entanto, como dito, apesar da expansão da agricultura para o Brasil Central, a estrutura das decisões econômicas e das centralidades das lideranças de grandes grupos hegemônicos não se desconcentrou e permanece fortemente no eixo do Centro-Sul brasileiro, onde se observa a permanência de sedes de grandes empresas ligadas à agricultura moderna e a atuação significativa do Estado através da disponibilização de créditos e infraestrutura necessária, como o avanço dos transportes e das comunicações.

Quanto a estes últimos, Santos e Silveira (2001, p.261) sustentam: “[...] nos países de maior extensão territorial e que também são países com grandes disparidades regionais e de renda, o processo de criação de fluidez é seletivo e não-igualitário." Assim, no Brasil, país com dimensões continentais e grandes disparidades regionais, a aplicação de determinadas políticas de instalação de infraestrutura de transportes e comunicação acaba excluindo inúmeras áreas e ampliando as diferenças entre elas. Daí, inferimos que é necessário questionar de forma crítica e propositiva eventos hegemônicos ligados à modernização e ao dito progresso, e uma das grandes

${ }^{35}$ Segundo Oliveira (1999) a expansão da agricultura acaba constituindo e formando novas áreas do agronegócio e, além disso, promove a inserção de áreas teoricamente condenadas à estagnação econômica. 
ferramentas do conhecimento científico está justamente na potencialidade de crítica às proposições ideológicas, evidenciando os limites e contradições de certos discursos (FOUREZ, 1995).

Destacamos, porém, que a temática da modernização agrícola na região do MAPITOBA é um tema complexo e grandioso, e não pretendemos esgotá-lo. Um desenvolvimento mais profundo do tema poderá ser realizado mais à frente, em trabalhos posteriores.

Assim, reforça-se assim a importância da produção acadêmica sobre essa temática, cuja natureza recente constitui desafio para acadêmicos de diferentes áreas, como Geografia, História, Agronomia, Sociologia, entre outras. É preciso, porém, avançar na tentativa de mostrar os novos contextos da temática. Assim, abordaremos, a seguir, as principais questões e tópicos sobre a criação da Agência de Desenvolvimento do MATOPIBA, uma iniciativa do Governo Federal que possui potencial para promover intensas transformações nos estados integrantes dessa região.

\subsection{A Agência de Desenvolvimento do MATOPIBA}

A criação do Plano de Desenvolvimento Agropecuário- PDA do MATOPIBA foi fundamentada pelo decreto presidencial n 8.447, de 06 de Maio de 2015. Esse Plano de Desenvolvimento do MATOPIBA reúne quatro estados: Maranhão, Tocantins, Piauí e Bahia. Não analisaremos profundamente a criação dessa agência, pois acreditamos que a ação é muito recente e pode render trabalhos futuros. A localização da área do MATOPIBA, portanto, pode ser observada a seguir: 
Figura 7: Proposta de Delimitação do MATOPIBA

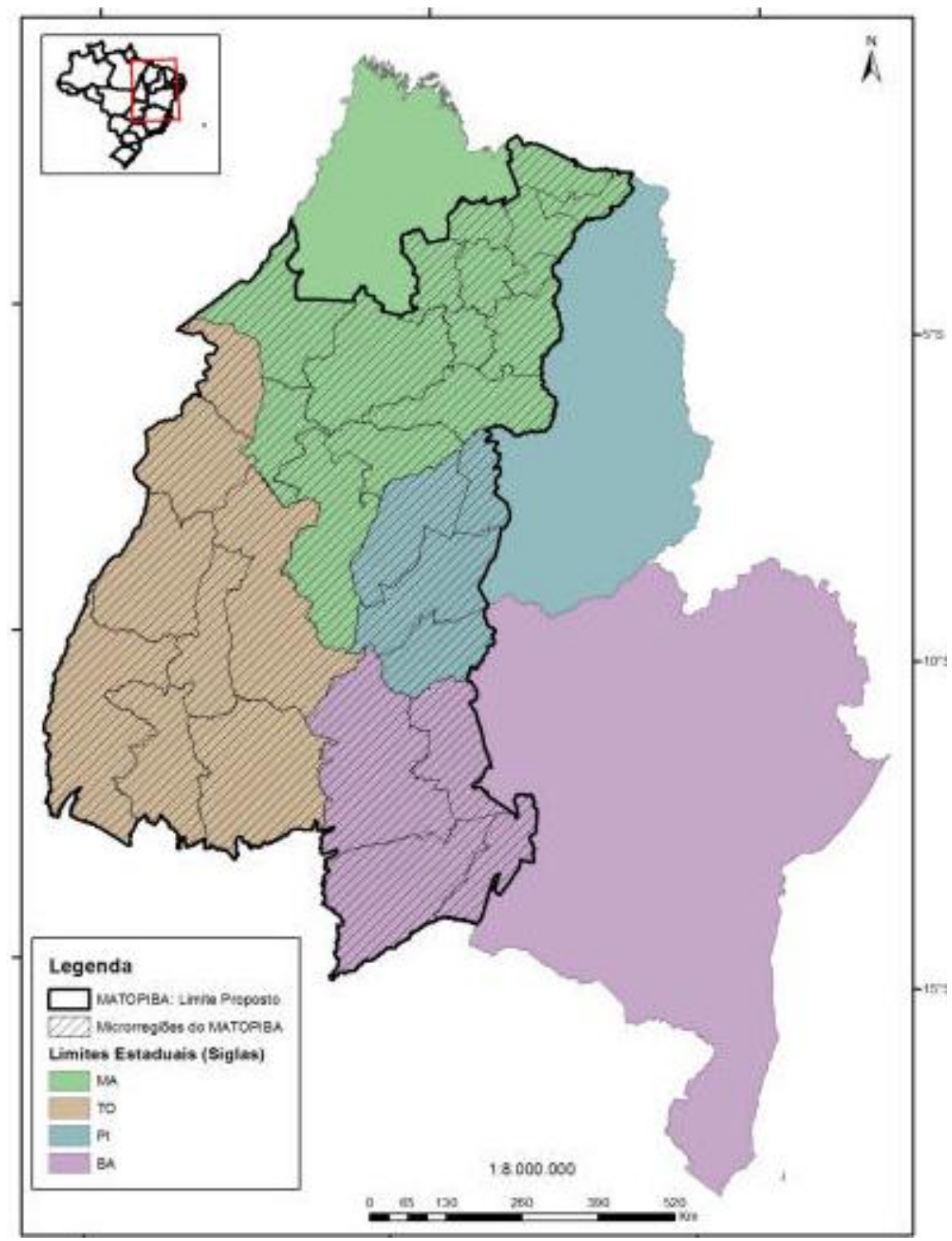

Fonte: EMBRAPA (2015b, p.15).

Percebe-se que o estado mais privilegiado em relação à área compreendida pelo PDA-MATOPIBA é o Estado de Tocantins, pois todos os municípios e microrregiões foram integrados à região. Segundo dados do PDA-MAPITOBA, 38\% da área dessa região pertence ao Estado de Tocantins, 33\%, ao Maranhão, 18\%, à Bahia, e 11\%, ao Piauí. Essa proposta de delimitação foi elaborada pelo Grupo de Inteligência Territorial Estratégica (GITE), idealizado através de acordo entre o Instituto Nacional de Colonização e Reforma Agrária (INCRA) e a Empresa Brasileira de Pesquisa Agropecuária (Embrapa). Nessa proposta, foram integrados 31 microrregiões e 337 municípios dos quatro estados integrantes, envolvendo uma área total de 73.173.484,58 ha. (BRASIL, 2015b). 
A criação do MATOPIBA envolveu a seleção de três eixos estruturantes: infraestrutura, inovação e tecnologia, e ampliação da classe média rural (BRASIL, 2015). A seleção dos municípios foi feitas com base nos quadro naturais, agrários, agrícolas, de infraestrutura e análise socioeconômica (BRASIL, 2015b). Lopes (2014, p.1), presidente da Embrapa, mostra-se muito otimista em relação à PDA-MAPITOBA: “[...] lá, agricultores inovadores, com muita coragem enfrentam o desafio de implantar uma agricultura moderna eficiente, baseada em ciência e tecnologia". Ressaltamos que o termo "coragem", utilizado pelo autor, parece inapropriado na medida em que grande parte desses agricultores dispôs de amplo apoio do Estado e domina as bases produtivas em um contexto que envolve muitas situações de exclusão socioespacial.

O comitê gestor do MATOPIBA é composto por um representante de cada órgão do Poder Executivo Federal, a saber, a) Ministério da Agricultura, Pecuária e Abastecimento; b) Ministério do Desenvolvimento Agrário; c) Ministério do Desenvolvimento, Indústria e Comércio; d) Ministério da Integração Nacional; e) Ministério da Ciência, Tecnologia e Inovação; f) Ministério da Educação. Além disso, conta também com os representantes do poder executivo dos quatro estados integrantes; com seis representantes do setor empresarial e de entidades sindicais patronais da agroindústria e da agropecuária da área de abrangência do MAPITOBA; e dois representantes de instituições de ensino e pesquisa na área de abrangência do MAPITOBA.

O discurso envolvido na criação do MATOPIBA é o de que essa agência pretende promover o desenvolvimento dessa região com o objetivo de elevar a qualidade de vida da população. $O$ artigo $1^{\circ}$ do decreto afirma que a criação da agência “[...] tem por finalidade promover e coordenar políticas voltadas ao desenvolvimento econômico sustentável fundado nas atividades agrícolas e pecuárias que resultem na melhoria da qualidade de vida da população" (BRASIL, 2015, p.2). Devemos considerar, porém, que as contradições do agronegócio, já abordadas neste trabalho, podem agravar as contradições socioespaciais nesses estados integrantes do MATOPIBA. É preciso que nos perguntemos se a criação dessa agência realmente proporcionará melhorias para a população local, ou se o Estado privilegiará os grandes agentes hegemônicos ligados à agropecuária moderna.

Kátia Abreu, ministra da agricultura, afirmou, em uma entrevista para um veículo de notícias, que "A experiência nos mostra que a mola propulsora de tudo são 
os empresários. A agência terá que trabalhar ao lado daqueles que gerarão emprego"36 (AIBA, 2015, p.1). Nesse sentido, pressupõe-se que a grande preocupação da agência do MATOPIBA não será exatamente os pequenos produtores, mas sim os grandes agricultores e as empresas ligadas ao agronegócio e ao grande capital. A questão da geração de emprego destacada pela ministra é umas das maiores controvérsias em relação à moderna agricultura, pois ela gera relações de trabalho desiguais, aprofundamento do trabalho assalariado e expropriação de terras de pequenos agricultores locais, bem como a submissão dos mesmos aos empregos temporários gerados no desenvolvimento das grandes lavouras, o aumento do desmatamento, e utilização de trabalho semiescravo e escravo, conflitos fundiários, violência, etc. Nesse sentindo, a agência do MATOPIBA deveria se preocupar com esses fatores.

A Comissão Pastoral da Terra (CPT) (2015) observou alguns pontos ${ }^{37}$ fundamentais sobre a criação da agência MATOPIBA, em uma Audiência Pública na Comissão de Meio Ambiente e Desenvolvimento Sustentável da Câmara dos Deputados. Dentre eles, destaca-se o fato de que a instituição considera que não houve transparência na criação da agência, pois não houve consulta prévia às comunidades locais, sobretudo as tradicionais, como pequenos agricultores familiares, indígenas, posseiros. Nas palavras de Lopes (2014, p.1), “A região chama a atenção por seu dinamismo, complexidade e diversidade. Lá convivem a agricultura empresarial, áreas de preservação, agricultura familiar, quilombolas e indígenas.” Percebe-se que o autor não vislumbra os conflitos que envolvem essa "convivência", gerados, sobretudo, pela presença de grandes empresas e agricultores que acabam empreendendo inúmeras disputas por terras. Lopes (2014) é ainda mais otimista, na medida em que afirma que

\footnotetext{
Sua produção será fator de segurança alimentar para o Nordeste, assolado por secas que matam as plantas de sede e os animais de fome. Milho, sorgo e soja são essenciais para manter a produção animal, como ovos, carnes de frango e de suínos e leite. Ganha a região e o Brasil como um todo: desenvolvimento regional mais equilibrado, com geração de mais empregos e renda e menos perdas na pecuária do semiárido. (LOPES, 2014).
}

36 Trecho retirado da reportagem disponível no seguinte endereço eletrônico: http://aiba.org.br/noticias/aiba-apresenta-suas-propostas-para-a-futura-agencia-de-desenvolvimento-domatopiba/\#.ViFhYH6rTIV. Acesso em 20 de set. 2015.

37 Tais apontamentos estão disponíveis no seguinte endereço eletrônico: http://www.cptnacional.org.br/index.php/publicacoes/noticias/articulacao-cpt-s-do-cerrado/2815-redecerrado-questiona-governo-sobre-plano-matopiba. Acesso em 20 set. 2015. 
Se o foco da PDA-MATOPIBA for de fato a pequena agricultura e o fortalecimento da agricultura familiar, há possibilidade, sim, dessa região ganhar em relação à segurança alimentar. Porém, se o foco forem os grandes agricultores, existem grandes chances de ampliação da insegurança alimentar e das contradições socioespaciais nessas áreas.

Vários autores, como Elias (2011, 2012) e Thomaz Junior (2010), mostram que a agricultura moderna acaba gerando inúmeros impactos contraditórios, como a concentração da estrutura fundiária, aumento dos conflitos, maior desvalorização da agricultura familiar, etc. Thomaz Junior (2010) inclusive afirma que história do Brasil é marcada pela desvalorização dos camponeses. Nas palavras dele,

Durante toda a história da Brasil, os camponeses, bem como todos os trabalhadores, foram mantidos à margem do poder, por meio da violência; o golpe militar e o avanço do capitalismo no campo fizeram aumentar a miséria, a acumulação e a concentração fundiária e de riqueza. (THOMAZ JUNIOR, 2010, p.3).

Lopes (2014), por outro lado, se mostra novamente muito otimista:

\begin{abstract}
Matopiba é uma boa notícia. A agricultura floresce e acelera o crescimento de uma região que era carente, demandava alimentos e desenvolvimento social. Com maior produção, fazendeiros aumentam sua renda; indústria e comércio crescem mais. Surgem cidades com infraestrutura e empregos, atraindo profissionais como agrônomos, engenheiros, médicos, advogados e professores. Um ciclo social e econômico vigoroso, alimentado pela agropecuária. (LOPES, 2014, p.1).
\end{abstract}

O autor novamente faz análise pouco criteriosa sobre o processo no MATOPIBA, pois analisa apenas transformações em benefício de grandes agentes, como fazendeiros. A questão da geração de empregos é outra polêmica, já que, ainda que surjam postos de trabalhos especializados, como os citados pelo autor, grande parte da população não dispõe de formação para ser incorporada ao novo e reconfigurado mercado de trabalho.

A Comissão Pastoral da Terra também chama atenção para a questão ambiental, pois o MATOPIBA está em uma área ambiental delicada, em que se observa o contato entre diferentes biomas, no caso, a floresta amazônica, os Cerrados e a caatinga, que podemos observar abaixo: 


\section{Figura 8: Biomas do MAPTOPIBA}

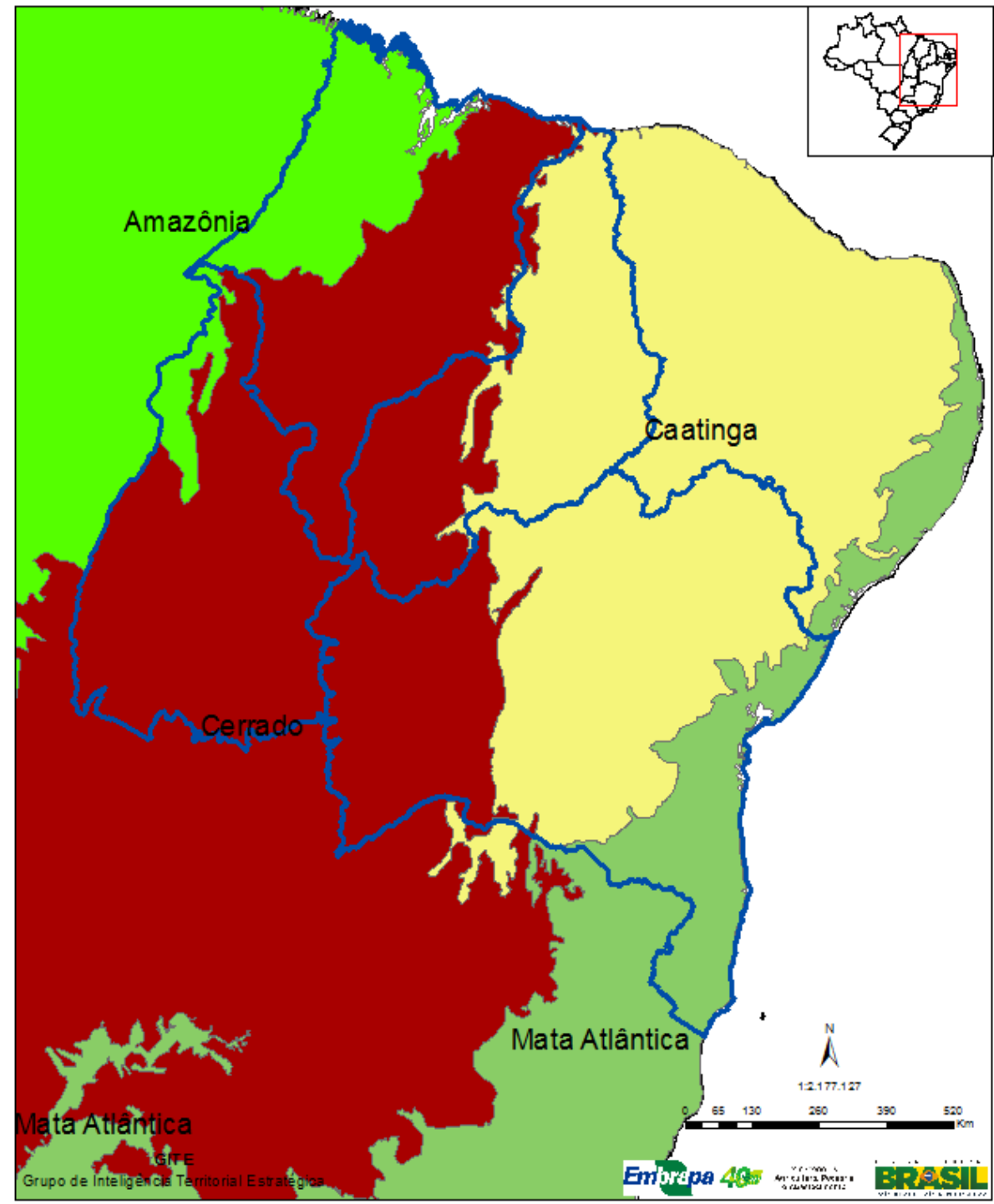

Fonte: EMBRAPA (2015b, p.14)

Nesse caso, a incorporação dessas áreas às dinâmicas agropecuárias modernas pode acentuar a substituição dos espaços naturais pelas culturas monocultoras ligadas à produção moderna. É preciso, também, chamar a atenção para a necessidade de se evitar que essa agência efetive apenas a expansão da agricultura de grande escala, ao invés de favorecer os agentes locais.

Segundo dados do PDA-MATOPIBA o cerrado é bioma predominante nessa região, com cerca de 90,94\% de toda a área; o bioma amazônico representa 7,27\% e, a Caatinga, 1,64\%, esta última mais presente nos Estados da Bahia e do Piauí.

Por ser uma ação e política muito recentes, não se sabe ainda a verdadeira finalidade da agência MATOPIBA. Nesse sentido, novos estudos e análises sobre essa agência são fundamentais para o reconhecimento das transformações socioespaciais e 
socioeconômicas dos estados integrantes. Lopes (2014, p.1), por exemplo, fala de algumas obras na região do MATOPIBA: "Há estradas em construção, a ferrovia NorteSul levará as safras a portos do Maranhão e Pará, a Leste-Oeste ligará Figueirópolis (TO) a Ilhéus (BA) e a hidrovia Tocantins-Araguaia deverá reduzir os custos de transporte."

No entanto, já é possível alertar para algumas questões verificadas em saída de campo nos municípios de Bom Jesus, Monte Alegre do Piauí e Uruçuí: observamos que grande parte da população, inclusive pequenos agricultores locais, nem mesmo estão cientes existência da criação da agência do MATOPIBA, o que evidencia a grande possibilidade da agência ser voltada aos grandes agricultores e empresas presentes nesse estado. Além disso, é importante destacar que a sede da agência no Estado do Piauí será na cidade de Bom Jesus, que nos últimos anos vem, cada vez mais, centralizando as ações referentes ao agronegócio globalizado. Nesse sentido, a instalação da sede em Bom Jesus pode acentuar ainda mais a centralidade dessa cidade no contexto piauiense.

Em relação ao contexto piauiense no PDA-MATOPIBA, foram selecionadas as seguintes microrregiões, localizadas na Mesorregião Sudoeste Piauiense, para integrarem a região:

Tabela 8: Microrregiões Piauienses pertencentes ao PDR- MAPITOBA

\begin{tabular}{|c|c|c|}
\hline Microrregião/PI & Área da microrregião (ha) & Municípios \\
\hline Alto Médio Gurguéia & $2.760 .895,75$ & 4 \\
\hline Alto Parnaíba Piauiense & $2.548 .521,38$ & 9 \\
\hline Chapadas do Extremo Sul & $1.785 .354,25$ & 9 \\
\hline Piauiense & $1.109 .816,78$ & 33 \\
\hline Bertolínia & $8.204 .588,16$ & \multicolumn{2}{|c|}{} \\
\hline Total & & \\
\hline
\end{tabular}

Fonte: Dados Embrapa (2015b), elaborada pelo autor.

Observa-se que as duas microrregiões selecionadas como recorte espacial para a pesquisa estão integradas ao PDR-MAPITOBA. Além disso, Corrente, cidade situada na microrregião Chapadas do Extremo Sul Piauiense, também é contemplada por esse plano de desenvolvimento agropecuário. No total, o plano contempla quatro microrregiões e 33 municípios, com uma área total 8.204.588,16 ha, que equivale a $11 \%$ do Estado do Piauí. Dentre os estados integrantes, o Piauí possui a menor área integrada ao MAPITOBA. (BRASIL, 2015b). 
Abaixo, apresentamos a tabela com os dados da produção de soja e o total da produção de grãos, com os devidos percentuais de crescimento no período de 1993 a 2011.

Tabela 9: Evolução da Produção de soja e de grãos no MAPITOBA entre 1933 e 2011

\begin{tabular}{|c|c|c|c|c|c|c|}
\hline \multirow[b]{2}{*}{ ESTADO } & \multicolumn{2}{|c|}{ Produção de Soja (t) } & \multirow{2}{*}{$\begin{array}{l}\text { Crescimento } \\
(\%)\end{array}$} & \multicolumn{2}{|c|}{ Produção de Grãos (t) } & \multirow{2}{*}{$\begin{array}{l}\text { Crescimento } \\
(\%)\end{array}$} \\
\hline & 1993 & 2011 & & 1993 & 2011 & \\
\hline Maranhão & 84.012 & 1.511 .321 & $1.698,93 \%$ & 734.209 & 2.508 .849 & $237.56 \%$ \\
\hline Tocantins & 31.782 & 1.153 .902 & $3.530 .67 \%$ & 476.243 & 1.987 .421 & $317.31 \%$ \\
\hline Piauí & 4.745 & 1.081 .643 & $22.695 .42 \%$ & 114.569 & 1.736 .335 & $1.415 .53 \%$ \\
\hline Bahia & 648.551 & 3.279 .429 & $405.65 \%$ & 1.179 .531 & 6.271 .497 & $431.69 \%$ \\
\hline TOTAL & 769.090 & 7.026 .296 & - & 2.504 .552 & 12.504 .101 & - \\
\hline
\end{tabular}

Fonte: Embrapa (2015b), adaptada pelo autor.

A partir dos dados, pode-se afirmar que a produção total de grãos e de soja que mais obteve crescimento é justamente a do Estado do Piauí. De 1993 a 2011, a produção de soja cresceu extraordinários $22.695 \%$, e a produção total cresceu $1.415 \%$. Esse alto percentual em relação aos demais estados pode ser explicado pelo fato dos Cerrados piauienses terem sido intensamente ocupados somente a partir da segunda metade da década de 1990, como aponta Alves (2005).

Nesse caso, pode-se considerar que a produção agropecuária piauiense ainda se encontra em processo de maturação, pois, no ano de 2011, dos quatro estados integrantes do MAPITOBA, o Piauí obteve a menor produção total de grãos. Esse papel pode, contudo, ser revertido nos próximos anos.

Nesse sentido, precisamos analisar o papel do Estado como agente responsável e totalmente atrelado ao contexto do desenvolvimento do agronegócio no MATOPIBA e dos cerrados do Brasil Central.

\subsection{O papel do Estado como indutor da Modernização Agrícola, em especial nos} Cerrados brasileiros

O Estado brasileiro teve um papel central como indutor do processo de modernização da agricultura, e também como promotor da expansão agrícola para 
diferentes estados. Devemos, porém, analisar mais amplamente a sua atuação, questionando seu papel na promoção de melhorias para a sociedade e na atuação na esfera econômica.

Nesse cenário de processos globalizantes e da enorme necessidade de redução das desigualdades sociais e regionais, o Estado precisa de uma ressignificação numa sociedade em que a informação pode ser considerada a matéria prima do capitalismo; além do mais, a inovação, a tecnologia, a informática e as telecomunicações, no geral, adquirem uma importância cada vez maior no cenário mundial. Sendo assim, entende-se que o Estado necessita incorporar novos ideais no planejamento, sem privilegiar determinados segmentos e agentes.

$\mathrm{O}$ atual estágio de globalização necessita de uma leitura crítica na medida em que afeta diretamente a atuação do Estado. Dessa forma, recorremos à Santos (2010), para quem é necessário entender a globalização nos mais diversos aspectos, analisando as fabulações, como, por exemplo, a insistência da possível morte do Estado e a dita homogeneização do planeta, quando o que se observa, na verdade, é seu fortalecimento em detrimento dos interesses das grandes corporações transnacionais, sem falar que, através da globalização, as diferenças locais acentuam-se.

Além disso, é necessário entender as perversidades dos processos globalizantes: apesar do atual momento econômico e político, destaca-se a pobreza, o aumento das desigualdades de renda, a perda da qualidade de vida da parcela mais pobre da população, e a mortalidade infantil em contraposição ao avanço da ciência, da medicina e tecnologia. Por último, é vital que o Estado assimile a ideia de que a globalização pode ser outra, fundada em princípios mais humanos, em um novo discurso pautado nas diversidades e no maior ativismo da sociedade. Têm-se, então, construído, o pensamento da globalização como fábula, como perversidade e como possibilidade (SANTOS, 2010).

Em relação à necessidade de redefinição do Estado, Harvey (2000) considera a importância dessa figura no atual cenário de processos globalizantes, em virtude da perda de alguns dos seus significas face ao grande capital e aos interesses hegemônicos. Segundo o autor, a função do Estado no mundo atual é de criar possibilidades de efervescência de climas favoráveis às grandes corporações transnacionais, o que sublinha a atuação ativa do Estado no ambiente político-econômico e certa neutralidade em segmentos das áreas sociais. 
Conforme sustentam Santos e Silveira (2001), no Brasil, a partir da influência da globalização no início do século XX e início do século XXI, o Estado, que antes era unificador, passa a ser centrifugador, no sentindo de exercer papel essencial na formulação de planos e metas para o desenvolvimento do Brasil, especialmente com a criação de ambientes propícios ao desenvolvimento. De acordo com os autores, trata-se de uma centralidade causadora de conflitos. Em suas palavras,

No caso brasileiro, além da participação por via de empréstimos e créditos, de organismos financeiros internacionais, é o próprio Estado que investe para dotar certas partes do país das condições de circulação indicadas como indispensáveis para a chamada "abertura" ao comércio externo. (SANTOS; SILVEIRA, 2001, p. 261).

Santos e Silveira (2001) ainda destacam o papel do Estado na criação de espaços de fluidez, evidenciando, assim, o seu papel seletivo e desigual no atendimento a demandas de grandes agentes hegemônicos, muitas vezes sem demonstrar preocupação com as pequenas comunidades locais. Assim, o Estado realiza fortes investimentos em infraestrutura rodoviária, comunicação, tecnologia, além de políticas fiscais.

Esses investimentos foram extremamente setorizados distribuídos de maneira altamente desigual, favorecendo pequenos grupos de agricultores e empresas hegemônicas de diferentes lugares: “[...] a concentração de meios modernos de produção e de acesso aos favores estatais, na agricultura brasileira recente, não somente reflete, mas perpetua, uma estrutura social profundamente desigual." (MARTINE, 1989, p.24). Dessa forma, os investimentos do Estado em infraestruturas, ligados à maior fluidez dos espaços, possuem o claro objetivo de atender às urgências econômicas, e, inclusive, é preciso levar em conta que a localização das estruturas viárias e infoviárias não estão diretamente ligadas ao tamanho e à densidade da população (SANTOS; SILVEIRA, 2001).

Nesse sentido, os investimentos do Estado na área da agricultura moderna e no favorecimento de grandes agricultores e empresas agrícolas não estão diretamente relacionados às necessidades da população, nem à tentativa de efetivar melhorias para a mesma. Pode-se afirmar, portanto, que, de acordo com Oliveira (1999, p.95), “[...] a ação do Estado por intermédio da política de incentivos fiscais para o reflorestamento também contribuiu para alterar, em várias áreas do país, o uso da terra."

A ação do Estado, tanto na promoção de incentivos fiscais, como na instalação de novas infraestruturas e equipamentos, efetiva a mudança do uso do solo em 
determinadas áreas, que também implicam na mudança das atividades ligadas ao campo e à cidade, sobretudo no comércio, na atividade empresarial e na questão imobiliária.

Além do investimento em infraestrutura e na questão da disponibilização de crédito, Martine (1989) acrescenta que o Estado também atua:

[...] no fortalecimento de assistência técnica e de infra-estrutura, na garantia de preços e de taxas de câmbio favoráveis, no seguro da safra contra as intempéries, na geração, implementação e subsídio de programas especiais de toda natureza- inclusive o Proálcool- em suma, na viabilização do lucro na atividade agrícola realizada pro grandes empresas. (MARTINE, 1989, p.23).

Nesse aspecto, percebe-se que a atuação do Estado na promoção do desenvolvimento da grande produção acaba gerando grande dependência dos grandes agricultores em relação aos investimentos do Estado. Nas palavras de Martine,

Diante da constatação se seu grau de dependência para com o Estado em todas as fases da modernização e em quando todas as etapas do processo produtivo. Durante as várias fases da modernização, os incentivos e subsídios têm dinamizado, em grau maior ou menor, a compra de sementes, insumos e máquinas e, de modo geral, têm viabilizado o processo de acumulaçãomesmo em circunstâncias em que houve mudança no processo produtivo (e até onde não houve produção nenhuma, como nos muitos dos projetos agropecuários financiados por incentivos fiscais no Norte e Nordeste). (MARTINE, 1989, p.23).

O Estado promoveu a ocupação de diferentes áreas no Norte e Nordeste, ou seja, áreas de cerrado do Brasil Central, com um discurso de promover suposto desenvolvimento dessas áreas.

O incentivo à produção agropecuária moderna se efetivou por meio de políticas públicas visando à constituição de novas áreas/pólos de desenvolvimento, dentre as quais políticas destaca-se o Programa de Desenvolvimento dos Cerrados (Polocentro), o Programa de Desenvolvimento do Nordeste (Polonordeste) e o Programa de Desenvolvimento da Amazônia (Polamazônia). (OLIVEIRA, 1999). Oliveira (1999) caracteriza-as na seguinte passagem:

O Polocentro esteve e está voltado para a expansão da cultura de grãos- soja e arroz, principalmente no cerrado do Brasil central. O Polonordeste foi responsável, sobretudo, pelos investimentos na Zona da Mata nordestina e no sertão [...] O Poloamazônia foi responsável pelo estabelecimento dos pólos de desenvolvimento agromineral e agropecuário na região amazônica. (OLIVEIRA, 1999, p.94). 
Nesse caso, pode-se afirmar que a expansão da agricultura para as áreas dos Cerrados do Brasil Central teve grande participação do Estado, por meio do programa Polocentro, o que contribuiu grandemente para a alteração das áreas naturais dos Cerrados no campo e nas cidades localizados nessa porção territorial brasileira. No caso do Polonordeste, essa política, de acordo com Oliveira (1999), promoveu algumas ações e investimentos em projetos destinados à irrigação e na construção de reservatórios de água, os chamados açudes, presentes no sertão nordestino. O Poloamazônia também é uma política controversa, pois o Estado incentivou a ocupação e expansão, por parte de atividades agropecuárias e de atividades ligadas à mineração, de áreas delicadas ambientalmente, sobretudo considerando que trata-se de áreas com presença da floresta amazônica e de áreas de transição com o cerrado, que tem sido intensamente alteradas.

Deve-se ressaltar que a fronteira agrícola, além de expandir de forma impressionante para estados da região Nordeste, também tem avançado para áreas da região amazônica ${ }^{38}$, sobretudo para recortes territoriais dos estados do Tocantins, Maranhão, Pará, norte de Mato Grosso e sul de Rondônia, caracterizando uma extensa área conhecida como Arco do Desmatamento ${ }^{39}$. É interessante ressaltar, aqui, que grande parte do norte de Mato Grosso já é uma área consolidada do ponto de vista do agronegócio.

Segundo Oliveira (1999), a pecuária brasileira é mais concentrada na região Centro-Sul do Brasil, sobretudo com a criação de bovinos e suínos. Estes últimos recebem inclusive investimentos e incentivos de grandes empresas, como a Sadia e a antiga Perdigão, que incentivaram grandemente a produção de carne suína destinada à produção de embutidos.

No caso da agricultura moderna, de acordo com Oliveira (1999), por meio das lavouras permanentes e temporárias, o Estado possui um papel mais ativo até mesmo do que na pecuária, pois promove políticas de incentivos mais efetivas, inclusive para grandes empresas agrícolas. Isso se explica pelo papel do Brasil no cenário de comercialização mundial, na medida em que lidera a exportação de várias culturas agrícolas no mundo. Também em relação à expansão da agricultura moderna para áreas do Brasil Central, o Estado teve papel fundamental, pois o Brasil efetivou uma parceria com o governo japonês em 1974, denominado de Programa de Cooperação Nipo-

\footnotetext{
${ }^{38}$ Consideramos aqui as regiões geoeconômicas, por acreditarmos que mostram de forma mais real o nível de desenvolvimento das diferentes regiões brasileiras.

39 Programas federais consideram essa área, sobretudo os programas de combate ao desmatamento do Sistema Nacional de Proteção da Amazônia (SIPAM).
} 
Brasileira de Desenvolvimento do Cerrado (Prodecer) (OLIVEIRA, 1999). Segundo Inocêncio e Calaça (2009),

\begin{abstract}
Os Estados Unidos em 1970 impuseram uma barreira dificultando a exportação da soja. Como o Japão era dependente desse mercado e possuía um consumo elevado desse produto, houve a necessidade de se buscar outras áreas que pudessem suprir o abastecimento. Como o Brasil já havia implantado programas como o POLOCENTRO, PADAP (Programa de Assentamento Dirigido do Alto Paranaíba), e o PCI (Programa de Crédito Integrado do Cerrado), todos voltados para o Cerrado, o PRODECER foi como que uma continuidade desses programas. (INOCÊNCIO; CALAÇA, 2009, p.3).
\end{abstract}

Nesse sentido, a atuação do Estado nos Cerrados brasileiros já vinha ocorrendo e a implementação do Proceder consolidou essa atuação, o que alavancou a ocupação de diferentes áreas e a expansão da fronteira agrícola. Segundo Oliveira (1999, p.91) a parceria entre o Brasil e o Japão: “[...] viabilizou a expansão da soja para Mato Grosso do Sul, Mato Grosso, Goiás, Minas Gerais e oeste da Bahia.” Depois da chegada da moderna agricultura no oeste baiano, esse processo também espalhou-se para outros estados, como o sul Maranhense, o Sudoeste Piauiense e o norte tocantinense.

De acordo com Inocêncio e Calaça (2009), o PRODECER teve três etapas:

\begin{abstract}
As ações do PRODECER fixaram-se em Estados das Regiões Centro-Oeste, Sudeste, Norte e Nordeste, todas recobertas por vegetação de Cerrado. Na primeira etapa, (PRODECER I) que teve início em 1980, foi implantada no oeste de Minas Gerais. A segunda (PRODECER II) estabeleceu-se em 1987, nos estados de Goiás, Mato Grosso do Sul, Mato Grosso e Bahia. A terceira e última etapa (PRODECER III), fixou-se a partir de 1995 nos estados do Maranhão e Tocantins. (INOCÊNCIO; CALAÇA, 2009, p.5).
\end{abstract}

Percebe-se que os Cerrados piauienses foram incorporados diretamente por essas ações do Estado. Veremos, mais à frente, que a ocupação desse recorte territorial do Piauí pelos grandes agricultores possui grande influência do oeste baiano e do sul do Maranhão ${ }^{40}$.

Além dos planos já citados, o Estado também promoveu a chamada desconcentração da estrutura produtiva brasileira através da criação da SUDENE e da SUDAM ${ }^{41}$ no contexto do Governo Militar no Brasil, com inúmeros incentivos fiscais com o claro propósito de expandir a estrutura econômica do Brasil para outras regiões

\footnotetext{
${ }^{40}$ Preferimos não abordar neste capítulo, mas no próximo, as políticas do Estado que tiveram influência direta sobre a incorporação dos cerrados piauienses na rota do desenvolvimento da agricultura moderna.

41 SUDENE- Superintendência de Desenvolvimento do Nordeste. Sudam- Superintendência de Desenvolvimento da Amazônia.
} 
brasileiras. (SOLIMÕES; AMARAL, 2011). É o que Inocêncio e Calaça (2009) denominam de retomada da "Marcha para o Oeste", que objetivou maior integração do país e interiorização das atividades econômicas, sendo a agropecuária moderna um dos carros chefes desse processo.

Nessa perspectiva, considera-se que o Estado pode conferir significado a determinadas áreas ou, até mesmo, isolar outros locais, já que os investimentos em políticas fiscais e de infraestrutura pressupõem uma seleção. A ação do Estado, portanto, pode atribuir e remover evidência dos diferentes lugares, como, por exemplo, na instalação de uma importante rodovia, de cuja rota alguma cidade é excluída.

Um bom exemplo de atuação do Estado é o mandato do Governo de Fernando Henrique Cardoso (1994-2002), que, segundo Elias (2006), foi determinante para a incorporação de novas áreas dos Cerrados nordestinos às novas dinâmicas globalizantes, pois neste período o país foi submetido a ideologias de grandes grupos econômicos hegemônicos, dos conglomerados, e com destaque para as políticas neoliberais e, consequentemente, com o papel mais ativo de grandes corporações transnacionais e a valorização das privatizações no país. Bezerra (2008), por outro lado, considera que o mandato de Fernando Collor no início da década de 1990 teve maior êxito no sentido da permissividade da entrada de capitais internacionais no país e da adoção de políticas neoliberais. Esse mesmo autor também sustenta que os governos FHC e Lula mantiveram esse ideal neoliberal, o que acaba refletindo na estrutura econômica brasileira e, consequentemente, nas atividades agropecuárias.

Nesse sentido, a postura do Estado deve ser analisada criteriosamente tanto no tocante às ações empreendidas como na sua imparcialidade e neutralidade. A década de 1990, marcada pela liberalização econômica, marca a ação neutra do Estado, que abre maiores possibilidades para grupos hegemônicos, sobretudo grandes empresas agrícolas de promoveram a expansão da fronteira agrícola no país.

Siqueira (2010) diz que, apesar de algumas melhorias na economia, como o Plano Real, a década de 1990 marca a liberalização da economia, a preocupação com a alta da inflação, os baixos investimentos do Estado e a neutralidade do mesmo. Consequentemente, as políticas de Planejamento Regional e redução das desigualdades regionais e sociais foram deixadas de lado pelo Estado nesse período, que podemos identificar, em grande parte, como a década do neoliberalismo no país, pois se trata de um momento em que o Estado manteve neutralidade e um papel quase que inativo no 
planejamento regional de longo prazo, na questão da estrutura fundiária concentradora e nos conflitos que envolvem essa questão (THOMAZ JUNIOR, 2010).

Dessa maneira, a década de 1990 é, também, decisiva para a definição do desenvolvimento regional brasileiro, em função da neutralidade e do caráter passivo do Estado no momento de liberalização econômica. Esse período marca, ademais, uma época de grande avanço do desenvolvimento tecnológico no mundo, o que acabou gerando um grandioso fortalecimento de grandes corporações transnacionais. O enfraquecimento do Estado, nesse momento, portanto, gerou a acentuação das desigualdades regionais e sociais no país e sérias dificuldades de projeção econômica, que se refletem até mesmo hoje (POCHMANN, 2004).

Outra característica marcante da década de 1990, segundo Oliveira e Lima (2012), foram as privatizações e a quebra de barreiras protecionistas, que se relacionam com posição neutra do Estado. Outro fato relacionado às políticas de desenvolvimento regional foi a ênfase de investimentos em regiões consideradas dinâmicas e com capacidade competitiva, visando a inserção das mesmas no mercado externo, sendo isso efetivado através de políticas públicas de corte nacional/setorial, que provocou verdadeira guerra fiscal entre os diferentes mercados dinâmicos na atração de investimentos e a completa negligência das áreas com ausência de dinamismo. A justificativa para tais fatos, com destaque para as privatizações de empresas nacionais, seria a de que o Estado reduziria seus investimentos na esfera econômica e aumentaria os investimentos nas áreas sociais. (OLIVEIRA; LIMA, 2012). Dessa forma, grande parte de empresas ligadas ao agronegócio, inclusive multinacionais, se viram livres e com amplo poder para consolidar a agricultura moderna no país. Pode-se afirmar que essas empresas contaram com o amplo apoio do Estado na questão dos subsídios e políticas fiscais.

Nesse período (década de 1990), houve a seleção de eixos nacionais de integração e de desenvolvimento através do Ministério do Planejamento, com os programas Brasil em Ação e, mais tarde, o Programa Avança Brasil, revelando, assim, o caráter seletivo e excludente das novas políticas desenvolvimentistas (ELIAS, 2006a). Pois o Estado na década de 1990 realizou pífios investimentos nas áreas sociais, especialmente os que visavam a redução das desigualdades regionais e sociais, intensificando, assim, o quadro de das desigualdades regionais e sociais, cuja ampliação era motivada pela ênfase dos investimentos na região Sudeste do país. 
Santos e Silveira (2001) já chamavam atenção para o que os autores denominam de espaços luminosos e espaços opacos. Os primeiros são caracterizados pela grande acumulação de conteúdo técnico e informacional, e atraem, assim, mais investimentos. Os segundos seriam aqueles onde as características do primeiro estariam ausentes. Os espaços luminosos, é claro, atendem os interesses de grandes empresas.

Embora, como já afirmamos, exista, no século XX, centralização dos investimentos no eixo Sul-Sudeste, que favoreceu a consolidação de centros metropolitanos no Brasil como São Paulo e Rio de Janeiro, no presente momento observa-se o crescimento da importância de cidades médias no país, seja por meio do setor secundário, seja por meio do primário, como no caso de cidades do agronegócio.

De acordo com Martine (1989), muitas vezes uma grande empresa agrícola verdadeiramente não mostra um poder econômico significativo, mas sim um poder político significativo. Além disso, esse autor ainda afirma que o capital subsidiado pelas grandes empresas e grandes agricultores possui o poder de manipular o Estado para o fornecimento de incentivos e suporte à grande produção, ou seja, as grandes empresas agrícolas, principalmente multinacionais, possuem grande poder de atração dos investimentos e incentivos do Estado. "Assim, o acesso às benesses do Estado não é determinado pela capacidade e performance produtiva, senão pelo poder de "pressão" dos diferentes segmentos de um pequeno subgrupo dominante". (MARTINE, 1989, p.25).

O Estado, em seu papel de regulador empresarial, segundo Martine (1989), pode ser denominado complacente ou conivente, no sentido de privilegiar o grande capital. Nesse sentido, Martine (1989) destaca a seguinte questão em relação à dependência do Estado por parte das grandes empresas:

\footnotetext{
Não somente a dependência da agropecuária brasileira sobre o Estado continua muito elevada- característica de certa forma comum também aos países de capitalismo avançado- mas também as formas dessa dependência refletem claramente os contornos de uma sociedade concentradora, fortemente desigual, e acostumada a ter no Estado o único tomador de risco. (MARTINE, 1989, p.25).
}

Como se pode notar, a dependência das grandes empresas em relação ao Estado também reflete uma dependência do Estado por parte da sociedade. No entanto, muitos segmentos da sociedade brasileira tem sido negligenciados, como é o caso da questão indígena no Brasil, em especial a questão fundiária que envolve esse grupo. $\mathrm{O}$ 
planejamento, considerado aqui como um instrumento de poder atrelado ao cenário de modernização da agricultura, exclui de forma evidente a participação popular. Os verdadeiros agentes locais presentes em áreas de moderna agricultura são desprezados.

É preciso reelaborar essa ideia e construir um novo ideal de planejamento e de Estado, e, sobretudo na realidade de cidades do agronegócio, é necessário potencializar a participação popular de forma a construir modelos contra-hegemônicos e contra as naturalizações de eventos hegemônicos, caracterizados por severos impactos socioespaciais, o que revela novas possibilidades, ainda que utópicas ${ }^{42}$. É necessário rever e questionar o Estado em relação ao favorecimento de classes dominantes e hegemônicas (COSTA; SUZUKI, 2012).

Sendo assim, o planejamento público ligado ao atendimento dos interesses dos grandes agentes e processos hegemônicos pode ser considerado um instrumento de poder e controle, pois há a definição de áreas prioritárias, como, por exemplo, para a implementação de grandes obras, ou aplicação de certas políticas públicas, o que pode determinar também a expansão de algumas das cidades do agronegócio. O planejamento e processos hegemônicos podem representar, assim, a acentuação das desigualdades em determinadas regiões do Brasil, que, no entanto, também estão inseridas no circuito econômico mundial.

Segundo ELIAS (2006) a expansão da agricultura, com a atuação massiva do Estado, privilegiou determinados segmentos sociais e econômicos. Nesse caso, pode-se considerar que a efetivação do agronegócio no Brasil Central contou com a ativa participação do Estado no estímulo à produção moderna de grãos, em especial a soja e o milho.

O aumento da produção e produtividade revela uma grande importância atribuída pelo Estado aos dados quantitativos e um desprezo dos qualitativos, seguido de uma extrema valorização das atividades agropecuárias modernas, cuja grande parte da produção é destinada ao mercado exterior. Trata-se uma visão neoliberal, que, segundo Martine (1989), propaga a visão de que, sem uma alta escala de produção, não há desenvolvimento econômico, mostrando, assim, que os espaços para a pequena produção tornam-se cada vez mais desvalorizados.

\footnotetext{
${ }^{42}$ Parágrafo fundamentado nas ideias de COSTA e SUZUKI (2012) em relação à crítica do planejamento, integrando ideias em relação às cidades do agronegócio, onde há o favorecimento de grupos hegemônicos na implantação de infraestrutura básica e negligência dos mais pobres na formulação do planejamento. Nesse sentido, há necessidade de pressupostos considerados utópicos.
} 
Essa extrema preocupação com os dados estatísticos, de acordo com Martine (1989), revela o grande foco do Estado em uma questão extremamente imediatista. Assim, o Estado, juntamente com seus segmentos prediletos, em especial as grandes empresas e grandes agricultores, privilegia as medidas de curto prazo, para promover o lucro rapidamente. Ainda de acordo com o autor, não há existência de um plano a longo prazo e que, de alguma forma, verdadeiramente pretenda a melhoria da qualidade de vida da população.

Martine (1989) cita ainda três visões de conservadores ligados à agropecuária brasileira:

a) maior é melhor, ad infinitum, em todos os setores e ocasiões; b) a grande propriedade rural brasileira insere-se, necessariamente, dentro da lógica de produção capitalista; e c) o pequeno, o não integrado e o informal devem necessariamente desaparecer no curto ou médio prazo. (MARTINE, 1989, p.18).

A precisão da definição se evidencia quando se observa que, mesmo com o atual momento da economia brasileira, sobretudo no ano de 2015, a agricultura é setor econômico que não sofreu queda representativa, o que demonstra como o Estado valoriza a maturidade desta atividade econômica.

A agronomia também confere extrema valorização à modernização agrícola e à alta produção, e, de alguma forma, não vislumbra os impactos sociais gerados a médio e longo prazo (MARTINE, 1989). Tal postura é comum em estudantes de cursos ligados à agropecuária, como agronomia, zootecnia, engenharia florestal, engenharia de produção e até mesmo estudantes de administração, dos quais a grande maioria valoriza de forma exagerada a grande produção e tendência modernizante da mesma. Não pretendemos desvalorizar a modernização das atividades produtivas, mas questionar a centralização dessa modernização em projetos e atividades de grandes agricultores.

É importante ressaltar que a economia brasileira, atualmente sob gestão do Governo Dilma, vive um contexto de crise política e econômica, acompanhadas de cortes de gastos e despesas, com redução nos orçamentos destinados à educação, à saúde e às causas ambientais. Nesse caso, as prioridades do Estado revelam-se contraditórias devido ao foco dos investimentos e disponibilização de créditos, atribuindo maior atenção e relevância às atividades agropecuárias e aos grandes agentes hegemônicos ligados ao agronegócio, o que mostra que as políticas neoliberais tiveram 
continuidade entre os governos da década de 1990, a primeira década do século XXI e a segunda década deste mesmo século.

Os dados estatísticos, valorizando a alta produção, passam uma ideia de país desenvolvido. Além disso, os dados quantitativos fazem parecer que essa produção pertence ao povo e ao país e, de certa forma, leva à ignorância das consequências sociais, ambientais e políticas da constituição e consolidação do agronegócio em certas áreas. Segundo Martine (1989), as supersafras da agricultura moderna acabam gerando uma grande euforia, passando a ideia de uma agricultura moderna que beneficia a população e promove o desenvolvimento.

Nesse caso, há uma grande e evidente oposição entre a grande produção e produtividade de grãos advindos da moderna agricultura e os problemas sociais com que o país ainda convive, como a fome, a desigual distribuição de renda, a miséria, o preço de alimentos elevados, a destruição da biodiversidade e do meio ambiente, a poluição e diminuição dos recursos hídricos, dentre outras várias problemáticas presentes no país.

A produção moderna da agricultura possui um papel significante na economia do país, representando cerca de um quinto do total do Produto Interno Bruto (PIB) brasileiro, conforme propaganda do Ministério da Agricultura, Pecuária e Abastecimento nos veículos de comunicação, como forma de valorização do agronegócio no país. Frederico (2013) denomina esse crescimento da importância da exportação de produtos primários como commoditização da economia e do território brasileiro, pois verifica-se grande expansão da fronteira agrícola nas últimas décadas.

Além disso, é necessário destacar que a produção moderna da agricultura possui o importante papel de abastecedor do mercado interno, com grande destaque no cenário brasileiro de exportações. Martine (1989) reconhece a importância da agricultura moderna para o país:

Não há dúvida que o aumento da produção e da produtividade na agricultura é uma condição sine qua non do desenvolvimento e da melhoria das condições de vida da população. Sem aumento de produção não há o que distribuir. Entretanto, o aumento da produção não é condição suficiente para o bem-estar-geral, pois nada garante que os benefícios do crescimento serão redistribuídos entre todos os setores da sociedade. O que determina o padrão de crescimento econômico, e a repartição dos seus benefícios, é o estilo de desenvolvimento de uma sociedade, que, por sua vez, é cunhado no confronto e na negociação entre sistemas distintos, provenientes de diferentes setores da sociedade. (MARTINE, 1989, p.34). 
Nesse caso, enfatiza-se que a intenção desse trabalho não é o de satanizar o processo de modernização agrícola, mas sim evidenciar e analisar as suas facetas contraditórias. É sim uma área muito importante da economia brasileira, no entanto, deve-se considerar os impactos gerados por esse processo. No caso da modernização agrícola piauiense, procuraremos responder, no próximo capítulo: a quem o agronegócio beneficia? Quais são os municípios concentradores dos benefícios ganhos através das mudanças geradas a partir do agronegócio? Quais os impactos na rede urbana do Sudoeste Piauiense?

Ao se considerar a ligação entre a modernização da agricultura e o planejamento como um instrumento de poder, deve-se enfatizar o processo de agricultura moderna como hegemônico, que envolve dominação política, econômica e até mesmo cultural. De acordo com Fourez (1995), é necessário entender que conhecimento científico envolve poder e que os discursos globalizantes devem ser questionados visando a ruptura de epistemologias, enfatizando que os diferentes discursos ideológicos envolvem potencialmente a legitimação em detrimento da descrição. O Sudoeste Piauiense, por exemplo, é reflexo dessa realidade, pois migrantes sulistas impõem novas dinâmicas culturais no comércio, nas atividades produtivas e no padrão de ocupação do solo, estabelecendo, assim, rupturas de antigas tradições da região dos Cerrados piauienses.

No dizer de GALVÃO (2007), a condução do Desenvolvimento Regional pelo Estado deve ser pautada na inclusão, na competitividade ambientalmente responsável e territorialmente integradora, e nesse sentido o autor enfatiza o papel das políticas públicas no desenvolvimento regional como forma de redução das desigualdades sociais e de efetivação da dinâmica econômica das diferentes localidades. Nesse cenário de destaque para a atuação do Estado como propulsor do Desenvolvimento Regional, com ênfase na formulação e implementação de políticas públicas, a ausência dessas últimas pode significar aderência do Estado a políticas liberais da economia, que gera impactos sociais acentuados e perda de dinamismo econômico (GALVÃO, 2007).

De acordo com Carleial (2012), diante das características do país de concentração econômica em certas áreas e de presença de desigualdades regionais e sociais, as políticas públicas tornam-se essenciais em virtude do potencial do contrabalanceamento de tais tendências, visando um desenvolvimento nacional mais igualitário para as diferentes regiões do país. É necessário enfatizar, ainda, que o Brasil 
já não é o mesmo país de 20 e 10 anos atrás em muitos aspectos, sobretudo no viés econômico, demográfico, social e até mesmo cultural, em função das atuais características do mundo globalizado, como o predomínio da Internet, o poder das redes sociais, tecnologia e mudanças de hábitos e configurações das famílias. Em razão disso, o Estado necessita de uma ressignificação.

Outros contextos no Brasil revelam um momento que deve ser analisado de forma diferenciada, ainda que se leve em conta o contexto favorável do país no cenário mundial, especialmente no que diz respeito às relações exteriores, com o advento da diversificação de parceiros econômicos - aproximação com a África e América do Sul, por exemplo -, a economia relativamente estável, além de melhorias nos índices de educação (expansão de universidades federais, institutos de tecnologia e educação técnica) ${ }^{43}$, além da presença de bancos públicos com potencial de financiamento, matriz energética diversificada e com potencial para ampliação, dentre outras realidades emergentes (CALEIAL, 2012).

Esses avanços, contudo, precisam ser analisados de forma criteriosa para que se entenda que ainda persistem problemas demasiadamente complexos para o Estado e os diversos agentes, e que afetam diretamente a condução do desenvolvimento regional do país em detrimento da solução dos enormes problemas de desigualdades regionais e sociais no Brasil.

A realidade atual brasileira enfrenta um contexto de transformação da estrutura demográfica com o advento do "envelhecimento da população brasileira". Dessa forma, o Estado precisa ser reinventado, estando no contexto do mundo globalizado, da emergência e crescimento das redes, da tecnologia e inovação. Infere-se, então, que o Estado precisa considerar essas novas realidades e contextos tomando para si um papel mais ativo, visando a superação de mazelas da sociedade em relação à superação de problemáticas, especialmente no que diz respeito ao combate das desigualdades (DUPAS, 2001).

Sendo assim, o Estado brasileiro necessita evidenciar as atuais transformações no território brasileiro, dando ênfase aos fatores marcantes no país em relação às novas possibilidades de exclusão e de acentuação das desigualdades regionais e sociais. Dentre esses novos contextos, pode-se citar o surgimento de novas áreas agrícolas e expansão das cidades do agronegócio, aqui explicadas, e que podem provocar a acentuação das

${ }^{43}$ Carleial (2012, p.9) define o processo de expansão das universidades públicas no país como descentralização das possibilidades produtivas do país. 
desigualdades nessas áreas, tendência atual do chamado Brasil Central (áreas dos Cerrados).

Segundo Galvão (2007), alguns sinais de criação de um ambiente mais favorável no Brasil para a redução das desigualdades regionais podem ser constatados: quadro econômico favorável face à inserção competitiva externa, crescimento das exportações, esforços e políticas sociais - foco em programas de transferência de renda, como o Bolsa Família, e na ampliação de programas de universalização de serviços públicos, como o Programa Luz Para Todos, bem como Programas de Crédito, como o Pronaf. Além disso, pode-se citar a Política Nacional de Desenvolvimento Regional (PNDR) como uma das tentativas contemporâneas de diminuição das desigualdades sociais que merece reconhecimento, apesar das dificuldades reais de aplicabilidade dos planos e metas, além de possíveis problemas financeiros em relação à complexidade dos seus objetivos relacionados às desigualdades regionais e sociais (GALVÃO, 2007).

Apesar dos problemas evidenciados em algumas das políticas e novos contextos citados acima e das inúmeras dificuldades, o Brasil apresenta, hoje, maior aproximação do Estado em relação à superação de problemas relacionados às desigualdades e consequentemente uma proximidade de mudanças de algumas duras realidades do país, mesmo que ainda apresente situações singulares entre as diferentes regiões a serem enfrentadas não somente pelas ações do Estado, mas também pelo engajamento da sociedade e dos diversos agentes econômicos e sociais.

\subsection{Migrações de Sulistas para o Brasil Central, em especial para os estados nordestinos}

A ocupação das áreas dos Cerrados do Brasil Central, desde o seu início na região Centro-Oeste até os dias atuais, em Cerrados das regiões Norte e Nordeste, veio acompanhada da migração e ocupação por sulistas, que, no entanto, também são originários de outros estados brasileiros como Santa Catarina, Paraná, e São Paulo, sendo que nas áreas mais recentes, até mesmo pessoas que vem da região Centro-Oeste são denominados de sulistas ou gaúchos em algumas áreas. Essa corrente migratória para áreas do Brasil Central chegou em um nível de intensidade elevado, de maneira que esses migrantes sulistas também buscaram áreas fora do Brasil, como já destacado por Oliveira (1999) e Alves (2005b), em países como Paraguai, Argentina e Bolívia. 
Haesbaert (1998) é um autor que se preocupa em relação aos estudos que envolvem a migração sulista. Ele utiliza a palavra "diáspora" para enfatizar a complexidade e pujança do processo migratório, principalmente para áreas do Nordeste brasileiro, e defende que o padrão de migração "gaúcha" atrela-se aos fatores de identidades culturais, nos quais estão inclusos processos políticos, sociais, históricos e geográficos.

Com a chegada desses novos agentes, há claras alterações no meio urbano e rural dessas áreas de destino. Elias (2006) faz algumas considerações sobre a migração gaúcha para áreas do Nordeste, afirmando que:

\begin{abstract}
Associada à difusão da soja nos cerrados do Nordeste, dá-se uma série de transformações na dinâmica populacional, sendo a chamada migração de "gaúchos" um dos principais fatos a considerar para análise8; na economia urbana, que passa a crescer de forma bem distinta do até então ocorrido, com grande destaque para o crescimento dos setores inerentes ao consumo produtivo, ou seja, o consumo associado às demandas da agricultura científica e do agronegócio, mas também ao consumo consumptivo, associado às demandas dos migrantes descendentes, que impõem seus padrões de consumo às respectivas áreas, que serão, em parte, atendidos localmente. O nível de renda destes empresários ligados ao complexo agroindustrial da soja acaba também sendo um importante propulsor da economia urbana (ELIAS, 2006a, p.38).
\end{abstract}

Pode-se afirmar, assim, que o processo de migração sulista para as áreas dos Cerrados, primeiramente para estados do Centro-Oeste e, mais tarde, para o oeste baiano, sul do Maranhão, para o centro-Norte de Tocantins e, por último, para os Cerrados piauienses, implica uma série de fatores, tais como motivações políticas e econômicas, com objetivos bem fundamentados e com o apoio do Estado.

Nesse sentido, o Estado incentivou a migração de sulistas para as áreas dos Cerrados brasileiros, e observamos que grande parte dessa população tem descendência europeia. Dessa forma, pode-se afirmar que a migração sulista para o Brasil Central sustenta ideais similares ao ideal europeu no período de colonização e das grandes conquistas territoriais no mundo.

O Estado buscou em um grupo, no caso, os sulistas, características apropriadas para efetivar o processo de ocupação das áreas dos Cerrados. Segundo Alves (2005, p.50), “[...] o agricultor escolhido seria o colo sulista, pois ele melhor personificaria o perfil procurado". Com isso, o Estado implementou incentivos à produção agropecuária moderna, incentivando a tendência de migração e desbravamento de outras áreas no 
país. Alves (2005) destaca que grande parte dos sulistas tem origem italiana e alemã. Nas palavras do autor,

Não foi aleatória, entretanto, a escolha de tal grupo para comandar a ocupação das terras do que viria a ser a fronteira agrícola, mas fazia parte da estratégia de reforçar um modelo econômico sustentado na produção de commodities agrícolas para exportação. Tal modelo se tornaria viável adotando dois conjuntos de diretrizes em articulação: a) incorporação de novas áreas, a serem ocupadas mantendo o sentido de produzir para o mercado externo; b) concentração da propriedade da terra nas antigas áreas de ocupação, na própria região Sul do Brasil, para começar por lá o processo de modernização agropecuária. (ALVES, 2005, p.49).

Haesbaert (1997) ainda acrescenta que:

\begin{abstract}
Essa migração sulista na verdade remonta ao início do século, quando se consolida o processo de privatização das terras no Rio Grande do Sul e os "colonos" descendentes de imigrantes (especialmente italianos e alemães) começam a deslocar-se para novas áreas, inicialmente áreas de mata (como nos seus espaços de origem, já que no século XIX lhes foram destinadas as áreas de mata ainda desocupadas do Sul do país), no oeste de Santa Catarina e oeste do Paraná. Somente mais tarde é que, naquele que alguns supõem ser uma confirmação da "índole naturalmente desbravada" dos sulistas (na verdade referindo-se a um grupo bem definido: pequenos agricultores e capitalistas ligados à atividade rural, descendentes de imigrantes), passa-se a “colonizar” também áreas de campo e cerrados (HAESBAERT, 1998, p.57).
\end{abstract}

Dessa forma, a migração sulista para áreas do Brasil Central também foi motivada pela grande saturação das terras do sul do país. Nesse contexto, os sulistas vão para o centro do Brasil em busca de terras mais baratas e com grande potencial para a produção. Haesbaert (1997) aponta que esse encontro entre gaúchos e nordestinos acaba resultando em embates políticos ideológicos, e que o processo de migração gaúcha para o Nordeste inverte o fluxo migratório, já que o padrão de migração no Brasil, até certa época, era de nordestinos migrando para o sul/sudeste do Brasil.

Esse processo migratório, motivado pela alta do preço da terra no sul e grande ocupação do solo, foi marcado pelas políticas de facilitação de crédito, pela doação de vastas terras e pelas políticas voltadas para a modernização tecnológica dessas áreas. Tal subsídio do Estado também foi promovido através da EMBRAPA e da SUDENE, com o objetivo de impulsionar o processo de ocupação das novas áreas, o que pode ser denominado de processo de interiorização da estrutura produtiva do Brasil, na qual o Estado incentivou a produção agropecuária com investimentos em tecnologias 
descobertas de novas tendências modernas, como a seleção de sementes adaptadas ao solo dos Cerrados brasileiros (HAESBAERT, 1998).

O processo de migração sulista, de acordo com Haesbaert (1998), envolve a noção de rede regional, que segundo o autor é "“[...] imbricada de forma complexa, em diferentes níveis, a várias outras redes, é um dos componentes fundamentais dos processos de construção e reconstrução de territórios (ou de dês-re-territorizalização) no espaço brasileiro contemporâneo". (HAESBAERT, 1998, p. 55-56). Sendo assim, os processos migratórios impõem novas transformações socioespaciais nas novas áreas inseridas no circuito da produção moderna de grãos. Haesbaert (1998) destaca que:

[...] apesar da manutenção de vários traços identitários comuns, ela adquire feições diferentes de acordo com a área de destino (por exemplo, os gaúchos" que estão no Nordeste não reproduzem sua identidade da mesma forma que aqueles que estão no Triângulo Mineiro, na Amazônia mato-grossense ou em Roraima). (HAESBAERT, 1998, p. 66)

Nesse sentido, quando os sulistas conquistam novas áreas para se inserirem na grande produção agropecuária moderna, acabam incutindo seus ideais e o traço característico de sua cultura nessas áreas, alterando inclusive o comércio das cidades, o padrão de moradia, normalmente com a tendência da formação de condomínios fechados, como veremos mais à frente no caso de Bom Jesus do Piauí.

Assim, pode-se dizer que a rede regional gaúcha é seletiva, pois acaba excluindo inúmeras áreas em razão de priorizar aquelas mais valiosas do ponto de vista produtivo, formando, assim, áreas com intenso dinamismo econômico, muitas vezes rodeadas de áreas extremamente pobres e decadentes.

A rede regional estabelece grande ligação das novas áreas às origens dos sulistas, pois há nas novas áreas de agricultura moderna uma demanda alta de mão de obra especializada provinda do sul do país, e também dos laços estabelecidos com empresas e cooperativas dessas regiões com sede no sul do país (HAESBAERT, 1998). No entanto, as redes também excluem certos territórios em virtude dos interesses e objetivos estabelecidos.

Essa questão da maior demanda de trabalhos especializados é um dos pontos a serem destacados, pois, segundo Haesbaert (1997, p.4), “[...] no início do processo os próprios trabalhadores eram trazidos do Sul pelos capitalistas, e até hoje é muito difundido o preconceito de que os nordestinos são "preguiçosos", "acomodados" e sem “iniciativa" (capitalista)". Nesse sentindo, ainda segundo o autor, o povo gaúcho se 
autodenomina como o "povo mais trabalhador do Brasil". Esse preconceito em relação aos nordestinos é muito evidente, tanto é que nas cidades do agronegócio, a presença de condomínios fechados, voltados para moradia de sulistas e também de professores das universidades federais, bem como empresários, comerciantes, engenheiros, agrônomos, etc, mostra que os novos agentes têm necessidade de não se misturarem com os nordestinos, a fim de manter seus traços gaúchos.

Segundo Haesbaert (1997) essa manutenção da cultura gaúcha acaba sendo mantida através da difusão dos CTGs (Centro de Tradições Gaúchas) e do consumo do chimarrão e do churrasco, que são inclusive disseminados no comércio das cidades do agronegócio.

As redes regionais de ligação entre as diferentes regiões estabelecem processos particulares que proporcionam novas significações aos novos territórios e regiões. Haesbaert (2010) enfatiza o caráter transformador e inovador que as redes acabam proporcionando, em especial a rede regional "gaúcha", pois, segundo o autor,

Quando a intensidade dos contatos a distância provoca a manutenção ou mesmo o fortalecimento de algum tipo de elo "regional", seja por mobilidade física e/ou por contatos virtuais, temos a construção de um outro tipo de espaço regional. Nesse caso, como para os migrantes sulistas (percebidos sempre como "gaúchos") no interior do Brasil, trata-se não mais de uma "região" em sentido estrito- pela não consolidação de um espaço regional em sentido tradicional-, mas de uma "rede urbana" em que, ainda que a materialidade da região como tal esteja evidenciada, a maioria dos traços de uma "regionalidade" encontra-se reproduzidos. (HAESBAERT, 2010, p.22).

Segundo Haesbaert (1998), a migração sulista impõe nos novos espaços regionais inseridos na produção agropecuária moderna novos padrões, inclusive de urbanização. Em Barreiras- BA e Balsas, no Maranhão, os processos migratórios de sulistas são responsáveis pelo surgimento de novos bairros urbanos gaúchos. Além disso, na atualidade, há grande ligação dessas novas áreas às origens dos sulistas, o que pode ser verificado no quantitativo de linhas de ônibus que transportam e ligam passageiros de Santa Maria- RS a Barreiras- BA (HAESBAERT, 1998). Segundo Alves (2005),

[...] a ideologia da positivação do trabalho, advinda da cultura europeia trazida pelos imigrantes; o pioneirismo na ocupação dos Cerrados para o desenvolvimento da agricultura moderna; os hábitos alimentares originários principalmente do Rio Grande do Sul, como o chimarrão e churrasco; as instalações dos Centros de Tradições Gaúchas (CGTs) nas áreas onde fixa o grupo. (ALVES, 2005, p.44) 
Todos esses traços levados para as novas áreas pelos sulistas acabam influenciando na configuração do comércio e nos serviços das cidades do agronegócio, como as redes de supermercados com produtos da cultura gaúcha e a instalação dos pontos de encontro gaúchos, como o CTGs.

Considera-se, então, que o Estado obteve êxito no seu papel de promotor de ocupação do Brasil Central, pois grande parte desse recorte territorial já se encontra ocupado por sulistas, que, no início, se mostravam receosos em relação ao futuro nas novas áreas, e até mesmo receosos quanto à potencialidade dos Cerrados. Com efeito, é bem comum nos noticiários em jornais a abordagem sobre a migração sulista para áreas antigamente estagnadas no Brasil Central, que comumente destacam o espírito aventureiro do sulista, e as suas principais dificuldades ${ }^{44}$. Além disso, essas reportagens sustentam que grande parte dos agricultores vendia suas terras no sul e comprava terras na região dos Cerrados com preços baixíssimos.

No entanto, é preciso destacar que a migração e ocupação gaúcha desencadearam inúmeros casos de grilagens de terras, como já apontado por Thomas Júnior (2010) e Elias (2012), e, consequentemente, a ampliação da concentração de terras, ou seja, da estrutura fundiária dessas áreas recentemente ocupadas, ampliando assim a segregação socioespacial.

Esse processo de migração sulista para áreas do Brasil Central desencadeia uma série de consequências políticas nos Estados ocupados. Como exemplo, pode-se citar as claras tentativas e os incentivos às emancipações político-administrativas de novos Estados como o de Araguaia, no Mato Grosso, e o do São Francisco, no estado da Bahia. Pode-se elencar, também, o desejo de emancipação e desmembramento políticoadministrativo nos Estados do Piauí e do Maranhão, que possuem movimentos políticos que lutam para a constituição dos Estados do Gurguéia e o Maranhão do Sul, motivados por fatores e questões econômicas, políticas e culturais. Esses dois possíveis Estados estariam localizados justamente nas áreas com presença dos grandes projetos de agricultura moderna e maior presença de sulistas. Destes últimos, observa-se que alguns acabam se envolvendo em questões políticas, sendo que alguns chegam ao poder

${ }^{44}$ Como na reportagem do Globo Rural intitulada "Todo o potencial do cerrado piauiense para a agricultura, disponível em: http://curimata.blogspot.com.br/2011/05/todo-o-potencial-do-cerradopiauiense.html. Acesso em 20 set. 2015. 
executivo de diferentes municípios localizados em Regiões Produtivas Agrícolas, denominadas por Elias (2012).

A migração sulista e o contexto político, motivado pelos desejos desses agentes, foram fundamentais, por exemplo, para a emancipação do município de Luiz Eduardo Magalhães em relação à Barreiras no Estado da Bahia (ALVES, 2005). É vital, também, destacar que a migração sulista para áreas do Brasil Central é pautada em uma lógica diferente da migração comum, como no caso de Nordestinos em direção ao Centro-Sul do Brasil, pois grande parte dos migrantes sulistas tem ampla qualificação profissional e maiores recursos. Outro aspecto muito importante é que grande parte dos sulistas impõe novas tendência de ocupação do solo, normalmente valorizando áreas mais planas face às áreas mais movimentadas do ponto de vista topográfico.

Oliveira (1999) também já alertava sobre a migração de sulistas para as novas áreas de Cerrados do Brasil Central incorporadas ao agronegócio:

[...] a presença desses projetos e as transformações pelas quais o campo vem passando nos últimos anos têm sido responsáveis pela intensificação e pelo redirecionamento dos fluxos migratórios para o Centro-Oeste e principalmente para a Amazônia, abrindo, dessa forma, novas fronteira agrícolas no território brasileiro. Essas transformações estão na base dos processos de luta pela terra desencadeados no campo. Os movimentos sociais têm-se intensificado nos últimos anos e a luta pela reforma agrária vem se ampliando, chegando às grandes cidades do país. (OLIVEIRA, 1999, p.97).

O autor destaca também a migração de sulistas para estados da Amazônia brasileira, como no caso do MAPITOBA, onde temos os Estados de Tocantins, do Maranhão, do Pará e Mato Grosso cada vez mais expandindo a sua produção e produtividade.

Ao final deste tópico, é preciso destacar que não pretendíamos esgotar a temática da migração "gaúcha", mas evidenciar que a realidade de ocupação do Brasil Central está atrelada à migração sulista, e que o Sudoeste Piauiense está inserido nesse processo maior.

A migração sulista enquadra-se no contexto das novas regiões do agronegócio do Brasil Central, sendo assim necessitamos realizar análise sobre a configuração e expansão das Regiões Produtivas Agrícolas, para, logo em seguida, adentrarmos na temática específica da pesquisa. 


\title{
2.6 Expansão e Reconfigurações das Regiões Produtivas Agrícolas e Reestruturação do Processo de Urbanização ${ }^{45}$
}

Ultimamente, diversos espaços no Brasil vêm passando por grandes transformações, sobretudo nas áreas urbanas. Essas transformações surgem em virtude da expansão de atividades modernas pelo país, sendo uma delas a agricultura moderna, como já mencionado anteriormente. Sabemos que o Estado teve papel fundamental na expansão dessa agricultura, pois, como já dito, promoveu incentivos através das políticas públicas, o que ocasionou, segundo Oliveira (1999, p.94), “[...] uma reordenação territorial, produto da combinação contraditória e desigual da expansão da agricultura especificamente capitalista e da agricultura camponesa. Assim, a reordenação territorial do campo provoca até mesmo alterações na fronteira". Portanto, as transformações surgem em decorrência da emergência e mutação das atividades agropecuárias no país. Essas áreas são conhecidas como Regiões Produtivas Agrícolas $(\text { RPAs })^{46}$, que Elias (2012) caracteriza como:

\begin{abstract}
Arranjos territoriais produtivos agrícolas, os territórios das redes agroindustriais, ou seja, os territórios produtivos do agronegócio, escolhidos para receber os mais expressivos investimentos produtivos inerentes ao agronegócio globalizado, representando suas áreas mais competitivas. (ELIAS, 2012, p.2).
\end{abstract}

Em decorrência da expansão das Regiões Produtivas Agrícolas, como as que direcionam para a região Nordeste, sobretudo para o MAPITOBA, percebe-se no país que algumas cidades são selecionadas como o epicentro do agronegócio, de maneira a serem caracterizadas como áreas de apoio ao agronegócio. Essas cidades passam a ter novas funcionalidades, novas relações com o campo e transformações na urbanização. Dessa forma, pode-se afirmar que, no Brasil, há a emergência de novos espaços urbanos reconfigurados e diferenciados. Essa diferenciação em relação às outras cidades pode agravar o quadro de desigualdades regionais e sociais presentes no país, e, nesse caso, a análise das novas transformações nessas áreas de expansão do agronegócio é fundamental para o entendimento das novas dinâmicas relacionadas às áreas urbanas.

${ }^{45}$ Esse tópico deste capítulo se baseará nas obras de Elias (2011, 2012, 2006b). Isso será vital para a consolidação da pesquisa, pois é justamente a partir desses trabalhos que se selecionou os eixos estruturantes dessa pesquisa. Tais eixos escolhidos serão apontados aqui e aprofundados no capítulo seguinte.

${ }^{46}$ Em trabalhos mais recentes, a autora Denise Elias vem utilizando o termo "Região do Agronegócio" em substituição ao termo RPA. 
A preocupação em relação ao agravamento das desigualdades sociais e regionais no país é fundamental. Segundo Santos e Silveira (2001, p.260), “[...] o território mostra diferenças de densidades quanto às coisas, aos objetos, aos homens, ao movimento das coisas, dos homens, das informações, do dinheiro e também quanto às ações”. Ainda nas palavras dos autores, “[...] as regiões onde se situam produções destinadas à exportação e ao comércio distante têm prioridade nesse equipamento, criando-se no território áreas com maior densidade viária e infoviária a serviços de um dos aspectos da economia nacional".

Os espaços de fluidez seguem o padrão de desenvolvimento econômico do país. Sendo assim, a reestruturação produtiva de algumas áreas, seguida das transformações inerentes a esse processo, se desenvolveu de forma excludente e seletiva, o que acaba contribuindo para a manutenção e ampliação de certas características no Brasil, como o caso da concentração da estrutura fundiária e das desigualdades sociais (ELIAS, 2006b).

As Regiões Produtivas Agrícolas apresentam, de acordo com Elias (2006, 2006b, 2011), mudanças e ressignificações dos espaços urbanos e regionais. É necessário enfatizar que por mais que essas RPAs estejam se reconfigurando por conta de um processo hegemônico, no caso a expansão da agropecuária moderna, as mesmas apresentam particularidades e especificidades, pois embora a tendência de reestruturação das Regiões Produtivas em diferentes Estados brasileiros seja um processo comum, os resultados são diferentes em cada lugar.

Ademais, considerando a complexidade do território brasileiro, marcado pela heterogeneidade de paisagens, o estudo sobre esses novos processos são fundamentais para a melhor compreensão e desbravamento dos eventuais processos em emergência no Brasil, acompanhado da maior ocupação do nosso território (ELIAS, 2012). Sendo assim, as RPAs e suas áreas de influência têm alterado de maneira significativa os elementos técnicos e sociais da estrutura agrária do país, modificando as formas e tendências relacionadas à produção no campo, alterando a estrutura agrária dos estados e do país, e influenciando a alteração dos elementos sociais da produção (ELIAS, 2012).

Um dos fatores que são alterados com a reestruturação de áreas rurais é o mercado de trabalho. Bezerra (2008, p.68) afirma que “[...] as transformações em curso na agropecuária caracterizada pela reestruturação do processo produtivo foram responsáveis pelo estabelecimento de um novo perfil do mercado de trabalho nas áreas de expansão do agronegócio." 
As RPAs são compostas tanto pelos espaços agrícolas como pelos espaços urbanos selecionados para a recepção de pesados investimentos de atores hegemônicos, o que caracteriza uma verticalização das decisões que estão concentradas nas mãos das corporações nacionais e multinacionais, o que acaba reconfigurando os espaços urbanos à medida que surgem novos equipamentos urbanos e elementos físicos e sociais na cidade, com grande ligação ao agronegócio globalizado. (ELIAS, 2012).

No entanto, as horizontalidades também são marcantes, visto que se pode evidenciar a expansão das atividades econômicas, alterações demográficas, mudanças no mercado de trabalho, e surgimento de novos agentes econômicos e sociais ligados à grande produção (ELIAS, 2012). Nesse aspecto, as grandes empresas nacionais e multinacionais do agronegócio, acompanhadas por empresas ligadas ao transporte e logística e grandes equipamentos urbanos, estabelecem novas imposições ao mercado agropecuário e às cidades do agronegócio.

Dessa forma, é possível dizer que as cidades do agronegócio são reféns de imposições estabelecidas por grandes agentes, sobretudo de empresas multinacionais e nacionais e do Estado. De acordo com Frederico (2013),

Dos grandes centros decisórios, internos e externos à formação sócio-espacial brasileira, provêm as ordens das grandes empresas, instituições, especuladores financeiros e Estados, que designam direta ou indiretamente a forma de produzir (técnicas de manejo), de armazenar, de transportar, a disponibilidade e o custo do dinheiro, o câmbio, os lucros dos intermediários, os preços, os prazos e as quantidades adquiridas. (FREDERICO, 2013, p. $15)$.

Para Elias (2012, p.3), “[...] o agronegócio globalizado se realiza totalmente a partir da dialética entre a ordem global e a ordem local’. Essa tensão entre a ordem local e a ordem global, que envolvem processos globalizantes, já foi abordada por Santos (2008), segundo quem, à medida que o processo de globalização avança, a tensão entre a localidade e a globalidade se acirra ainda mais.

No caso do agronegócio, a transformação de áreas antigamente esquecidas em áreas produtoras do agronegócio, acompanhadas de transformações das áreas urbanas, acaba impondo novas realidades e colocando em choque as tendências locais com as tendências globalizantes. De fato, segundo Elias (2012), existe uma diferença entre as RPAs e o conceito tradicional de região presente na Geografia. A região tradicional nos remete à ideia de que existe a independência de um lugar fechado, visto que a mesma não depende da escala nacional e internacional. Já as RPAs dependem do contexto 
internacional e das realidades exógenas, sobretudo tecnológicas e voltadas para a produção.

Para muitos estudiosos, fala-se em "morte" do conceito de região em decorrência da expansão do capital e da tecnologia. No entanto, Elias (2012) defende que as diferenças entre os lugares estão aumentando cada vez mais. No caso das RPAs, cada cultura agrícola possui necessidades diferenciadas, como, por exemplo, o cultivo de grãos, que demanda maior utilização de máquinas na produção, em contrapartida à produção de determinadas frutas, que demanda maior utilização de mão de obra humana, como apontado no trabalho realizado por Bezerra (2008).

Há de se considerar também que, de acordo com Elias (2011, p.157), “[...] a configuração das RPAs não respeita os limites político-administrativos oficiais e, assim, é bastante comum uma mesma RPA ser formada por diferentes Estados”. Nesse caso, pode-se afirmar que no MATOPIBA existem RPAs com essa caracterização, que são constituídas por municípios de diferentes estados, interligados pela presença da agricultura moderna, como é o caso da intensa ligação das cidades do agronegócio dos outros estados integrantes dessa região ao oeste baiano, principalmente com os municípios de Barreiras e Luís Eduardo Magalhães.

As Regiões Produtivas Agrícolas podem ser consideradas como uma mistura de espaço agrário e de espaço urbano. Verifica-se que as alterações no urbano obedecem às necessidades impostas pelo meio rural, onde fica localizada a grande produção de diferentes culturas agrícolas, pois cada uma possui necessidades distintas. Quanto maior a reestruturação produtiva, acompanhada da formação de redes agroindustriais, mais complexa se torna a relação campo-cidade. Os dois espaços em questão passam a receber inúmeros fluxos de informações, de mercadorias e de novos agentes econômicos. (ELIAS, 2012).

Então, pode-se considerar que a relação campo-cidade pode ser resumida nas relações de complementaridade, que ganha cada vez mais força em seu caráter dialético, e que revela uma reversão de antigos padrões de oposição entre o campo e a cidade, pois agora os dois se relacionam, e, em alguns momentos, é até mesmo difícil definir os limites que os separam (ELIAS, 2012).

Nesse caso, algumas áreas urbanas brasileiras estão recebendo grande influência das áreas rurais e vice e versa, o que revela um processo complexo e relativamente novo 
no caso brasileiro. A urbanização de algumas áreas brasileiras, portanto, está totalmente associada à expansão do agronegócio e seus processos complementares.

De acordo com Martine (1989), a reconfiguração de regiões produtivas, com a devida modernização dessas áreas, acaba empreendendo novas realidades. Nesse caso, um dos pontos fundamentais de análise diz respeito às questões urbanas. A urbanização “implica maior produtividade do trabalho e, portanto, liberação maciça de mão de obra que, fatalmente, deverá dirigir-se às cidades [...].” (MARTINE, 1989, p.31).

Assim, a expansão da modernização agrícola no campo brasileiro provocou grande aumento no processo de urbanização brasileiro. Esse intenso processo influi até os dias de hoje, quando se observa que grande parte da população brasileira está localizada em grandes centros urbanos, o que, de alguma forma, impactou diretamente na agricultura familiar, pois grande parte das pessoas que passaram a residir nas cidades tinha um papel fundamental na produção de culturas agrícolas de menor escala, que está atrelada à alimentação básica da população brasileira. Isso acaba provocando, de acordo com Martine (1989), uma queda na situação nutricional e alimentar de grande parte da população brasileira, pois o consumo de produtos industrializados aumentou de forma demasiada nos últimos anos.

A metropolização acompanhada do crescimento de cidades de porte médio, e até mesmo de cidades pequenas, foram as grandes marcas do século $\mathrm{XX}$, que muitos autores denominam como urbanização dispersa, urbanização extensiva e de cidades difusas. Para Solimões e Amaral (2001),

[...] em 50 anos passamos de um país rural para um país metropolitano". O êxodo rurul significou não apenas a migração do campo para a cidade como também a concentração da população nas capitais estaduais, que crescentemente se tornaram áreas metropolitanas, constituídas pela capital e um conjunto heterogêneo de cidades satélites. (SOLIMÕES; AMARAL, p.558-559).

Nesse caso, o século XX pode ser entendido como um período marcado pelo grande crescimento populacional das cidades, com transformações nas suas bases sociais e econômicas, além da emergência de poucas metrópoles e do crescimento de cidades médias e pequenas. Então, o início do século XXI marca o período quando o processo de urbanização é gerado tanto pela sociedade como no território brasileiro. (ELIAS, 2012). 
Nesse sentido, pode-se dizer que o grande crescimento da população urbana tem relação com a modernização no campo brasileiro, visto que, de acordo com Martine (1989), houve uma expulsão de cerca de 30 milhões de pequenos produtores, famílias e trabalhadores rurais do campo brasileiro. De certa forma, tem sido um grande empecilho ao desenvolvimento do Brasil, pois o inchaço e o crescimento desordenado de algumas cidades brasileiras traz inúmeros problemas urbanos. (MARTINE, 1989).

Nesse caso, a expansão das áreas agroindustriais no país deve ser analisada criteriosamente, pois esse processo gera intensa reformulação das redes urbanas antigas no Brasil. Isso é uma possibilidade graças à formulação de grandes projetos de construção e expansão de rodovias e de infraestruturas de apoio, como de telecomunicações. Santos (1999) enfatiza que os processos globalizantes impõem novas necessidades aos diferentes espaços, como:

[...] capitais fixos (estradas, pontes, silos, terra arada etc.) e dos capitais constantes (o maquinário, veículos, sementes especializadas, fertilizantes, pesticidades etc.), aumenta também a necessidade de fluxos, inclusive financeiros, e dando um relevo especial à vida de relações. (SANTOS, 1999, p.11).

O espaço passa por reconfigurações e isso é sentido nas mudanças da economia urbana, na especialização desses espaços, no surgimento de novos fluxos, e na alteração da relação entre o campo e a cidade (ELIAS, 2011). O velho passa dar lugar ao novo e, de certa forma, uma nova rede urbana se estabelece em diferentes recortes territoriais no Brasil, com profundas transformações nas características demográficas, no trabalho, e na estrutura fundiária dessas diferentes áreas.

No entanto, deve-se destacar a questão das reconfigurações urbanas e alteração das centralidades urbanas a partir do agronegócio, pois, como já foi apontado, a modernização da agricultura acaba impondo novas realidades às cidades, alterando a economia urbana e incrementando ainda mais a urbanização. De acordo com Elias (2006b),

É possível identificar várias áreas nas quais a urbanização se deve diretamente à consecução do agronegócio globalizado. Como é notório, a modernização e expansão destas atividades promoveram o processo de urbanização e de crescimento das áreas urbanas, cujos vínculos principais se devem às inter-relações cada vez maiores entre campo e cidade. (ELIAS, 2006, p15). 
A economia urbana das cidades do agronegócio se reconfigura e acaba centralizando as ações e estabelecendo uma área de influência significativa. Elias (2006b) afirma que nessas cidades é possível perceber a associação desta atividade econômica com outros setores econômicos, tais como:

\begin{abstract}
As empresas agropecuárias, fornecedores de insumos químicos e implementos mecânicos, laboratórios de pesquisa biotecnológica, prestadores de serviços, agroindustriais, empresas de distribuição comercial, empresas de pesquisa agropecuária, empresas de marketing, cadeias de supermercados, empresas de fast food etc. Como resultado temos a intensificação da divisão do trabalho, das trocas intersetoriais, da especialização da produção e a formação de diferentes arranjos territoriais agrícolas, assim como na reestruturação das cidades nas suas adjacências, a mostrar o aprofundamento da territorialização do capital no campo e monopolização do espaço agrícola. (ELIAS, 2006b, p.20).
\end{abstract}

Este processo de substituição do velho, incorporação do novo e reestruturação da rede urbana vem acontecendo em algumas áreas do estado do Piauí, em especial na mesorregião Sudoeste Piauiense ${ }^{47}$. Analisaremos os impactos que o advento da agricultura moderna proporciona para a rede de cidades piauiense, considerando que, de acordo com Elias (2006b), a realidade do país nos mostra a formação de cidades e de redes urbanas associadas e influenciadas pelas atividades do agronegócio, caracterizando o que essa autora denomina Brasil agrícola moderno. Nesse caso, revelam-se importantes os estudos sobre esses novos processos no Brasil decorrentes da expansão da moderna agricultura e as transformações dos espaços urbanos. Entender o processo, as características e as relações torna-se um bom exercício de compreensão das tendências dos atuais espaços urbanos brasileiros.

\title{
2.6.1 Definição dos Eixos Estruturantes para análise do Processo de Modernização
} Agrícola Piauiense e os impactos na rede urbana desse Estado

Elias (2011, 2012, p.164) define cinco eixos estruturantes (variáveis), utilizados como orientação metodológica, e consequentemente para “[ [...] reconhecer a especificidade atual da racionalização do espaço agrícola, das relações campo-cidade e a produção dos espaços não metropolitanos, assim como a reestruturação regional”. Tais variáveis são agrupadas nos seguintes eixos: "Eixo 1 - uso e ocupação do espaço

47 A caracterização do processo de ocupação dessa mesorregião e as transformações recentes, sobretudo na escala do urbano, serão desenvolvidas no capítulo 3 deste trabalho. 
agrário; Eixo 2 - ramos industriais representativos das redes agroindustriais; Eixo 3 economia urbana; Eixo 4 - mercado de trabalho e dinâmica populacional; Eixo 5 infraestrutura e equipamentos urbanos." (ELIAS, 2011, p.164).

Pressupõe-se que a agricultura moderna acaba reconfigurando a rede urbana na Mesorregião Sudoeste Piauiense, focando as microrregiões Alto Médio Gurguéia e Alto Parnaíba Piauiense, e considerando, também, o município de Corrente, localizado na Microrregião Chapadas do Extremo Sul Piauiense. Daremos maior foco às cidades que servem de suporte ao agronegócio e à economia desse recorte espacial, no caso, Uruçuí, Bom Jesus e Corrente, especialmente a segunda cidade, já que pressupomos que é a que mais tem centralizado o comando das ações em torno da agricultura moderna, setores econômicos e serviços complementares.

Visando, portanto, analisar, verificar e caracterizar as novas dinâmicas e transformações urbanas e o papel das cidades face ao agronegócio, selecionaram-se os seguintes eixos estruturantes: 1) Uso e Ocupação do Espaço Agrário; 2) Economia Urbana e 3) Infraestrutura e equipamentos urbanos.

O primeiro eixo selecionado, Uso e Ocupação do Espaço Agrário, de acordo com Elias (2012), consiste em verificar as mudanças das densidades técnicas e normativas, como a presença de sistemas de objetos eletrificação rural, telecomunicações, armazenamento da produção, etc. Neste eixo, analisaremos as transformações na questão do uso do solo em áreas agrícolas, que envolvem a substituição de culturas e atividades tradicionais em atividades agrícolas modernas, e as questões ligadas ao uso do solo, como a concentração fundiária e valorização do preço da terra. Nesse sentido, acredita-se que as imagens de satélite, os dados da produção e produtividade, a composição das propriedades rurais, e a presença de empresas nacionais e transnacionais colaboram para a discussão.

O segundo eixo selecionado, o da Economia Urbana, de acordo com Elias (2012), se baseia na discussão das novas funções desempenhadas pelas cidades localizadas na área da pesquisa selecionada, e na verificando das alterações no comércio e nos serviços; em suma, de todas as dinâmicas dessas áreas. Assim, destacaremos quais as cidades se beneficiam do agronegócio e quais centralizam as ações, caracterizando também a nova relação entre o campo e a cidade.

No terceiro eixo, o da Infraestrutura e Equipamentos Urbanos, segundo Elias (2012), analisa-se a questão da modernização e expansão das infraestruturas e 
equipamentos urbanos que servem de apoio e suporte para a grande produção agropecuária, evidenciando as infraestruturas complementares que influenciam diretamente no escoamento da produção e nos fluxos de capitais e de pessoas. Elias cita as principais variáveis a serem analisadas nesse eixo temático:

[...] rodovias; ferrovias; rodoviárias; porto; aeroporto e voos comerciais regulares; terminais intermodais; shopping centers; hotéis de alto padrão pertencentes a redes nacionais e internacionais; existência ou não de distritos industriais; espaços fixos e transitórios para a promoção de eventos (festas, feiras, convenções); supermercados e hipermercados pertencentes a redes nacionais ou internacionais; fixos associados à rede bancária e financeira; empresas do setor imobiliário, entre outros. (ELIAS, 2012, p.13-14).

Evidenciaremos a presença dessas novas infraestruturas principalmente nas chamadas cidades do agronegócio do Estado do Piauí, com destaque para Bom Jesus, Uruçuí e até mesmo Corrente.

A escolha desses eixos estruturantes se deu por conta da sua ligação com a discussão das transformações urbanas das Regiões Produtivas do Agronegócio. Destaca-se que a escolha enquanto base metodológica não elimina a importância dos outros dois eixos, sendo que os mesmos serão abordados indiretamente durante o andamento do trabalho, sem, porém, a mesma intensidade dos eixos selecionados, pois entende-se que estes estão em grande consonância com o que se propõe nesse estudo. 


\section{CAPÍTULO III - MODERNIZAÇÃO AGRÍCOLA E TRASNFORMAÇÕES URBANAS NO SUDOSTE PIAUIENSE: NOVAS DINÂMICAS, AGENTES, NÚCLEOS URBANOS E ALTERAÇÃO DAS CENTRALIDADES URBANAS}

Até o momento, analisamos a nova relação entre o campo e a cidade, desenvolvida no capítulo 1, destacando algumas tendências da atual rede urbana brasileira, com o auxílio do documento intitulado Regiões de Influência de Cidades 2008, produzido pelo IBGE. A partir deste documento, caracterizamos os principais centros urbanos do Estado do Piauí, e ainda analisamos o processo histórico de formação territorial deste Estado, principalmente o de ocupação territorial piauiense.

No capítulo 2, a fim de evidenciar que o Estado do Piauí participa de uma dinâmica econômica, histórica e política que empreende novas transformações socioespaciais nessa nova fronteira agrícola brasileira, realizamos análise crítica do processo de modernização agrícola no Brasil, em especial no Brasil Central, extensa região com presença do bioma dos Cerrados, abordando, também, brevemente, a região denominada MAPITOBA e os principais municípios do agronegócio de cada Estado integrante, bem como a recente criação do Plano de Desenvolvimento Agropecuário (PDA) do MAPITOBA.

Neste capítulo, por sua vez, analisaremos o processo de inserção dos Cerrados piauienses nessa nova dinâmica de modernização da agricultura e expansão da fronteira agrícola no país, e as transformações urbanas decorrente desse processo, em especial no início do século XXI, com ênfase na questão da alteração das centralidades urbanas e das novas dinâmicas urbanas. Assim, abordaremos, primeiramente, a questão da divisão mesorregional do Piauí, da distribuição populacional e rede de cidades.

\subsection{Divisão Mesorregional do Piaú, Rede Urbana e distribuição populacional}

O Sudoeste Piauiense é uma das quatro mesorregiões estabelecidas pelo IBGE (1990), em conjunto com o Norte Piauiense, o Centro-Norte Piauiense e o Sudeste Piauiense, com base em fatores naturais, sociais, históricos, na rede de comunicação e na articulação espacial (IBGE, 1990). A localização do Sudoeste Piauiense pode ser observada na figura abaixo: 
Figura 9- Mesorregiões Geográficas do Piauí

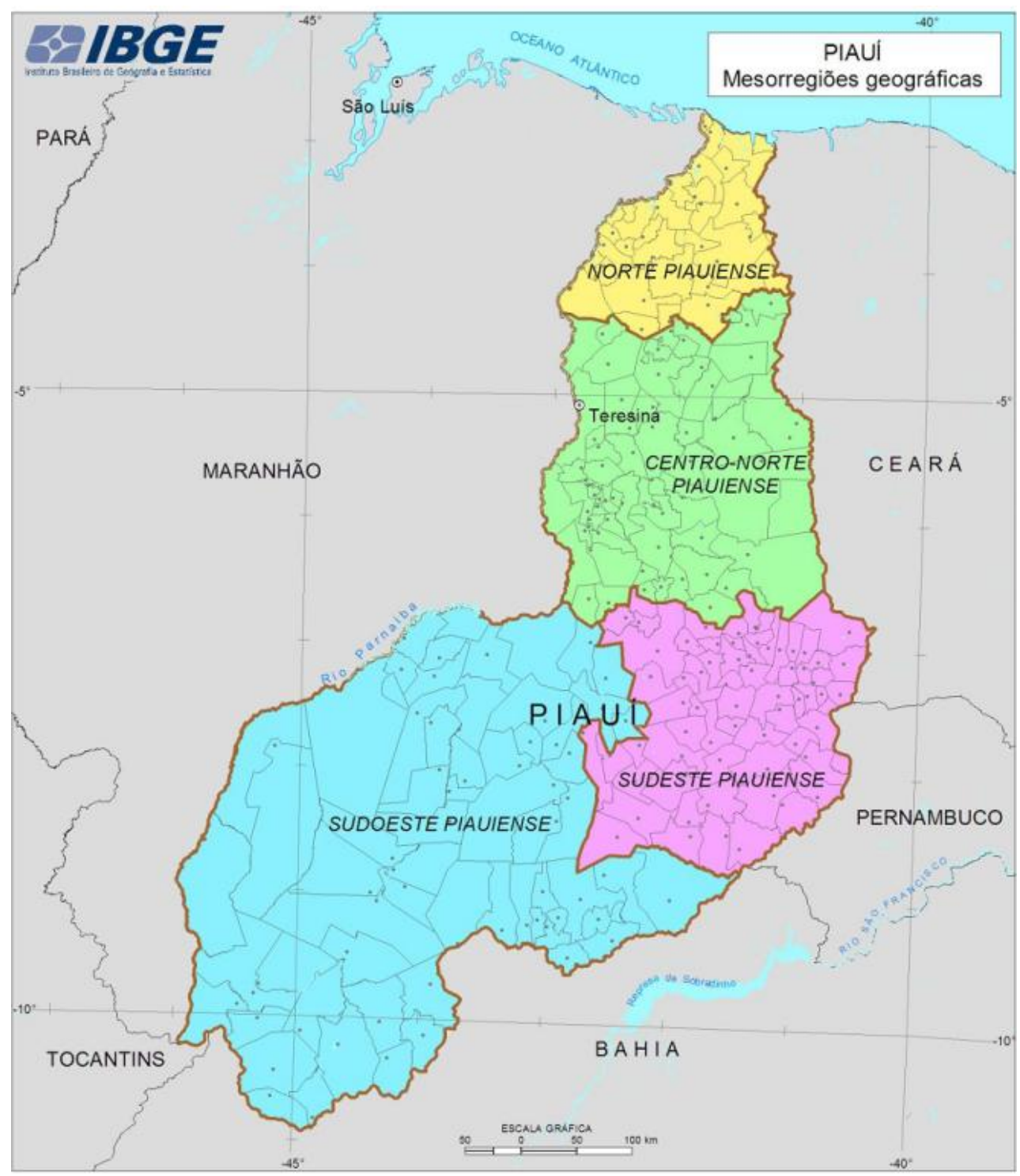

Fonte: Censo Demográfico 2010 - Retratos do Brasil e do Piauí.

Esta é uma área de vegetação dos Cerrados com baixa densidade demográfica, que, atualmente, possui papel relevante nas dinâmicas globais, em consequência da geração de novos fluxos e redes, que decorrem da expansão da fronteira agropecuária no Piauí. Observa-se, abaixo, a figura referente à densidade demográfica do Estado do Piauí: 


\section{Figura 10: Densidade Demográfica no Estado do Piauí}

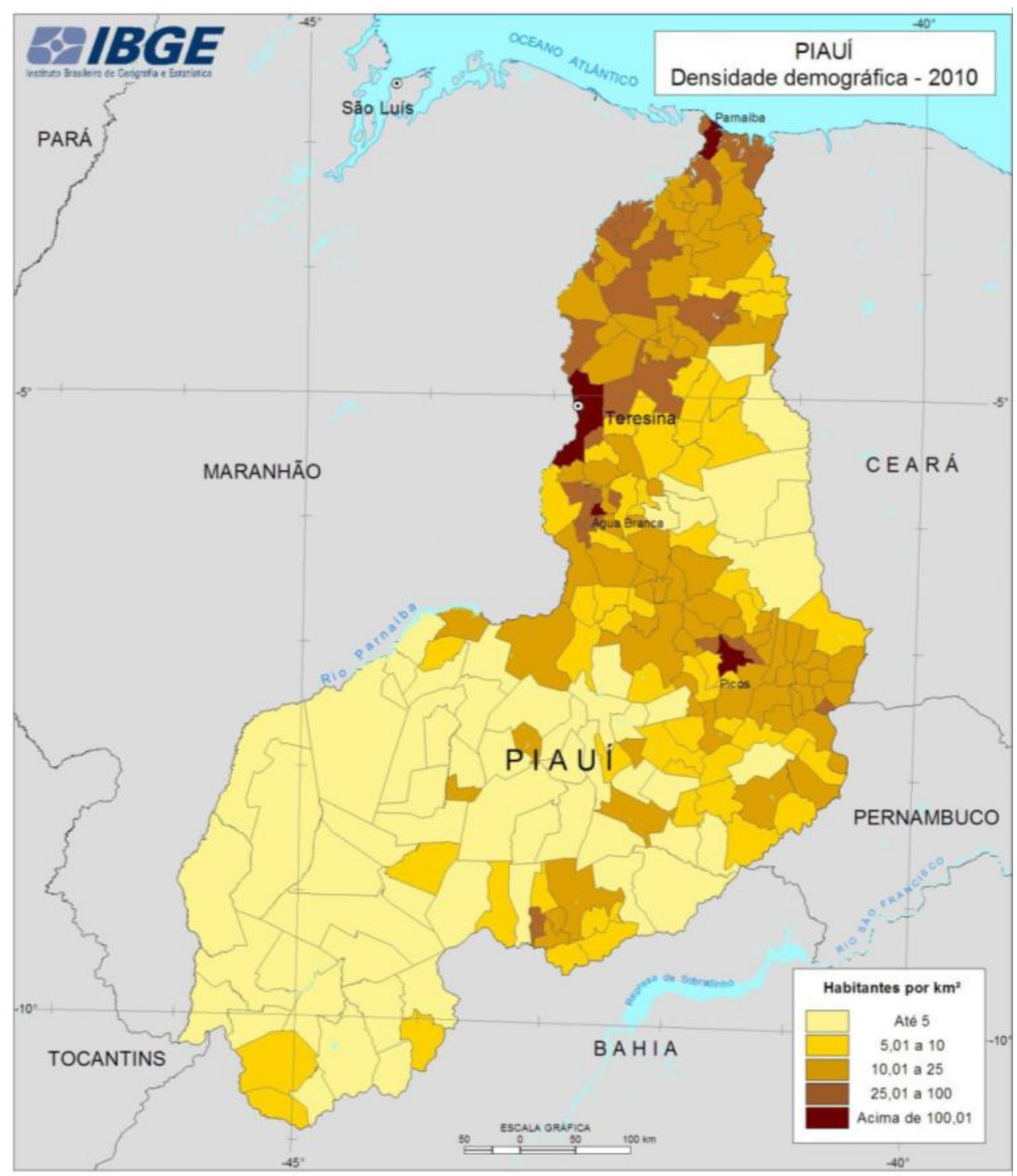

Fonte: Censo Demográfico 2010 - Retratos do Brasil e do Piauí.

A porção Sudoeste do Piauí, como é possível notar, possui baixa densidade demográfica, o que é uma das características de grande parte dos municípios dessa mesorregião. A comparação com a figura anterior evidencia que, mesmo possuindo a maior extensão territorial do Estado do Piauí, o Sudoeste Piauiense é também a área de povoamento menos denso, o que, de certa forma, revela-se como condição favorável à expansão do agronegócio nos Cerrados piauienses. De fato, no geral, o Estado do Piauí é marcado pela assimetria em relação à distribuição populacional, já que existe maior concentração populacional na porção centro-norte do Estado, muito em função da presença da capital Teresina e de cidades como Picos, Piripiri, Campo Maior, Parnaíba e 
até mesmo Floriano, cidade que, ainda que esteja localizada no Sudoeste Piauiense, encontra-se nos limites com o Centro-Norte Piauiense.

Atualmente, no contexto de mudanças nas áreas urbanas e rurais do Estado, um dos grandes desafios do Piauí é a preservação da sua integridade política, devido à distância física da capital Teresina em relação à porção sul do Estado e à concentração populacional próxima a essa cidade. Esse distanciamento da capital é mais intenso especialmente no que concerne os municípios da Mesorregião Sudoeste Piauiense. De fato, a pouca articulação da rede urbana piauiense é tal que existem propostas separatistas, mais especificamente a criação de um novo Estado, o Gurguéia ${ }^{48}$. A justificativa seria de que essa região não está plenamente conectada à porção central e norte do Piauí, e ligar-se-ia antes à porção central do Brasil.

As sub-regiões com características de estagnação e pobreza, algumas marcadas pelo isolamento e desintegração em relação ao restante do estado (BRASIL, 2005), portanto, não fazem senão acentuar a fragmentação e os contrastes territoriais que afetam a integridade política do Piauí, e que constituem desafios a serem superados no Estado, muito embora essa problemática tenha sido amenizada, nos últimos anos, em decorrência do ganho de centralidade de algumas cidades do Sudoeste Piauiense, como Bom Jesus, Uruçuí e Corrente. Antes de adentrarmos essa questão, porém, analisaremos a tabela abaixo, que evidencia o fato de que, atualmente, a rede urbana Piauiense é caracterizada pelo crescimento dos índices de urbanização e por certo esvaziamento do meio rural - os índices de residentes no campo, porém, ainda são elevados, e muitos municípios piauienses ainda são essencialmente rurais, principalmente na porção sul do Estado:

48 Proposta de nova unidade federativa do Brasil. O estado seria constituído pela atual área da Mesorregião Sudoeste Piauiense. O nome alude ao rio Gurguéia, o maior afluente do Rio Parnaíba, e a capital seria a cidade de Alvorada do Gurguéia, ou Bom Jesus. 
Tabela 10: População Residente por Situação do Domicílio em 2000 e 2010

\begin{tabular}{|c|c|c|c|c|}
\hline \multirow{2}{*}{$\begin{array}{l}\text { UF e Mesorregiões do } \\
\text { Estado do Piauí }\end{array}$} & \multicolumn{4}{|c|}{ População Residente } \\
\hline & $\begin{array}{c}\text { Urbana } \\
2000\end{array}$ & $\begin{array}{l}\text { Urbana } \\
2010\end{array}$ & $\begin{array}{l}\text { Rural } \\
2000\end{array}$ & $\begin{array}{l}\text { Rural } \\
2010\end{array}$ \\
\hline Piauí & $\begin{array}{l}1.788 .592 \\
(62,91 \%)\end{array}$ & $\begin{array}{l}2.050 .959 \\
(65,77 \%)\end{array}$ & $\begin{array}{l}1.054 .686 \\
(37,09 \%)\end{array}$ & $\begin{array}{l}1.067 .401 \\
(34,23 \%)\end{array}$ \\
\hline MESORREGIÕES & \multirow{2}{*}{$\begin{array}{c}336.123 \\
(58,32 \%)\end{array}$} & \multirow[b]{2}{*}{$\begin{array}{l}376.672 \\
(59,52 \%)\end{array}$} & \multirow[b]{2}{*}{$\begin{array}{c}240.220 \\
(41,68 \%)\end{array}$} & \multirow[b]{2}{*}{$\begin{array}{l}256.211 \\
(40,48 \%)\end{array}$} \\
\hline Norte Piauiense & & & & \\
\hline Centro-Norte Piauiense & $\begin{array}{l}1.008 .879 \\
(75,94 \%)\end{array}$ & $\begin{array}{l}1.129 .160 \\
(77,63 \%)\end{array}$ & $\begin{array}{c}317.107 \\
(24,06 \%)\end{array}$ & $\begin{array}{l}325.306 \\
(22,37 \%)\end{array}$ \\
\hline Sudoeste Piauiense & $\begin{array}{c}243.243 \\
(51,84 \%)\end{array}$ & $\begin{array}{c}299.542 \\
(58,55 \%)\end{array}$ & $\begin{array}{l}225.975 \\
(48,16 \%)\end{array}$ & $\begin{array}{l}212.074 \\
(41,45 \%)\end{array}$ \\
\hline Sudeste Piauiense & $\begin{array}{c}208.347 \\
(43,43 \%)\end{array}$ & $\begin{array}{c}245.585 \\
(47,28 \%)\end{array}$ & $\begin{array}{c}271.384 \\
(56,57 \%)\end{array}$ & $\begin{array}{c}273.810 \\
(52,72 \%)\end{array}$ \\
\hline
\end{tabular}

Fonte: IBGE. Censo Demográfico 2010, elaborada pelo autor.

Esses dados destoam das porcentagens gerais do restante do país, pois enquanto o Brasil possui $80 \%$ da sua população urbana, no Piauí, em 2010, esse índice era de cerca de $65,77 \%$. Além disso, é possível apontar que não houve aumento significativo da população urbana e rural no Estado do Piauí entre os anos 2000 e 2010. Dentre as quatro Mesorregiões Piauienses, a que obteve maior aumento da população urbana (6,71\% de acréscimo) foi justamente o Sudoeste Piauiense. Quando se observa, porém, que a Mesorregião Sudoeste Piauiense possui ao todo 62 municípios, esse crescimento torna-se inexpressivo; ele se dá precisamente em função das migrações de sulistas e do êxodo rural em alguns municípios. Além disso, algumas cidades do Sudoeste Piauiense, como Floriano, centralizam serviços ligados à educação superior.

Grande parte da população urbana do Piauí concentra-se na Mesorregião CentroNorte Piauiense devido à influência da capital Teresina, cidade mais populosa do Estado, com cerca de 814.230 habitantes. Outra grande parte concentra-se na Mesorregião Norte Piauiense devido às cidades litorâneas de Parnaíba e Luiz Corrêa. Nas Mesorregiões Sudeste e Sudoeste, há certa equivalência entre a população urbana e a rural entre os anos 2000 e 2010. No Sudeste Piauiense, a população residente na zona rural supera a população urbana. No Sudoeste Piauiense, por outro lado, a população urbana supera, por pouco, a população rural, devido à presença de cidades mais populosas e com alta urbanização para os padrões piauienses, como, por exemplo, Floriano, Bom Jesus, Corrente, Uruçuí e São Raimundo Nonato. Tais municípios 
localizam-se distantes da hoje capital Teresina, mas lembremos que Oeiras, cidade localizada na porção central do Piauí, era anteriormente a capital desse Estado.

Com efeito, a transferência da capital em 1852 evidencia as tentativas características desse período de consolidar o Brasil como fornecedor e exportador de matéria prima e de gêneros alimentícios (SOUSA, 2008). A mudança objetivava inserir o Estado do Piauí no comércio e favorecer o escoamento da produção, pois Teresina possuía uma posição estratégica próxima aos rios Parnaíba e Poti, com grande potencial de navegação fluvial (SOUSA, 2008). A mudança de capital desencadeou uma série de transformações no Estado e influenciou outras cidades litorâneas, como Parnaíba, ponto de comércio e de escoamento da produção, e, inclusive, é possível dizer que prejudicou a unidade territorial do Estado do Piauí, pois a capital situa-se agora muito distante de diversos municípios localizados na porção sul do território piauiense. Atualmente, essa é uma das grandes dificuldades de administração do Piauí, já que a estrutura administrativa, a população e os serviços concentram-se na capital Teresina.

Na tabela a seguir, observamos os municípios mais populosos do Estado do Piauí: 
Tabela 11: Municípios mais populosos do Piauí

\begin{tabular}{|c|c|c|c|c|}
\hline $\begin{array}{c}\text { Municípios mais } \\
\text { populosos }\end{array}$ & $\begin{array}{c}\text { População } \\
2000\end{array}$ & $\begin{array}{c}\text { População } \\
2010\end{array}$ & $\begin{array}{l}\text { Taxa Geométrica } \\
\text { de crescimento }\end{array}$ & $\begin{array}{c}\text { Mesorregião } \\
\text { correspondente }\end{array}$ \\
\hline Teresina & 715.360 & 814.230 & 1,30 & Centro-Norte \\
\hline Parnaíba & 132.282 & 145.705 & 0,97 & Norte \\
\hline Picos & 68.974 & 73.414 & 0,63 & Sudeste \\
\hline Piripiri & 60.154 & 61.834 & 0,28 & Norte \\
\hline Floriano & 54.594 & 57.690 & 0,55 & Sudoeste \\
\hline Campo Maior & 43.126 & 45.177 & 0,47 & Centro-Norte \\
\hline Barras & 40.891 & 44.850 & 0,93 & Norte \\
\hline União & 39.801 & 42.654 & 0,69 & Centro-Norte \\
\hline Altos & 39.122 & 38.822 & $-0,08$ & Centro-Norte \\
\hline Esperantina & 34.094 & 37.767 & 1,03 & Norte \\
\hline Pedro II & 36.201 & 37.496 & 0,35 & Centro-Norte \\
\hline José de Freitas & 32.858 & 37.085 & 1,22 & Centro-Norte \\
\hline Oeiras & 33.910 & 35.640 & 0,50 & Sudeste \\
\hline $\begin{array}{l}\text { São Raimundo } \\
\text { Nonato }\end{array}$ & 26.890 & 32.327 & 1,86 & Sudoeste \\
\hline
\end{tabular}

Fonte: IBGE, Censos Demográficos 2000 e 2010, elaborada pelo autor.

Com base nos dados da tabela, é possível afirmar que a Mesorregião CentroNorte Piauiense possui o maior número de municípios populosos, incluindo Teresina. A Mesorregião Norte Piauiense abrange quatro municípios, entre os quais o segundo município mais populoso do Estado. Já as Mesorregiões Sudoeste e Sudeste possuem apenas dois municípios cada entre os mais populosos do Estado do Piauí. Na Mesorregião Sudeste, especialmente, encontra-se o município de Picos, o terceiro mais populoso do Estado, e também a ex-capital Oeiras. A Mesorregião Sudoeste Piauiense, por outro lado, abrange os municípios de Floriano e São Raimundo Nonato.

Ao todo, a Mesorregião do Sudoeste Piauiense possui seis microrregiões: Alto Médio Gurguéia, Alto Parnaíba Piauiense, Bertolínia, Chapadas do Extremo Sul

\footnotetext{
${ }^{49}$ Percentual de incremento médio anual da população residente em determinado espaço geográfico, no período considerado, que indica o ritmo de crescimento populacional, influenciado pela dinâmica da natalidade, da mortalidade e das migrações.
} 
Piauiense, Floriano e São Raimundo Nonato. É possível observar a divisão Microrregional do Estado do Piauí na figura abaixo:

Figura 11: Microrregiões Geográficas do Piauí

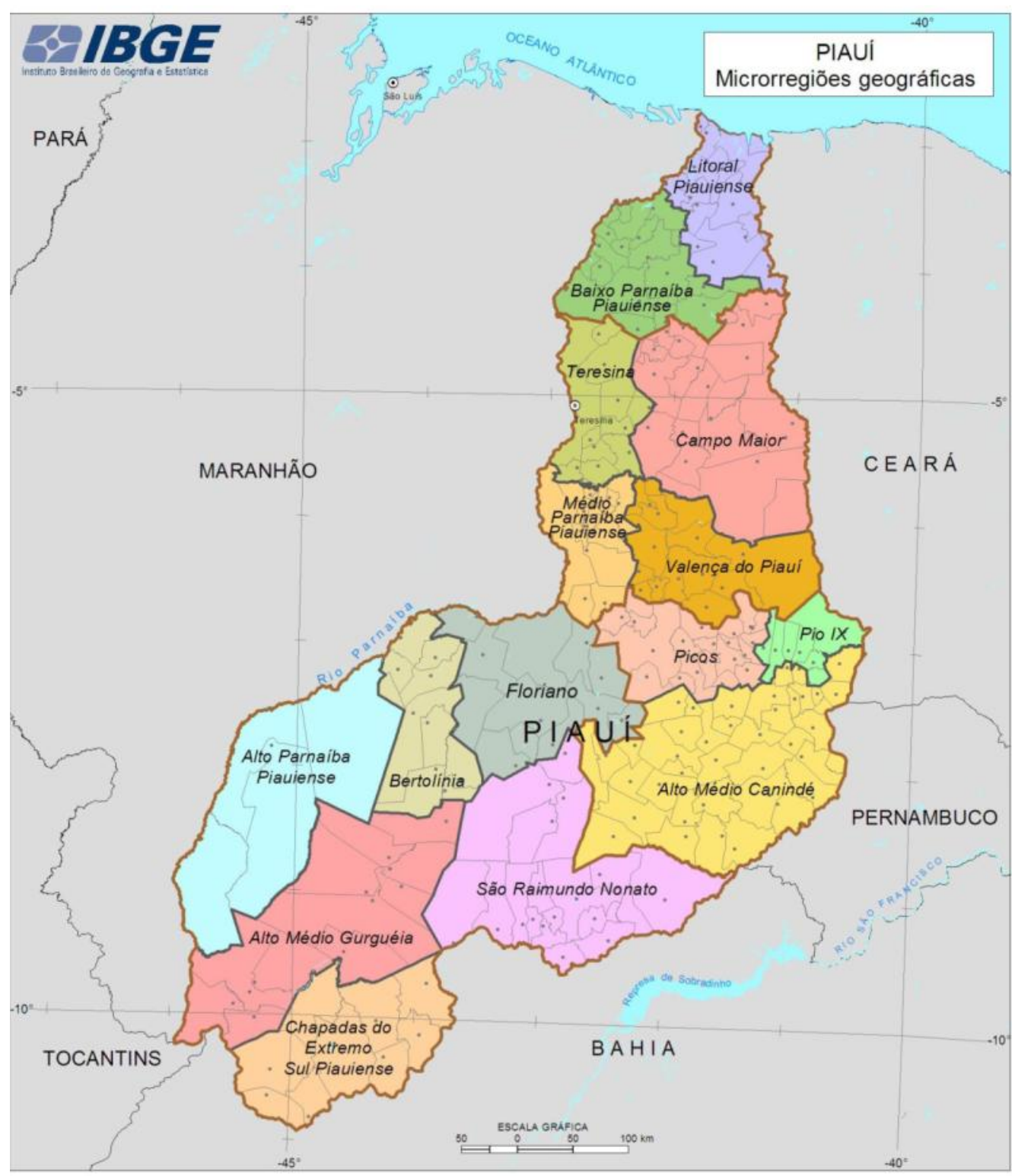

Fonte: Censo Demográfico 2010 - Retratos do Brasil e do Piauí.

Como já mencionamos o seguinte recorte territorial foi selecionado como área de estudo: os municípios da Microrregião Alto Médio Gurguéia e Alto Parnaíba Piauiense, além do município de Corrente, pertencente à Microrregião Chapadas do Extremo Sul Piauiense. Focaremos as cidades do agronegócio, Uruçuí, Corrente e especialmente Bom Jesus, a qual vem adquirindo maior centralidade neste contexto, comandando as ações em torno da questão do agronegócio. Com efeito, segundo Alves (2005), 
[...] o avanço da agricultura capitalista nos cerrados nordestinos outorgou a algumas cidades o papel de comando regional. Elas se destacam como áreas de fluxo de investimentos decorrentes da instalação de cooperativas, empresas de apoio à produção agrícola (revendedoras de insumos, implementos agrícolas, transportadoras, indústria de beneficiamento, de serviços especializados na agricultura, etc.), além de agricultores capitalizados e de trabalhadores qualificados ou sem qualificação em busca de empregos. Esses fatores deram um grande impulso à urbanização da região, sobretudo nas cidades pólos. (ALVES, 2005, p.2).

Nesse sentido, Bom Jesus e Uruçuí exercem, atualmente, o papel de comando regional juntamente com a cidade de Corrente, no extremo sul piauiense, as duas primeiras mais atreladas ao agronegócio e a terceira como centro sub-regional; Corrente, porém, tem perdido para Bom Jesus o papel de centro urbano de maior importância dos Cerrados piauienses, o que comprovaremos através da análise dos dados em relação aos eixos estruturantes da pesquisa. Assim, portanto, o recorte territorial foi definido de modo a integrar os três municípios na área de pesquisa, que procura analisar as microrregiões que participam mais ativamente da agricultura moderna no Estado do Piauí. Na tabela abaixo, constam as seis Microrregiões com a maior produção agrícola da região do MATOPIBA.

Tabela 12: As 6 microrregiões maiores produtoras de soja do MAPITOBA em 2012

\begin{tabular}{|c|c|c|}
\hline Microrregião & UF & Quantidade Porduzida (t) \\
\hline Barreiras & BA & 2.894 .546 \\
\hline Gerais de Balsas & MA & 986.166 \\
\hline Alto Parnaíba Piauiense & PI & 800.987 \\
\hline Chapadas das Mangabeiras & MA & 406.111 \\
\hline Alto Médio Gurguéia & PI & 361.578 \\
\hline Jalapão & TO & 358.490 \\
\hline
\end{tabular}

Fonte: Embrapa (2015)

Duas das seis microrregiões maiores produtoras da região do MATOPIBA em 2012 estão no Sudoeste Piauiense e foram selecionadas para essa pesquisa, pois são nelas que se localizam as cidades que articulam novos dinamismos a partir da agricultura moderna. O Alto Parnaíba Piauiense é a terceira microrregião em produção do MATOPIBA, atrás apenas da Microrregião de Barreiras, e da Microrregião de Balsas, polo do agronegócio no Maranhão. O Alto Médio Gurguéia é a quinta microrregião nesse quesito. 
O foco nas cidades do agronegócio piauiense - Bom Jesus, Uruçuí e Corrente se dá em consonância com as ideias de Elias (2012), que afirma que nem toda cidade localizada em uma Região Produtiva pode ser considerada uma cidade do agronegócio. Isso se aplica à realidade piauiense, na qual nem todas as cidades participam ativamente da dinâmica da agricultura moderna, e poucas delas se beneficiam com as novas realidades, tal como a expansão de comércio e serviços diferenciados - em outras palavras, com as modificações na economia urbana, como afirma Elias (2006b).

A escolha de Corrente para integrar a área de pesquisa se deve ao fato de tratarse de um município no qual atividades agropecuárias modernas e concentração de serviços e equipamentos urbanos, como universidades públicas, agências bancárias, serviços jurídicos, etc, fazem-se presentes. Ademais, além de possuir 25.408 habitantes (IBGE, 2010), destacando-se como um dos mais populosos municípios da Mesorregião Sudoeste Piauiense, Corrente também possui forte tradição na pecuária, especialmente na criação de bovinos, sendo o maior pólo pecuário de todo o Piauí, e abriga grande quantidade de estudantes devido à presença de campus da Universidade Federal do Piauí (UFPI), da Universidade Estadual do Piauí (UESPI) e do Instituto Federal de Educação, Ciência e Tecnologia do Piauí (IFPI).

Para justificar a seleção apenas do município de Corrente da Microrregião Chapadas do Extremo Sul Piauiense, partimos dos dados da tabela abaixo, referentes às atividades agropecuárias e à densidade populacional, segundo dados do IBGE (2010), dos municípios integrantes dessa microrregião.

\section{Tabela 13: Chapadas do Extremo Sul Piauiense- Dados da População (2010) e da} produção agropecuária em 2013

\begin{tabular}{|c|c|c|c|c|c|}
\hline \multirow{2}{*}{ Municípios } & \multirow{2}{*}{$\begin{array}{c}\text { População } \\
\mathbf{( 2 0 1 0 )}\end{array}$} & \multicolumn{2}{|c|}{$\begin{array}{c}\text { Quantidade Produzida em } \\
\text { 2013 (em toneladas) }\end{array}$} & \multirow{2}{*}{$\begin{array}{c}\text { Bovinos } \\
\text { (2013) }\end{array}$} \\
\cline { 3 - 5 } & & Arroz & Milho & Soja & \\
\hline Avelino Lopes & 11.067 & - & 202 & - & 12.650 \\
\hline Corrente & 25.407 & 37 & 1.584 & 11.419 & 52.635 \\
\hline Cristalândia-PI & 7.881 & 284 & 480 & 540 & 25.533 \\
\hline Curimatá & 10.761 & - & 150 & - & 22.655 \\
\hline Júlio Borges & 5.373 & - & 135 & - & 14.026 \\
\hline $\begin{array}{c}\text { Morro Cabeça no } \\
\text { Tempo }\end{array}$ & 4.068 & - & 90 & - & 9.614 \\
\hline Parnaguá & 10.272 & 36 & 276 & - & 40.510 \\
\hline Riacho Frio & 4.241 & 5 & 61 & - & 18.976 \\
\hline Sebastião Barros & 3.560 & 222 & 120 & 128 & 26.558 \\
\hline
\end{tabular}

Fonte: Elaborada pelo autor, dados do IBGE (2010) e site do IBGE Cidades. 
Percebe-se que grande parte dos municípios da Microrregião em destaque participa de forma tímida em relação à produção de grãos advindos da agricultura moderna, especialmente se compara com a produção agrícola de grande parte dos municípios das Microrregiões Alto Parnaíba Piauiense e Alto Médio Gurguéia ${ }^{50}$, que estão entre as maiores produtoras do Sudoeste Piauiense. A caatinga é a vegetação de muitos desses municípios, sendo que as áreas dos chapadões com presença dos Cerrados é bem menor em relação ao restante do Estado do Piauí, como é o caso de Curimatá, Júlio Borges e Parnaguá. Além disso, possuem uma quantidade de cabeças de gado pouco representativa, se comparado à Corrente, com exceção de Parnaguá.

Analisando a tabela, observa-se que Corrente é justamente o município com a maior produção agrícola, liderando a produção de culturas ligadas à moderna agricultura, como a soja e o milho. Ademais, o município possui grande quantidade de bovinos para a realidade do Sudoeste Piauiense. Este fato influencia diretamente na dinâmica da cidade, que passa a receber, todos os anos, a chamada ExpoCorrente, feira agropecuária focada na pecuária moderna, especialmente em gado de corte e leiteiro. Esse evento é realizado todos os anos no mês de julho - de fato, no ano de 2015, a então ministra da agricultura Kátia Abreu compareceu ao evento, ocasião na qual falou sobre a implantação do Plano de Desenvolvimento Agropecuário do MATOPIBA, lançado pelo Governo Federal, e discutido no I Simpósio de Desenvolvimento Regional da cidade de Corrente. Assim, justifica-se a seleção apenas do município de Corrente, pertencente à microrregião Chapadas do Extremo Sul Piauiense, para este estudo.

Abaixo, encontra-se a lista dos municípios integrantes de cada microrregião, além do município de Corrente, da Microrregião Chapadas do Extremo Sul Piauiense:

\footnotetext{
${ }^{50}$ Esses dados referentes à produção agrícolas nos municípios dessas duas microrregiões serão mostrados logo mais à frente.
} 
Tabela 14: Dados populacionais dos municípios da área de Estudo

\begin{tabular}{|c|c|c|c|c|c|}
\hline Microrregião & Municípios & $\begin{array}{c}\text { População } \\
\text { (2010) }\end{array}$ & $\begin{array}{l}\text { Densidade } \\
\text { Hab./Km² }\end{array}$ & $\begin{array}{c}\text { IDH-M } \\
(2010)\end{array}$ & $\begin{array}{c}\text { PIB a } \\
\text { preços } \\
\text { correntes } \\
\text { em reais } \\
(2012) \\
\end{array}$ \\
\hline \multirow{4}{*}{$\begin{array}{l}\text { Alto Parnaíba } \\
\text { Piauiense }\end{array}$} & Baixa Grande do Ribeiro & 10.516 & 1,35 & 0,564 & 132.460 \\
\hline & Ribeiro Gonçalves & 6.845 & 1,72 & 0,601 & 85.190 \\
\hline & Santa Filomena & 6.096 & 1,15 & 0,544 & 49.854 \\
\hline & Uruçuí & 20.149 & 2,40 & 0,631 & 654.724 \\
\hline \multirow{11}{*}{$\begin{array}{c}\text { Alto Médio } \\
\text { Gurguéia }\end{array}$} & Alvorada do Gurguéia & 5.050 & 2,37 & 0,578 & 29.432 \\
\hline & Barreiras do Piauí & 3.234 & 1,59 & 0,557 & 12.933 \\
\hline & Bom Jesus & 22.629 & 4,14 & 0,668 & 337.495 \\
\hline & Cristino Castro & 9.981 & 5,41 & 0,566 & 45.631 \\
\hline & Currais & 4.704 & 1,49 & 0,542 & 38.361 \\
\hline & Gilbués & 10.402 & 2,98 & 0,548 & 82.476 \\
\hline & Monte Alegre & 10.345 & 4,28 & 0,578 & 56.593 \\
\hline & Palmeira & 4.993 & 2,47 & 0,557 & 28.857 \\
\hline & Redenção do Gurguéia & 8.400 & 3,40 & 0,589 & 36.381 \\
\hline & Santa Luz & 5.513 & 4,65 & 0,588 & 23.202 \\
\hline & São Gonçalo do Gurguéia & 2.825 & 2,04 & 0,560 & 14.131 \\
\hline $\begin{array}{c}\text { Chapadas do } \\
\text { Extremo Sul } \\
\text { Piauiense } \\
\end{array}$ & Corrente $^{51}$ & 25.407 & 8,33 & 0,642 & 152.782 \\
\hline
\end{tabular}

Fonte: Elaborada pelo autor, dados do IBGE (2010) e site do IBGE Cidades.

A partir de análise da tabela, é possível afirmar que grande parte dos municípios selecionados não possui expressivo contingente populacional. Os mais populosos são, respectivamente, Corrente, Bom Jesus e Uruçuí. A seguir, estão Baixa Grande do Ribeiro, localizado na Microrregião Alto Parnaíba Piauiense, com 10.516 habitantes, Gilbués, com 10.402 habitantes, e Monte Alegre, com 10.345 habitantes, os dois últimos localizados na Microrregião Alto Médio Gurguéia. Vale ressaltar que o município de Gilbués foi considerado pelo REGIC 2008 como um Centro de Zona B, que centraliza os municípios de Barreiras do Piauí e Monte Alegre do Piauí, formando um eixo importante.

\footnotetext{
${ }^{51}$ Único município selecionado dessa microrregião, como já justificado anteriormente.
} 
Os dados da tabela provam, ainda, que a rede municipal selecionada abrange municípios de baixa densidade demográfica, sendo que as cinco maiores densidades demográficas estão nos municípios de Corrente (densidade de 8,33 hab./Km²), em Cristino Castro (densidade de 5,41 hab./ $\mathrm{Km}^{2}$ ), em Santa Luz (densidade de 4,65 hab./Km²), em Monte Alegre (densidade de 4,28 hab./ $\mathrm{Km}^{2}$ ) e, finalmente, em Bom Jesus (densidade de 4,14 hab./ $\mathrm{Km}^{2}$ ). O município de Uruçuí, que é conhecido pela grande produção de grãos no Estado do Piauí, é marcado, ao contrário, por baixa densidade demográfica, com 2,40 hab./ $\mathrm{Km}^{2}$. Apesar de estar entre três mais populosos do recorte selecionado, sua população se concentra basicamente no perímetro urbano, o que acaba por torná-lo um dos municípios mais relevante em relação à agricultura moderna e atividades complementares e subsidiárias. Segundo CEPRO ${ }^{52}$ (2007, p.41), nessa região do Alto Parnaíba, "Uruçuí é o que mais se destaca, dada a oferta de serviços como saúde, intermediação financeira, comércio atacadista, além de disponibilizar uma variedade de máquinas e implementos agrícolas."

Em relação ao PIB municipal, novamente os três municípios que mais se destacam são justamente Uruçuí, com PIB a preços correntes de 654.724 mil reais, Bom Jesus, com 337.495 mil reais, e, por fim, Corrente, com 152.782 mil reais. Já quanto ao Índice de Desenvolvimento Humano Municipal (IDH-M) ${ }^{53}$, por outro lado, percebe-se que todos os municípios apresentam índices médios. Os maiores IDH-M's desse recorte, porém, são justamente os dos municípios do agronegócio, Bom Jesus (IDH-M de 0,668), Corrente (IDH-M de 0, 642), e Uruçuí (IDH-M de 0,631).

A análise da tabela ajuda a compreender o contexto do Piauí, Estado onde se observa a existência de um IDH médio, que figura entre os menores do país. Segundo dados do Atlas Brasil 2013, em 2010, o Estado do Piauí tinha IDH de 0,646, enquanto que o Brasil apresentava IDH de $0,727^{54}$, ou seja, o IDH piauiense está abaixo da média nacional. As figuras abaixo mostram, entretanto, que, nos últimos anos, este índice tem melhorado no Estado:

\footnotetext{
${ }^{52}$ Relatório Final de Identificação das potencialidades econômicas e áreas carentes de qualificação de mão de obra no Estado do Piaú, realizado em 2007.

${ }^{53}$ Um IDH-M baixo- entre 0 e 0,499; Médio- 0,500 a 0,799; e Alto- igual ou maior que 0,800.

${ }^{54}$ Dados disponíveis no site <http://www.atlasbrasil.org.br/2013/pt/perfil_uf/piauil\#caracterizacao>, acesso em set. 2015.
} 
Figura 12: IDH-M- Estado do Piauí (2000)

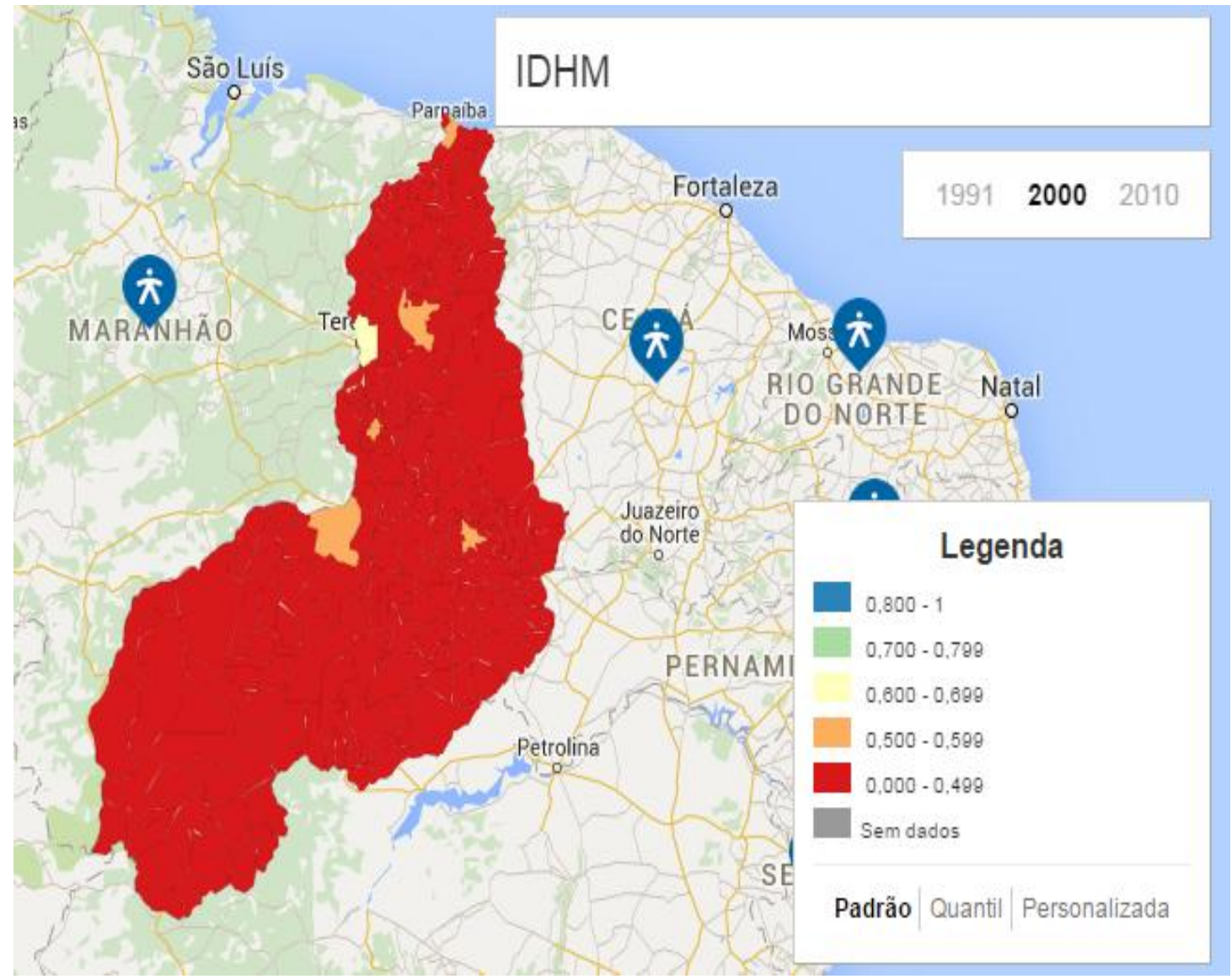

Fonte: Atlas Brasil (2015)

No ano 2000, a esmagadora maioria dos municípios piauienses apresentava um IDH baixo, com exceção de alguns municípios como Teresina e Floriano, o que demonstra o quanto as cidades piauienses apresentam um péssimo quadro no que diz respeito à expectativa de vida e aos índices educacionais e de renda per capita.

Como já destacamos anteriormente, no primeiro capítulo, o passado de ocupação do Piauí, caracterizado pelo favorecimento dos grandes proprietários de terra em detrimento dos pequenos pecuaristas e agricultores locais, acarretou sérias consequências para o Estado. Hoje, o Piauí é um dos Estados brasileiros com maiores índices referentes à pobreza, o que de certa forma justifica a ideia que se forma sobre o Estado enquanto local de pobreza e atraso econômico.

Tal tendência, segundo Braz (2011), deve-se à inserção desvantajosa no projeto nacional de desenvolvimento, visto que o Estado não procurou combater as disparidades regionais, mas, pelo contrário, estabeleceu políticas que favoreciam as elites locais. Ainda segundo o autor, a economia piauiense, fundamentou-se, desde o início, em atividades econômicas secundárias, como a pecuária e o extrativismo, pois, na época, o 
foco era cultivo de cana de açúcar. Aos poucos, porém, como já mencionado, o Piauí tem melhorado os índices referentes ao IDH-M, o que se pode também verificar na figura abaixo:

Figura 13: Índice de Desenvolvimento Humano o Piauí- 2010 (IDHM 2010)

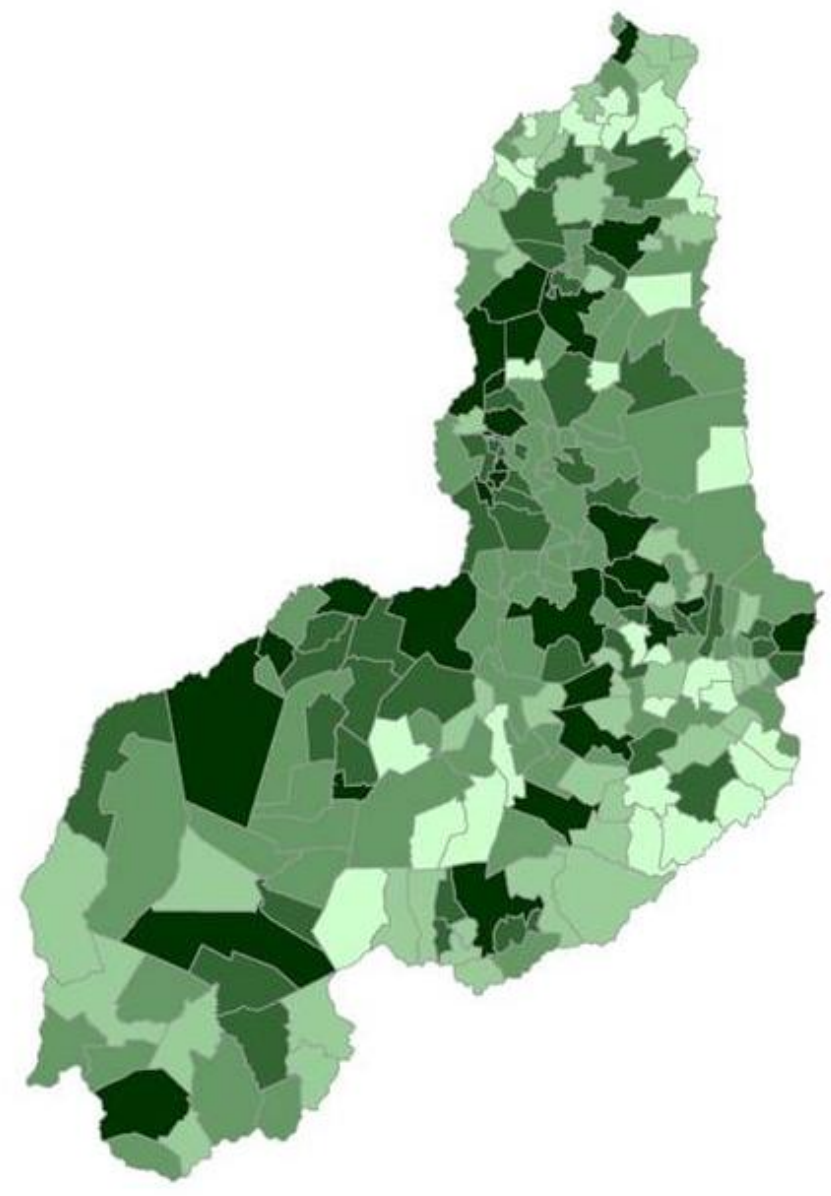

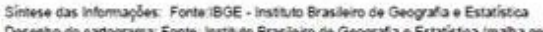

Fonte: IBGE Cidades

Percebe-se claramente a melhora do IDHM no Estado do Piauí, sobretudo nos últimos 10 anos. A maior parte dos municípios piauienses possui IDHM médio entre 0, 556 a 0,582, de maneira que existe um grande contraste entre a situação dos municípios referentes ao desenvolvimento em 10 anos. 
Todos os dados analisados até aqui possibilitaram uma visão geral da área de estudo e também uma percepção dos aspectos demográficos do Estado do Piauí. Na próxima parte deste estudo analisaremos os dados da região dos Cerrados piauienses.

\subsubsection{Dados Populacionais da área de estudo}

A Microrregião Alto Médio Gurguéia abrange onze municípios, dos quais os mais populosos são Bom Jesus (23.642 habitantes), Cristino Castro (9.981 habitantes), Gilbués (10.393 habitantes) e Monte Alegre do Piauí (10.349 habitantes) (IBGE, 2010). O município de Bom Jesus, como já dissemos, destaca-se por ser, atualmente, o segundo maior produtor de grãos do Estado, e por abrigar muito migrantes sulistas.

A Microrregião do Alto Parnaíba Piauiense possui quatro municípios: Baixa Grande do Ribeiro, Ribeiro Gonçalves, Santa Filomena e Uruçuí. Este último é o mais populoso e o que mais se destaca, na medida em que é, atualmente, maior produtor de grãos originados do agronegócio do Estado do Piauí. Sua população, em 2010, era de aproximadamente 20.152 habitantes (IBGE, 2010). A população de Baixa Grande do Ribeiro, por sua vez, é de 10.516 habitantes (IBGE, 2010), e o município também apresenta uma das maiores produções de grãos do Estado do Piauí, embora, no geral, Uruçuí exerça maior influência em função da expansão da fronteira agrícola.

É importante ressaltar, também, que grande parte dos municípios selecionados apresenta população rural bastante expressiva em relação aos padrões nacionais. Isso pode ser observado a partir dos dados referentes à população urbana e rural nas microrregiões selecionadas.

Tabela 15: População Residente por situação de Domicílio (2010)- Área de estudo

\begin{tabular}{|c|c|c|}
\hline \multirow{2}{*}{ Microrregiões } & Urbana & Ropulação Residente \\
\cline { 2 - 3 } & $49.932(56,7 \%)$ & $38.144(43,3 \%)$ \\
\hline Alto Médio Gurguéia & $29.985(68,8 \%)$ & $13.621(31,2 \%)$ \\
\hline Alto Parnaíba Piauiense & $15.693(61,8 \%)$ & $9.714(38,2 \%)$ \\
\hline $\begin{array}{c}\text { Chapadas Extremo Sul Piauiense } \\
\text { (Corrente) }\end{array}$ & $95.610(60,9 \%)$ & $61.479(39,1 \%)$ \\
\hline Subtotal & Total População da área de estudo= 157.089 habitantes \\
\hline
\end{tabular}

Fonte: Censo IBGE 2010, adaptada pelo autor. 
A população total da área de estudo é 157.089 habitantes, sendo que a população urbana supera por $21,8 \%$ a população rural, o que permite afirmar que a quantidade de residentes na zona rural na área de estudo é de fato representativo. Esse panorama pode ser observado na figura baixo:

Figura 14: População Urbana -Piauí

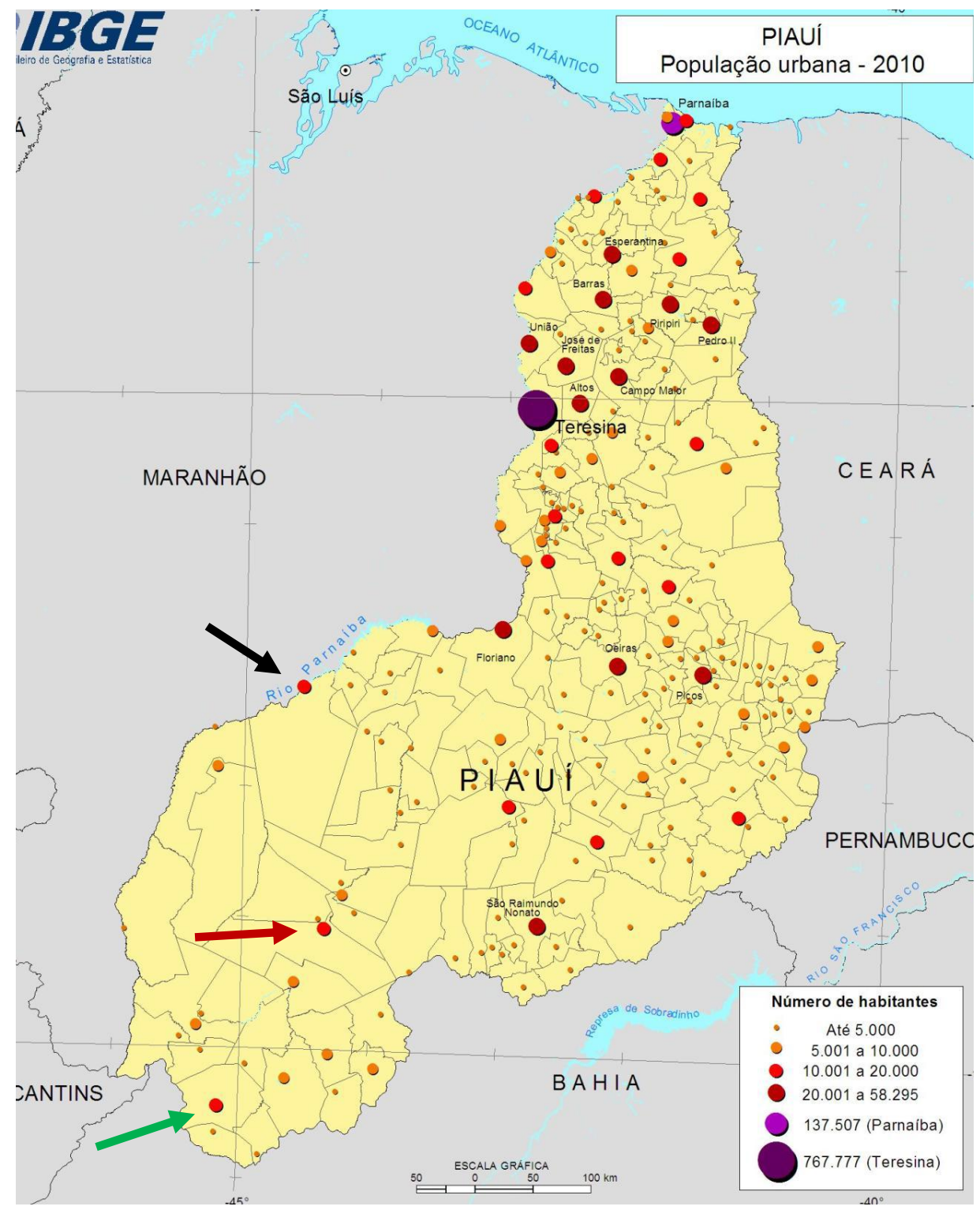

Fonte: Censo Demográfico 2010 - Retratos do Brasil e do Piauí. (*) Uruçuí- seta preta; Bom Jesus- seta vermelha, Corrente- seta verde.

Verifica-se um grande contraste em relação à urbanização no Piauí, pois a porção centro-norte do Estado mostra-se uma rede de municípios mais urbanizada, ao contrário da porção sul. É justamente Uruçuí (seta preta), Bom Jesus (seta vermelha) e 
Corrente (seta verde) que mais se destacam em relação à urbanização na porção sul do Piauí. Com efeito, se desconsideramos os três principais municípios mais populosos e também com maiores taxas de urbanização da área de estudo, a população residente na zona rural torna-se ainda mais representativa. Analisemos os dados referentes à população urbana e rural dos municípios da área de estudo na tabela abaixo:

Tabela 16: População Urbana e Rural dos municípios da Microrregião Alto Médio Gurguéia e em Corrente (Chapadas do Extremo Sul Piauiense) (2010).

\begin{tabular}{|c|c|c|c|c|}
\hline Microrregiões & Municípios & $\begin{array}{c}\text { População } \\
\text { Total }\end{array}$ & $\begin{array}{c}\text { População } \\
\text { Rural }\end{array}$ & $\begin{array}{c}\text { População } \\
\text { Urbana }\end{array}$ \\
\hline \multirow{10}{*}{$\begin{array}{l}\text { Alto Médio } \\
\text { Gurguéia }\end{array}$} & Alvorada do Gurguéia & 5.505 & $3.201(58,2 \%)$ & $1.849(41,8 \%)$ \\
\hline & Barreiras do Piauí & 3.234 & $1.359(42 \%)$ & $1.875(58 \%)$ \\
\hline & Bom Jesus & 22.629 & $5.006(22,1 \%)$ & $17.623(77,9 \%)$ \\
\hline & Cristino Castro & 9.981 & $2.719(27,2 \%)$ & $7.262(72,8 \%)$ \\
\hline & Currais & 4.704 & $3.780(80,4 \%)$ & $924(19,6 \%)$ \\
\hline & Gilbués & 10.402 & $4.411(42,4 \%)$ & $5.991(57,6 \%)$ \\
\hline & Monte Alegre & 10.345 & $7.364(71,2 \%)$ & $2.981(28,8 \%)$ \\
\hline & Palmeira do Piauí & 4.993 & $3.229(64,7 \%)$ & $1.764(35,3 \%)$ \\
\hline & Redenção do Gurguéia & 8.400 & $3.065(36,5 \%)$ & $5.335(63,5 \%)$ \\
\hline & $\begin{array}{c}\text { São Gonçalo do } \\
\text { Gurguéia }\end{array}$ & 2.825 & $1.606(56,8 \%)$ & $1.219(43,2 \%)$ \\
\hline \multirow{5}{*}{$\begin{array}{l}\text { Alto Parnaíba } \\
\text { Piauiense }\end{array}$} & $\begin{array}{c}\text { Baixa Grande do } \\
\text { Ribeiro }\end{array}$ & 10.516 & $4.029(38,3 \%)$ & $6.487(61,7 \%)$ \\
\hline & Ribeiro Gonçalves & 6.845 & $2.396(34,8 \%)$ & $4.449(65,2 \%)$ \\
\hline & Santa Filomena & 6.096 & $2.552(41,9 \%)$ & $3.544(58,1 \%)$ \\
\hline & Uruçuí & 20.149 & $4.644(23 \%)$ & $15.505(77 \%)$ \\
\hline & $\begin{array}{c}\text { Baixa Grande do } \\
\text { Ribeiro }\end{array}$ & 10.516 & $4.029(38,3 \%)$ & $6.487(61,7 \%)$ \\
\hline $\begin{array}{c}\text { Chapadas do } \\
\text { Extremo Sul } \\
\text { Piauiense }\end{array}$ & Corrente & 25.407 & $9.714(38,2 \%)$ & $15.693(61,8 \%)$ \\
\hline
\end{tabular}

Fonte: Dados do Atlas Brasil, elaborada pelo autor.

Bom Jesus e Corrente estão entre os municípios cuja maior parcela da população reside em áreas urbanas. Os municípios de Cristino Castro, Redenção e Corrente também apresentam alta urbanização, maior, inclusive, do que a do município de Corrente. No entanto, é importante observarmos que, na Microrregião Alto Médio 
Gurguéia, existem situações bastante paradoxais em relação às taxas de urbanização e população rural, como o caso dos municípios de Currais, Monte Alegre, Palmeira do Piauí, Alvorada do Gurguéia e São Gonçalo do Gurguéia, nos quais a população rural supera em termos percentuais a população urbana. Currais apresenta incríveis 80,35\% da população vivendo em áreas rurais, e Monte Alegre do Piauí, 71,2\%. O restante dos municípios apresenta porcentagens mais equilibradas. Dos integrantes da Microrregião Alto Parnaíba Piauiense, o município de Uruçuí apresenta população urbana de $77 \%$. Embora a taxa de urbanização dos outros municípios dessa microrregião seja representativa para o contexto da malha municipal selecionada, a população rural ainda é bastante significativa, sobretudo se considerarmos a grande ligação desses municípios com a zona rural.

Se consideramos os municípios com as maiores taxas de urbanização em cada microrregião selecionada, perceberemos que são Bom Jesus, na Alto Médio Gurguéia, Uruçuí, na Alto Parnaíba Piauiense e Corrente, que é único município da Microrregião Chapadas do Extremo Sul Piauiense selecionado para pesquisa. Estes são justamente os três municípios mais populosos e com as maiores centralidades urbanas da área de estudo, de acordo com o REGIC 2007. Além disso, Corrente e Bom Jesus são considerados pelo IBGE como Centros de Zona A, e, Uruçuí, como Centro de Zona B. Passamos agora à proposta de desconsiderar esses três municípios na análise entre as taxas das populações rurais e urbanas da área de estudo. Observemos a tabela:

Tabela 17: População Residente por situação de Domicílio (2010)- Área de estudo, com exceção dos três municípios mais populosos e com maior urbanização

\begin{tabular}{|c|c|c|}
\hline \multirow{2}{*}{ Microrregiões } & \multicolumn{2}{|c|}{ População Residente } \\
\cline { 2 - 3 } & Urbana & Rural \\
\hline \multirow{2}{*}{ Alto Médio Gurguéia } & $32.309(49,4 \%)$ & $33.138(50,6 \%)$ \\
\hline Alto Parnaíba Piauiense & $14.480(61,7 \%)$ & $8.977(38,3 \%)$ \\
\hline Subtotal & $46.789(52,6 \%)$ & $42.115(47,4 \%)$ \\
\hline \multicolumn{2}{|c|}{ População da área de estudo, desconsiderado Bom Jesus, Corrente e Uruçuí= 88.904 habitantes } \\
\hline
\end{tabular}

Fonte: Censo IBGE 2010, adaptada pelo autor. 
A comparação entre os dados das tabelas 15 e 16 e os da tabela acima evidencia que Bom Jesus, Corrente e Uruçuí possuem grande peso populacional na área de estudo, já que a população dos três municípios soma 68.185 habitantes $^{55}$, equivalente a $43,4 \%$ da população total do recorte selecionado. Considerando a análise de todos os municípios, a população urbana soma 60,9\%, e a rural, 39,1\%. Desconsiderando os três municípios mais populosos e urbanizados de cada microrregião, porém, a população urbana cai para $52,6 \%$, e a rural aumenta para $47,4 \%$ - do que se apreende que não somente Bom Jesus, Corrente e Uruçuí possuem peso populacional, mas também em relação ao quantitativo da população urbana.

Sendo assim, podemos afirmar que, fora os três municípios mais populosos, há certo equilíbrio entre a população urbana e rural nos municípios da área de estudos. Com efeito, a grande maioria destes municípios possui grande ligação com as áreas rurais, inclusive aqueles mais importantes do ponto de vista da centralidade, o que verificaremos mais à frente, quando analisarmos a economia urbana dos principais centros urbanos.

Neste recorte territorial, portanto, Bom Jesus, Corrente e Uruçuí se destacam, cada um em relação a sua própria área de influência, em decorrência de seu contingente populacional, do IDH-M e PIB maiores, e de suas taxas de urbanização elevadas. Esses municípios ligados à agropecuária do Sudoeste Piauiense acabam articulando a rede urbana mesorregional à nova região do MAPITOBA e às cidades do agronegócio de cada Estado integrante, estabelecendo, assim, uma rede urbana regional ligada à modernização das atividades agricultoras e, também, no caso de Corrente, à pecuária moderna. Configura-se, assim, uma rede de "cidades agrícolas", que Miranda (2012) define como

[...] aquelas que surgem dotadas de um fator urbano próprio e sob o efeito do alcance do processo de expansão da fronteira agropecuária e das migrações entre regiões, transferindo contingentes social e culturalmente diferenciados de populações para subespaços regionais que se caracterizam como verdadeiras plataformas exportadoras de grãos ou carne bovina ou como retaguardas territoriais para a realização da produção agropecuária. São cidades agrícolas no sentido de abrigarem no interior do município ou da hinterlândia modalidades de produção agropecuária, e o fator urbano se manifesta de modo uniforme, como um "implante urbano" para favorecer a logística de escoamento dessa produção. O espaço rural do município, todavia, perde características naturais e singularidades. (MIRANDA, p. 192, 2012)

${ }^{55}$ A população total da área de estudo com todos os municípios considerados é de 157.089 habitantes. Sem as populações de Bom Jesus, Uruçuí e Corrente a população total cai para 88.904. 
No contexto de transformações socioespaciais do espaço urbano, verifica-se maior circulação de pessoas e de fluxos financeiros, e, ainda, expansão dos mercados e de comércios ligados à produção da agricultura moderna, principalmente nos municípios onde a produção de grãos é maior, o que releva a lógica seletiva e, por conseguinte excludente do processo de modernização agrícola. Nas palavras de Souza e Barbosa (2011),

Tal modernização, no Nordeste brasileiro, constitui-se de maneira descontínua e especializada; no Estado do Piauí, de todos os 29 (vinte e nove) municípios que integram o cerrado, somente 4 (quatro) estão totalmente dentro do circuito da produção agrícola moderna, são eles: Uruçuí, Ribeiro Gonçalves, Baixa Grande do Ribeiro e Bom Jesus. (SOUSA; BARBOSA, 2011, p.11).

Souza \& Barbosa (2011) consideram os municípios de Ribeiro Gonçalves e Baixa Grande do Ribeiro como destaques do agronegócio por conta da sua alta produção e da transformação de suas paisagens urbanas e rurais. Ressaltamos, ainda, que nos municípios pertencentes ao circuito da agricultura moderna há grande ocupação das áreas dos Cerrados, localizados nas áreas de platôs, o que evidencia o caráter de concentração da estrutura fundiária presente no processo de modernização da agricultura, tendência decorrente do início da ocupação do Estado, em que os primeiros proprietários incorporavam grandes extensões de terras às suas fazendas de gado (AGUIAR e MONTEIRO, 2005).

Pretendemos agora analisar as transformações urbanas ocasionadas pela inserção desse recorte territorial à expansão da fronteira agrícola, com base nos eixos temáticos já apresentados no capítulo anterior, mas é preciso, primeiramente, analisar o contexto da modernização agrícola no Estado do Piauí, procurando evidenciar as fases desse processo no Sudoeste Piauiense.

\subsection{O processo de modernização agrícola no Sudoeste Piauiense: inserção, fases e atuais contextos}

A modernização da agricultura no Sudoeste Piauiense está intimamente relacionada aos processos migratórios de sulistas, provenientes, principalmente, dos Estados do Centro-Sul brasileiro, tal como Rio Grande do Sul, Paraná, Santa Catarina, São Paulo e Mato Grosso, que tiveram início na década de 1970 e atingiram seu ápice 
na década de 1990 (MONTEIRO, 2002), e deve ser entendida como um processo arquitetado pelo Estado e claramente interessado em beneficiar grandes agentes como as grandiosas corporações nacionais e transnacionais ligadas ao agronegócio e a diferentes grupos políticos. Este processo se deu através do estabelecimento de um quadro econômico favorável, com políticas públicas e incentivos fiscais voltados para esses agentes, bem como com a instalação de infraestrutura necessária a este setor econômico (HAESBAERT, 1998).

Nota-se que o processo de ocupação e modernização agrícola dos Cerrados piauienses se assemelha, assim, ao de outras áreas em que este processo já está consolidado, como o oeste baiano, o sul do Maranhão, o norte do Estado do Tocantins, o norte de Minas Gerais e a região Centro-Oeste do Brasil. Esses territórios foram inseridos em políticas de desenvolvimento agrícola com forte apoio e incentivo do Estado, com a instalação de indústrias, o desmatamento e as modificações na rede urbana. Nesse caso, pode-se afirmar que esses recortes territoriais brasileiros têm participado de inúmeras transformações na dinâmica socioespacial, principalmente em relação às alterações das áreas urbanas, com o surgimento de municípios extremamente ligados ao agronegócio e com centralização dos serviços, e às alterações das áreas rurais, como a intensificação do desmatamento e do uso do solo voltado para as atividades agropecuárias modernas.

Nesse sentido, o Piauí se insere em um processo de modernização agrícola iniciado nas áreas do Cerrado brasileiro, incentivado e implantado pelo governo brasileiro na década de 1970, e caracterizado pela ocupação dos Cerrados objetivando a modernização de áreas de economia agropecuária estagnadas no território brasileiro (MATOS; PESSÔA, 2011). Assim, de acordo com Santos (2004), cada fração do território, por mais reduzida que seja sua escala de abrangência, participa de processos hegemônicos e globalizantes, imprimindo relações diretas e indiretas com outros lugares. $\mathrm{O}$ autor ainda considera que essas relações e elementos do espaço (firmas, instituições, homens e infraestruturas) são ligados por uma organização controlada por atores hegemônicos e suas normas ideais. Com efeito, nas palavras de Moura (2009, p.32), “os pequenos municípios sofrem mais fortemente esses efeitos, pela dificuldade de contrabalancear com outras atividades o poder hegemônico dos grandes estabelecimentos, e mesmo de exercer sobre eles o controle que faz parte de suas 
competências". É possível afirmar, portanto, que os pequenos municípios se vêem subjugados pelas grandes empresas hegemônicas.

Atualmente, a Mesorregião Sudoeste Piauiense tem passado exatamente por essas transformações em decorrência da expansão da modernização agrícola nas áreas de Cerrados sobre os platôs piauienses, com a instalação de empresas e indústrias agrícolas ligadas ao setor agropecuário. No entender de Milton Santos (2008, p.40) "O espaço é tornado único à medida que os lugares se globalizam. Cada Lugar, não importa onde se encontre, revela o mundo (no que ele é, mas também no que ele não é), já que todos os lugares são suscetíveis de intercomunicação". Com efeito, os processos globalizantes, dos quais também participa a Mesorregião Sudoeste Piauiense, são complexos e envolvem competição, manutenção de um sistema que privilegia apenas algumas parcelas da sociedade e imposição de padronizações.

Os avanços na ciência e o advento da modernização agrícola fizeram com que grandes áreas antes condenadas à estagnação entrassem na rota do agronegócio e fossem incorporadas às novas dinâmicas econômicas e produtivas ligadas às commodities de grãos. O Sudoeste Piauiense, especificamente, insere-se na dinâmica das áreas dos Cerrados presentes no "Brasil Central", em que o campo passa a viver uma nova realidade. Na passagem de SANTOS (2008) reproduzida a seguir, é possível notar a pertinência da fala do autor em relação ao contexto atual das áreas dos Cerrados piauienses, que acaba por contrastar com o passado de ocupação territorial do Estado:

Ciência, tecnologia e informação fazem parte dos afazeres cotidianos do
campo modernizado, através das sementes especializadas, da correção e
fertilização do solo, da proteção das plantas pelos inseticidas, da
superimposição de um calendário agrícola inteiramente novo, fundado na
informação, o que leva para as cidades médias do interior um coeficiente de
modernidade. Não raro, maior do que o da metrópole. (SANTOS, 2008,
p.41).

O autor alude à desconcentração da estrutura produtiva do país, acompanhada das inovações tecnológicas, que agora são largamente utilizadas na produção em áreas antigamente isoladas e distantes dos grandes centros urbanos. No Estado do Piauí, a ocupação das primeiras áreas por parte de agricultores sulistas inicia-se na Mesorregião Sudoeste Piauiense, nas áreas conhecidas como Gerais, especialmente nas chamadas Serras do Uruçuí e do Quilombo. Atualmente, existe um intenso processo de expansão das áreas agrícolas, com ênfase nas culturas de soja, milho, arroz e algodão. Essas 
transformações resultam em nova configuração das áreas rurais e urbanas, que, por sua vez, origina novas realidades espaciais, econômicas e demográficas.

Dado o caráter recente dessas transformações no Estado do Piauí, portanto, fazse necessário maior aprofundamento na análise dos problemas e dos potenciais econômicos e naturais da área de expansão da fronteira agrícola. $\mathrm{O}$ estudo sobre a temática possibilita, ademais, o pensar crítico em relação às mudanças socioespaciais de recortes territoriais do "Brasil Central", como o crescimento das cidades e a alteração dos índices demográficos e de urbanização nos diferentes estados envolvidos com processos hegemônicos ligados ao grande capital agropecuário.

De fato, o processo de ocupação da área de modernização agrícola no Sudoeste Piauiense envolveu uma série de fatores, tanto naturais como políticos, econômicos e culturais. A topografia do relevo, a qualidade do solo e do clima tropical quente e úmido, a vegetação pouco densa e de fácil remoção, os recursos hídricos suficientes, os subsídios e incentivos fiscais governamentais e os créditos bancários facilitados são fatores que possibilitaram a instalação da moderna agricultura nos Cerrados piauienses. O relevo dessa área, de fato, apresenta características particulares, como as áreas rebaixadas que são conhecidas como baixões, e que localizam-se próximas aos rios e às principais cidades, que denotam herança do processo histórico de ocupação do território.

De acordo com Pragrana (2011), os Cerrados piauienses, devido às condições propícias, vêm sendo alvo da exploração agropecuária de forma intensiva e sem devido controle da preservação dos recursos naturais da região. O conjunto de serras do Sudoeste Piauiense (Chapadas Altas), dentre as quais a do Quilombo e do Uruçuí, possuem características de aplainamento do relevo, formando uma superfície tabular, constituindo grandes mesas tabulares, com altitude média de 400-600 metros, características que favorecem o desmatamento das áreas verdes pela máquinas agrícolas, o que, por conseguinte, intensifica os processos de degradação ambiental, como as erosões. Soma-se, a isso, o uso de intensivo de agrotóxicos e revolvimento da terra, e o resultado é a aceleração dos efeitos negativos do uso intensivo do solo nessas áreas, que já apresentam recortes territoriais, sobretudo em Gilbués e Monte Alegre do Piauí, em processo avançado de desertificação (PRAGRANA, 2011), o que confere 
caráter peculiar a essa região de fronteira agrícola, inserida no Núcleo de Desertificação de Gilbués, que envolve os onze municípios da Microrregião Alto Médio Gurguéia ${ }^{56}$. Na figura abaixo, observa-se a localização das áreas dos platôs piauienses:

${ }^{56}$ Destaca-se que o Sudoeste Piauiense, em especial os municípios da Microrregião Alto Médio Gurguéia, atualmente é considerado nova fronteira mineral no Brasil, por abrigar importantes jazidas de diamantes. Inclusive muitos municípios dessas áreas tiveram seu passado ligado às atividades de mineração, especialmente na procura pelo diamante, é o caso, por exemplo, de Gilbués e Monte Alegre do Piauí. 
Figura 15: Mapa Hipsométrico dos municípios da área de estudo
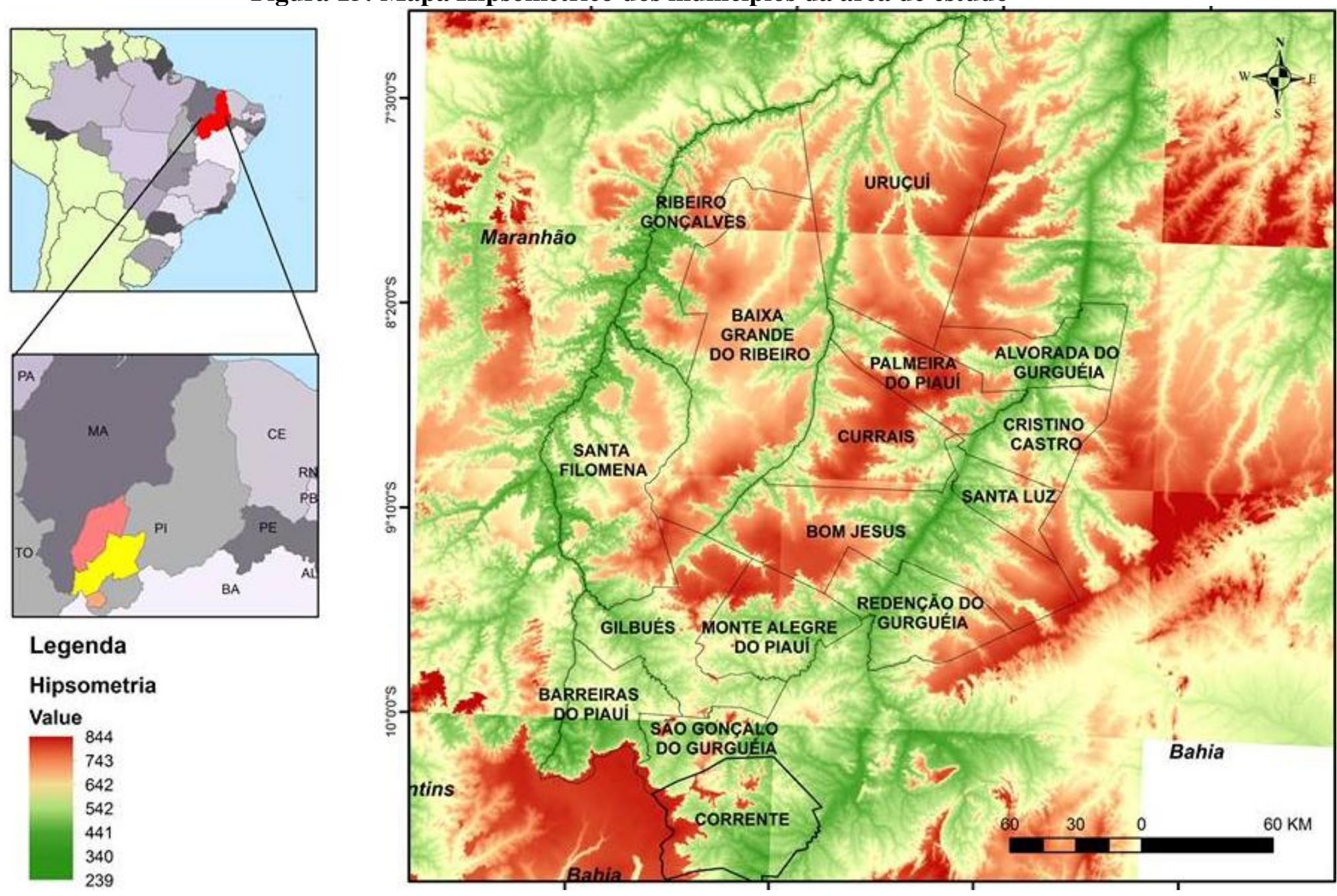

Fonte: Satélite USGS, elaborado por Lucas Garcia (Colaborador) e Tiago Rufo. 
Observa-se que as áreas em laranja, de maiores altitudes, são os platôs piauienses (Chapadões, com presença predominante dos Cerrados), também denominadas Serras ${ }^{57}$. As áreas em verde, de altitudes menores, são as chamadas áreas dos baixões, ou de fundo de vales, justamente onde estão localizadas a maior parte das cidades selecionadas para estudo, situadas, no geral, próximas a cursos d'água. Os Platôs são permeados por esses pequenos, médios e grandes rios que foram seus recortes. Na área de fronteira com o Maranhão, onde passa o Rio Parnaíba, notamos que os platôs adentram o Estado do Maranhão. Podemos notar, ainda, que municípios como Baixa Grande do Ribeiro, Uruçuí e Bom Jesus possuem extensa área de platôs, fator que se revela decisivo para a análise dos índices de produção agrícolas da área de estudo, uma vez que são precisamente estes três municípios que figuram entre os maiores produtores de grãos da área de pesquisa.

Ressaltamos, ainda, que os municípios integrantes da Microrregião Alto Parnaíba Piauiense, com exceção de Santa Filomena, possuem áreas expressivas em relação aos platôs, especialmente se compararmos com a maior parte dos municípios do Alto Médio Gurguéia, fator decisivo no que diz respeito à produção agrícola, pois quanto maior a área disponível e adequada para o desenvolvimento dos projetos, maior é a probabilidade de expansão do uso intensivo das áreas agricultáveis nesses município.

Na figura abaixo, observa-se a vista parcial das áreas dos baixões e a presença dos platôs piauienses:

\footnotetext{
${ }^{57}$ Nas saídas de campo pode-se perceber que muitos moradores locais de alguns municípios, sobretudo Bom Jesus e Monte Alegre, denominam essas áreas como simplesmente "cerrados".
} 
Figura 16: Vista parcial dos baixões e dos platôs

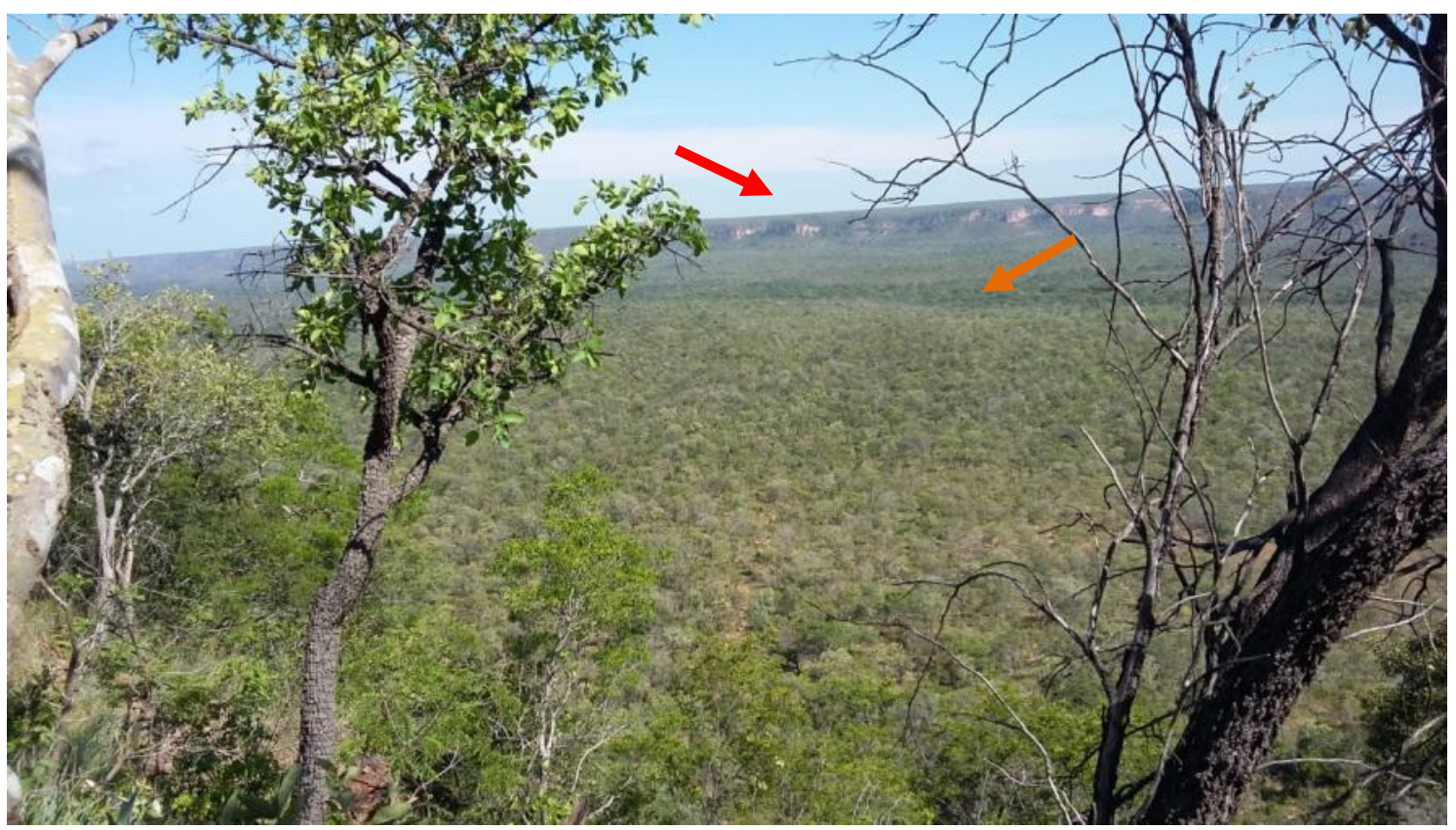

Fonte: o autor, (2015).

Para auxiliar a observação dos dois tipos de relevo, inserimos simbologia na foto, sendo que a seta em vermelho indica as áreas do platôs, com altitude maior, e a em laranja indica as áreas dos fundos de vale ou dos baixões. A imagem acima foi fotografada próximo ao ponto de fronteira entre os municípios de Monte Alegre, Gilbués e Bom Jesus, de maneira que nos encontrávamos sobre as áreas dos platôs. Já a imagem abaixo foi fotografada nos baixões:

Figura 17: Vista dos platôs da Serra do Quilombo- município de Cristino Castro

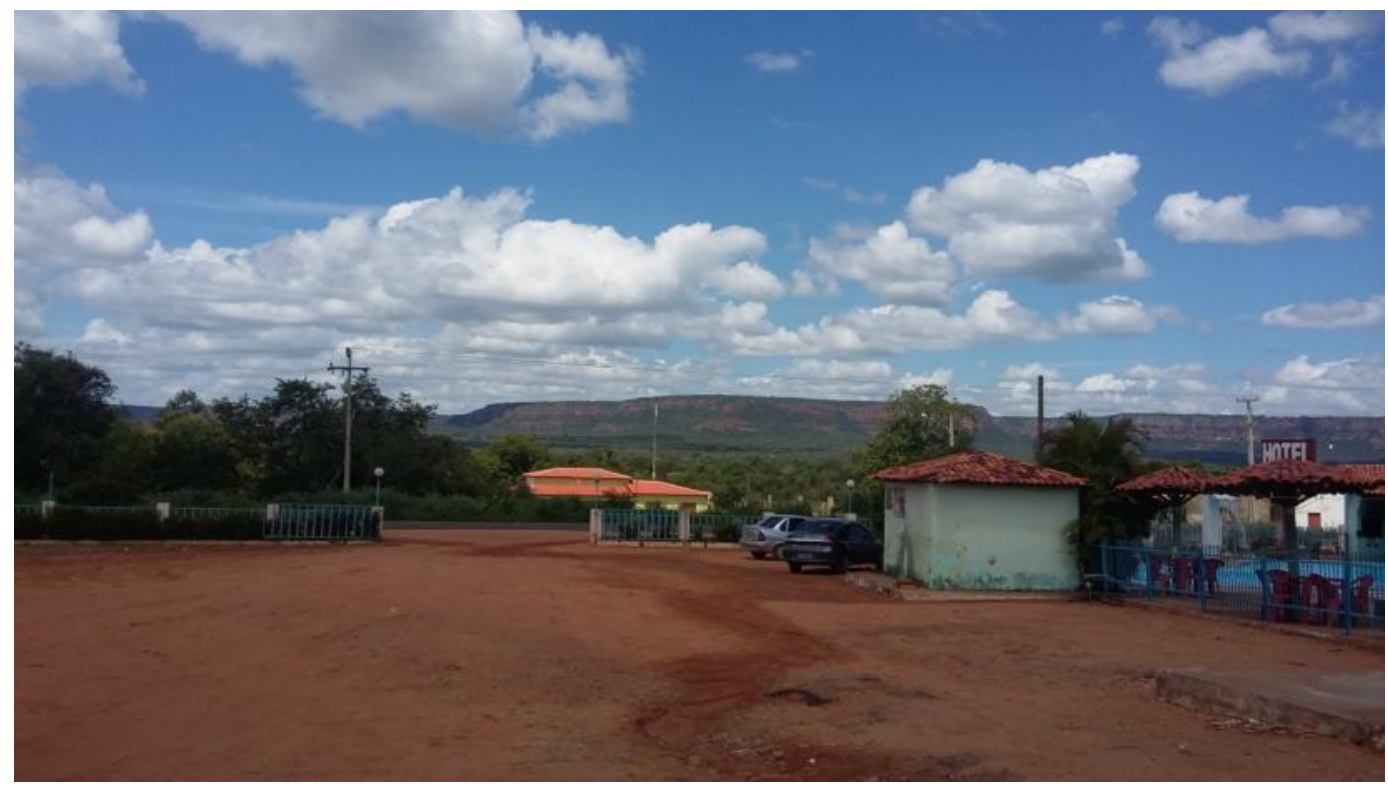

Fonte: o autor, (2015). 
$\mathrm{Na}$ imagem, nota-se, ao fundo, as áreas dos platôs piauienses, mais especificamente no município de Cristino Castro, que dista cerca de $30 \mathrm{~km}$ de Bom Jesus. A imagem foi fotografada exatamente em uma área dos baixões, onde localiza-se o estacionamento de um bar local com piscinas próximo à entrada dessa cidade. Reafirmamos, ainda uma vez, que as áreas dos platôs piauienses não eram valorizadas até a chegada dos grandes agricultores na década de 1970, e com maior intensidade na década de 1990. As atividades agropecuárias desenvolvidas nessa região, sobretudo a criação de bovinos e o cultivo de pequenas culturas agrícolas, valorizavam as áreas dos Baixões. Essa questão evidencia algo que é recorrente nos diversos recortes territoriais com presença dos Cerrados, pois, segundo AB' Saber (2003),

\begin{abstract}
Até 1950 as faixas de preferência para o uso agrícola no Planalto Central eram as calhas aluviais onde existissem densas matas de galeria. [...] A partir de 1960 e, sobretudo, ao longo da década de 1960, extensas áreas dos interflúvios passaram a ser utilizadas para a sivicultura, rizicultura, o plantio de abacaxi e logo depois de lavouras nobres (soja, café e trigo). A agricultura comercial, sobretudo a do arroz, atingiu o espaço dos cerrados, descolando fronteiras e viabilizando a economia rural de grandes glebas, até então mal aproveitados e improdutivas. (AB'SABER, 2003, p.131).
\end{abstract}

A constatação do autor é corroborada pela realidade piauiense, em que as áreas dos platôs não eram valorizadas por serem elevadas, mas passaram a ser incorporadas no circuito da produção moderna de grãos a partir da expansão do agronegócio.

A expansão da fronteira agrícola no Brasil, como já dissemos, teve a participação do Estado em parceria com empresários nacionais e capital estrangeiro, especialmente o japonês (AGUIAR; MONTEIRO, 2005). Podemos citar as seguintes políticas públicas, promovidas pelo Governo Federal (Decreto-Lei no 1.376, de 12.12.74) com o objetivo de ocupação do Cerrado, que contemplam o Estado do Piauí: o FINOR e o FISET. Nas palavras de Aguiar \& Monteiro (2005, p. 4), “[...] o primeiro foi um investimento de cunho regional; o segundo, um investimento setorial. Todavia, ambos objetivavam desenvolver as regiões e os setores considerados frágeis economicamente".

Nesse caso, é necessário questionar o discurso ideológico do Estado e de agentes hegemônicos em relação à modernização agrícola enquanto processo econômico, social, político e cultural, que afirma a suposta necessidade de levar o progresso para áreas teoricamente condenadas à estagnação e pobreza, como é o caso da Mesorregião Sudoeste Piauiense, na qual o Estado tem investido de maneira seletiva. 
A figura a seguir contempla as fases da expansão da fronteira agrícola nos Cerrados piauienses, destacando também as mudanças no padrão de uso do solo e algumas transformações socioespaciais no contexto do Sudoeste Piauiense. Percebe-se claramente o papel ativo do Estado e de corporações privadas na promoção de infraestrutura necessária e equipamentos urbanos acessórios e complementares.

Figura 18: Fases da Expansão da Fronteira Agrícola nos Cerrados Piauienses
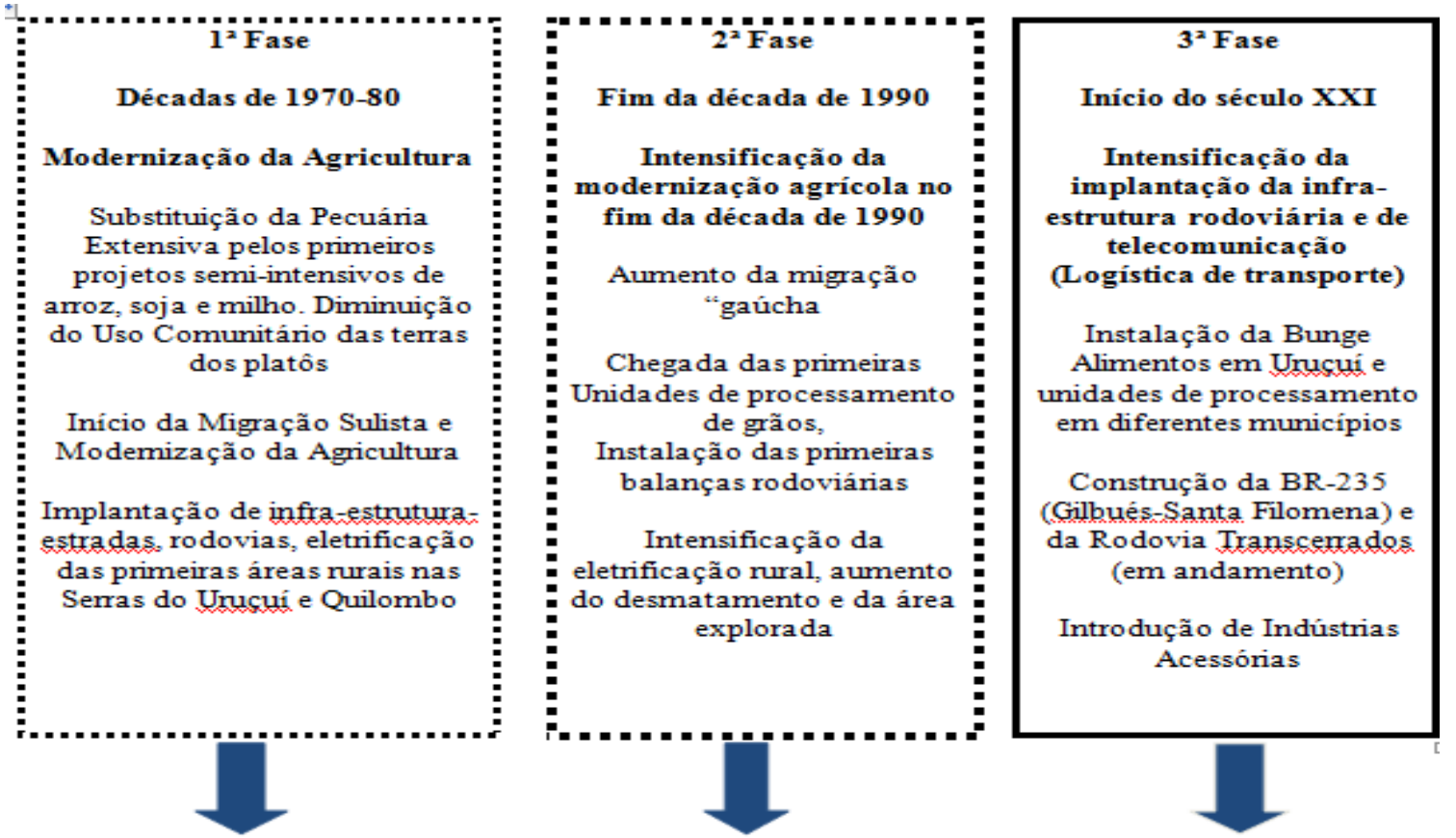

POLÍTICAS E FINANCIAMENTOS PÚBLICOS

Autor: Elaborado pelo autor, baseado em Pizarro (2015).

A partir de Pizarro (2015), construímos este esquema que resume as fases da modernização agrícola no Estado do Piauí ${ }^{58}$. A primeira fase compreende o período entre as décadas de 1970-80, o qual foi denominado Modernização da Agricultura, e que caracteriza-se pela substituição da pecuária extensiva, do extrativismo e do uso comunitário pelos primeiros projetos semi-intensivos de arroz, soja e milho - é, portanto, um período de instalação dos primeiros projetos de agricultura moderna influenciada pelo aumento da migração sulista, quando o incentivo do Estado mostra-se fundamental por conta da implantação de infraestrutura viária e da implantação de eletrificação rural em algumas áreas das serras do Uruçuí e do Quilombo. Com efeito, segundo Elias (2008), o processo de ocupação de algumas áreas do Nordeste foi

${ }^{58}$ Essa periodização proposta foi baseada nos trabalhos de Alves (2012), Monteiro (2002) e Haesbaert (1998) e até mesmo nas saídas de campo realizadas em dezembro de 2014 e Julho de 2015 na área de estudo. 
iniciado entre as décadas de 1960 e 1970, embora a estrutura agropecuária destes espaços tenha permanecido quase que inalterada até 1980. No caso dos Cerrados piauienses, porém, a modernização da agricultura intensificou-se apenas na década de 1990 (MONTEIRO, 2002) (justamente o que consideramos como a terceira fase da modernização agrícola do Sudoeste Piauiense).

A segunda fase, que compreende a segunda metade da década de 1990, denominou-se Intensificação da Modernização Agrícola, período marcado pela intensificação da ocupação dessas áreas e também pelo aumento da migração sulista, como sustenta Monteiro (2002). É também neste período a chegada das primeiras unidades de processamento de grãos, a instalação das primeiras balanças rodoviárias e a intensificação do uso do solo por parte das atividades modernas ligadas à agricultura.

Por fim, o terceiro período, denominado de Intensificação da Implantação da Infraestrutura Rodoviária e de Telecomunicações (Logística de Transportes), compreende o período que se inicia no século XXI, ou seja, o período atual, em que percebemos que a agricultura moderna no Sudoeste Piauiense vem se consolidando como uma das mais importantes fronteiras agrícolas do Nordeste e uma das mais recentes do país, sendo conhecida como a última fronteira agrícola. É neste período, com efeito, que se observa o aumento da instalação de empresas agrícolas no Sudoeste Piauiense, como a Bunge Alimentos no município de Uruçuí - PI (ALVES, 2012b), e o crescimento do número de comércios e serviços voltados para a agricultura mecanizada, além do estabelecimento de infraestruturas e surgimento de indústrias acessórias e complementares ao agronegócio, sobre as quais falaremos mais à frente na abordagem do eixo estruturante denominado Infraestrutura e Equipamentos Urbanos. Este período, porém, revela-se desvantajoso, pois, de acordo com Braz (2007), com o advento do neoliberalismo, no fim da década de 1990 e início do século XXI, a inserção da economia piauiense por meio do agronegócio pode ser considerada atrasada em decorrência da baixa infraestrutura que forneça suporte suficiente à produção agrícola moderna. Assim sendo, confirmamos nossa hipótese de que o agronegócio piauiense ainda é um processo em consolidação.

As transformações decorrentes da expansão e modernização agrícola pelas quais passa a Mesorregião Sudoeste Piauiense fazem com que vários municípios ganhem uma enorme diversidade devido aos processos migratórios dos chamados "gaúchos". Nas 
cidades de Uruçuí e Bom Jesus, por exemplo, há crescimento das áreas urbanas e aumento da população (BRASIL, 2005). Mota (2012) corrobora essa ideia ao dizer que

[...] as cidades em emergência recebem tal contingente populacional e tem um crescimento vertiginoso. Tanto no que se refere aos novos arranjos produtivos, como de meios de acumulação de capital e de reprodução de um modo de vida específico, ligado ao trabalho assalariado e ao consumo. (MOTA, 2012, p.279).

Atualmente, portanto, não apenas Floriano, a cidade mais populosa do Sudoeste Piauiense, exerce papel de centralidade urbana no contexto mesorregional, já que Bom Jesus, Uruçuí e Corrente também ganham centralidade. De fato, Sampaio (2011) defende que um espaço urbano exerce centralidade quando possui reais possibilidades de intermediação entre forma, função, estrutura e processo, promovendo as relações capitalistas de produção. Nesse sentido, a centralidade urbana exerce com maior intensidade articulações dentro de uma rede urbana - cuja dimensão e complexidade variam - na qual está inserida.

Para evidenciar as modificações e a reestruturação produtiva nos Cerrados piauienses, focando as transformações urbanas, analisaremos, na próxima seção, baseando-nos em Elias (2011, 2012), três eixos estruturantes: a) Uso e Ocupação do Espaço Agrário; b) Economia Urbana e c) Infraestruturas e Equipamentos Urbanos.

\subsection{Uso e Ocupação do Espaço Agrário ${ }^{59}$}

Como já destacado, os Cerrados piauienses eram áreas encaradas como estagnadas e de pouca potencialidade, sendo utilizadas, basicamente, pelos pequenos agricultores e pecuaristas locais. A partir dos anos 1990, porém, com a modernização da agricultura, os grandes agricultores e empresas agrícolas começaram a ocupar os Cerrados piauienses. Consideramos, entretanto, que este processo veio a se desenvolver com maior intensidade no século XXI, pois é somente então que os primeiros projetos, principalmente de soja e milho, chegam a outros municípios, como Redenção do Gurguéia e São Gonçalo do Gurgueía, e intensificam-se os projetos em Monte Alegre,

59 No prosseguimento do trabalho, veremos que foram inseridas muitas figuras referentes às transformações socioespaciais da área de estudo, especialmente nos espaços urbanos. Sposito (2006) defende que a seleção de imagens sobre a área de estudo articulada à produção de uma pesquisa é fundamental para a consolidação do trabalho, assim como a experiência e vivência do pesquisar da área de estudo. Dessa forma, muitas figuras e colocações durante a produção estão embasadas nos trabalhos de campo e na vivência da área de estudo. 
Gilbués, Santa Filomena, entre outros, inclusive com maior fluxo de máquinas agrícolas, expansão dos projetos de agricultura moderna, maior movimento de trabalhadores dos projetos, e aumento da quantidade de migrantes sulistas.

Assim, os Cerrados piauienses são inseridos na dinâmica da agricultura moderna no Brasil e hoje o Estado do Piauí se destaca, ao lado de Bahia e Maranhão, como um dos Estados nordestinos que figura entre maiores produtores e exportadores de grãos, principalmente de soja. Abaixo, podemos analisar a figura 19, referente à expansão da área plantada de soja entre anos de 2005 a 2009 nas áreas do Brasil Central:

Figura 19: Expansão da área plantada de soja 2005-2009

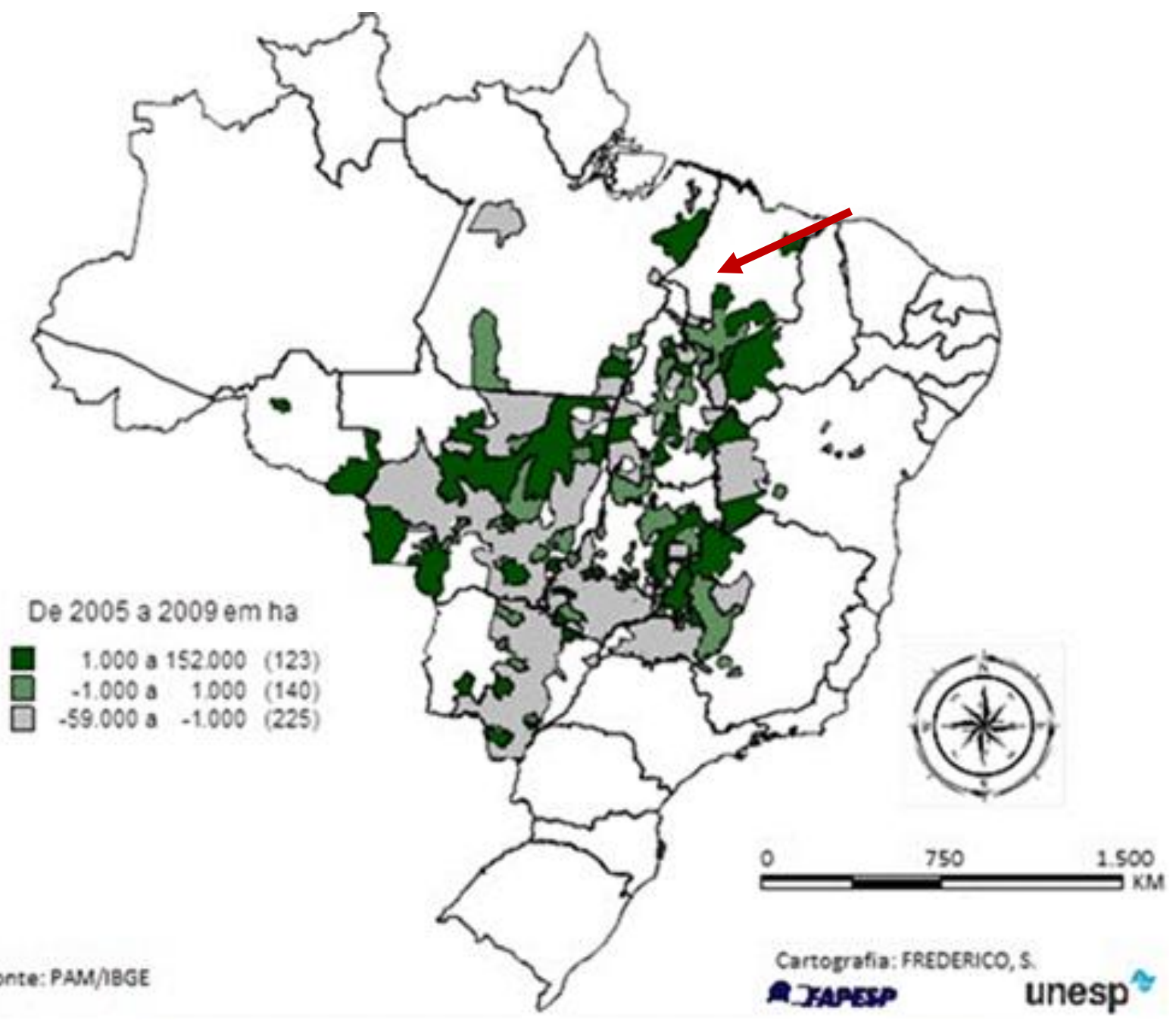

Fonte: FREDERICO (2013). (*) Seta vermelha- Cerrados piauienses.

As áreas em verde escuro correspondem às com maior expansão da área plantada entre os anos de 2005 e 2009. Nesse caso, verifica-se que as Microrregiões Alto Parnaíba Piauiense e Alto Médio Gurguéia e Alto Médio Gurgueía são as que mais 
sofreram expansão da área plantada em hectares. As áreas em cinza, por sua vez, representam recortes territoriais em que o agronegócio já está consolidado - parte do oeste baiano, do sul dos Estados de Goiás e Mato Grosso e na região conhecida como triângulo mineiro. Frederico (2013) e Elias (2006b) já apontavam que há clara tendência de diminuição das áreas plantadas e aumento da produtividade nos Estados do CentroOeste e aumento das áreas plantadas em Estados do Nordeste brasileiro, como é possível verificar a partir da figura, na qual nota-se que o sul do Maranhão, o Sudoeste Piauiense e parte do oeste da Bahia apresentaram aumento da área plantada.

A figura ainda corrobora que o século XXI é, de fato, o mais representativo para o agronegócio em parte do Sudoeste Piauiense. Alves (2006) aborda um dos importantes motivos para o aumento da produção agrícola em muitos municípios do Sudoeste Piauiense justamente nos primeiros anos do século XXI. Nas palavras do autor,

O salto na produção de soja nos municípios em questão ocorre principalmente a partir de 2002 e se justifica pelo fato de que naquele ano a Bunge Alimentos iniciava a instalação de uma fábrica de esmagamento dessa oleaginosa em Uruçuí, o que desencadeou uma expansão da produção sojicultora no sul do Piauí para atender à demanda da empresa. A chegada da Bunge nos cerrados piauienses consolidou as mudanças que já vinham se projetando no perfil agrícola daquela área, as quais apontavam para a substituição da cultura do arroz pela da soja. (ALVES, 2006, p.165).

A instalação da Bunge Alimentos em Uruçuí contribuiu ativamente para alavancar a produção agrícola nos Cerrados piauienses e, consequentemente, incorporar mais terras às atividades agrícolas modernas. Ressaltamos que essa empresa tem cada vez mais se consolidado como uma das maiores exportadoras do Estado do Piauí, ficando em segundo lugar na classificação geral de principais empresas exportadoras. Segundo dados da CEPRO (2015), a Bunge exportou, de janeiro a fevereiro de 2015, US\$ 4.810.789, valor que representa $18,86 \%$ das exportações piauienses.

Com a intensificação e expansão desses projetos houve, também, grande modificação no uso do solo, pois as possibilidades de migração para as cidades aumentam na medida em que o campo se moderniza, por conta do enfraquecimento da pequena agricultura, dos conflitos por terra e da expropriação de terras, ideias já apontadas no capítulo 2, e defendidas por autores como Martine (1989). Na tabela abaixo, observamos os números referentes aos Censos Agropecuários de 1970/2006, referentes à Utilização das terras e ao número de tratores: 
Tabela 18: Confronto dos resultados dos dados estruturais dos Censos

Agropecuários- Piauí-1970/2006

\begin{tabular}{|c|c|c|c|c|c|c|}
\hline \multirow{2}{*}{$\begin{array}{c}\text { Utilização das } \\
\text { terras } \\
\text { (ha) }\end{array}$} & \multirow{2}{|c|}{ Censos } & & \\
\cline { 2 - 7 } & 1970 & 1975 & 1980 & 1985 & 1995 & 2006 \\
\hline Lavouras & 636.092 & 682.538 & 993.010 & 1.074 .949 & 676.166 & 1.642 .417 \\
\hline Pastagens & 3.352 .483 & 3.699 .835 & 3.683 .392 & 3.550 .084 & 2.398 .446 & 2.783 .101 \\
\hline Tratores & 244 & 370 & 1.622 & 2.057 & 2.402 & 3.737 \\
\hline
\end{tabular}

Fonte: Censo Agropecuário 2006 (IBGE), adaptada pelo autor

Notamos que houve uma diminuição de cerca de $17 \%$ das áreas de pastagens entre os anos de 1970 e 2006; por outro lado, as áreas de lavouras aumentaram cerca de $158 \%$, o que evidencia a tendência de substituição das áreas de pastagens, sobretudo naturais, pelas atividades ligadas à agricultura moderna, principalmente na Mesorregião Sudoeste Piauiense, que é justamente onde se encontram as áreas dos Cerrados inseridas no circuito da produção agrícola moderna. Além disso, o número de tratores no Estado do Piauí aumentou $1.431 \%$, o que contribui para evidenciar a modernização agrícola neste Estado.

Na tabela abaixo, encontramos os dados referentes à condição do produtor em relação às terras:

Tabela 19: Condição do produtor em relação à terra- Confronto dos resultados dos censos 1995 e 2006

\begin{tabular}{|c|c|c|c|c|}
\hline \multirow{2}{*}{$\begin{array}{c}\text { Condição do produtor } \\
\text { em relação à terra }\end{array}$} & \multicolumn{2}{|c|}{1995} & \multicolumn{2}{c|}{2006} \\
\cline { 2 - 5 } & Estabelecimentos & $\begin{array}{c}\text { Área } \\
\text { (ha) }\end{array}$ & Estabelecimentos & $\begin{array}{c}\text { Área } \\
\text { (ha) }\end{array}$ \\
\hline Proprietário & 94.032 & 8.975 .733 & 140.597 & 8.328 .196 \\
\hline Arrendatário & 19.141 & 51.519 & 18.139 & 94.481 \\
\hline Ocupante & 63.261 & 560.895 & 45.619 & 486.566 \\
\hline Parceiro & 31.667 & 71.825 & 14.543 & 80.637 \\
\hline
\end{tabular}

Fonte: Censos Agropecuários de 1995 e 2006, adaptada pelo autor.

Os dados revelam que houve grande aumento, de 50\%, do número de estabelecimentos com produtores considerados proprietários. No entanto, a porcentagem de área plantada manteve-se relativamente estabilizada em relação aos proprietários. Quanto aos arrendatários, percebe-se uma diminuição do número de estabelecimentos e aumento da área plantada. O índice de ocupantes apresentou queda nos dois quesitos 
analisados. A porcentagem de produtores considerados parceiros apresentou aumento do número de estabelecimentos e da área plantada.

É possível afirmar, assim, que a concentração de terras no Estado do Piauí acentuou-se em função da expansão do agronegócio, que, da mesma forma, determinou processos migratórios em decorrência do enfraquecimento da agricultura familiar. Porém, como não havia, no Piauí, grande concentração populacional nas áreas dos platôs, as migrações não são tão afetadas - de fato, um processo hegemônico como o da modernização da agricultura apresenta diversos processos contraditórios.

De toda forma, atualmente o agronegócio nos Cerrados piaueinses se destaca como uma das atividades econômicas de maior protagonismo do Estado, que contribui ativamente para o aumento das exportações. Para analisarmos a questão da consolidação da agricultura moderna no Sudoeste Piaueinse, em especial no recorte selecionado, analisaremos a figura abaixo, referente à produção de soja: 
Figura 20: Produção de Soja no MATOPIBA (2012)

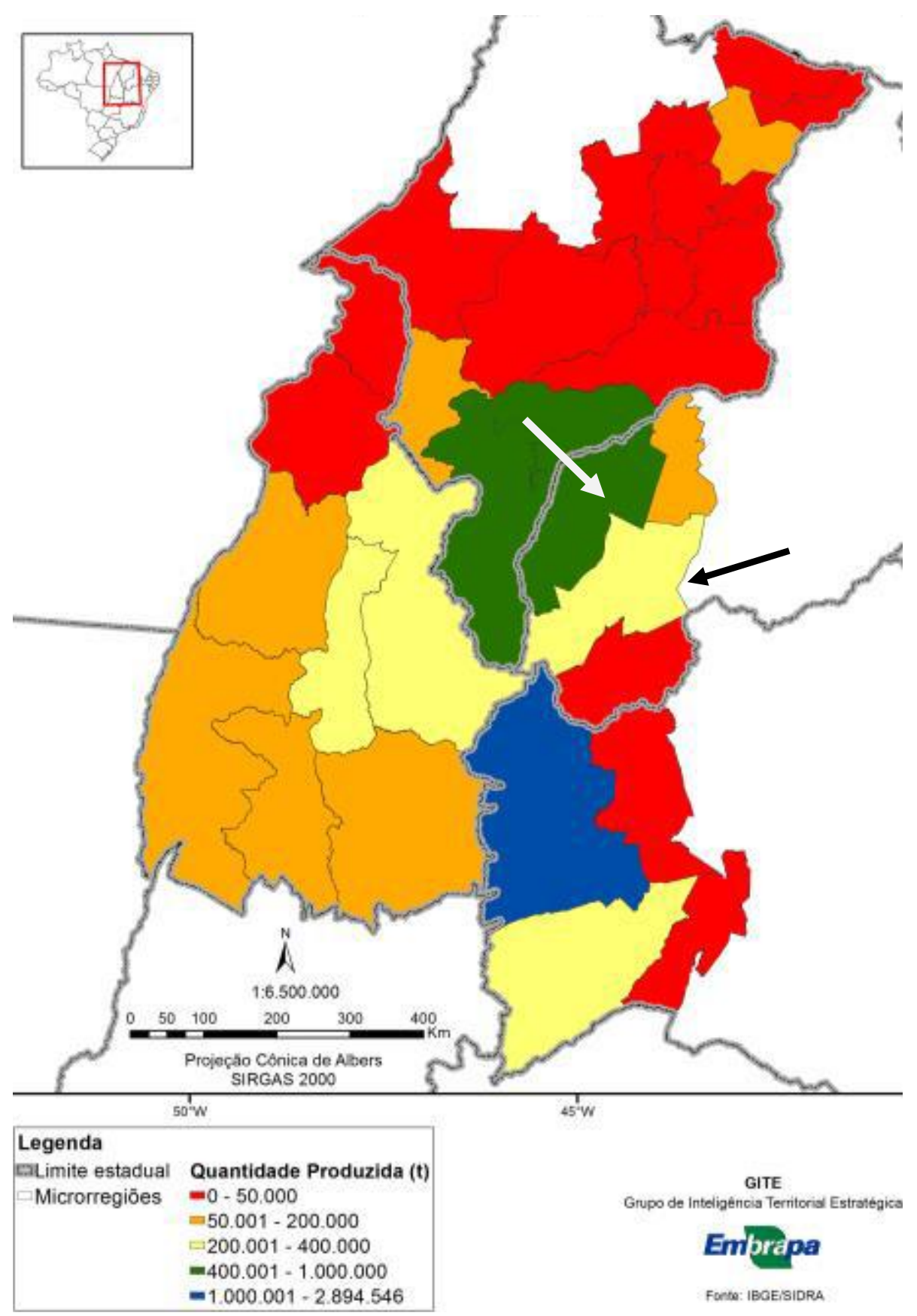

Fonte: Embrapa (2015b, p.34). Microrregião Alto Parnaíba Piauiense- seta branca, Microrregião Alto Médio Gurguéia- seta preta.

Verifica-se que, no Estado do Piauí, a Microrregião Alto Parnaíba Piauiense, indicada com a seta azul, destaca-se como a principal microrregião produtora de soja. Logo em seguida está a Alto Médio Gurguéia, destacada pela seta preta. Da região do MAPITOBA, o oeste baiano, mais especificamente a Microrregião de Barreiras, configura-se a maior produtora em termos de quantidade dessa extensa região produtiva. As microrregiões Chapadas das Mangabeiras e Gerais de Balsas, no Maranhão, e a 
Microrregião Alto Parnaíba Piauiense são outras que se destacam em relação à produção de soja. Na figura abaixo consta a produção de soja no ano de 2012 na região do MAPITOBA:

Figura 21: Produção de milho no MAPITOBA (2012)

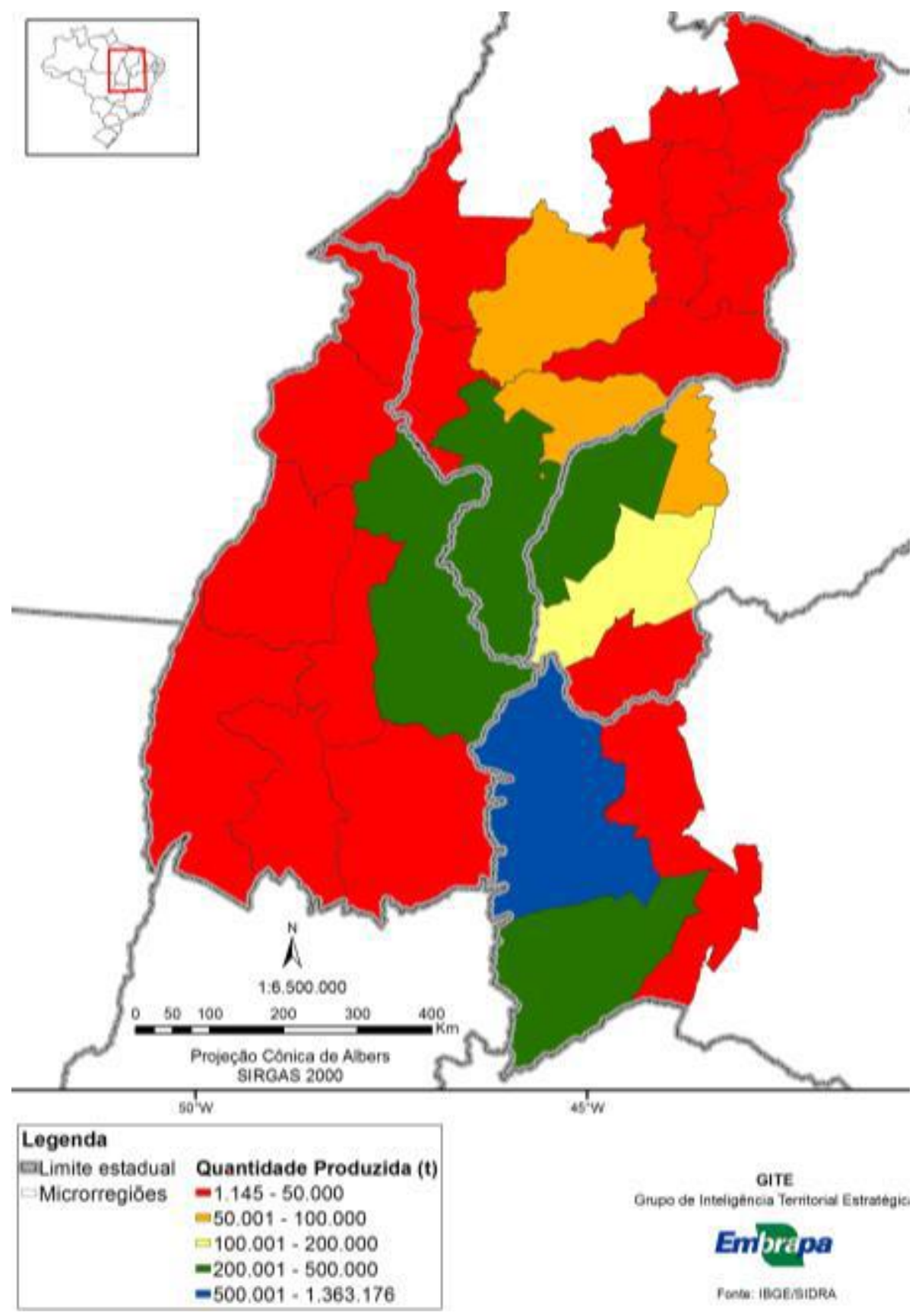

Fonte: Embrapa (2015, p.35)

Constata-se praticamente a mesma situação da produção de soja, em que mais uma vez a Microrregião de Barreiras se sobressai, sendo a única com o mais alto padrão de produção. No Piauí, ainda de maneira análoga ao padrão de produção de soja, a 
Microrregião Alto Parnaíba Piauiense é a maior produtora de milho, seguida por Alto Médio Gurguéia. Recorremos às palavras de Elias (2011), que cita as novas transformações e realidades a partir da chegada da modernização agrícola e constituição das Regiões Produtivas:

\footnotetext{
Cito alguns dos mais importantes: a intensa substituição dos sistemas técnicos agrícolas, que passam a ter alta densidade de capital e tecnologia; a significativa mudança das formas de uso e ocupação do espaço agrícola, com forte substituição da produção de alimentos pela produção de commodities, com a implantação de monoculturas, substituindo vocações naturais pelas imposições econômicas, difundindo especializações produtivas. (ELIAS, 2011, p.158).
}

Essas mudanças no contexto mesorregional evidenciam a transformação do "espaço natural" piauiense em "espaço construido", em função do forte incentivo do Estado e do investimento do capital privado (ARAÚJO; MORAES, 2006), e também revelam a lógica de ocupação de novas áreas do cerrado por parte da agricultura mecanizada, que, de acordo com Frederico (2013), acaba substituindo a cobertura original e até mesmo as atividades econômicas ditas atrasadas e tradicionais. Nesse aspecto, o mesmo autor atribui um grande destaque à produção de soja, em rotação com o milho e algodão, que pode ser considerada a principal commodity, funcionando como articuladora entre a escala global e a local, sobretudo com os mercados consumidores, o que pode ser atribuído ao processo de ocupação das áreas do cerrado piauiense, em que houve substituição do uso comunitário, principalmente direcionadas às pequenas atividades agropecuárias, sobretudo pecuárias nas áreas dos platôs piauienses.

Segundo Alves (2006), essas áreas não foram intensamente povoadas devido à menor disponibilidade de recursos hídricos, sobretudo provindos de rios, e pela maior dificuldade de acesso, embora fossem utilizadas como complementação das atividades desenvolvidas nos baixões. Dessa forma, a migração sulista para a região e a implantação dos primeiros projetos agrícolas acarreta, de fato, mudanças no padrão de uso do solo nessas áreas. A figura abaixo demonstra os efeitos da grande redução do uso comunitário dessas áreas, e da implantação de novos padrões de ocupação do solo: 


\section{Figura 22: Composição colorida com imagens Lansat-TM 5 obtidas em junho de}

\section{0- Bom Jesus-PI}

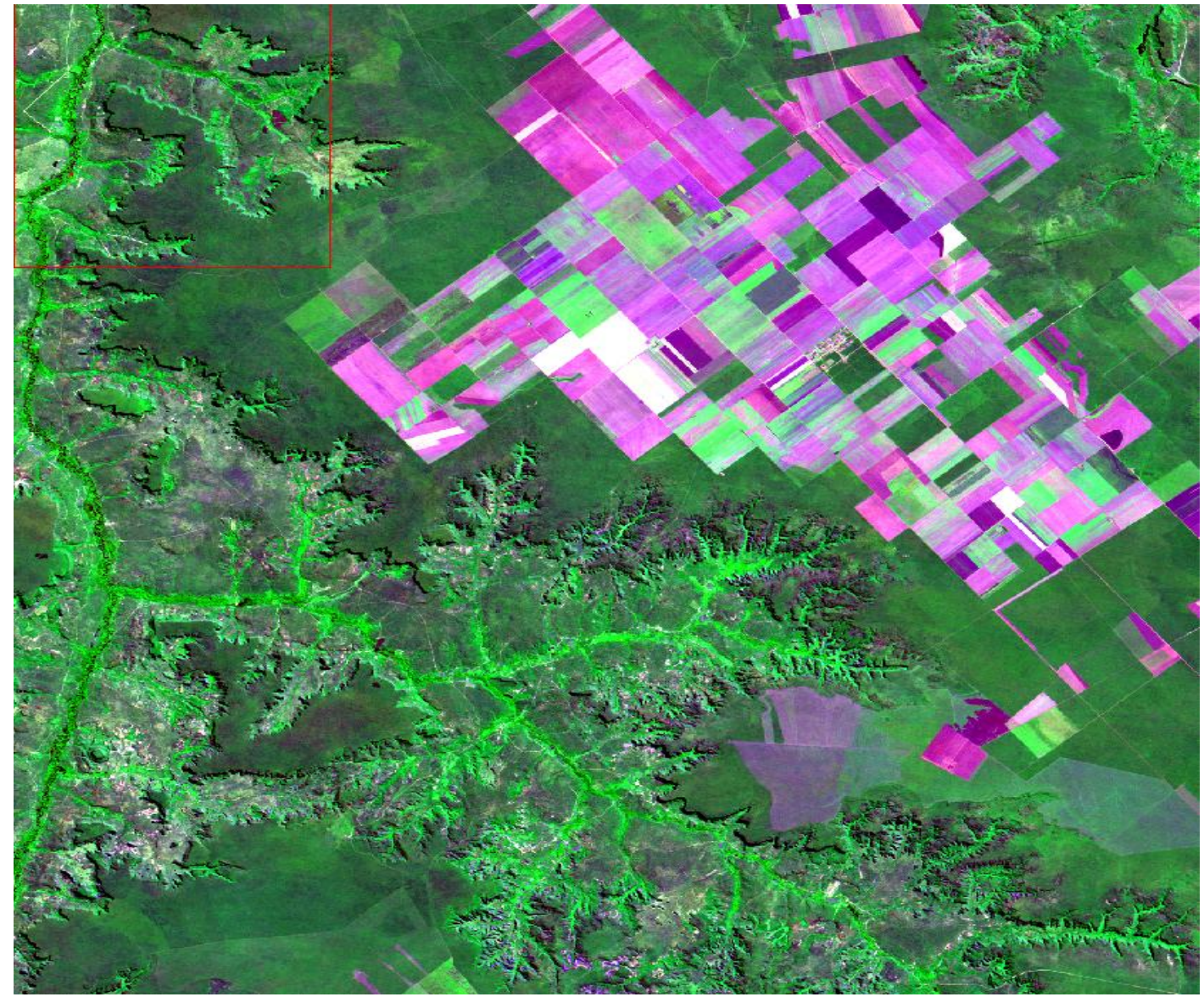

Fonte: Base cartográfica do INPE (2010), elaborado por Rufo, T. F. (2013), na disciplina Sensores Remotos do Departamento de Geografia (UnB).

As áreas em rosa, localizadas em maiores altitudes, representam os projetos de agricultura moderna, e é possível verificar que invadem a borda das chapadas, podendo comprometer as cabeceiras de drenagens presentes nos platôs piauienses. Com o advento dos grandes projetos, os moradores locais são impedidos de circular de forma livre nas áreas dos platôs, pois verifica-se a instalação de cercas em algumas áreas. Elias (2011) ainda destaca que

[...] uma vez que passa a ter forte densidade técnica e normativa, e já evidencia outro processo também bastante significativo associado, qual seja, o de destruição de saberes e fazeres historicamente construídos, porquanto, como a difusão do agronegócio não se dá sobre espaços desocupados, inviabiliza a atividade para milhares de pequenos agricultores, que viviam da subsistência ou da produção simples de mercadorias. Esses são expropriados ou expulsos, em grande parte, gerando muitos conflitos sociais. (ELIAS, 2006, p.158) 
Nessa mesma linha de pensamento, Elias (2006) defende que a modernização da agricultura gera profunda remodelação do território e reorganização de um novo sistema urbano altamente complexo, o que confirma a tendência de substituição do meio natural e do meio técnico pelo meio técnico-científico-informacional. Dessa forma, o crescimento da urbanização pode ser considerado reflexo dos objetivos de grandes agentes ligados ao agronegócio, como empresas multinacionais.

No caso das cidades ligadas ao agronegócio, é possível dizer que o rural possui caráter de preenchimento do urbano, pois existe complementação entre ambos (MIRANDA, 2012). De acordo com Oliveira (1999),

\begin{abstract}
A cidade, hoje, revela estas contradições. Ela é, pois, palco e lugar dessas lutas rurais/urbanas e/ou urbana/rurais. $O$ que significa dizer que a compreensão dos processos que atuam na construção/expansão de grande parte das cidades passa igualmente necessária compreensão dos processos que atuam no campo. (OLIVEIRA, 1999, p.104).
\end{abstract}

Desta maneira, o argumento do autor é uma das justificativas para a definição do eixo de pesquisa "Uso e ocupação do espaço agrário", pois a compreensão das transformações urbanas exige a identificação das características dessa área rural em parte ressignificada pelas atividades agropecuárias modernas, que imprimem novas características à zona rural das regiões produtivas agrícolas. Além de tudo, em consonância com as ideias de Gomes (2007), à medida em que o espaço agrário é reconfigurado, a economia urbana também sofre sérias transformações e influencia diretamente a alteração da relação entre campo e cidade. Nessa perspectiva, com o avanço da agricultura moderna, o campo passa a conviver com novas realidades econômicas e referentes ao uso do solo. Gomes (2007) destaca que:

Atualmente a terceirização da economia está presente no campo, por meio da utilização da informática. Há uma interligação entre as médias e grandes propriedades e a rede global em busca de todos os tipos de informações, compras de insumos e cotações mercadológicas em geral. (GOMES, 2007, p.81).

Pudemos constatar a pertinência da fala da autora no trabalho de campo realizado nas áreas dos platôs, cujo principal objetivo era verificar os novos e reconfigurados padrões de uso do solo, a caracterização dos grandes projetos e a estrutura das fazendas. Esse trabalho foi realizado na Fazenda da empresa agrícola Celeiro, cuja sede fica no município de Monte Alegre. A extensão dos seus projetos, 
porém, ultrapassa as fronteiras municipais; a própria sede localiza-se bastante próxima dos limites entre Monte Alegre, Gilbués e Bom Jesus. Ressaltamos que embora a análise das situações verificadas no trabalho de campo contribuíam para o entendimento do contexto dos Cerrados piauienses, não se pode aplica-la de maneira geral, pois existem fazendas e instalações com diferentes níveis de utilização de tecnologia e com diferentes níveis de produção agrícolas e uso do solo.

A figura abaixo mostra a ladeira de subida para as áreas dos platôs, localizada na Serra do Quilombo.

\section{Figura 23: Placa da entrada da ladeira}

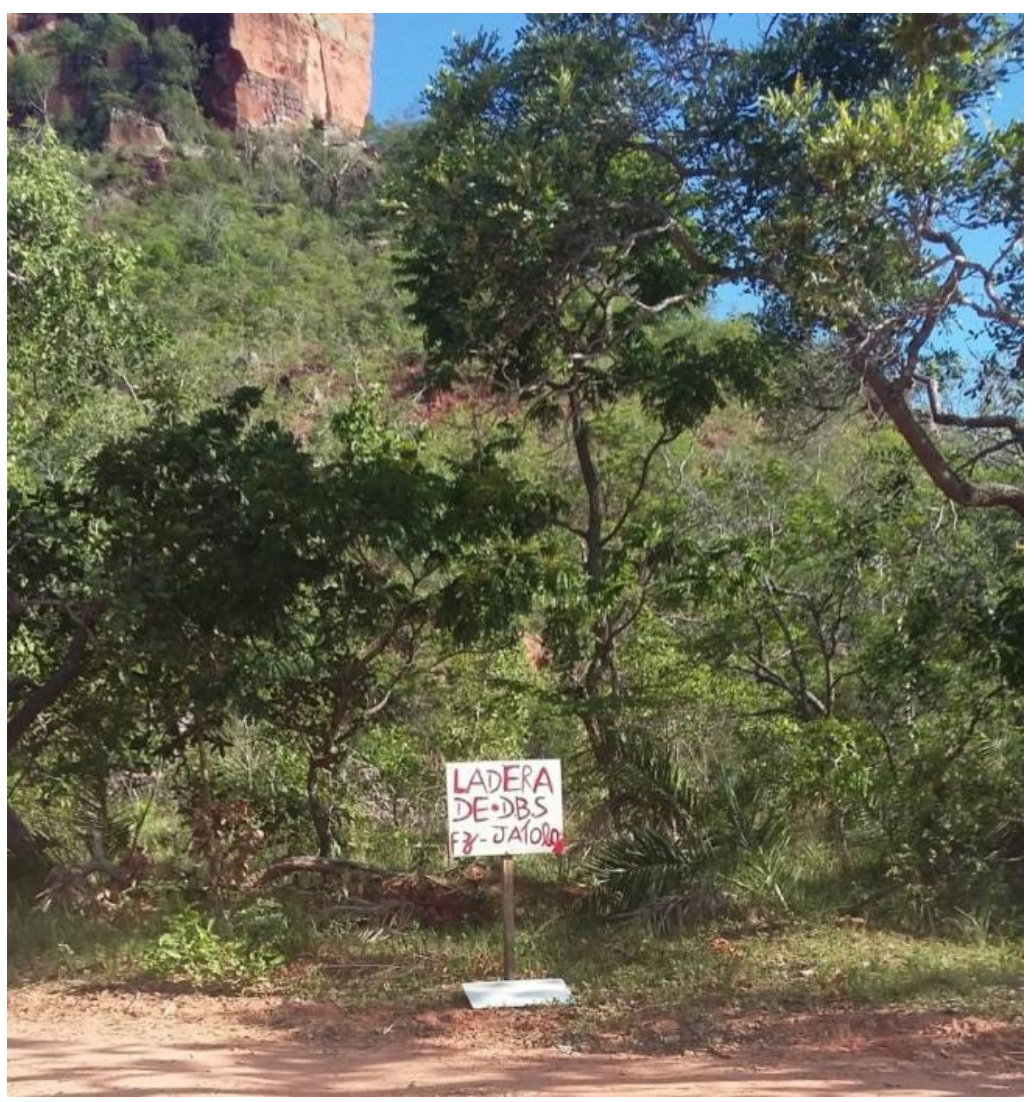

Fonte: o autor, (2015).

A subida da serra fica exatamente no povoado Jatobá, no município de Monte Alegre do Piauí. Os moradores locais fixaram a placa que se vê na foto, e onde lê-se o nome DBS, que faz alusão a Domingos Barros de Sousa, morador local que foi o descobridor do caminho no qual seria construída a estrada por alguns proprietários das fazendas de agricultura moderna. Esse caminho, entretanto, não é utilizado ainda para o tráfego de caminhões e carretas de grande porte, somente para o deslocamento de 
trabalhadores das fazendas localizados próximos à descida da Serra e que residem em Monte Alegre e até mesmo em Gilbués. Abaixo, observa-se a subida da ladeira DBS:

Figura 24: Subida da ladeira DBS- Monte Alegre do Piauí

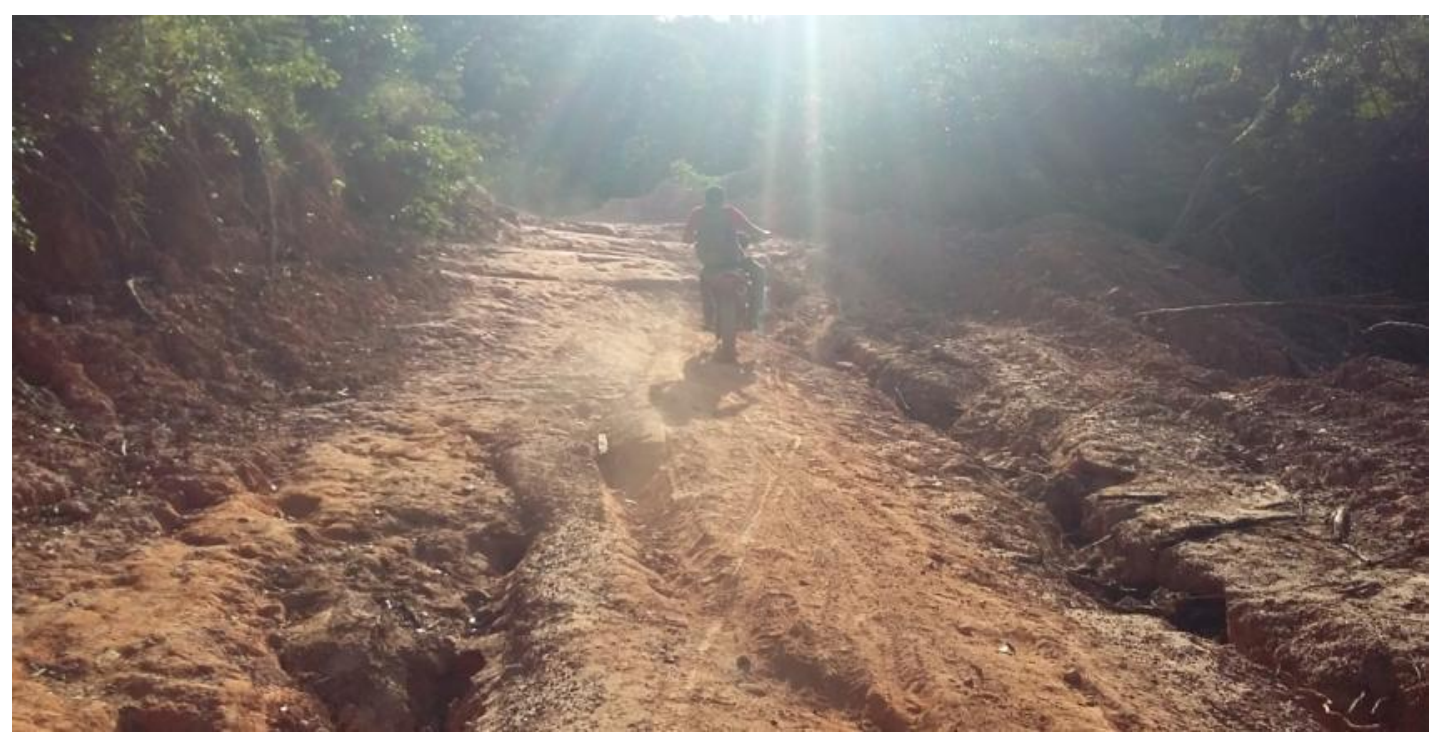

Fonte: o autor, (2015).

Nota-se que as suas condições são precárias, e existem rumores de que os grandes agricultores das áreas dos platôs pretendem melhorá-las, inclusive com o objetivo de otimizar o transporte da produção. Moradores locais acreditam que essa ladeira ainda causará conflitos por terra no futuro, pois os grandes agricultores construíram-na em terras pertencentes a uma família do povoado Jatobá.

No trabalho de campo, percebemos alguns padrões em relação ao uso do solo, como pode-se observar na figura abaixo: 


\section{Figura 25: tanques para controle do fluxo da água}

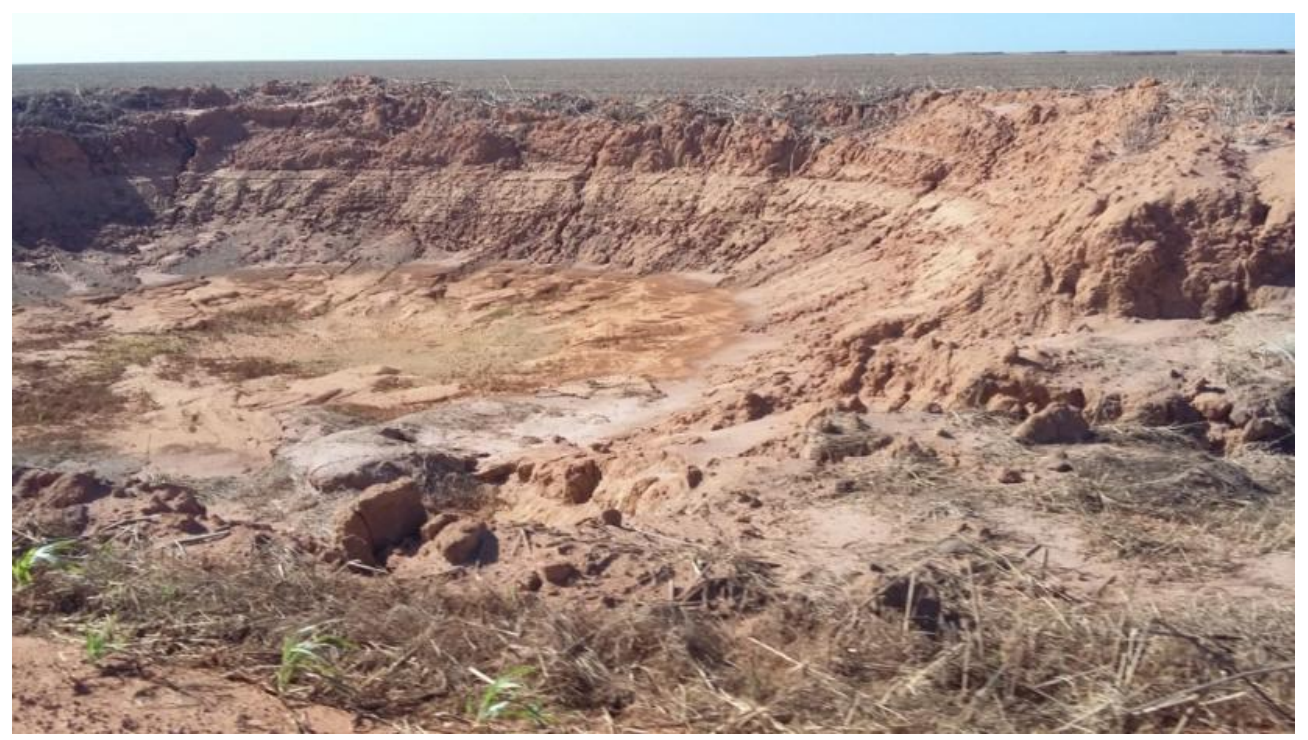

Fonte: o autor, (2015).

$\mathrm{Na}$ imagem, observa-se um tanque, que fica próximo a uma estrada de chão, e que foi construído com o objetivo de estocar água e controlar melhor o escoamento superficial no período chuvoso, visando também a manutenção das condições ideais das estradas para evitar o acúmulo excessivo de água nas plantações, sobretudo de soja e milho. Dessa forma, observamos cuidado especial em relação à preparação do solo para a recepção das culturas agrícolas. Uma das maneiras de se verificar os novos padrões referentes ao uso do solo e à caracterização do espaço agrário é, com efeito, analisar e identificar quais são os padrões referentes às instalações das fazendas, como afirma Elias (2012, p.12): “Contribuem para o aumento dessa densidade técnica e normativa do espaço agrícola os sistemas de objetos associados à eletrificação rural, à armazenagem, às telecomunicações, à reorganização dos recursos hídricos."

Na tabela abaixo, constam os dados referentes à energia elétrica utilizada pelos estabelecimentos, por tipo de fonte, no Estado do Piauí. 
Tabela 20: Energia Elétrica utilizada pelos estabelecimentos, por tipo de fonte, Estado do Piauí-2006

\begin{tabular}{|c|c|c|c|c|c|c|c|c|}
\hline \multicolumn{9}{|c|}{ Energia Elétrica utilizada pelos estabelecimentos, por tipo de fonte } \\
\hline \multicolumn{3}{|c|}{ Externa } & \multicolumn{5}{|c|}{ Gerada no estabelecimento } & \\
\hline $\begin{array}{c}\text { Total } \\
\text { (1) }\end{array}$ & Comprada & $\begin{array}{c}\text { Obtida } \\
\text { por } \\
\text { cessão }\end{array}$ & $\begin{array}{c}\text { Total } \\
\text { (1) }\end{array}$ & $\begin{array}{c}\text { Por } \\
\text { energia } \\
\text { Solar }\end{array}$ & $\begin{array}{c}\text { Pelo } \\
\text { vento } \\
\text { (eólica) }\end{array}$ & $\begin{array}{c}\text { Por } \\
\text { energia } \\
\text { Hidráulica }\end{array}$ & $\begin{array}{c}\text { Por queima } \\
\text { de } \\
\text { combustíveis }\end{array}$ & $\begin{array}{l}\text { Outras } \\
\text { fontes }\end{array}$ \\
\hline 118.432 & 103.213 & 15.303 & 2.587 & 1.192 & 3 & 254 & 885 & 274 \\
\hline
\end{tabular}

Fonte: Censo Agropecuário 2006, adaptada pelo autor, inclusive os que declararam mais de um grupo.

A maior parte dos estabelecimentos agropecuários do Estado do Piauí, assim, recebe fornecimento de energia de fontes externas, principalmente compradas e cedidas. Nas áreas dos platôs não é diferente, pois a maior parte das fazendas conta com o fornecimento de energia. A fazenda Celeiro e a maior parte das outras propriedades dispõem de energia elétrica, disponibilizada pela Eletrobrás, companhia responsável pela distribuição de energia elétrica no Estado do Piauí, como pode ser observado na figura abaixo:

\section{Figura 26: Eletrificação Rural na entrada da Fazenda Celeiro}

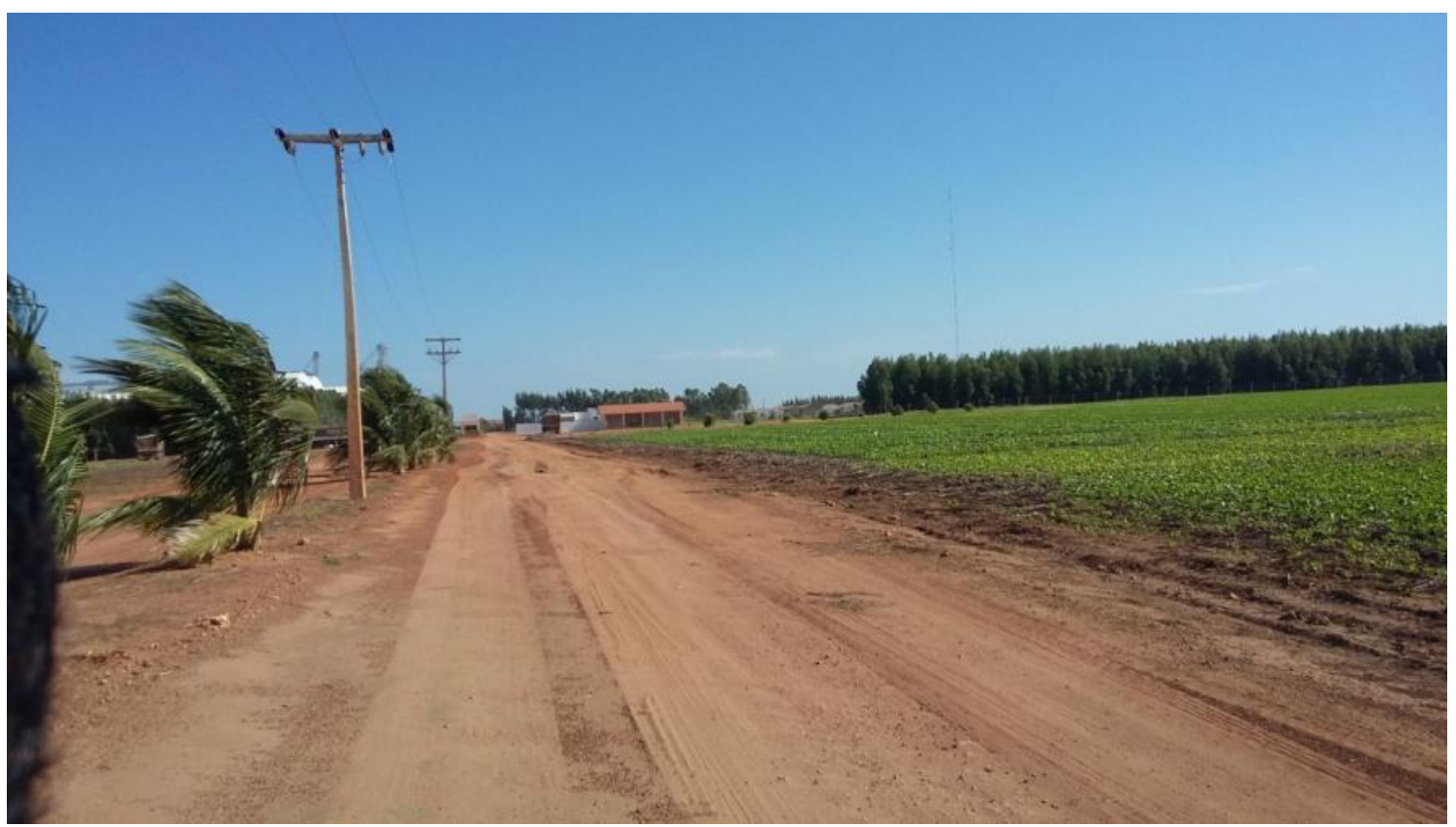

Fonte: o autor, (2015).

A disponibilização de energia elétrica para as áreas dos platôs indica o esforço do Estado em fornecer condições ideais ao desenvolvimento dos grandes projetos, na 
medida em que, até certo tempo atrás, grande parte das fazendas não dispunha de energia elétrica. É possível dizer, porém, que a realidade verificada na Fazenda Celeiro não pode ser tomada como típica, pois trata-se de uma área mais elevada e isolada do ponto de vista do relevo em relação à maior parte das fazendas das áreas dos platôs, de maneira que a distribuição de energia torna-se um grande complicador. Nesse caso, muitos proprietários de grandes fazendas ainda utilizam energia gerada nos estabelecimentos. O Programa Luz Para Todos, no entanto, denotou o grande esforço do Estado em fornecer energia para a maior parte dos grandes projetos.

Outros dados sobre a energia elétrica e telecomunicações são os referentes à presença de aparelhos eletrodomésticos nos estabelecimentos. Na tabela abaixo, é possível analisar seu uso, por tipo, no Estado do Piauí:

Tabela 21: Estabelecimentos com eletrodomésticos utilizados, por tipo, no Estado do Piauí- 2006

\begin{tabular}{|c|c|c|c|c|c|c|c|}
\hline \multicolumn{7}{|c|}{ Estabelecimentos com eletrodomésticos utilizados, por tipo } \\
\hline $\begin{array}{c}\text { Televisão } \\
\text { com } \\
\text { antena } \\
\text { comum }\end{array}$ & $\begin{array}{c}\text { Televisão } \\
\text { com } \\
\text { antena } \\
\text { parabólica }\end{array}$ & Videocassete & DVD & Rádio & Computador & $\begin{array}{c}\text { Acesso à } \\
\text { Internet }\end{array}$ & Nenhum \\
\hline 26.821 & 79.662 & 1.808 & 25.144 & 163.151 & 1.030 & 426 & 63.112 \\
\hline
\end{tabular}

Fonte: Censo Agropecuário 2006, adaptada pelo autor.

Ainda que a tabela apresente dados de 2006, é possível apreender uma ideia geral da situação dos estabelecimentos agropecuários. Já em relação à infraestrutura verificada na área da fazenda, observamos a presença de sistemas de objetos ligados às telecomunicações e aos transportes. Na figura abaixo, vê-se o escritório da fazenda Celeiro, onde fica a parte da logística de transportes e comercialização da produção. 


\section{Figura 27: Escritório de Logística de transportes e comercialização da Fazenda Celeiro}

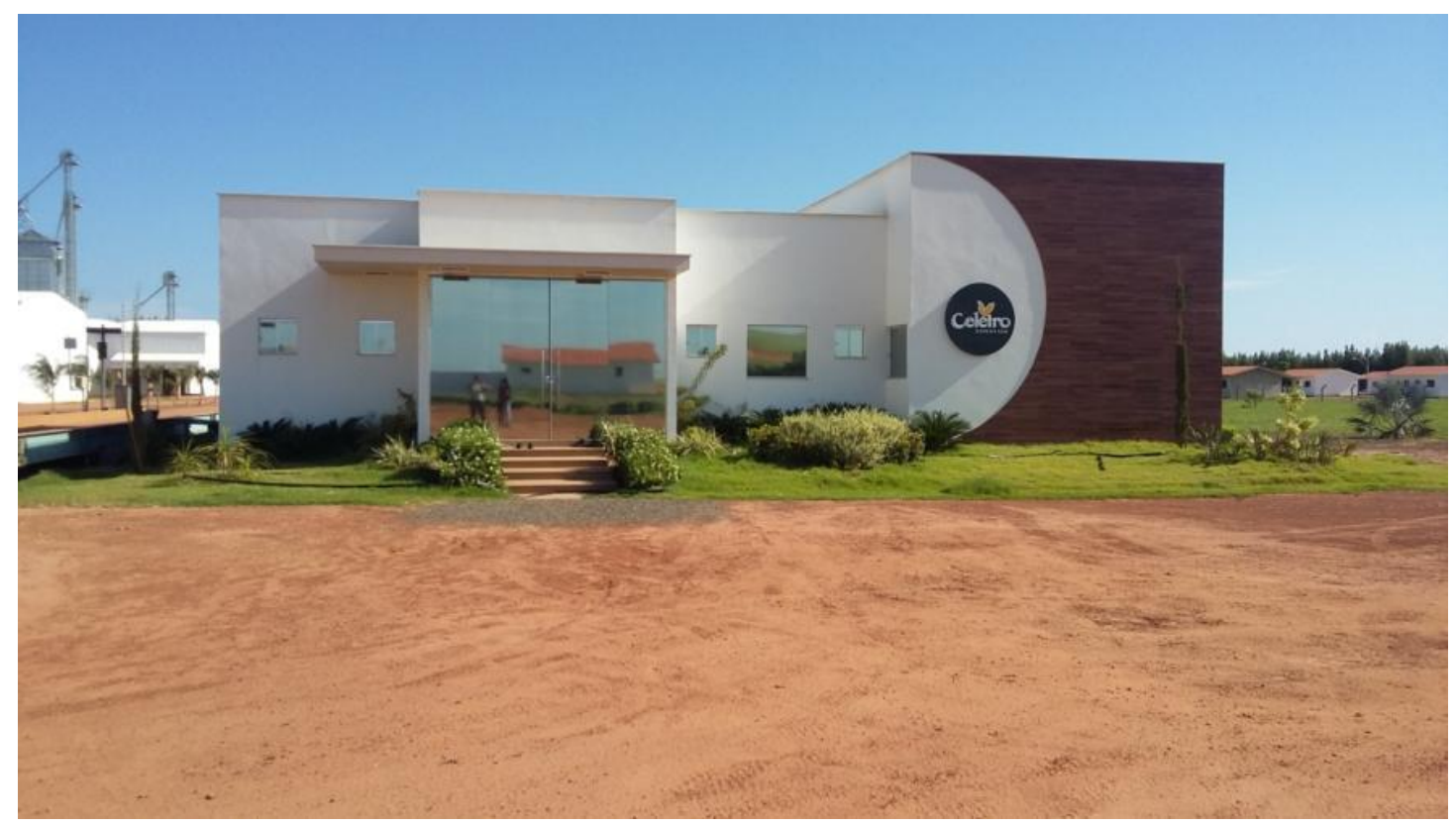

Fonte: o autor, (2015).

Como é possível ver, o escritório possui estrutura moderna, aparelhos de telecomunicação, como computadores com sinal de internet, telefones celulares e fixos. Santos (2008, p.40) já alertava que “[...] ciência, tecnologia e informação são a base técnica da vida social atual." Nesse escritório, tivemos a oportunidade de ter uma conversa formal com o chefe da logística de transportes da empresa, o senhor Jaílson, que afirmou que a principal função do escritório está relacionada ao transporte da produção, através do aluguel e agendamento de carretas para o transporte da produção de acordo com as vendas. Jaílson afirmou, também, que a maior parte da produção é destinada primeiramente aos municípios de Balsas-MA, Bom Jesus-PI e Uruçuí-PI. Ele mostrou-se muito otimista quanto ao futuro do agronegócio na região dos platôs piauienses, destacando que, apesar das dificuldades em relação à infraestrutura ligada aos transportes, a produção agrícola tem aumentado a cada ano. No entanto, afirmou que as vendas são sempre baseadas nos preços praticados no mercado internacional, de maneira que o escritório está ligado ao contexto regional, nacional e internacional, além, é claro, da interligação direta com a sede principal da empresa, localizada no município de Luziânia-GO.

Essa conexão se relaciona com a visão de ELIAS (2006), que defende que os novos arranjos territoriais ligam-se à escala internacional, organizando-se a partir das 
imposições e necessidades do mercado globalizado. Nesse sentido, os novos padrões tecnológicos verificados nos platôs piauienses são reflexos de uma conjuntura e imposição mundial.

Verificou-se, também, a existência de uma balança de pesagem para quantificar a produção de grãos, como pode ser observado na figura abaixo:

\section{Figura 28: Balança de pesagem de cargas- Fazenda Celeiro}

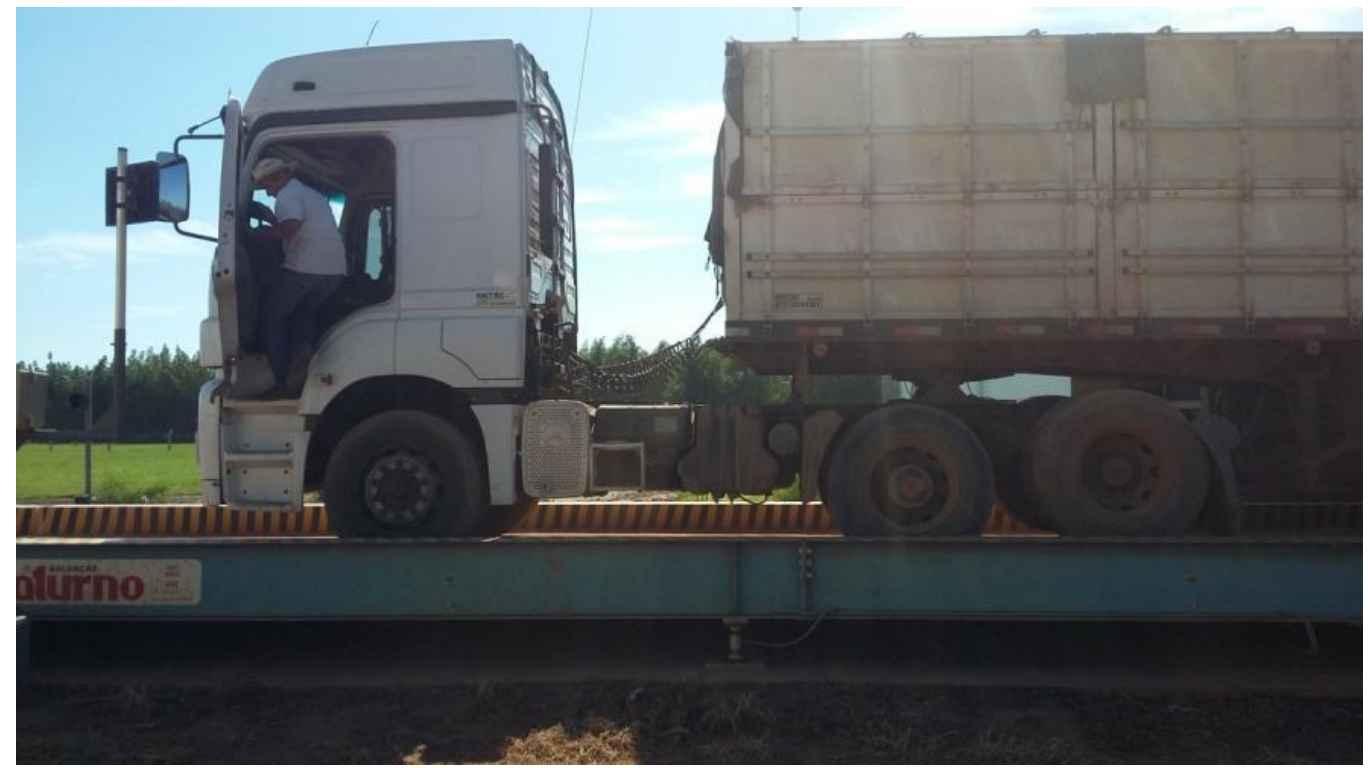

Fonte: o autor, (2015).

A existência da balança mostra a modernização da fazenda. A tendência de implantação de balanças de pesagem de cargas iniciou-se no segundo período da nossa proposta de periodização, qual seja, no final da década de 1990 e começo do século XXI.

Outra questão importante é a das estruturas de armazenagem de grãos. A tabela abaixo mostra o quantitativo de silos e depósitos para a guarda da produção no Estado do Piauí: 
Tabela 22: silos para forragens e depósitos e silos para guarda da produção de grãos existentes nos estabelecimentos- Piauí- 2006

\begin{tabular}{|c|c|c|c|c|c|c|}
\hline \multirow{2}{*}{ Total } & \multicolumn{4}{|c|}{ Silos para forragens } & \multicolumn{3}{c|}{ Depósitos e silos para guarda da produção de } \\
grãos
\end{tabular}

Fonte: Censo Agropecuário 2006 (IBGE), adaptada pelo autor

(1) Total Estabelecimentos

A comparação com os dados referentes à quantidade de silos nos estabelecimentos do Estado da Bahia, onde o agronegócio é mais consolidado na porção oeste, pode ser-nos útil para que compreendamos melhor a tabela. Enquanto no Piauí o número total de estabelecimentos era de 245.738, na Bahia era de 761.528. O Piauí tem um total de 13.263 estabelecimentos com depósitos e silos para guarda da produção de grãos, com capacidade de 344.386 toneladas. Já o Estado da Bahia tem 72.705 silos de armazenagem da produção, com capacidade de 1.876 .302 toneladas. Podemos afirmar, assim, que a agricultura dos Cerrados piauienses, no início do século XXI, apresentava padrões bastante inferiores aos do oeste baiano.

Verificamos, ainda, no trabalho de campo, os pontos de armazenagem de grãos, como pode-se observar nas imagens a seguir:

Figura 29: Silos de armazenagem de grãos- Fazenda Celeiro

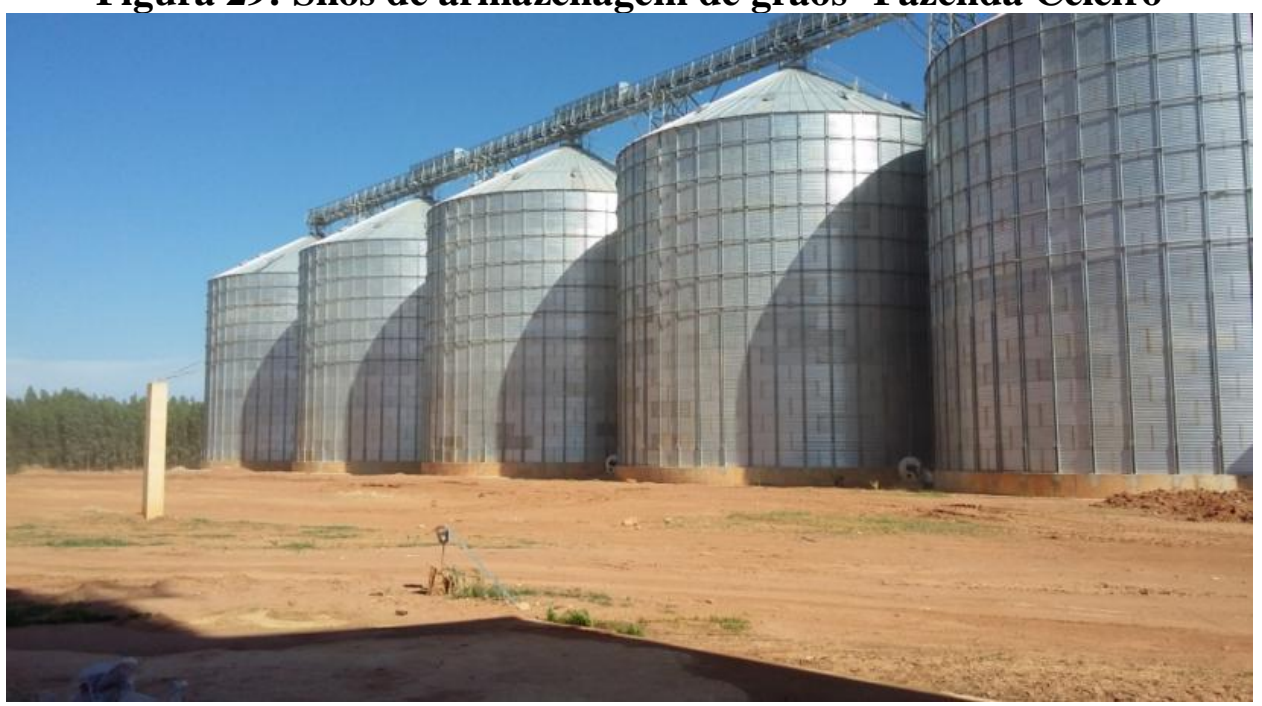

Fonte: o autor, (2015). 
Figura 30: Prédio de armazenagem de grãos e insumos

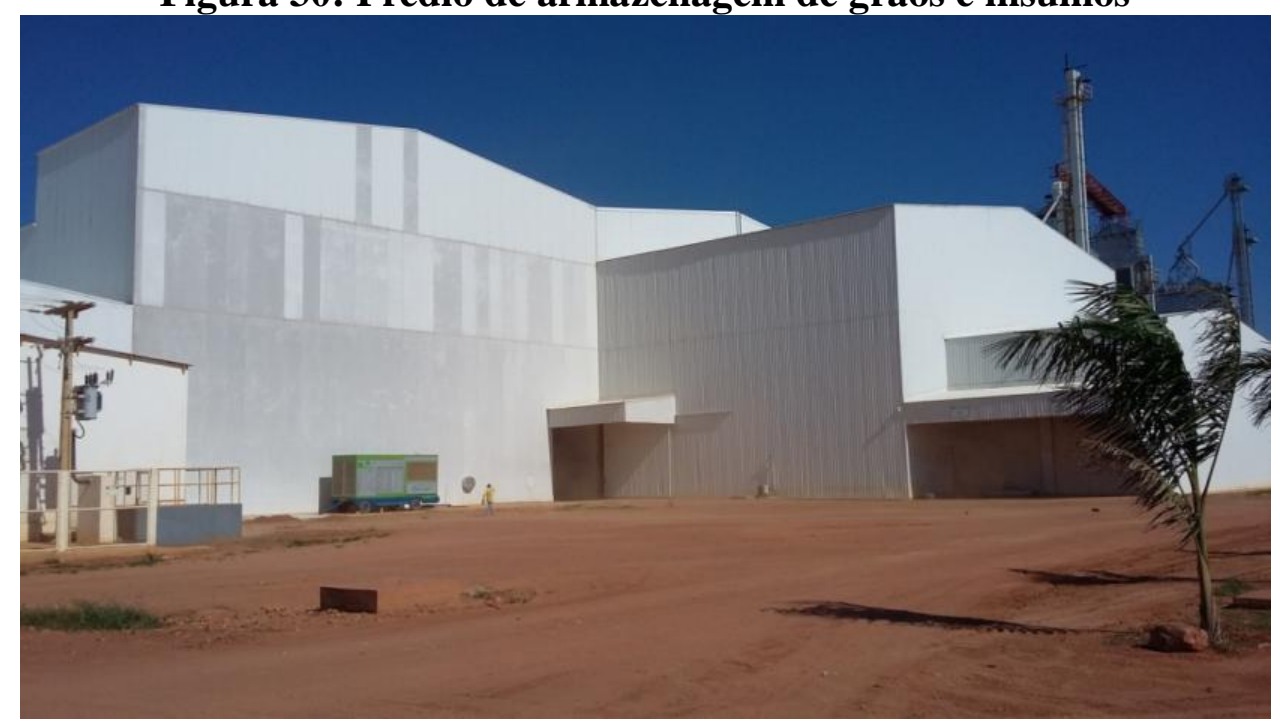

Fonte: o autor, (2015).

Verificou-se a existência de cinco silos de armazenagem de grãos, o que foge do padrão das outras fazendas, nas quais constatou-se uma média de 2 tanques para armazenamento da produção. Além dos tanques de armazenagem, a fazenda conta com um prédio com dois andares e um subsolo, que serve também como ponto de armazenagem de grãos e insumos químicos.

Depois de apurar as principais tendências em relação aos espaços agrícolas da área de estudo e ao uso do espaço agrário, uma das etapas importantes da pesquisa é confirmar a questão da produção agrícola municipal para evidenciarmos os principais municípios produtores da área de estudo. No entanto, evidenciaremos, primeiramente, em imagens de satélite, o avanço da fronteira agrícola na área de estudo na seguinte figura: 
Figura 31: Expansão da agricultura moderna nos cerrados piauienses- 1995, 2005, 2015
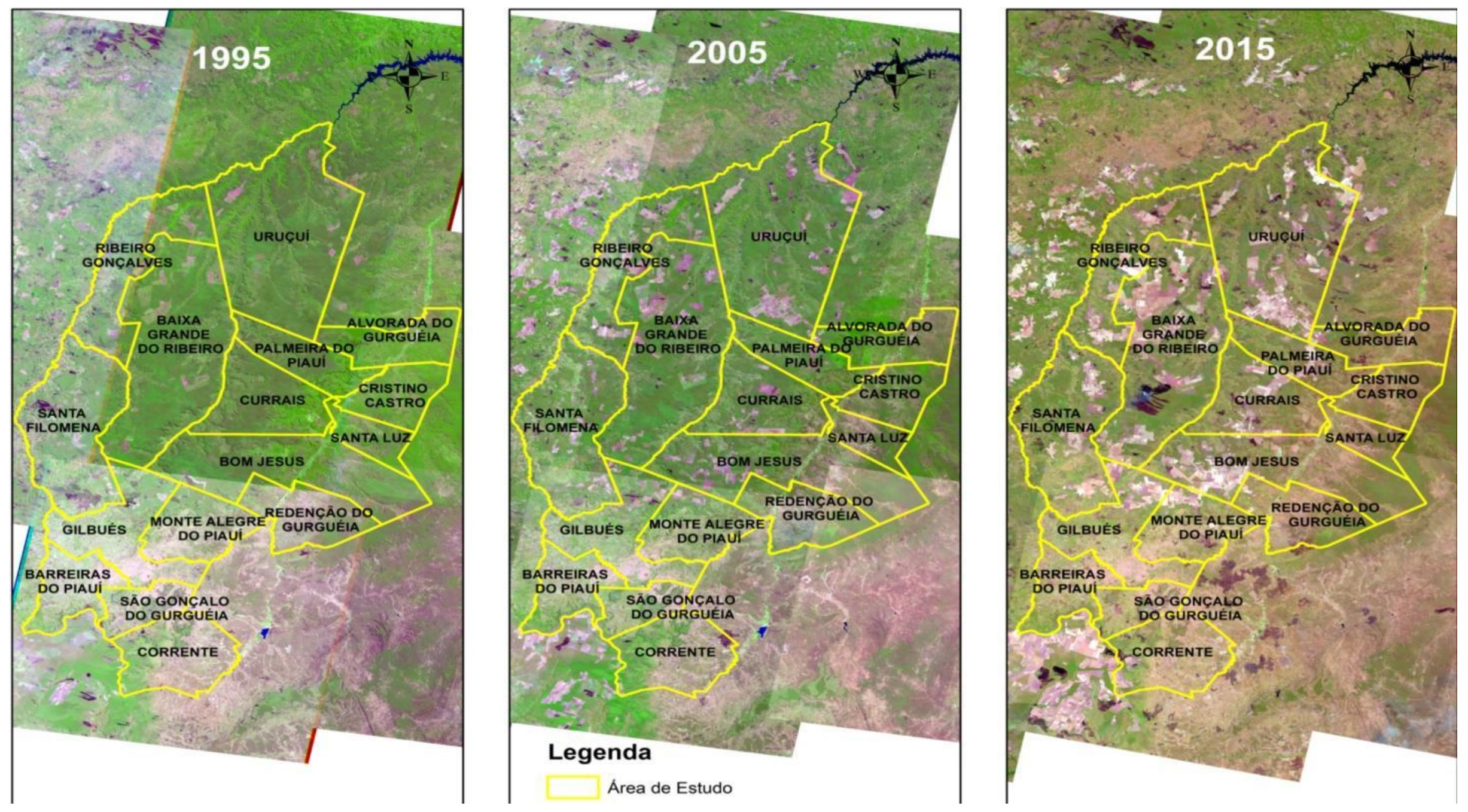

Fonte: Satélite USGS, elaborado por Lucas Garcia (Colaborador) e Tiago Rufo. 
A figura evidencia a expansão da agricultura moderna nos Cerrados piauienses e corrobora colocações defendidas neste trabalho, como, por exemplo, a de que o agronegócio no Estado do Piauí ganha maior destaque a partir dos anos de 2005. Nesse sentido, a agricultura moderna nessa porção territorial do Brasil ainda caminha para um estágio de consolidação. Pela figura, nota-se claramente, em rosa, a evolução das áreas dos projetos em 20 anos, o que reafirma a ideia de que o processo objeto deste estudo vem acontecendo de forma rápida e intensa.

Ainda com base na análise da figura, nota-se que, em 1995, surgem os primeiros espaços destinados à instalação dos projetos de agricultura moderna, principalmente no município de Uruçuí. Em 2005, constata-se grande expansão das áreas cultivadas, principalmente em municípios como Uruçuí, Baixa Grande do Ribeiro e Bom Jesus. Em 2015, é possível ver uma grandiosa área destinada às atividades agrícolas modernas, o que significa a substituição da vegetação natural, no caso, os Cerrados. Podemos notar, ademais, com base na análise da figura, a existência de alguns que não participam da dinâmica da agricultura moderna, no sentindo de que não possuem áreas de platôs, tais como Barreiras do Piauí, São Gonçalo, Santa Luz e Cristino Castro. Além disso, verifica-se que algumas áreas de platôs de certos municípios foram incorporadas à fronteira agrícola, tais como Gilbués, Monte Alegre do Piauí, Currais, Palmeira, Santa Filomena, entre outros. Observa-se que Corrente, por possuir alguns fragmentos dos platôs e pelos mesmos serem continuidade dos platôs baianos, começa a ser inserido no contexto do agronegócio como um município de cultivo de grãos.

Analisemos, ainda, a tabela abaixo, cujos dados demonstram a consolidação da fronteira agrícola no Estado do Piauí.

Tabela 23: Estado do Piauí; Produção agrícola estimada em 2015 e realizada em 2014 (t)- Principais culturas

\begin{tabular}{|c|c|c|c|}
\hline Produtos & Produção 2014 & Estimativa 2015 & Variação \% \\
\hline Arroz & 144.309 & 138.902 & $-3,7$ \\
\hline Milho & 1.036 .825 & 1.272 .097 & 22,7 \\
\hline Soja & 1.488 .646 & 1.839 .170 & 23,5 \\
\hline Algodão & 30.113 & 34.581 & 14,8 \\
\hline
\end{tabular}

Fonte: CEPRO (2015), adaptada pelo autor

De acordo com a tabela, a produção de soja, milho e algodão aumentará consideravelmente de 2014 para de 2015. Esse aumento da produção em meio a crise econômica no país demonstra a consolidação da agricultura moderna nos Cerrados piauienses. 
Dessa forma, seria possível dizer que a crise ainda não chegou ao Piauí. Paradoxalmente, nota-se a produção de arroz no Estado cairá, o que revela a tendência de substituição dessa cultura pelos grãos advindos da agricultura moderna. Na tabela abaixo, constam os dados referentes às estimativas de evolução da área plantada no Estado do Piauí:

Tabela 24: Área Plantada do Piauí (ha)- Principais culturas

\begin{tabular}{|c|c|c|c|}
\hline Produtos & Área Plantada 2014 & Estimativa 2015 & Variação \% \\
\hline Arroz & 104.079 & 82.071 & $-21,9$ \\
\hline Milho & 405.631 & 398.040 & $-9,9$ \\
\hline Soja & 626.793 & 664.339 & 6 \\
\hline Algodão & 12.130 & 14.271 & 17,7 \\
\hline
\end{tabular}

Fonte: CEPRO (2015), adaptada pelo autor

Os dados confirmam, novamente, a redução da área plantada de arroz, além de uma redução de 6\% da área plantada de milho. De acordo com Araújo (2006),

\footnotetext{
A cultura de arroz, considerada preparatória para a produção da soja, tem perdido espaço no cenário produtivo municipal. A principal causa da perda de espaço é o fato de que o arroz ser uma cultura preparatória para a soja. Assim, com acréscimo da área plantada de soja ocorrerá o decréscimo da área destinada à rizicultura. (ARAÚJO, 2006, p.93).
}

Dessa forma, o arroz é um grão de importância secundária para a agricultura moderna, o que é uma contraposição ao padrão alimentar brasileiro. Verifica-se, ademais, um aumento no cultivo de algodão, o que nos fornece indícios mais fortes do encaminhamento da consolidação da fronteira agrícola nos Cerrados piauienses, pois tem-se a inserção de novas culturas agrícolas após a consolidação da soja e do milho.

Para sublinharmos a expansão da fronteira agrícola e evidenciarmos o aumento da produção nos Cerrados piauienses, selecionamos os principais grãos cultivados na região, quais sejam, soja e milho, e elencamos aleatoriamente os dados da produção agrícola de três anos: 2004 e 2013. Tenhamos em mente que as estimativas de produção agrícola no Estado do Piauí, focando na questão da agricultura moderna, possuem tendências de crescimento. Observemos a tabela abaixo. 
Tabela 25: Produção Agrícola Municipal- Microrregião Alto Médio Gurguéia-2004 e 2013

\begin{tabular}{|c|c|c|c|c|c|c|}
\hline \multirow{3}{*}{ Municípios } & \multicolumn{6}{|c|}{ SOJA } \\
\hline & \multicolumn{3}{|c|}{2004} & \multicolumn{3}{|c|}{2013} \\
\hline & $\begin{array}{c}\text { Quantidade } \\
\text { Produzida } \\
\text { (t) }\end{array}$ & $\begin{array}{c}\text { Área } \\
\text { Plantada } \\
\text { (ha) }\end{array}$ & $\begin{array}{c}\text { Rendimento } \\
\text { Médio } \\
(\mathrm{Kg} / \mathrm{ha})\end{array}$ & $\begin{array}{c}\text { Quantidade } \\
\text { Produzida } \\
\text { (t) }\end{array}$ & $\begin{array}{c}\text { Área } \\
\text { Plantada } \\
\text { (ha) }\end{array}$ & $\begin{array}{l}\text { Rendimento } \\
\text { Médio } \\
(\mathrm{Kg} / \mathrm{ha})\end{array}$ \\
\hline $\begin{array}{c}\text { Alvorada do } \\
\text { Gurguéia }\end{array}$ & 6.129 & 2.270 & 2.700 & 12.099 & 8.898 & 1.361 \\
\hline $\begin{array}{c}\text { Barreiras do } \\
\text { Piauí }\end{array}$ & - & - & - & - & - & - \\
\hline Bom Jesus & 60.295 & 21.866 & 2.757 & 45.098 & 58.504 & 908 \\
\hline $\begin{array}{l}\text { Cristino } \\
\text { Castro }\end{array}$ & - & - & - & - & - & - \\
\hline Currais & 10.954 & 9.774 & 1.745 & 27.247 & 39.642 & 853 \\
\hline Gilbués & 14.012 & 5.210 & 2.638 & 40.551 & 32.150 & 1.261 \\
\hline Monte Alegre & 11.010 & 4.434 & 2.483 & 25.500 & 20.802 & 1.288 \\
\hline $\begin{array}{c}\text { Palmeira do } \\
\text { Piauí }\end{array}$ & 7.650 & 2.600 & 2.942 & 14.592 & 15.474 & 943 \\
\hline $\begin{array}{c}\text { Redenção do } \\
\text { Gurguéia }\end{array}$ & - & - & - & 1.546 & 1.680 & 920 \\
\hline $\begin{array}{l}\text { São Gonçalo } \\
\text { do Gurguéia }\end{array}$ & - & - & - & 120 & 200 & 600 \\
\hline Corrente * & - & - & - & 11.419 & 9.821 & 1.163 \\
\hline
\end{tabular}

Fonte: IBGE Cidades, Produção Agrícola Municipal, elaborada pelo autor. (*) Pertencente à Microrregião Chapadas do Extremo Sul Piauiense. 
A análise da tabela permite admitir que Bom Jesus é o município com a maior produção de grãos da Microrregião Alto Médio Gurguéia, mas apresentou uma situação atípica, pois o aumento da área plantada (cerca de 167\%) acompanhou redução da quantidade produzida (cerca de $25 \%$ ) e da taxa de rendimento médio. Tal situação pode ter sido fruto de condições climáticas adversas na região no ano de 2013. Verifica-se que, no Alto Médio Gurguéia, alguns municípios não participam das atividades ligadas à agricultura moderna, pois praticamente não apresentam área de platôs, estando localizados próximos ao fundo de vales. É o caso de Barreiras do Piauí e Cristino Castro. Observa-se, também, a inserção de outros municípios à dinâmica da agricultura moderna, como São Gonçalo do Gurguéia, Redenção, e Corrente (Chapadas do Extremo Sul Piauiense), bem como maior intensificação da produção em outros municípios como Monte Alegre, Gilbués, Currais e Alvorada do Gurguéia, alguns deles por disporem de grande extensão das áreas dos platôs. Embora Redenção e São Gonçalo do Gurguéia possuam um pequeno recorte territorial das áreas dos platôs, também vem sendo inseridas na rota da produção agrícola moderna de grãos.

A análise confirma nossa hipótese inicial de que o início do século XXI possui maior representatividade para a agricultura moderna no Estado do Piauí. Destaca-se o caso do município de Gilbués, que vem se consolidando como segundo município com a maior produção do Alto Médio Gurguéia, apresentando crescimento de quase $190 \%$ da quantidade produzida e expansão de $517 \%$ da área plantada. O município de Currais, por outro lado, alcançou o posto de terceiro maior produtor, assumindo a vaga de Monte Alegre. Currais apresentou aumento de cerca de $149 \%$ da quantidade produzida e expansão de $306 \%$ da área plantada. Já Monte Alegre, por sua vez, apresentou crescimento de $132 \%$ da quantidade produzida e expansão de $369 \%$ da área plantada. Nesse caso, é importante ressaltar que Currais, antes pertencente à Bom Jesus, possui grande área dos platôs, ou seja, grande parte do território municipal fica em áreas propícias ao desenvolvimento dos projetos de agricultura moderna. Monte Alegre, apesar de ter uma área menor dos platôs, também se configura com um dos municípios com a maior produção dessa microrregião.

O município de Corrente, conhecido regionalmente por ser um polo da pecuária, também vem sendo inserido na dinâmica da agricultura moderna, apresentando, já em 2013, uma quantidade produzida significativa para o contexto da área de estudo. Nesse caso, devese considerar que Corrente também possui alguns fragmentos das áreas dos platôs e que podem ser incorporados cada vez mais ao agronegócio da região. Além disso, Corrente conta com universidades com cursos focados na produção agropecuária, o que pode contribuir ainda 
mais para esse município se tornar um grande produtor no futuro próximo, o que analisaremos mais à frente.

Agora, observemos, na tabela abaixo, os dados referentes à produção agrícola na Microrregião Alto Parnaíba Piauiense.

Tabela 26: Produção Agrícola Municipal- Microrregião Alto Parnaíba Piauiense

\begin{tabular}{|c|c|c|c|c|c|c|}
\hline \multirow{2}{*}{ Municípios } & \multicolumn{5}{|c|}{ SOJA } \\
\cline { 2 - 7 } & $\begin{array}{c}|c| \\
\text { Quantidade } \\
\text { Produzida } \\
\text { (t) }\end{array}$ & $\begin{array}{c}\text { Área } \\
\text { Plantada } \\
\text { (ha) }\end{array}$ & $\begin{array}{c}\text { Rendimento } \\
\text { Médio } \\
\text { (Kg/ha) }\end{array}$ & $\begin{array}{c}\text { Quantidade } \\
\text { Produzida } \\
\text { (t) }\end{array}$ & $\begin{array}{c}\text { Área } \\
\text { Plantada } \\
\text { (ha) }\end{array}$ & $\begin{array}{c}\text { Rendimento } \\
\text { Médio } \\
\text { (Kg/ha) }\end{array}$ \\
\hline $\begin{array}{c}\text { Baixa Grande } \\
\text { do Ribeiro }\end{array}$ & 52.604 & 19.258 & 2.731 & 265.427 & 135.317 & 1.968 \\
\hline $\begin{array}{c}\text { Ribeiro } \\
\text { Gonçalves }\end{array}$ & 62.063 & 21.718 & 2.857 & 145.940 & 56.005 & 2.606 \\
\hline $\begin{array}{c}\text { Santa } \\
\text { Filomena }\end{array}$ & 15.989 & 6.499 & 2.460 & 76.269 & 42.047 & 1.814 \\
\hline Uruçuí & 122.463 & 53.552 & 2.286 & 189.978 & 100.636 & 1.897 \\
\hline
\end{tabular}

Fonte: IBGE Cidades, Produção Agrícola Municipal, elaborada pelo autor.

O município com maior produção de soja mudou de 2004 para 2013. Primeiramente, Uruçuí ocupava este posto; em 2013, Baixa Grande do Ribeiro se torna o maior produtor desse grão. O crescimento da produção nesse município deu-se em função de sua localização privilegiada para o agronegócio, pois possui uma grande extensão da área municipal localizada nas áreas dos platôs. Observou-se um crescimento de 212.823 toneladas em um intervalo de nove anos, o que representa um salto de cerca de $405 \%$ da quantidade produzida, além de $606 \%$ de crescimento da área plantada. Nesse caso, pode-se afirmar que os solos dos platôs piauienses do município são cada vez mais intensamente utilizados, embora o rendimento médio tenha sofrido queda de 28\%. Em Ribeiro Gonçalves também observa-se crescimento da área quantidade produzida - cerca de 135\% -, além de $158 \%$ de crescimento da área plantada. O Rendimento médio também apresentou baixa, com redução de quase 9\%, ainda que o município se destaque por abranger as áreas com os maiores rendimentos médios do recorte territorial de estudo. Já em Santa Filomena houve crescimento de $377 \%$ da quantidade produzida, aumento de $547 \%$ da área plantada e queda de cerca de $26 \%$ do rendimento médio das áreas plantadas. 
Apesar desse grande crescimento da produção dos três municípios, Uruçuí ainda se destaca como o principal município dessa microrregião, com destaque para a comercialização de insumos, fertilizantes e máquinas agrícolas, além de abrigar os principais equipamentos urbanos entre os cinco municípios. Todos os municípios da Microrregião Alto Parnaíba Piauiense apresentaram queda do rendimento médio da produção, o que pode ter sido causado pelas condições climáticas e regime de chuvas na região, ou até mesmo por disseminação de pragas, que foi algo verificado nos trabalhos de campo.

Essa queda do rendimento médio em praticamente todos os municípios está em harmonia com as visões de Frederico (2013) e Elias (2006b), que defendem que existe uma tendência, nos Cerrados nordestinos, com exceção de parte do oeste baiano, de aumento da área plantada sem o devido aumento do rendimento médio.

A tabela reproduzida a seguir contempla os dados referentes à produção de milho nos municípios da Microrregião Alto Médio Gurgueía e em Corrente: 
Tabela 27: Produção Agrícola Municipal- Milho- Microrregião Alto Médio Gurguéia

\begin{tabular}{|c|c|c|c|c|c|c|}
\hline \multirow{3}{*}{ Municípios } & \multicolumn{6}{|c|}{ Milho } \\
\hline & \multicolumn{3}{|c|}{2004} & \multicolumn{3}{|c|}{2013} \\
\hline & $\begin{array}{c}\text { Quantidade } \\
\text { Produzida } \\
(\mathrm{t})\end{array}$ & $\begin{array}{c}\text { Área } \\
\text { Plantada } \\
\text { (ha) }\end{array}$ & $\begin{array}{c}\text { Rendimento } \\
\text { Médio } \\
(\mathrm{Kg} / \mathrm{ha})\end{array}$ & $\begin{array}{c}\text { Quantidade } \\
\text { Produzida } \\
\text { (t) }\end{array}$ & $\begin{array}{c}\text { Área } \\
\text { Plantada } \\
\text { (ha) }\end{array}$ & $\begin{array}{c}\text { Rendimento } \\
\text { Médio } \\
(\mathrm{Kg} / \mathrm{ha})\end{array}$ \\
\hline $\begin{array}{c}\text { Alvorada do } \\
\text { Gurguéia }\end{array}$ & 6.607 & 2.160 & 3.607 & 4.629 & 2.240 & 2.067 \\
\hline $\begin{array}{c}\text { Barreiras do } \\
\text { Piauí }\end{array}$ & 144 & 180 & 800 & 242 & 48 & 198 \\
\hline Bom Jesus & 5.666 & 2.377 & 2.383 & 9.631 & 9.014 & 1.556 \\
\hline $\begin{array}{l}\text { Cristino } \\
\text { Castro }\end{array}$ & 169 & 650 & 359 & 108 & 600 & 180 \\
\hline Currais & 117 & 321 & 364 & 11.351 & 5.060 & 2.340 \\
\hline Gilbués & 2.720 & 1000 & 2.720 & 9.563 & 2.448 & 3.906 \\
\hline Monte Alegre & 316 & 360 & 877 & 9.420 & 4.270 & 3.199 \\
\hline $\begin{array}{c}\text { Palmeira do } \\
\text { Piauí }\end{array}$ & 141 & 350 & 486 & 7.437 & 3.361 & 3.441 \\
\hline $\begin{array}{c}\text { Redenção do } \\
\text { Gurguéia }\end{array}$ & 378 & 350 & 1.800 & 138 & 630 & 460 \\
\hline $\begin{array}{l}\text { São Gonçalo } \\
\text { do Gurguéia }\end{array}$ & 311 & 415 & 749 & 912 & 700 & 1303 \\
\hline Corrente * & 1.999 & 2.380 & 839 & 1.584 & 3.000 & 528 \\
\hline
\end{tabular}

Fonte: IBGE Cidades, Produção Agrícola Municipal, elaborada pelo autor.

Com base nos dados, pode-se afirmar que a produção de milho na Microrregião Alto Médio Gurguéia não é muito expressiva. No entanto, nota-se um processo crescente em relação à quantidade produzida e às áreas plantadas, principalmente em municípios que também se destacam em relação à produção de soja, como Bom Jesus, Gilbués, Monte Alegre, Palmeira do Piauí e Currais. Este último se destaca, mais uma vez, como um dos municípios com maior expansão dos projetos e, consequentemente, maior intensificação do uso do solo, pois apresentou um aumento de $9.601 \%$ da quantidade produzida de milho, expansão de $1.476 \%$ da área plantada e aumento de cerca de $543 \%$ do rendimento médio da produção desse grão, de maneira a tornar-se o maior produtor de milho da Microrregião. No entanto, como já mencionado anteriormente, Currais apresenta uma população urbana muito pequena, o que nos leva à conclusão de que as transformações urbanas nessa cidade não serão 
tão significativas como em outros municípios. Monte Alegre é outro município que surpreende, pois apresentou um aumento de $2.881 \%$ da quantidade produzida.

Os municípios de Barreiras do Piauí, Cristino Castro, São Gonçalo e Redenção apresentam uma fraca produção de milho em razão de praticamente não disporem de áreas de platôs, o que revela que nem todos os municípios da área de estudo estão inseridos na dinâmica da agricultura moderna. Além disso, Corrente também apresenta índices modestos referentes à produção desse grão, relativamente estática.

A tabela abaixo nos mostra os dados referentes à produção de milho no Alto Parnaíba Piauiense:

Tabela 28: Produção Agrícola Municipal- Milho- Microrregião Alto Parnaíba Piauiense

\begin{tabular}{|c|c|c|c|c|c|c|}
\hline \multirow{2}{*}{ Municípios } & \multicolumn{5}{|c|}{2004} & \multicolumn{2}{c|}{2013} & \\
\cline { 2 - 7 } & \multicolumn{7}{|c|}{$\begin{array}{c}\text { SOJA } \\
\text { Quantidade } \\
\text { Produzida } \\
\text { (t) }\end{array}$} & $\begin{array}{c}\text { Área } \\
\text { Plantada } \\
\text { (ha) }\end{array}$ & $\begin{array}{c}\text { Rendimento } \\
\text { Médio } \\
\text { (Kg/ha) }\end{array}$ & $\begin{array}{c}\text { Quantidade } \\
\text { Produzida } \\
\text { (t) }\end{array}$ & $\begin{array}{c}\text { Área } \\
\text { Plantada } \\
\text { (ha) }\end{array}$ & $\begin{array}{c}\text { Rendimento } \\
\text { Médio } \\
\text { (Kg/ha) }\end{array}$ \\
\hline $\begin{array}{c}\text { Baixa Grande } \\
\text { do Ribeiro }\end{array}$ & 7.532 & 1.014 & 7.428 & 73.647 & 16.802 & 4.450 \\
\hline $\begin{array}{c}\text { Ribeiro } \\
\text { Gonçalves }\end{array}$ & 13.555 & 2.467 & 5.494 & 47.271 & 14.623 & 4.260 \\
\hline $\begin{array}{c}\text { Santa } \\
\text { Filomena }\end{array}$ & 2.997 & 1.580 & 1.896 & 7.360 & 2.148 & 3.780 \\
\hline Uruçuí & 1.833 & 676 & 2.711 & 241.069 & 43.672 & 5.785 \\
\hline
\end{tabular}

Fonte: IBGE Cidades, Produção Agrícola Municipal, elaborada pelo autor.

Todos os municípios apresentam grande aumento referente aos índices considerados. Baixa Grande do Ribeiro mais uma vez se destaca como um dos maiores produtores da área de estudo, ficando em segundo lugar na produção de milho, atrás do município de Uruçuí. Além disso, verifica-se um crescimento impressionante dos índices referentes à produção desse grão: $13.051 \%$ da quantidade produzida, $6.360 \%$ da área plantada e $113 \%$ do rendimento médio da produção.

Comparando os dados dessa tabela com o da tabela anterior, constata-se que a produção de milho no Alto Parnaíba Piauiense é muito superior que a do Alto Médio Gurguéia. Deve-se considerar, entretanto, que a primeira é mais consolidada em relação ao 
agronegócio, pois foi justamente em seus municípios integrantes que tiveram início os primeiros projetos de agricultura moderna. Além disso, os quatro municípios integrantes do Alto Parnaíba Piauiense apresentam áreas de platôs mais extensas, como a figura referente à Hipsometria da área de estudo evidenciou. Dessa forma, o Alto Médio Gurguéia está ainda está em fase de inserção de algumas áreas na rota da agricultura moderna.

Os dados da tabela 29 são úteis para analisar a questão da ligação entre os municípios e destacar quais os municípios com maior importância em relação à produção agrícola e à recepção dessa produção.

Tabela 29: Destino da produção agrícola (soja e milho)

\begin{tabular}{|c|c|c|c|c|}
\hline \multirow{2}{*}{ Microrregião } & \multirow{2}{*}{ Municípios } & \multicolumn{3}{|c|}{ Municípios de Destino da produção agrícola } \\
\hline & & Soja & Milho & Arroz \\
\hline \multirow{4}{*}{$\begin{array}{c}\text { Alto } \\
\text { Parnaíba } \\
\text { Piauiense }\end{array}$} & $\begin{array}{c}\text { Baixa Grande do } \\
\text { Ribeiro }\end{array}$ & Uruçuí & $\begin{array}{l}\text { Uruçuí, Recife } \\
\text { (PE) }\end{array}$ & Uruçuí, Recife (PE) \\
\hline & Ribeiro Gonçalves & $\begin{array}{l}\text { Uruçuí, Recife } \\
\text { (PE) }\end{array}$ & $\begin{array}{l}\text { Uruçuí, Recife } \\
\text { (PE) }\end{array}$ & Recife (PE) \\
\hline & Santa Filomena & $\begin{array}{l}\text { Balsas (MA), } \\
\text { Tasso Fragoso } \\
\text { (MA). }\end{array}$ & $\begin{array}{l}\text { Balsas (MA), } \\
\text { Tasso Fragoso } \\
\text { (MA). }\end{array}$ & - \\
\hline & Uruçuí & Uruçuí & $\begin{array}{c}\text { Balsas (MA), } \\
\text { Uruçuí }\end{array}$ & - \\
\hline \multirow{11}{*}{$\begin{array}{l}\text { Alto Médio } \\
\text { Gurguéia }\end{array}$} & $\begin{array}{c}\text { Alvorada do } \\
\text { Gurguéia }\end{array}$ & Uruçuí & $\begin{array}{c}\text { Floriano, Picos e } \\
\text { Teresina } \\
\end{array}$ & - \\
\hline & Barreiras do Piauí & - & Barreiras do Piauí & - \\
\hline & Bom Jesus & $*$ & $*$ & $*$ \\
\hline & Cristino Castro & - & $\begin{array}{c}\text { Bom Jesus, } \\
\text { Floriano e Picos }\end{array}$ & Bom Jesus \\
\hline & Currais & $\begin{array}{c}\text { Teresina, Uruçuí e } \\
\text { Fortaleza (CE) }\end{array}$ & - & $\begin{array}{c}\text { Picos, Teresina e } \\
\text { Fortaleza }(\mathrm{CE}) \\
\end{array}$ \\
\hline & Gilbués & Uruçuí & - & Uruçuí \\
\hline & Monte Alegre & Uruçuí & - & $\begin{array}{c}\text { Tasso Fragoso, } \\
\text { Uruçuí }\end{array}$ \\
\hline & Palmeira & $\begin{array}{c}\text { Teresina, Uruçuí e } \\
\text { Fortaleza (CE) }\end{array}$ & - & - \\
\hline & $\begin{array}{c}\text { Redenção do } \\
\text { Gurguéia }\end{array}$ & - & - & $\begin{array}{c}\text { Bom Jesus, } \\
\text { Corrente }\end{array}$ \\
\hline & Santa Luz & - & $\begin{array}{c}\text { Bom Jesus, Picos, } \\
\text { Teresina. }\end{array}$ & $\begin{array}{c}\text { Bom Jesus e } \\
\text { Cristino Castro }\end{array}$ \\
\hline & $\begin{array}{c}\text { São Gonçalo do } \\
\text { Gurguéia }\end{array}$ & - & $\begin{array}{c}\text { São Gonçalo do } \\
\text { Gurguéia }\end{array}$ & $\begin{array}{c}\text { Água Branca, São } \\
\text { Gonçalo do } \\
\text { Gurguéia }\end{array}$ \\
\hline $\begin{array}{l}\text { Chapadas do } \\
\text { Extremo Sul } \\
\text { Piauiense }\end{array}$ & Corrente & * & $*$ & (2) gon \\
\hline
\end{tabular}

Fonte: IBGE, 2008, dados do REGIC 2007. (*) Centros de Zona A não considerados nos dados do IBGE. 
Nota-se que um dos municípios que mais recebe a produção de soja e milho é Uruçuí, justamente por abrigar a Bunge Alimentos; consequentemente, o município destaca-se em relação à recepção da produção de arroz e de milho. Além disso, é importante observar a ligação dos municípios do Alto Parnaíba Piauiense ao município de Balsas, localizado no Maranhão, que é justamente uma das capitais do agronegócio do MAPITOBA.

Ao final deste tópico, partindo da análise dos dados e das figuras, pode-se defender que a agricultura moderna dos Cerrados piauienses ainda está em fase de consumação, já que os grandes projetos de agricultura moderna ainda estão se adaptando às particularidades do Sudoeste Piauiense, como a existência marcante de áreas de platôs e a ausência de cidades nessas áreas. Além disso, grande parte das fazendas não possui ainda pivô central, ou seja, essa tendência modernizante da agricultura não é tão difundida nos platôs piauienses como se verifica no oeste baiano, por exemplo.

Esse atraso em relação às demais áreas é justificado por Braz (2007), que afirma que os Cerrados piauienses não foram inseridos nas três etapas do PRODECER, implementado entre 1979 e 2001. Nas palavras do autor,

\footnotetext{
As consequências são duras e bastante evidentes atualmente. Após mais de vinte anos do início da exploração dos cerrados setentrionais brasileiros, o Piauí utiliza apenas por volta de $10 \%$ de suas terras agricultáveis na região e a infra-estrutura é inexistente ou inadequada. Os pólos mais dinâmicos economicamente se consolidam na Bahia e no Maranhão, [...] Certamente o efeito multiplicador da exploração dos cerrados será bem mais lento e menor no Piauí do que nos outros Estados. (BRAZ, 2007, p.10).
}

Além disso, a efetivação da agricultura moderna nos Cerrados piauienses é marcada por particularidades tais como a localização dos projetos de agricultura moderna em áreas mais elevadas (platôs) e as rede de cidades localizadas nos baixões. Verifica-se, ainda, a existência de municípios que se destacam em relação aos demais no que concerne a produção agrícola, como no caso de Uruçuí e Baixa Grande do Ribeiro. O primeiro, contudo, desempenha papel diferenciado na rede de cidades da área de estudo em função dos serviços e comércios que oferece, constituindo-se como uma das capitais do agronegócio do Estado do Piauí, juntamente com Bom Jesus, título defendido por essa própria cidade na entrada da mesma, como pode ser observado na figura abaixo: 
Figura 32: Entrada da cidade de Bom Jesus: reflexo do agronegócio

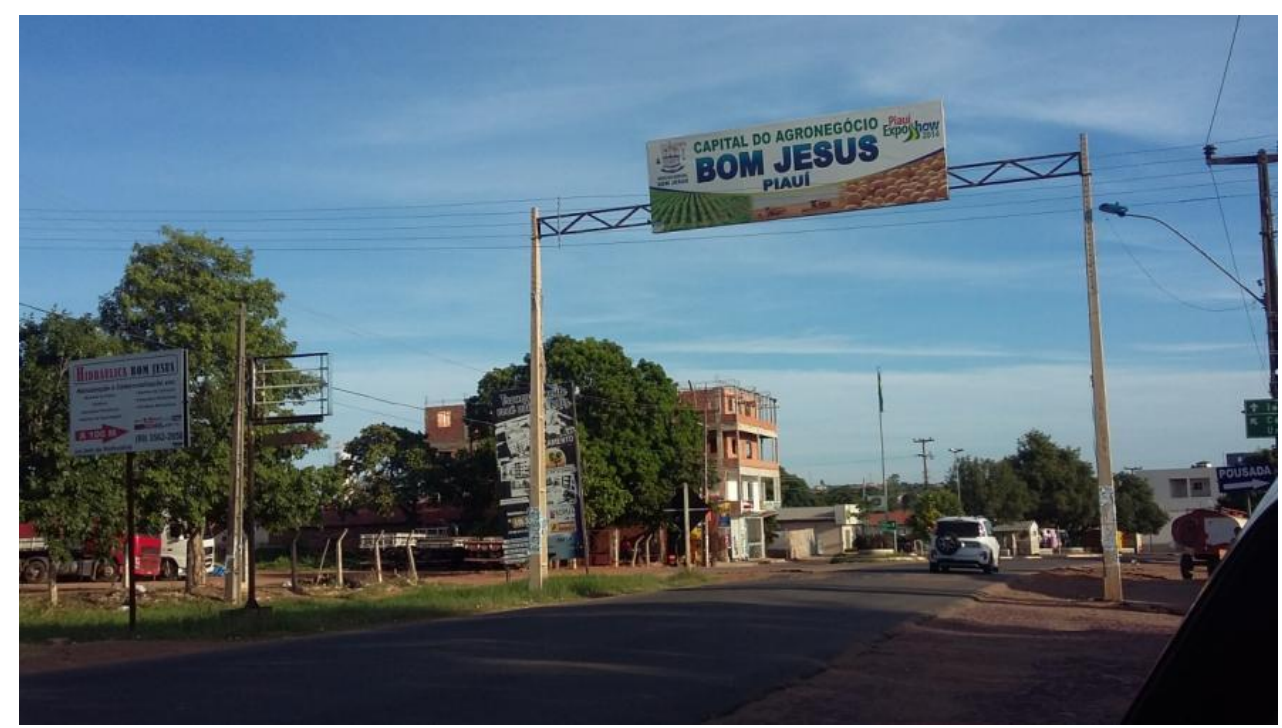

Fonte: o autor, (2015).

Apesar do grande protagonismo de Bom Jesus, o agronegócio é mais consolidado nas áreas da Microrregião Alto Parnaíba Piauiense, pois foi nesse recorte que tiveram início os primeiros projetos de agricultura moderna, sobretudo em Uruçuí. Dessa forma, a Microrregião Alto Médio Gurguéia foi inserida mais tardiamente na dinâmica da agricultura moderna no Estado do Piauí. Além disso, o município de Corrente também começa a ser inserido como um produtor de grãos. Esse município já se sobressai na questão da produção pecuária, sendo um dos polos pecuários do Piauí.

Sendo assim, verificam-se transformações no uso do solo e maior efetivação da expansão da fronteira agrícola nos Cerrados piauienses, que leva à tendência de modificação da relação entre campo e cidade nos Cerrados piauienses, pois, segundo Elias (2012), quanto maior a reestruturação produtiva, acompanhada da formação de redes agroindustriais, mais complexa torna-se a relação campo-cidade. Os dois espaços passam a receber inúmeros fluxos de informações, de mercadorias e de novos agentes econômicos.

\subsection{Economia Urbana}

Este é um dos eixos mais importantes da pesquisa, pois, de acordo com Elias (2012), a análise da Economia Urbana permite verificar quais são os papéis das cidades e novas funções desempenhadas pelas mesmas na região produtiva agrícola na qual estão inseridas. A mesma autora, em outro trabalho, destaca transformações na economia urbana decorrentes do agronegócio e da reconfiguração da rede urbana inserida em uma região produtiva agrícola: 


\begin{abstract}
A reestruturação produtiva da agropecuária cria demandas até então inexistentes nas áreas de difusão do agronegócio. Tais demandas incrementam o crescimento de uma série de atividades comerciais e de serviços especializados. Dessa forma, a difusão do agronegócio não apenas amplia e reorganiza a produção material (agropecuária e industrial), como é determinante para a expansão quantitativa e qualitativa do comércio e dos serviços, especialmente dos ramos associados ao circuito superior da economia agrária. $\mathrm{O}$ crescimento do terciário se deve ainda ao crescimento da população e à revolução do consumo, este último erigido sob os auspícios do consumo de massa associado à existência individual e das famílias (ELIAS, 2011, p.159).
\end{abstract}

Dessa forma, de acordo com a autora, há maior valorização do setor terciário em decorrência do maior dinamismo econômico e do aumento populacional. Nesse sentido, na rede urbana da área de estudo, as cidades com maior contingente populacional acabam se destacando, como Bom Jesus, Corrente e Uruçuí, e mesmo cidades de menor porte, mas que desempenham importantes funções, como Gilbués. Ressaltamos, porém, que cada uma desempenha funções diferentes que diz respeito ao comércio e serviços e ao atendimento das demandas do agronegócio, como veremos mais à frente, com o apoio dos dados.

Assim, o agronegócio altera a função das cidades piauienses, influenciando diretamente na modificação da hierarquia das cidades. De acordo com Elias (2011), a modernização da agricultura e a constituição de Regiões Produtivas acabam intensificando

[...] as relações campo-cidade e a urbanização, uma vez que redes agroindustriais necessitam também de processos que se dão no espaço urbano próximo às áreas de produção agrícola e agroindustrial, incrementando o crescimento de cidades totalmente funcionais ao agronegócio, as quais passam a ter novas funções, tal como a de gestão desse agronegócio globalizado. Processa-se, em última instância, a produção de territórios especializados e corporativos inerentes a esse agronegócio. (ELIAS, 2011, p.154).

O agronegócio, assim, segundo a autora, exige que as cidades se reinventem para atender suas necessidades e as dos novos agentes ligados ao agronegócio e à expansão populacional.

Ao enfatizar-se a totalidade urbana do Sudoeste Piauiense, é vital destacar que o urbano dessa mesorregião ainda é muito baseado em tradições rurais, visto que ainda persiste uma intensa ligação ao rural, o que também se deve ao fato da grande maioria dos municípios ainda concentrar a maioria da população no campo. Sendo assim, pode-se afirmar os municípios piauienses ainda apresentam grande dependência da zona rural. No entanto, a moderna agricultura pode, no futuro, reverter esse quadro, devido às pressões e novas aquisições de terras das áreas dos baixões destinadas para reserva legal, o que gera migração do campo para as cidades, como no caso de Bom Jesus. 
É preciso, contudo, evidenciar as principais tendências em relação à economia urbana na rede de cidades piauienses, e as transformações fundamentais sob influência da agricultura moderna. Soma-se, a isso, a necessidade de definição do papel da rede de cidades face ao agronegócio globalizado e as principais questões evidenciadas nos trabalhos de campo realizados em algumas cidades da área de pesquisa. Abaixo estão os dados referentes ao quantitativo de empresas presentes na área de estudo.

Tabela 30: Estatísticas do cadastro central de empresas-2013

\begin{tabular}{|c|c|c|c|c|}
\hline Microrregião & Municípios & $\begin{array}{c}\mathrm{N}^{\mathbf{o}} \\
\text { Empresas } \\
\text { atuantes }\end{array}$ & $\begin{array}{c}\text { Pessoal } \\
\text { Ocupado } \\
\text { Assalariado }\end{array}$ & $\begin{array}{c}\text { Pessoal } \\
\text { Ocupado } \\
\text { total }\end{array}$ \\
\hline \multirow{4}{*}{$\begin{array}{l}\text { Alto Parnaíba } \\
\text { Piauiense }\end{array}$} & $\begin{array}{l}\text { Baixa Grande do } \\
\text { Ribeiro }\end{array}$ & 168 & 1.750 & 1.906 \\
\hline & Ribeiro Gonçalves & 136 & 1.329 & 1.458 \\
\hline & Santa Filomena & 82 & 425 & 503 \\
\hline & Uruçuí & 600 & 3.409 & 4.089 \\
\hline \multirow{11}{*}{$\begin{array}{c}\text { Alto Médio } \\
\text { Gurguéia }\end{array}$} & Alvorada do Gurguéia & 57 & 414 & 597 \\
\hline & Barreiras do Piauí & 22 & 125 & 142 \\
\hline & Bom Jesus & 705 & 2.457 & 3.324 \\
\hline & Cristino Castro & 242 & 634 & 870 \\
\hline & Currais & 28 & 401 & 462 \\
\hline & Gilbués & 120 & 640 & 809 \\
\hline & Monte Alegre & 67 & 733 & 853 \\
\hline & Palmeira & 55 & 241 & 294 \\
\hline & Redenção do Gurguéia & 101 & 601 & 706 \\
\hline & Santa Luz & 62 & 293 & 364 \\
\hline & $\begin{array}{c}\text { São Gonçalo do } \\
\text { Gurguéia }\end{array}$ & 14 & 180 & 201 \\
\hline $\begin{array}{c}\text { Chapadas do } \\
\text { Extremo Sul } \\
\text { Piauiense }\end{array}$ & Corrente & 414 & 1.395 & 1.841 \\
\hline
\end{tabular}

Fonte: IBGE Cidades, Cadastro Central de Empresas 2013.

Na Microrregião Alto Parnaíba Piauiense, o município que mais se destaca em relação à concentração de empresas é Uruçuí, com um total de 600 empresas de diferentes setores econômicos. Além disso, é o município com o maior número de pessoal ocupado, 4.089 no total. Pressupomos, inicialmente, que esse maior número de empregados se deve à maior 
quantia de projetos de agricultura moderna, de maneira que o município recebe uma quantidade expressiva de trabalhadores que vêm de outros municípios da área de estudo e de fora dela. Uruçuí, assim, é um município atípico. Baixa Grande do Ribeiro e Ribeiro Gonçalves também se destacam em relação aos outros municípios no que se refere à quantidade de empresas atuantes.

Bom Jesus é o município com o maior número de empresas atuantes, total de 705 , destacando-se também em relação ao quantitativo de pessoal ocupado assalariado e ocupado total, o que se deve aos setores de comércio e de serviços mais diversificados em relação ao restante da área de estudo. Percebe-se que Bom Jesus possui maior quantitativo de empresas até mesmo em relação ao município de Corrente, polo comercial, educacional e pecuário da região. Bom Jesus possui grande quantidade de empresas ligadas ao agronegócio, o que confirma a tendência apontada por Catelan (2012, p.162), segundo o qual "As cidades médias convivem com esta transformação da economia global e de respostas dos interesses dos agentes locais e regionais. Os principais responsáveis por este movimento são as empresas, que atuam em escala global.”

No Alto Médio Gurguéia, outro município que se destaca em relação aos demais é o de Cristino Castro, onde se nota maior presença de redes de hotéis e pousadas e empreendimentos ligados ao lazer em decorrência da presença dos famosos poços jorrantes ${ }^{60}$ de origem natural. Na figura abaixo, observa-se um desses empreendimentos ligados ao lazer, que acabam contribuindo para a maior presença de empresas nessa cidade:

${ }^{60}$ Os poços jorrantes predominam na cidade de Cristino Castro, inserida na Bacia Hidrográfica do Rio Gurguéia, que possui a maior reserva de água subterrânea do Nordeste, demonstrando assim, um grande potencial turístico e hídrico, que vem sendo desperdiçado constantemente nessa região. 
Figura 33: Empreendimento de lazer em Cristino Castro

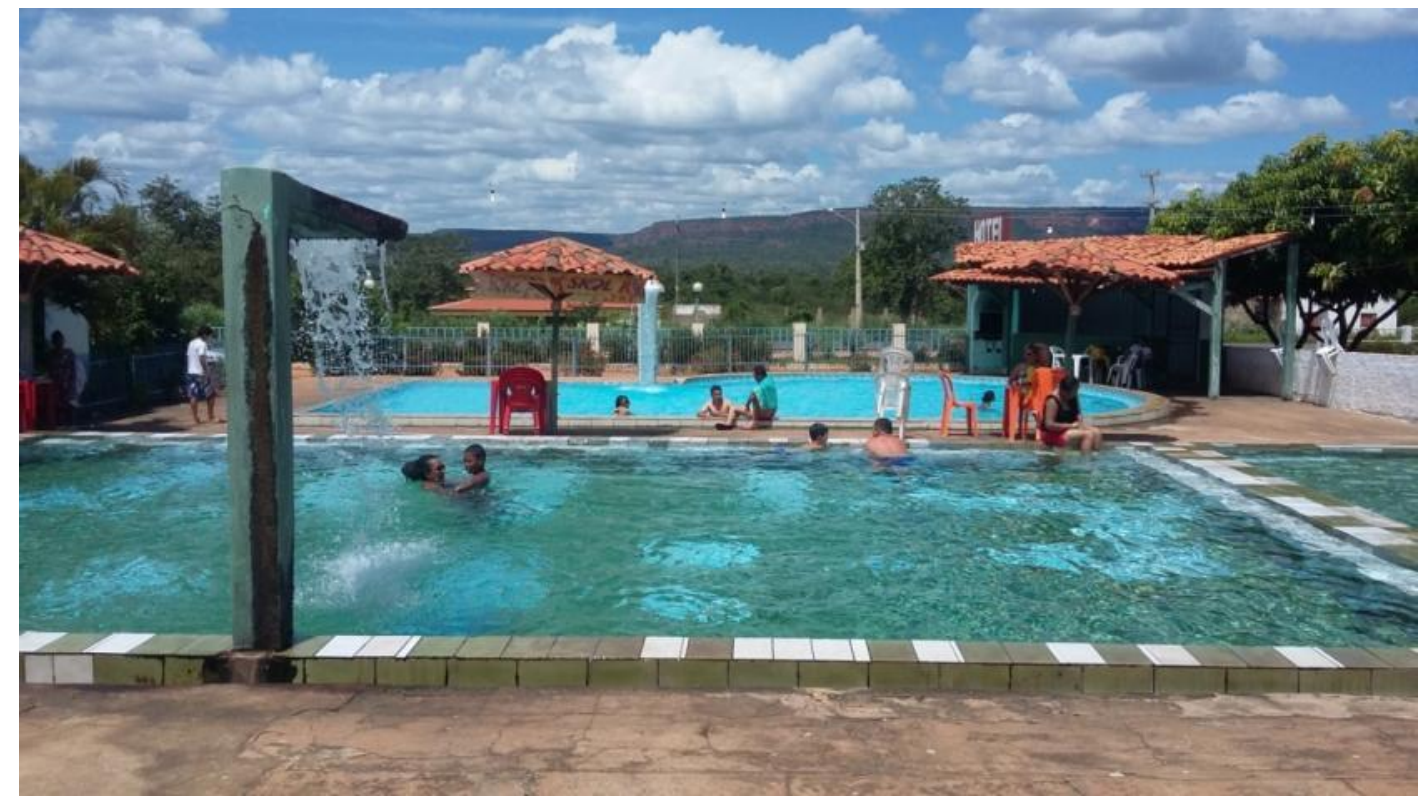

Fonte: o autor, (2015).

A potencialidade turística de Cristino Castro pode ser um atrativo para mais pessoas provenientes de outras regiões do país, como os chamados "gaúchos" que trabalham com o agronegócio ou até mesmo nos setores de comércio e serviços. Outro município que se destaca em relação à presença de empresas atuantes é Gilbués, onde verifica-se maior diversificação do comércio e do setor de serviços. Essa cidade, considerada pelo REGIC 2007 como um Centro de Zona $B$, também possui certo destaque no cenário da área de estudo, polarizando Monte Alegre e Barreiras do Piauí, na medida em que a população dessas cidades é dependente de equipamentos urbanos presentes em Gilbués, como serviços bancários, ligados à saúde, educação, dentre outros. Na tabela abaixo, observamos a proporção de ocupados nos diferentes setores da economia. 
Tabela 31: Proporção de ocupado com 18 anos ou mais nos diferentes setores econômicos da economia (2010)

\begin{tabular}{|c|c|c|c|c|c|c|}
\hline Municípios & $\begin{array}{c}\% \text { dos } \\
\text { ocupados no } \\
\text { setor } \\
\text { agropecuário }\end{array}$ & $\begin{array}{c}\% \text { dos } \\
\text { ocupados no } \\
\text { setor } \\
\text { extrativo } \\
\text { mineral } \\
\end{array}$ & $\begin{array}{c}\% \text { dos } \\
\text { ocupados na } \\
\text { indústria de } \\
\text { transformação }\end{array}$ & $\begin{array}{c}\text { \% dos } \\
\text { ocupados } \\
\text { no setor } \\
\text { de } \\
\text { serviços } \\
\end{array}$ & $\begin{array}{c}\text { \% no dos } \\
\text { ocupados } \\
\text { setor de } \\
\text { construção }\end{array}$ & $\begin{array}{c}\% \text { dos } \\
\text { ocupados } \\
\text { no setor } \\
\text { comércio }\end{array}$ \\
\hline $\begin{array}{c}\text { Baixa } \\
\text { Grande do } \\
\text { Ribeiro } \\
\end{array}$ & 45,69 & - & 2,36 & 31,74 & 6,10 & 8,00 \\
\hline $\begin{array}{c}\text { Ribeiro } \\
\text { Gonçalves }\end{array}$ & 39,77 & 1,18 & 3,55 & 30,81 & 2,96 & 6,96 \\
\hline $\begin{array}{c}\text { Santa } \\
\text { Filomena } \\
\end{array}$ & 50,10 & 0,65 & 3,86 & 31,15 & 3,55 & 6,66 \\
\hline Uruçuí & 26,39 & 0,15 & 4,96 & 39,91 & 9,37 & 14,46 \\
\hline $\begin{array}{c}\text { Alvorada do } \\
\text { Gurguéia }\end{array}$ & 51,34 & - & 5,80 & 29,84 & 5,18 & 6,64 \\
\hline $\begin{array}{c}\text { Barreiras do } \\
\text { Piauí }\end{array}$ & 48,16 & - & 6,43 & 31,36 & 4,11 & 9,42 \\
\hline Bom Jesus & 24,67 & 0,11 & 3,19 & 42,79 & 10,31 & 17,43 \\
\hline $\begin{array}{c}\text { Cristino } \\
\text { Castro }\end{array}$ & 41,62 & 0,14 & 3,43 & 36,32 & 6,63 & 11,56 \\
\hline Currais & 70,22 & - & 3,01 & 20,43 & 4,57 & 1,56 \\
\hline Gilbués & 35,52 & 0,90 & 3,09 & 36,91 & 8,15 & 13,03 \\
\hline $\begin{array}{l}\text { Monte } \\
\text { Alegre }\end{array}$ & 47,87 & 0,12 & 1,63 & 35,48 & 5,61 & 6,94 \\
\hline Palmeira & 60,33 & 0,66 & 3,47 & 22,67 & 4,79 & 6,94 \\
\hline $\begin{array}{c}\text { Redenção } \\
\text { do Gurguéia }\end{array}$ & 47,04 & & 2,13 & 35,12 & 4,91 & 9,44 \\
\hline Santa Luz & 45,48 & 0,15 & 9,93 & 28,51 & 6,57 & 8,71 \\
\hline $\begin{array}{c}\text { São } \\
\text { Gonçalo do } \\
\text { Gurguéia } \\
\end{array}$ & 42,97 & - & 5,00 & 36,21 & 5,99 & 9,83 \\
\hline Corrente & 31,96 & - & 3,75 & 38,04 & 9,92 & 14,37 \\
\hline
\end{tabular}

Fonte: Atlas Brasil, dados do Censo de 2010.

Fica claro que a maior parte da população da maioria dos municípios ocupa-se do setor agropecuário, com exceção de Uruçuí, Bom Jesus e Corrente. Bom Jesus é o que apresenta menor porcentagem da população empregada no setor agropecuário, o que demonstra um fortalecimento dos outros setores econômicos, como comércio e serviços. Com efeito, o município também apresenta a maior parcela percentual da população empregada nos setores de comércio e de serviços; contudo, ainda apresenta baixo índice de atividades industriais. Bom Jesus é, ainda, a cidade com o maior percentual de ocupados no setor de construção, algo que pudemos verificar em trabalho de campo, quando observamos a presença de muitos empreendimentos em construção motivados pela expansão do comércio e pela expansão da 
cidade, mais especificamente da expansão de novos bairros urbanos, como pode-se observar nas figuras abaixo:

\section{Figura 34: Construção de Shopping Center em Bom Jesus (PI)}

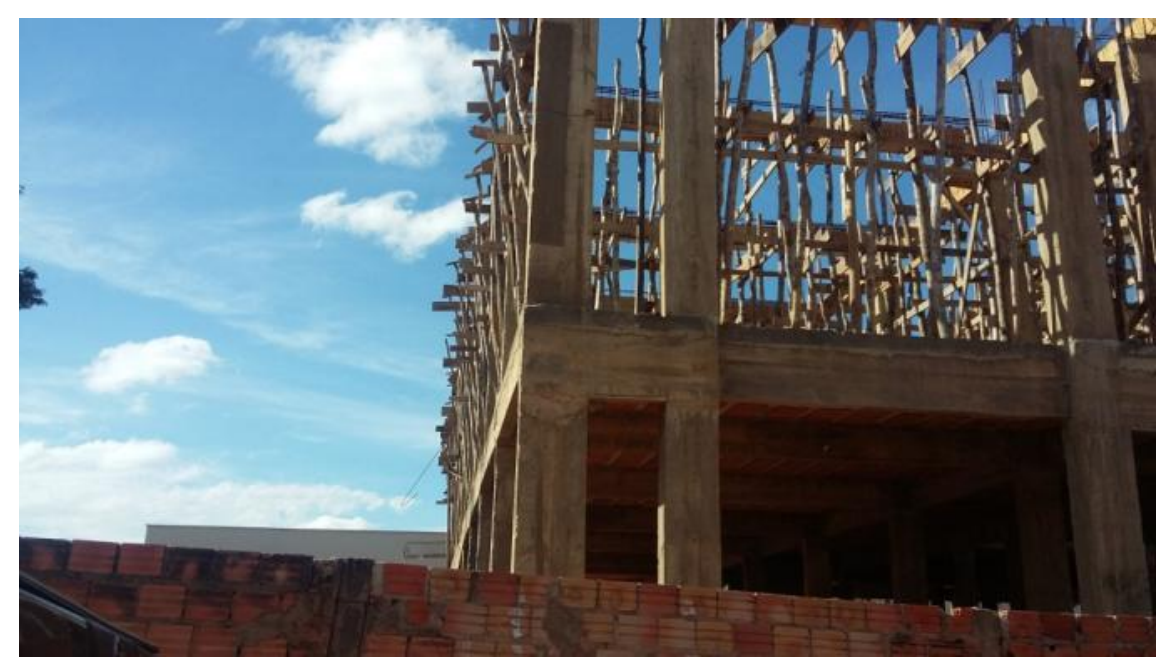

Fonte: oautor, (2015).

Figura 35: Obra de construção civil presente em Bom Jesus

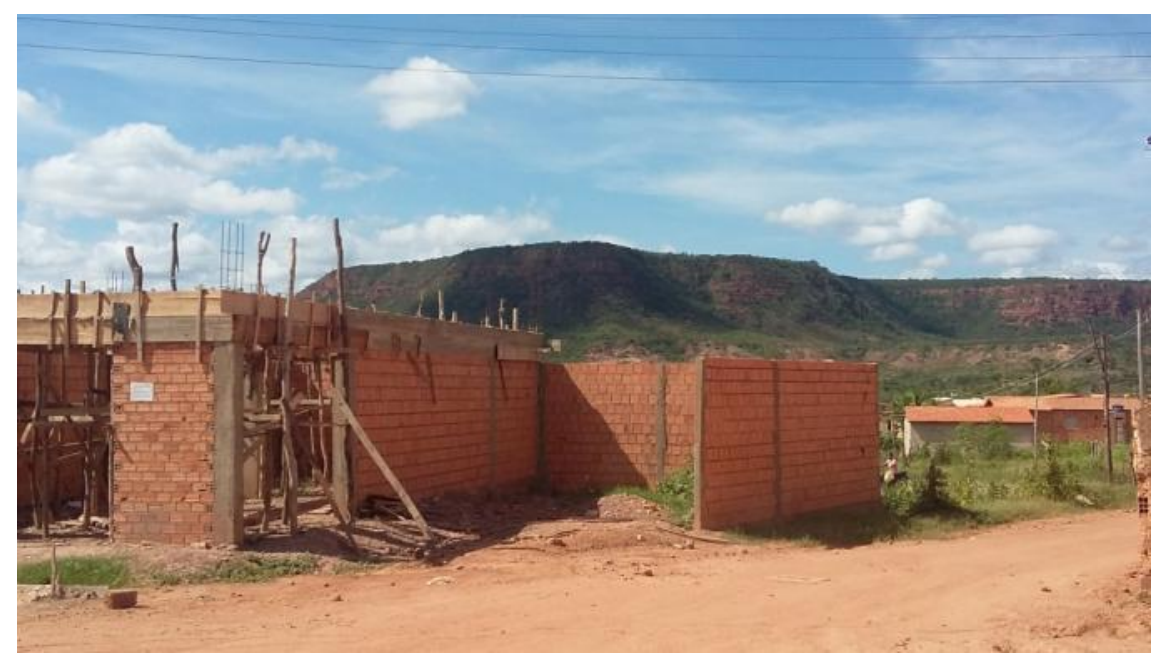

Fonte: o autor, (2015).

Bom Jesus, portanto, vem sofrendo transformações na paisagem urbana com o surgimento de empreendimentos diferenciados das demais cidades, como, por exemplo, de um Shopping Center. Em uma das saídas de campo, conversamos informalmente com o pedreiro Cleidson, baiano, que estava em Bom Jesus trabalhando em uma obra no Condomínio Consórcio das Águas I, e que afirmou que “[...] das cidades do Piauí, Bom Jesus é a melhor na geração de empregos." 
Alves (2005) aborda a questão do surgimento de processos migratórios nas cidades do agronegócio no Piauí, sobretudo em Bom Jesus e Uruçuí, dizendo que

\begin{abstract}
Além dos sulistas, o movimento de modernização provocou um aumento do fluxo de outros grupos em direção das áreas urbanas, sobretudo de camponeses desses municípios que perderam suas terras por conta da expansão agrícola moderna. Essas áreas também receberam trabalhadores de outros lugares do estado atraídos pela propaganda que se faz a respeito das cidades piauienses do agronegócio. As novas oportunidades de ocupação que alimentaram as esperanças dos novos moradores dessas cidades, além de serem insuficientes, são geradas principalmente para aquelas profissões especializadas: tratoristas, técnicos agrícolas, veterinários, agrônomo, mecânicos, etc. O restante da população - os não especializados ou os agricultores de subsistência e, freqüentemente, seus filhos - pouco se insere na nova economia sul piauiense. (ALVES, 2005, p.8).
\end{abstract}

Consideramos que novos moradores são atraídos para Bom Jesus não apenas pelos trabalhos especializados, mas também em busca de trabalho no comércio da região, no setor de serviços e na área de construção civil, como é o caso do pedreiro Cleidson, de quem coletamos o depoimento já mencionado. Para retratar a questão da urbanização também em relação às possibilidades de expansão das cidades, trazemos os dados da tabela abaixo: 
Tabela 32: Cadastro Nacional de endereços para fins estatísticos (2010)

\begin{tabular}{|c|c|c|c|c|c|}
\hline Microrregião & Municípios & $\begin{array}{c}\text { Total de } \\
\text { endereços }\end{array}$ & $\begin{array}{c}\text { Total de } \\
\text { endereços } \\
\text { urbanos }\end{array}$ & $\begin{array}{c}\text { Total de } \\
\text { endereços } \\
\text { rurais }\end{array}$ & $\begin{array}{c}\text { Total de } \\
\text { edificações } \\
\text { em } \\
\text { construção }\end{array}$ \\
\hline \multirow{4}{*}{$\begin{array}{c}\text { Alto Parnaíba } \\
\text { Piauiense }\end{array}$} & $\begin{array}{c}\text { Baixa Grande do } \\
\text { Ribeiro }\end{array}$ & 3.681 & 2.260 & 1.421 & 159 \\
\hline & Ribeiro Gonçalves & 2.429 & 1.604 & 825 & 64 \\
\hline & Santa Filomena & 2.421 & 1.519 & 872 & 103 \\
\hline & Uruçuí & 7.955 & 6.132 & 1.823 & 392 \\
\hline \multirow{11}{*}{$\begin{array}{l}\text { Alto Médio } \\
\text { Gurguéia }\end{array}$} & Alvorada do Gurguéia & 2.003 & 684 & 1.319 & 88 \\
\hline & Barreiras do Piauí & 1.179 & 740 & 139 & 60 \\
\hline & Bom Jesus & 9.159 & 7.137 & 1.996 & 708 \\
\hline & Cristino Castro & 4.071 & 2.853 & 1.218 & 112 \\
\hline & Currais & 1.683 & 379 & 1.304 & 45 \\
\hline & Gilbués & 3.880 & 2.465 & 1.415 & 227 \\
\hline & Monte Alegre & 3.615 & 1.224 & 2.391 & 203 \\
\hline & Palmeira & 2.045 & 786 & 1.259 & 57 \\
\hline & Redenção do Gurguéia & 3.072 & 1.996 & 1.106 & 171 \\
\hline & Santa Luz & 2.239 & 1.250 & 989 & 80 \\
\hline & $\begin{array}{c}\text { São Gonçalo do } \\
\text { Gurguéia }\end{array}$ & 1.134 & 528 & 606 & 53 \\
\hline $\begin{array}{c}\text { Chapadas do } \\
\text { Extremo Sul } \\
\text { Piauiense } \\
\end{array}$ & Corrente & 9.805 & 6.367 & 3.438 & 491 \\
\hline
\end{tabular}

Fonte: IBGE Cidades, dados do Censo de 2010, elaborada pelo autor.

Percebe-se que a cidade com a maior quantidade de endereços urbanos é Bom Jesus, com um total de 7.137, o que representa $77 \%$ dos endereços totais - mesma porcentagem de Uruçuí - e, além disso, evidencia o caráter predominantemente urbano dessa cidade. Corrente, apesar de possuir a maior parte dos endereços totais, por ser o mais populoso de todos, possui $65 \%$ dos endereços urbanos. A grande maioria dos municípios elencados possui a maior parte dos endereços urbanos, porém com número significativo de endereços rurais.

Em relação ao total de edificações em construção, Bom Jesus destaca-se mais uma vez, com um total de 708 construções, que é um dado contrastante com os outros municípios. Destaca-se também o caso de Gilbués e Monte Alegre, que, apesar de serem pequenos municípios, apresentaram um número significativo de construções. 
A qualificação da mão de obra das diferentes cidades da área de estudo é outro fator de análise importante. Observemos a tabela abaixo:

Tabela 33: Grau de formação dos ocupados- 18 anos ou mais (2010)

\begin{tabular}{|c|c|c|c|c|}
\hline Microrregião & Municípios & $\begin{array}{c}\text { \% ocupados com } \\
\text { fundamental } \\
\text { completo }\end{array}$ & $\begin{array}{c}\text { \% dos ocupados } \\
\text { com médio } \\
\text { completo }\end{array}$ & $\begin{array}{c}\% \text { ocupados } \\
\text { com superior } \\
\text { completo } \\
\end{array}$ \\
\hline \multirow{4}{*}{$\begin{array}{c}\text { Alto Parnaíba } \\
\text { Piauiense }\end{array}$} & Baixa Grande do Ribeiro & 39,33 & 24,22 & 4,83 \\
\hline & Ribeiro Gonçalves & 41,81 & 28,00 & 9,06 \\
\hline & Santa Filomena & 29,79 & 18,49 & 6,09 \\
\hline & Uruçuí & 49,28 & 33,09 & 8,14 \\
\hline \multirow{11}{*}{$\begin{array}{c}\text { Alto Médio } \\
\text { Gurguéia }\end{array}$} & Alvorada do Gurguéia & 43,75 & 26,02 & 8,97 \\
\hline & Barreiras do Piauí & 42,56 & 23,59 & 8,50 \\
\hline & Bom Jesus & 52,06 & 37,03 & 12,11 \\
\hline & Cristino Castro & 36,07 & 21,09 & 5,85 \\
\hline & Currais & 30,04 & 16,37 & 2,89 \\
\hline & Gilbués & 42,78 & 23,30 & 9,14 \\
\hline & Monte Alegre & 40,80 & 28,52 & 7,32 \\
\hline & Palmeira & 28,44 & 17,12 & 3,26 \\
\hline & Redenção do Gurguéia & 43,72 & 24,50 & 7,62 \\
\hline & Santa Luz & 42,51 & 27,32 & 5,74 \\
\hline & $\begin{array}{c}\text { São Gonçalo do } \\
\text { Gurguéia }\end{array}$ & 43,56 & 27,65 & 7,20 \\
\hline $\begin{array}{c}\text { Chapadas do } \\
\text { Extremo Sul } \\
\text { Piauiense }\end{array}$ & Corrente & 52,70 & 37,87 & 13,85 \\
\hline
\end{tabular}

Fonte: IBGE Cidades, elaborada pelo autor.

A situação da qualificação da mão de obra nos municípios da área de estudo é extremamente delicada, pois nota-se percentuais elevados em todos os municípios de trabalhadores com ensino fundamental incompleto, abaixo inclusive da média nacional. $\mathrm{Na}$ área de estudo, Corrente e Bom Jesus, respectivamente, são os municípios com os maiores percentuais de ocupados com fundamental completo, seguidos pelo município de Uruçuí. Nos percentuais referentes ao número de ocupados com ensino médio completo, Corrente, Bom Jesus e Uruçuí, são que mais se destacam. A situação se altera quando observamos os percentuais de ocupados com ensino superior completo: Corrente e Bom Jesus permanecem 
com os maiores quantitativos, mas Gilbués, com 9,14\%, figura como o terceiro município, o que, de certa forma, confirma a sua relevância no contexto da área de estudo.

O destaque de Bom Jesus, Corrente e Uruçuí é claro reflexo da realidade de cada uma das três cidades, pois são polos receptores de grande quantidade de estudantes universitários. Inclusive, o município de Corrente supera a média nacional de ocupados com nível superior, que é de 13,19\%. Além disso, essas cidades recebem também uma grande quantidade de profissionais da educação que trabalham nas instituições de ensino públicas e privadas. Somase, a isso, o fato de concentrarem migrantes sulistas, que, de acordo com Haesbaert (1997), normalmente são pessoas com nível de escolaridade maior que os índices das populações locais dos municípios do agronegócio. É importante, por conseguinte, analisarmos o quantitativo referente às regiões de nascimento da área de estudo, o que podemos observar na tabela abaixo: 
Tabela 34: População Residente por lugar de Nascimento

\begin{tabular}{|c|c|c|c|c|c|}
\hline Municípios & $\begin{array}{c}\text { Região } \\
\text { Centro } \\
\text { Oeste }\end{array}$ & $\begin{array}{c}\text { Região } \\
\text { Nordeste }\end{array}$ & $\begin{array}{l}\text { Região } \\
\text { Norte }\end{array}$ & $\begin{array}{l}\text { Região } \\
\text { Sudeste }\end{array}$ & Região Sul \\
\hline $\begin{array}{c}\text { Baixa Grande } \\
\text { do Ribeiro }\end{array}$ & 88 & 10.135 & 76 & 55 & 107 \\
\hline $\begin{array}{c}\text { Ribeiro } \\
\text { Gonçalves }\end{array}$ & 3 & 3.316 & - & 7 & 18 \\
\hline Santa Filomena & 77 & 5.872 & 53 & 15 & 12 \\
\hline Uruçuí & 259 & 19.087 & 234 & 170 & 110 \\
\hline $\begin{array}{c}\text { Alvorada do } \\
\text { Gurguéia }\end{array}$ & 50 & 2.319 & 6 & 22 & 8 \\
\hline $\begin{array}{c}\text { Barreiras do } \\
\text { Piauí } \\
\end{array}$ & 72 & 3.130 & 10 & 3 & 18 \\
\hline Bom Jesus & 846 & 20.877 & 46 & 347 & 455 \\
\hline Cristino Castro & 139 & 4.731 & 6 & 46 & 22 \\
\hline Currais & 46 & 2.155 & 11 & 8 & 6 \\
\hline Gilbués & 302 & 9.972 & 6 & 40 & 41 \\
\hline Monte Alegre & 340 & 9.902 & 9 & 72 & 15 \\
\hline Palmeira & 54 & 4.915 & - & 12 & 8 \\
\hline $\begin{array}{c}\text { Redenção do } \\
\text { Gurguéia }\end{array}$ & 357 & 7.970 & 3 & 48 & 23 \\
\hline Santa Luz & 50 & 2.566 & 9 & 21 & - \\
\hline $\begin{array}{c}\text { São Gonçalo do } \\
\text { Gurguéia }\end{array}$ & 70 & 2.700 & 12 & 33 & - \\
\hline Corrente $^{61}$ & 775 & 24.254 & 68 & 224 & 65 \\
\hline Total & 3.528 & 133.913 & 549 & 1.123 & 908 \\
\hline
\end{tabular}

Fonte: IBGE Cidades, 2010.

É importante analisar o quantitativo de pessoas de pessoas de outras regiões presentes nos municípios da área de estudo por conta das questões migratórias, pois a presença dos chamados sulistas ou "gaúchos" 62 impõe novas realidades ao comércio, à estrutura das cidades e a sua vida urbana, principalmente nos centros urbanos do agronegócio. Nesse caso, observa-se que a área de estudo possui um quantitativo representativo de pessoas com origem do Centro-Oeste, o que se explica pelo fato da maior parte desses municípios possuírem grande ligação com Brasília, já que, até pouco tempo atrás, muitas mães buscavam serviços de saúde nessa cidade, de maneira que muitas crianças nasceram na capital brasileira.

${ }^{61}$ Único município selecionado dessa microrregião, como já justificado anteriormente.

${ }^{62}$ Muitas vezes, os moradores locais das cidades da área de estudo denominam a maior parte dos novos moradores como gaúchos, não importando o seu local de nascimento. 
Certamente Monte Alegre, Gilbués e Redenção do Gurguéia são reflexo dessa ligação com Brasília. Assim, o número de pessoas com origem no Centro-Oeste não revela muito sobre a dinâmica do agronegócio. Bom Jesus, Corrente e Uruçuí, respectivamente, são os municípios com o maior quantitativo de pessoas da região Centro-Oeste do país. Bom Jesus ocupa este posto ainda que não seja o município mais populoso, o que pode ser consequência do maior dinamismo da cidade. Esse fato propõe um novo panorama demográfico em Bom Jesus, que, de acordo com Conte (2013), reflete a tendência atual de acréscimo populacional das cidades médias brasileiras, e também da maior participação que essas cidades vem desempenhando nos diferentes setores da economia brasileira.

Nota-se um número expressivo de pessoas provenientes da região Sudeste do país; Bom Jesus, Corrente e Uruçuí, respectivamente, são as cidades que mais receberam sudestinos. Uruçuí e Baixa Grande do Ribeiro contemplam o maior número de pessoas nortistas, certamente em função da maior proximidade do Maranhão e da forte ligação com o município de Balsas (MA), já mais próximo da realidade da região Norte, mas também da intensificação dos projetos de agricultura moderna, pois os dois municípios em questão são os maiores produtores de grãos da área de estudo.

O quantitativo mais relevante para a análise da realidade da área de estudo, porém, é de pessoas originárias da região Sul do Brasil; nota-se um quantitativo já bem expressivo na cidade de Bom Jesus, onde havia, em 2010, 455 "gaúchos", como são conhecidos na cidade. Se agruparmos as pessoas com origem na região Sudeste e Sul, Bom Jesus possui, ao todo, 802 "gaúchos". Atrelado a isso, é importante destacar que a maior presença de sulistas atribui um caráter singular à cidade, pois já se verifica inclusive o surgimento dos chamados "piúchos", que seriam uma mescla de piauienses com "gaúchos".

Desta forma, a cidade de Bom Jesus atualmente é caracterizada por uma situação complexa do ponto de vista demográfico, pois constantemente recebe migrantes de outras regiões do país, principalmente sulistas, bem como grande parcela da população que migra do campo para a cidade, e que normalmente se estabelece em bairros aos quais falta infraestrutura básica, como pode ser observado na figura abaixo: 


\section{Figura 36: Expansão da área urbana da cidade de Bom Jesus-PI}

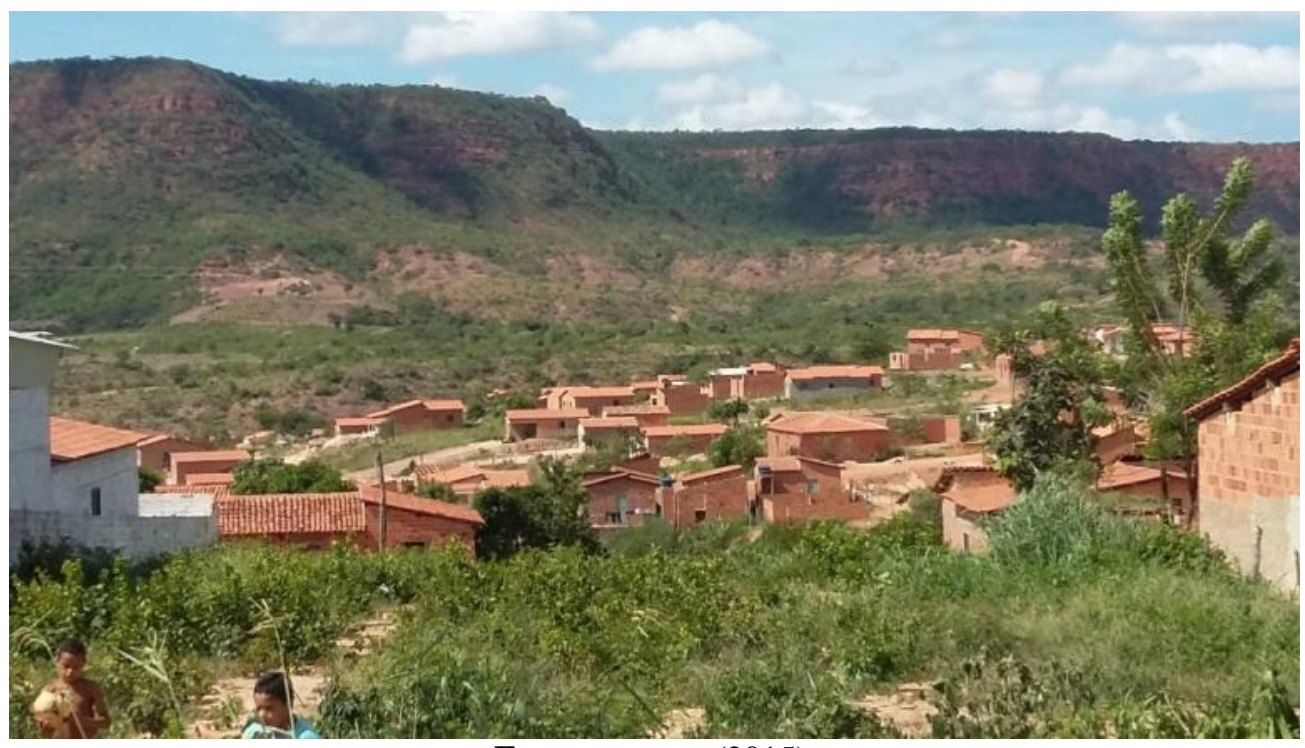

Fonte: o autor, (2015).

A migração de sulistas para a região dos Cerrados piauienses indica um novo marco no padrão de migração no país, em que migrantes sulistas ligados à agricultura moderna buscam a todo custo novas áreas para a produção de grãos. Dessa forma, deve-se considerar, de acordo com Santos (2004), que os tipos, formas e significações dos movimentos migratórios são diferenciados de acordo com os objetivos e diferentes situações. Além disso, que os diferentes elementos do espaço possuem valores diferenciados de acordo com a realidade de cada lugar. No quadro atual do Sudoeste Piauiense, há realidades semelhantes a outras regiões ligadas à agricultura moderna, mas há também características particulares em relação aos municípios integrantes (caráter ainda rural), aos atores locais e às características físicas diferenciadas do seu território.

Essas modificações no âmbito das cidades podem ser verificadas quando se identifica o aparecimento de novos tipos de comércio ligados à agricultura, aos sulistas e também ao grande capital, pois passa a existir comércio de insumos e máquinas agrícolas, além de mais agropecuárias, lojas de eletrodomésticos, restaurantes, empresas imobiliárias, concessionárias e revendedoras de motocicletas, carros, e especialmente caminhonetes (BRASIL, 2005). Surgem, ainda, churrascarias, supermercados, padarias, pousadas e hotéis, todos conectados ao crescimento do número de migrantes "gaúchos" nas novas áreas produtoras do Piauí. Essas novas tendências no comércio e serviços da cidade de Bom Jesus podem ser observadas na seguinte figura: 


\section{Figura 37: Churrascaria e hotel de alto padrão em Bom Jesus, próximo à BR-135-PI.}

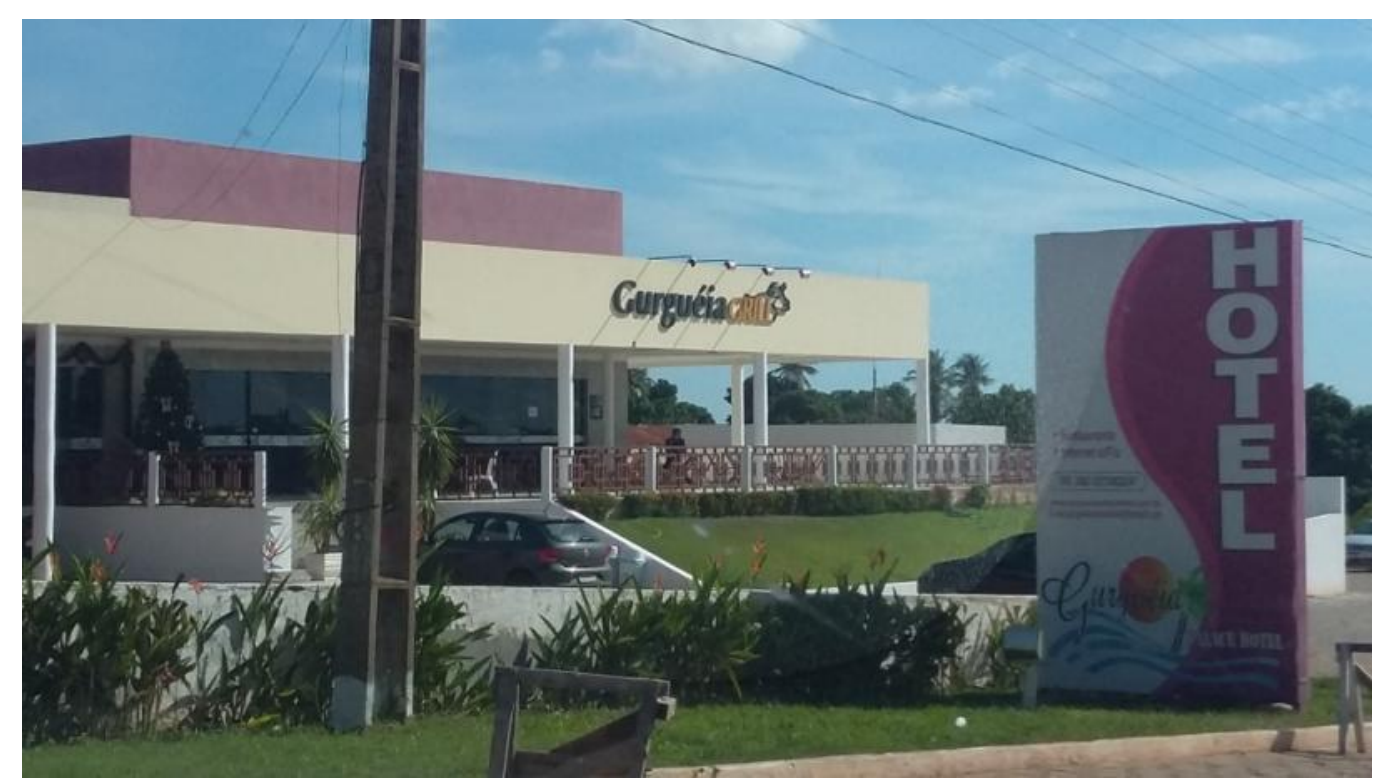

Fonte: o autor, (2015).

Essas transformações influenciam diretamente a atração de novos migrantes para os municípios que ganham destaque com o desenvolvimento do agronegócio, em busca de trabalho ou até mesmo como forma de investimento em função das oportunidades no comércio e serviços ligados ao agronegócio, o que acarreta dificuldades no planejamento da urbanização nessas áreas (ALVES, 2006). Nas palavras de Alves (2005) sobre Bom Jesus e Uruçuí,

É possível hoje, ao adentrar em qualquer supermercado desses municípios, encontrar erva mate para o preparo do chimarrão, ou deparar-se com pizzarias que vendem variedades de pizzas só encontradas no sul do Brasil, ou ainda, churrascarias com suas carnes preparadas ao estilo dos novos moradores. (ALVES, 2005, p.8).

Dentre as novas dinâmicas emergentes na rede urbana do Sudoeste Piauiense, pode-se destacar o caso da cidade de Bom Jesus, que teve elevado crescimento urbano, com a instalação de novas empresas, especialmente as associadas ao agronegócio, e para atendimento da demanda desse setor - maquinários agrícolas, de defensivos, fertilizantes e consultoria agrícola, como se pode observar nas fotos a seguir: 


\section{Figura 38: Loja especializada em atividades agropecuárias em Uruçuí-PI}

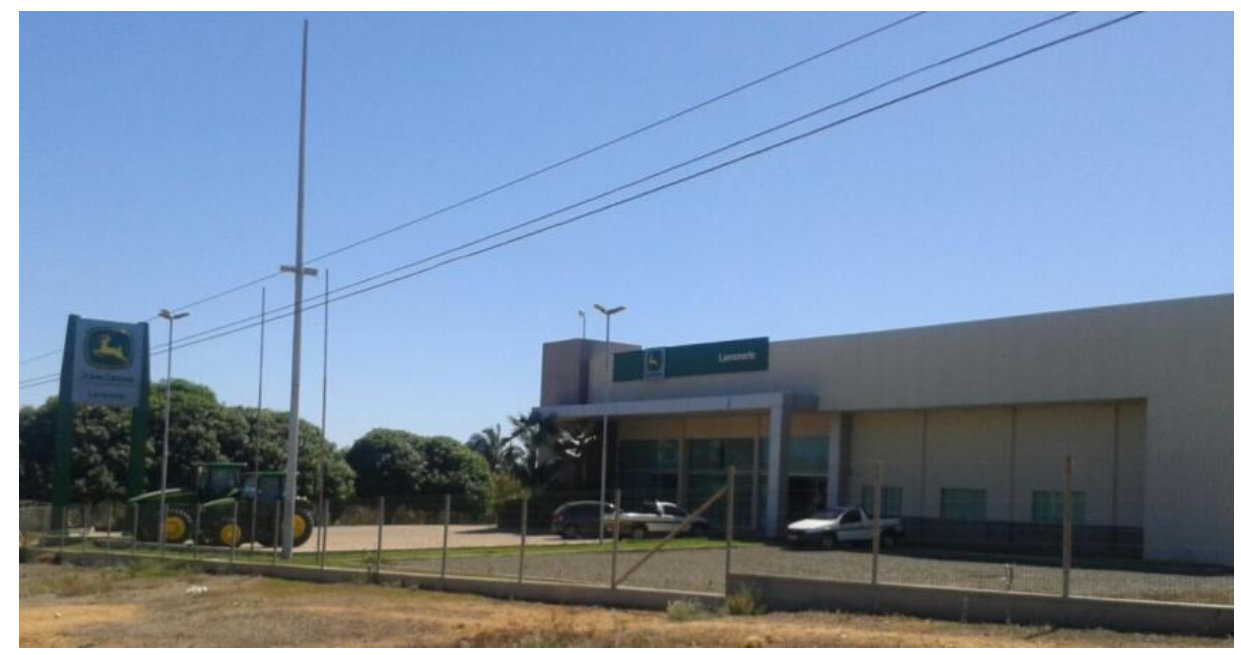

Fonte: o autor, (2015).

Figura 39: Loja especializada em atividades agropecuárias em Bom Jesus-PI

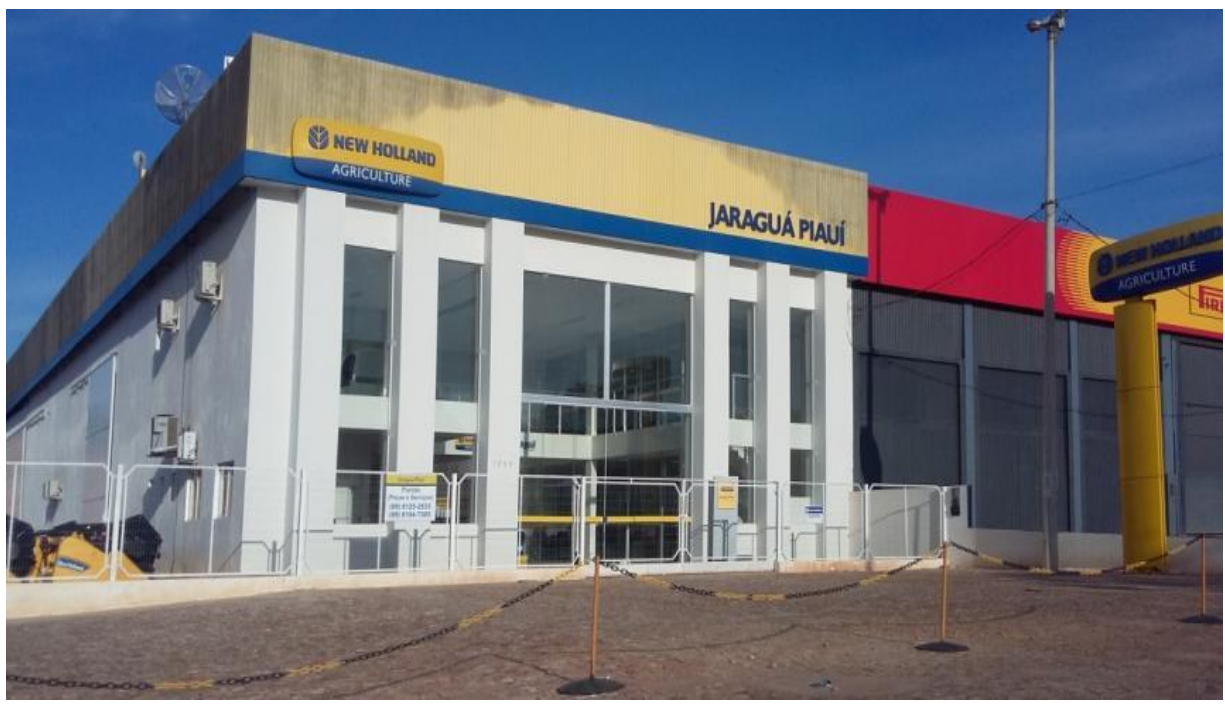

Fonte: o autor, (2015).

As imagens acima são claros exemplos das alterações nos serviços e comércio nas cidades de Bom Jesus e Uruçuí, com direcionamento às atividades agropecuárias da região e visando o atendimento das demandas do setor agropecuário, contribui diretamente para maior centralização das duas cidades, que, cada vez mais, passam a integrar o processo produtivo global da moderna agricultura, estabelecendo assim relações econômicas diferenciadas. As duas cidades do agronegócio do Piauí, nesse caso, são centros urbanos com serviços especializados para o atendimento da demanda do setor agropecuário, destacando-se em 
função da quantidade de empresas nos setores de comércio e serviços que fornecem insumos agrícolas, como pode ser notado na tabela abaixo:

Tabela 35: Origem dos insumos

\begin{tabular}{|c|c|c|c|}
\hline \multirow{2}{*}{ Microrregião } & \multirow{2}{*}{ Municípios } & \multicolumn{2}{|c|}{ Origem dos insumos (Município) } \\
\hline & & Soja & Milho \\
\hline \multirow{4}{*}{$\begin{array}{l}\text { Alto Parnaíba } \\
\text { Piauiense }\end{array}$} & $\begin{array}{c}\text { Baixa Grande do } \\
\text { Ribeiro }\end{array}$ & Floriano, Uruçuí & Floriano, Uruçuí \\
\hline & Ribeiro Gonçalves & Floriano, Uruçuí & Floriano, Uruçuí \\
\hline & Santa Filomena & Balsas (MA) & - \\
\hline & Uruçuí & Balsas (MA), Uruçuí & Balsas (MA), Uruçuí \\
\hline \multirow{11}{*}{ Alto Médio Gurguéia } & $\begin{array}{l}\text { Alvorada do } \\
\text { Gurguéia }\end{array}$ & $\begin{array}{c}\text { Bom Jesus, Antônio } \\
\text { de Almeida (PI), } \\
\text { Uruçuí }\end{array}$ & $\begin{array}{c}\text { Bom Jesus, Cristino } \\
\text { Castro }\end{array}$ \\
\hline & Barreiras do Piauí & - & - \\
\hline & Bom Jesus & $*$ & $*$ \\
\hline & Cristino Castro & - & Bom Jesus e Teresina \\
\hline & Currais & Bom Jesus, Uruçuí & - \\
\hline & Gilbués & Balsas (MA) & - \\
\hline & Monte Alegre & $\begin{array}{c}\text { Balsas (MA), Tasso } \\
\text { Fragoso (MA) }\end{array}$ & - \\
\hline & Palmeira & Bom Jesus & - \\
\hline & $\begin{array}{c}\text { Redenção do } \\
\text { Gurguéia }\end{array}$ & - & - \\
\hline & Santa Luz & & $\begin{array}{c}\text { Bom Jesus, Cristino } \\
\text { Castro }\end{array}$ \\
\hline & $\begin{array}{l}\text { São Gonçalo do } \\
\text { Gurguéia }\end{array}$ & - & - \\
\hline $\begin{array}{c}\text { Chapadas do } \\
\text { Extremo Sul } \\
\text { Piauiense }\end{array}$ & Corrente & $*$ & $*$ \\
\hline
\end{tabular}

Fonte: IBGE (2008), REGIC 2007. (*) Centros de Zona A

Verifica-se que as cidades inseridas no Alto Parnaíba Piauiense são atendidas, no geral, pelos insumos de Uruçuí. Já no Alto Médio Gurguéia é a cidade de Bom Jesus a grande fornecedora de insumos agrícolas no que se refere à soja e milho. Assim, as duas cidades exercem o comando das ações em relação ao atendimento das demandas do setor primário da economia dos municípios da área de estudo. É possível notar, também, grande influência de Balsas (MA) como fonte de insumos agrícolas, o que evidencia a ligação entre as cidades presentes no MATOPIBA. 
Em conjunto com as modificações demográficas e na economia urbana dessas cidades, verificou-se, nos trabalhos de campo, que a cidade de Bom Jesus é a que mais se destaca em relação ao comércio e serviços diferenciados, como, por exemplo, empreendimentos comerciais modernos:

Figura 40: Loja vinculada à construção civil em Bom Jesus

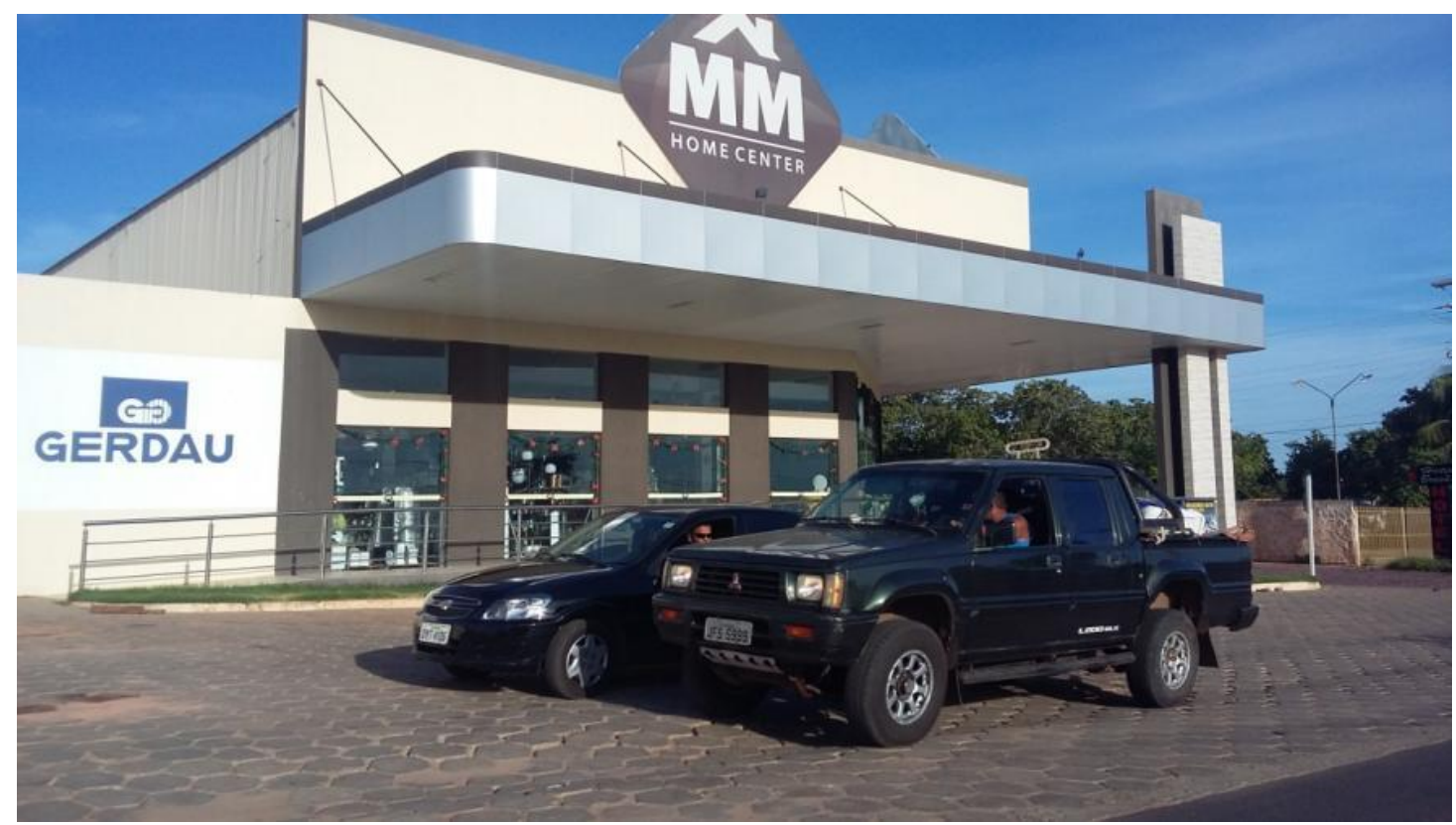

Fonte: o autor, (2015).

Substituindo o padrão 'materiais para construção' ou 'casa de construção', surgem as lojas com status mais modernos, agora denominadas "Home Center", evidenciando um padrão totalmente diferenciado das demais cidades presentes na área de estudo e, de certa forma, expondo a tentativa de transmissão de que a modernidade e o progresso se instalam em Bom Jesus. Além disso, nota-se o surgimento de laboratórios médicos e clínicas de saúde privadas, como observado nas figuras abaixo: 
Figura 41: Laboratório Médio em Bom Jesus-PI

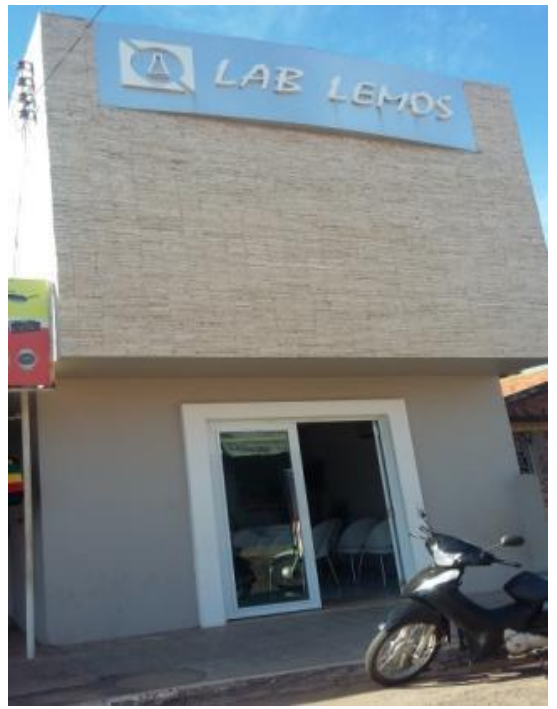

Fonte: o autor, (2015).
Figura 42: Clínica em Bom Jesus-PI

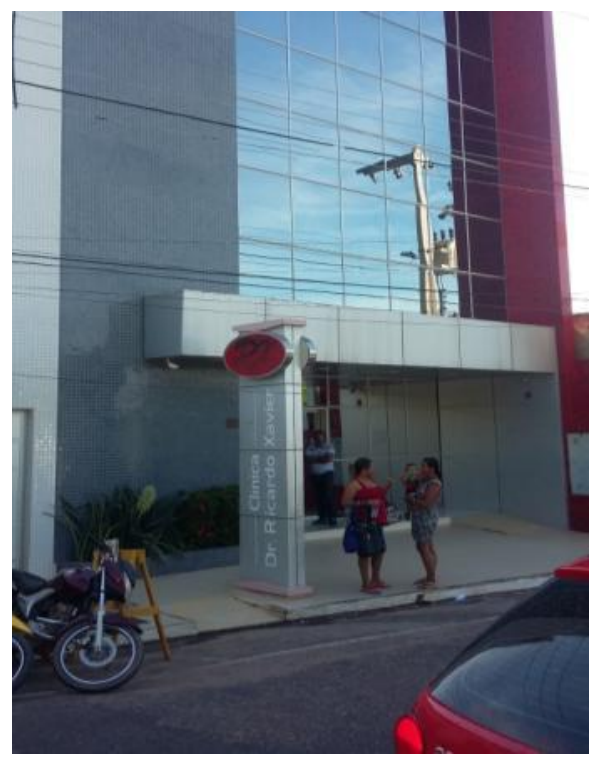

Fonte: o autor, (2015).

A oferta de tais serviços específicos, bem como o tamanho físico da cidade - em expansão e recebendo novos agentes - torna Bom Jesus completamente diferenciada em relação às demais cidades. Observemos a figura a seguir, exemplo de uma loja diferenciada:

Figura 43: Boutique em Bom Jesus

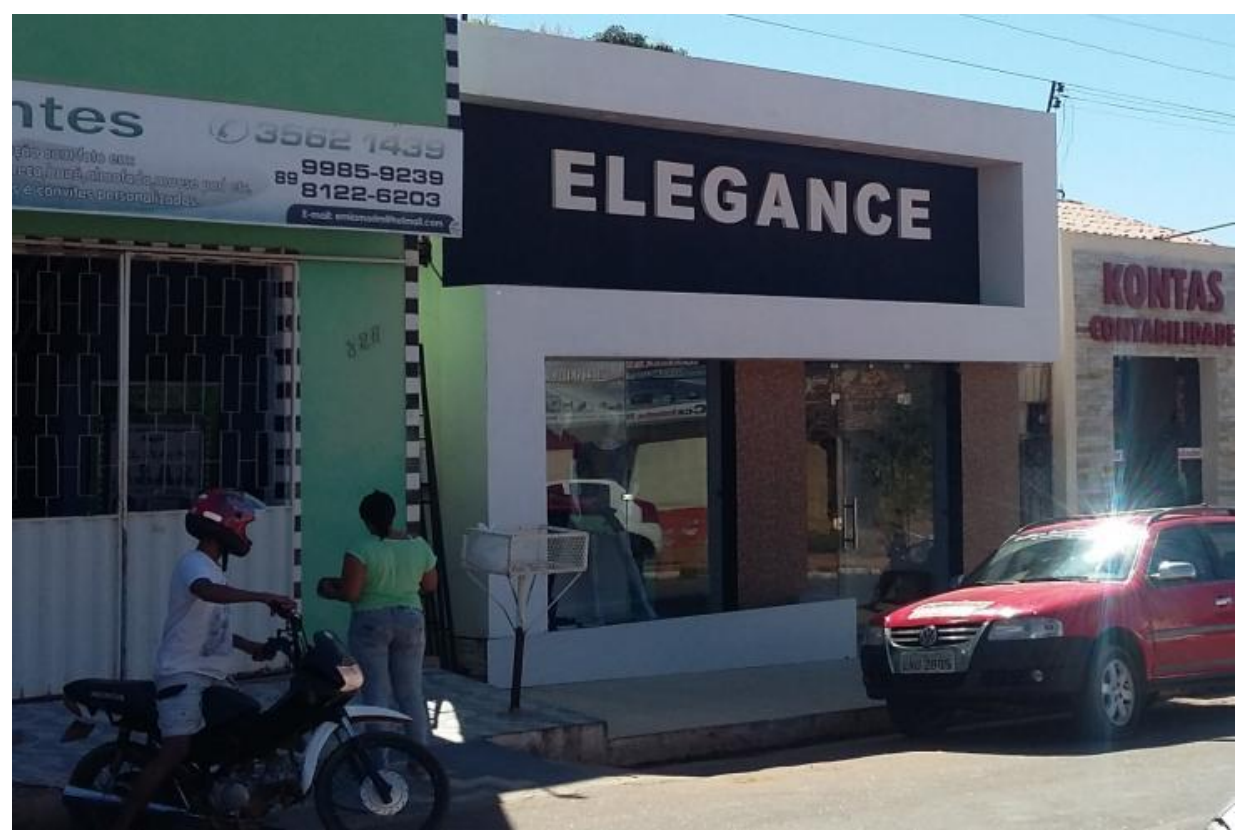

Fonte: o autor, (2015). 
Lojas como a retratada na figura, que revendem marcas mais caras, são destinadas ao atendimento da classe média do agronegócio, ou seja, apenas uma pequena parcela da população de Bom Jesus. Como o município é também uma cidade universitária, não raro os atendentes e vendedores das lojas são estudantes que se veem obrigados a trabalhar para custear as despesas do dia a dia.

Na figura abaixo, observa-se presença de uma rede de ótica, de origem maranhense, em Bom Jesus:

Figura 44: Redes de óticas de Brasília presente em Bom Jesus

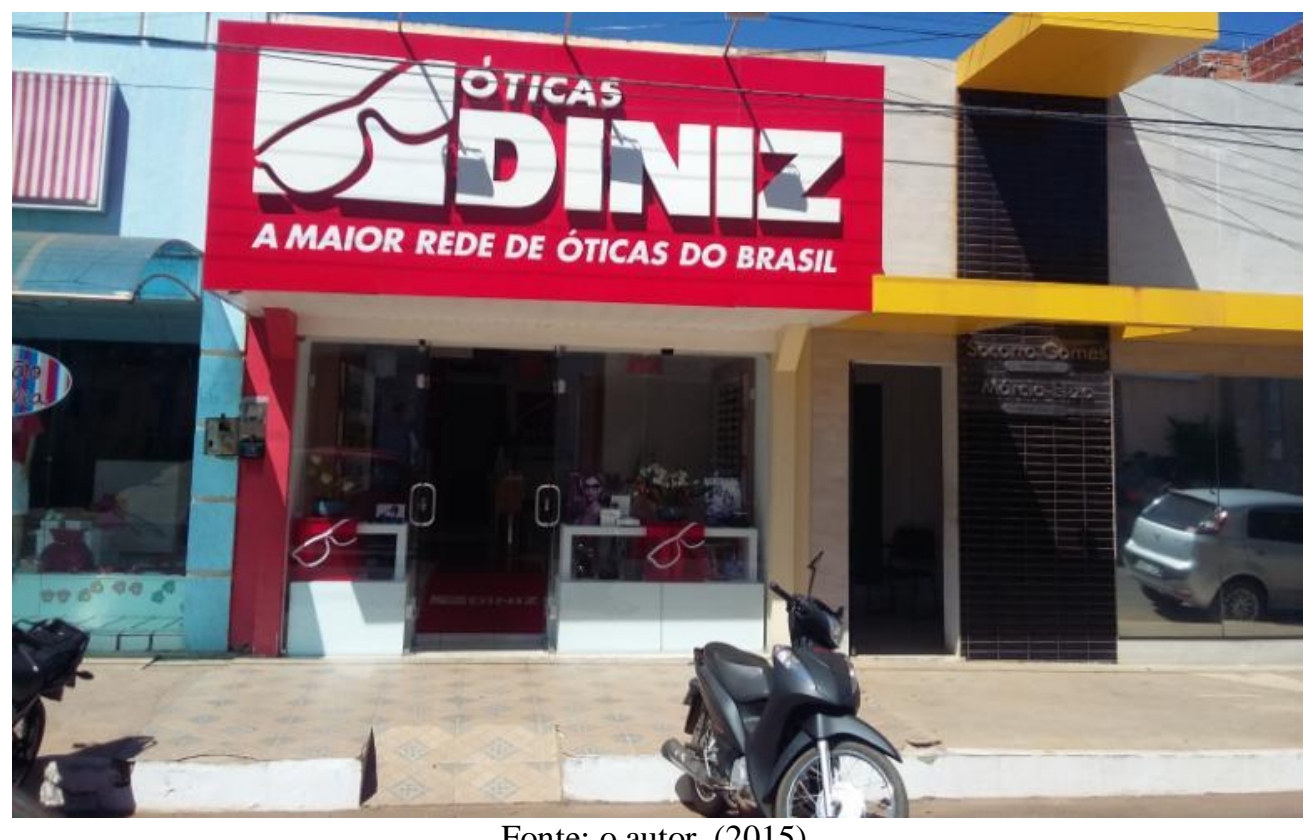

Fonte: o autor, (2015).

Pressupõe-se que Bom Jesus foi selecionada pela rede de ótica devido ao maior dinamismo econômico e a sua urbanização. Essa figura retrata uma das tendências das diferentes cidades do agronegócio: as mesmas dispõem de comércios e serviços semelhantes, praticamente com a instalação das mesmas lojas e empresas, o que caracteriza um domínio hegemônico do comércio das cidades do agronegócio. Diante disso, Uruçuí e Bom Jesus, principalmente esta última, passam a receber os mesmos tipos de comércio e serviços verificados, por exemplo, em Luís Eduardo Magalhães ou em Balsas.

Notamos que Uruçuí, em comparação com Bom Jesus, é um espaço mais pacato, no qual não se verifica a mesma movimentação de veículos, e com o comércio menos desenvolvido. $\mathrm{Na}$ imagem abaixo, observa-se a avenida comercial da cidade, com elementos diferenciados em relação à rede de cidades: 
Figura 45: Avenida Comercial da Cidade de Uruçuí-PI

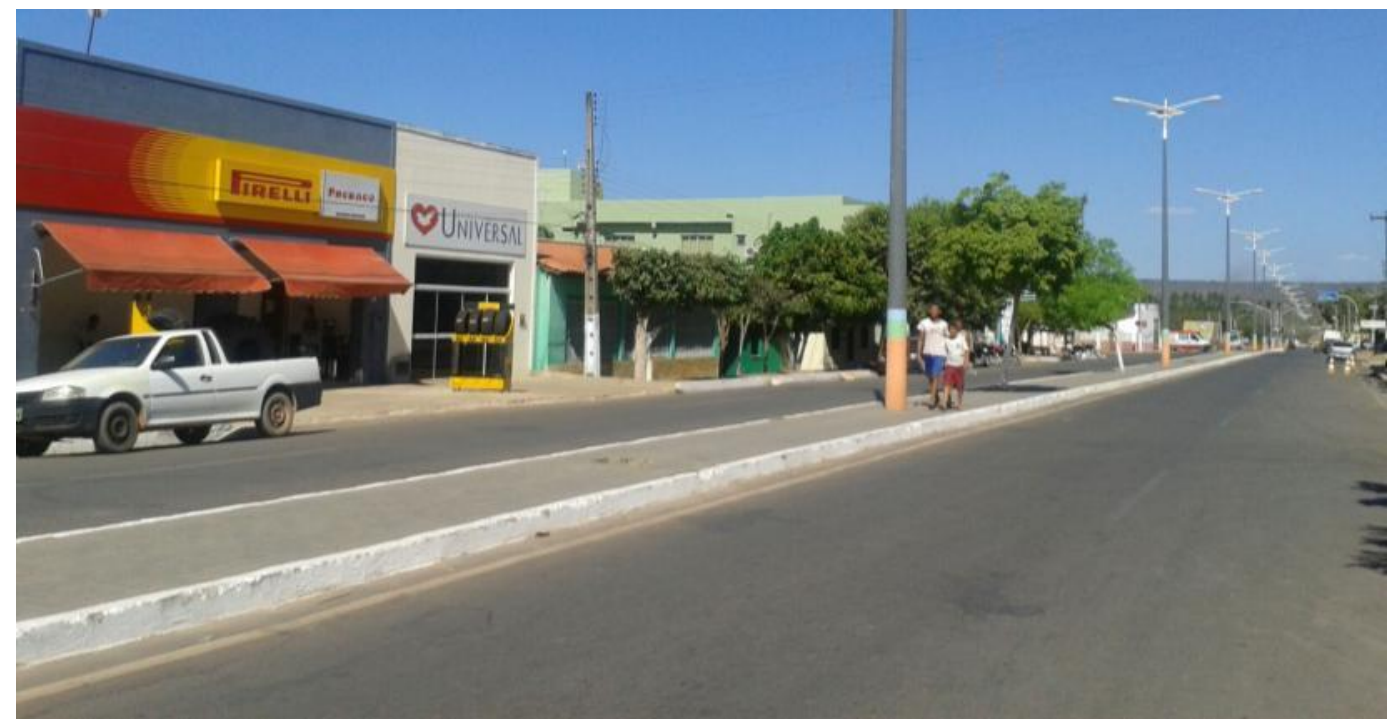

Fonte: o autor, (2015).

Constatou-se, no trabalho de campo e na coleta dos dados apresentados, que a cidade de Corrente ainda desempenha um papel de grande relevância no cenário dos Cerrados piauienses, no que diz respeito ao comércio e serviços, principalmente pela concentração de equipamentos urbanos, como bancos, instituições públicas e instituições de ensino. No entanto, com as transformações verificadas em Bom Jesus, Corrente passa a perder centralidade para essa cidade. Como exemplo, tem-se o município de Monte Alegre do Piauí, Centro local, de acordo com o REGIC 2007, ligado à Gilbués, Centro de Zona B, que está atrelado à Corrente, e também sob a área de influência direta de Bom Jesus (PI), de maneira que o município se relaciona intensamente com as duas cidades. Os trabalhos de campo, porém, evidenciaram a tendência de que Monte Alegre passe a estabelecer mais relações com Bom Jesus, mesmo que sua localização seja mais próxima à Corrente, devido à grande centralização e crescimento da importância de Bom Jesus no cenário dos Cerrados piauienses.

A fim demonstrar a importância de Bom Jesus, Corrente e Uruçuí para a Mesorregião Sudoeste do Estado do Piauí, analisaremos agora os dados da tabela abaixo referentes ao destino dos transportes coletivos presentes nessas na área de estudo: 
Tabela 36: Destino transportes coletivos

\begin{tabular}{|c|c|c|}
\hline Microrregião & Municípios & Nome do município de destino \\
\hline \multirow{4}{*}{ Alto Parnaíba Piauiense } & Baixa Grande do Ribeiro & $\begin{array}{c}\text { Balsas (MA), Ribeiro Gonçalves, } \\
\text { Teresina, Uruçuí. }\end{array}$ \\
\hline & Ribeiro Gonçalves & $\begin{array}{c}\text { Teresina, Balsas, Uruçuí, Baixa } \\
\text { Grande do Ribeiro, }\end{array}$ \\
\hline & Santa Filomena & $\begin{array}{l}\text { Gibués, Balsas (MA), Alto } \\
\text { Parnaíba (MA) }\end{array}$ \\
\hline & Uruçuí & $\begin{array}{l}\text { Teresina, Bertolínea (PI), } \\
\text { Floriano, Jurumenha (PI), Balsas } \\
\text { (MA), São João dos Patos (MA) }\end{array}$ \\
\hline \multirow{11}{*}{ Alto Médio Gurguéia } & Alvorada do Gurguéia & $\begin{array}{l}\text { Teresina, Bom Jesus, Cristino } \\
\text { Castro, Canto do Buruti (PI), } \\
\text { Floriano (PI), São Raimundo } \\
\text { Nonato. }\end{array}$ \\
\hline & Barreiras do Piauí & Gilbués \\
\hline & Bom Jesus & $*$ \\
\hline & Cristino Castro & $\begin{array}{l}\text { Bom Jesus, Corrente, Teresina, } \\
\text { Palmeira do Piauí, Santa Luz, } \\
\text { São Raimundo Nonato. } \\
\end{array}$ \\
\hline & Currais & Bom Jesus \\
\hline & Gilbués & $\begin{array}{l}\text { Teresina, Barreiras (BA), } \\
\text { Corrente. }\end{array}$ \\
\hline & Monte Alegre & $\begin{array}{c}\text { Teresina, Gilbués, Corrente, Bom } \\
\text { Jesus }\end{array}$ \\
\hline & Palmeira & Bom Jesus, Cristino Castro \\
\hline & Redenção do Gurguéia & $\begin{array}{c}\text { Teresina, Bom Jesus, Avelino } \\
\text { Lopes, Curimatá, São Raimundo } \\
\text { Nonato. }\end{array}$ \\
\hline & Santa Luz & Bom Jesus, Cristino Castro \\
\hline & $\begin{array}{l}\text { São Gonçalo do } \\
\text { Gurguéia }\end{array}$ & $\begin{array}{c}\text { Teresina, Corrente, Gilbués, } \\
\text { Barreiras (BA) } \\
\end{array}$ \\
\hline $\begin{array}{c}\text { Chapadas do Extremo Sul } \\
\text { Piauiense }\end{array}$ & Corrente $^{63}$ & $*$ \\
\hline
\end{tabular}

Fonte: IBGE (2008), REGIC 2007. (*) Centro de Zona A

Verifica-se que Bom Jesus é o destino dos transportes coletivos da maior parte dos municípios listados, com exceção daqueles pertencentes à Microrregião Alto Médio Parnaíba Piauiense, estes mais ligados ao contexto maranhense, com a cidade de Balsas (MA) como principal destino. Outro município que possui destaque no Alto Médio Gurguéia é Corrente, que, no entanto, perde para Bom Jesus se analisarmos a totalidade dos dados da tabela.

Todas essas transformações dos espaços urbanos da área de estudo analisadas até o momento atribuem novas características a uma região ainda em processo de formação e reconfiguração. As cidades de Bom Jesus e Uruçuí ganham cada vez mais centralidade na

\footnotetext{
${ }^{63}$ Único município selecionado dessa microrregião, como já justificado anteriormente.
} 
escala mesorregional como consequência da concentração de agentes ligados ao agronegócio. Infere-se, então, que, implícita nesta centralidade existe a clara intenção dos principais agentes em relação à concentração das decisões internas, da produção, dos equipamentos urbanos, serviços ligados à saúde e educação (todos imbricados ao planejamento do Estado e de grandes corporações). Assim como afirmam COSTA e SUZUKI (2012),

[...] o planejamento e os instrumentos urbanísticos são, como recorda o termo, instrumentos e, por isso, manipulados e manipuláveis para o bem ou para o mal; caminho deve ser o da busca de uma nova existência da e para a humanidade, em nome de novas relações. (COSTA e SUZUKI, 2012, p.125).

Na visão de SOUZA (1999, p.12), “a cidade é uma intencionalidade”, e ainda o lugar da concentração das redes, da identificação, da coexistência da liberdade, e da vigilância, além de estarem ligadas ao controle do território. De acordo com Sampaio (2011, p.3), com efeito, "A cidade permite, mais do que qualquer outro lugar, e coexistência dos diferentes, albergando uma multiplicidade de redes, fluxos, de conexões, de projetos." Miranda (2012), por sua vez, destaca que, no caso das cidades agrícolas presentes nos Cerrados Nordestinos, o urbano funciona como uma espécie de implante, cuja função é suportar os serviços ligados à agricultura voltada para o mercado exterior. Alves (2005, p.1) corrobora essa ideia, destacando ainda que essas cidades "ganham centralidade diante do crescimento da agricultura produtivista."

Em consonância com Aguiar e Monteiro (2005), entendemos que a expansão da fronteira agrícola nas áreas dos Cerrados fundamenta-se justamente na alta produção de grãos voltada para o exterior, acompanhada de profundas alterações das paisagens rurais através do desmatamento, mecanização da agricultura, utilização de fertilizantes químicos e pouca utilização de mão de obra.

Neste caso, Bom Jesus é palco de transformações que dizem respeito ao padrão de migração, das atividades econômicas e de novas dinâmicas urbanas, como o aumento do setor de construção civil, como resultado da expansão física da cidade. Comparando as cidades da área de estudo, percebe-se que Corrente e Uruçuí, juntamente com Bom Jesus, sobressaem em relação ao setor de comércio e de serviços. No entanto, em Bom Jesus, nos trabalhos de campo realizados, nota-se um ritmo diferenciado em relação à dinâmica urbana. Notou-se, em Uruçuí, o foco na questão do agronegócio, de maneira que o ritmo da cidade e a vida urbana são ditados pelas necessidades da grande produção e dos agentes atrelados a essa atividade econômica. 


\subsection{Infraestrutura e Equipamentos Urbanos}

De acordo com Elias (2012), os novos agentes e dinamismos gerados a partir do agronegócio impõem novas necessidades em relação ao apoio no desenvolvimento dessa atividade econômica, exigindo assim reconfigurações e modernizações nas infraestruturas e equipamentos urbanos, que funcionam como suporte à sequência e maior fluidez da atividade econômica. Nesse caso, a autora cita alguns pontos relevantes a serem considerados em uma pesquisa:

[...] rodovias; ferrovias; rodoviárias; porto; aeroporto e voos comerciais regulares; terminais intermodais; shopping centers; hotéis de alto padrão pertencentes a redes nacionais e internacionais; existência ou não de distritos industriais; espaços fixos e transitórios para a promoção de eventos (festas, feiras, convenções); supermercados e hipermercados pertencentes a redes nacionais ou internacionais; fixos associados à rede bancária e financeira; empresas do setor imobiliário, entre outros. (ELIAS, 2012, p.14)

De acordo com Santos (1999),

[...] os novos subespaços são mais ou menos capazes de rentabilizar uma produção. Cada combinação tem sua própria lógica e autoriza formas de ação específicas aos agentes econômicos e sociais. As ações hegemônicas se estabelecem e se realizam por intermédio de objetos hegemônicos. Então, como num sistema de sistemas, o resto do espaço e o resto das ações são chamados a colaborar. (SANTOS, 1999, p.12).

A grande presença dos migrantes sulistas em Bom Jesus impacta diretamente o setor de comércio e de serviços e também o padrão de uso do espaço urbano, na questão da infraestrutura das habitações e no surgimento novos bairros urbanos para servirem de moradia para a classe média e alta dessa cidade. O município é dotado, assim, de infraestrutura e de um ritmo diferenciado das demais cidades de sua área de influência. Além disso, há diversos agentes que convivem na cidade, embora pratiquem tempos diferenciados. O paradoxo é perceptível quando se observa a presença de sulistas, que vivem nas áreas nobres, principalmente em condomínios fechados de alto padrão, em contraposição aos moradores locais. Além disso, o contraste também é observado nas pequenas atividades agropecuárias tradicionais locais em contraposição à grande produção advinda da agricultura moderna.

Para caracterizarmos o contexto atual do Sudoeste Piauiense, consideramos a ideia de SANTOS (2008), que defende que os diferentes agentes do atual mundo globalizado, dentre 
eles instituições, grupos e indivíduos, coabitam os mesmos espaços, porém não praticam o mesmo tempo. Nas palavras do autor,

[...] Grupos, instituições e indivíduos convivem juntos, mas não praticam os mesmos tempos. O território é, na verdade, uma superposição de sistemas de engenharia diferentemente datados e, hoje, usados segundo tempos diversos. [...] os ritmos de cada qual- empresas e pessoas- não são os mesmos. Talvez fosse mais correto utilizar aqui o termo temporalidade em vez da palavra tempo. (SANTOS, 2008, p.42).

Nesse sentido, há desigualdade e conflito entre atores hegemônicos e não hegemônicos. Nota-se, por exemplo, em Bom Jesus, o surgimento de bairros onde se concentra a população pobre, originária da zona rural de vários municípios, em contraposição ao surgimento de bairros destinados de bairros nobres, com infraestrutura moderna e com casas de luxo, como pode ser observado nas figuras abaixo:

\section{Figura 46: Entrada do Condomínio Consórcio das Águas- Bom Jesus}

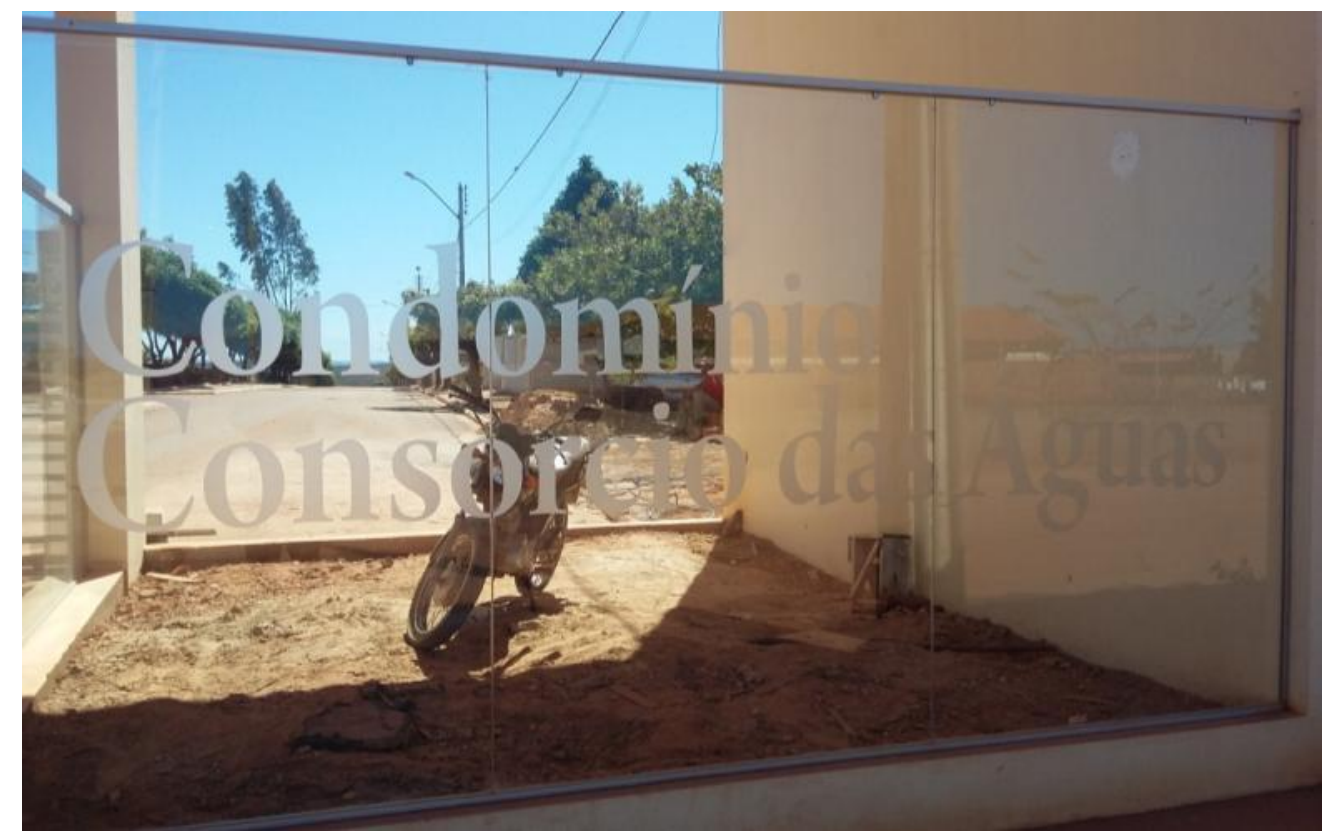

Fonte: o autor, (2015).

Na figura acima, observa-se a entrada do Condomínio Consórcio das Águas I, que serve como residência para classe média do agronegócio, que contempla agricultores, professores das universidades federais, engenheiros, empresários locais, banqueiros, etc. Nota-se um padrão de moradia totalmente diferenciado do restante da cidade, como pode ser observado na foto abaixo, que mostra uma moradia de alto padrão dentro do condomínio residencial: 
Figura 47: Casa de alto padrão do Condomínio Consórcio das Águas

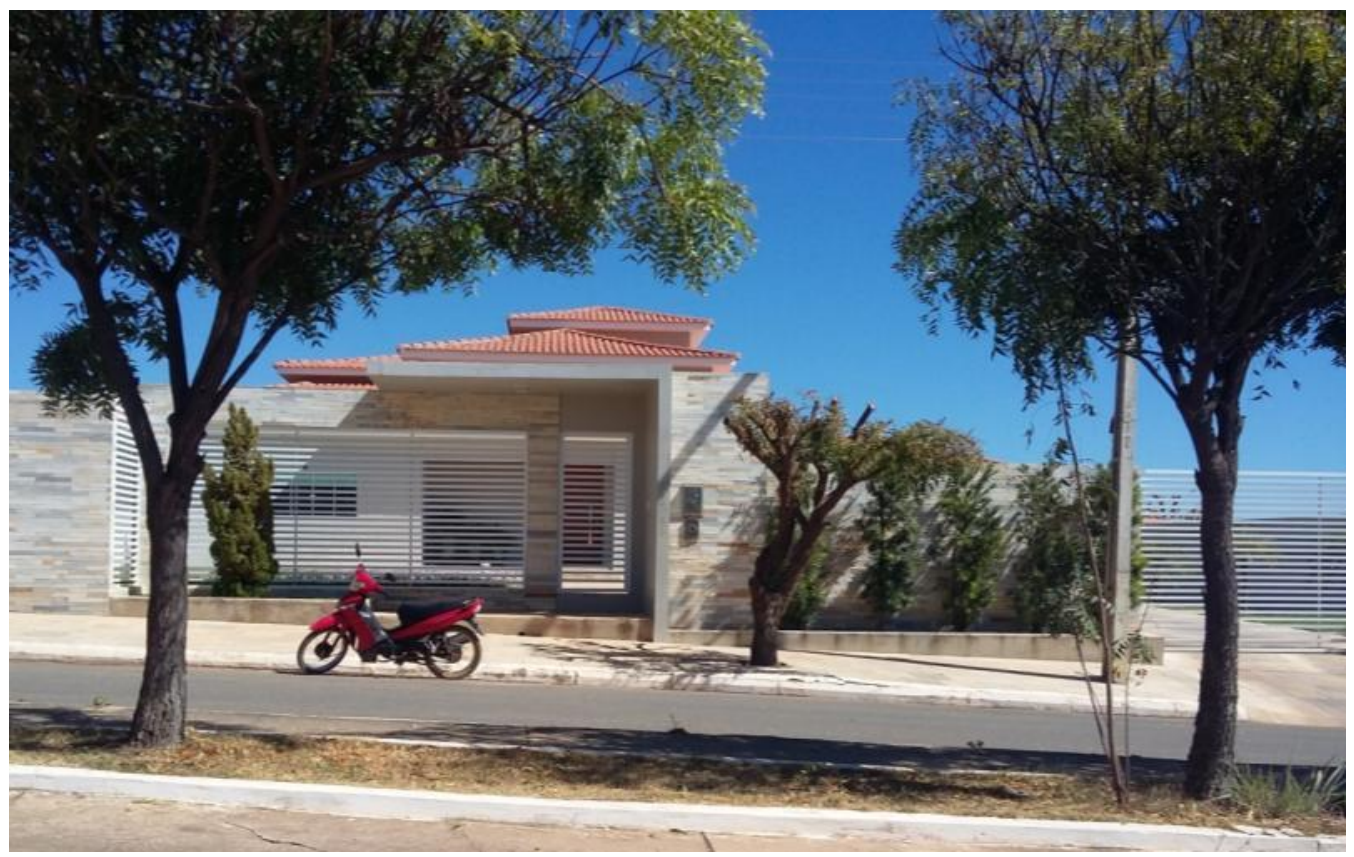

Fonte: o autor, (2015).

A impressão que tivemos dentro do condomínio é a de que estávamos em outra realidade, totalmente diferenciada do restante da cidade, o que reflete a grande desigualdade socioespacial presente em Bom Jesus, bem como a tendência verificada nas áreas com reestruturação produtiva agrícola, como apontamos nos capítulos anteriores, com as teorias, por exemplo, de Elias (2006b) e Alves (2005), que sustentam que o agronegócio produz efeitos contraditórios, excludentes e influenciam diretamente na ampliação das desigualdades sociais. Este último autor fala, inclusive, sobre a formação de "ilhas da riqueza" e "ilhas da pobreza" em uma mesma cidade do agronegócio.

Em Bom Jesus, observou-se que os moradores do novo condomínio possuem preocupação extrema com a segurança mesmo em um local de moradia fechado, como pode ser observado na figura abaixo: 
Figura 48: Casas com cercas elétricas no Condomínio Consórcio das Águas

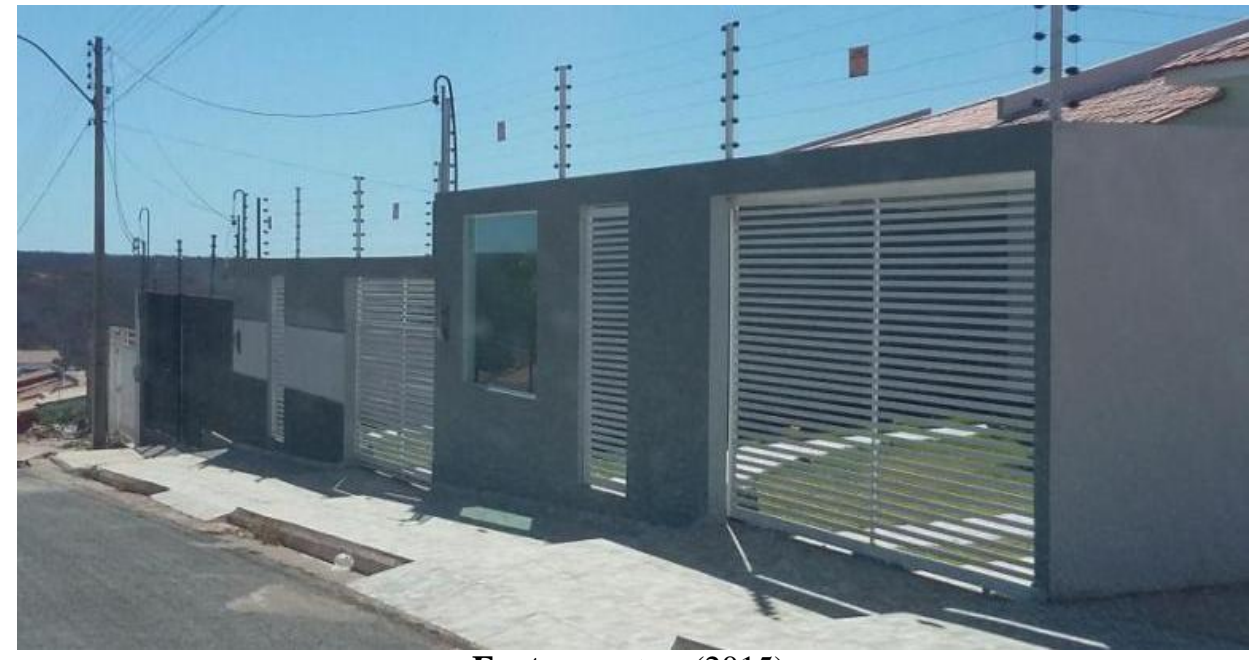

Fonte: o autor, (2015).

A preocupação com a segurança foi verificada tantos em bairros de alto padrão como nos de baixo padrão, como é o caso do Condomínio Consórcio das Águas II, que ainda não é uma área fechada. Além disso, os novos moradores acabam alterando o padrão das moradias da cidade por meio da maior valorização da questão estética, como podemos notar na figura abaixo, com o desenho do portão:

\section{Figura 49: Residência no Condomínio Consórcio das Águas II}

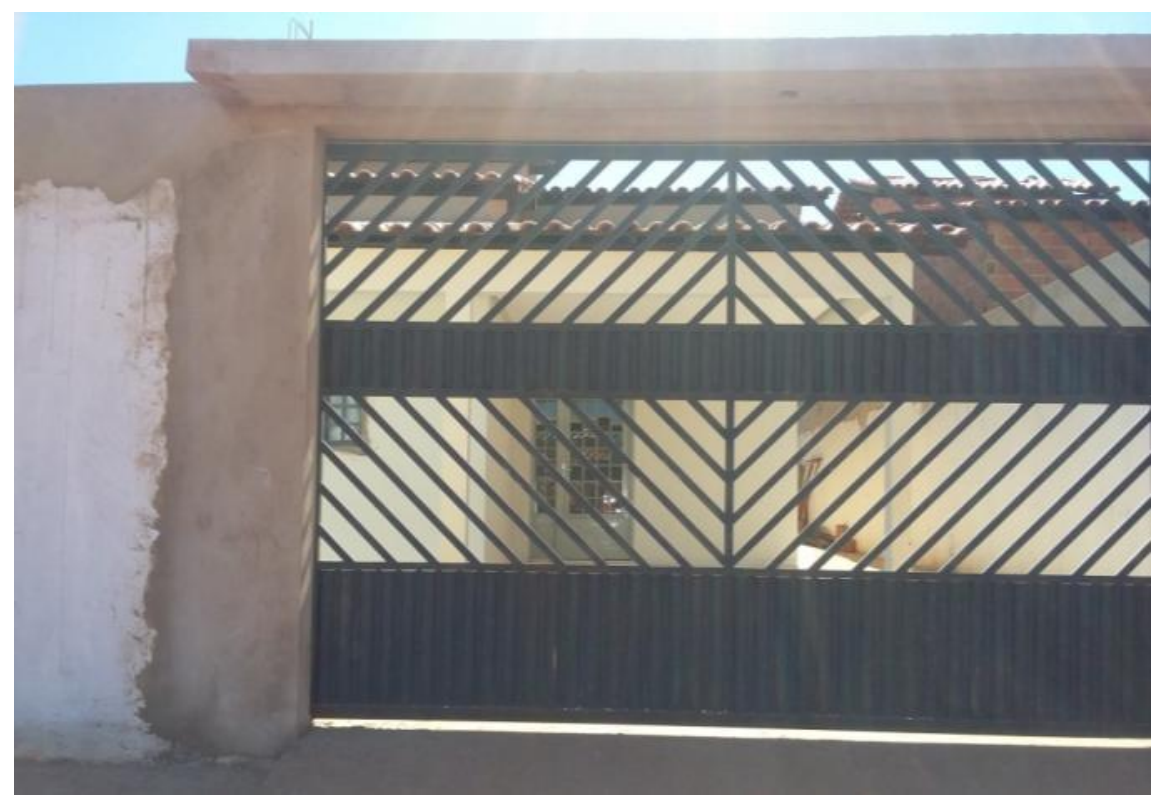

Fonte: o autor, (2015).

Portanto, de acordo com Costa (2011), é preciso entender que as diferenças entre setores urbanos em uma cidade refletem o processo especulativo da terra urbana baseados na 
implementação diferenciada dos serviços e equipamentos urbanos para os diferentes atores presentes na escala do urbano. Assim, a diferenciação entre bairros urbanos em Bom Jesus-PI reflete a atenção especial do Estado na implementação de infraestrutura necessária aos bairros dos mais ricos e a negligência dos segmentos mais pobres da cidade, o que reflete a tendência das cidades do agronegócio e constitui uma característica intrínseca do processo de modernização da agricultura. De acordo com as proposições de Alves (2005), nas cidades do agronegócio cria-se uma face moderna e outra atrasada. No Piauí, Bom Jesus é um claro exemplo disso, pois se verifica o surgimento de condomínios de alto padrão, em contraposição ao surgimento de bairros periféricos. A fala de Costa (2011) pode ser corroborada se compararmos as fotos anteriores do condomínio Consórcio das Águas I com a figura abaixo:

\section{Figura 50: Ruas sem asfaltamento em Bom Jesus-PI}

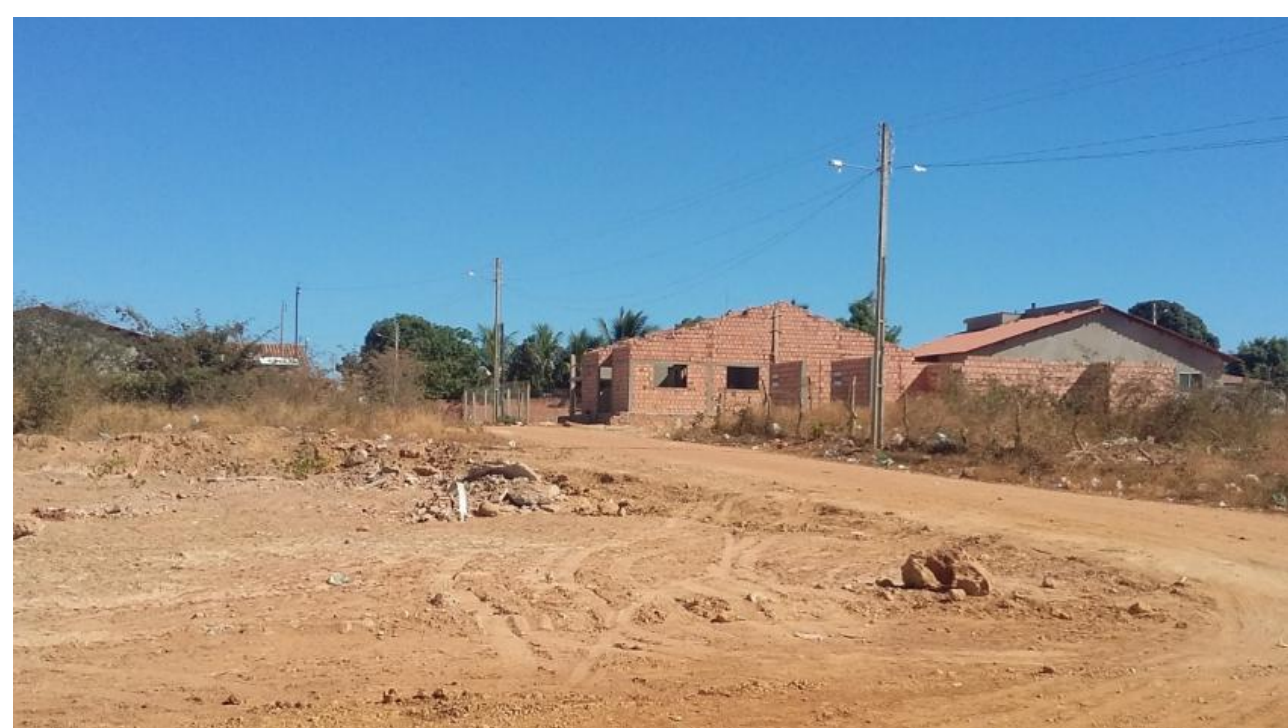

Fonte: o autor, (2015).

Nesse caso, observa-se clara diferenciação socioespacial na cidade de Bom Jesus, onde os bairros de alto padrão possuem boa infraestrutura e os bairros da população com menor renda são desprovidos de condições básicas como o asfaltamento das ruas. Em concordância com as ideais de Alves (2005), confirma-se então a tendência de criação de "ilhas" de alto dinamismo em meio a uma imensidão pobre e estagnada nas cidades do agronegócio, reforçando, assim, as diferenciações espaciais. Nas palavras de Santos (2008, p.41), "Nesse mundo refeito, pode-se falar em tempos hegemônicos e em tempos nãohegemônicos. O tempo hegemônico é o da ação e dos atores hegemônicos, e o tempo não hegemônico é o da ação e dos atores não hegemônicos. 
Outra questão a ser considerada é a ligação entre a moderna agricultura e setor de transporte. Nesse sentido, o agronegócio impõe a necessidade de melhorias e implementação de rodovias para o transporte da produção. A principal rodovia para o transporte da produção no Piauí é a BR-135, que atravessa grande parte do Estado. Pode-se observar um trecho da rodovia na figura abaixo:

\section{Figura 51: Trecho da BR-135-PI}

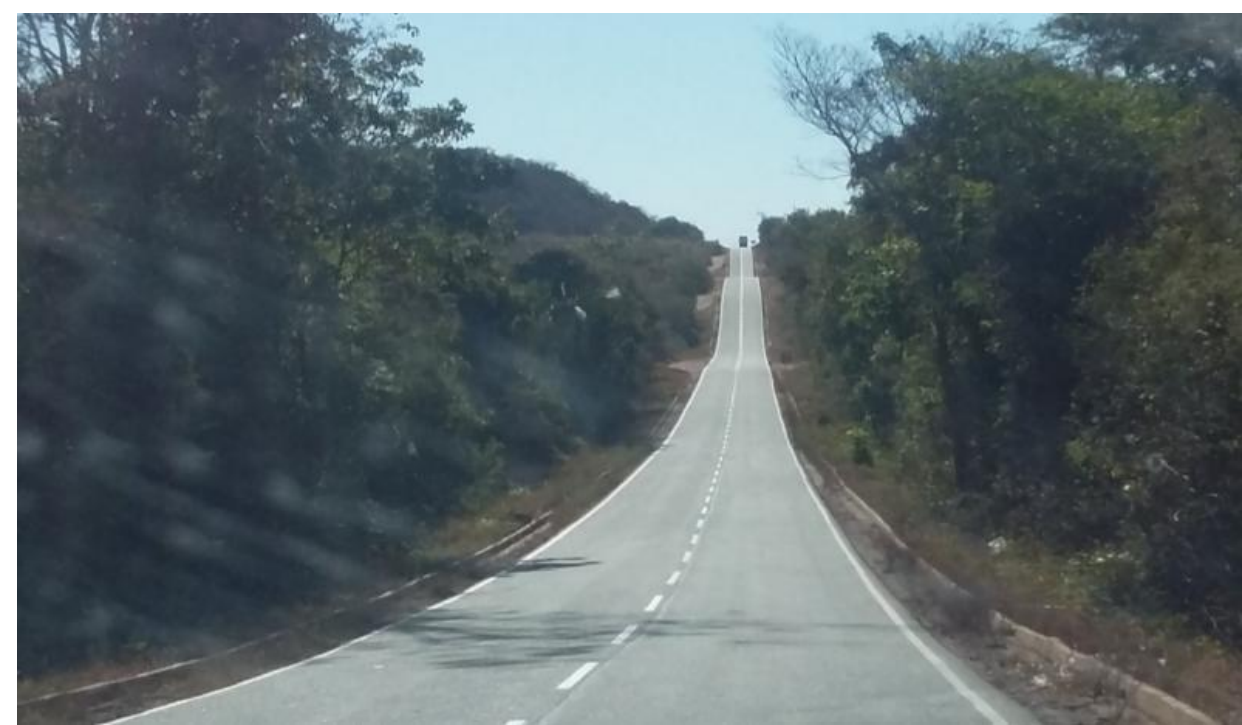

Fonte: o autor, (2015).

A BR-135 revela-se muito importante para a porção sul do Estado do Piauí, pois a maior parte das cidades está localizada nas suas proximidades, mas apresenta inúmeros problemas, como o estreitamento da pista, a manutenção insuficiente, e consequentemente, a ocorrência de muitos acidentes, pois nessa pista trafegam com muita intensidade motocicletas e grandes carretas e caminhões de cargas. Tal problemática foi apontada nos trabalhos de campo como um dos grandes problemas para a produção.

No entanto, já se observa a atuação do Estado na implementação de novas infraestruturas visando a inserção de novas áreas do Sudoeste Piauiense na dinâmica da agricultura moderna. Sendo assim, como já afirmamos, o Estado vem atuando de forma a atender os interesses de grandes agentes econômicos e sociais ligados ao agronegócio, visto que vem implantando infraestrutura necessária aos grandes projetos de agricultura moderna do Estado, além de oferecer inúmeros incentivos fiscais aos grandes agricultores e empresas hegemônicas.

Nos Cerrados Piauienses, observa-se a construção de novas rodovias, como a BR-235PI (Gilbués- Santa Filomena) e a PI-397, conhecida como Transcerrados, visando o melhor 
escoamento da produção agrícola do Estado do Piauí. Além disso, podem-se notar avanços nas áreas de comunicação. Este contexto caracteriza a ótica das relações de transporte e comunicação como fatores de "anulação do espaço pelo tempo" (HARVEY, 2005).

Surge, também, nas cidades agrícolas piauienses, novas formas e equipamentos urbanos, como a construção de estabelecimentos de ensino de educação superior e escolas técnicas, com cursos vinculados à produção da agricultura moderna, como engenharia agronômica, engenharia florestal, veterinária, administração e técnicos agrícolas, o que revela a ótica de transformação das bases estruturais defendidas por Elias (2011).

Nesse âmbito, citaria as casas de comércio de implementos agrícolas, sementes, grãos e fertilizantes; os escritórios de marketing e de consultoria contábil; os centros de pesquisa biotecnológica; as empresas de assistência técnica e de transportes de cargas; os serviços de especialista em engenharia genética, veterinária, administração, meteorologia, agronomia, economia, administração pública; os cursos técnicos de nível médio e os cursos superiores voltados ao agronegócio, entre tantas outras atividades (ELIAS, 2011, p.159).

Em relação aos equipamentos e infraestruturas associados à educação profissional/técnica e superior, elaboramos a seguinte tabela para demonstrar o quantitativo com os dados referentes a esses elementos do espaço: 
Tabela 37: Número de Estabelecimentos de Ensino Superior, Técnico/Profissional da área de estudo.

\begin{tabular}{|c|c|c|c|c|}
\hline Microrregião & Municípios & $\begin{array}{c}\text { Estabelecimentos } \\
\text { Ensino Superior } \\
\text { Públicos } \\
\end{array}$ & $\begin{array}{c}\text { Estabelecimentos } \\
\text { Ensino Superior } \\
\text { Privados } \\
\end{array}$ & $\begin{array}{c}\text { Institutos de } \\
\text { Educação } \\
\text { Profissional }\end{array}$ \\
\hline \multirow{4}{*}{$\begin{array}{l}\text { Alto Parnaíba } \\
\text { Piauiense }\end{array}$} & Baixa Grande do Ribeiro & - & - & - \\
\hline & Ribeiro Gonçalves & - & - & - \\
\hline & Santa Filomena & - & - & - \\
\hline & Uruçuí & 2 & 1 & 1 \\
\hline \multirow{11}{*}{$\begin{array}{c}\text { Alto Médio } \\
\text { Gurguéia }\end{array}$} & Alvorada do Gurguéia & - & - & - \\
\hline & Barreiras do Piauí & - & - & - \\
\hline & Bom Jesus & 3 & 2 & 1 \\
\hline & Cristino Castro & - & - & - \\
\hline & Currais & - & - & - \\
\hline & Gilbués & 1 & & \\
\hline & Monte Alegre & - & - & - \\
\hline & Palmeira & - & - & - \\
\hline & Redenção do Gurguéia & 1 & & \\
\hline & Santa Luz & - & - & - \\
\hline & $\begin{array}{c}\text { São Gonçalo do } \\
\text { Gurguéia }\end{array}$ & - & - & - \\
\hline $\begin{array}{c}\text { Chapadas do } \\
\text { Extremo Sul } \\
\text { Piauiense } \\
\end{array}$ & Corrente $^{64}$ & 2 & 1 & 1 \\
\hline
\end{tabular}

Fonte: MEC, 2015. http://emec.mec.gov.br/;

A partir da tabela, pode-se notar que as instituições de ensino superior e técnico profissional estão bem concentradas em algumas cidades, sobretudo nas ligadas ao agronegócio globalizado, como Bom Jesus, Uruçuí e também Corrente, centro educacional e pecuário do Sul do Piauí.

Começaremos a análise com Corrente, que, segundo os dados da tabela, possui um total de cinco instituições no total: a Universidade Estadual do Piauí (UESPI), que oferece os cursos de Agronomia, Ciências Biológicas, Direito, Pedagogia e Zootecnia; a Universidade Aberta do Brasil (UAB), vinculada à Universidade Federal do Piauí (UFPI) e à Universidade Estadual do Piauí (UESPI); a Universidade Estadual do Piauí, que oferece os cursos de

\footnotetext{
${ }^{64}$ Único município selecionado dessa microrregião, como já justificado anteriormente.
} 
Pedagogia, Administração Pública, Letras/Espanhol, Ciências Biológicas e cursos de pósgraduação na área de Gestão Publica Municipal e de gestão em Saúde; a UFPI, que oferece os cursos de Filosofia, Matemática e Pedagogia; e, por fim, o Instituto Federal de Educação do Piauí (PI), que ministra os cursos Técnico em Agronegócio e Técnico em Informática. Nas figuras abaixo, é possível observar as fotos de algumas dessas instituições:

\section{Figura 52: UAB- Corrente-PI}

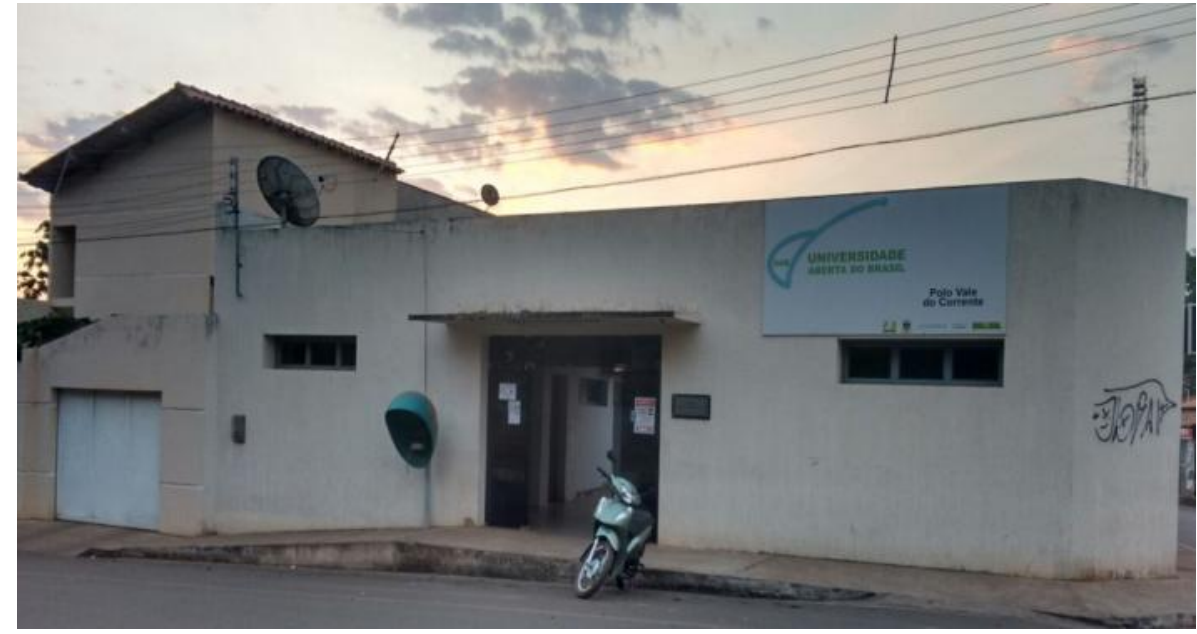

Fonte: o autor, (2015).

Figura 53: Campus IFPI- Corrente

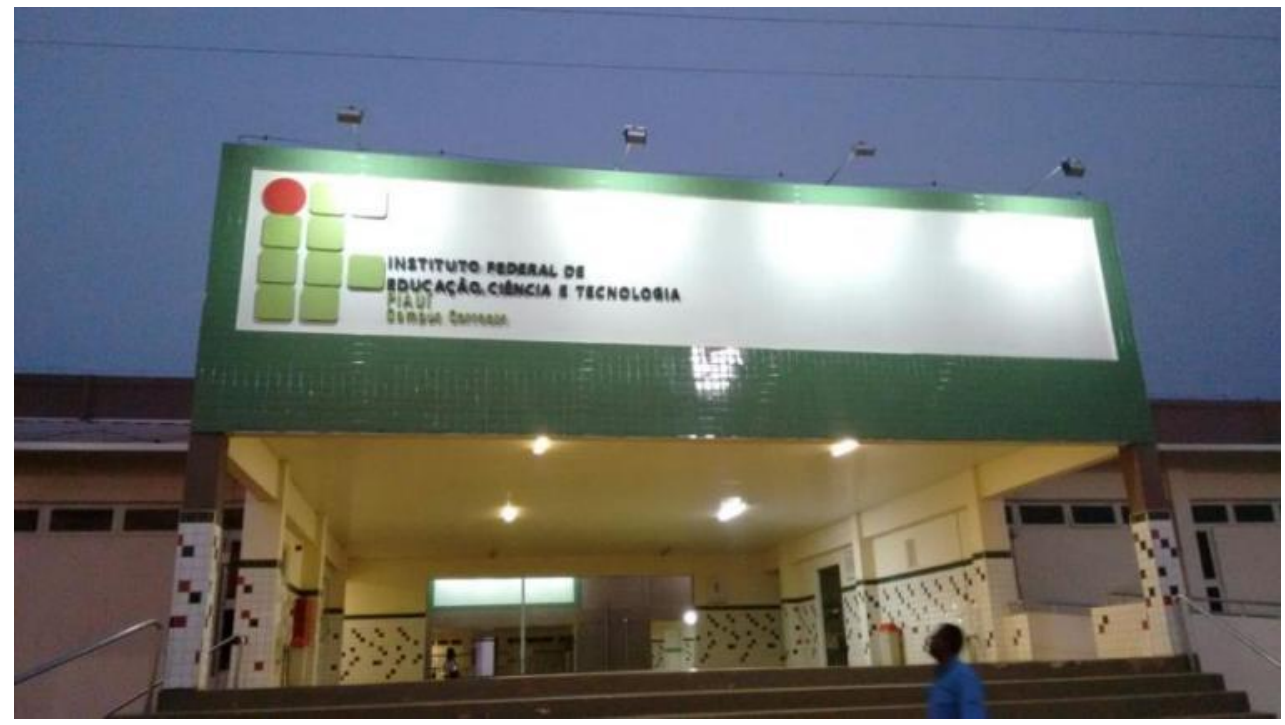

Fonte: o autor, (2015).

Corrente também conta com a Faculdade dos Cerrados Piauienses, que oferece os cursos de Direito, Ciências Contábeis, Administração e Letras/Português, além de outras instituições ligadas ao ensino, como o Serviço Nacional de Aprendizagem Industrial (SENAI) 
e algumas escolas particulares que atraem grande quantidade de estudantes de outras cidades vizinhas, como Júlio Borges, Cristalândia, Monte Alegre, São Gonçalo, etc.

Em Uruçuí, há cinco instituições ligadas ao ensino superior e profissional: as principais são Universidade Estadual do Piauí (UESPI), em que são oferecidos os cursos de Administração de Empresas, Agronomia, Pedagogia e Pós Graduação em Gestão Pública Municipal; o Polo do Centro de Educação à Distância - Universidade Aberta do Brasil (UAB), que conta com o apoio da Universidade Federal do Piauí (UFPI), e oferece os cursos de Bacharelado em Administração, Licenciatura em Química, Bacharelado em Sistemas de informação e Licenciatura em Filosofia; e o Instituto Federal de Ciência e Tecnologia do Piauí (IFPI), que oferece os cursos de Licenciatura em Matemática, Técnico em Agroindústria e Técnico em Agronegócio, além de disponibilizar Especialização em Ciências Ambientais. Os cursos são claramente direcionados ao atendimento das necessidades de mão de obra qualificada por parte do agronegócio. Nesse sentido, observa-se, em Uruçuí, grande associação do ensino superior e técnico/profissional às demandas da agricultura moderna. Nas figuras abaixo se pode observar a UESPI e IFPI presentes em Uruçuí:

Figura 54: Entrada do IFPI- Uruçuí-PI

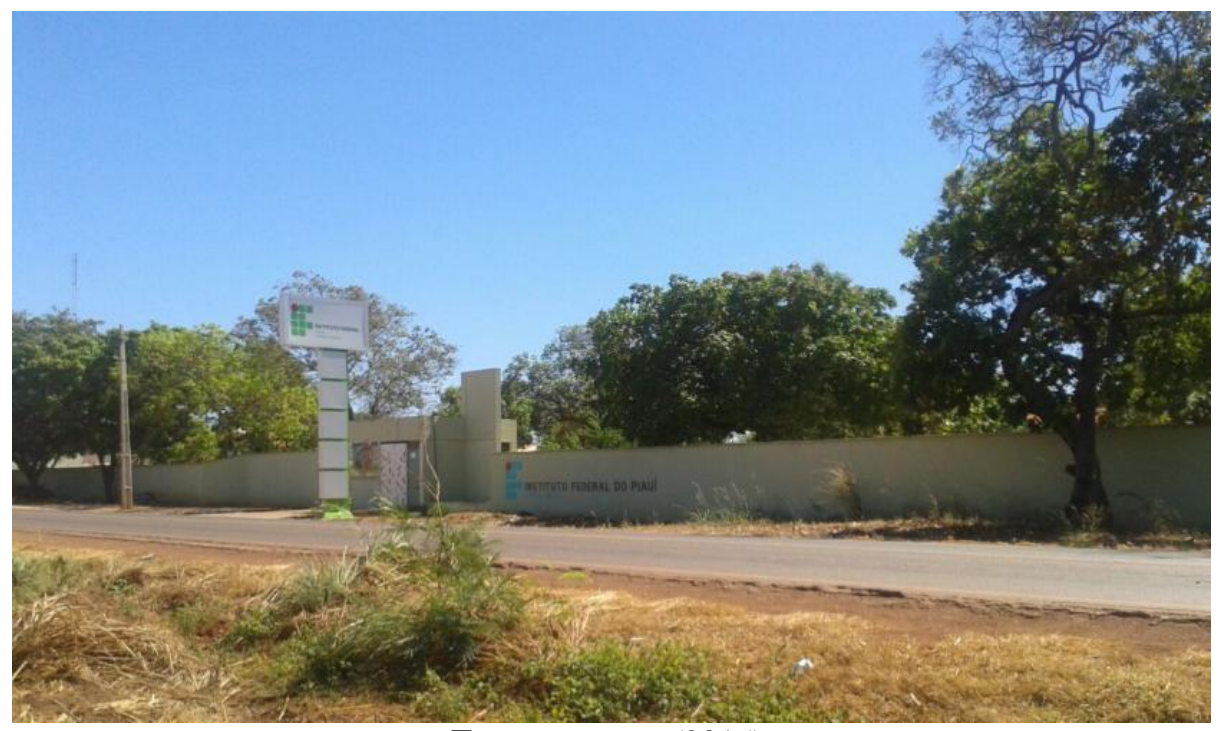

Fonte: o autor, (2015).

Além das instituições de ensino superior públicas, Uruçuí também conta com o Centro Universitário da Faculdade de Saúde, Ciências Humanas e Tecnológicas do Piauí (NOVAPI), que oferece os cursos de Bacharelado em Administração e Serviço Social.

Bom Jesus, por sua vez, abriga seis instituições ligadas ao ensino superior e profissional/técnico, sendo três instituições Públicas e duas particulares. Uma das instituições 
públicas é a Universidade Federal do Piauí (UFPI), campus Professora Cinobelina Elvas, na qual são oferecidos os cursos de Bacharelado em Administração, Bacharelado em Enfermagem, Engenharia Agronômica, Medicina Veterinária, Zootecnia, Licenciatura em Ciências Biológicas, Engenharia Florestal, Licenciatura em Educação no Campo, e Licenciatura em Pedagogia, além dos cursos de pós-graduação, nas áreas de Mestrado em Solos e Nutrição de Plantas, Mestrado em Fitotecnia e Mestrado em Zootecnia. É possível dizer, assim, que os cursos de graduação e principalmente os de mestrado são bem focados no atendimento das demandas da moderna agricultura, evidenciando mais uma vez grande associação entre o ensino e o agronegócio.

Bom Jesus revela, ainda, uma particularidade em relação ao conjunto de cidades piauienses e até mesmo em relação ao restante do país, pois, segundo dados do Ministério da Educação (MEC), através da Avaliação Nacional de Aprendizagem (ANA) de $2014^{65}$, Bom Jesus possui um doutor a cada 306 moradores, enquanto a média brasileira é de um doutor a cada 1,6 mil habitantes, sendo a cidade com o maior percentual de doutores do Brasil. Isso pode ser explicado pela presença dos cursos de pós-graduação da UFPI e pela quantidade de universidades. Nesse caso, é possível afirmar que Bom Jesus vem, cada vez mais, se tornando como um dos pólos de educação do Estado do Piauí.

A figura abaixo mostra entrada de um dos prédios da UFPI- Bom Jesus:

Figura 55: Universidade Federal do Piauí- Campus Professora Cinobelina Elvas

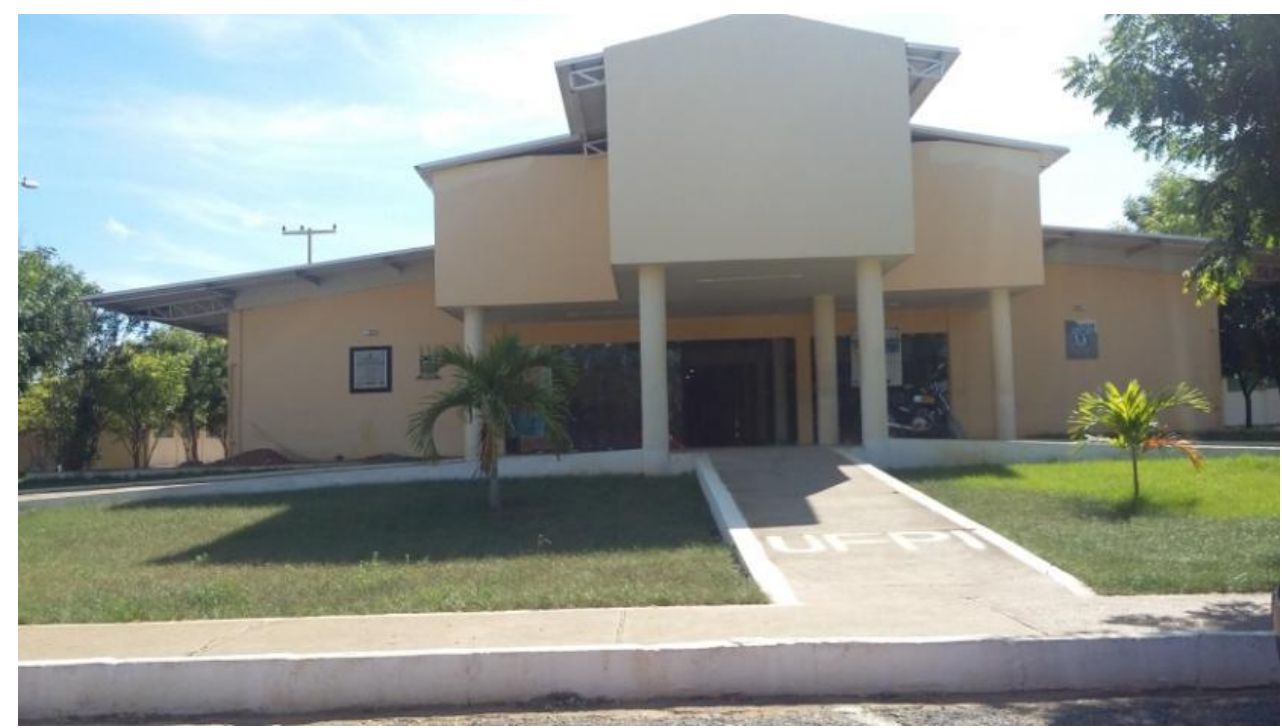

Fonte: o autor, (2015).

65 Esse estudo foi destaque na mídia brasileira, inclusive com reportagem no Jornal Hoje da Rede Globo, disponível no link a seguir: <http://g1.globo.com/jornal-hoje/noticia/2015/09/um-em-cada-cinco-alunos-doensino-fundamental-nao-le-ou-escreve-direito.html>, acesso em 19/09/2015. 
Verificou-se nos trabalhos de campo que esse Campus UFPI em Bom Jesus possui grande infraestrutura e conta com Hospital Veterinário Universitário, um Centro de Análises de Solos e a denominada Fazenda Escola, onde são desenvolvidas aulas práticas de alguns cursos. Na figura abaixo se pode observar a presença do Hospital Veterinário Universitário, vinculado ao curso de Medicina Veterinária da UFPI:

\section{Figura 56: Hospital Veterinário Universitário- Campus UFPI- Bom Jesus}

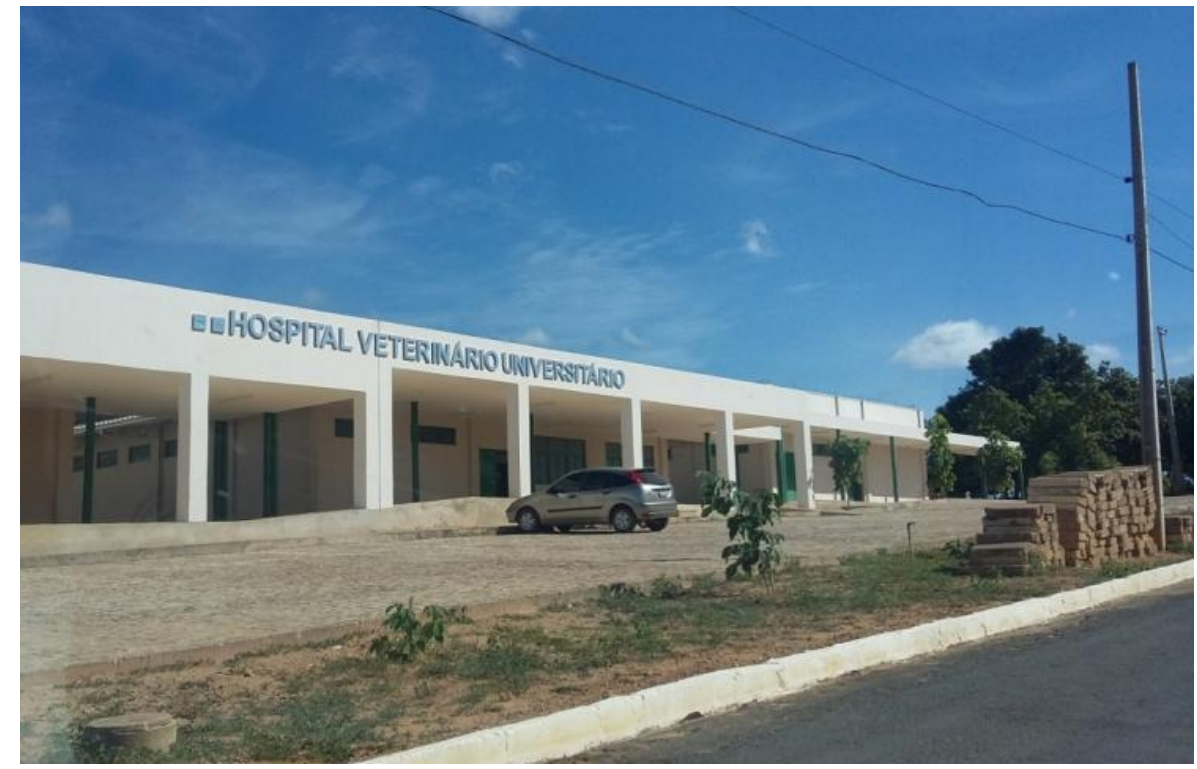

Fonte: o autor, (2015).

Outra instituição é a Universidade Estadual do Piauí, campus D. José Vásquez Díaz, na qual são oferecidos os cursos de Direito e Licenciatura Plena em Letras/Português e Pedagogia. Bom Jesus também conta com um Pólo do Centro de Educação à Distância-UAB, que oferece o curso de Administração (Bacharelado), disponibilizado pela UFPI. Além disso, a UESPI também disponibiliza os cursos de Licenciatura Plena em Pedagogia, Licenciatura Plena em Letras Espanhol, Licenciatura Plena Letras/Português, Pós graduação em Gestão Pública e Pós graduação em Gestão Pública Municipal.

Temos ainda o Colégio Técnico/Agrícola de Bom Jesus, onde são oferecidos os cursos de Técnico em Agropecuária, Técnica em Informático e Técnico em Enfermagem. Observa-se nas figuras abaixo a entrada UESPI e do Colégio Técnico de Bom Jesus: 
Figura 57: UESPI- Campus D. José Vásquez Díaz- Bom Jesus

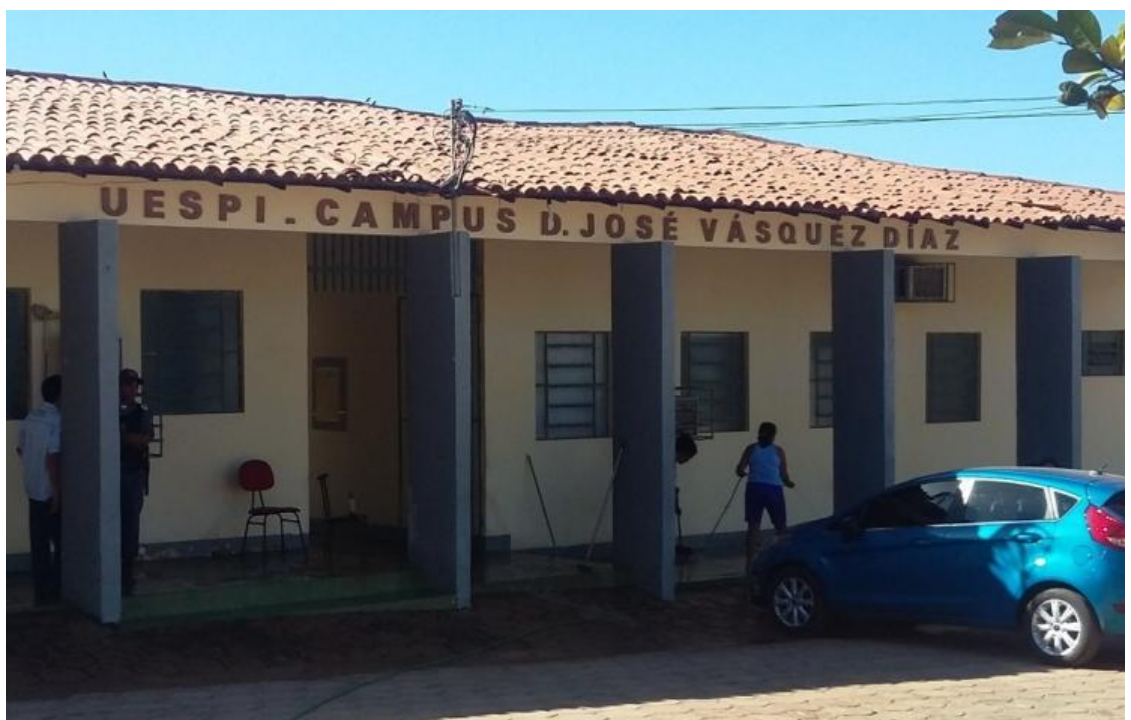

Fonte: o autor, (2015).

Figura 58: Colégio Técnico de Bom Jesus, vinculado à UFPI

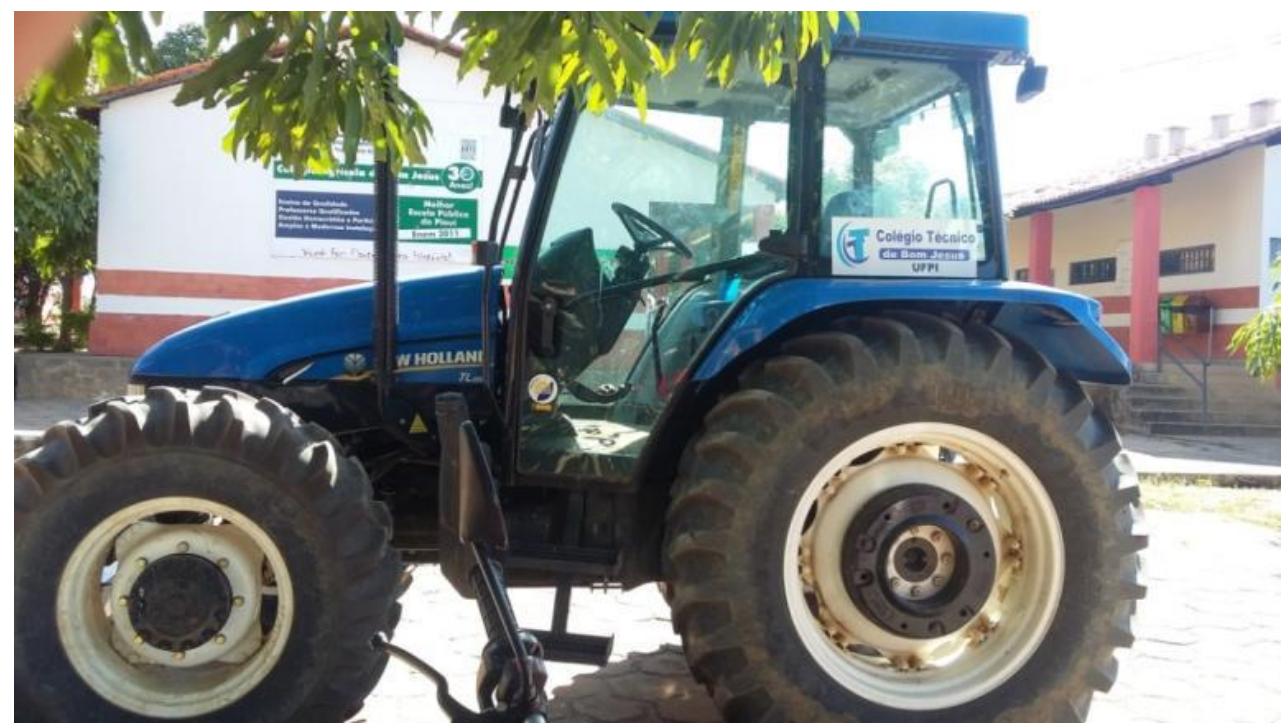

Fonte: o autor, (2015).

Além das instituições públicas, como as verificadas nas imagens anteriores, temos em Bom Jesus duas instituições de ensino superior privadas, a Universidade Anhanguera, que oferece cursos à distância de Administração e Gestão, Saúde e Medicina, Administração Pública e Contabilidade, e a Universidade Norte do Paraná (UNOPAR), que oferece vários cursos à distância como Administração, Artes Visuais (Licenciatura), Ciências Contábeis, Geografia, História, Engenharia de Produção, entre outros. Abaixo, encontra-se a foto do prédio da Universidade Anhanguera em Bom Jesus: 
Figura 59: Prédio da Universidade Anhanguera- Bom Jesus-PI

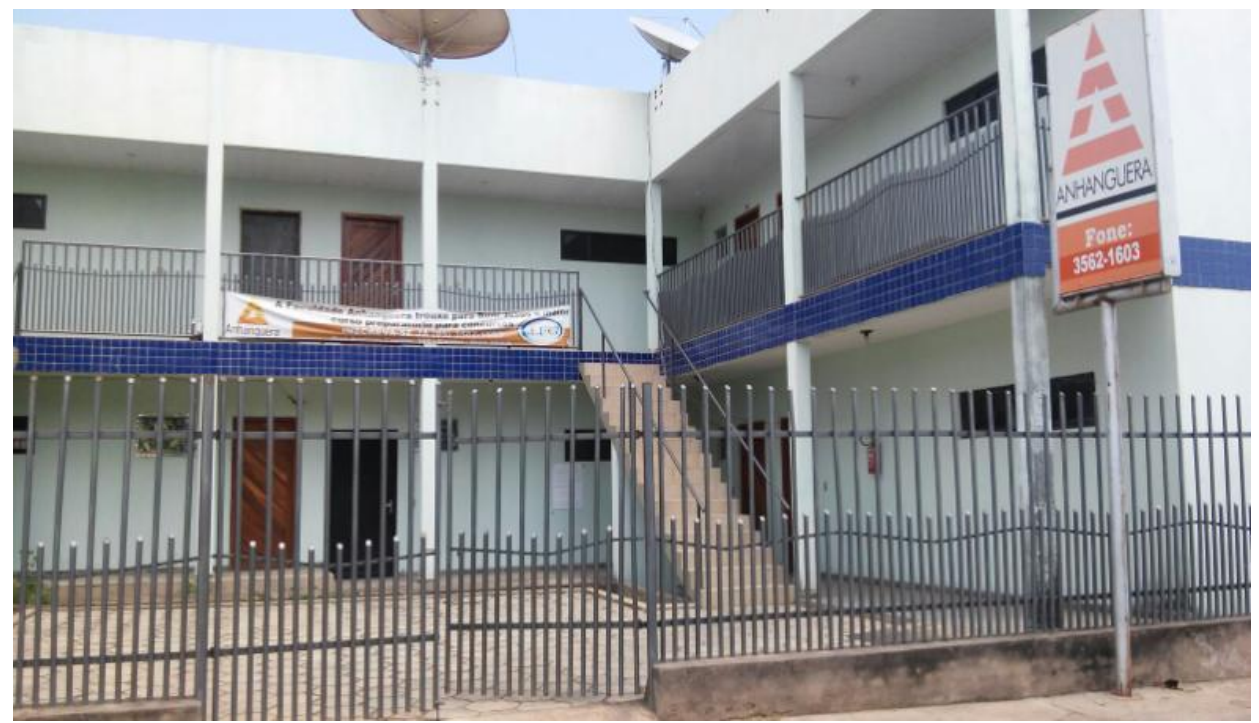

Fonte: o autor, (2015).

Além das instituições de ensino públicas e privadas, verifica-se nessas cidades outras instituições ligadas aos cursos preparatórios para concursos e para exames de como o da Ordem dos Advogados do Brasil (OAB), que ainda oferecem cursos de pós-graduação, como foi verificado em Bom Jesus, onde temos a presença da instituição denominada LFG, presente neste mesmo prédio da Faculdade Anhanguera (inclusive, na figura, pode-se perceber um cartaz de divulgação dessa instituição).

Percebeu-se, nos trabalhos de campo em Bom Jesus, o início da instalação de empresas focadas no ensino de línguas estrangeiras, como pode ser observado na figura abaixo:

Figura 60: empresa de ensino de línguas estrangeiras em Bom Jesus

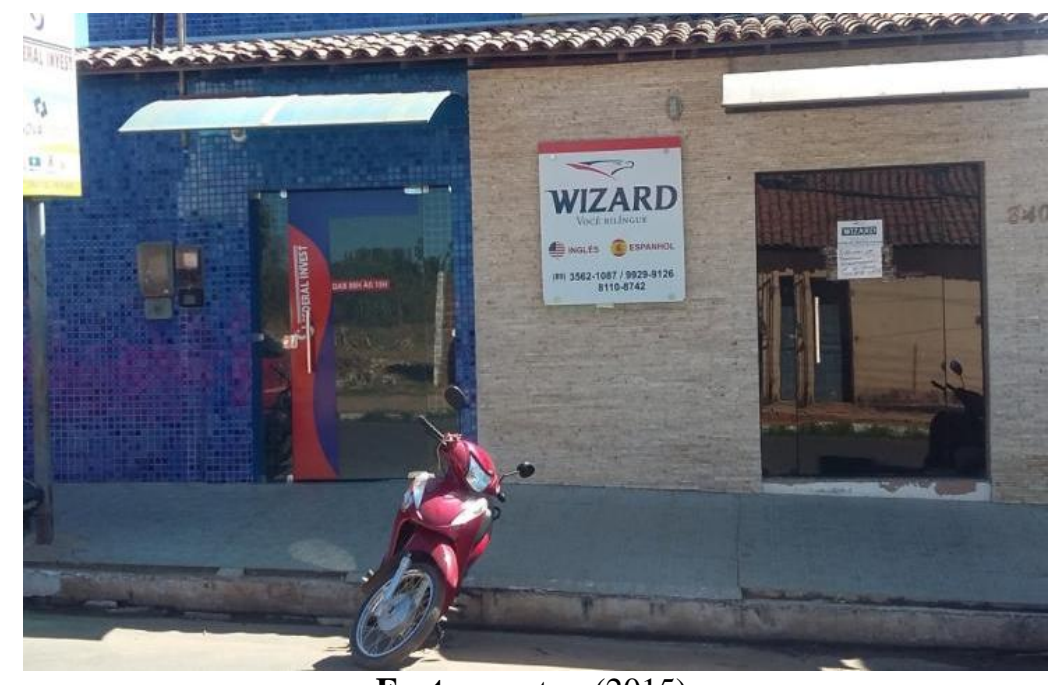

Fonte: o autor, (2015). 
Considera-se que essas instituições privadas, tanto de ensino superior, como as de línguas estrangeiras e preparatórias para concursos são destinadas ao que denominamos de classe média do agronegócio, que são não somente os filhos e familiares dos grandes agricultores, como também de professores universitários das instituições públicas e privadas, de empresários e comerciantes locais, de engenheiros, agrônomos e profissionais qualificados empregados nos grandes projetos, e grandes e médios pecuaristas e agricultores das cidades vizinhas.

Assim, esses novos equipamentos urbanos e instituições são retratos da exclusão social, pois grande parte da população local não tem acesso a elas, sobretudo os adultos e idosos. Apesar de muitos jovens moradores locais das cidades do agronegócio e das cidades vizinhas integrarem-se ao ensino superior, verifica-se que uma enorme parcela da população é excluída desses benefícios que o dinamismo econômico e o avanço da fronteira agrícola proporcionam a determinados segmentos sociais e econômicos. A presença dessas instituições, portanto, sobretudo nas três cidades do agronegócio, reforça as diferenciações das mesmas em torno da infraestrutura, do comércio, do movimento e das centralidades em relação ao restante da rede de cidades da área de estudo selecionada.

Antes de prosseguirmos a análise, destacamos que o município de Gilbués também contém um Polo de Ensino à Distância da UAB, no qual são oferecidos os cursos de Administração (Bacharelado), de Biologia (Licenciatura) e Sistema de Informação (Bacharelado), disponibilizados pela UFPI. Além disso, são oferecidos pela UESPI os cursos de Licenciatura Plena em Pedagogia e Licenciatura Plena Letras/Português e Inglês.

Uma questão importante a ser abordada é o embate entre Corrente e Bom Jesus pelo status de pólo comercial e educacional da porção sul do Estado do Piauí. Inclusive, esse é um dos pontos assinalados por Deianny Santos ${ }^{66}$, Técnica de Assuntos Educacionais do IFPI, campus Corrente, que afirmou que o desenvolvimento do agronegócio no Piauí e a emergência de Bom Jesus trouxe disputas políticas entre os municípios na questão da atração de empreendimentos e equipamentos urbanos, como universidades, fóruns, tribunais de justiça. O mais interessante foi que a técnica educacional afirmou que Bom Jesus e Corrente travaram um embate na questão da recepção do campus IFPI, que estava previsto para ser construído em Corrente, e que Bom Jesus tentou receber. Entretanto, segundo a entrevistada,

\footnotetext{
${ }^{66}$ A conversa com a entrevistada ocorreu em Julho de 2014, quando estabelecemos diálogos com estudantes e profissionais do IFPI.
} 
certas articulações políticas conseguiram que os planos iniciais fossem mantidos e, assim, o campus foi construído em Corrente.

Elias (2012) defende que a análise dos fixos atrelados à rede bancária e financeira deve ser elencada nos estudos que envolvem uma região produtiva agrícola. Nesse caso, elencamos, na tabela abaixo, a quantidade de bancos presentes nas diferentes cidades da área de estudo:

Tabela 38: Número de Agências Bancárias- 2014

\begin{tabular}{|c|c|c|c|}
\hline Microrregião & Municípios & $\begin{array}{c}\text { Total de } \\
\text { Agências } \\
\text { Bancárias } \\
\end{array}$ & Agências Bancárias \\
\hline \multirow{4}{*}{$\begin{array}{c}\text { Alto Parnaíba } \\
\text { Piauiense }\end{array}$} & Baixa Grande do Ribeiro & 0 & \\
\hline & Ribeiro Gonçalves & 1 & Banco do Brasil \\
\hline & Santa Filomena & 0 & \\
\hline & Uruçuí & 4 & $\begin{array}{c}\text { Banco do Brasil, } \\
\text { Bradesco, Caixa } \\
\text { Econômica Federal, } \\
\text { Banco do Nordeste }\end{array}$ \\
\hline \multirow{11}{*}{$\begin{array}{l}\text { Alto Médio } \\
\text { Gurguéia }\end{array}$} & Alvorada do Gurguéia & 0 & \\
\hline & Barreiras do Piauí & 0 & \\
\hline & Bom Jesus & 4 & $\begin{array}{c}\text { Banco do Brasil, } \\
\text { Bradesco, Caixa } \\
\text { Econômica Federal, } \\
\text { Banco do Nordeste }\end{array}$ \\
\hline & Cristino Castro & 1 & Banco do Brasil \\
\hline & Currais & 0 & \\
\hline & Gilbués & 1 & Banco do Brasil \\
\hline & Monte Alegre & 0 & \\
\hline & Palmeira & 0 & \\
\hline & Redenção do Gurguéia & 0 & \\
\hline & Santa Luz & 0 & \\
\hline & São Gonçalo do Gurguéia & 0 & \\
\hline $\begin{array}{l}\text { Chapadas do } \\
\text { Extremo Sul } \\
\text { Piauiense }\end{array}$ & Corrente & 4 & $\begin{array}{c}\text { Banco do Brasil, } \\
\text { Bradesco, Caixa } \\
\text { Econômica Federal, } \\
\text { Banco do Nordeste }\end{array}$ \\
\hline
\end{tabular}

Fonte: IBGE Cidades, dados do Banco Central, 2014

Existem poucos bancos nos municípios elencados; novamente, as três cidades que mais se destacam são Uruçuí, Bom Jesus e Corrente, cada qual com quatro bancos - Banco do 
Brasil, Caixa Econômica Federal, Bradesco e Banco do Nordeste. Gilbués, Cristino Castro e Ribeiro Gonçalves contam com uma agência do Banco do Brasil. Note-se que, dos 16 municípios da área de estudo, 11 não contam com nenhuma agência bancária. Abaixo, foto da agência Banco do Brasil em Bom Jesus:

\section{Figura 61: Banco do Brasil em Bom Jesus}

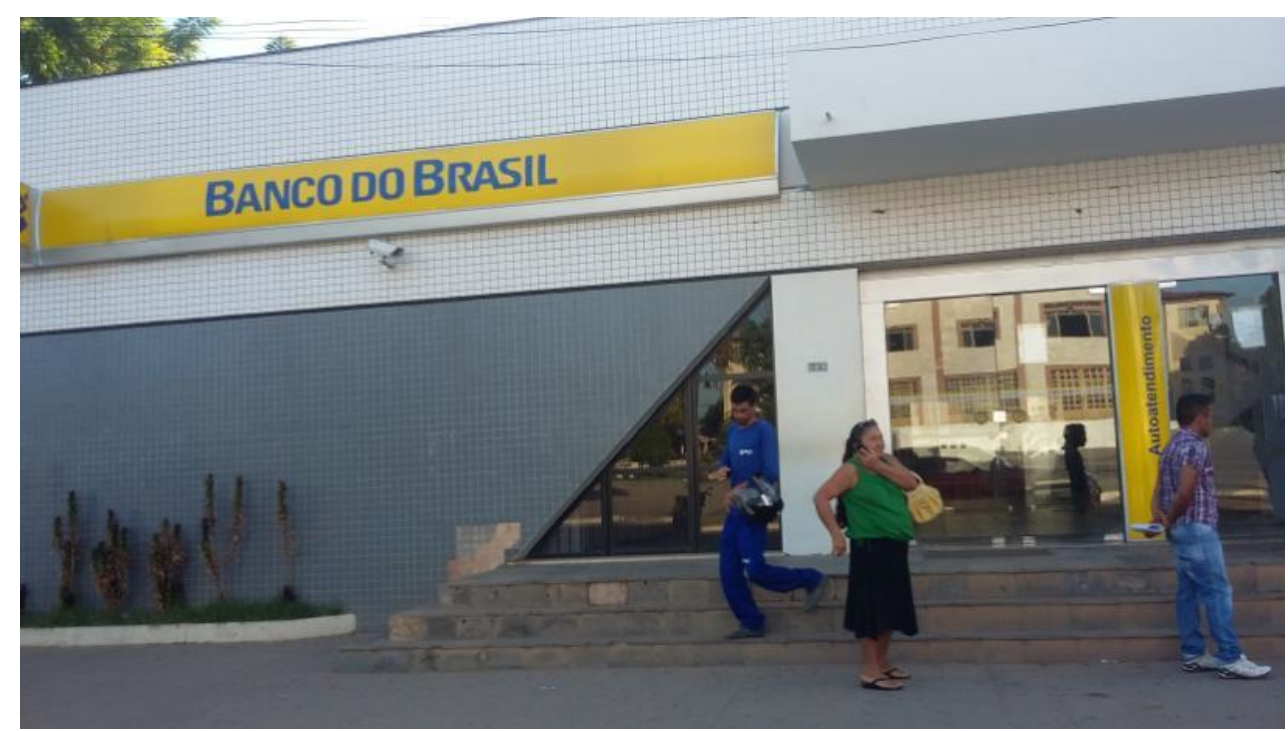

Fonte: o autor, (2015).

A realidade dos fixos bancários e financeiros na área de estudo revela-se uma grande problemática, pois as três cidades com mais bancos acabam recebendo uma grande demanda de pessoas em busca dos serviços financeiros, o que sobrecarrega os atendimentos e acarreta a formação de longas filas. Destaca-se que grande parte dos municípios da área de estudo possui uma população dependente de aposentadorias rurais e do funcionalismo público, e que necessita, assim, dos serviços bancários. Ainda verificamos, em trabalho de campo, que até mesmo as maiores cidades não dispõem dos chamados "caixas 24 horas".

Para ter-se dimensão da presença de equipamentos urbanos e estabelecimentos comerciais e de serviços na área de estudo, analisemos a tabela seguinte: 
Tabela 39: Total de estabelecimentos agropecuários, de ensino e de saúde em 2010

\begin{tabular}{|c|c|c|c|c|}
\hline Microrregião & Municípios & $\begin{array}{c}\text { Estabelecimentos } \\
\text { agropecuários }\end{array}$ & Ensino & Saúde \\
\hline \multirow[t]{4}{*}{$\begin{array}{l}\text { Alto Parnaíba } \\
\text { Piauiense }\end{array}$} & $\begin{array}{c}\text { Baixa Grande do } \\
\text { Ribeiro }\end{array}$ & 77 & 43 & 5 \\
\hline & Ribeiro Gonçalves & 142 & 34 & 8 \\
\hline & Santa Filomena & 14 & 24 & 4 \\
\hline & Uruçuí & 109 & 46 & 29 \\
\hline \multirow{11}{*}{$\begin{array}{l}\text { Alto Médio } \\
\text { Gurguéia }\end{array}$} & $\begin{array}{c}\text { Alvorada do } \\
\text { Gurguéia }\end{array}$ & 40 & 11 & 3 \\
\hline & Barreiras do Piauí & 0 & 19 & 2 \\
\hline & Bom Jesus & 615 & 46 & 24 \\
\hline & Cristino Castro & 77 & 31 & 7 \\
\hline & Currais & 48 & 23 & 6 \\
\hline & Gilbués & 5 & 47 & 8 \\
\hline & Monte Alegre & 22 & 44 & 5 \\
\hline & Palmeira & 224 & 37 & 7 \\
\hline & $\begin{array}{c}\text { Redenção do } \\
\text { Gurguéia }\end{array}$ & 363 & 16 & 6 \\
\hline & Santa Luz & 278 & 14 & 3 \\
\hline & $\begin{array}{c}\text { São Gonçalo do } \\
\text { Gurguéia }\end{array}$ & 3 & 13 & 5 \\
\hline $\begin{array}{c}\text { Chapadas do } \\
\text { Extremo Sul } \\
\text { Piauiense } \\
\end{array}$ & Corrente & 37 & 68 & 28 \\
\hline
\end{tabular}

Fonte: IBGE Cidades, dados do Censo de 2010, elaborada pelo autor.

Bom Jesus é a cidade com o maior número de estabelecimentos agropecuários, o que revela que é uma grande fornecedora de insumos agrícolas e funciona como um suporte ao agronegócio no Piauí. Alguns municípios, como Redenção e Santa Luz, apresentam um representativo número de estabelecimentos agropecuários, mas pouco vinculados à agricultura moderna. Quanto ao número de estabelecimentos de ensino, Corrente ganha destaque, por servir como um polo educacional da região dos Cerrados, também associada ao fornecimento de mão de obra qualificada, como a formação de engenheiros agrônomos, e outros serviços, como os de advocacia. Gilbués, por sua vez, também se destaca com 47 instituições de ensino, muito influenciado pela representativa área de influência sob os municípios de Monte Alegre e Barreiras do Piauí. Em relação aos estabelecimentos de saúde, mais uma vez Uruçuí, Corrente e Bom Jesus ganham destaque, pois atendem grande parte dos municípios das suas áreas de influência. 
No REGIC de 2007 constam informações relacionadas à centralidade referentes aos serviços de saúde, como pode-se constatar na tabela abaixo:

Tabela 40: Nível de Centralidade de Saúde

\begin{tabular}{|c|c|c|}
\hline Microrregião & Municípios & $\begin{array}{c}\text { Nível de } \\
\text { centralidade de } \\
\text { saúde }\end{array}$ \\
\hline \multirow{4}{*}{ Alto Parnaíba Piauiense } & Baixa Grande do Ribeiro & - \\
\hline & Ribeiro Gonçalves & - \\
\hline & Santa Filomena & - \\
\hline & Uruçuí & 6 \\
\hline \multirow{11}{*}{ Alto Médio Gurguéia } & Alvorada do Gurguéia & - \\
\hline & Barreiras do Piauí & - \\
\hline & Bom Jesus & 6 \\
\hline & Cristino Castro & - \\
\hline & Currais & - \\
\hline & Gilbués & - \\
\hline & Monte Alegre & - \\
\hline & Palmeira & - \\
\hline & Redenção do Gurguéia & - \\
\hline & Santa Luz & - \\
\hline & São Gonçalo do Gurguéia & - \\
\hline $\begin{array}{c}\text { Chapadas do Extremo } \\
\text { Sul Piauiense }\end{array}$ & Corrente & 6 \\
\hline
\end{tabular}

Fonte: IBGE (2008), REGIC 2007.

Uruçuí, Bom Jesus e Corrente, segundo o estudo, possuem o mesmo nível em relação aos serviços de saúde. Bom Jesus, entretanto, vem cada vez mais centralizando os serviços de saúde, muito por conta do Hospital Manoel de Souza Santos, instituição pública que recebe grande quantidade de pacientes de outros municípios além dos da própria cidade; atrelado a isso, Bom Jesus também conta com um número significativo de clínicas e laboratórios de saúde e odontológicos, que contribuem com o aumento da centralidade da cidade.

Outro dado importante em relação à infraestrutura, ao tamanho e à dinâmica urbana das cidades é a quantidade de veículos circulantes. A tabela abaixo sistematiza a densidade do fluxo de veículos nas cidades da área de estudo: 
Tabela 41: Quantidade total de veículos por municípios em 2009 e 2014

\begin{tabular}{|c|c|c|c|c|}
\hline Microrregião & Municípios & Veículos 2009 & Veículos 2014 & $\begin{array}{l}\text { Crescimento } \\
\text { da frota }(\%)\end{array}$ \\
\hline \multirow{4}{*}{$\begin{array}{l}\text { Alto Parnaíba } \\
\text { Piauiense }\end{array}$} & Baixa Grande do Ribeiro & 426 & 2.031 & $376,8 \%$ \\
\hline & Ribeiro Gonçalves & 232 & 757 & $226 \%$ \\
\hline & Santa Filomena & 170 & 570 & $235,29 \%$ \\
\hline & Uruçuí & 2.997 & 7.135 & $138 \%$ \\
\hline \multirow{11}{*}{$\begin{array}{l}\text { Alto Médio } \\
\text { Gurguéia }\end{array}$} & Alvorada do Gurguéia & 241 & 573 & $137,8 \%$ \\
\hline & Barreiras do Piauí & $*$ & 210 & - \\
\hline & Bom Jesus & 4.050 & 8.590 & $112 \%$ \\
\hline & Cristino Castro & 825 & 1.658 & $100,9 \%$ \\
\hline & Currais & 106 & 438 & $313.20 \%$ \\
\hline & Gilbués & 663 & 1.293 & $95 \%$ \\
\hline & Monte Alegre & 412 & 860 & $108,7 \%$ \\
\hline & Palmeira & 274 & 790 & $188.3 \%$ \\
\hline & Redenção do Gurguéia & 424 & 1.214 & $186.3 \%$ \\
\hline & Santa Luz & 280 & 675 & $141 \%$ \\
\hline & $\begin{array}{c}\text { São Gonçalo do } \\
\text { Gurguéia }\end{array}$ & 103 & 239 & $132 \%$ \\
\hline $\begin{array}{c}\text { Chapadas do } \\
\text { Extremo Sul } \\
\text { Piauiense } \\
\end{array}$ & Corrente $^{67}$ & 3.002 & 5.803 & $93,3 \%$ \\
\hline
\end{tabular}

Fonte: Fundação CEPRO, 2011; IBGE Cidades, 2014.

(*) frota inferior a 100 veículos.

No geral, é possível afirmar que as cidades apresentam uma frota de veículos pouco numerosa nos dois anos, sobretudo em 2009 - no mesmo ano, os municípios mais populosos do Estado do Piauí, Teresina, Parnaíba e Picos, tinham, respectivamente, 262.972, 43.874 e 32.626 veículos (CEPRO, 2011). Quanto maior a população, portanto, maior a quantidade de veículos. Com efeito, os dados mostram o crescimento da frota de veículos nos municípios considerados; em alguns deles, como Baixa Grande do Ribeiro, Santa Filomena e Currais, o aumento foi bastante significativo. Essa tendência é observada em praticamente todos os municípios, com exceção de Corrente e Gilbués, os mesmos que, paradoxalmente, quase dobraram a sua frota durante os cinco anos considerados.

\footnotetext{
${ }^{67}$ Único município selecionado dessa microrregião, como já justificado anteriormente.
} 
Observa-se, a partir dos dados da tabela, que a maior frota de veículos da área de estudo é do município de Bom Jesus, com 4.050 veículos em 2009 e 8590 em 2014, o que representa um aumento de $112 \%$ da frota de veículos em termos percentuais. Os municípios de Corrente e Uruçuí também se destacam em relação a quantidade de veículos, o que, em contrapartida ao fato de que os demais municípios apresentam uma frota de veículos inferior a mil veículos, revela um grande contraste entre as três cidades do agronegócio e o restante das cidades listadas.

Considerado que Corrente é a cidade mais populosa da área de estudo, Bom Jesus acaba contrariando a tendência comum do paralelo entre a população e a frota de veículos, o que pode ser explicado pelo seu maior dinamismo no comércio e maior intensificação das atividades ligadas à agricultura, pois nos grandes projetos e sedes de fazendas verifica-se grande utilização de veículos, como tratores, caminhões, camioneta e caminhonetes, bem como pela taxa de urbanização, pois, como já destacado anteriormente, a cidade de Bom Jesus supera o percentual de Corrente neste quesito. Inclusive, um dos pontos mais interessantes dos trabalhos de campo foi a observação de um diferencial da cidade, que é a organização e fiscalização do trânsito organizada por policiais militares. Observamos também que, dentro do perímetro urbano, em razão da maior movimentação de veículos, existem várias placas e elementos de sinalização e controle do trânsito, como, por exemplo, a presença de semáforos, que praticamente não existem nas outras cidades da área de estudo, com a exceção de Corrente, onde se verificou a existência de apenas um deles e de menor fiscalização do trânsito. Abaixo, reproduzimos a foto de um semáforo em Bom Jesus: 
Figura 62: Elemento de controle do trânsito em Bom Jesus-PI.

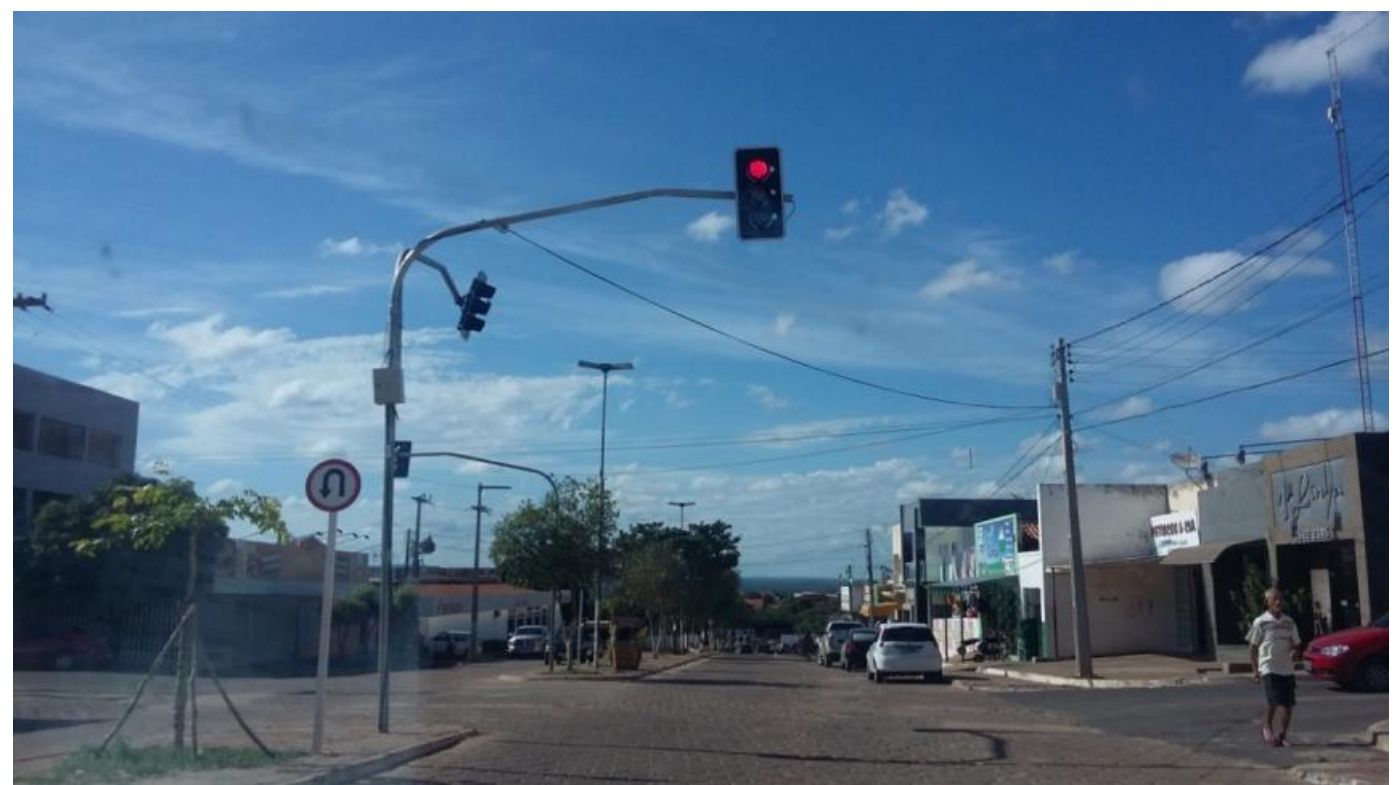

Fonte: o autor, (2015).

Antes de prosseguirmos, ressaltamos que pode parecer inusitado conferir tal destaque a uma questão supostamente banal como a do controle do trânsito através de elementos de controle do fluxo e fiscalização, como visto na imagem acima, no entanto, tais elementos simplesmente não fazem parte da maior parte das pequenas cidades das microrregiões consideradas.

Para evidenciar a questão da modernização agrícola, analisemos agora os dados sobre a quantidade de caminhões e tratores em cada cidade: 
Tabela 42: Número de Caminhões e Tratores na área de estudo (2014)

\begin{tabular}{|c|c|c|c|c|}
\hline Microrregião & Municípios & Caminhões & Trator & Total \\
\hline \multirow{4}{*}{$\begin{array}{c}\text { Alto } \\
\text { Parnaíba } \\
\text { Piauiense }\end{array}$} & $\begin{array}{l}\text { Baixa Grande do } \\
\text { Ribeiro }\end{array}$ & 93 & 114 & 207 \\
\hline & Ribeiro Gonçalves & 25 & 2 & 27 \\
\hline & Santa Filomena & 22 & 2 & 24 \\
\hline & Uruçuí & 169 & 105 & 274 \\
\hline \multirow{11}{*}{$\begin{array}{l}\text { Alto Médio } \\
\text { Gurguéia }\end{array}$} & $\begin{array}{c}\text { Alvorada do } \\
\text { Gurguéia }\end{array}$ & 15 & 1 & 16 \\
\hline & Barreiras do Piauí & 5 & 1 & 6 \\
\hline & Bom Jesus & 251 & 65 & 316 \\
\hline & Cristino Castro & 40 & 5 & 45 \\
\hline & Currais & 3 & 0 & 3 \\
\hline & Gilbués & 8 & 10 & 18 \\
\hline & Monte Alegre & 15 & 2 & 17 \\
\hline & Palmeira & 37 & 1 & 38 \\
\hline & $\begin{array}{c}\text { Redenção do } \\
\text { Gurguéia }\end{array}$ & 17 & 0 & 17 \\
\hline & Santa Luz & 11 & 0 & 11 \\
\hline & $\begin{array}{c}\text { São Gonçalo do } \\
\text { Gurguéia }\end{array}$ & 4 & 0 & 4 \\
\hline $\begin{array}{c}\text { Chapadas do } \\
\text { Extremo Sul } \\
\text { Piauiense } \\
\end{array}$ & Corrente $^{68}$ & 126 & 12 & 138 \\
\hline
\end{tabular}

Fonte: IBGE Cidades (2014)

Acredita-se que caminhões e tratores estão mais ligados à agricultura moderna, embora a frota desses veículos na área de estudo não seja tão numerosa como em outras áreas de expansão do agronegócio, como, por exemplo, no município de Luís Eduardo, que, em 2014, segundo o IBGE Cidades, tinha 3.137 tratores e caminhões. No mesmo período, BalsasMA tinha 2.225 desses veículos. A quantidade destes últimos nos municípios da área de estudo não é, portanto, representativa quando se comparada a outras áreas em que o processo de modernização da agricultura já está consolidado. No entanto, ainda é possível dizer que, sobretudo Bom Jesus, Uruçuí, Corrente e Baixa Grande do Ribeiro possuem um número muito maior desses veículos, pois essas cidades dependem de centros urbanos de outros estados, principalmente do oeste baiano, dos municípios de Luís Eduardo Magalhães e

\footnotetext{
${ }^{68}$ Único município selecionado dessa microrregião, como já justificado anteriormente.
} 
Barreiras. Nesse caso, infere-se que existem mais veículos nessas cidades piauienses, com placa de outros estados, no entanto; tal fato foi observado na saída de campo, quando observamos muitos veículos com placa de municípios baianos e de Brasília. Essa foi uma questão abordada na conversa com o professor e engenheiro agrônomo Raimundo Falcão Neto, do Colégio Técnico de Bom Jesus ${ }^{69}$, que afirmou que as compras da maior parte dos carros, principalmente caminhonetes, caminhões e tratores, além de peças automotivas, vinham de Luiz Eduardo Magalhães e Barreiras, inclusive destacando a grande presença de placas de veículos de Bom Jesus com origem dessas cidades baianas. O professor ainda acrescentou que os serviços de aviação, sobretudo os de menor porte, da maior parte dos municípios da porção sul do Estado do Piauí são dependentes do município de Barreiras-BA.

Em relação aos espaços e fixos para promoção de eventos, como festas, feiras, convenções, etc., destacamos a já mencionada ExpoCorrente, evento realizado anualmente na cidade de Corrente (PI) e que já conta com 40 edições; o evento promove exposições, palestras, e simpósios sobre atividades ligadas às atividades agropecuárias, e toma lugar em um espaço destinado exclusivamente a ele, localizado no bairro Nova Corrente.

Em Bom Jesus, tem lugar algumas festas de tradições gaúchas, além de receber anualmente as edições do Piauí ExpoShow, evento promovido pela da parceria entre a iniciativa privada e a prefeitura, realizado em um espaço próprio, denominado Parque do Vale do Gurguéia, que fica próximo ao campus da UFPI; este é o maior evento agropecuário do Piauí. Segundo veículos de notícias, em 2014, o evento movimentou 230 milhões em negócio $\operatorname{diretos}^{70}$; dessa forma, é uma oportunidade de exposição de máquinas e insumos agrícolas de diferentes empresas instaladas nos Cerrados piauienses. Em 2014, na sua sétima edição, as seguintes empresas/expositoras compareceram: Agrex do Brasil, Agrícola Manna, Agrobahia Ltda, Agromac, Agrosul John Deere, Agrovale, Baldan, Banco do Brasil, Banco do Nordeste, Máquinas Caetano, Maxum, Celeiro Sementes, Dow AgroSciences, Dureino, Floriano Veículos, Ibar Nordeste, Jaraguá Piauí, MM Home Center, Multigrãos, Newland, Nufarm, Plantec, Posto Café, Produtécnica, Prosul, Sotreq, Valfran, Vence Tudo e Visão Agrícola, além de expositores (estudantes e professores) da UFPI, o que confirma a grande associação e complementaridade entre essa instituição de ensino e a agricultura moderna.

\footnotetext{
${ }^{69}$ Instituição ligada vinculada à Universidade Federal do Piauí (UFPI).

70 Notícia disponível em: < http://www.appm.org.br/noticias/eventos/bom-jesus-se-prepara-para-a-segundaedicao-do-piaui-exposhow-4508.html\#.VjQks7erTIU. Acesso em 31 out. 2015.
} 
A cidade de Uruçuí não conta com nenhum evento agropecuário de grandes proporções, o que, mais uma vez, evidencia o destaque das cidades de Corrente e Bom Jesus, sobretudo esta última; é interessante ressaltar que, de fato, as duas cidades localizam-se em posição privilegiada, próximas da BR-135, na medida em que Uruçuí já está na fronteira com o Estado do Maranhão. Portanto, a realização dos eventos em Corrente e Bom Jesus naturalmente atrai mais empresas para as exposições e contempla um maior número de municípios próximos.

Depois de apresentadas todas essas novas infraestruturas, equipamentos e realidades, é preciso destacar que o Sudoeste Piauiense, em especial as microrregiões selecionadas para este estudo, ainda caracteriza-se pela presença de imensas áreas vazias, com ausência de transporte, comunicação e integração entre os diversos municípios e cidades existentes nessa Mesorregião. Existem também problemas relacionados à infraestrutura e setores básicos necessários à população, como a deterioração de rodovias, falta de escoamento das águas, reduzido acesso a educação, saneamento ambiental incipiente, saúde precária, além de problemas ambientais como desertificação, erosões e voçorocas.

Outro entrave é a presença de pequenos municípios, muitos deles inexpressivos e caracterizados pela falta de autonomia financeira e administrativa e pela pouca organização da arrecadação tributária, de maneira que desenvolvem grande dependência dos repasses da União, impactando diretamente a autonomia financeira das administrações locais (BRASIL, 2005). A maioria desses pequenos municípios desmembrou-se entre a década de 1980 e os anos iniciais do século XXI, em função da promulgação, em 1988, da nova Constituição Federal, que abria brechas para o surgimento de novos municípios, que atualmente são marcados pela fragilidade econômica e grande dependência ao governo federal (BRASIL, 2005), bem como pela informalidade e pela predominância das receitas geradas no setor primário. Entre os anos 1989 e 2011 houve a criação de 116 municípios na área da Bacia do Rio Paranaíba ${ }^{71}$ (BRASIL, 2005). Em consequência disso, esses municípios são extremamente dependentes do Fundo de Participação dos Municípios (FPM) ${ }^{72}$ e apresentam população e comércio local também dependente das aposentarias rurais e do funcionalismo público ligado às prefeituras locais.

\footnotetext{
71 Abrange os Estados do Maranhão, Piauí e Ceará, situado em uma região de transição entre os Cerrados, a Caatinga e a Amazônia.

${ }^{72}$ Transferência constitucional (CF, Art. 159, I, b), da União para os Estados e o Distrito Federal, composto de $22,5 \%$ da arrecadação do Imposto de Renda (IR) e do Imposto sobre Produtos Industrializados (IPI).
} 
Além disso, outro entrave é a dificuldade da articulação entre as cidades no que diz respeito à telecomunicação, pois observamos que não há harmonia entre as operadoras de telefones fixos e móveis nas cidades da área de estudo. Como exemplo, a cidade de Corrente não é atendidada por torre da operadora Vivo, mas nas cidades vizinhas, como São Gonçalo, Gilbués, Monte Alegre e Bom Jesus, esta é a operadora mais utilizada. Outra fragilidade diz respeito ao sistema bancário, que é ausente em algumas cidades, mesmo instituições como Caixa Econômica Federal, Banco do Brasil e lotéricas da Caixa. Presume-se que a rede urbana do Sudoeste Piauiense ainda carece de uma série de melhorias principalmente ligadas à infraestrutura e integração da rede urbana mesorregional, tanto fisica como virtualmente através de redes de comunicação.

Embora rede de cidades piauienses se transforme cada vez mais em virtude da expansão do agronegócio na região, o que evidencia uma tendência do Brasil Central e, consequentemente, de várias cidades consideradas centros do agronegócio, destacamos o caráter ainda embrionário dessas transformações, dado o caráter recente do processo. Nesse caso, considera-se que os Cerrados piauienses ainda não estão intensamente ocupados, pois, de acordo com Braz (2011, p.3), “O Piauí é um Estado de imensas possibilidades. Impressiona a todos a aptidão para a produção de grãos dos Cerrados piauienses, ainda quase inexplorados."

Nesse sentido, a instalação de diferentes infraestruturas, como grandes redes de supermercados, redes de shopping centers, ferrovias, aeroporto e voos comerciais regulares, distritos industriais e grandes empresas do setor imobiliário ainda estão distantes da realidade. Nesse sentido, as transformações destacadas, por mais que pareçam simples e pequenas, possuem caráter significativo e representam o início de rupturas e surgimento de novos processos socioespaciais.

Depois de analisar todos os dados e discutir inúmeras questões durante este capítulo, nota-se uma grande importância de Bom Jesus e a emergência dessa cidade como o grande centro urbano da região dos Cerrados Piauienses. Portanto, torna-se vital discutirmos um pouco mais sobre essa cidade piauiense. 


\subsection{Bom Jesus: cidade média? ${ }^{73}$}

É possível afirmar, a partir dos dados apresentados, que a cidade de Bom Jesus tem apresentado as maiores transformações urbanas na região dos Cerrados piauienses; as novas dinâmicas urbanas, demográficas e econômicas são claros reflexos da modernização agrícola nessa porção do Estado do Piauí e do aumento dos processos migratórios para essa cidade, motivados tanto pela atração de mão de obra, como pelo êxodo rural, que, cada vez mais, tende a aumentar. Na tabela abaixo, observa-se a evolução da população por situação do domicílio em Bom Jesus:

Tabela 43: População residente por situação do domicílio- Bom Jesus-PI

\begin{tabular}{|c|c|c|c|}
\hline ANO & URBANA & RURAL & TOTAL \\
\hline \multirow{2}{*}{2000} & 10.961 & 4.963 & 15.924 \\
& $(68,8)$ & $(31,2 \%)$ & 19.532 \\
\hline \multirow{2}{*}{2007} & 14.381 & 5.151 & 22.632 \\
\hline \multirow{2}{*}{2010} & $(73,6 \%)$ & $(26,4 \%)$ & \\
\hline
\end{tabular}

Fonte: IBGE, Censo Demográfico- 2000/2010- Contagem da População- 2007

Observa-se um aumento de cerca $60 \%$ da população urbana, se considerarmos o intervalo entre o ano 2000 e 2010, já o número absoluto saltou de 10.961 para 17.627 habitantes. Além disso, Bom Jesus apresentou um crescimento de $42 \%$ da sua população em um intervalo de 10 anos. Segundo estimativas oficiais do IBGE, em 2015, a população de Bom Jesus gira em torno de 24.327 habitantes, o que representa um aumento de 7,5\% na população em um intervalo de apenas cinco anos.

Em consonância com as ideias de Sampaio (2011), que discute o papel de Vitória da Conquista na rede urbana baiana, pode-se afirmar que, na realidade dos Cerrados piauienses, Bom Jesus pode ser entendido como um espaço de mediação entre pequenas cidades, servindo também como elo para outros maiores centros do Nordeste e as cidades do agronegócio da região do MATOPIBA. Bom Jesus poderia, assim, ser encarado como centro do crescimento econômico regional dos Cerrados piauienses.

\footnotetext{
${ }^{73}$ Esse tópico, em que defendemos que Bom Jesus, de acordo com o contexto o qual está inserida, desempenha um verdadeiro papel de cidade média, é apenas um esforço inicial e não tem com o objetivo exaurir a temática. Nesse sentido, abrem-se brechas para estudos futuros.
} 
Bom Jesus, portanto, tem desempenhado maior protagonismo face às outras cidades e aumentado sua área de influência no cenário mesorregional, o que pode ser comprovado com a comparação entre Bom Jesus, Corrente e Uruçuí nos três REGIC's dos anos de 1987, 1993 e 2007. Tais dados estão na tabela abaixo:

Tabela 44: Situação de Bom Jesus, Corrente e Uruçuí nos REGIC de 1987, 1993 e 2007

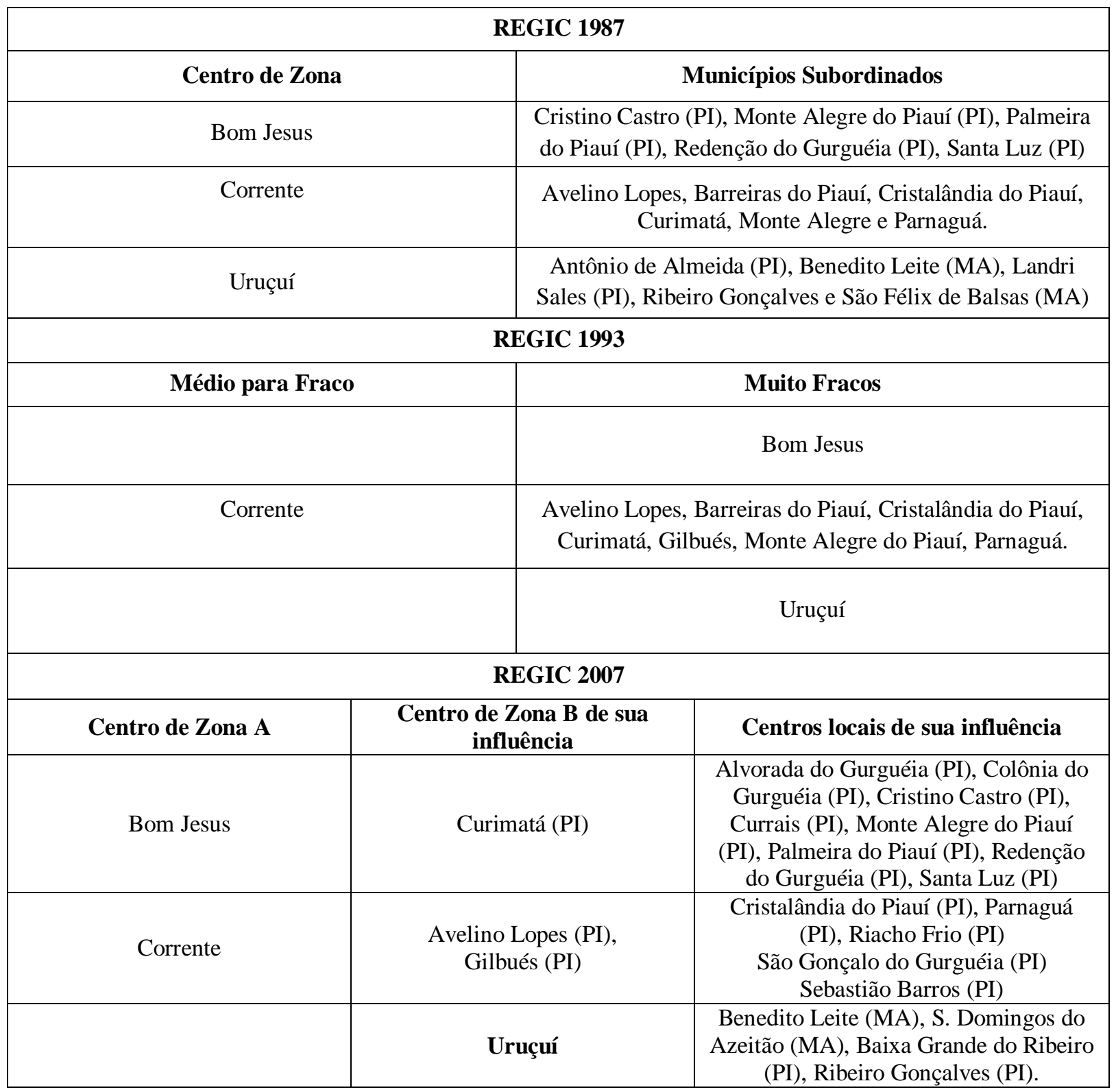

Fonte: REGIC's de 1987, 1993 e 2007.

No REGIC de 1987, o IBGE utilizou as seguintes classificações: Metrópole Regional, Centro Submetropolitano, Capital Regional, Centro Sub Regional e Centro de Zona, e as três cidades estavam sob influência de duas Metrópoles Regionais, Fortaleza (CE) e Recife (PE). 
Bom Jesus, Corrente e Uruçuí, segundo o REGIC 1987, eram subjugadas por Floriano, considerada como uma Capital Regional.

Em 1993, o IBGE utilizou as seguintes classificações em relação ao nível de hierarquia: Máximo, Forte, Forte para Médio, Médio, Médio para Fraco, Fraco e Muito fraco. Neste ano, as três cidades piauienses estavam subordinadas à Teresina, considerada centro urbano Muito Forte, influenciada, por sua vez, por São Paulo, centro urbano máximo. No Censo de 1993, Bom Jesus e Uruçuí eram ainda considerados municípios fracos e subordinados por Floriano, considerado Forte para Médio. Já Corrente se apresentava como uma cidade com nível de hierarquia Médio para fraco.

No REGIC de 2007, a situação já se altera, pois Uruçuí passa a ser considerada um Centro de Zona B, ou seja, de importância secundária, enquanto Bom Jesus é classificada como um Centro de Zona, o que denota sua relevância regional. Nesse sentido, Bom Jesus se iguala a Corrente, também considerada um Centro de Zona A, o que confirma nossa hipótese inicial da importância crescente de Bom Jesus no contexto mesorregional, especialmente na área dos Cerrados piauienses.

Além disso, é importante ressaltar que Bom Jesus ainda vem ampliando a sua área de influência, pois a análise dos REGIC's evidenciou que, em 1987, Bom Jesus possuía apenas cinco municípios subordinados, quais sejam, Cristino Castro (PI), Monte Alegre do Piauí (PI), Palmeira do Piauí (PI), Redenção do Gurguéia (PI), e Santa Luz (PI). Já no REGIC de 2007, o município passa a ter oito centros locais sob sua influência direta: Alvorada do Gurguéia (PI), Colônia do Gurguéia (PI), Cristino Castro (PI), Currais (PI), Monte Alegre do Piauí (PI), Palmeira do Piauí (PI), Redenção do Gurguéia (PI), e Santa Luz (PI). Se considerarmos que Bom Jesus ainda possui Curimatá, Centro de Zona B, sob sua área de influência, que por sua vez subordina o centro local Júlio Borges, Bom Jesus passaria a ter dez municípios sob sua área de influência direta.

Corrente também vem potencializando sua área de influência; em 1987, subordinava Avelino Lopes, Barreiras do Piauí, Cristalândia do Piauí, Curimatá, Monte Alegre e Parnaguá. Já no REGIC de 2007, Corrente já passa a influenciar Cristalândia do Piauí (PI), Parnaguá (PI), Riacho Frio (PI), São Gonçalo do Gurguéia (PI), e Sebastião Barros (PI). O município também possui dois Centros de Zona B: Avelino Lopes, que centraliza o município de Morro Cabeça no Tempo, e Gilbués, que centraliza Monte Alegre do Piauí, de maneira que, consideramos os centros locais e os Centros de Zona B que Corrente influencia, a cidade passa a centralizar um total de dez municípios. Tanto Bom Jesus como Corrente, assim, 
apresentam crescimento de suas áreas de influência, porém, o primeiro tem demonstrado a tendência de expandir ainda mais seu protagonismo.

Nota-se que Uruçuí, no REGIC de 1987, possuía cinco municípios sob sua área de influência: Antônio de Almeida (PI), Benedito Leite (MA), Landri Sales (PI), Ribeiro Gonçalves e São Félix de Balsas (MA). Já no REGIC de 1993, passou a ter apenas quatro: Benedito Leite (MA), S. Domingos do Azeitão (MA), Baixa Grande do Ribeiro (PI), Ribeiro Gonçalves (PI). Destaca-se que Baixa Grande do Ribeiro desmembrou-se de Ribeiro Gonçalves em 1993, portanto é um município muito novo. É curioso também notar que a cidade de Santa Filomena, apesar de pertencer à Microrregião Alto Médio Gurguéia, no REGIC de 1993 consta na área de influência de Balsas (MA), de maneira que pode oferecer um risco à Uruçuí em relação ao poder de centralidade. Ademais, é importante ressaltar que, com a construção da BR-235, que liga os municípios de Gilbués e Monte Alegre à Santa Filomena, há uma tendência de maior articulação entre essas cidades, o que pode favorecer e potencializar a região de influência de Bom Jesus e Corrente ao mesmo tempo, já que Monte Alegre e Gilbués estão ligados a esses dois centros urbanos dos Cerrados piauienses.

$\mathrm{Na}$ figura abaixo, pode-se notar a região de influência dos três principais centros da área de estudo, considerados pelo REGIC de 2007: 
Figura 63: Região de Influência dos principais centros urbanos do Sudoeste Piauiense

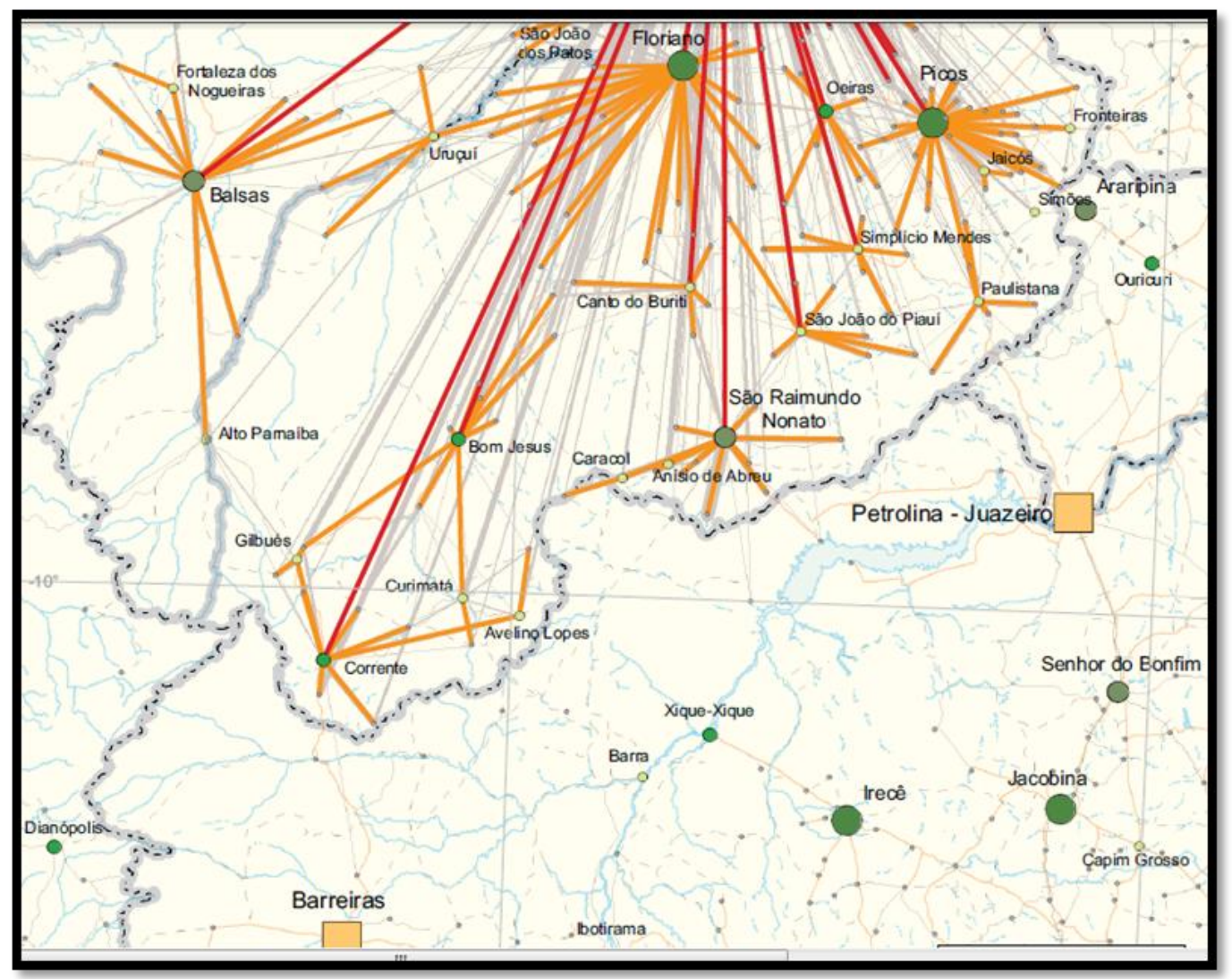

Fonte: REGIC 2007/IBGE, adaptado pelo autor

Considerando a área de estudo, percebe-se que os três principais centros urbanos são justamente as cidades de Bom Jesus e Corrente, consideradas como Centro de Zona A, e Uruçuí, considerado como Centro de Zona B e como um dos grandes centros urbanos focados no atendimento às demandas do agronegócio, sobretudo na venda de produtos como fertilizantes, máquinas e insumos. No entanto, é importante focar Bom Jesus e Corrente, pois observa-se o acirramento da rivalidade entre as duas cidades, como na questão das tentativas de recepção de novos equipamentos urbanos, e Corrente tem, nos últimos anos, perdido o lugar face ao crescimento da importância de Bom Jesus no cenário mesorregional. Esse embate entre as duas cidades pode vir a ter o mesmo nível de rivalidade entre Barreiras e Luís Eduardo Magalhães, localizadas no oeste baiano.

Nessa realidade de disputa, revela-se a lógica de regiões agrícolas e de expansão da fronteira econômica. A competição entre os municípios em detrimento da cooperação entre os mesmos é, assim, um dos grandes desafios para os pequenos municípios brasileiros (MOURA, 2009), o que certamente pode ser aplicado ao caso piauiense, em que muitos municípios inseridos na expansão da fronteira agrícola e econômica do Estado intensificam 
disputas fiscais, por controle de terras, fronteiriças, e na atração de grandes empresas e de estabelecimentos públicos e privados - por exemplo. Bom Jesus e Corrente, Bom Jesus e Monte Alegre do Piauí, e Gilbués e Monte Alegre do Piauí. Esse fato intensifica a fragmentação territorial do Estado do Piauí.

Segundo Moura (2009, p.36),

É necessário também criar articulações intermunicipais: consórcios, associações, agências, fóruns, redes, câmaras intermunicipais, que auxiliem na solução de problemas comuns, e ter claras, na cooperação, as responsabilidades, evitando a subordinação dos mais fracos pelos fortes, pois a cooperação implica (re)definição do poder.

No entanto, para que isso se consolide e obtenha-se ganho, é necessário um amplo apoio do Estado no sentido da valorização das atividades econômicas desenvolvidas nos pequenos municípios, empoderando as populações locais e também as pequenas atividades. Com efeito, considera-se que a subordinação das pequenas cidades da área de estudo em relação à Bom Jesus poderá agravar as desigualdades regionais no Sudoeste Piauiense, e, por conseguinte, ressalta-se a necessidade da criação de situações que favoreçam a cooperação mais igualitária entre as cidades. Observa-se também que os ganhos e novos recursos gerados na região, a partir da moderna agricultura, não são verdadeiramente revertidos no território piauiense, o que provoca a acentuação das desigualdades regionais e sociais no país.

Além disso, é necessário entender essa nova tendência de migração para outras áreas como um novo período, caracterizado pela invasão de agentes econômicos e sociais do Sul e Sudeste do país em outras regiões, e que evidencia o pouco aproveitamento das potencialidades locais pelos próprios agentes internos do Sudoeste Piauiense por razões históricas de negligência do Estado.

Bom Jesus, portanto, passa a ser destino de sulistas e isso contribui diretamente para a ampliação e modificação do comércio, serviços e equipamentos urbanos. A presença de migrantes sulistas atribui um caráter singular à população do município de Bom Jesus em virtude dos traços marcantes da "cultura gaúcha" ${ }^{74}$ que acaba influenciando nas características da população. Em decorrência disso, já se observa modificações no comércio em razão do crescimento do número de estabelecimentos ligados ao agronegócio, maior tráfego de veículos pesados na cidade, surgimento de hotéis e pousadas, influência do

\footnotetext{
74 A cultura gaúcha representa não apenas os traços culturais dos migrantes sulistas, mas também toda uma ideologia e intencionalidade presente no processo migratório para regiões consideradas estagnadas e nas quais reproduzem os seus objetivos e intenções.
} 
churrasco e do chimarrão gaúcho no comércio, instalação de novas empresas e maior crescimento populacional (ALVES, 2005), o que nos permite inferir que os migrantes sulistas carregam características e identidades ligadas ao desbravamento e ocupação de novas áreas, que de alguma forma estão ligadas à descendência europeia da maioria. As características impostas pela "cultura gaúcha”, porém, são reproduzidas de formas diferenciadas de acordo com as particularidades e especificidades de cada local (HAESBAERT, 1998).

A cidade de Bom Jesus, atualmente, é grande exemplo de que certos centros urbanos são reflexos da modernização do campo. Além disso, a cidade concentra grande parte de serviços necessários para a maioria dos onze municípios integrantes da região, como os relacionados à educação, saúde e comércio. Araújo (2006, p.8) destaca essa particularidade da cidade de Bom Jesus no seguinte trecho: "A dinâmica das redes também pode explicar o fenômeno da migração Centro-sulista, que trouxe na esteira novos modos de produzir e viver, numa relação que complexifica as dimensões econômicas e culturais naquele espaço."

Bom Jesus passa por um momento de total reconstrução da sua paisagem urbana, pois se verifica um grande crescimento no número de loteamentos e novas construções, inclusive de grandes empreendimentos comerciais, como Shopping Center e comércios diferenciados no contexto mesorregional, como churrascarias, pousadas, hotéis, padarias e lojas de eletrodomésticos de alto padrão. Além disso, nota-se uma extrema valorização de certas áreas do espaço urbano do município, como, por exemplo, casas do condomínio Consórcio das Águas I, que pode ser observado na figura abaixo:

Figura 64: Placa de casa à venda no Condomínio Consórcio das Águas- Bom Jesus-PI

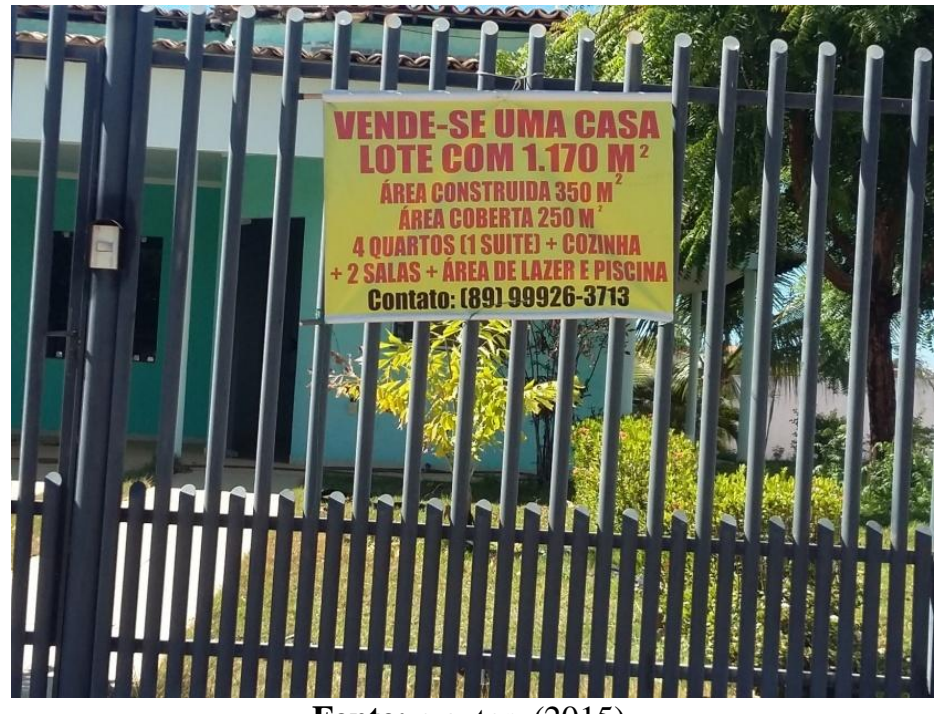

Fonte: o autor, (2015). 
Pelas informações contidas na placa, verifica-se a dimensão da residência colocada à venda, fato observado no segundo trabalho de campo em Bom Jesus, quando conversamos com o porteiro do condomínio, que afirmou que as casas variam de 400 mil a 800 mil reais, o que é um valor absurdamente alto para a realidade local de Bom Jesus e das demais cidades da área de estudo. Através da placa, pode-se evidenciar também a emergência da especulação imobiliária em Bom Jesus, além de uma maior valorização do preço da terra.

Araújo (2006) destaca também que a cidade de Bom Jesus passa a conviver com realidades urbanas diferenciadas ligadas aos agentes sulistas e ao grande capital, tais como pista de pouso para a aviação próximo à cidade, aumento do perímetro urbano, e valorização do preço da terra, principalmente nas áreas próximas ao centro da cidade e à BR-135, que é onde há uma grade concentração de centros comerciais ligados ao setor hoteleiro, combustível, reparação de máquinas agrícolas e automotivas.

Reis e Cunha (2009) consideram que:

O município de Bom Jesus passa a se adaptar ao ritmo dos novos moradores e das novas exigências produzidas para atender as necessidades do capital. $O$ novo comportamento do município subordina-se a essas novas exigências, organizando seu espaço, sua vida econômica e social ao ritmo e às vontades da produção agrícola moderna. (REIS; CUNHA, 2009, p.1)

Dessa forma, Bom Jesus passa por grande processo de urbanização, o que é corroborado pelo fato de que quase $80 \%$ da população sua municipal é urbana, e que confirma a tendência de maior urbanização das cidades agrícolas localizadas nas áreas dos Cerrados Nordestinos inseridos no processo de expansão e consolidação da fronteira agrícola do país (MIRANDA, 2012). Para esse mesmo autor, quanto maior os percentuais de áreas agrícolas, maior é a tendência de urbanização em função dos movimentos ligados ao êxodo rural, o que pode contribuir para a aceleração e precarização do crescimento urbano nas cidades do agronegócio.

Bom Jesus é resultado, assim, da dispersão urbana presente no Brasil, mais especificamente da terceira modalidade dessa dispersão, abordada por Becker e Egler (1993) e analisada no capítulo 2. Essa terceira modalidade de dispersão é composta por cidades que crescem como resultado da expansão da fronteira econômica, sobretudo com a expansão da fronteira agropecuária e mineral, constituindo, assim, local de concentração da força de trabalho. 
Corrêa (2001, p.424) defende que "podem ser alterados os centros urbanos, assim como a natureza, intensidade, periodicidade e alcance espacial das interações e a forma espacial da rede.” Dessa forma, com o encaminhamento da consolidação do agronegócio no Piauí, de acordo com as proposições de Sposito (2015), Bom Jesus pode se beneficiar pela grande quantidade de pequenos municípios ao seu redor. Ainda segundo a mesma autora, a modernização da agricultura pode fazer com que certos municípios percam sua funcionalidade, pois grande parte das pessoas abandona essas cidades pequenas em direção às cidades médias locais, em busca de emprego nas áreas urbanas, nos setores de serviços e comércio. Dessa forma, há a tendência de que as cidades influenciadas por Bom Jesus passem a ter saldo migratório negativo por conta da atração do município, e também pela modernização do campo e pressões na escala fundiária, pois a mão de obra se torna mecanizada, empregando poucas pessoas, o que contribui para a acentuação do êxodo rural.

Pode-se afirmar que Bom Jesus reina sozinha dentro do Alto Médio Gurguéia pois não há, nessa microrregião, outra cidade com o seu porte e possibilidade de crescimento. Sendo assim, pelas funções que a cidade desempenha, considera-se que Bom Jesus vem, cada vez mais, assumindo um papel de cidade média na rede urbana em que está inserida, mas deixamos claro que, ao admitirmos essa classificação, conceito discutido por Becker e Egler (1993), estamos relativizando a questão quantitativa, pois, para o IBGE, uma cidade é considerada média quando supera os 100 mil habitantes, e, mais importante, estamos valorizando o contexto que Bom Jesus está inserida. De acordo com Araújo; Moura e Dias (2011), as cidades médias brasileiras são resultados dos novos papéis do Brasil na divisão internacional do trabalho, em que ele figura como um país exportador de commodities. Nesse caso, Bom Jesus, cidade média dos Cerrados piauienses, amplia seu papel na rede urbana do Sudoeste Piauiense à medida que o agronegócio se consolida na região.

Segundo Deus (2004), ao considerarmos que a maior parte das cidades com mais de 100 mil habitantes está localizada na região Centro-Sul do Brasil, os parâmetros de definição de cidade média do IBGE revelam-se inconsistente, pois parte considerável do território brasileiro não possui cidades com o peso populacional estabelecido pela instituição, especialmente estados do Nordeste, como o Piauí, por exemplo. Picos, a terceira cidade mais populosa do Piauí, por exemplo, não possui mais que 73.414 habitantes. Nesse caso, devemos considerar que Bom Jesus, apesar ter somente quase 25 mil habitantes, segundo as projeções populacionais do IBGE, está inserida em um contexto em que ela demonstra possuir maior importância em relação às demais cidades. 
Assim, nas palavras de Deus (2004),

Entre os fatores de conceituação das cidades, incluindo as cidades médias, está a função que o núcleo urbano exerce na região em que está inserida e na hierarquia das redes urbanas. É a função urbana que define o papel da cidade no complexo geográfico, sem a qual a aglomeração urbana deixa de ter sentido. (DEUS, 2004, p.84).

O autor considera importantes as análises dos centros urbanos com menor contingente populacional, atitude que, por outro lado, é criticada por Veiga (2005), autor mencionado no capítulo 1, na medida em que, para ele, não se deve considerar pequenas cidades como centros urbanos, mas sim como espaços rurais. Deus (2004), ao contrário, defende veementemente que devemos considerar os diferentes contextos presentes no território piauiense. Com efeito, de acordo com Silva (2013), “Assim, o critério populacional não traduz a dinâmica do conjunto de cidades médias ou mesmo não é sinônimo de uma dada realidade, pois, mesmo que se considere um intervalo de número de habitantes, há muita discrepância entre estes espaços."

Dessa forma, concordamos com Deus (2004) e Silva (2013), pois a rede urbana piauiense apresenta particularidades evidentes em relação à grande parte do território do Brasil. Apesar da existência de pequenas cidades muitos ligadas à escala do rural na área de estudo, entendemos que as cidades de Bom Jesus, Corrente, Uruçuí e até mesmo Gilbués, podem ser encaradas como áreas verdadeiramente urbanas e não rurais. Deus (2005), ao analisar as funções das pequenas cidades do noroeste de Goiás, defende que a funcionalidade das mesmas é dar "suporte à produção, com comércio e serviços, garantidos a eficiência da agropecuária e o escoamento dos produtos exportados para outras unidades da federação ou país, ou ainda, para agroindústrias instaladas nos municípios maiores.” (DEUS, 2005, p.86). Tal situação se repete até certos aspectos em grande parte das cidades da área de estudo, principalmente em Bom Jesus, Uruçuí e até mesmo Corrente.

Segundo França e Soares (2009, p.3), "Do ponto de vista do nível hierárquico das cidades, uma cidade média é aquela que se localiza entre a grande cidade e a pequena cidade, tendo dessa forma, uma posição intermediária." Sposito (2004, p.126) complementa, afirmando que "As cidades médias são aquelas que, numa dada divisão territorial do trabalho, são centros urbanos regionais importantes em função de serem os elos de ligação entre cidades maiores e menores.”, contexto em que se encaixa Bom Jesus, localizada em meio à capital e um conjunto de pequenas cidades presentes nos Cerrados piauienses. Nesse sentido, 
é uma cidade de articulação da rede urbana dos Cerrados piauienses a outros centros urbanos piauienses e até mesmo de fora do Piauí, como as cidades do oeste baiano, Brasília, Balsas (MA), entre outras. Sampaio (2011) ainda reforça a conceituação sobre cidade média:

[...] além de ser a principal característica dessa categoria de cidade, uma vez que nela se apóia o seu poder de articulação entre os diferentes níveis de centros urbanos, a sua atuação como centro de oferta de bens e serviços para sua área de influência e como nó de diferentes tipos de redes, funções que estão no cerne do conceito de centralidade. (SAMPAIO, 2011, p.5).

Assim, não julgamos que essa definição não seja passível de reconstrução, já que, de acordo com Sposito (2006, p.147), "Atualmente, o reconhecimento da inserção de uma cidade média no âmbito de uma rede urbana tornou-se extremamente mais complexo." Tal complexidade, segundo a autora, é resultado dos efeitos do processo de mundialização da economia, sobretudo das transformações do setor de telecomunicações, que garante à cidade de Bom Jesus novas possibilidades de articulações. Sampaio (2011, p.2) sustenta que "[...] na medida em que as informações conectam lugares diversos no mundo e quanto maior a inserção da ciência e tecnologia, mais aumenta o número, intensidade e qualidade de fluxos que chegam e saem de uma área."

Como estamos analisando a questão da agricultura moderna, um processo ligado à globalização, a tarefa de definição do papel de Bom Jesus nessa rede urbana inserida em área de expansão agrícola se torna ainda mais complexo. No entanto, entende-se que Bom Jesus é a cidade que mais vem se fortalecendo depois da inserção dos piauienses na dinâmica da agricultura moderna, ampliando sua área de influência, o que fortalece nossa tese que essa cidade tem se consolidado em relação ao desempenho de funções intermediárias na rede urbana dos Cerrados piauienses. Com o advento da moderna agricultura, Bom Jesus tem participado de novos fluxos apoiados pelos avanços das telecomunicações, até mesmo em áreas mais remotas, como é o caso dos platôs piauienses, onde há escritórios de empresas agrícolas e lojas de insumos agrícolas, que articulam-se e realizam transações e atividades por meio de informatização por computação e telefonia com outras cidades brasileiras, e até mesmo com a escala internacional, o que amplia ainda mais as articulações promovidas por Bom Jesus.

Tal consideração é confirmada por Conte (2013, p.46), que afirma que, nos estudos sobre as funções desempenhadas pelas cidades médias, "Deve-se enfatizar a ampliação de uma base técnica, associada principalmente as comunicações e aos transportes, que 
possibilitou a diversificação das interações espaciais." A mesma autora ainda complementa dizendo que

Ora a cidade intermédia estabelece a ligação entre os níveis superiores e inferiores da hierarquia, ora a cidade intermédia é também a que estabelece relações com cidades do mesmo nível hierárquico, as quais desenvolvem funções complementares e/ou similares, seja no espaço nacional ou internacional, interligando-se em rede, numa perspectiva de integração dentro de um espaço mais abrangente. (CONTE, 2013, p.53)

Esse autor ainda considera que o processo de reestruturação econômica mundial, promovido pelo capitalismo global e a globalização, acaba atribuindo novos papéis e funções às cidades. No caso dos Cerrados piauienses, verificamos que Bom Jesus é mais que uma cidade do agronegócio, na medida em que desenvolve também outros setores econômicos, ainda que não apresente, por exemplo, atividades industriais, o que pode ser algo a ser desenvolvido em um futuro de curto ou médio prazo.

Nesse sentido, Bom Jesus constitui-se como uma cidade média em razão da migração de agentes hegemônicos nacionais e internacionais para o município, além da centralização dos serviços, equipamentos urbanos e infraestruturas. Os autores Araújo, Moura e Dias (2011, p.61) já chamavam atenção para a "[...] possibilidade de estas cidades se converterem em centros de serviços e equipamentos regionais, reforçando seus vínculos com o território e hinterland, não só pelo desempenho funcional, mas também pela interação das escalas social, econômica e cultural.” Segundo Sposito (2006, p.144),

\footnotetext{
Assim, há o desafio de se avançar na abordagem de processos, dinâmicas e fenômenos de caráter geográfico, a partir da consideração do tempo e do espaço, de suas múltiplas articulações e da apreensão das escalas geográficas, que se configuram por meio dessas articulações. (SPOSITO, 2006, p.144).
}

Outro fato que julgamos necessário destacar é que a posição geográfica de Bom Jesus lhe beneficia, pela distância em relação à capital do Piauí, Teresina, pois torna-se um grande centro local, por conta da centralização dos serviços, do comércio, de equipamentos urbanos, como de saúde e educação, e serviços diferenciados em relação à conjuntura local. As pequenas cidades da região de influência de Bom Jesus, por exemplo, dispõem de atendimento médico fraco, somado à presença de hospitais de pequeno porte. Ademais, a presença de serviços educacionais diferenciados, sobretudo de graduação e pós-graduação em Bom Jesus, acaba atraindo mais pessoas para a cidade, em detrimento à Teresina, por 
exemplo. Sampaio destaca pontos fundamentais em relação à atração de pessoas rumo às cidades médias inseridas em um contexto com pequenas cidades, como é o caso de Bom Jesus:

\begin{abstract}
Do ponto de vista do mercado consumidor, as cidades médias continuam a desempenhar o papel dos pólos para os quais moradores de cidades menores e de áreas rurais estão dispostos a se deslocar em virtude que o tempo para esses deslocamentos tem diminuído, diante das melhorias dos transportes, inclusive, com o aumento de veículos próprios, bem como a frequiência das viagens propiciadas pelo sistema de transporte coletivo. Esses fluxos definem-se, assim, no âmbito da região e marcam e são marcadas pela existência de um espaço de continuidade territorial cuja configuração é a de uma área. (SAMPAIO, 2001, p.6).
\end{abstract}

Tal contexto de crescimento, também característicos de Bom Jesus, cidade média dos Cerrados piauienses, segundo Conte (2013), é um claro reflexo de desconcentração da estrutura produtiva e aumento populacional das cidades interioranas, o que revela, segundo o autor, o processo de desconcentração populacional verificado nos centros metropolitanos e grande centros urbanos, como já apontamos também no primeiro capítulo deste trabalho.

Realizamos anteriormente, baseando-nos em dados dos REGIC's, um panorama da evolução da área de influência, e consequentemente da importância de Bom Jesus no cenário da Mesorregião Sudoeste Piauiense. Dessa forma, julgamos relevante considerar não apenas as articulações que Bom Jesus realiza, mas também o reconhecimento de como o tempo e o processo incide sobre o recorte territorial considerado, como aborda Sposito (2006):

[...] reconhecer uma escala geográfica não seria apenas avaliar o resultado das articulações entre diferentes recortes territoriais, mas a forma como o tempo incide sobre diferentes territórios, oferecendo condições para o estabelecimento de relações de diferentes tipos - naturais, econômicas, políticas, sociais, culturais..., que se refletem no espaço e nele se apóiam e que são, de fato, interações espaço-temporais. (SPOSITO, 2006, p.149-150).

No entanto, deve-se considerar que o crescimento de Bom Jesus não significa necessariamente que a cidade está se desenvolvendo, no sentido de estabelecimento de melhores condições de vida. Pelo contrário, nota-se a ampliação das desigualdades socioespaciais, com o surgimento de uma face moderna, ligada à elite local, e de espaços mais pobres e atrasados, ligados à população pobre.

Ao final, ressalta-se a importância da consolidação das três cidades piauienses, Bom Jesus, Corrente e Uruçuí, especialmente a primeira, para maior integridade do Estado do Piauí, pois a capital Teresina está distante fisicamente da porção sul do Estado. O acirramento do embate entre Bom Jesus e Corrente na disputa pela hegemonia da rede urbana na qual 
estão inseridas pode ser benéfico para as duas cidades, principalmente para Bom Jesus, pois, de acordo com Conte (2013), se uma cidade média estiver localizada em área e a mesma estiver isolada como único centro urbano de maior importância, tal cidade terá mais dificuldades de manutenção da sua posição como cidade média. Pode-se afirmar que, nesse embate entre Corrente e Bom Jesus, esta última se sobressai, em partes em decorrência de sua localização geográfica mais favorável, já que está no Centro da Mesorregião Sudoeste Piauiense e, claramente, mais próxima de Floriano, de Teresina e de mais cidades piauienses. Corrente localiza-se no extremo sul piauiense, o que confere dificuldade nas articulações com outras cidades piauienses localizadas mais ao centro e norte do Estado do Piauí.

Dessa forma, com o maior protagonismo, essas cidades, e em especial de Bom Jesus, acabam articulando melhor a rede de cidades da região dos Cerrados piauienses. Segundo Conte (2013)

\footnotetext{
As cidades médias passaram então a serem valorizadas como fator de equilíbrio para as redes urbanas de diversos países, principalmente aqueles onde a diferença e/ou distância entre as cidades grandes e pequenas é mais acentuada, como no caso do Brasil. Neste mesmo sentido, outro aspecto bastante relevante diz respeito às funções de relação de intermediação exercidas por elas, entre, de um lado, as pequenas cidades e de outro, as grandes cidades e o meio rural regionais. (CONTE, 2013, p.57).
}

Sendo assim, Bom Jesus contribui no papel de intermediação da porção sul do Estado do Piauí aos outros centros urbanos mais importantes do Piauí, como Floriano, Picos e Teresina, porém, esse desenvolvimento relacionado ao agronegócio pode agravar a diferenciação socioespacial presente no Estado do Piauí, o que acarreta até mesmo em mudanças de cunho políticas e territoriais. 


\section{CONSIDERAÇÕES FINAIS}

O Sudoeste Piauiense participa de forma ativa do processo de modernização da agricultura presente no Brasil Central, gerando inúmeras transformações socioespaciais, especialmente no que diz respeito à questão urbana. A rede de cidades da mesorregião vem se reconfigurando nos aspectos sociais, econômicos, demográficos e políticos. Nessa lógica de expansão das áreas de moderna agricultura, é importante destacar que o Estado foi um dos grandes responsáveis por essas novas ocupações, efetivando novas áreas na fronteira agrícola da agricultura moderna, utilizando como justificativa o argumento de que a expansão do agronegócio propicia o desenvolvimento econômico dessas novas áreas agricultáveis dos Cerrados.

Dessa forma, pode-se destacar o caráter importante das políticas públicas, atreladas ao Estado, pois pode, reorganizar diferentes redes urbanas em determinados territórios em decorrência do surgimento de novas centralidades no âmbito urbano, como no caso do Sudoeste Piauiense. Nesse sentido, novas políticas públicas podem colocar ou retirar a evidência de determinados municípios e cidades de rotas de circulação e concentração de dinâmicas ligadas à grande produção.

Portanto, é preciso sair da zona de conforto em relação ao questionamento de processos ligados ao "desenvolvimento", “modernização" e "progresso". É preciso qualificálos como processos contraditórios. Nota-se, na escala urbana do Sudoeste Piauiense, por exemplo, que a valorização da terra urbana é também dependente da precarização dos mais pobres, de maneira que se pode considerar essa problemática como um processo complexo que envolve especulação imobiliária e que também a acentuação das desigualdades, que é uma característica inerente ao capitalismo.

É eminente a necessidade do questionamento sobre a objetivação do país em relação ao crescimento econômico focado na concentração da produção da agricultura baseada na alta produção de grãos, em especial a soja. Além dos impactos sociais consideráveis gerados a partir desse processo, é necessário destacar que o Brasil possui uma biodiversidade gigantesca, que rapidamente vem sendo ameaçada pelo desmatamento através da implementação de projetos agrícolas.

Além disso, é essencial uma ação mais compacta do Estado em relação ao surgimento de ilhas de dinamismos em ambientes de grande pobreza, isolamento físico, e dificuldades de inserção e integração. O Estado do Piauí já possui sérios problemas de fragmentação 
territorial que podem ser agravados com a emergência da modernização agrícola, processo hegemônico, que impõe ao Sudoeste Piauiense alterações socioespaciais bastante significativas. Assim, o agronegócio pode fomentar ainda mais o aprofundamento das desigualdades regionais e sociais presentes no Estado do Piauí, especialmente nas áreas dos Cerrados.

Nota-se hoje uma modificação da hierarquia dos centros urbanos regionais do Sudoeste Piauiense, pois os municípios do agronegócio ganham cada vez mais destaque no cenário mesorregional, havendo alterações consideráveis em torno das áreas de influências das cidades, especialmente de Bom Jesus e Uruçuí, o que acontece em virtude principalmente das novas configurações no urbano e modificações em diversos setores como nas áreas de serviços e comércio, pois tomam lugar novas conjunturas ligadas à agricultura moderna. Nesse sentido, defende-se que, no contexto dos Cerrados piauienses, Bom Jesus desempenha um papel de cidade média da rede de cidades, o que gera profundas alterações nas relações entre os diferentes centros urbanos presentes nessas áreas.

Assim, as transformações socioespaciais presentes nas cidades piauienses, apesar das particularidades, revela um contexto contido em diversos recortes brasileiros, e que caracteriza a economia brasileira atual: baseada na exportação das commodities, sobretudo de grãos. O que gera novas necessidades e novas tipologias de cidades, pois o agronegócio necessita de áreas urbanas que forneçam apoio às atividades ligadas à agricultura moderna. Isso, de alguma forma, impacta diretamente na emergência de novas centralidades urbanas como consequência da centralização dos equipamentos urbanos, do comércio e serviços, principalmente daqueles focados na disponibilização de insumos, máquinas agrícolas e tecnologia.

Dessa forma, as chamadas cidades do agronegócio mostram-se muito mais do que simples cidades de apoio ao agronegócio, visto que as mesmas tornam-se também centros da concentração populacional, causada pela atração da mão de obra e de sulistas, da concentração de universidades públicas e, consequentemente, atraem um número maior de professores e alunos. Tal situação foi verificada nessa pesquisa, onde nota-se o "surgimento" de Bom Jesus como o grande centro urbano de apoio à agricultura moderna, concentração de migrantes sulistas e emergência de um comércio e serviços reconfigurados, como consequência das atividades agrícolas modernas e da migração sulista.

Entretanto, apesar das transformações urbanas verificadas neste trabalho, percebe-se que o agronegócio beneficia as cidades de forma muito tímida. Isso porque quando 
observamos a dimensão dos projetos de agricultura moderna e analisamos o contexto econômico e social dessas cidades, percebemos uma contradição muito perceptível, ao ponto de afirmarmos que das cidades da área de estudo, poucas participaram ativamente das transformações que o agronegócio empreende. Constatamos inclusive que municípios como São Gonçalo do Gurguéia, Barreiras do Piauí e Santa Luz ficam à margem do agronegócio por não possuírem áreas de platôs. O que pode gerar uma acentuação ainda maior das desigualdades sociais e regionais nos Cerrados piauienses, pois observamos cidades que se beneficiam mais em detrimento das outras, principalmente Bom Jesus e Uruçuí.

Além disso, constatou-se que os municípios da Microrregião Chapadas do Extremo Sul Piauiense, com exceção de Corrente, não participam da agricultura moderna, sendo municípios bem focados na pecuária, seja das pequenas atividades ou as com maior escala de grandiosidade e modernidade. Nesse caso, podemos caracterizá-los como municípios da resistência ao agronegócio, sendo ainda a pecuária a base das economias municipais, especialmente as pequenas atividades pecuárias.

Outro ponto fundamental a ser destacado é que o agronegócio piauiense possui particularidades evidentes se comparado a outras áreas, como o oeste baiano, por exemplo. Nos Cerrados piauienses, as cidades ficam localizadas distantes dos projetos de agricultura moderna, já no oeste baiano observa-se que a maior parte das cidades está próxima às áreas de cultivo. Esse maior distanciamento entre as áreas urbanas e as áreas dos platôs piauienses pode contribuir para certa amenização das migrações, especialmente do êxodo rural, visto que as pressões às terras dos pequenos agricultores tornam-se "menores".

No entanto, nos últimos anos já se observa que alguns grandes agricultores sulistas já começam a adquirir terras nas áreas mais baixas (baixões) para destinação de reservas legais obrigatórias. Nesse processo, já é evidente a emergência de grilagem de terras e opressão aos pequenos produtores e moradores locais, o que pode influenciar nos processos migratórios em direção às cidades. Têm-se assim múltiplas possibilidades de consequências em relação à estrutura fundiária da região, visto que o agronegócio piauiense ainda está em fase de consolidação, onde observamos uma maior intensificação do uso do solo e expansão dos projetos nos últimos dez anos, o que mostra o caráter recente da efetiva ocupação dos Cerrados piauienses. Assim, fica muito precoce afirmamos com veemência os possíveis desdobramentos mais complexos ainda em emergência nessa área de estudo.

A emergência de Bom Jesus como grande centro urbano dos Cerrados piauienses, considerando também as cidades de Corrente e Uruçuí, pode gerar dois processos: maior 
integridade territorial ao Piauí ou maior fragmentação da porção Sudoeste do Estado do Piauí. Bom Jesus, inclusive, é uma das candidatas a ser a capital do possível Estado do Gurguéia. No entanto, essa intenção separatista do Estado do Piauí esbarra na distribuição da população, pois a maior parte dos habitantes concentra-se na porção central e norte do Estado. Isso seria decisivo se houvesse consulta à população, por meio de plebiscito ou referendo, para decidir sobre a criação do Estado do Gurguéia, já que a população da Mesorregião Sudoeste Piauiense, que seria propriamente o novo Estado, é infinitamente menor que a população localizada na porção central e norte do Piauí. Nesse caso, acredita-se que o restante do Piauí não desejaria a separação, pois os Cerrados piauienses revelam-se como a área com o maior crescimento econômico do Estado do Piauí e acabam liderando o desenvolvimento da economia piauiense.

Em relação à Bom Jesus, trata-se de um caso emblemático, pois como apontamos durante o trabalho, é a cidade brasileira com o maior número de doutores ao considerarmos o tamanho da sua população. Além disso, essa cidade concentra as universidades públicas dessa porção territorial do Estado do Piauí. No entanto, devemos ressaltar que esse fato mostra que uma pequena parcela da população de Bom Jesus participa ativamente dos benefícios gerados a partir do agronegócio, pois grande parte do ensino superior de Bom Jesus é focado em cursos voltados às atividades ligadas à agricultura moderna. Assim, têm-se uma grande parte da população que não é capaz de acompanhar as mudanças que o agronegócio empreende, sobretudo na questão da qualificação da mão de obra, visto que a agricultura moderna necessita de profissionais especializados, como agrônomos, administradores e técnicos agrícolas.

Além do mais, Bom Jesus apresenta uma reconfiguração da sua paisagem urbana, inclusive com intensa expansão do perímetro urbano por meio do surgimento de novos bairros na cidade, que certamente, é um reflexo da desigualdade e dos efeitos contraditórios do agronegócio presentes na cidade, pois de um lado observamos o surgimento de condomínios fechados de alto padrão, que são os locais de moradia da classe média do agronegócio, e do outro lado, nota-se a emergência e expansão de bairros com pouca infraestrutura e com baixo padrão das residências, que são, basicamente, os locais de moradia de trabalhadores do comércio de Bom Jesus, dos projetos de agricultura moderna, sendo moradores que anteriormente residiam nos pequenos municípios ou em áreas rurais de Bom Jesus, o que pode acentuar o êxodo rural na região dos Cerrados piauienses. Por esse contexto, Bom Jesus apresenta uma situação demográfica complexa, pois possui a maior quantidade de migrantes 
sulistas da rede de cidades selecionada, apresenta grande quantidade de estudantes de outras cidades e até mesmo de outros estados brasileiros e um grande número de professores das universidades e de outras instituições de ensino.

Com o possível crescimento populacional de municípios como Bom Jesus, Uruçuí e Corrente, em decorrência da desconcentração da estrutura produtiva do Brasil, pode-se atribuir um peso populacional maior ao Sudoeste Piauiense, e gerar, assim, consequências políticas, como, por exemplo, a separação do Estado, mas apenas a longo prazo. Assim, o desenvolvimento do agronegócio e as transformações urbanas nas redes de cidades devem ser acompanhados e analisados com o passar dos anos, para verificarmos os processos que decorrerão desse desenvolvimento.

É importante sublinharmos também que, além de Bom Jesus, Uruçuí e Corrente, outros centros urbanos também merecem destaque em relação ao maior protagonismo, nesse caso, consideramos, a partir dos dados já analisados, que as cidades de Gilbués e Cristino Castro merecem serem considerados como pequenos centros urbanos que desempenham um importante papel na rede de cidades da área de estudo, sobretudo a primeira cidade citada. Essas duas cidades apresentam certa concentração de serviços, comércio e de equipamentos urbanos. Gilbués centraliza duas cidades: Barreiras do Piauí e Monte Alegre do Piauí. Portanto, temos um pequeno agrupamento de cidades ligadas à cidade de Gilbués, que acaba articulando as duas cidades em relação à disponibilização de serviços importantes, como os bancários, rede escolar e ao comércio da cidade, como por exemplo, na revenda de motocicletas. Cristino Castro possui um potencial muito grande em relação ao turismo, por abrigar a maior parte dos poços jorrantes da região. Nesse caso, essa cidade possui um número diferenciado de serviços relacionados à rede hoteleira, restaurantes e bares. Portanto, Cristino Castro, a partir das transformações empreendidas pelo agronegócio, especialmente pela maior presença de migrantes sulistas, poderá se reconfigurar ainda mais e se tornar um polo turístico e comercial da região dos Cerrados.

Por ora, a rede de cidades do Sudoeste Piauiense ainda é marcada pelos inúmeros problemas relacionados à falta de infraestrutura, como a falta de saneamento ambiental adequado - não há abastecimento de água tratada e coleta de esgoto difundido em todos os municípios -, além do fato de que as cidades do Sudoeste Piauiense caracterizam-se pela quase ausência de serviços de saúde, com uma quantidade muito reduzida de médicos, hospitais e postos de saúde no contexto mesorregional. Assim, a maioria das cidades do Sudoeste Piauiense apresenta graves problemas relacionados à proliferação de doenças 
relacionadas à falta de saneamento básico, como a dengue e a malária. Além disso, os municípios apresentam uma rede de telefonia fixa e móvel desconectada e fragmentada no contexto mesorregional, bem como a precariedade e insuficiência dos transportes públicos ligando as diferentes cidades. Consequentemente, no contexto geral da rede de cidades do recorte selecionado, observamos pouca articulação entre as cidades no que se refere ao transporte público ligando os diferentes centros urbanos e pouca integração da rede telefônica.

Além desses problemas, verifica-se alguns empecilhos ao desenvolvimento do agronegócio nos Cerrados piauienses, como por exemplo, a baixa qualidade das rodovias. Soma-se a isso a péssima situação das estradas que ligam os baixões às áreas dos platôs, onde ficam localizados os projetos de agricultura moderna. Esse fato foi evidenciado nos trabalhos de campo realizados e pelo contato com os agentes locais. Nesse sentido, isso pode ser representar um sério desafio ao progresso da agricultura moderna nos Cerrados piauienses. No entanto, percebemos que o Estado já vem assumindo a responsabilidade na questão da implementação de infraestruturas de apoio ao agronegócio, como por exemplo, a construção da BR-235, que liga os municípios de Gilbués e Monte Alegre do Piauí à Santa Filomena, localizado na fronteira com o Estado do Maranhão. Assim, o Estado tem como grande objetivo a maior interligação dos Estados pertencentes à região do MAPITOBA.

Em se tratando do MAPITOBA, é vital destacar que essa região se constitui como o centro das atenções de grandes empresas multinacionais, sendo que múltiplas causas e fatores influenciam nesse processo, dentre eles destacamos o menor preço das terras, incentivos fiscais, disponibilização de crédito aos grandes agricultores e empresas, além do clima favorável. Nesse contexto, evidenciamos criação do Plano de Desenvolvimento (PDA) do MATOPIBA, iniciativa do Governo Federal e que pode influenciar diretamente na emergência de novos contextos e dinâmicas nas áreas dos Cerrados dos três Estados nordestinos e no Tocantins.

Devido ao caráter recente da criação desse plano de desenvolvimento agropecuário, não podemos listar ou indicar algumas das ações do Estado a partir desse projeto, no entanto, já deixamos claro que a lei de criação do PDA-MATOPIBA já prevê claramente a ampliação das infraestruturas de apoio ao agronegócio nos Estados que integram essa região agrícola do país. Sendo assim, os Cerrados piauienses podem ser, nos próximos anos, palco da implementação de projetos de infraestruturas que funcionam como suporte ao agronegócio, como por exemplo, na construção de aeroportos e pistas de pouso de menores escalas, novas rodovias e equipamentos urbanos, o que pode favorecer a intensificação das desigualdades 
entre os municípios, pois nota-se, por exemplo, que Bom Jesus vem centralizando as ações em torno da agricultura moderna e seus efeitos, sendo que a sede da agência do MATOPIBA no Estado do Piauí será exatamente nessa cidade.

É importante ressaltar que tivemos que deixar alguns processos que ocorrem nos Cerrados de lado, tais como o processo de desertificação de algumas áreas, pois na região dos Cerrados piauienses está localizado o Núcleo de Desertificação de Gilbués, o que intensifica ainda mais os contrastes presentes na região, pois há dois processos paralelos: modernização agrícola nos platôs e desertificação em grande parte das áreas dos baixões. Nesse sentido, abrem-se mais leques de possibilidades de estudos futuros.

Nesse sentido, a modernização agrícola dos Cerrados piauienses e as evidentes transformações urbanas atribuem um caráter singular às regiões dos Cerrados piauienses, pois as áreas dinâmicas do agronegócio estão inseridas lado a lado com áreas que apresentam inúmeros problemas a serem enfrentados.

Como trata-se de um processo muito recente, isso representa um desafio ao pesquisador a acompanhar as consequências decorrentes desse evento hegemônico para o recorte selecionado, e, por conseguinte, para o território Piauiense. Além disso, é importante ressaltar que, durante a redação deste trabalho, tivemos a necessidade de realizar algumas modificações no tamanho do recorte selecionado, pois inicialmente tratávamos como área de estudo a Mesorregião Sudoeste Piauiense, que possui, ao todo, 62 municípios, o que impossibilitava uma análise mais profunda das transformações urbanas. Assim sendo, optamos por trabalhar com as duas microrregiões com a maior produção, mais o município de Corrente, e com a presença abundante da vegetação dos Cerrados mais intensamente nos platôs piauienses. A distância do pesquisador em relação à área de estudo foi uma complicação, no entanto, a vivência de parte desse recorte territorial e as inúmeras viagens realizadas facilitaram o surgimento de ideias e colocações.

Ao final, espera-se que a pesquisa tenha contribuído ao debate sobre o processo de modernização agrícola nos Cerrados brasileiros, e que, mais especificamente, tenha possibilitado o entendimento das consequências da modernização agrícola sobre a rede de cidades dos Cerrados piauienses. Espera-se, também, que este estudo, encabeçado pela problemática da pesquisa, possa inspirar novas produções e trabalhos sobre a temática. 


\section{REFERÊNCIAS BIBLIOGRÁFICAS}

AB' SABER, A. N. Os domínios de natureza no Brasil: potencialidades paisagísticas. 2. Ed. São Paulo: Ateliê Educacional, 2003. Cap. 8: O domínio dos cerrados- p. 115-135.

AIBA. Aiba apresenta suas propostas para a futura agência de desenvolvimento do MATOPIBA. 2015. Disponível em: <http://aiba.org.br/noticias/aiba-apresenta-suaspropostas-para-a-futura-agencia-de-desenvolvimento-do-matopiba/\#.ViFhYH6rTIV>. Acesso em 20 set. 2015 .

ADORNO, T; HORKHEIMER, M. Dialética do esclarecimento: fragmentos filosóficos. Trad. Guido Antônio de Almeida. Rio de Janeiro: Zahar, 1985, p. 11-46.

AGUIAR, T. J. A.; MONTEIRO, M.S.L. Modelo Agrícola e Desenvolvimento Sustentável: A ocupação do Cerrado Piauiense. Ambiente \& Sociedade, 2005. v.8, n.2.

ALVES, E; CONTINI, E.; HAINZELIN, É. Transformações da agricultura brasileira e pesquisa agropecuária. Cadernos de Ciência \& Tecnologia, Brasília, v. 22, n. 1, p.37-51, 2005.

ALVES, V. E. L.; A Consolidação da Fronteira Agrícola na Região Centro-Norte do Brasil e as Transformações nos Espaços Rurais e Urbanos. 07/2012, In: XVII Encontro Nacional de Geógrafos - XVII ENG - Entre escalas, poderes, ações, Geografias, Vol. 1, pp.1-10, Belo Horizonte, MG, Brasil, 2012a.

As bases históricas da formação territorial piauiense. Geosul, Florianópolis, v.18, n.36, p.55-76, jul/dez 2003. Disponível em: <http://www.periodicos.ufsc.br/indexphp/geosul/article/viewFile/13577/12450>. Acesso em: 05 de maio. 2013.

"A mobilidade sulista e a expansão da fronteira agrícola brasileira". In: Agrária. São Paulo, no 2, 2005b. pp. 40-68.

A presença das grandes empresas do agronegócio nos cerrados nordestinos: O caso da Bunge Alimentos no sul do Piauí. Boletim Campineiro de Geografia. V.2, 2012b.

Barreiras (BA), Balsas (MA), Uruçui (PI): três cidades para o agronegócio.

In: Anais III Simpósio Nacional de Geografia Agrária. Presidente Prudente, 2005.

Mobilização e Modernização nos Cerrados Piauienses: Formação Territorial no Império do Agronegócio. São Paulo: Universidade de São Paulo, Faculdade de Filosofia, Letras e Ciências Humanas, Departamento de Geografia, Tese de Doutorado, 2006.

ARAÚJO, M. R. S; MORAES, M. D. C. Cerrados Piauienses: de Espaço Natural a Espaço Construído. III Encontro da ANPPAS. 23 a 26 de Maio de 2006, Brasília-DF.

Expansão da fronteira agrícola nos cerrados piauienses,(des) territorialização e os desafios para o desenvolvimento territorial: o caso do município de 
Bom Jesus. 188 f (Dissertação- Mestrado em Desenvolvimento e Meio Ambiente)Universidade Federal do Piauí, Teresina). UFPI, 2006.

ARAÚJO, M. M. S; MOURA, R.; DIAS, P. C. Rede Urbana e interfaces. In : Dinâmica urbana-regional: rede urbana e suas interfaces, IPEA 2011. p.61-78.

BECKER, B.K; EGLER, C. A. G. O legado da modernização conservadora e a modernização do território. In Brasil: uma nova potência regional na economia-mundo. Rio de Janeiro: Bertrand Brasil, 1993, p.169-213.

BEZERRA, J. E. Agronegócio e a nova divisão social e territorial do trabalho agropecuário formal no Nordeste. 2008. 260 f. Dissertação (Mestrado em Geografia)Universidade Estadual do Ceará, Fortaleza-Ceará.

BRASIL. Decreto $n^{\circ} 8.447 N^{o} 8.447$, de 6 de maio de 2015. Dispõe sobre o Plano de Desenvolvimento Agropecuário do Mapitoba e a criação de seu Comitê Gestor. Diário Oficial da União Brasília, DF, 7 mai. 2015. Disponível em: $<$ http://pesquisa.in.gov.br/imprensa/jsp/visualiza/index.jsp?.jornal=1\&pagina=2\&data=07/05/ 2015>. Acesso em 07 mai. 2015.

Ministério do Meio Ambiente. Zoneamento Ecológico-Econômico da bacia do Rio Parnaíba: um foco nos cerrados do sul do Piauí e Maranhão: subsídios para o diagnóstico/ MMA, Secretaria de Políticas para o Desenvolvimento Sustentável, Programa ZZE, Consórcio ZEE BRASIL- Brasília. MMA, 2005.

BRAZ, M. Inserção Desvantajosa, atraso e subordinação das políticas de desenvolvimento na economia piauiense. 2007. Disponível em: http://ufpi.br/subsiteFiles/economia/arquivos/files/texto_12.pdf. Acesso em 30 out. 2015.

CARLEIAL, L; CRUZ, B. A Hora e a Vez do Desenvolvimento Regional Brasileiro: Uma Proposta de Longo Prazo. Brasília, IPEA, Textos para Discussão 1729, 2012, 36 p.

CATELAN, M. J. Heterarquia Urbana: Interações espaciais interesses interescalares e cidades médias. 2012. 227 f. Tese- Departamento de Pós Graduação em Geografia, Universidade Estadual Paulista "Júlio Mesquita Filho", Presidente Prudente-SP.

CPT. Rede Cerrado questiona governo sobre o Plano MATOPIBA. 2015. Disponível em: http://www.cptnacional.org.br/index.php/publicacoes/noticias/articulacao-cpt-s-docerrado/2815-rede-cerrado-questiona-governo-sobre-plano-matopiba. Acesso em 20 set. 2015.

CONTE, C. H. Cidades médias: Discutindo o tema. Revista Sociedade e Território, Natal, v.25, nº1, p.45-61, jan./jun. 2013.

CORRÊA, R. L. Rede Urbana e Formação Espacial- Uma Reflexão Considerando o Brasil. Revista Território, Rio de Janeiro, no 8, p.123 a 129, 2000.

Reflexões sobre a dinâmica recente da rede urbana brasileira. In: Anais do IX Encontro Nacional da Anpur. Rio de Janeiro, Anpur, v.1, 2001. 
COSTA, E. B; SUZUKI, J. C. Materialismo histórico e existência: discurso geográfico e utopias. Revista Espaço e Geografia, vol. 15, nº1, 2012, p.115-147.

Geografia urbana aplicada: possibilidades, utopias e metodologias. XII SinpurbSimpósio Nacional de Geografia Urbana, Belo Horizonte- UFMG, 2011, p. 1-16.

DEUS, J. As cidades médias na nova configuração territorial brasileira. Boletim Goiano de Geografia, Goiânia, v. 24, n. 1-2, p. 81-91. Jan./Jun. 2004.

DUPAS, G. As Duas contradições do Capitalismo Global. In: Economia Global e Exclusão Social- Pobreza, Emprego, Estado e o Futuro do Capitalismo. São Paulo, Paz e Terra, 2001, p. 39-81.

EMBRAPA. Agência do MATOPIBA foi lançada no primeiro dos quatro estados. 2015a. Disponível em: https://www.embrapa.br/busca-de-noticias/-/noticia/3139994/agencia-domatopiba-foi-lancada-no-primeiro-dos-quatro-estados. Acesso em: 20 set. 2015.

. MATOPIBA: Delimitação, Caracterização, Desafios e Oportunidades para o desenvolvimento-Piauí. $\quad$ Brasília, 2015b. Disponível em: https://www.embrapa.br/gite/projetos/matopiba/150514_MATOPIBA_PI.pdf. Acesso em 17 de jul. 2015.

ELIAS, D. Agronegócio e novas regionalizações no Brasil. In: XIV Encontro Nacional da Anpur. Rio de Janeiro - RJ, 2011.

Ensaios sobre espaços agrícolas de exclusão. In: Revista NERA (UNESP), Presidente Prudente (SP), v.1, n.8, 2006a, p.29-51.

Globalização e fragmentação do espaço agrícola no Brasil. In: Scripta Nova Revista Electrónica de Geografia Y Ciencias Sociales. Universidade de Barcelona, vol. X, $\mathrm{n}^{\circ} 218$ (03), 1 agosto de 2006b.

Relações campo-cidade, reestruturação urbana e regional do Brasil. In: Colóquio Internacional de Geocrítica, nº12, 2012, Bogotá.

FOUREZ, Gérard. A construção das ciências. Introdução à filosofia e á ética das ciências. São Paulo: EdUNESP, 1995, p.179-193.

FRANÇA, I. S.; SOARES, B. R. A cidade média e suas centralidades: o exemplo de Montes Claros no norte de Minas Gerais. 2009. Disponível em: <http://www.redbcm.com.br/arquivos/bibliografia/a\%20cidade $\% 20 \mathrm{~m} \% \mathrm{C} 3 \%$ A9dia\%20e\%20s uas $\% 20$ centralidades $\% 20 \mathrm{o} \% 20$ exemplo\%20de\%20montes.pdf $>$. Acesso em: 30 nov. 2015.

FREDERICO, S. Agricultura científica globalizada e fronteira agrícola no Brasil. In: Revista Franco-Brasileira de Geografia, vol. 17, 2013. Disponível em: http://confins.revues.org/8153?lang=pt\#quotation. Acesso em: 21 Set. 2015.

FUNDAÇÃO CEPRO. Piauí em Números. Teresina, 8 ed., 2011. 
Identificação das potencialidades econômicas e áreas carentes de qualificação de mão de obra no Estado do Piauí. Teresina, 2007.

Teresina, 2015

Conjuntura Econômica- Boletim Analítico Trimestral (Jan./Fev./ Mar.).

FURTADO, C. Formação Econômica do Brasil. São Paulo: Companhia Editora Nacional, vol. 32, 2005.

GALVÃO, A. C. F. Política Brasileira de Desenvolvimento Regional e o Ordenamento Territorial. In: Campolina Diniz, Clélio (Org.) Políticas de Desenvolvimento Regional: Desafios e Perspectivas a partir das Experiências da União Europeia e do Brasil. Brasília, Editora da Universidade de Brasília, 2007, p. 329-351.

GOMES, I. R. Agricultura e urbanização: novas dinâmicas territoriais no Nordeste Brasileiro. 2007. 200f. Dissertação- Departamento de Geociências (CCT), Universidade Estadual do Ceará (UECE), Fortaleza.

GOMES JUNIOR, E. Fronteira e reestruturação produtiva na Amazônia brasileira (2003-2013): um estudo sobre a mudança na hierarquia urbana do município de Araguaina (TO) na Amazônia oriental. Campinas, SP: [s.n], 2015.

HAESBAERT, R. A noção de rede-regional: reflexões a partir da migração "gaúcha" no Brasil. In: Revista Território, Rio de Janeiro, v. 4, jan./jun.1998. Disponível em: http://www.revistaterritorio.com.br/pdf/04_5_haesbaert.pdf. Acesso em: 01 fev. 2013.

Território e Identidade: O Encontro Entre Gaúchos e Nordestinos No Brasil.

In: ENCUENTRO DE GEOGRAFOS DE AMERICA LATINA, 6, 1997. ANAIS. BUENOS AIRES. Urbanos. Série Estudos e Pesquisas. 1ed. Salvador: Super Intendência de Estudos Econômicos e Sociais da Bahia, 2012, v. 94, p. 183-195.

Região, regionalização e regionalidade: questões contemporâneas. Revista ANTARES, $n^{\circ}$ 3, 2010, p.2-24

HARVEY, D. A globalização Contemporânea. In: Harvey, D. Espaços de Esperança, Loyola, São Paulo, p.79-103, 2000.

HESPANHOL, R. A. M. Campo e Cidade, Rural e Urbano no Brasil Contemporâneo. In: Revista Mercator, Fortaleza, v.12, nº especial (2)., p.103-112, set. 2013.

IBGE. Regiões de influências das cidades 2007 (REGIC). Rio de Janeiro: Ministério do Planejamento, Orçamento e Gestão, 2008.

. Sinopse do Censo Demográfico 2000. Rio de Janeiro 2000.

. Sinopse do Censo Demográfico 2010. Rio de Janeiro 2010.

Censo Demográfico de 2010- Retratos do Brasil e do Piauí, 2010. 
Divisão Regional do Brasil em Mesorregiões e Microrregiões Geográficas.

Vol. 1. Rio de Janeiro, 1990.

. Censo agropecuário 1995. Rio de Janeiro: IBGE, 1995-1996.

Censo agropecuário 2006. Rio de Janeiro: IBGE, 2007.

Regiões de influência das cidades de 2007 (REGIC). Rio de Janeiro, 1988.

Regiões de influência das cidades de 1993. Rio de Janeiro, 1994.

. Divisão Regional do Brasil em Mesorregiões e Microrregiões Geográficas.

Vol. 1. Rio de Janeiro, 1990.

IPEA. Inserção internacional brasileira: temas de economia internacional/Instituto de Pesquisa Aplicada.- Brasília: Ipea, 2010. V. 2 (516 p): grafs., mapas, tabs. (Série Eixos Estratégicos do Desenvolvimento Brasileiro; Inserção Internacional Brasileira Soberana; Livro 3).

INOCÊNCIO, M. E; CALAÇA, M. Fronteira da produção agrícola capitalista do século XX. In: XIX Encontro Nacional de Geografia Agrária, São Paulo, 2009, PP.1-16.

KUHN, T. S. A estrutura das Revoluções Científicas. São Paulo: Editora Perspectiva, $5^{\text {a }}$ Ed, 1998.

OLIVEIRA, A. U. "A Geografia Agrária e as Transformações Territoriais Recentes no Campo Brasileiro". In: CARLOS, Ana Fani A. (org). Novos Caminhos da Geografia. $5^{\text {a }}$ Ed.São Paulo, Contexto, 1999, p. 62-106.

OLIVEIRA, L. V. N; LIMA, J. F. L. Política Nacional de Desenvolvimento Regional: Um Processo em Construção. In: ETGES, Virgínia Elisabete e Silvio Cezar Arend (2012). CEPAL: Leituras sobre o Desenvolvimento Latino-Americano. Santa Cruz do Sul: EDUNISC, 2012, p.163-193.

O’NEILL, M. M. Redes Geográficas. In: Atlas Nacional do Brasil Milton Santos/IBGE, Diretoria de Geociências- Rio de Janeiro: IBGE, p.261-272 2010.

LOPES, M. A. Matopiba, na nova ousadia da agricultura brasileira. In: Correio Braziliense, Brasília, 11 maio de 2014. Disponível em: <https://www.embrapa.br/sala-de-imprensaartigos/-/asset_publisher/D02sE8gXQO4I/content/id/1705615>. Acesso em 21. ago. 2015.

MARTINE, G. Fases e faces da modernização agrícola brasileira. In: Revista Planejamento e Polítcas Públicas, IPEA/IPLAN 1 (1): 3-43.

MARTINS, J. S. A sujeição da renda da terra ao capital e o novo sentido da luta pela reforma agrária. In: Os camponeses e a política no Brasil. $2^{\text {a }}$ Ed. Petrópolis: Vozes, 1986.

MATOS, P. F.; PESSÔA, V. L S.. Territorialização do Agronegócio nas áreas de cerrado. In: PORTUGUEZ, Anderson P.; MOURA, Geruza Gonçalves e COSTA, Rildo A.(Org.). 
Geografia do Brasil Central: Enfoques teóricos e particularidades regionais. Uberlândia: Assis, 2011. p. 235-264.

MIRANDA, H. Expansão da agricultura e sua vinculação com o processo de urbanização na Região Nordestel Brasil (1990-2010). EURE (Santiago), 38 (114), 173-201.

MONTEIRO, M. S. L. Ocupação do cerrado piauiense: estratégia empresarial e especulação fundiária. 2002. 250f. Tese (Doutorado em economia) - Universidade Estadual de Campinas, Campinas, 2002.

MOTA, F. L. Relação campo-cidade no sul do Maranhão. In: CHELOTTI, Marcelo C. et al (Org). Geografia e diversidades territoriais do campo brasileiro. Uberlândia: Assis, 2012. p. 279-295.

MOTA, F. L; PESSÔA, V. L. S. O Agronegócio como (re) produtor e um novo território: Balsas no Contexto do Agronegócio da soja. Disponível em:http://www.uff.br/vsinga/trabalhos/Trabalhos\%20Completos/FRANCISCO\%20LIMA\%2 0MOTA.pdf. Acesso em 02 de outubro de 2013.

MOTA, L.A. Capitalismo Contemporâneo, Desigualdades Sociais e Crise de 2008. In: Revista Brasileira de Desenvolvimento Regional, Blumemau, vol. 1: 51-64, 2013.

MOTTA, D. M; AJARA, C. Configuração da Rede Urbana no Brasil. In: Revista Paranaense de Desenvolvimento, Curtiba, vol. 100, p.7-25, 2001.

MOURA, R. Qual o papel dos pequenos municípios na escala local do desenvolvimento. In: ENDLICH, Angela Maria e ROCHA, Márcio Mendes (org.). Pequenas cidades e desenvolvimento local. Maringá, PGE, 2009.

PRADO JÚNIOR, C. História Econômica do Brasil. $47^{\mathrm{a}}$ reimpressão. São Paulo, Brasiliense, 2006.

POCHMANN, M. Desenvolvimento Capitalista e Divisão do Trabalho. In: POCHMANN, M. (Org.) Reestruturação Produtiva - Perspectivas de Desenvolvimento Local com Inclusão Social. Petrópolis, RJ, Vozes, 2004, p. 15-61.

PIZARRO, Roberto. Estado e o Agronegócio no Sudoeste Goiano: o caso da BRF. Relatório de Qualificação. Brasília, Universidade de Brasília, 2015.

PRAGANA, R. B. Caracterização pedológica e diagnóstico da qualidade de solos sob plantio direto na Serra do Quilombo, Sudoeste Piauiense. Recife, Universidade Federal Rural de Pernambuco, 2011. 159p. (Tese de Doutorado).

REIS, L; CUNHA, P. Influência do agronegócio no perímetro urbano do Município de Bom Jesus-PI. In: IV Congresso de Pesquisa e Inovação da Rede Norte e Nordeste de Educação Tecnológica. Belém-PA, 2009. 
RUFO, T. F. Modernização Agrícola no Sudoeste Piauiense: impactos da rede urbana regional, no meio ambiente e nas comunidades. $129 \mathrm{f}$. Monografia- Departamento de Geografia, Universidade de Brasília, Campus Darcy Ribeiro- DF, 2013.

SAMPAIO, A. V. O. As cidades médias e a drenagem da renda regional. In: Anais da $\mathbf{X}$ Semana de Geografia da UESB. 2001. Disponível em: <http://www.uesb.br/eventos/ebg/anais/2g.pdf. Acesso em 30 set. 2015.

SANTOS, M; SILVEIRA, M. L. As diferenciações no território. In: SANTOS, M.; SILVEIRA, M. L. O Brasil: território e sociedade no início do século XXI. São Paulo, Rio de Janeiro, Editora Record, 2001.

- Modo de Produção Técnico-Científico e Diferenciação Espacial. In: Revista Território, ano IV, nº 6, 1999, p-5-20.

2004, p.15-33.

O espaço e seus elementos- questão de método. In: Espaço e Método. EdUSP,

Por uma outra globalização: do pensamento único à consciência universal. $19^{\text {a }}$ Ed.- Rio de Janeiro: Record, 2010.

Técnica, Espaço, Tempo: globalização e meio técnico-científicoinformacional. São Paulo: EdUSP, 2008, p. 37-63.

SILVA, A. L. Breve discussão o conceito de cidade média. In: Revista do Programa de PósGraduação em Geografia da Universidade Estadual de Maringá (UEM). Maringá, v. 5, n.1, p.58-76, 2013.

SILVA, J. G. O Novo Rural Brasileiro. In: Revista Nova Economia, Belo Horizonte, Vol. 7, p. 43-81, 1997.

SILVEIRA, M. L. O espaço geográfico: da perspectiva geométrica à perspectiva existencial. São Paulo: GEOUSP- Espaço e Tempo, nº19, PP. 81-91, 2006.

SIMÕES, R.; AMARAL, P.V. Interiorização e Novas Centralidades Urbanas: Uma Visão Prospectiva para o Brasil. In: Revista Anpec, vol.12, p.553-579.

SIQUEIRA, H. Aspectos Estruturais da Dinâmica Regional Brasileira e o Referencial Analítico da Divisão Inter-regional do Trabalho. In: Desenvolvimento Regional Recente no Brasil. Rio de Janeiro: E-Papers, 2010, p.27-38.

SOARES, B. R; MELO, N.A. Revisando o tema da pequena cidade: uma busca de caminhos mitológicos. In: MARAFON, Gláucio José e Pessôa, Vera Lúcia Salazar. Agricultura, desenvolvimento e transformações socioespaciais: reflexões interinstitucionais e constituição de grupos de pesquisa no rural e urbano. Uberlândia, Assis Editora, 2008.

SOUSA, Marcelo Lopes de. Capítulo 3: Da cidade individual à rede urbana. In $\mathrm{ABC}$ do desenvolvimento urbano. Bertrand Brasil, 2003. p.49-61. 
SOUSA, V. V. Piauí: Apossamento, integração e desenvolvimento (1684-1887). 2008. Disponível

http://poshistoria.historia.ufg.br/uploads/113/original_43_ValfridoSousa_PiauiApossamentoI ntegracao.pdf. Acesso em: 12 de Jul. de 2013.

SOUZA, M. A. A. Cidade: lugar e geografia da existência. In: VASCONCELOS, P; MELOO, S (orgs). Novos estudos de Geografia urbana brasileira. EdUFBA, 1999, p. 9-18.

SOUZA, R. M.; BARBOSA, A. M. F. Reflexões sobre paisagem e território na organização espacial do cerrado piauiense. Revista de Geografia (UFPE), v.28, n.2. 2011.

SPOSITO, M. E. B. O desafio metodológico da abordagem interescalar no estudo de cidades médias no mundo contemporâneo. In: Revista Cidades, v. 3, n.5, 2006, p. 143-157.

SPOSITO, M. E. B. Conjunto de pequenas cidades faz região crescer menos, avalia geógrafa [agosto 2015]. Heloise Hamada. In: G1, Globo. Presidente Prudente, São Paulo, 28 agosto 2015. Disponível em: <http://g1.globo.com/sp/presidente-prudenteregiao/noticia/2015/08/conjunto-de-pequenas-cidades-faz-regiao-crescer-menos-avaliageografa.html>. Acesso em: 29 ago.2015.

Novos conteúdos nas periferias urbanas das cidades médias do Estado de São Paulo, Brasil. In: Investigaciones Geográficas, Boletin Del Instituto de Geografia-UNAM, n. 54, 2004, p.114-139.

THOMAZ JUNIOR, A. Povoando o território da luta pela terra e pela Reforma Agrária no Brasil Contemporâneo. In: Revista Pegada, vol. 11, nº 2, 2010.

VEIGA, J. E. A história não os absorverá nem a geografia. Campinas, SP: Armazém do Ipê (Autores Associados), 2005.

J. E. O Brasil não encontrou seu eixo de desenvolvimento. In: Revista Estudos Avançados, vol. 15, 2001, p.101-120.

Sites Consultados:

www.cidades.ibge.gov.br http://curimata.blogspot.com.br/2011/05/todo-o-potencial-do-cerrado-piauiense.html http://www.appm.org.br/ 